Anderson Rodrigues Brandão de Paiva

Leucodistrofias e leucoencefalopatias genéticas em adultos: caracterização clínica, molecular e de neuroimagem

Tese apresentada à Faculdade de Medicina da Universidade de São Paulo para obtenção do título de Doutor em Ciências

Programa Neurologia

Orientador: Prof. Dr. Fernando Kok 
Dados Internacionais de Catalogação na Publicação (CIP)

Preparada pela Biblioteca da

Faculdade de Medicina da Universidade de São Paulo

Creprodução autorizada pelo autor

Paiva, Anderson Rodrigues Brandão de

Leucodistrofias e leucoencefalopatias genéticas

em adultos : caracterização clínica, molecular e de

neuroimagem / Anderson Rodrigues Brandão de Paiva. -

- São Paulo, 2019.

Tese (doutorado)--Faculdade de Medicina da

Universidade de São Paulo.

Programa de Neurologia.

Orientador: Fernando Kok.

Descritores: 1.Leucoencefalopatias

2.Adrenoleucodistrofia 3. CADASIL 4.Genética

5. Neuroimagem 6.Doença de Pelizaeus-Merzbacher

$\mathrm{USP} / \mathrm{FM} / \mathrm{DBD}-179 / 19$

Responsável: Erinalva da Conceição Batista, CRB-8 6755 


\section{Dedicatória}

Aos meus filhos, Artur e Beatriz, fontes inesgotáveis de inspiração e alegria.

À Carla, minha esposa, por seu apoio incondicional, incentivo, suporte e companheirismo.

À minha irmã, Mayara, por todo seu apoio, exemplo e ensinamentos.

Aos meus pais, Marta e Joaquim, por serem os alicerces de toda a minha formação como indivíduo - devo tudo a vocês. 


\section{Agradecimentos}

Ao longo desta longa e desafiadora jornada, muitas pessoas foram importantes para a execução deste trabalho e a todas serei eternamente grato.

Agradeço enormemente ao Professor Dr. Fernando Kok, por todo incentivo, orientação e paciência. Muito além dos ensinamentos sobre neurogenética, ficam a amizade e a admiração por sua perspicácia e singular capacidade de colocar temas áridos da genética em termos simples e ainda mais fascinantes.

Ao Professor Dr. Leandro Lucato, neurorradiologista professor livre-docente do Instituto de Radiologia do HCFMUSP, por toda a sua disponibilidade e presteza em discutir os casos comigo e ajudar na elaboração dos artigos. Sua contribuição foi muito enriquecedora e determinante para este trabalho.

Aos colegas do ambulatório de Neurogenética do HCFMUSP, pela agradável convivência e que muito me ensinaram e contribuíram para este trabalho em diversos momentos e contextos: Dr. David Schlesinger, Dr. Paulo Ribeiro da Nóbrega, Dr. Fernando Freua, Dr. Bruno Della Ripa, Dra. Fernanda Monti, Dra. Simone Amorim, Dra. Denise Dória, Dra. Katiane Sayão, Dra. Isabella Barcelos e Mara Dell Ospedale Ribeiro.

À Dra. Lúcia Inês Macedo-Souza e ao Dr. Uirá Souto Melo, biólogos do Centro de Estudos do Genoma Humano (CEGH) da USP, que foram imprescindíveis para que as análises moleculares deste trabalho fossem feitas. Sempre muito prestativos e dispostos a compartilhar o intricado conhecimento de ciência básica.

Ao Professor Dr. Henry Houlden e ao Dr. David S. Lynch, da Queen Square University College London, pela inestimável ajuda na solução de vários casos desafiadores. Suas colaborações permitiram que este trabalho atingisse patamares não previamente imaginados. Esperamos continuar trabalhando juntos.

À Professora Dra. Juliana Gurgel-Giannetti, que contribuiu de forma decisiva para a investigação de uma família com um quadro totalmente novo, viabilizando biópsias musculares e colaborações internacionais. 
Às Dras. Eliana Garzon e Joaquina Andrade, neurofisiologistas responsáveis pelo setor de Eletroencefalograma do HCFMUSP, que minuciosa e pacientemente revisaram os traçados de EEG dos pacientes desta tese.

Às Professoras Angela M. Vianna-Morgante e Carla Rosemberg, do CEGHUSP, por contribuírem com a realização de testes genéticos em casos selecionados desta tese.

Aos Professores do HCFMUSP que me formaram como médico neurologista e que tenho como grandes referências, em especial: Dr. Getúlio Daré Rabello, Dr. Paulo Eurípedes Marchiori, Dra. Mônica Santoro Haddad e Dr. Egberto Reis Barbosa.

À imensa equipe do HCFMUSP, em especial Sueli e Reiko, secretárias do Departamento de Neurologia, pelo apoio irrestrito nas questões administrativas.

Aos pacientes, motivo último do esforço aqui empreendido, por compartilharem comigo suas histórias, terem disponibilidade de participar do estudo e por tanto me ensinarem.

À toda minha família, por todo apoio e vibração a cada conquista, e em especial ao meu tio, José Rodrigues Brandão, amigo e conselheiro, por quem tenho grande admiração.

À minha irmã, Mayara, por seu apoio, incentivo e exemplo de determinação. Mesmo distante, faz-se sempre presente - e como nossas conversas "filosóficas" e "científicas" estão cada vez mais deliciosas...

Aos meus pais, Marta e Joaquim, meus maiores professores e exemplos na vida. Sempre foram meus maiores incentivadores e torcedores. Muito obrigado por sempre me estimularem a buscar realizar meus sonhos, mesmo quando não coincidiram com os seus. Devo todas as conquistas a vocês.

À minha esposa, Carla, que compreendeu que este projeto era muito importante para mim e me deu todo o suporte com muita paciência. Ao longo de uma empreitada como esta, não foram poucos os momentos difíceis - e eu não teria conseguido superá-los sem ter você a meu lado. 
Na verdade só sabemos quão pouco sabemos - com o saber cresce a dúvida.

Goethe (1826) 


\section{Normatização}

Esta tese está de acordo com as seguintes normas, em vigor no momento desta publicação:

Referências: adaptado de International Committee of Medical Journals Editors (Vancouver).

Universidade de São Paulo. Faculdade de Medicina. Divisão de Biblioteca e Documentação. Guia de apresentação de dissertações, teses e monografias. Elaborado por Anneliese Carneiro da Cunha, Maria Julia de A. L. Freddi, Maria F. Crestana, Marinalva de Souza Aragão, Suely Campos Cardoso, Valéria Vilhena. 3a ed. São Paulo: Divisão de Biblioteca e Documentação; 2011.

Abreviaturas dos títulos dos periódicos de acordo com List of Journals Indexed in Index Medicus. 


\section{Sumário}

\section{LISTA DE ABREVIATURAS E SIGLAS}

LISTA DE FIGURAS

LISTA DE TABELAS

LISTA DE QUADROS

RESUMO

ABSTRACT

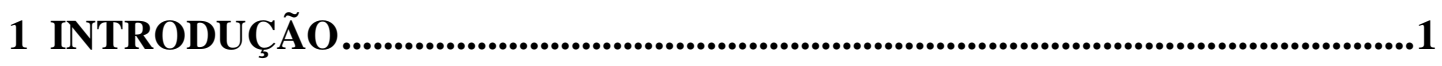

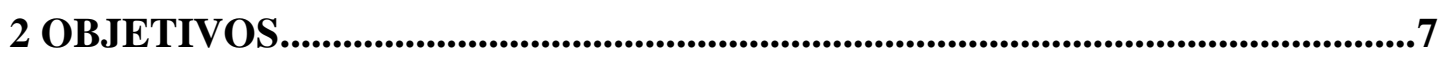

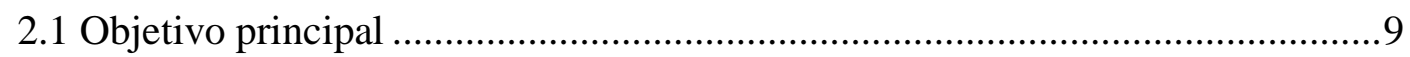

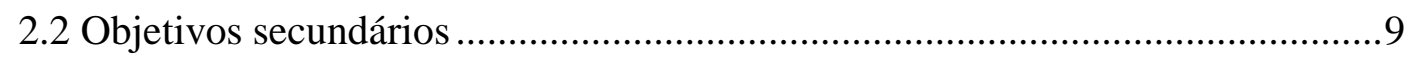

3 REVISÃO DA LITERATURA ..................................................................11

3.1 Leucodistrofias e leucoencefalopatias genéticas ............................................. 13

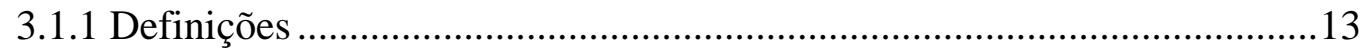

3.1.1.1 Leucoencefalopatia versus leucodistrofia ....................................... 13

3.1.1.2 Desmielinização versus dismielinização .........................................17

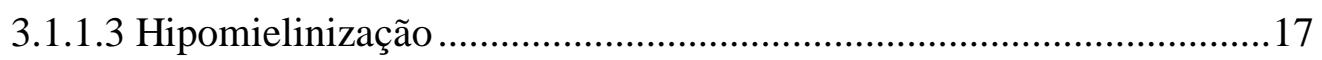

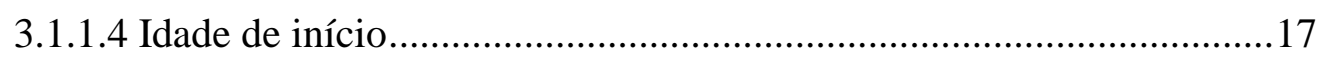

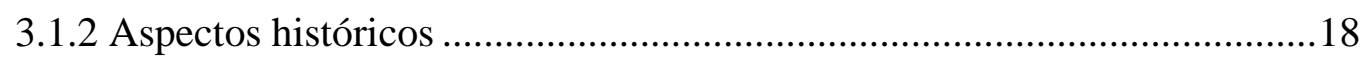

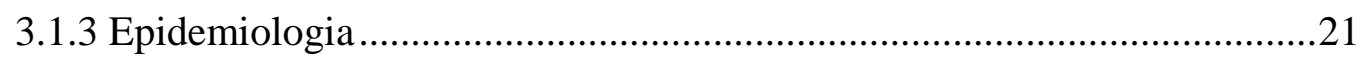

3.2 Leucodistrofias e leucoencefalopatias genéticas em adultos ..........................21

3.2.1 Importância ................................................................................... 21

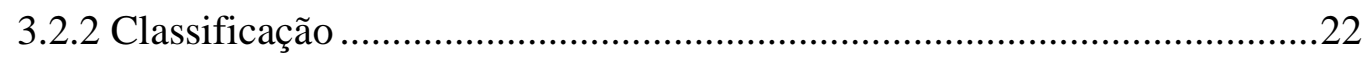

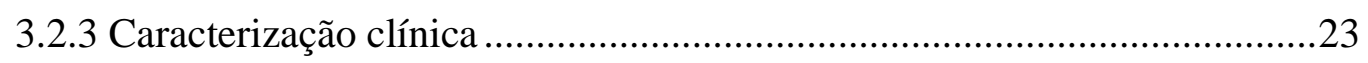

3.2.4 Caracterização neurorradiológica .......................................................28

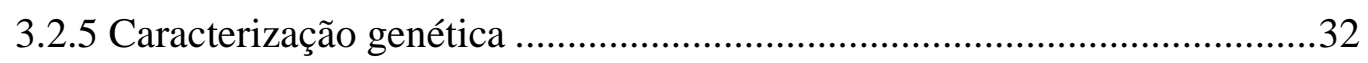

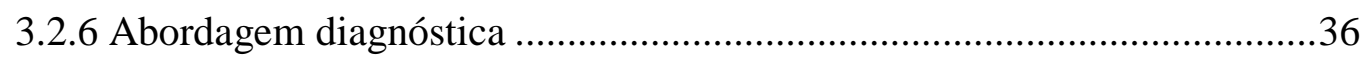

3.3 Principais leucodistrofias e leucoencefalopatias genéticas em adultos ............36

3.3.1 Adrenoleucodistrofia/adrenomieloneuropatia ligada ao X (OMIM

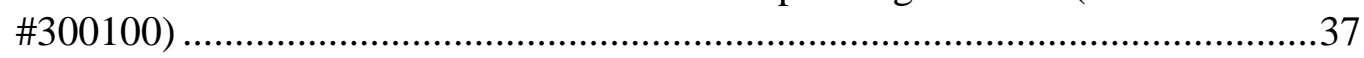

3.3.2 Doença da substância branca evanescente (OMIM \#603896) ....................40

3.3.3 Acidúria L2-Hidroxiglutárica (OMIM \#236792) .......................................42

3.3.4 Leucoencefalopatias genéticas de origem vascular .................................4

3.3.5 Leuroencefalopatias genéticas e origem mitocondrial ............................47 
3.3.6 Leucoencefalopatia difusa hereditária com esferóides (OMIM \#221820)

3.3.7 Doença de Alexander (OMIM \#203450).

3.3.8 Leucodistrofia desmielinizante autossômica dominante de início no adulto (OMIM \#169500) ................................................................................5

3.3.9 Síndrome de Sjögren-Larsson (OMIM \#270200)....................................55

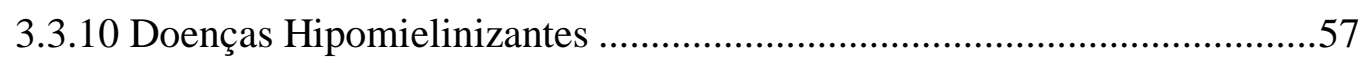

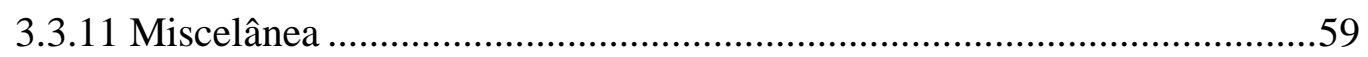

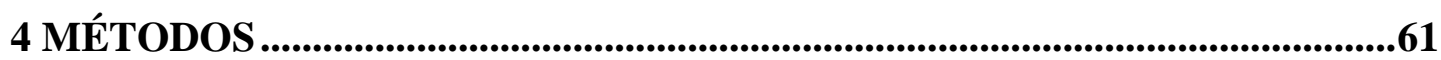

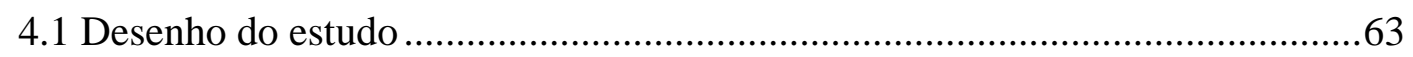

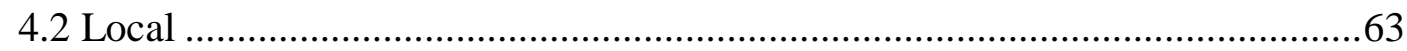

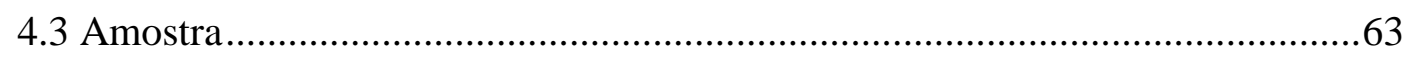

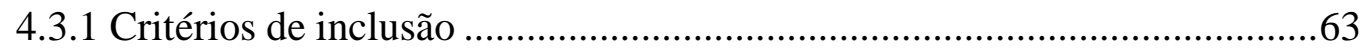

4.3.2 Critérios de exclusão............................................................................64

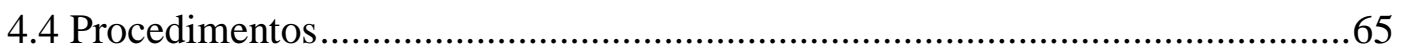

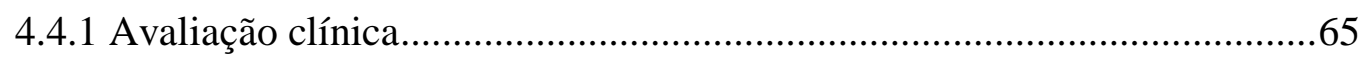

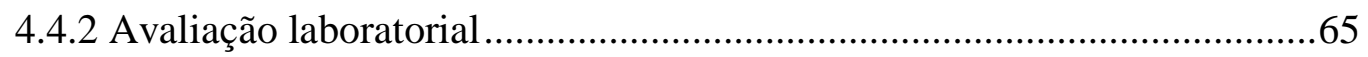

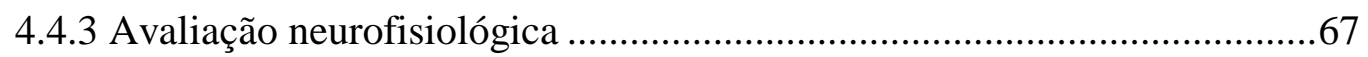

4.4.4 Avaliação por ressonância magnética .....................................................69

4.4.5 Avaliação anatomopatológica de biópsia muscular ..................................70

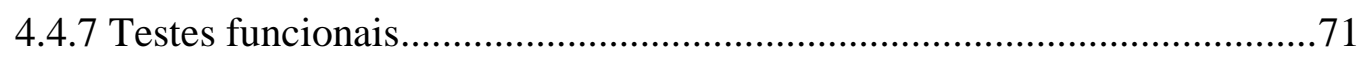

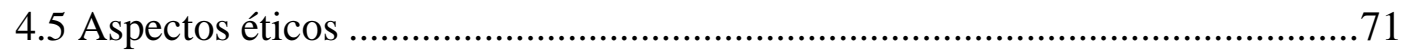

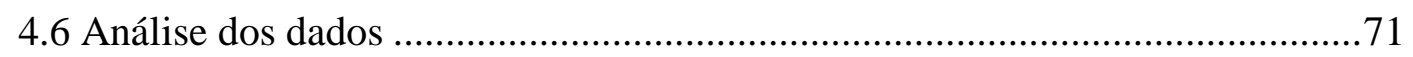

5 RESULTADOS ….............................................................................................73

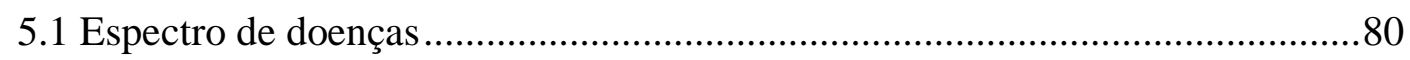

5.1.1 Adrenoleucodistrofia/adrenomieloneuropatia ligada ao X .......................80

5.1.1.2 Adrenomieloneuropatia ligada ao X ..............................................81

5.1.1.2.1 Adrenomieloneuropatia ligada ao $\mathrm{X}$ - aspectos clínicos .............81

5.1.1.2.2 Adrenomieloneuropatia ligada ao $\mathrm{X}$ - aspectos

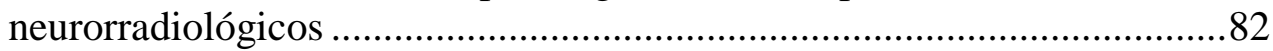

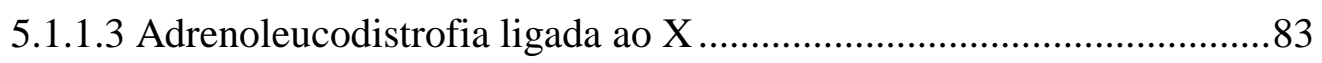

5.1.1.3.1 Adrenoleucodistrofia ligada ao $\mathrm{X}$ - casos típicos - aspectos clínicos

5.1.1.3.2 Adrenoleucodistrofia ligada ao $\mathrm{X}$ - casos típicos -aspectos

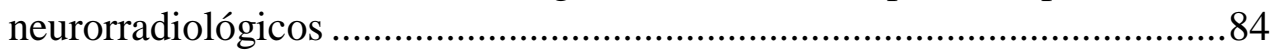

5.1.1.3.4 Adrenoleucodistrofia ligada ao $\mathrm{X}$ - um caso atípico ...................85

5.1.2 Doença da substância branca evanescente ...............................................8

5.1.2.1 Doença da substância branca evanescente - aspectos clínicos ...........87

5.1.2.2 Doença da substância branca evanescente - aspectos

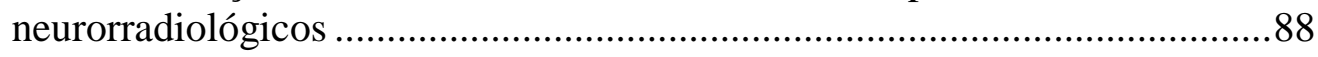

5.1.2.3 Doença da substância branca evanescente - aspectos genéticos .......89 
5.1.3 Acidúria L2-hidroxiglutárica .90

5.1.3.1 Acidúria L2-hidroxiglutárica - aspectos clínicos ............................90

5.1.3.2 Acidúria L2-hidroxiglutárica - aspectos neurorradiológicos .............92

5.1.3.3 Acidúria L2-hidroxiglutárica - aspectos genéticos ..........................94

5.1.4 Leucoencefalopatia difusa hereditária com esferóides ............................94

5.1.4.1 Leucoencefalopatia difusa hereditária com esferóides - aspectos clínicos. .95

5.1.4.2 Leucoencefalopatia difusa hereditária com esferóides - aspectos neurorradiológicos .96

5.1.4.3 Leucoencefalopatia difusa hereditária com esferóides - aspectos genéticos

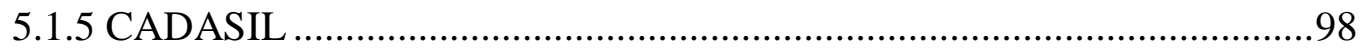

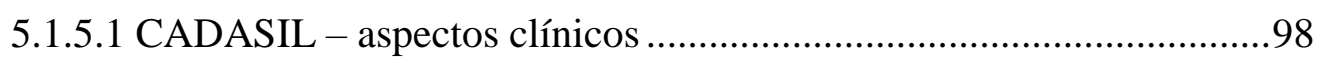

5.1.5.2 CADASIL - aspectos neurorradiológicos ........................................99

5.1.5.3 CADASIL - aspectos genéticos .....................................................99

5.1.6 Leucodistrofia desmielinizante autossômica dominante de início no adulto

5.1.6.1 Leucodistrofia desmielinizante autossômica dominante de início no adulto - aspectos clínicos

5.1.6.2 Leucodistrofia desmielinizante autossômica dominante de início no adulto - aspectos neurorradiológicos.

5.1.6.3 Leucodistrofia desmielinizante autossômica dominante de início no adulto - aspectos genéticos

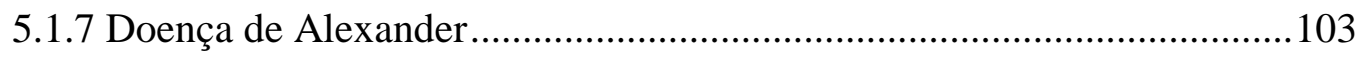

5.1.7.1 Doença de Alexander - aspectos clínicos .......................................103

5.1.7.2 Doença de Alexander - aspectos neurorradiológicos ........................104

5.1.7.3 Doença de Alexander - aspectos genéticos ..................................... 104

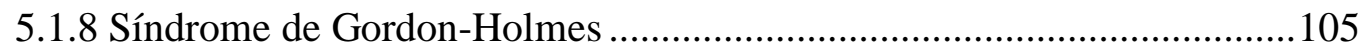

5.1.8.1 Síndrome de Gordon-Holmes - aspectos clínicos ............................105

5.1.8.2 Síndrome de Gordon-Holmes - aspectos neurorradiológicos ...........106

5.1.8.3 Síndrome de Gordon-Holmes - aspectos genéticos .........................107

5.1.9 Leucoencefalopatia com acometimento de tronco encefálico e

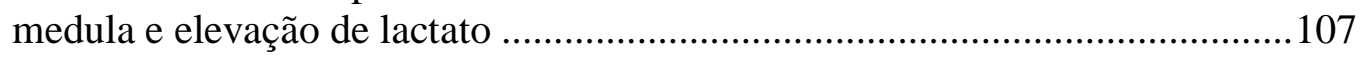

5.1.9.1 Leucoencefalopatia com acometimento de tronco encefálico e medula e elevação de lactato - aspectos clínicos........................................... 108

5.1.9.2 Leucoencefalopatia com acometimento de tronco encefálico e medula e elevação de lactato - aspectos neurorradiológicos........................ 108

5.1.9.3 Leucoencefalopatia com acometimento de tronco encefálico e medula e elevação de lactato - aspectos genéticos ......................................109

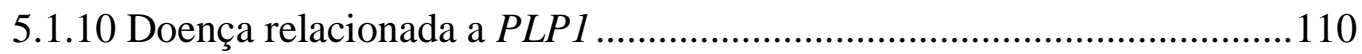

5.1.10.1 Doença relacionada a $P L P 1$ - aspectos clínicos ...........................110

5.1.10.2 Doença relacionada a $P L P 1$ - aspectos neurorradiológicos ...........111 
5.1.10.3 Doença relacionada a $P L P 1$ - aspectos genéticos

5.1.11 Síndrome de Sjögren-Larsson ..........................................................112

5.1.11.1 Síndrome de Sjögren-Larsson - aspectos clínicos.........................112

5.1.11.2 Síndrome de Sjögren-Larsson - aspectos neurorradiológicos ........113

5.1.11.3 Síndrome de Sjögren-Larsson - aspectos genéticos ......................114

5.1.12 Deficiência intelectual autossômica recessiva 55 (relacionada a PUS3)

5.1.12.1 Deficiência intelectual autossômica recessiva 55 (relacionada a PUS3) - aspectos clínicos

5.1.12.2 Deficiência intelectual autossômica recessiva 55 (relacionada a PUS3) - aspectos neurorradiológicos

5.1.12.3 Deficiência intelectual autossômica recessiva 55 (relacionada a PUS3) - aspectos genéticos

5.1.13 Encefalomioneuropatia relacionada a $F D X 2$

5.1.13.1 Encefalomioneuropatia relacionada a FDX2 - aspectos clínicos ...120

5.1.13.2 Encefalomioneuropatia relacionada a FDX2 - aspectos neurorradiológicos

5.1.13.3 Encefalomioneuropatia relacionada a FDX2 - aspectos neurofisiológicos.

5.1.13.4 Encefalomioneuropatia relacionada a $F D X 2$ - aspectos laboratoriais

5.1.13.5 Encefalomioneuropatia relacionada a FDX2 - aspectos da biópsia muscular

5.1.13.6 Encefalomioneuropatia relacionada a FDX2 - aspectos genéticos

5.1.13.7 Encefalomioneuropatia relacionada a $F D X 2$ - um novo fenótipo

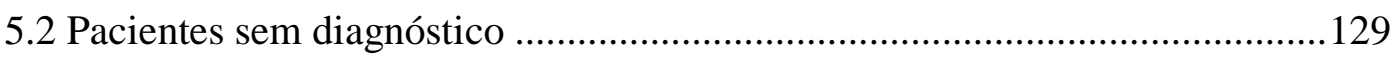

6 DISCUSS $\tilde{A}$ O................................................................................................131

6.1 - Doenças mais comuns em nossa casuística ..............................................136

6.1.1 - Adrenomieloneuropatia e adrenoleucodistrofia ligada ao X ................136

6.1.2 - Doença da substância branca evanescente ..........................................137

6.1.3 - Acidúria L2-hidroxiglutárica ...........................................................139

6.1.4 - Leucoencefalopatia difusa hereditária com esferóides ..........................140

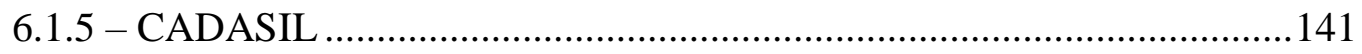

6.2 - Doenças com apenas um paciente diagnosticado ........................................142

6.2.1 - Doença de Alexander......................................................................... 142

6.2.2 - Leucoencefalopatia com acometimento de tronco encefálico e medula e elevação de lactato - LBSL ............................................................143

6.2.3 - Síndrome de Sjögren-Larsson.........................................................143

6.2.4 - Leucodistrofia desmielinizante autossômica dominante de início no adulto - ADLD 
6.2.5 - Síndrome de Gordon-Holmes 146

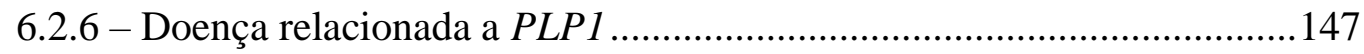

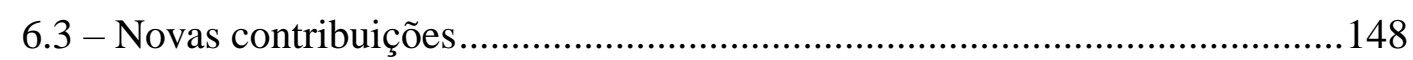

6.3.1 - Deficiência intelectual autossômica recessiva 55 (relacionada a PUS3) 148

6.3.2 - Encefalomioneuropatia relacionada a FDX2 …..................................150

6.4 - Painel de genes, exoma clínico e exoma completo.......................................152

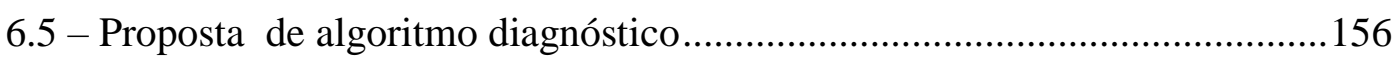

6.5.1 - Quando suspeitar de uma LD/LG genética:.......................................158

6.5.2 - Excluir doenças adquiridas: ........................................................... 158

6.5.3 - Rever história familiar: ................................................................ 160

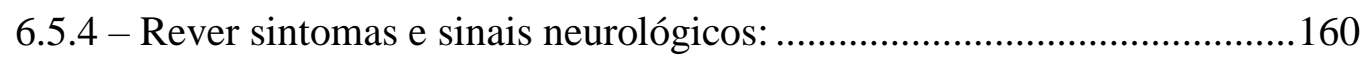

6.5.5 - Rever achados extra-neurológicos: .................................................... 161

6.5.6 - Rever achados neurorradiológicos: ....................................................161

6.6.7 - Investigação metabólica ou genética: ................................................162

7 CONCLUS ÕES ....................................................................................................163

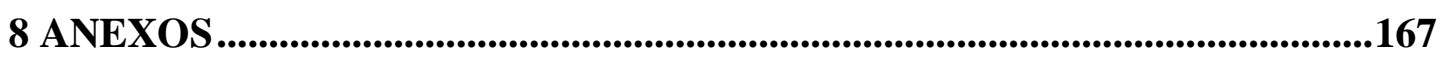

9 REFERÊNCIAS ......................................................................................179

10 APÊNDICES ..........................................................................................211

10.1 Apêndice A - Aprovação da Comissão de Ética para Análise de Projetos de Pesquisa da Faculdade de Medicina da Universidade de São Paulo

10.2 Apêndice B - Termo de Consentimento Livre e Esclarecido

10.3 Apêndice $\mathrm{C}$ - Endereços eletrônicos dos artigos científicos relacionados a esta tese publicados em revistas indexadas

10.4 Apêndice D - Imaging of adult leukodystrophies. Arq Neuropsiquiatr 2014

10.5 Apêndice E - Leukodystrophy with premature ovarian failure: think on white matter disease. Arq Neuropsiquiatr 2015

10.6 Apêndice F - A novel GFAP mutation in a type II (late-onset) Alexander disease patient. J Neurol 2016

10.7 Apêndice G - Clinical and genetic characterization of leukoencephalopathies in adults. Brain 2017

10.8 Apêndice $\mathrm{H}$ - When multiple sclerosis and X-linked adrenoleukodystrophy are tangled. Neurol Clin Pract 2018

10.9 Apêndice I- Typical clinical and neuroimaging features in SjögrenLarsson syndrome. Arq Neuropsiquiatr 2018

10.10 Apêndice J - A novel complex neurological phenotype due to a homozygous mutation in FDX2. Brain 2018

10.11 Apêndice K - Practical approach to the diagnosis of adult-onset leukodystrophies: an updated guide in the genomic era. J Neurol Neurosurg Psychiatry 2019 
10.12 Apêndice L - Adult Leukodystrophies: A Step-by-Step Diagnostic Approach. Radiographics 2019

10.13 Apêndice M - PUS3 mutations are associated with intellectual disability, leukoencephalopathy, and nephropathy. Neurol Genet 2019 


\section{Listas}

\section{ABREVIATURAS E SIGLAS}

$4 \mathrm{H}$

"Hypomyelination with hypogonadotrophic hypogonadism and hypodontia" - Hipomielinização com hipogonadismo hipogonadotrófico e hipodontia

ADC "Apparent diffusion coeficiente" - coeficiente de difusão aparente

ADLD "Autosomal Dominant adult-onset Demyelinating Leukodystrophy" - Leucodistrofia autossômica dominante desmielinizante do adulto

ALD-X Adrenoleucodistrofia ligada ao $\mathrm{X}$

ALD/AMN-X Adrenoleucodistrofia/adrenomieloneuropatia ligada ao X

AGCML Ácidos graxos de cadeia muito longa

AMN-X Adrenomieloneuropatia ligada ao X

Array-CGH "Array comparative genomic hibridization" - hibridização comparativa com genomas em arranjos

cADL-X Adrenoleucodistrofia ligada ao $\mathrm{X}$ - forma cerebral

CAPPesq Comissão de ética para análise de projetos de pesquisa

CARASAL "Cathepsin-A Related Arteriopathy with Strokes And Leukoencephalopathy" - Arteriopatia com acidentes vasculares e leucoencefalopatia relacionada à catepsina $\mathrm{A}$

CARASIL "Cerebral Autosomal Recessive Arteriopathy with Subcortical Infarcts and Leukoencephalopathy" - Arteriopatia cerebral autossômica recessiva com infartos subcorticais e leucoencefalopatia

CADASIL "Cerebral Autosomal Dominant Arteriopathy with Subcortical Infarcts and Leukoencephalopathy" - Arteriopatia cerebral autossômica dominante com infartos subcorticais e leucoencefalopatia

CNV "Copy number variation" - variação no número de cópias

COX "Cytochromo c oxidase"

CPK Creatinofosfoquinase

DFT Degeneração Fronto-Temporal

DI Deficiência intelectual 
DNA Ácido desoxirribonucleico

DWI "Diffusion-weighted imaging" - imagem pesada em difusão

EDSS "Expanded Disability Status Scale" - Escala do status de incapacidade expandida

EEG Eletroencefalograma

EM Esclerose Múltipla

ENMG Eletroneuromiografia

ExAC "Exome Aggregation Consortium"

FAD Flavina Adenina Dinucleotideo

FLAIR "Fluid attenuated inversion recovery"

FOV "Field of view"

FSPGR "Fast spoiled gradient echo"

FXTAS "Fragile X Tremor/Ataxia Syndrome" - Síndrome tremor-ataxia ligada ao $\mathrm{X}$

GTP Guanosine-trifosfato

$\mathrm{H}-\mathrm{ABC}$ "Hypomyelination with atrophy of the basal ganglia and cerebellum" - Hipomielinização com atrofia de gânglios da base e cerebelo

HC-FMUSP Hospital das Clínicas da Faculdade de Medicina da Universidade de São Paulo

HDLS "Hereditary Diffuse Leukoencephalopathy with Spheroids" Leucoencefalopatia difusa hereditária com esferoides

HGMD "Human Gene Mutation Database"

$\mathrm{HH}$

Hipogonadismo hipogonadotrófico

HLD "Hypomyelinating leukodystrophy" - leucodistrofia hipomielinizante

HSP "Hereditary spastic paraplegia" - paraplegia espástica hereditária

L2HGA "L-2-Hydroxyglutaric Aciduria" - Acidúria L2-hidroxiglutárica

LBSL

"Leukoencephalopathy with Brainstem and Spinal cord involvement and Lactate elevation" - Leucoencefalopatia com acometimento de tronco encefálico e medula espinhal e elevação de lactato

LCR Líquido cefalorraquiano

LD Leucodistrofias

LEMP Leucoencefalopatia multifocal progressiva

LG Leucoencefalopatias genéticas 
LTBL "Leukoencephalopathy with thalamus and brainstem involvement and high lactate" - Leucoencefalopatia com acometimento de tálamo e tronco encefálico e elevação de lactato

MEEM Miniexame do estado mental

MNGIE "Mitochondrial Neuro Gastrointestinal Encephalopathy" Encefalopatia mitocondrial neurogastrointestinal

mtDNA DNA mitocondrial

NAA N-acetilaspartato

NGS

"Next-generation sequencing" - sequenciamento de nova geração

OMIM "Online mendelian inheritance in man"

PCR

PMD

"Polymerase chain reaction" - reação da polimerase em cadeia

"Pelizaeus-Merzbacher Disease" - Doença de PelizaeusMerzbacher

RM Ressonância Magnética

RNA Ácido ribonucléico

RNAm RNA mensageiro

RNAr RNA ribossomal

RNAt RNA transportador

SDH Succinato desidrogenase

SNC Sistema Nervoso Central

SNP Sistema Nervoso Periférico

SPG "Spastic paraplegia" - paraplegia espástica

TE Tempo de eco

TI Tempo de inversão

TR Tempo de repetição

TSE "Turbo spin-echo"

UCL "University College London"

UFMG Universidade Federal de Minas Gerais

VWM "Vanishing Whitte Matter Disease" - doença da substância branca evanescente

WES "Whole-exome sequencing" - sequenciamento completo do exoma

WGS "Whole-genome sequencing" - sequenciamento completo do genoma

XCT Xantomatose Cerebrotendínea 


\section{FIGURAS}

Figura 1 - Manifestações extra-neurológicas ................................................... 27

Figura 2 - Achados adicionais de neuroimagem .............................................. 32

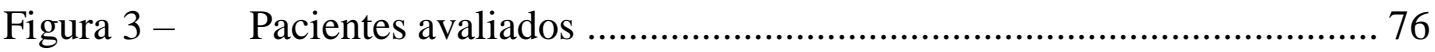

Figura $4-\quad$ Frequência dos diagnósticos entre os 31 probandos ……….............. 78

Figura 5 - $\quad$ Padrões de herança genética das doenças diagnosticadas .................. 79

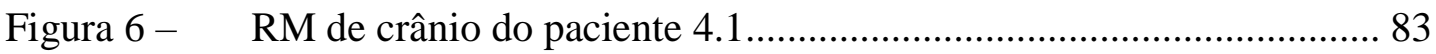

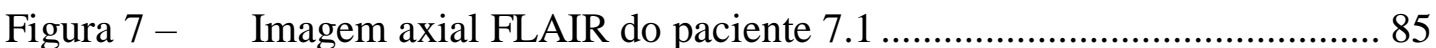

Figura 8- Paciente 1.2 com ALD-X de apresentação assimétrica relacionada a trauma em região parietal direita .................................. 86

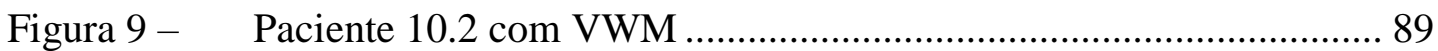

Figura 10 - Paciente 14.1 com diagnóstico de L2HGA ....................................... 93

Figura 11 - Paciente 15.1 com diagnóstico de L2HGA …..................................... 94

Figura 12 - Paciente 17.1 com diagnóstico de HDLS ......................................... 96

Figura 13 - Paciente 18.1 com diagnóstico de HDLS .......................................... 97

Figura 14 - Axial FLAIR do paciente 20.1 diagnosticado com CADASIL.......... 99

Figura 15 - Imagens do paciente com diagnóstico de ADLD ............................ 102

Figura 16 - Paciente com diagnóstico de doença de Alexander do adulto .......... 104

Figura 17 - Paciente com diagnóstico de síndrome de Gordon-Holmes.............. 107

Figura 18 - Paciente com diagnóstico de LBSL ............................................... 109

Figura 19 - Paciente com diagnóstico de doença relacionada ao PLP1.............. 111

Figura 20 - Paciente com síndrome de Sjögren-Larsson em fase avançada ....... 113

Figura 21 - Pacientes com deficiência intelectual relacionada a PUS3 ............. 117

Figura 22 - RM de crânio da paciente 22.2 com diagnóstico de deficiência intelectual relacionada a PUS3 ....................................................... 118

Figura 23 - Eletroferogramas do sequenciamento Sanger de PUS3 ................. 119 
Figura 24 - Heredograma dos pacientes com diagnóstico de doença relacionada ao FDX2 .......................................................... 120

Figura 25 - RM de crânio de pacientes com diagnóstico de doença relacionada a FDX2 ................................................................ 124

Figura 26 - Biópsia de músculo dos pacientes 12.1 e 12.4 ................................ 127

Figura 27 - Possível história natural da doença relacionada a FDX2 ................ 129

Figura 28 - Fluxograma de abordagem diagnóstica de pacientes com suspeita de leucodistrofia ou leucoencefalopatia genética ............... 157 
TABELAS

Tabela 1 - Caracterização clínica …................................................................. 170

Tabela 2 - Caracterização genética............................................................... 174

Tabela 3 - Caracterização neurorradiológica................................................... 176 


\section{QUADROS}

Quadro 1 - Doenças classificadas como leucodistrofias ..................................... 16

Quadro 2 - Achados neurológicos de maior valor diagnóstico ............................. 24

Quadro 3 - Padrão de herança das principais leucodistrofias e leucoencefalopatias genéticas

Quadro 4 - Achados extra-neurológicos de maior valor diagnóstico em pacientes com leucodistrofia ou leucoencefalopatia genética

Quadro 5 - Padrão de lesões vistas na neuroimagem das principais leucodistrofias e leucoencefalopatias genéticas

Quadro 6 - Achados adicionais de neuroimagem com maior valor diagnóstico

Quadro 7 - Avaliação laboratorial em três etapas............................................... 67

Quadro 8 - Resultados da $1^{\mathrm{a}}$ etapa de avaliação ................................................. 79

Quadro 9 - Resultados das $2^{\mathrm{a}}$ e $3^{\mathrm{a}}$ etapas de avaliação ........................................ 80 


\section{Resumo}

Paiva ARB. Leucodistrofias e leucoencefalopatias genéticas em adultos: caracterização clínica, molecular e de neuroimagem [tese]. São Paulo: Faculdade de Medicina, Universidade de São Paulo; 2019.

As leucodistrofias e as leucoencefalopatias genéticas constituem um grupo heterogêneo de doenças raras que afetam preferencialmente a substância branca encefálica, sendo mais comuns na infância. Possuem amplo espectro fenotípico, com manifestações clínicas muitas vezes inespecíficas, mais comumente sintomas neuropsiquiátricos e acometimento de tratos longos. Os achados de neuroimagem são igualmente muito heterogêneos, mas tendem a ser consistentes para cada doença individualmente, por vezes permitindo precisa correlação fenotípica-genotípica. $O$ uso crescente das técnicas de sequenciamento de nova geração têm possibilitado a identificação das bases genéticas de muitas destas doenças e a descrição de novas entidades, principalmente na faixa etária pediátrica. Já são mais de 60 genes associados a este grupo de doenças, adicionando complexidade à abordagem destes pacientes. No entanto, ainda se conhece pouco a respeito dos fenótipos e genótipos de pacientes adultos com leucodistrofia ou leucoencefalopatia genética. O objetivo do presente estudo foi descrever aspectos clínicos, neurorradiológicos e genéticos de pacientes adultos com leucodistrofia ou leucoencefalopatia genética. Foi realizado um estudo clínico retrospectivo e parcialmente prospectivo dos pacientes em acompanhamento no nosso serviço de neurogenética. Todas as 31 famílias (38 pacientes) incluídas foram submetidas a avaliação clínica e neurorradiológica. Exames neurofisiológicos foram realizados de acordo com a apresentação clínica. Exames diagnósticos bioquímicos ou genéticos foram solicitados em três etapas sequenciais. Na primeira etapa, após avaliação clínica e de neuroimagem, os pacientes foram submetidos a avaliação bioquímica ou teste genético específico conforme a hipótese diagnóstica. Nesta etapa 13 probandos obtiveram diagnóstico definitivo - sete com adrenoleucodistrofia/adrenomieloneuropatia ligada ao X, três com acidúria L2-hidroxiglutárica, um com leucodistrofia autossômica dominante do adulto, um com doença de Alexander e um com síndrome de Sjögren-Larsson. Na segunda etapa, os pacientes foram submetidos a avaliação por sequenciamento do exoma clínico. Nesta etapa, mais 13 probandos obtiveram diagnóstico: quatro com doença de substância branca evanescente, três com CADASIL, três com leucoencefalopatia difusa hereditária com esferoides, um com leucoencefalopatia com acometimento de tronco encefálico e medula espinhal e elevação de lactato, um com a síndrome de Gordon-Holmes e um com a doença relacionada a PLP1. Na terceira etapa, os probandos sem diagnóstico foram submetidos a avaliação por sequenciamento completo do exoma e mais dois probandos obtiveram diagnóstico. Uma família foi diagnóstica com deficiência intelectual relacionada a PUS3, uma condição extremamente rara que cursa com deficiência intelectual sindrômica, leucoencefalopatia e, em nossas pacientes, nefropatia, que não havia sido previamente descrita. A outra família apresentou um fenótipo totalmente novo associado a $F D X 2$. Os pacientes apresentavam atrofia óptica congênita, miopatia mitocondrial, polineuropatia periférica axonal e leucoencefalopatia reversível. Após as três etapas, 28 dentre 31 probandos $(90 \%)$ obtiveram diagnóstico definitivo e três probandos continuaram sem diagnóstico definitivo. Concluímos que o quadro clínico e neurorradiológico das leucodistrofias e leucoencefalopatias genéticas em adultos é muito heterogêneo e depende da etiologia subjacente. A avaliação clínica e neurorradiológica minuciosas associadas a avaliação genética não enviesada, seja por sequenciamento do exoma clínico, seja por sequenciamento completo do exoma, foi determinante para o diagnóstico correto na maioria dos pacientes.

Descritores: Leucoencefalopatias; Adrenoleucodistrofia; CADASIL; Genética; Neuroimagem; Doença de Pelizaeus-Merzbacher. 


\section{Abstract}

Paiva ARB. Leukodystrophies and genetic leukoencephalopathies in adults: clinical, genetic and neuroimaging characterization [thesis]. São Paulo: "Faculdade de Medicina, Universidade de São Paulo"; 2019.

Leukodystrophies and genetic leukoencephalopathies are a heterogeneous group of rare disorders that affect predominantly the cerebral white matter. They are more common in children and have a wide phenotypic spectrum with non-specific clinical features dominated by neuropsychiatric manifestations and long-tract symptoms. The neuroimaging findings are highly heterogeneous, but commonly have the same features for the same disorders, allowing precise phenotypic-genotypic correlation. As next-generation sequencing techniques become widely used, the genetic basis of a great number of these disorders has been established, as new disorders have been identified, especially in the pediatric population. At least 60 genes have been associated to these disorders, adding complexity to the diagnostic approach of such patients. However, little is known about the phenotypes and the genotypes of adult patients with leukodystrophies and genetic leukoencephalopathies. The aim of the present study was to describe clinical, neuroradiological and genetic aspects of adult patients with leukodystrophy or genetic leukoencephalopathy. A retrospective and partially prospective clinical study was conducted in our neurogenetics service. All 31 families included (38 patients) were clinically and neuroradiologically evaluated. Neurophysiological studies were performed as needed. Biochemical or genetic diagnostic tests were ordered in three sequential steps. On the first step, based on the clinical and neuroradiological presentations, biochemical or single-gene test were ordered according to the diagnostic hypothesis. On this step, 13 probands had a definitive diagnosis - seven with X-linked adrenoleukodystrophy/ adrenomyeloneuropathy, three with L2-hydroxyglutaric aciduria, one with autosomal dominant adult-onset demyelinating leukodystrophy, one with Alexander disease ando ne with Sjögren-Larsson syndrome. On the second step, patients were evaluated by focused exome sequencing and 13 patients were diagnosed: four with vanishing white matter disease, three with CADASIL, three with hereditary diffuse leukoencephalopathy with spheroids, one with leukoencephalopathy with brainstem and spinal cord involvement and lactate elevation, one with Gordon-Holmes syndrome and ne with $P L P 1$-related disorder. On the third step, the probands without diagnosis were evaluated by whole-exome sequencing and two had a definitive diagnosis. One family was diagnosed with PUS3-related intellectual deficiency, an extremely rare condition that causes syndromic intellectual deficiency, leukoencepahlopathy and, in our patients, nephropathy, something that was not previously described in this condition. The other family presented a totally new phenotype associated with $F D X 2$. The patients presented congenital optic atrophy, mitochondrial myopathy, axonal peripheral polyneuropathy and reversible leukoencephalopathy. After the three steps, 28 out of 31 probands (90\%) had a definitive diagnosis and three probands, remained undiagnosed. We concluded that the clinical and neuroradiological picture of adult patients with leukodystrophies and genetic leukoencephalopathies are highly heterogeneous and depends on the specific etiology. Careful clinical and neuroradiological evaluations associated with a nonbiased genetic test - focused exome sequencing or whole-exome sequencing -, can define the correct diagnosis in a great proportion of patients.

Descriptors: Leukoencephalopathies; Adrenoleukodystrophy; CADASIL; Genetics; Neuroimaging; Pelizaeus-Merzbacher Disease. 


\section{Introdução}





\section{INTRODUÇÃO}

As leucoencefalopatias constituem um grupo heterogêneo de doenças que afetam preferencialmente a substância branca encefálica. É comum que o neurologista encontre pacientes com hipersinal da substância branca nas sequências ponderadas em T2 e FLAIR nos exames de ressonância magnética (RM) do encéfalo, sendo este na maioria das vezes secundário a doenças adquiridas de etiologia inflamatória, infecciosa, vascular, tóxica, metabólica ou neoplásica (Renaud, 2016; Ahmed et al., 2014). O termo leucodistrofia é historicamente usado para indicar as doenças da substância branca de origem genética, indicando um grupo extremamente variado de doenças frouxamente agrupados por apresentarem em comum marcado acometimento da substância branca.

Em 2015, Vanderver et al. definiram pela primeira vez de forma mais precisa o termo leucodistrofia e cunharam a expressão leucoencefalopatia genética. Assim, leucodistrofias (LD) seriam doenças hereditárias com acometimento primário da substância branca do sistema nervoso central, com ou sem comprometimento do sistema nervoso periférico, que têm em comum alterações de células da glia ou da bainha de mielina. Já as leucoencefalopatias genéticas (LG) seriam as doenças hereditárias da substância branca que não preenchem critérios para serem classificadas como LD e são decorrentes de comprometimento primário neuronal, vascular ou sistêmico.

As LD/LG são mais comuns na infância e, em menor proporção, na adolescência, sendo o acometimento em adultos considerado raro. No entanto, o uso disseminado da ressonância magnética e, mais recentemente, o crescente emprego das técnicas de sequenciamento de nova geração ("next-generation sequencing" NGS) possibilitaram a identificação em adultos das mesmas doenças descritas na infância, embora com fenótipo muitas vezes diferente (Leite et al., 2014). Também têm sido identificadas novas LD/LG de surgimento exclusivo na idade adulta (Di Donato et al., 2014).

As manifestações neurológicas, tanto em adultos como em crianças, são muitas vezes inespecíficas, por acometimento de tratos longos, sendo as LD/LG 
raramente consideradas no diagnóstico diferencial antes da realização da RM de encéfalo. Os pacientes adultos apresentam mais comumente alterações cognitivas e/ou comportamentais, associadas ou não a acometimento motor do tipo paraparesia espástica e/ou ataxia progressivas (Labauge et al., 2014). Em crianças, por sua vez, costumam predominar as manifestações motoras.

Os padrões de herança genética podem ajudar a orientar as hipóteses diagnósticas, sendo todos os padrões passíveis de serem encontrados (formas autossômicas recessivas, autossômicas dominantes com graus variados de expressividade e penetrância, ligadas ao X, e mitocondriais) (Parikh et al., 2015). Salienta-se que em adultos há um número relevante de casos esporádicos e formas autossômicas dominantes, ao contrário de crianças, nas quais predominam as formas autossômicas recessivas (Di Donato et al., 2014). Ainda assim, pode não haver história familiar, pois existem formas de penetrância incompleta e apresentações decorrentes de evento mutacional de novo.

As manifestações extra-neurológicas também podem ajudar a limitar as hipóteses diagnósticas. Em adultos, são particularmente úteis as informações sobre insuficiência adrenal (presente na adrenoleucodistrofia/adrenomieloneuropatia ligada ao X (ALD/AMN-X)), menopausa precoce (presente na doença da substância branca evanescente - "vanishing white matter disease (VWM)"-e na leucoencefalopatia progressiva com falência ovariana relacionada a AARS2 - Lynch et al., 2016), hipogonadismo hipogonadotrófico (HH) (como ocorre na síndrome de GordonHolmes - Margolin et al., 2013), xantomas tendinosos (na xantomatose cerebrotendínea - XCT) e sintomas gastrointestinais (diarreia em pacientes com XCT e encefalopatia mitocondrial neurogastrointestinal (MNGIE) - Parikh et al., 2015).

Como regra geral, suspeita-se de uma LD/LG quando se está frente a um paciente com doença de curso crônico e acometimento de substância branca de distribuição bilateral, simétrico ou confluente em imagens de RM de encéfalo seriadas (Renaud, 2016). No entanto, esta sugestão neurorradiológica tem dois problemas: as exceções são comuns e este padrão também pode ocorrer em quadros tóxicos, metabólicos ou estágios avançados de qualquer outra etiologia. Lesões assimétricas, com captação de gadolínio e evolução rápida falam a favor de doenças 
adquiridas (Labauge et al., 2014), mas também existem etiologias genéticas que podem apresentar estas mesmas características.

Ressalta-se que embora os achados de RM possam ser muito heterogêneos nas diversas LD/LG, estes achados tendem a ser consistentes para cada doença, muitas vezes permitindo a identificação das mesmas a partir da imagem. Assim, ficou clara a necessidade de uma abordagem sistemática dos exames de RM para orientar a investigação destes casos. O trabalho de Schiffmann e van der Knaap de 2009 pode ser apontado como o mais abrangente e prático para uma abordagem inicial, incluindo dentre os diagnósticos diferenciais as doenças adquiridas e separando as doenças de substância branca inicialmente em 2 grandes grupos, hipomielinizantes versus as demais (desmielinizantes). No entanto, tal abordagem precisou ser refinada, principalmente para abordagem de casos suspeitos de LD/LG em adultos, o que foi feito por Labauge et al. (2014) e Ayrignac et al. (2015). Estes autores separaram as LD/LG em 3 grandes grupos: LG vasculares, LD/LG cavitantes e LD/LG não-vasculares, não-cavitantes. A identificação de achados específicos, como acometimento de tronco encefálico em alguns tratos específicos ou de medula espinhal e a presença de calcificações e/ou cistos podem ajudar ainda mais a direcionar o diagnóstico (Vanderver et al., 2015).

O diagnóstico definitivo pode ser obtido por meio de testes bioquímicos, como a dosagem dos ácidos graxos de cadeia muito longa (AGCML) no sangue de pacientes com suspeita de ALD/AMN-X, ou por meio de testes genéticos, como a pesquisa de variante patogênica em $A B C D 1$ em casos de ALD/AMN-X. Nos casos em que a clínica ou a imagem são muito sugestivos, como por exemplo na doença do Alexander do adulto ou leucoencefalopatia com acometimento de tronco encefálico e medula espinhal e elevação de lactato ("leukoencephalopathy with brainstem and spinal cord involvement and lactate elevation”- LBSL), a pesquisa de um único gene pode ser custo-efetiva. No entanto, existem cerca de 60 genes implicados em LD/LG e muitas vezes não é possível apontar um único gene candidato a partir dos achados clínicos (Parikh et al., 2015).

Neste contexto, técnicas de NGS vêm mostrando melhor relação custobenefício e têm ampliado rapidamente o nosso conhecimento sobre as LD/LG particularmente nas formas de início precoce (Vanderver et al., 2016 e Lynch et al., 
2017) e também apresentações atípicas. No entanto, conhece-se menos a respeito das apresentações clínicas e bases genéticas das formas do adulto. Estes são frequentemente diagnosticados como esclerose múltipla atípica ou doença neurodegenerativa de início precoce (Sundal et al., 2012).

Nesta tese revisamos a abordagem diagnóstica e caracterização clínica, de imagem e genética de pacientes adultos com LD/LG, bem como apresentamos uma breve revisão sobre as principais LD/LG diagnosticadas em adultos. Nossa casuística consistiu de pacientes atendidos no Ambulatório de Neurogenética do Hospital das Clínicas da Faculdade de Medicina da Universidade de São Paulo (HC-FMUSP) com hipótese diagnóstica de LD/LG entre os anos de 2012 e 2016. Descrevemos o espectro de manifestações clínicas, neurorradiológicas e, sempre que possível, genéticas. 
2 Objetivos

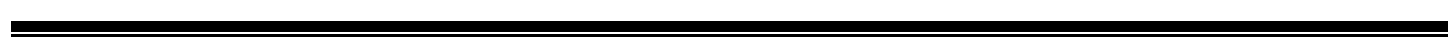





\section{OBJETIVOS}

\subsection{Objetivo principal}

Descrever os seguintes aspectos de pacientes adultos portadores de LD/LG:

- clínicos

- neurorradiológicos

- genéticos

\subsection{Objetivos secundários}

Identificar as características de:

- exame físico geral

- exame neurológico

- exames laboratoriais

- exames neurofisiológicos

- exames neurorradiológicos

que possam contribuir para a identificação da etiologia das LD/LG;

Avaliar o impacto da investigação genética na definição diagnóstica;

Estabelecer correlações genótipo-fenótipo. 



\section{Revisão da Literatura}





\section{REVISÃO DA LITERATURA}

\subsection{Leucodistrofias e leucoencefalopatias genéticas}

\subsubsection{Definições}

Muitas são as doenças que afetam exclusiva ou predominantemente a substância branca, e múltiplas são suas origens - vascular, inflamatória, tóxica, metabólica, infecciosa, neoplásica ou genética. Também muitos termos já foram usados para descrever estas doenças, por vezes pobremente definidos ou com sobreposição de significados, adicionando complexidade ao estudo do tema (van der Knaap et al., 2005a).

Dentre estes termos, destacamos os seguintes: leucoencefalopatias, leucodistrofias, desmielinização, dismielinização e hipomielinização.

\subsubsection{Leucoencefalopatia versus leucodistrofia}

O termo leucoencefalopatia refere-se etimologicamente a doenças da substância branca de uma forma genérica, sem inferências sobre a etiologia subjacente, como sinônimo de "doenças da substância branca" e assim será usado neste texto.

Já o termo leucodistrofia carece de uma definição perfeita e universalmente aceita, sendo as definições propostas até hoje influenciadas pelo conhecimento disponível à época em que foram formuladas. Há grande debate na literatura sobre qual seria a melhor definição, sendo as duas mais atuais as propostas por "GLIA Consortium" (Vanderver et al. (2015)) e por Kevelam et al. (2016).

O grupo chamado "GLIA Consortium" definiu pela primeira vez de forma consensual o termo leucodistrofia, adotando o critério neuropatológico. Para este grupo, leucodistrofias são doenças hereditárias que afetam a substância branca do sistema nervoso central, com ou sem acometimento do sistema nervoso periférico e que possuem em comum alterações das células da glia ou da bainha de mielina. 
No mesmo artigo definiram também leucoencefalopatia genética como: “distúrbio hereditário que resulta em anormalidades da substância branca, mas que não preenche necessariamente critérios estritos para leucodistrofias”. São doenças com envolvimento neuronal primário ou manifestações sistêmicas proeminentes. Assim, toda leucodistrofia é também uma leucoencefalopatia genética, mas nem toda leucoencefalopatia genética é uma leucodistrofia.

Uma tentativa de classificar as doenças da substância branca hereditárias já conhecidas foi feita, e duas listas foram apresentadas por Vanderver et al. (2015) uma de leucodistrofias e uma de leucoencefalopatias genéticas.

As definições apresentadas pelo "GLIA Consortium” permitem que doenças novas sejam classificadas prospectivamente e as já conhecidas eventualmente reclassificadas conforme o entendimento das mesmas aumente.

Em editorial que acompanha o referido artigo, Salsano (2015) começa citando Aristóteles - natura non facit saltus ("a natureza não dá saltos”) - para nos lembrar de como é difícil a elaboração de classificações e faz algumas observações críticas.

Por exemplo, a hipomielinização com atrofia de gânglios da base e cerebelo ("hypomyelination with atrophy of the basal ganglia and cerebellum" - H-ABC , relacionada a $T U B B 4 A$ ) é apresentada como leucodistrofia, embora não existam até o momento estudos neuropatológicos desta doença e seu gene se expresse predominantemente em neurônios. Também a XCT é apresentada como leucodistrofia, embora saibamos tratar-se de uma doença sistêmica.

Cerca de um ano após a publicação destas definições, Kevelam et al. (2016), questionam o foco sobre a mielina como critério central da definição de leucodistrofia. À luz dos novos conhecimentos, tal foco não se justificaria e argumenta com alguns exemplos: novamente a leucodistrofia $\mathrm{H}-\mathrm{ABC}$, que se deve a um defeito na produção de microtúbulos e leva a uma axonopatia com perda secundária de mielina; o gene $C S F 1 R$ codifica fator de crescimento específico para micróglia, macrófago e monócito, mas quando mutado leva ao fenótipo de leucoencefalopatia com esferoides axonais e glia pigmentada ("hereditary diffuse leukoencephalopathy with spheroids" - HDLS), com achados anátomo-patológicos de axonopatia. 
Assim, para Kevelam et al. (2016), leucodistrofias são "doenças geneticamente determinadas que afetam primariamente a substância branca do sistema nervoso central, independentemente do componente estrutural envolvido, do processo molecular afetado ou do curso da doença." Tal definição foi ratificada por van der Knaap e Bugiani em 2017, em artigo de revisão.

Chamamos a atenção ainda para a questão do curso da doença. Historicamente, as leucodistrofias foram entendidas como doenças de curso crônico e progressivo, mas na verdade existem casos de evolução estática (como a acidúria L2-hidroxiglutárica - L2HGA) e até de melhora da doença após uma manifestação inicial (em geral na infância). Como exemplos destas citamos a leucoencefalopatia megalencefálica com cistos subcorticais, a leucoencefalopatia com acometimento de tálamo e tronco encefálico e elevação de lactato ("leukoencephalopathy with thalamus and brainstem involvement and high lactate" - LTBL) e a doença relacionada ao $F D X 2$, que descreveremos em detalhes nesta tese. Este aspecto temporal foi observado pelo "GLIA Consortium”, que não considera mais o curso da doença na sua definição de leucodistrofia.

Todos os autores citados aqui são unânimes em reconhecer que as definições de leucodistrofia são necessariamente imperfeitas e deverão ser continuamente aprimoradas. Nesta tese usaremos sempre que possível as definições propostas pelo "GLIA Consortium", pois vem sendo a preferida nas publicações que a sucederam e nos parece a mais apropriada do ponto de vista etimológico.

No entanto, como bem notou Salsano (2015), estamos mudando as classificações basedas em termos clínicos (como distonias (DYTs), ataxias espinocerebelares (SCAs), paraplegias espásticas (SPGs)), ou bioquímicos (acidúria L2-hidroxiglutárica), ou patológicos (HDLS), por termos baseados em genética. Assim, como exemplo, coexistem na literatura atual os termos doença de PelizaeusMerzbacher (PMD) ou SPG2 ou leucodistrofia hipomielinizante 1 (HDL1) ou doenças relacionadas a PLP1 para se referir a um genótipo com vários fenótipos. Algumas áreas do conhecimento já começaram a reorganizar a sua nomenclatura para melhor incorporar a linguagem genética, como a nova classificação de neuropatias periféricas hereditárias (Mathis et al., 2015) e de distúrbios de movimento (Marras et al., 2016). 
Acreditamos que este possa vir a ser o caminho adotado para o estudo das LD/LG nos próximos anos (Fussiger et al, 2017).

No Quadro 1 listamos as doenças que consensualmente foram classificadas como leucodistrofias, segundo Vanderver et al. (2015). As doenças que não constam no quadro se encaixam melhor na definição de leucoencefalopatia genética.

Quadro 1 - Doenças classificadas como leucodistrofias

Adrenoleucodistrofia/adrenomieloneuropatia ligada ao $\mathrm{X}$

Displasia oculodentodigital

Doença da substância branca evanescente

Doença de Alexander

Doença de Canavan

Doença de Krabbe

Doença de Pelizaeus-Merzbacher

Doença de Pelizaeus-Merzbacher-like

Doença por corpos de poliglicosanos

Doença relacionada a SOX10

Doenças da biogênese peroxissomal

Doenças do armazenamento de ácido siálico

Fucosidose

Hipomielinização com acometimento de tronco encefálico e medula espinhal e espasticidade em pernas

Hipomielinização com atrofia de gânglios da base e cerebelo (H-ABC)

Hipomielinização com catarata congênita

Leucodistrofia autossômica dominante desmielinizante do adulto

Leucodistrofia metacromática

Leucoencefalopatia com acometimento de tálamo e tronco encefálico e elevação de lactato

Leucoencefalopatia com acometimento de tronco encefálico e medula espinhal e elevação de lactato

Leucoencefalopatia com edema intramielínico relacionada a ClC-2

Leucoencefalopatia difusa hereditária com esferoides (HDLS)

Leucoencefalopatia megalencefálica com cistos subcorticais

Leucoencefalopatia por deficiência de RNAse T2

Síndrome 18q-

Síndrome 4H (hipomielinização, hipodontia, hipogonadismo hipogonadotrófico) - doença relacionada a Pol-III

Síndrome de Aicardi-Goutières

Síndrome de Sjögren-Larsson

Xantomatose cerebrotendínea

Fonte: adaptado de Vanderver et al., 2015 


\subsubsection{Desmielinização versus dismielinização}

Os termos desmielinização e dismielinização também podem ser confundidos e aqui adotaremos as definições propostas por van der Knaap et al. em 2005a.

A desmielinização é o processo de perda da mielina por acometimento primário e seletivo das células da glia ou da bainha de mielina propriamente dita. Assim, esclerose múltipla e leucodistrofia metacromática, por exemplo, são doenças que causam desmielinização.

Já dismielinização refere-se ao processo que leva a formação de uma bainha de mielina anormal, podendo ser acompanhanda ou não de perda de mielina, tal como ocorre na fenilcetonúria.

\subsubsection{Hipomielinização}

Por fim, hipomielinização refere-se à redução da produção de mielina com consequente déficit permanente de sua constituição. É um sinal radiológico extremamente útil, pois permite reduzir sobremaneira a lista de genes a serem testados.

As doenças classicamente descritas como leucodistrofias hipomielinizantes da infância são a PMD, doença de Pelizaeus-Merzbacher símile, a síndrome 18q- e a doença de Cockayne, sendo que as duas primeiras já foram descritas em adultos (Cailloux et al., 2000; Orthman-Murphy et al., 2009). Os outros genes já relacionados a leucodistrofia hipomielinizante com casos em adultos são: TUBB4A, POLR3A, POLR3B, CLCN2 e NKX6-2 - todos serão comentados na seção 3.3.10 Doenças Hipomielinizantes.

\subsubsection{Idade de início}

Um outro fator que adiciona complexidade ao estudo das LD/LG em adultos é a idade de início dos sintomas, pois temos os seguintes cenários possíveis:

- pacientes em que os primeiros sintomas surgiram na idade adulta;

- pacientes em que os primeiros sintomas surgiram na infância e persistiram na idade adulta; 
- pacientes em que os primeiros sintomas surgiram na infância e melhoraram ao longo do desenvolvimento, podendo ter deixado sintomas residuais ou não.

Há que se considerar também a possível distinção entre início dos sintomas sistêmicos ou início dos sintomas neurológicos. Por exemplo, pacientes com XCT têm diarreia crônica de início na infância, mas os sintomas neurológicos podem surgir somente no fim da adolescência ou início da vida adulta.

Estas distinções não são feitas com frequência na literatura, sendo que a maioria dos trabalhos envolvendo pacientes adultos agrupam os cenários descritos acima.

Uma outra forma de abordar esta questão é a partir da genética, observando que já foram descritos genes que se expressam na infância, adolescência e vida adulta, genes que se expressam exclusivamente na vida adulta e genes que se expressam (até onde sabemos) somente na infância.

A maioria dos trabalhos define como adulto indivíduos maiores de 16 anos e aqui seguiremos esta convenção.

\subsubsection{Aspectos históricos}

As pesquisas sobre as doenças da substância branca começaram há cerca de 180 anos, com os primeiros estudos anátomo-patológicos. Podemos dividir didaticamente em três grandes períodos: a era da patologia (1830-1980), a era da neuroimagem (1980-2000), e a era da genética (2000-dias atuais).

Em 1838, o talentoso patologista e ilustrador escocês Robert Carswell publicou em seu atlas a primeira ilustração da doença hoje conhecida como esclerose múltipla (Kevelam et al., 2016). Este talvez possa ser considerado o marco zero dos estudos sobre as doenças da substância branca.

Em 1897, Otto Heubner descreveu uma doença neurológica rara em crianças cuja os aspectos histopatológicos eram de acometimento difuso da substância branca e marcado endurecimento da mesma. Passou-se então a adotar o termo "esclerose difusa" em oposição à esclerose múltipla. Em 1899 Pelizaeus e em 1910 Merzbacher 
descreveram o acometimento familiar da "esclerose difusa" (Heubner (1897) ${ }^{1}$ apud Kevelam et al. 2016; Pelizaeus (1899) ${ }^{2}$ apud Kevelam et al. 2016; Merzbacher $(1910)^{3}$ apud Kevelam et al 2016).

O termo leucodistrofia foi proposto pela primeira vez por Bielschowsky e Henneberg em 1928 para descrição da leucodistrofia metacromática e sugerido para a descrição de doenças hereditárias progressivas que afetam a substância branca (Bielschowsky e Henneberg ${ }^{4}$ apud van der Knaap e Bugiani, 2017). O termo provem do grego, "leuco"= branco, "dis"= falta de, e "trofia"= crescimento.

Foi somente em 1984 que Seitelberg definiu leucodistrofia como "um processo desmielinizante progressivo e crônico do sistema nervoso central, com características de distúrbio metabólico da manutenção da bainha de mielina. No que concerne a etiologia, a maioria é causada por elementos endógenos".

Também em 1984, Morell e Wiesmann definiram leucodistrofia como “distúrbios que afetam primariamente a oligodendroglia ou a mielina (...) de origem endógena, com padrão compatível com transferência genética de um defeito metabólico (...) com deterioração progressiva".

Interessante notar a adoção do critério anátomo-patológico centrado na mielina por estas definições. Ressalta-se que à época de tais definições o número de condições conhecidas era pequeno, suas bases bioquímicas pouco compreendidas e suas bases genéticas totalmente desconhecidas (van der Knaap e Bugiani, 2017). O diagnóstico era feito até então por achados bioquímicos ou anátomo-patológicos.

A década de 1980 foi particularmente importante para a história dos estudos sobre LD/LG, pois nela surgiram a ressonância magnética (RM) e os primeiros estudos genéticos de leucodistrofias.

A RM revolucionou o estudo das LD/LG. Foi possível verificar que pacientes que tinham o mesmo diagnóstico confirmado por testes bioquímicos, tinham o mesmo padrão de acometimento visível nas imagens de RM (Kevelam et al., 2016).

\footnotetext{
Heubner O. Ueber diffuse hirnsklerose. Charité-Ann 1897;22:298-310.

2 Pelizaeus F. Ueber eine eigenartige familiäre Entwicklungshemmung vornehmlich auf motorischem Gebiet. Arch Psychiatrie Nervenkr 1899;31:100-104.

3 Merzbacher L. Eine eigenartige familiär-hereditäre Erkrankungsform (aplasia axialis extracorticalis congenita). Z Gesamte Neurol Psychiatrie 1910;3:1-138.

4 Bielschowsky M, Henneberg R. Ueber familiare diffuse sklerose (Leukodystrophia cerebri progressive hereditária). J Psychol Neurol (Lpz) 1928;36:131-81.
} 
Assim se deu o início do reconhecimento de padrão de imagem de RM para o diagnóstico das LD/LG.

Na década de 1990 e início dos anos 2000, várias doenças foram descritas a partir de critérios de imagem, como, por exemplo: leucoencefalopatia megalencefálica com cistos subcorticais, VWM, H-ABC, LBSL, síndrome de hipomielinização, hipodontia e hipogonadismo hipogonadotrófico (síndrome 4H) e LTBL (van der Knaap et al., 1995; van der Knaap et al., 1997; van der Knaap et al., 2002a; van der Knaap et al., 2002b; Atrouni et al., 2003; Steenweg et al., 2012).

Os primeiros genes relacionados a $\mathrm{LD} / \mathrm{LG}$ foram identificados no final dos anos 1980 e início dos anos 1990, a saber: PLP1, ARSA, ASPA, ABCD1, GALC (Hudson et al., 1989; Polten et al., 1991; Kaul et al., 1993; Mosser et al., 1993; Sakai et al., 1994). Tais descobertas foram feitas a partir da abordagem de estudos de genes candidatos ou estudos de ligação.

Em 2001, as primeiras doenças definidas a partir da imagem por RM, tiveram suas bases genéticas estabelecidas: VWM foi relacionada a 5 genes (EIF2B1 a 5) e a leucoencefalopatia megalencefálica com cistos subcorticais foi relacionada a $M L C 1$.

Até então, os estudos genéticos necessários para a definição de uma nova doença (estudos de ligação) eram bastante trabalhosos, caros e dependentes de grande número de indivíduos afetados para a comprovação dos mesmos. Foi somente a partir de 2005, com a introdução da tecnologia de NGS que uma nova mudança de paradigma ocorreu na abordagem das doenças mendelianas raras ( $\mathrm{Ng}$ et al., 2009).

Em 2012, o uso do sequenciamento completo do exoma permitiu relacionar variantes patogênicas em CSF1R à HDLS (Rademakers et al, 2012). Esta foi a primeira leucodistrofia que teve sua base genética estabelecida por técnicas de NGS. Desde então, outros genes vêm sendo descobertos, dos quais podemos citar: EARS2, TUBB4A, RNF216, AARS2, etc. (Steenweg et al., 2012; Simons et al., 2013; Margolin et al., 2013; Dallabona et al., 2014).

A identificação e estudo de pacientes adultos com LD/LG foram bastante limitados até o início dos anos 2010, com apenas alguns relatos de casos e pequenas séries publicadas. Com o crescente uso das técnicas de NGS observamos a ampliação de fenótipos de genes previamente descritos em LD/LG da infância, muitas vezes com manifestações em adultos completamente diferentes das encontradas na 
infância. Não por acaso, houve um significativo aumento da literatura referente a estes casos nos últimos oito anos, com várias revisões de literatura sobre LD/LG em adultos já publicadas (Renaud 2012, 2016; Leite et al., 2014; Ahmed et al., 2014; Vanderver 2016b; Lynch et al., 2018).

\subsubsection{Epidemiologia}

Os dados epidemiológicos sobre LD e/ou LG são limitados e referem-se principalmente à faixa etária pediátrica (Vanderver et al., 2014).

Embora individualmente cada condição seja bastante rara, segundo Costello et al. (2009), em conjunto (LD/LG em crianças e adultos), sua prevalência pode se aproximar da prevalência da esclerose múltipla - atualmente estima-se que esta afeta 2,3 milhões de pessoas em todo o mundo (Jones, 2016). Se por um lado esta projeção pareça exagerada, por outro vale lembrar que o uso com maior liberalidade de métodos diagnósticos de neuroimagem e o uso mais intensivo do NGS possibilitarão a identificação de um número crescente de indivíduos.

Estimava-se que até $50 \%$ dos casos de LD/LG em adultos permaneciam sem diagnóstico definitivo, mesmo após extensa avaliação, embora esta realidade pareça estar começando a mudar (Renaud, 2012).

\subsection{Leucodistrofias e leucoencefalopatias genéticas em adultos}

\subsubsection{Importância}

O grupo das $\mathrm{LD} / \mathrm{LG}$ vem ganhando progressivo destaque na literatura neurológica na medida em que os testes genéticos têm possibilitado o maior reconhecimento destas doenças e a descrição de novas entidades.

No entanto, há ainda enormes lacunas na compreensão destes casos: qual é a prevalência e a incidência destas doenças? Por que as manifestações em adultos e crianças são muitas vezes tão diferentes? Quais as relações genotípicas-fenotípicas? Qual o espectro de fenótipos possíveis? Qual a melhor forma de abordagem diagnóstica? Qual a melhor forma de classificá-las? Estas são apenas algumas das 
perguntas para as quais ainda não temos respostas adequadas - nem mesmo para a população pediátrica.

Assim, o neurologista de adultos quando frente a um caso suspeito de LD/LG tem o enorme desafio de lidar com doenças raras, pouco compreendidas e para as quais há ainda poucos dados de literatura. Daí a importância de novos trabalhos nesta área.

\subsubsection{Classificação}

Não há consenso sobre a melhor forma de classificação das LD/LG em adultos. Muitas das classificações propostas não fazem distinção entre adultos e crianças, tornando confusa a abordagem de pacientes adultos a partir destas.

Alturkustani et al. (2013) foi o primeiro a propor uma classificação exclusiva para LD/LG de início no adulto, adotando critérios clínicos e patológicos. O primeiro passo seria excluir LD/LG clássicas da infância, que porventura estivessem se manifestando tardiamente. Sugere especificamente a pesquisa de ALD/AMN-X, doença de Krabbe, leucodistrofia metacromática, doença de Alexander e VWM.

O segundo passo seria a identificação de disautonomia precoce, sugerindo o diagnóstico de leucodistrofia autossômica dominante do adulto (ADLD) ligada a $L M N B 1$. Não havendo disautonomia, o próximo passo seria a análise patológica, útil para os diagnósticos de HDLS e doença de Nasu-Hakola (ligada a TYROBP (DAP12) ou TREM2).

Sem dúvida, a classificação proposta por Alturkustani é bastante incompleta e de difícil aplicação em sua totalidade, por requerer o uso da patologia - com suas dificuldade inerentes de obtenção e interpretação de amostras. No entanto, deve ser reconhecida como a primeira proposta de abordagem de pacientes adultos com $\mathrm{LD} / \mathrm{LG}$ presente na literatura.

No entanto, sendo a imagem por RM o principal exame complementar individual para o estudo das LD/LG, uma abordagem a partir da mesma tem maior lógica. Assim, o maior estudo realizado até o momento usou como critério o padrão de acometimento visto na ressonância magnética, dividindo os pacientes em três grupos: doenças vasculares, doenças cavitantes e doenças sem aspecto vascular ou 
cavitante. Foram avaliados 154 pacientes franceses distribuídos por todo o país (Ayrignac et al., 2015) adotando-se esta classificação.

O padrão vascular foi definido pela presença de hipersinal da substância branca profunda, ponte e/ou cápsula externa nas sequências ponderadas em T2/FLAIR com sinais de micro-hemorragias na sequência T2*/SWI. Este foi o grupo com maior número de casos com diagnóstico definitivo, sendo que os diagnósticos encontrados foram CADASIL, doenças relacionadas a variantes patogênicas de COLAAl e a síndrome de Labrune (leucoencefalopatia com calcificações e cistos).

O padrão cavitante foi o menor grupo e foi definido pela presença de marcado hipossinal em T1 dentro de áreas de hipersinal em T2/FLAIR. A VWM foi a única doença encontrada neste grupo.

Por fim, o grupo de pacientes sem aspectos vasculares ou cavitantes em suas ressonâncias constituiu o maior e mais heterogêneo grupo. A ALD-X foi $o$ diagnóstico mais frequente, tendo sido também encontrados casos de doença de Krabbe, leucodistrofia metacromática, XCT, ADLD dentre outras. Foi também este grupo que teve o maior número de casos sem diagnóstico definitivo (45\%).

Esta segunda classificação tem seu valor, pois pode orientar a investigação clínica de forma prática. Os autores ainda destacam que no terceiro grupo, uma avaliação detalhada da clínica e dos exames de imagem por profissionais com experiência no atendimento de pacientes com LD/LG permitiram o diagnóstico presuntivo correto em $21 / 82$ pacientes.

\subsubsection{Caracterização clínica}

As manifestações neurológicas mais comuns das LD/LG em adultos são: alterações cognitivas e/ou comportamentais, alterações da marcha, disartria, síndrome piramidal, ataxia cerebelar e por vezes movimentos anormais ou até mesmo epilepsia (Leite et al., 2014). O curso clínico tende a ser crônico e lentamente progressivo, mas por vezes pode ser rápido, como em alguns casos de HDLS ou acelerado por fatores externos, principalmente trauma, como ocorre em VWM.

Alguns achados neurológicos podem ajudar a reduzir a lista de diagnósticos diferenciais. O Quadro 2 traz estes achados. 
Quadro 2 - Achados neurológicos de maior valor diagnóstico

\begin{tabular}{|l|l|}
\hline Neuropatia óptica & $\begin{array}{l}\text { Doenças mitocontriais } \\
\text { Leucodistrofia metacromática } \\
\text { Doença de Krabbe } \\
\text { Doença de Pelizaeus-Merzbacher }\end{array}$ \\
\hline $\begin{array}{l}\text { Nistagmo / alterações da motricidade } \\
\text { ocular extrínseca }\end{array}$ & $\begin{array}{l}\text { Doença de Pelizaeus-Merzbacher } \\
\text { Doença de Pelizaeus-Merzbacher símile }\end{array}$ \\
\hline Neuropatia periférica & $\begin{array}{l}\text { Doenças mitocondriais } \\
\text { ADLDLeucodistrofia metacromática } \\
\text { Doença de Krabbe } \\
\text { Doenças peroxissomais (ADL/AMN-X) } \\
\text { Síndrome de Cockayne } \\
\text { Doença de Pelizaeus-Merzbacher } \\
\text { Doença de Pelizaeus-Merzbacher símile }\end{array}$ \\
\hline Disautonomia & $\begin{array}{l}\text { ADLD (precoce) } \\
\text { Doença por corpos de poliglicosanos do adulto }\end{array}$ \\
\hline Enxaqueca & CADASIL \\
\hline Tremor palatal & Doença de Alexander \\
\hline Acidente vascular encefálico & CADASIL \\
CARASIL \\
CARASAL \\
Doença de Fabry
\end{tabular}

Fonte: adaptado de Ahmed et al., 2014 e Renaud, 2016

A história familiar quando sugere algum padrão de herança também é extremamente útil. Em adultos, ao contrário das crianças, há uma representação significativa de casos esporádicos e doenças autossômicas dominantes - embora isto nem sempre fique evidente pela história. Variantes patogênicas de novo podem ocorrer principalmente em doença de Alexander e ALD/AMN-X. Há também doenças autossômicas dominantes que apresentam penetrância incompleta, como a HDLS. O Quadro 3 traz as doenças separadas por forma de herança. 
Quadro 3 - Padrão de herança das principais leucodistrofias e leucoencefalopatias genéticas

\begin{tabular}{|l|l|}
\hline Autossômicas dominantes & CADASIL \\
& ADLD \\
& HDLS \\
& Doença de Alexander \\
& Doenças associadas ao COL4Al \\
& Leucodistrofia cerebral com vasculopatia retiniana \\
& $($ TREXI) \\
\hline Ligadas ao X & ADL/AMN-X \\
& Doença de Pelizaeus-Merzbacher \\
& Síndrome tremor-ataxia ligada ao X \\
& Doença de Fabry \\
\hline Autossômicas recessivas & Todas as demais \\
\hline
\end{tabular}

No entanto, são os achados extra-neurológicos aqueles com maior potencial discriminatório (Parikh et al., 2015). O Quadro 4 mostra os principais achados. 
Quadro 4 - Achados extra-neurológicos de maior valor diagnóstico em pacientes com leucodistrofia ou leucoencefalopatia genética

\begin{tabular}{|c|c|}
\hline Insuficiência adrenal & $\begin{array}{l}. \text { ADL/AMN-X } \\
\text {.Síndrome } 4 \mathrm{H}\end{array}$ \\
\hline Falência ovariana precoce & $\begin{array}{l}\text {.Doença da substância branca evanescente } \\
\text {.Leucoencefalopatia relacionada a } A A R S 2 \\
\text {.Síndrome tremor-ataxia ligada ao } \mathrm{X} \\
\end{array}$ \\
\hline $\begin{array}{l}\text { Hipogonadismo } \\
\text { hipogonadotrófico }\end{array}$ & $\begin{array}{l}. \text { Síndrome } 4 \mathrm{H} \\
\text {.Distúrbios relacionados ao PNPLA6 }\end{array}$ \\
\hline Ictiose & $\begin{array}{l}. \text { Síndrome de Sjögren-Larsson } \\
\text {.Deficiência de múltiplas sulfatases } \\
\text {.Doença de Refsum } \\
\text {.Síndrome de Cockayne } \\
\text {.Tricotiodistrofia }\end{array}$ \\
\hline Xantomas cutâneos & Xantomatose cerebrotendínea \\
\hline Alterações gastrointestinais & $\begin{array}{l}\text {.Xantomatose cerebrotendínea } \\
\text {.Encefalopatia mitocondrial neurogastrointestinal } \\
\text {.Leucodistrofia metacromática (colelitíase) }\end{array}$ \\
\hline Catarata & $\begin{array}{l}\text { Xantomatose cerebrotendínea } \\
. \text { Síndrome } 4 \mathrm{H} \\
\text {.Doença de Fabry } \\
\text {.Doenças mitocondriais } \\
\text {.Doenças peroxissomais }\end{array}$ \\
\hline Retinopatia & $\begin{array}{l}\text {.Doença de Krabbe } \\
\text {.Doença de Refsum } \\
\text {.Síndrome de Cockayne } \\
\text {.Gangliosidoses GM1 e GM2 } \\
\text {.Síndrome de Sjögren-Larsson } \\
\text {.Doenças mitocondriais } \\
\text {.Doenças peroxissomais } \\
\text {.Microangiopatia cerebroretiniana com calcificações e cistos } \\
\text { (síndrome de Labrune) } \\
\text {.Doenças associadas ao COLAA1 } \\
\text {.Leucodistrofia cerebral com vasculopatia retiniana (TREXI) }\end{array}$ \\
\hline Perda auditiva & $\begin{array}{l}\text {.Doenças mitocondriais } \\
\text {.Doença de Refsum }\end{array}$ \\
\hline Hipo/oligodontia & $\begin{array}{l}. \text { Síndrome } 4 \mathrm{H} \\
\text {.Síndrome de Cockayne }\end{array}$ \\
\hline Alterações esqueléticas & $\begin{array}{l}\text { Síndrome de Nasu-Hakola } \\
\text {.Deficiência de múltiplas sulfatases } \\
\text {.Sialidose }\end{array}$ \\
\hline Macrocrania & $\begin{array}{l}\text {.Doença de Alexander } \\
\text {.Acidúrias orgânicas } \\
\text {.Leucoencefalopatia megalencefálica com cistos subcorticais }\end{array}$ \\
\hline
\end{tabular}

Fonte: (adaptado de Ahmed et al. (2014) e Renaud 2016) 
Dismorfismos e hepatoesplenomegalia (como ocorre em doenças de depósito lisossomal) são extremamente incomuns em pacientes com LD/LG de início na idade adulta. No entanto, para aqueles em que a doença teve início precoce e chegaram à idade adulta, tais achados podem perdurar.

Frente a um paciente com LD/LG a busca sistemática pelos achados supracitados podem ser decisivos para um diagnóstico correto e/ou a orientação das investigações adicionais a serem realizadas. Na Figura 1 apresentamos alguns exemplos.

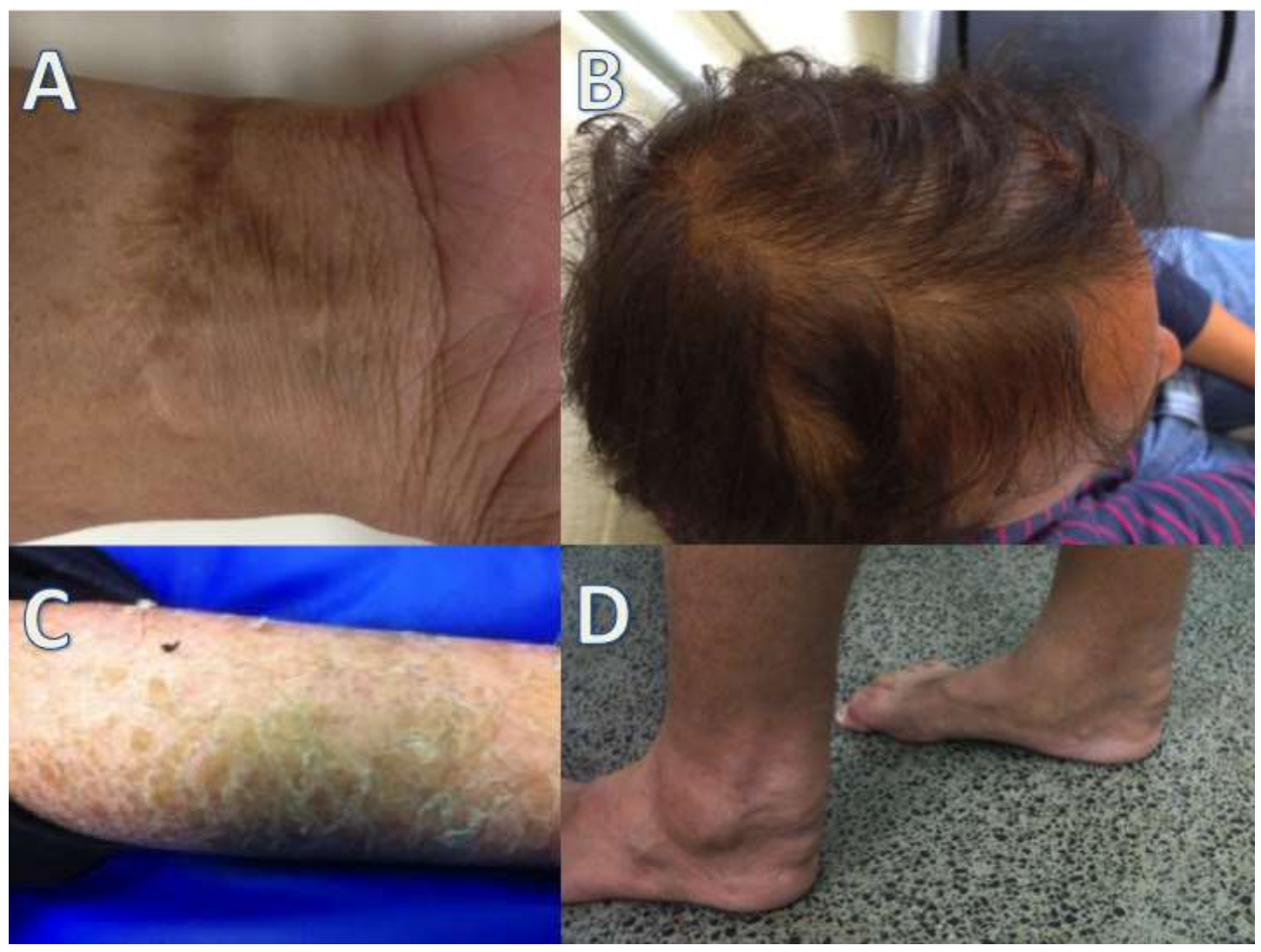

Figura 1 - Manifestações extra-neurológicas: A- hipercromia de cicatriz, comum na síndrome de Addison, sugerindo ALD/AMN-X ou síndrome $4 \mathrm{H} ; \mathbf{B}-$ alopécia precroce, sugerindo ALD/AMN-X; C- ictiose, comum na síndrome de Sjögren-Larsson e na doença de Refsum; D- xantomas em calcanhar de Aquiles, sugerindo XCT 


\subsubsection{Caracterização neurorradiológica}

Embora os estudos sobre doenças da substância branca tenham se iniciado nos anos 1830 com estudos patológicos, foi somente na década de 1980 que estes começaram a ganhar força, e com a ressonância magnética mudou-se por completo a abordagem destas doenças (Kevelam et al., 2016). A RM é indispensável na investigação das LD/LG. Eventualmente, a TC de crânio pode complementar a investigação - principalmente na busca de calcificações. Embora as LD/LG constituam um grupo bastante heterogêneo, pacientes com a mesma doença tendem a apresentar os mesmos achados de RM, possibilitando a identificação de padrões característicos de cada doença (Schiffmann e van der Kaanp, 2009).

Encontramos na literatura três abordagens diagnósticas diferentes e ao mesmo tempo complementares dos achados de RM. O primeiro e mais influente trabalho foi o de Schiffmann e van der Knaap (2009), que propõe um algoritmo no qual a primeira distinção é entre doenças hipomielinizantes e as demais. O grupo das hipomielinizantes é subsequentemente dividido entre as doenças com ou sem acometimento de sistema nervoso periférico. Já o grupo das não-hipomielinizantes é dividido conforme o padrão das lesões em multifocais ou confluentes. Este último grupo é ainda subdividido conforme a localização predominante das lesões - frontal, parieto-occipital, periventricular, subcortical, difuso e fossa posterior.

As LD/LG com hipomielinização são muito raras em adultos. Assim, seguindo esta abordagem, destacamos no Quadro 5 as principais LD/LG semhipomielinização do adulto. 
Quadro 5 - Padrão de lesões vistas na neuroimagem das principais leucodistrofias e leucoencefalopatias genéticas (adaptado de Ahmed et al. (2014) e Renaud 2016)

\begin{tabular}{|c|c|c|c|}
\hline \multicolumn{2}{|l|}{ Multifocais } & \multirow{2}{*}{\multicolumn{2}{|c|}{$\begin{array}{l}. \text { Vasculopatias } \\
\text {.Doenças mitocondriais } \\
. \text { HDLS } \\
\text {.Acidúria L2-hidroxiglutárica } \\
\text {.Doença de Fabry } \\
\text {.Leucodistrofia metacromática } \\
\text {.Variante frontal da ALD-X } \\
\text {.HDLS } \\
\text {.Doença de Alexander }\end{array}$}} \\
\hline \multirow[t]{7}{*}{ Confluentes } & Frontal & & \\
\hline & Parieto-occipital & \multicolumn{2}{|c|}{$\begin{array}{l}\text {.ALD-X } \\
\text {.Doença de Krabbe }\end{array}$} \\
\hline & Periventricular & \multicolumn{2}{|c|}{$\begin{array}{l}\text {.Leucodistrofia metacromática } \\
\text {.Doença de Krabbe } \\
\text {.Síndrome de Sjögren-Larsson } \\
\text {.LBSL } \\
\text {.Doença por corpos de poliglicosanos do adulto }\end{array}$} \\
\hline & Subcortical & \multicolumn{2}{|c|}{$\begin{array}{l}\text { Síndrome de Kearns-Sayre } \\
\text {.Acidúria L2-hidroxiglutárica } \\
\text {.Doenças do ciclo da uréia }\end{array}$} \\
\hline & Difusa & \multicolumn{2}{|c|}{$\begin{array}{l}\text {.Doença da substância branca evanescente } \\
\text {.Doenças mitocondriais } \\
\text {.Distrofia muscular congênita por deficiência de } \\
\text { merosina } \\
\text {.Fase final de várias doenças }\end{array}$} \\
\hline & \multirow[t]{2}{*}{ Fossa posterior } & $\begin{array}{l}\text { Cerebelo e } \\
\text { pedúnculos } \\
\text { cerebelares médios }\end{array}$ & $\begin{array}{l}. \text { Xantomatose cerebrotendínea } \\
. \text { Doenças peroxissomais } \\
\text {.Doença de Alexander } \\
. \text {.LBSL } \\
\text {.ADLD } \\
\text {.FXTAS }\end{array}$ \\
\hline & & Tronco encefálico & $\begin{array}{l}\text {.LBSL } \\
\text {.Doenças peroxissomais } \\
\text {.Doença de Alexander } \\
\text {.ADLD } \\
\text {.Doença por corpos de } \\
\text { poliglicosanos do adulto }\end{array}$ \\
\hline
\end{tabular}


A segunda proposta de abordagem diagnóstica a partir da imagem foi feita por Labauge et al. em 2014 e aplicada numa população de 154 pacientes pelo mesmo grupo (Ayrignac et al., 2015). Esta proposta tem a vantagem de ter sido elaborada exclusivamente para LD/LG de início na idade adulta, enquanto que a primeira era mais abrangente (podendo por vezes confundir o neurologista clínico). De forma bastante pragmática, divide em vasculares, cavitantes e outras.

A terceira proposta, feita por Vanderver (2016b), também foca exclusivamente em pacientes adultos e divide os pacientes em dois grandes grupos: um com doenças de início multifocal, que pode muitas vezes lembrar uma doença desmielinizante ou vascular; e outro com as formas em adultos das LD/LG que tipicamente se apresentam em crianças, sendo a maioria confluente.

Vanderver et al. (2014) também propôs a busca sistemática de alguns achados que podem estreitar as possibilidades diagnósticas, os quais destacamos no quadro 6 e na figura 2.

Por último, o acometimento de fossa posterior em LD/LG em adultos foi recentemente revisado por Ayrignac et al. (2016). Segundo o mesmo, o hipersinal em T2/FLAIR em tronco pode estar presente na maioria das LD/LG, sendo em algumas o acometimento trato-específico. A atrofia leve de tronco encefálico é também relativamente frequente, mas a atrofia moderada ou grave têm maior valor diagnóstico, ocorrendo em LBSL, ADLD, doença por corpos de poliglicosanos do adulto e em doença de Alexander (a acentuada atrofia de bulbo leva a um aspecto de "girino").

O hipersinal de pedúnculos cerebelares, particularmente os médios, também não é muito específico, mas é mais frequentemente encontrado em: LBSL, ADLD, síndrome tremor-ataxia ligada ao X (FXTAS) e doença por corpos de poliglicosanos do adulto. Já o acometimento de pedúnculos cerebelares superior e inferior têm maior valor diagnóstico, sugerindo LBSL.

Outra avaliação que pode ser útil é a dos núcleos denteados do cerebelo. Estes são mais acometidos em XCT, L2HGA, doença de Alexander e doença por corpos de poliglicosanos do adulto. Nesta última pode haver também significativa atrofia cerebelar. 
Independente da abordagem inicial adotada, ressalta-se que muitas vezes é possível o reconhecimento de um padrão bem específico de imagem, como em LBSL ou VWM, por exemplo. Comentaremos um pouco mais sobre o padrão específico (quando houver) de cada doença quando abordarmos individualmente as principais $\mathrm{LD} / \mathrm{LG}$ em adultos.

Quadro 6 - Achados adicionais de neuroimagem com maior valor diagnóstico

\begin{tabular}{|c|c|}
\hline Cistos na substância branca & $\begin{array}{l}\text {.Doença da substância branca evanescente } \\
\text {.Leucoencefalopatia megalencefálica com cistos } \\
\text { subcorticais } \\
\text {.Microangiopatia cerebrorretiniana com calcificações e } \\
\text { cistos (síndrome de Labrune) } \\
\text {.Acidúria L2-hidroxiglutárica }\end{array}$ \\
\hline Calcificações & $\begin{array}{l}\text {.Microangiopatia cerebrorretiniana com calcificações e } \\
\text { cistos (síndrome de Labrune) } \\
\text {.Doenças associadas ao COLAA1 e COLAA2 } \\
\text {.Doença de Fabry } \\
\text {.Doenças mitocondriais }\end{array}$ \\
\hline Impregnação pelo contraste & $\begin{array}{l}. \text { ALD-X } \\
\text {.Doença de Alexander } \\
\text {.HDLS } \\
\text {.Microangiopatia cerebrorretiniana com calcificações e } \\
\text { cistos (síndrome de Labrune) } \\
\text {.Doenças mitocondriais }\end{array}$ \\
\hline Corpo caloso fino & $\begin{array}{l}. \text { HDLS } \\
. \text { Síndrome } 4 \mathrm{H}\end{array}$ \\
\hline $\begin{array}{l}\text { Lesões de núcleos da base não- } \\
\text { calcificantes }\end{array}$ & $\begin{array}{l}. \text { HDLS } \\
. \text { Doença de Alexander } \\
\text {.Microangiopatia cerebrorretiniana com calcificações e } \\
\text { cistos (síndrome de Labrune) } \\
\text {.Xantomatose cerebrotendínea } \\
\text {.Doença da substância branca evanescente } \\
\text {.Acidúria L2-hidroxiglutárica } \\
\text {.Doenças mitocondriais }\end{array}$ \\
\hline $\begin{array}{l}\text { Acometimento de medula } \\
\text { espinhal }\end{array}$ & $\begin{array}{l}. \text { LBSL } \\
\text {.ADLD } \\
\text {.Doença de Alexander } \\
\text {.Xantomatose cerebrotendínea } \\
\text {.Doença por corpos de poliglicosanos do adulto } \\
\text {.Doenças mitocondriais } \\
\text {.Homocistinúrias }\end{array}$ \\
\hline
\end{tabular}

Fonte: adaptado de Ahmed et al. (2014) e Vanderver et al 2014 


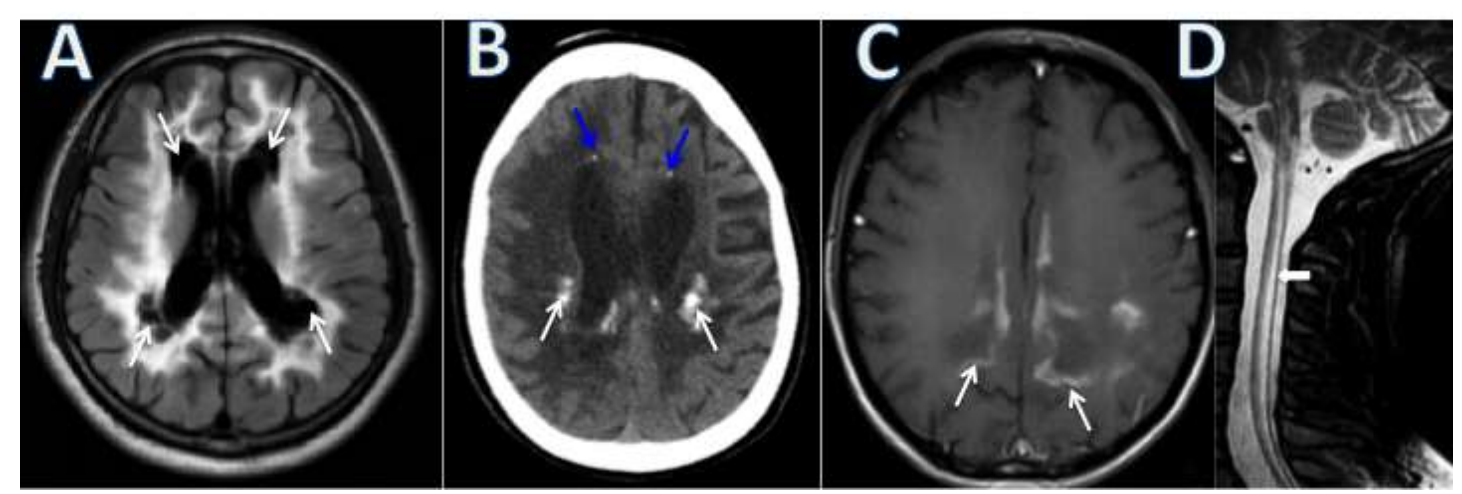

Figura 2 - Achados adicionais de neuroimagem: A - cistos periventriculares (setas) visualizados em imagem ponderada em FLAIR em paciente com VWM; B - imagem de TC de crânio mostrando calcificações em substância branca parietal (setas brancas) e calcificações puntiformes em substância branca frontal (setas azuis), bilateralmente, em paciente com $\mathrm{o}$ diagnóstico de HDLS; C - lesões parieto-occipitais bilaterais com impregnação pelo gadolínio (setas) em paciente com ALD-X; D acometimento de medula espinhal (seta) em paciente com diagnóstico de LBSL

\subsubsection{Caracterização genética}

Se a ressonância magnética promoveu a primeira grande revolução no estudo das doenças da substância branca, pode-se dizer que as técnicas de NGS estão produzindo a segunda.

Os primeiros genes associados a LD/LG foram identificados no final dos anos 1980, após estudos de ligação. A maioria das LD/LG que conhecemos tiveram suas bases genéticas estabelecidas por esta técnica entre os anos 1990 e 2010 (Kevelam et al., 2016).

No entanto, sabemos que os estudos de ligação são muito trabalhosos, demorados e requerem um número grande de acometidos ou famílias consangüíneas para se identificar o gene responsável. Assim, num mundo com famílias cada vez menores e diante de doenças muito raras, esta abordagem mostra-se de baixa custoefetividade.

Quando tratava-se de doença autossômica dominante porém, que na maior parte das vezes fosse decorrente de evento mutacional de novo, as técnicas 
tradicionais de investigação genética eram de pouca utilidade, pois não havia recorrência de casos na família.

Neste contexto, surgem as técnicas de NGS ("next-generation sequencing" NGS), com o sequenciamento completo do exoma ("whole exome sequencing" WES) e mais recentemente o sequenciamento completo do genoma ("whole genome sequencing" - WGS), trazendo uma mudança de paradigma para a pesquisa e prática clínicas. As técnicas de NGS são frequentemente chamadas de técnicas de sequenciamento paralelo massivo, pois sequenciam simultaneamente milhões ou até bilhões de pequenos fragmentos de DNA (Shendure; Ji, 2008).

De forma bastante simplificada, podemos dizer que as técnicas de NGS consistem em extrair o DNA, fragmentá-lo em pequenos pedaços, organizar uma "biblioteca" com estes fragmentos que serão por sua vez sequenciados gerando milhões de leituras, alinhar estas leituras a um genoma de referência e submetê-las a filtros em busca de selecionar variantes raras e de possível relevância clínica. (Biesecker; Green, 2014).

O WES é o sequenciamento paralelo massivo das regiões codificadoras de proteínas do genoma, o que corresponde a cerca de $1 \%(30 \mathrm{Mb})$ do genoma humano total (Shendure; Ji, 2008).

Trata-se de uma ferramenta poderosa, capaz de sequenciar os cerca de 21.000 genes humanos de forma maciça, sendo muito eficaz na pesquisa de mutações de ponto (trocas simples de aminoácidos, ou "missense", e do tipo perda de sentido, ou “nonsense"), pequenas inserções ou deleções de até 10 nucleotídeos e mutações de sítios de reformatação ("splice site junctions"). No entanto, não é capaz de detectar variantes patogênicas por expansões de repetições de nucleotídeos e grandes inserções/deleções (Biesecker e Green, 2014), e sua eficiência para detecção de variações do número de cópias (“copy number variations" - CNVs) necessita ser aprimorada.

A avaliação por WES pode ainda ser feita em trio, ou seja, no probando e seus genitores. Tal estratégia permite a identificação de novos genes em doenças dominantes ou mesmo em doenças ligadas ao $\mathrm{X}$ decorrentes de mutação de novo.

Existem ainda formas limitadas de sequenciamento paralelo massivo que utilizam técnicas de NGS. Os painéis de genes baseados em fenótipos têm se tornado 
bastante populares, por seu custo mais baixo. Embora permitam a avaliação de múltiplos genes em um só exame, oferecendo vantagem sobre o pedido em série de vários testes genéticos isolados, têm uma limitação inerente ao conhecimento disponível à época da montagem do painel. Assim, diferentes laboratórios podem oferecer painéis que incluam genes diferentes para o mesmo fenótipo.

Ainda, nem sempre a caracterização do fenótipo é fácil. Como exemplo podemos citar os casos de ataxias espásticas, que podem gerar dúvida na solicitação do exame - painel de ataxias ou de paraplegias espásticas? Ou casos de demência de início precoce com acometimento de substância branca - painel para demências ou para $\mathrm{LD} / \mathrm{LG}$ ?

Outra forma de avaliação limitada do exoma é a conhecida como exoma clínico (na literatura de origem inglesa - "focused exome sequencing"). É uma técnica NGS que sequencia os exons dos genes previamente relacionados a doenças humanas - cerca de 6000 genes (12Mb de sequencias exônicas). Permite uma avaliação ampla, não-enviesada, a um custo mais baixo quando comparado ao WES. No entanto, não permite a identificação de alterações genéticas em genes que estão fora desta lista, que está em expansão permanente.

O uso de NGS para a realização do WES em doenças neurológicas vem crescendo rapidamente, por permitir uma avaliação não enviesada de todos os genes codificantes de proteínas em pacientes com fenótipos complexos, com suspeita de etiologia genética, principalmente quando há múltiplos genes suspeitos ou não há genes suspeitos (Fogel et al., 2016).

Estas duas situações são bastante frequentes em casos de LD/LG e o WES tem sido usado para:

1- a caracterização genotípica de fenótipos que já haviam sido descritos antes da disponibilidade destas técnicas - como é o caso da HDLS, descrita por Lanska et al. (1994), com gene identificado por Rademakers et al. (2012); e

2- a definição de novas entidades clínicas, já com sua base molecular, como os casos de LTBL (Steenweg et al., 2012) e H-ABC (Simons et al., 2013), dentre outras. 
O WES tem permitido diminuir o número de pacientes sem diagnóstico. Em 2010, Bonkowsky et al. mostrou que em uma amostra de 122 crianças, 51\% permaneceram sem diagnóstico mesmo após extensa investigação.

Já Vanderver et al. (2016a) mostra uma realidade um pouco mais favorável. Numa amostra inicial de 191 pacientes sem diagnóstico, avaliação inicial em um centro de referência permitiu o diagnóstico em 101 pacientes utilizando o reconhecimento de padrões clínicos/neurorradiológicos e testes diagnósticos direcionados. Dos pacientes restantes, 71 foram submetidos ao WES e 25 obtiveram um diagnóstico definitivo enquanto outros 5 tiveram genes potencialmente patogênicos identificados.

Assim, numa população sem diagnóstico, o WES foi capaz de diagnosticar $42 \%$ dos casos e, se considerarmos a amostra inicial, houve uma aumento de $20 \%$ no poder diagnóstico. A avaliação sistemática associada a WES foi capaz de diagnosticar $73 \%$ dos casos.

No entanto, este estudo foi conduzido em uma população entre 3 e 26 anos, com idade de início dos sintomas entre o nascimento e 19 anos. Somente em 2017, Lynch et al. publicaram o primeiro estudo utilizando NGS em uma série composta exclusivamente por indivíduos adultos com LD/LG não resolvidos (contribuímos com este trabalho e parte dos pacientes aqui apresentados também integraram esta série). Em uma amostra de 100 indivíduos, um diagnóstico definitivo foi feito em 26.

No estudo francês que avaliou pacientes com início dos sintomas após os 16 anos de idade, 57/154 (37\%) pacientes permaneceram sem diagnóstico após avaliação minuciosa por um grupo de pesquisadores da área. Notadamente no grupo de pacientes com leucoencefalopatia não-vascular/não-cavitante $45 \%$ dos pacientes permaneceram sem diagnóstico (Ayrignac et al., 2015).

Ainda não há na literatura uma recomendação consensual sobre a melhor forma de buscar o diagnóstico genético de um dado paciente. Obviamente pode-se proceder a avaliação de um gene por vez conforme a hipótese diagnóstica, se o quadro clínico e neurorradiológico forem muito sugestivos, ou utilizar painéis com múltiplos genes, ou WES (Vanderver et al., 2014, 2016a). No entanto, esta última estratégia tem sido cada vez mais empregada. 


\subsubsection{Abordagem diagnóstica}

Pelo o que foi exposto até aqui, fica claro que precisamos de uma estratégia para abordagem racional destes pacientes. A avaliação clínica deve buscar sistematicamente os achados extra-neurológicos e, sempre que possível, tentar caracterizar o padrão de herança.

A avaliação da ressonância magnética deve buscar algum dos padrões típicos (discutidos com cada doença individualmente a seguir) ou pelo menos a categorização em uma das grandes categorias (vascular ou cavitante ou nãovascular/não-cavitante) propostas por Labauge et al., 2014.

Uma avaliação laboratorial como a proposta por Ahmed et al. (2014) que exclua doenças infecciosas, inflamatórias e metabólicas deve anteceder a solicitação de testes genéticos. $\mathrm{O}$ exame do líquor tem seu maior valor para excluir doenças adquiridas, raramente estando alterado em LD/LG.

Excluídas as causas adquiridas e identificado um padrão típico, pode-se proceder testes bioquímicos ou genéticos confirmatórios.

Caso até este ponto não exista uma hipótese diagnóstica, Ahmed et al. (2014) sugere uma "segunda rodada" de testes bioquímicos, e sua sugestão é seguida por Ayrignac et al. (2015). Estes exames visam investigar as LD/LG mais comuns ou tratáveis, como por exemplo ADL/AMN-X (dosagem dos ácidos graxos de cadeia muito longa), XCT (dosagem de colestanol), L2HGA (ácidos orgânicos urinários), leucodistrofia metacromática (atividade da arilsulfatase A em leucócitos) e doença de Krabbe (atividade da galactocerebrosidase em leucócitos ou fibroblastos), entre outras.

Caso ainda persista sem diagnóstico, deve-se considerar a realização de um painel de genes associados a LD/LG ou o sequenciamento do exoma (Vanderver, 2016b).

\subsection{Principais leucodistrofias e leucoencefalopatias genéticas em adultos}

A seguir discutimos algumas doenças selecionadas dentre as LD/LG descritas na vida adulta. 


\subsubsection{Adrenoleucodistrofia/adrenomieloneuropatia ligada ao $\mathrm{X}$ (OMIM \#300100)}

A adrenoleucodistrofia ligada ao $\mathrm{X}(\mathrm{ADL}-\mathrm{X})$ é uma doença metabólica causada por um defeito em $A B C D 1$ localizado no cromossomo Xq28, que leva a uma falha na beta-oxidação peroxissomal dos AGCML, ou seja, os que possuam cadeia com 22 ou mais carbonos. Há consequente acúmulo de AGCML, particularmente em substância branca cerebral, medula espinhal, córtex adrenal, células de Leydig e folículos capilares (Moser, 1997; Engelen et al., 2012). Sua incidência, considerando ambos os sexos, pode variar de 0,8:100.000 habitantes (Horn et al., 2013) a 6:100.000 (Bezman et al., 2001). No Brasil, Jardim et al. (2010), encontraram uma incidência de 2,9:100.000 habitantes.

Clinicamente, há considerável variabilidade fenotípica, sendo três os fenótipos principais, além dos portadores assintomáticos: a forma cerebral da ADL$\mathrm{X}$ (cADL-X), a adrenomieloneuropatia ligada ao X (AMN-X) e a doença de Addison isolada (Steinberg et al., 2015).

A doença de Addison pode se manifestar em qualquer idade a partir dos 2 anos e pode permanecer durante muitos anos como a única manifestação. Em fases avançadas, além da deficiência de glicocorticoides, pode apresentar deficiência de mineralocorticoides. Esta forma de apresentação é rara em mulheres, afetando menos de $2 \%$ das heterozigotas (Steinberg et al. (2015), Engelen et al., 2012).

A AMN-X é a forma mais comum em adultos, em geral se iniciando na $3^{\mathrm{a}}$ ou $4^{\mathrm{a}}$ década de vida com paraparesia espástica, ataxia sensitiva, perda da sensibilidade vibratória, distúrbios esfincterianos (principalmente urinário), disfunção erétil e dores em membros inferiores (Moser, 1997 e Engelen et al., 2012). Corresponde a cerca de 40 a $45 \%$ do total de afetados (Steinber et al., 2015).

$\mathrm{O}$ acometimento medular tende a ser predominante sobre as manifestações de neuropatia periférica. Entra, portanto, no diagnóstico diferencial das paraplegias espásticas hereditárias ("hereditary spastic paraplegia" - HSP) com concomitante neuropatia periférica. Esta é na maioria das vezes uma polineuropatia sensitivomotora axonal, podendo raramente ser desmielinizante. 
Alguns sinais adicionais extra-neurológicos podem ajudar no diagnóstico: hipercromia (melhor observada em cicatrizes e por vezes gengiva) e/ou hipotensão ortostática secundária a doença de Addison (presente em cerca de 70\% dos pacientes com AMN-X no momento do diagnóstico); alopecia precoce (com cabelo fino e esparso) e raramente insuficiência testicular (Engelen et al., 2012).

A RM pode mostrar hipersinal em T2/FLAIR nos tratos corticoespinhais, mas esta alteração não caracteriza a cADL-X. No entanto, cerca de $20 \%$ dos pacientes podem evoluir com desmielinização levando a déficit cognitivo. Pode então ocorrer estabilização ou evolução para neuroinflamação mais disseminada, com impregnação pelo gadolínio vista na RM, e evolução semelhante a cADL-X da infância (van Geel et al., 2001). Destacamos que traumatismos cranioencefálicos podem desencadear desmielinização focal (Leite et al., 2014) ou até precipitar a evolução catastrófica para cADL-X (Bouquet et al., 2015).

A forma cerebral da ADL-X em adultos pode ser isolada ou, mais comumente precedida por AMN-X (de Beer et al., 2014). A apresentação clínica é relativamente semelhante em adultos e crianças, com declínio cognitivo e motor de rápida evolução, embora no adulto tenda a ser um pouco mais lenta. O diagnóstico pode ser particularmente desafiador naqueles pacientes sem história familiar e sem disfunção adrenal no momento da instalação do quadro neurológico. Manifestações neuropsiquiátricas, por vezes simulando psicose ou demência, são frequentes. Pode ainda apresentar epilepsia, em geral de fácil controle, e, em fases mais avançadas, atrofia óptica.

A RM de crânio em adultos com cADL-X mostra hipersinal em T2/FLAIR parieto-occipital, em geral simétrico, com acometimento de corpo caloso. Pode haver impregnação pelo gadolínio sugerindo quadro inflamatório ativo. Alguns pacientes têm acometimento inicial da substância branca dos lobos frontais, podendo envolver o joelho do corpo caloso (Inoue et al., 2012). Há ainda uma forma mais rara de apresentação, chamada olivopontocerebelar, com acometimento predominante de cerebelo, pedúnculos cerebelares e trato corticoespinhal ao longo de todo o tronco encefálico (Ogaki et al., 2016). As alterações da RM podem anteceder a piora clínica, e o acompanhamento por RM periódicas pode ter implicações terapêutica. 
Sobre as manifestações clínicas no sexo feminino, Engelen et al. (2014) publicaram um estudo prospectivo de 46 mulheres heterozigotas mostrando que até $63 \%$ delas desenvolvem um quadro semelhante a adrenomieloneuropatia observada em homens. Há um significativo aumento da frequência de sintomas com o avançar da idade (88\% das mulheres acima de 60 anos eram sintomáticas). Um achado particularmente surpreendente foi o de incontinência fecal precoce, presente em $28 \%$ da amostra.

O diagnóstico da ADL/AMN-X pode ser bioquímico por meio da dosagem de ácidos graxos de cadeia muito longa (C24 a C30, particularmente C26) no sangue (plasma); porém, cerca de $20 \%$ das mulheres heterozigotas não apresentam este achado (Steinberg et al., 2015). A pesquisa da variante patogênica em $A B C D 1$ é o método de escolha nestes casos. Não há correlação entre os níveis de AGCML, o tipo de variante patogênica e o fenótipo clínico. São descritas cerca de 631 variantes patogênicas no "The Human Gene Mutation Database" - HGMD público (Stenson et al., 2003), a maioria levando à substituição simples de aminoácidos ("missense"), mas não há correlação entre o genótipo e o fenótipo.

O tratamento consiste na reposição de corticoides naqueles portadores de insuficiência adrenal - o que não altera as manifestações neurológicas - e em tratamento de suporte para as manifestações neurológicos. $\mathrm{O}$ transplante de células hematopoiéticas pluripotentes é uma opção para meninos e adolescentes com manifestações precoces de cADL-X. Como as alterações neurorradiológicas antecedem as manifestações clínicas, pacientes em risco devem ser monitorados com RM de crânio a cada seis meses (Steinber et al., 2015). O transplante células hematopoiéticas pluripotentes para cADL-X em adultos foi recentemente avaliado em 14 pacientes por Kühl et al. (2017), sendo que 6 não sobreviveram e aqueles com "Expanded Disability Status Scale score" $($ EDSS) $<6$ antes do transplante obtiveram melhor resultado de sobrevida e preservação da marcha.

Os resultados de um estudo aberto e sem grupo-controle sugerem que o uso do óleo de Lorenzo na fase pré-sintomática pode reduzir os níveis de C26:0 e, consequentemente, reduzir o risco de progressão para cADL-X (Moser et al., 2005). No entanto, alguns pacientes desenvolveram a doença mesmo com a redução dos 
níveis de AGCML. Assim, tais dados devem ser interpretados com cautela e acreditamos que o óleo de Lorenzo é ainda uma terapia sob investigação.

Em 2017, foram publicados os resultados preliminares de uma terapia gênica ex vivo usando infusão de células autólogas CD34+ modificadas com vetor lentiviral, com resultados promissores em meninos com a fase inicial de cADL-X (Eichler et al., 2017).

Para os portadores de AMN-X o tratamento é apenas de suporte.

\subsubsection{Doença da substância branca evanescente (OMIM \#603896)}

A doença da substância branca evanescente (Vanishing White Matter Disease - VWM) é uma leucodistrofia autossômica recessiva causada por alteração no fator de iniciação de tradução eucariótico 2B ("eukaryotic translation initiation factor 2B" - eIF2B), uma proteína de 5 subunidades, reguladora essencial da tradução do RNAm. Sua função é converter a forma inativa do fator de iniciação de tradução (eIF2) na sua forma ativa, ligada a GTP, precursora da iniciação da tradução proteica (Wortham e Proud, 2015). Embora expressa de forma ubíqua, a mutação em homozigose ou heterozigose composta em qualquer das 5 subunidades causa doença preferencialmente da substância branca do sistema nervoso central por acometimento de astrócitos e oligodendrócitos (Dooves et al. 2016, e Raini et al., 2017).

A prevalência de VWM é desconhecida, mas em estudos de pacientes com leucodistrofia sem diagnóstico prévio, foi uma das mais comuns tanto em uma abordagem a partir da RM (van der Knaap et al., 1999) quanto em uma abordagem utilizando WES (Vanderver et al., 2016a).

Clinicamente distinguem-se 5 apresentações conforme a idade de início, sendo a gravidade inversamente proporcional à idade. Assim existem as formas prénatal/congênita, forma infantil subaguda ( $<1$ ano), infantil precoce (1-5 anos), infantil tardia/juvenil (5-15 anos) e de início no adulto (Fogli e Boespflug-Tanguy, 2006). As formas de início precoce se caracterizam por grave quadro encefalopático, com hipomielinização, crises epilépticas e rápida progressão letal. Já para as crianças com apresentação após 1 ano, os sintomas predominantes são ataxia, síndrome 
piramidal e deficiência intelectual. Traumatismos cranianos ou febre podem piorar agudamente o quadro (Schiffmann et al., 2012).

Em adultos, as mulheres parecem ser mais frequentemente acometidas e as manifestações neurológicas iniciais costumam ser cognitivo-comportamentais. O quadro tende a ser de evolução lenta e podem surgir sinais piramidais, ataxia cerebelar e epilepsia - esta em geral de fácil controle (Labauge et al., 2009). Há relatos de pacientes com apresentação inicial de enxaqueca e sinais focais transitórios (Robinson et al., 2014). Não é comum o envolvimento dos nervos periféricos, embora este já tenha sido descrito. Em alguns pacientes as alterações na RM antecedem as manifestações neurológicas. A relação de piora dos sintomas neurológicos secundária a situações de estresse, tais como trauma ou infecção, também ocorre em adultos, porém é menos frequente (Labauge et al., 2009). Menopausa precoce por falência ovariana secundária é um achado que pode ser uma grande pista diagnóstica. Vale ressaltar que crianças também podem apresentar falência ovariana primária, por disgenesia ovariana, fato que deu origem ao termo "ovarioleucodistrofia".

A RM de crânio pode ser muitas vezes diagnóstica. Há envolvimento difuso e simétrico da substância branca e a progressiva substituição desta por líquor. Surgem inicialmente áreas de aspecto tigróide e posterior surgimento de cistos - áreas em que o sinal da substância branca fica semelhante ao sinal do líquor nas sequências ponderadas em T1, T2 e FLAIR.

Tais lesões cavitantes podem ser confundidas com esclerose múltipla (EM) cavitante, mas a localização e a morfologia das lesões ajudam na distinção pacientes com EM tendem a apresentar lesões ovoides perpendiculares aos ventrículos laterais e lesões isoladas puntiformes justacorticais, já pacientes com VWM tendem a apresentar hiperintensidades simétricas infratentoriais, principalmente em pedúnculos cerebelares médios e substância branca cerebelar. Os cistos em pacientes com VWM tendem a se localizar mais anteriormente (Ayrignac et al., 2016b).

Curiosamente, não é comum o aumento dos ventrículos, ficando estes com as suas dimensões e posições originais, bem como o córtex. Há envolvimento de cerebelo e tronco encefálico, mas sem degeneração cística nestes. A espectroscopia 
mostra redução global de todos os metabólitos (van der Knaap, 2005b). Em adultos, atrofia cortical e acometimento de corpo caloso são muito comuns e a degeneração cística pode estar ausente (Carra-Dallière et al, 2011).

O diagnóstico pode ser feito pelos achados típicos da RM de crânio, mas deve idealmente ser confirmado pela análise molecular dos cinco genes que codificam o fator de iniciação de tradução eucariótico 2B (EIF2B1 a EIF2B5). A maioria dos pacientes são heterozigotos compostos e o gene que com mais frequência mostra-se alterado é o EIF2B5 (Fogli et al., 2004).

Algumas correlações genotípicas-fenotípicas são possíveis: a variante patogênica p.Arg113His é a mais comum e, em homozigose em EIF2B5, nunca causa doença em crianças. Esta variante gera um fenótipo mais brando quando comparada aos heterozigotos compostos (van der Lei et al., 2010). Já a variante p.Val309Leu neste mesmo gene causa formas graves da doença (Fogli et al. (2004) e Carra-Dalliere et al. (2011)). Em geral as mulheres tendem a ter um curso mais brando da doença.

O tratamento é sintomático.

\subsubsection{Acidúria L2-Hidroxiglutárica (OMIM \#236792)}

A acidúria L2-hidroxiglutárica (L2HGA) é um erro inato do metabolismo de herança autossômica recessiva causado por uma diminuição da atividade de enzima relacionada ao FAD, localizada na membrana mitocondrial, a L2-hidroxiglutarato desidrogenase. Esta enzima catalisa a oxidação do L2-hidroxiglutarato a alfacetoglutarato. O consequente acúmulo de L2-hidroxiglutarato é tóxico para o sistema nervoso central (Rzem et al., 2004).

A incidência e prevalência exatas não são conhecidas e há pouco mais de 300 casos descritos na literatura desde que a doença foi descrita em 1980 (Duran et al. (1980) e Patay et al. (2015)). Em um estudo sobre acidemias orgânicas com 15 anos de duração, Wajner et al. (2009) analisaram a urina de 6866 crianças e apenas em 9 pacientes o diagnóstico final foi L2HGA.

Clinicamente, a doença se inicia na infância, em geral insidiosa ao longo do primeiro ano de vida, com atraso do desenvolvimento neuropsicomotor ou apenas 
dificuldade de aprendizagem. Muitos pacientes com quadro mais brando podem chegar à vida adulta sem um diagnóstico específico, apenas considerados portadores de deficiência intelectual leve, até que ocorra progressão dos sintomas (Faiyaz-UlHaque et al., 2014).

As manifestações motoras mais comuns se devem a ataxia cerebelar, mas distonia/coreodistonia também podem ocorrer, especialmente em membros superiores. Com a progressão do doença podem aparecer sinais piramidais e até mesmo tetraparesia espástica. Epilepsia é comum, e em geral de fácil controle. Podem ocorrer mioclonias negativas, nistagmo horizontal, atrofia óptica, perda auditiva e disfagia (Steenweg et al., 2010). Há uma tendência de progressão dos sintomas com o avançar da idade. Pacientes com L2HGA têm um risco aumentado de apresentar neoplasias de sistema nervoso central (SNC), especialmente gliomas de alto grau (Patay et al., 2012).

A RM de crânio é muito sugestiva deste diagnóstico. As lesões são inicialmente multifocais e subcorticais, com acometimento das fibras em $\mathrm{U}$, e tendem a confluir, inicialmente nas regiões frontoparietais. Mesmo em casos de doença grave e avançada, a substância branca periventricular tende a ser poupada, assim como estruturas mais centrais como corpo caloso, tronco encefálico e por vezes cápsula interna. Pode haver alteração de sinal em núcleo caudado, putamen e especialmente globo pálido. Há atrofia cerebelar com predomínio de vermis e alteração de sinal de núcleos denteados, sem no entanto alterar a substância branca cerebelar (van der Knaap, 2005c).

Diante de um quadro clínico sugestivo e uma RM de crânio característica, o passo seguinte é realizar a pesquisa de ácidos orgânicos na urina, que mostra um expressivo aumento de 2-hidroxiglutarato. É então necessária a distinção entre o isômero prevalente para a confirmação bioquímica do diagnóstico.

Pode ser também realizada a análise molecular de $L 2 H G D H$, sendo que a maioria dos casos descritos até hoje são homozigotos para mutações de ponto. Em um estudo de 18 famílias de origem portuguesa, Vilarinho et al. (2005) encontraram 3 variantes patogênicas mais frequentes: c.529delC, levando a mudança de matriz de leitura ("frameshift"), uma de perda de sentido c.208C>T (p.Arg70*) e uma substituição simples de aminoácido c.293A>G (p.His98Arg). 
O tratamento é sintomático.

\subsubsection{Leucoencefalopatias genéticas de origem vascular}

O acometimento de substância branca por doença de pequenos vasos cerebrais (microangiopatia) é um achado comum na prática neurológica, sendo na grande maioria dos casos secundário a causas adquiridas. No entanto, estima-se que cerca de 5\% destes pacientes apresentam doença de pequenos vasos de origem monogênica (Yamamoto et al., 2011). Em geral são pacientes jovens ou eventualmente idosos sem fatores de risco cardiovascular.

Dentre estas causas genéticas, destacamos as seguintes, que frequentemente entram no diagnóstico diferencial de LD/LG: CADASIL, CARASIL, doenças relacionadas a mutação do colágeno tipo IV, vasculopatia retiniana com leucodistrofia cerebral e doença de Fabry.

Clinicamente a maioria destas doenças se manifesta como acidente vascular encefálico em jovem, mas também é comum a ocorrência de demência vascular e/ou alteração da marcha (Sondergaard et al., 2017). As imagens de RM de crânio demonstram um padrão que é bastante familiar ao neurologista que atende idosos com doença cerebrovascular e apresenta infartos lacunares cumulativos com microhemorragias, supra e infratentoriais.

CADASIL (Cerebral Autosomal Dominant Arteriopathy with Subcortical Infarcts and Leukoencephalopathy - OMIM \#125310) é sem dúvida a mais importante e mais prevalente dentre as doenças citadas acima e se caracteriza por 4 achados clínicos principais: acidentes vasculares encefálicos isquêmicos subcorticais recorrentes de início no adulto jovem; declínio cognitivo; migrânea com aura e manifestações psiquiátricas (transtorno de humor e apatia). Os infartos cerebrais são tipicamente lacunares e o quadro demencial tem uma progressão em degraus, como ocorre em demência vascular relacionada aos fatores de risco cardiovasculares. A migrânea, as alterações de humor e apatia não estão presentes em todos os casos e o curso clínico é variável, com alguns pacientes totalmente incapacitados por volta dos 50 anos e outros ainda independentes aos 80 anos (Rutten e Lesnik, 2016). 
A RM de crânio em pacientes com CADASIL mostra lesões lacunares cumulativas, microhemorragias predominantemente em tálamo e as lesões mais sugestivas são o acometimento de polos temporais e cápsula externa (Rutten e Lesnik, 2016), embora estas lesões não estejam sempre presentes.

É uma doença de herança autossômica dominante, com raros casos descritos de mutação de novo, e se deve a variantes patogênicas em NOTCH3 - mais de 230 descritas. Este gene codifica o receptor Notch3, presente nas células musculares lisas vasculares e acredita-se que por um ganho tóxico de função o domínio extracelular da Notch3 se acumula nas paredes arteriais, levando à fibrose e estenose de arteríolas, especialmente cerebrais (Tikka et al., 2014).

O diagnóstico era classicamente feito pela análise por microscopia eletrônica de espécimes de biópsia de pele (em busca de Notch3 nas paredes dos vasos), mas atualmente pode ser feito pela pesquisa de variantes patogênicas em NOTCH3 (Joutel et al., 2001). O tratamento é sintomático e deve-se dar especial atenção ao controle dos fatores de risco cardiovasculares.

CARASIL (Cerebral Autosomal Recessive Arteriopathy with Subcortical Infarcts and Leukoencephalopathy - OMIM \#600142) é também uma doença hereditária de pequenos vasos, considerada bastante semelhante a CADASIL, diferindo principalmente pelo seu modo de herança (autossômica recessiva em contrapartida à herança autossômica dominante de CADASIL).

No entanto, algumas outras diferenças podem ser apontadas: CADASIL é panétnica, enquanto CARASIL predomina no Japão, embora já tenha sido descrita em outras populações, inclusive no Brasil (Tikka et al., 2014; Souza et al., 2016); clinicamente, alopecia precoce e dor lombar por hérnia discal e alterações espondilóticas são frequentes, pois CARASIL afeta também o tecido conectivo; os achados de RM de crânio são bastante semelhantes aos encontrados em CADASIL, mas tendem a ser mais homogêneos e poupar as fibras em "U".

O diagnóstico pode ser confirmado pelo encontro de variantes patogênicas bialélicas em HTRA1, porém, mais recentemente tem sido descrito que a variante em heterozigose também pode causar doença de pequenos vasos cerebrais com um padrão de herança autossômico dominante (Bougea et al., 2017). 
As doenças relacionadas ao colágeno tipo IV (COLAA1 e COL4A2) foram inicialmente descritas em crianças com porencefalia, mas há também descrições de pacientes adultos acometidos. Sendo o colágeno tipo IV um dos principais componentes da membrana basal em diversos tecidos, é de se esperar que as manifestações das variantes patogênicas em COLAA1 e COL4A2 sejam sistêmicas. Assim, estes pacientes se apresentam com combinações variadas de acidentes vasculares encefálicos recorrentes isquêmicos e/ou hemorrágicos, aneurismas, nefropatia, miopatia, cardiopatia e anormalidades oftalmológicas (Meuwissen et al., 2015).

A vasculopatia retiniana com leucodistrofia cerebral (OMIM \#192315) é uma doença autossômica dominante de início no adulto causado por variante patogênica em TREX1, que é o mesmo implicado na síndrome de Aicardi-Goutieres, encefalopatia grave da infância, autossômica recessiva, com calcificações em núcleos da base e leucodistrofia. Em adultos manifesta-se com perda visual, acidente vascular encefálico recorrente e consequente declínio cognitivo e sinais focais. Alguns apresentam manifestações sistêmicas como fenômeno de Raynaud, cirrose hepática e glomerulopatia (Richards et al., 2007).

A doença de Fabry (OMIM \#301500) é uma doença lisossomal ligada ao X causada pela diminuição da atividade da alfa-galactosidase A. Tipicamente apresenta-se na infância ou adolescência com acroparestesias (polineuropatia periférica), angioqueratomas, opacidades de córnea e cristalino e proteinúria, podendo evoluir mais tarde com cardiopatia e doença cerebrovascular. No entanto, caso haja uma atividade residual $(>1 \%)$ da alfa-galactosidase A, apresentações mais brandas podem surgir, por vezes apenas com acidente vascular encefálico isquêmico criptogênico. Ressalta-se também que mulheres portadoras da mutação podem apresentar manifestações apenas cardíacas e/ou cerebrovasculares na idade adulta. É fundamental que esta doença seja reconhecida, pois é passível de tratamento específico, com terapia de reposição enzimática (Mehta e Hughes, 2017). 


\subsubsection{Leucoencefalopatias genéticas de origem mitocondrial}

As disfunções mitocondriais resultam em distúrbios do metabolismo energético celular e, consequentemente, afetam preferencialmente os órgãos de maior demanda energética, como encéfalo e músculos, mas podem ser multissistêmicas. Tipicamente, as lesões encefálicas mais comuns afetam simetricamente os núcleos da base e o tronco encefálico, mas algumas síndromes levam a extenso acometimento de substância branca (Wong, 2012).

Antes de prosseguirmos com a descrição destas síndromes, destacamos que a mitocôndria é uma organela celular constituída a partir de dois genomas, o mitocondrial e o nuclear. O DNA mitocondrial (mtDNA) codifica 13 subunidades proteicas das cadeias respiratórias, 2 RNA ribossomais (RNAr) e 22 RNA transportadores (RNAt). Cerca de $99 \%$ das proteínas mitocondriais são codificadas por DNA nuclear (nDNA) (Koopman et al., 2012).

Assim, as doenças mitocondriais monogênicas podem ter herança autossômica recessiva, autossômica dominante, ligada ao $\mathrm{X}$ ou de transmissão materna pelo DNA mitocondrial.

Quando o DNA mitocondrial está envolvido na gênese da doença, há significativa variabilidade fenotípica, mesmo dentro de uma mesma família. Isto se deve a duas particularidades da mitocôndria, a saber: heteroplasmia e limiar de efeito.

Cada célula humana, exceto as hemácias, contém milhares de mitocôndrias, todas com o mesmo mtDNA (homoplasmia). No entanto, aqueles com variantes patogênicas no mtDNA carreiam uma mistura de mtDNA "mutante" e mtDNA "selvagem", a que chamamos heteroplasmia. Para que ocorram manifestações clínicas, deve haver uma certa quantidade de mtDNA "mutante", a que chamamos de limiar de efeito (Schon et al., 2012). Como a quantidade de mtDNA "mutante" pode variar entre indivíduos da mesma família e até mesmo entre tecidos do mesmo indivíduo, as manifestações clínicas podem também ser bastante variadas.

As manifestações clínicas que tipicamente podem ocorrer em doenças mitocondriais, independente de sua base genética, em diversas combinações, em qualquer idade, são: ptose palpebral, oftalmoparesia externa, miopatia, intolerância a 
exercícios, cardiomiopatia, atrofia óptica, hipoacusia/surdez neurossensorial, baixa estatura, retinopatia pigmentar, diabetes melito, encefalopatia, crises epilépticas, demência, espasticidade, ataxia, episódios "stroke-like" e migrânea (Chinnery, 2014).

Embora várias síndromes de origem mitocondrial possam cursar com lesões de substância branca, destacaremos apenas duas, por apresentarem leucoencefalopatia de forma mais consistente: leucoencefalopatia com acometimento de tronco encefálico e medula e elevação de lactato ("Leukoencephalopathy with brainstem and spinal cord involvement and lactate elevation" - LBSL - OMIM \#611105) e encefalomiopatia neurogastrointestinal mitocondrial ("Mitochondrial neurogastrointestinal encephalomyopathy" - MNGIE - OMIM \# 603041).

LBSL é uma síndrome mitocondrial de gravidade variável, com casos neonatais em geral bastante graves e aqueles de início na infância ou na idade adulta de evolução mais lenta (van Berge et al., 2014). Tipicamente os pacientes apresentam ataxia, espasticidade e disfunção de coluna dorsal, podendo também apresentar disartria, dificuldade de aprendizagem, epilepsia e neuropatia periférica (van der Knaap et al., 2003). Alguns pacientes apresentam piora do quadro clínico após febre ou pequenos traumas (van der Knaap e Salomons, 2015).

As alterações de RM de crânio são muito características e o diagnóstico pode ser feito baseado nos seguintes achados: lesões de substância branca multifocais ou homogêneas e confluentes poupando região subcortical associada a acometimento de colunas dorsais e tratos corticoespinhais laterais na medula e acometimento da decussação das pirâmides bulbares e/ou do leminisco medial no bulbo e concomitante lesão de pelo menos uma das seguintes estruturas: esplênio do corpo caloso, perna posterior da cápsula interna, pedúnculos cerebelares superiores ou inferiores, parte intraparenquimatosa do nervo trigêmeo, trato trigeminal mesencefálico, tratos espino cerebelares anteriores ou substância branca cerebelar (van der Knaap et al., 2003).

Para confirmação diagnóstica, pesquisa-se variante patogênica em DARS2, que codifica a aspartil-tRNA sintetase, enzima que liga o aspartato ao RNAt mitocondrial, o que é necessário para a correta tradução do RNAm mitocondrial. A doença é autossômica recessiva e curiosamente a maioria dos pacientes são 
heterozigotos compostos para DARS2, sendo que uma variante patogênica é quase sempre no sítio de processamento do intron 2, o leva a formação de RNAm anômalo que é incapaz de produzir proteína funcional (van Berge et al, 2014).

Já a encefalopatia mitocondrial neurogastrointestinal (MNGIE), também autossômica recessiva, caracteriza-se por neuropatia periférica, ptose, oftalmoparesia, perda auditiva, caquexia, leucoencefalopatia e dismotilidade gastrointestinal grave (Hirano, 2016). A leucoencefalopatia em geral é difusa, assintomática e pode por vezes poupar o corpo caloso. São raros os casos de MNGIE sem leucoencefalopatia. O diagnóstico é confirmado pela demonstração de variantes deletérias em TYMP.

\subsubsection{Leucoencefalopatia difusa hereditária com esferóides (OMIM \#221820)}

A leucoencefalopatia difusa hereditária com esferóides ("hereditary diffuse leukoencephalopathy with spheroids" - HDLS) é uma doença autossômica dominante, inicialmente definida a partir dos seus achados neuropatológicos como duas entidades distintas: leucodistrofia ortocromática pigmentada familial ("Familial Pigmented Orthochromatic Leukodystrophy" - POLD) e leucoencefalopatia difusa hereditária com esferoides axonais ("Hereditary Diffuse Leukoencephalopathy with axonal spheroids" - HDLS). Antes mesmo da definição de sua base genética em 2012 por Rademakers et al., em 2009 Wider et al. já tinham assinalado as semelhanças entre as duas condições. Na ocasião, propuseram o nome atual da doença. Tais semelhanças foram ratificadas por Nicholson et al. em 2013 quando demonstraram a base genética comum de pacientes inicialmente descritos como portadores de POLD e HDLS.

Os aspectos neuropatológicos únicos desta doença são: perda axonal na substância branca cerebral, com esferoides axonais (edema) e presença variável de micróglia pigmentada. Tais alterações decorrem da mutação em heterozigose em CSF1R, que codifica o receptor do fator-1 estimulador de colônia (colony stimulating fator-1 receptor), que é muito expresso em células da linhagem mielóide, incluindo a micróglia. Este receptor regula a proliferação, diferenciação e sobrevida da micróglia (Lynch et al., 2015). 
Não há dados robustos sobre incidência e prevalência de HDLS, mas estimase que seja mais frequente do que se imagina (Sundal e Wszolek, 2014). Em uma população de 114 pacientes com leucodistrofia de início na idade adulta, Guerreiro et al. (2013) encontraram 12 pacientes (11\%) com variante patogênica em CSF1R. Em uma coorte de 48 pacientes, Lynch et al. (2015) encontraram 5 pacientes (10\%). Já Karle et al. (2013), em uma população semelhante de 25 pacientes, confirmou este diagnóstico em 6 (24\%).

Clinicamente predominam os sintomas cognitivo-comportamentais, com predomínio de disfunção executiva e alterações de personalidade (desinibição, perda de autocrítica, perseveração), que costumam ser precoces (Sundal e Wszolek, 2014). Assim, HDLS é um importante diagnóstico diferencial da variante comportamental da degeneração lobar fronto-temporal (DFT). Inicia-se em geral na $5^{\text {a }}$ década, mas pode variar de 20 a 60 anos (Guerreiro et al., 2013).

Sintomas adicionais incluem: espasticidade (especialmente em membros inferiores), crises epilépticas, distonia, parkinsonismo, ataxia, cefaleia, síndrome pseudobulbar e defeitos de campos visuais. O curso é progressivo, podendo variar de 2 a 30 anos, com sobrevida média de 8 anos (Sundal e Wszolek, 2014).

Do ponto de vista neurorradiológico, os achados mais comuns são alterações de sinal da substância branca em lobos frontais ou frontoparietais, corpo caloso e tratos corticoespinhais. Tais lesões são inicialmente focais, assimétricas, podendo ser puntiformes, e tendem a se tornar confluentes (Sundal et al., 2012). Pode haver atrofia cortical e de corpo caloso. Notadamente não há lesão de substância cinzenta. Não há atrofia de tronco encefálico e o acometimento cerebelar é mínimo.

As alterações da RM de crânio podem anteceder os primeiros sinais clínicos em pelo menos 5 anos (Konno et al., 2014). Outro achado significativo é a presença de pequenas calcificações, predominantemente em lobos frontais, próximas aos cornos anteriores dos ventrículos laterais (Konno et al., 2014).

O diagnóstico historicamente era feito por biópsia de SNC, mas isto não mais se justifica desde a identificação do CSF1R como responsável pela doença. A maioria das variantes patogênicas descritas até o momento (mutações de ponto com trocas simples de aminoácidos, perda de sentido, mudança da matriz de leitura, em sítios de reformatação e também deleções) se localizam no domínio tirosina-quinase 
da proteína, codificado pelos exons 12-22. Esta é a porção intracelular que ativa uma série de vias que atuam na regulação da micróglia. No entanto, outras variantes patogênicas já foram identificadas em outros domínios (Miura et al., 2018). Todas as variantes patogênicas levam a formação de proteínas truncadas e à haploinsuficiência de CSF1R, ocasionando a doença (Stabile et al., 2016).

É interessante notar que a HDLS e a doença de Nasu-Hakola são leucoencefalopatias relacionadas à micróglia e que o papel desta na manutenção do SNC e em doenças mais comuns vem sendo desvendado (Lynch et al., 2015). O TREM2, outro receptor de superfície da micróglia, quando mutado em homozigose leva à doença de Nasu-Hakola, mas em heterozigose, é um fator de risco para doença de Alzheimer.

\subsubsection{Doença de Alexander (OMIM \#203450)}

A doença de Alexander é uma leucodistrofia autossômica dominante caracterizada pelo achado anatomopatológico de fibras de Rosenthal, que são corpos de inclusão intracelulares encontrados em astrócitos compostos de agregados da proteína filamentar intermediária GFAP ( glial fibrillary acidic protein), entre outras proteínas (Srivastava e Naidu, 2015).

Sua prevalência é desconhecida e, desde a sua descrição original em 1949 por Alexander, mais de 550 casos já foram registrados (Srivastava e Naidu, 2015).

Clinicamente, existem duas classificações mais usadas para a descrição da doença de Alexander. A primeira, proposta por Russo et al. em 1976, que antecede a descoberta da relação de GFAP com a doença (Brenner et al., 2001), classifica por idade de início dos sintomas em 3 subtipos: infantil (até 2 anos), juvenil ( 2 a 14 anos) e adulta (acima de 14 anos).

A segunda classificação, elaborada a partir da análise de 215 casos confirmados geneticamente, ratifica a relação da idade de início com as manifestações clínicas, mas divide a doença em dois subtipos clínicos que não dependem exclusivamente da idade de início: tipo I e tipo II (Prust et al., 2011). Esta é a classificação mais utilizada atualmente e por isso vamos detalhá-la um pouco mais. 
A doença de Alexander tipo I se caracteriza por encefalopatia, macrocefalia, crises epilépticas, atraso do desenvolvimento neuropsicomotor, início precoce (em geral antes dos 4 anos), pioras paroxísticas e alterações típicas na RM de crânio. Já o tipo II pode se manifestar em qualquer idade, mas tende a ser de início mais tardio e se caracteriza por manifestações bulbares, espasticidade, ataxia, anormalidades da movimentação ocular, disfunção autonômica e tremor palatal (este nem sempre presente). Os achados de RM de crânio foram chamados por Prust de atípicos, quando comparados com a forma mais frequente da infância, pois há atrofia e alteração de sinal em bulbo e medula espinhal, e a alteração de sinal da substância branca supratentorial é inconstante.

Vale ressaltar que há considerável variabilidade fenotípica, especialmente no tipo II, com os casos de início na adolescência apresentando características intermediárias entre as observadas no tipo I e o padrão mais consistentemente visto em adultos. Assim, estes pacientes podem apresentar déficit cognitivo, crises epilépticas e macrocefalia em combinações diversas com ataxia, espasticidade, disfagia e disartria (Balbi et al., 2010).

As manifestações mais características em adultos são as relacionadas ao acometimento de tronco encefálico baixo: disartria, disfonia, paralisia de corda vocal, rinolalia e disfagia. Estima-se a ocorrência de tremor palatal (também chamado de mioclonia palatal) em cerca de $41 \%$ dos pacientes (Pareyson et al., 2008). A busca ativa por este sinal clínico raro é de grande valor diagnóstico, pois sua lista de diagnósticos diferenciais é muito restrita - lesões focais do triângulo de Mollaret, doença de Alexander do adulto, síndrome PAPT ("progressive ataxia and palatal tremor") e idiopático. Curiosamente, apenas os pacientes com tremor palatal idiopático costumam se queixar de cliques audíveis.

Ainda relacionado ao tronco encefálico, distúrbios do sono como apnéia e transtorno comportamental do sono REM já foram descritos. Síndrome piramidal, por vezes assimétrica, causando paraparesia ou tetraparesia é muito frequente e por vezes a única manifestação, ocorrendo sem os sinais bulbares. A ataxia cerebelar é também bastante frequente, axial e apendicular. Crises epilépticas e declínio cognitivo são incomuns em adultos (Pareyson et al., 2008). 
Existem relatos de casos de adultos assintomáticos, apesar de a doença ser considerada autossômica dominante com penetrância completa. Discute-se na literatura se estes indivíduos permaneceriam realmente assintomáticos ou apenas présintomáticos (Shiihara et al., 2004).

Do ponto de vista neurorradiológico, as diferenças entre os achados de RM de crânio de crianças e adultos é marcante, com os pacientes de início na adolescência novamente apresentando achados intermediários. Farina et al. (2008) descreveu o padrão neurorradiológico típico observado em adultos, sendo a atrofia de bulbo e medula espinhal cervical, com hipersinal em T2, os achados mais sugestivos. É comum o envolvimento de hilo dos núcleos denteados e, em pacientes abaixo dos 40 anos, o acometimento da substância branca periventricular, com algumas áreas de impregnação pelo contraste. Um sinal bastante peculiar é o "sinal do girino", descrito por Namekawa et al. (2002), em que a marcada atrofia de bulbo e medula com a base da ponte preservada, formam uma imagem que se assemelha, nas aquisições sagitais, a um girino. Quanto mais tarde o início da doença, mais os achados de imagem tendem a se concentrar na fossa posterior.

A forma juvenil da doença, além do acometimento de bulbo e medula espinhal, também tem um padrão de imagem diferente, com características marcantes: lesões nodulares em tronco encefálico (por vezes simulando tumores) e a presença do "sinal da guirlanda", múltiplas pequenas protrusões na parede dos ventrículos laterais, por vezes com captação de contraste (van der Knaap et al., 2006). Tal achado se deve ao depósito de fibras de Rosenthal nos espaços perivasculares e subependimários.

O diagnóstico historicamente era feito por biópsia ou post mortem pela demonstração de fibras de Rosenthal, mas atualmente é feito pela presença de variante patogênica em heterozigose em GFAP. É doença com padrão de herança autossômico dominante, sendo em muitos casos decorrente de evento mutacional de novo. Há considerável variabilidade fenotípica, mesmo entre membros de uma mesma família, o que leva a considerar a presença de outros genes modificadores da expressão de GFAP (van der Knaap et al., 2005d). A quase totalidade das variantes patogênicas descritas até hoje são do tipo troca simples de aminoácido (“missense”).

O tratamento é de suporte. 


\subsubsection{Leucodistrofia desmielinizante autossômica dominante de início no adulto (OMIM \#169500)}

A leucodistrofia desmielinizante autossômica dominante de início no adulto ("adult-onset autosomal dominant demyelinating leukodystrophy" - ADLD) ou mais recentemente chamada de leucodistrofia autossômica dominante do adulto LMNB1relacionada (Finnsson et al., 2015) é uma doença causada pelo acúmulo da proteína lamina B1, pertencente à família das proteínas filamentares intermediárias (como a GFAP, implicada na doença de Alexander) e parte do envelope nuclear. Tal acúmulo protéico leva a desmielinização por disfunção de astrocitos com preservação da oligodendróglia (Padiath et al., 2006).

A prevalência da ADLD é desconhecida, mas há relatos de casos provenientes de diversos grupos étnicos (Nahhas et al., 2016).

Clinicamente, caracteriza-se por início entre a quarta e a sexta décadas de vida, com disautonomia precoce, antecedendo ou iniciando conjuntamente com alteração da marcha e incoordenação (Finnsson et al., 2015). Curiosamente, um dos poucos casos descritos na literatura em que os sintomas motores antecederam os autonômicos foi de um paciente brasileiro (Giorgio et al., 2013). Ainda assim, disautonomia (com disfunção vesical, constipação, hipotensão ortostática e disfunção erétil) é uma das manifestações mais constantes desta doença.

É lentamente progressiva, com sobrevida média de 18 anos, e geralmente segue uma ordem de surgimento dos sintomas: disautonomia seguida de paraparesia espástica que evolui para tetraparesia e finalmente paralisia pseudobulbar (Finnsson et al., 2015).

Sinais cerebelares tipicamente surgem ao mesmo tempo que os sinais piramidais. Assim, ADLD deve ser incluída no diagnóstico diferencial das síndromes atáxico-espásticas. Ataxia de marcha, dismetria, disdiadococinesia, tremor de intenção e seguimento sacádico são os achados mais comuns, sendo nistagmo encontrado em menor proporção de pacientes (Finnsson et al., 2015). Declínio cognitivo e manifestações psiquiátricas surgem mais tardiamente. Pode haver ainda perda de propriocepção e palestesia, principalmente em membros inferiores, por 
lesão medular. Neuropatia periférica ainda não foi descrita nesta condição (Nahhas et al., 2016).

As alterações neurorradiológicas podem anteceder o início dos sintomas em até 16 anos e por vezes se observa significativa dissociação clínico-radiológica, com alterações extensas na RM de crânio e relativamente poucas manifestações clínicas (Melberg et al., 2006). As alterações mais precoces parecem ser hipersinal em T2/FLAIR da substância branca abaixo do córtex motor se estendendo para perna posterior da cápsula interna e, posteriormente, para todo o trato corticoespinhal até o bulbo.

Subsequentemente há envolvimento de corpo caloso e pedúnculos cerebelares e finalmente da substância branca frontoparietal, com relativa preservação da substância branca periventricular (Melberg et al., 2006). Não há impregnação por contraste ou restrição à difusão das moléculas de água (Padiath et al., 2006). O acometimento de medula espinhal é também marcante e precoce em pacientes com ADLD. Há atrofia de toda a extensão da medula espinhal e leve alteração de sinal. Acredita-se que, pelo menos em parte, os sintomas disautonômicos se devem a este envolvimento medular (Sundblom et al., 2009).

O diagnóstico é confirmado pela demonstração de duplicação de LMNB1 (Padiath et al., 2006) ou, mais raramente, sua deleção desde que envolva a região promotora (Giorgio et al., 2015). A duplicação deste gene leva a super-expressão da proteína lamina B1. Curiosamente, são descritos autoanticorpos contra a lamina B em pacientes com doenças autoimunes, inclusive esclerose múltipla (Padiath et al., 2006). Assim, não causa surpresa o fato de ADLD e esclerose múltipla terem várias características em comum e a ADLD ser frequentemente diagnosticada como esclerose múltipla primariamente progressiva.

O tratamento é de suporte.

\subsubsection{Síndrome de Sjögren-Larsson (OMIM \#270200)}

A síndrome de Sjögren-Larsson é um erro inato do metabolismo lipídico decorrente do acúmulo de aldeídos e álcoois graxos por deficiência da enzima microssomal "fatty aldehyde dehydrogenase - FALDH" (Rizzo et al., 1988). Esta 
enzima catalisa a oxidação de vários aldeídos graxos de cadeia longa e média em ácidos graxos (Fuijkschot et al., 2012). O acúmulo destes afeta a formação normal multilamelar de membranas na camada córnea da pele e da bainha de mielina (van Domburg et al., 1999).

Descrita originalmente na Suécia, onde se estima uma prevalência de 0,4 para 100.000 habitantes (Cho et al., 2018), não há dados epidemiológicos de outros locais. Ainda assim, tem sido descrita em diversas localidades, inclusive no Brasil (Dutra et al., 2009).

Clinicamente, a apresentação clássica de início na infância consiste na tríade deficiência intelectual, diplegia espástica e ictiose congênita (Sjögren e Larsson, 1957). No entanto, há considerável variabilidade fenotípica e a evolução para neurodegeneração tende a não ocorrer, com muitos pacientes chegando à idade adulta (por vezes sem diagnóstico).

Na série de 11 pacientes de van Domburg et al. (1999), todos os pacientes eram nascidos pré-termo, mas esta não é uma constante. As alterações cutâneas já eram notadas logo ao nascimento, com eritema. Gradualmente ao longo do primeiro ano de vida a pele foi se espessando e se tornando escamosa, por vezes atingindo as regiões palmar e plantar. Por fim, hiperceratose amarelo-acastanhada se desenvolveu, com predomínio nas regiões de dobras, pescoço e periumbilical. A região central da face foi poupada. Os cabelos são normais ou finos (van Domburg et al., 1999). Uma característica marcante da ictiose em pacientes com SSL é a presença de prurido, que não é comum em outros distúrbios ictióticos. Alguns pacientes podem apresentar intolerância ao calor por hipo-hidrose e outros podem apresentar ictiose mais leve, por vezes somente com xerodermia (Fuijkschot et al., 2012).

As manifestações neurológicas em geral não estão presentes ao nascimento, mas surgem ao longo dos primeiros 30 meses de vida, tendem a ser não-progressivas e sem correlação de gravidade com a idade de início (Lossos et al., 2006). A característica mais marcante é a espasticidade, com para ou tetraparesia espástica (Fuijkschot et al., 2012). A maioria dos pacientes se tornam cadeirantes até a adolescência, mas não parece haver progressão além deste período (Verhoog et al., 2008). Observa-se ainda disartria (pseudobulbar) leve a moderada, distúrbios de linguagem e deficiência intelectual moderada (Fuijkschot et al., 2012). 
Alterações oftalmológicas também são frequentes, com perda visual (em geral simétrica e moderada) e fotofobia. Tal perda visual se deve a maculopatia de início precoce por inclusões cristalinas ou "pontos cintilantes" perifoveais (Jack et al., 2015). Assim como os achados neurológicos, as alterações oftalmológicas tendem a se estabilizar no fim da infância/início da adolescência. A tomografia de coerência óptica ("optical coherence tomography” - OCT) pode mostrar cristais maculares e pseudocistos, além de atrofia de retina (Fuijkschot et al., 2012).

Do ponto de vista neurorradiológico, há certo atraso da mielinização e, a partir de 2 a 3 anos, observa-se alteração difusa da substância branca. Eventualmente pode haver mielinização incompleta permanente (Willemsen et al., 2004). Tal padrão tende a ser manter estável após os 3 anos de idade. A intensidade das alterações de sinal da substância branca é variável e não há correlação entre a gravidade das lesões na RM de crânio, idade de início e gravidade dos sintomas clínicos (Willemsen et al., 2004). A espectroscopia pode ser valiosa para o diagnóstico ao demonstrar pico lipídico a 1.3ppm em áreas de substância branca não afetada (Fuijkschot et al., 2012).

O diagnóstico é confirmado pela demonstração variantes patogênicas bialélicas em $A L D H 3 A 2$, ou determinação da atividade de FALDH no sangue (Fuijkschot et al., 2012). As variantes patogênicas descritas são tanto do tipo troca simples de aminoácido ("missense") como variantes que levam a interrupção prematura da tradução proteica.

O tratamento é sintomático.

\subsubsection{Doenças Hipomielinizantes}

O achado de hipomielinização em RM de crânio em adultos pode reduzir sobremaneira o número de hipóteses diagnósticas. Os principais genes relacionados a LD/LG hipomielinizantes são: PLP1, GJC2, TUBB4A, POLR3A, POLR3B, CLCN2 e NKX6-2.

As doenças relacionadas a $P L P 1$ são as principais representantes deste grupo. De herança ligada ao cromossomo $\mathrm{X}$, possuem um amplo espectro de fenótipos que engloba a doença de Pelizaeus-Merzbacher (PMD - OMIM \#312080) e a paraplegia 
espástica hereditária tipo 2 (SPG2 - OMIM \#312920) (Hobson e Kamholz, 2013). PLP1 codifica duas proteínas importantes da bainha de mielina do SNC: a proteína proteolipídica da mielina (PLP, que é o componente mais abundante da mielina do SNC) e sua isoforma DM20. Há acúmulo somente de PLP ou das duas isoformas da proteína no retículo endoplasmático dos oligodendrócitos, que pode levar à apoptose (Southwood et al., 2002).

Há poucos dados epidemiológicos disponíveis e somente para PMD. Nos EUA, por exemplo, é de 1:200.000 a 1:500.000 (Hobson e Kamholz, 2013). Já na Alemanha, fica em 0,13:100.000 nascidos-vivos (Heim et al., 1997) e na República Tcheca 1:90.000 (Seeman et al., 2003). São bastante raras as descrições de pacientes com PMD de início na vida adulta (Suzuki et al., 2011).

Clinicamente, há grande variabilidade fenotípica, com casos graves de início neonatal a formas do adulto como SPG não-complicada. Parece haver correlação direta entre a gravidade da doença e quantidade de proteínas PLP/DM20 expressas, bem como com a morte de oligodendrócitos (Cailloux et al., 2000). O quadro clássico de PMD se inicia antes dos 5 anos de idade, em geral por volta de 2,5 anos, com nistagmo, hipotonia, ataxia e tremor cefálico. A hipotonia dá lugar à espasticidade nos 4 membros e é pior em membros inferiores. Há evolução com declínio cognitivo em muitos casos e pode haver epilepsia ou movimentos anormais como distonia (Golomb et al., 2004). Mulheres heterozigotas podem também apresentar sintomas, em geral mais leves (Hurst et al., 2006).

Os pacientes classificados como SPG2 podem se apresentar com paraparesia espastica progressiva, sem outros sintomas e sinais associados ou como SPG2 complicada, com ataxia, nistagmo, disautonomia, declínio cognitivo, atrofia óptica, neuropatia periférica e leucoencefalopatia (Hobson e Komholz, 2013). Assim, muitos vezes pode ser difícil distinguir uma forma leve de PMD de uma forma complicada de SPG2. Adultos tendem a se apresentar com o fenótipo SPG2 "pura" ou complicada, sendo muito raros os casos de início após os 30 anos [Suzuki et al. (2011) e Rubegni et al. (2017)].

Do ponto de vista neurorradiológico, as formas de início na infância se caracterizam por hipomielinização difusa em diferentes graus, com afilamento de corpo caloso (Nezu et al., 1998). Em pacientes adultos, leucoencefalopatia 
periventricular e difusa com afilamento de corpo caloso também é encontrada (Suzuki et al., 2011). Um padrão de lesões salpicadas e confluentes também é descrito (Rubegni et al., 2017).

O diagnóstico é confirmado pela demonstração de variante patogênica em PLP1. As mais comumente encontradas são duplicações (Mimault et al., 1999), mas inserções, deleções, rearranjos cromossômicos e mutações de ponto também são descritas (Cailloux et al., 2000). Não há correlação entre o tamanho da duplicação e o fenótipo (Regis et al., 2008), mas mutações do tipo troca simples de aminoácido ("missense") em regiões altamente conservadas têm correlação com a gravidade do fenótipo (Cailloux et al., 2000).

O tratamento é sintomático.

Já a doença de Pelizaeus-Merzbacher-like é relacionada a variantes patogênicas em GJC2, com herança autossômica recessiva (Uhlenberg B et al, 2004). O fenótipo é muito semelhante ao dos distúrbios relacionados a $P L P 1$, com a maioria dos pacientes com doença de início precoce. Há alguns relatos de casos de início tardio, com evolução lenta, manifestando-se principalmente por paraparesia espástica e ataxia cerebelar (Orthmann-Murphy JL et al, 2009).

Uma causa muito rara de leucoencefalopatia hipomielinizante de início no adulto são as variantes patogênicas em $C L C N 2$. O padrão de herança é autossômico recessivo e os pacientes tipicamente se apresentam com ataxia cerebelar leve. A RM de crânio mostra acometimento de perna posterior de ambas as cápsulas internas, núcleos denteados, pedúnculos cerebrais e pedúnculos cerebelares médios. Pode haver restrição à difusão nestas áreas e acometimento mais amplo de substância branca cerebral e cerebelar com padrão de hipomielinização (Depienne et al, 2013).

Os demais genes relacionados à hipomielinização (TUBB4A, POLR3A, POLR3B e NKX6-2) até o momento não foram associados a casos de início no adulto.

\subsubsection{Miscelânea}

Há pelo menos 60 genes relacionados a LD/LG (Parikh et al., 2015) e é muito provável que esta lista continue a crescer dada a maior disponibilidade das técnicas 
de NGS. Pela relevância para este trabalho, destacamos mais duas condições, ambas autossômicas recessivas: doença relacionada a RNF216 (OMIM \#212840) e deficiência intelectual relacionada a PUS3 (OMIM \#617051).

O RNF216 foi vinculado à síndrome de Gordon-Holmes por Margolin et al., 2013. Clinicamente os pacientes se caracterizavam por ataxia cerebelar, demência e hipogonadismo hipogonadotrófico. A RM de crânio mostrava hipersinal multifocal de substância branca no T2/FLAIR que antecedia os sintomas e sinais clínicos. Posteriormente os pacientes evoluíram com atrofia cortical e cerebelar.

Em 2015, Santens et al. descreveram mais duas famílias belgas com variante patogênica bialélica em RNF216. Clinicamente, havia predomínio do quadro demencial e, além de ataxia e hipogonadismo, os pacientes apresentavam coréia generalizada. A RM de crânio mostrava hipersinal difuso da substância branca no T2/FLAIR, supra e infratentorial, com atrofia cortical, cerebelar e putaminal bilateral.

Em 2016, Shaheen et al. identificaram variante patogênica em homozigose em PUS3 que segregava com um fenótipo de deficiência intelectual em uma família saudita. Clinicamente, os pacientes apresentavam deficiência intelectual grave, microcefalia, fácies sindrômica, estrabismo, esclera acinzentada, manchas mongólicas e crises convulsivas de fácil controle. Do ponto de vista neurorradiológico, havia ventriculomegalia, cistos aracnoides, disgenesia de corpo caloso, alteração de sinal de globos pálidos e núcleos denteados e alterações multifocais simétricas da substância branca subcortical, especialmente frontal. 



\section{MÉTODOS}

\subsection{Desenho do estudo}

Foi realizado um estudo clínico retrospectivo e parcialmente prospectivo.

Os dados retrospectivos foram originários de pacientes já diagnosticados e que se encontravam em seguimento na Clínica Neurológica do Hospital das Clínicas. O caráter prospectivo do estudo permitiu avaliar os pacientes com diagnóstico recente além daqueles já em seguimento que não tiverem completado a investigação, com padrão neurorradiológico de leucoencefalopatia, segundo a metodologia proposta pelo estudo.

Os pacientes foram identificados a partir de uma base de dados do Ambulatório de Neurogenética do Hospital das Clínicas da Faculdade de Medicina da Universidade de São Paulo (HCFMUSP) na qual constam todos os pacientes que já foram atendidos no ambulatório desde a sua criação em 2008.

\subsection{Local}

Ambulatório de Neurogenética da Clínica Neurológica do Hospital das Clínicas da Faculdade de Medicina da Universidade de São Paulo.

\subsection{Amostra}

\subsubsection{Critérios de inclusão}

Foram incluídos pacientes que preenchiam os seguintes critérios $a$ ou $b$ associados aos critérios $c$ e $d$, ou ao critério $e$.

a- Pacientes com idade igual ou superior a 16 anos no momento da avaliação, independente da idade de início dos sintomas;

b- Familiares sintomáticos com idade inferior a 16 anos e suspeita de terem a mesma doença do probando; 
c- Pacientes com alterações na substância branca do sistema nervoso central na ressonância magnética;

d- Pacientes com suspeita de etiologia genética feita a partir das manifestações clínicas ou história familiar ou padrão de neuroimagem.

e- Pacientes com idade igual ou superior a 16 anos, com adrenomieloneuropatia ligada ao $\mathrm{X}$, independentemente de haver alteração ou não na RM de crânio.

Consideramos manifestações clínicas suspeitas de etiologia genética o acometimento de tratos longos associado ou não alterações cognitivocomportamentais.

As histórias familiares consideradas sugestivas de etiologia genética foram: presença de consanguinidade explítica; suspeita de consanguinidade oculta (pais e avós provenientes de cidades pequenas, com populações inferiores a 50.000 habitantes); presença de mais de um familiar acometido na mesma geração ou em geração distinta.

Já os padrões de neuroimagem considerados suspeitos de etiologia genética foram: acometimento difuso e simétrico da substância branca do SNC; acometimento trato-específico; acometimento heterogêneo, porém confluente.

\subsubsection{Critérios de exclusão}

- Pacientes com contra-indicação absoluta à realização de ressonância magnética de encéfalo;

- Pacientes ou responsáveis que se negaram à realização de ressonância magnética ou que não quiseram participar do estudo;

- Pacientes que receberam diagnóstico final alternativo, de origem não genética. 


\subsection{Procedimentos}

\subsubsection{Avaliação clínica}

A avaliação clínica consistiu de anamnese, exame físico geral e exame neurológico.

$\mathrm{Na}$ anamnese foram valorizados dados como: a idade de inicio da doença, os sintomas apresentados, a progressão, a presença ou ausência de historia familiar e consangüinidade. Em relação ao exame físico geral foram avaliadas alterações nos sistemas cardiovascular, respiratório, digestivo, osteoarticular e dermatológico, além de dismorfismos.

O exame neurológico incluiu avaliação de: funções cognitivas (miniexame do estado mental, expansão de dígitos, bateria breve, fluência verbal fonêmica e semântica e desenho do relógio), equilíbrio, marcha, coordenação, tônus, força, reflexos superficiais e profundos, sensibilidade superficial e profunda e exame de nervos cranianos.

As alterações foram caracterizadas pela presença de síndromes como: dismórfica, cognitiva, epiléptica, hipotônica, piramidal, cerebelar, medular, de unidade motora e/ou de nervos cranianos e presença ou ausência movimentos anormais.

\subsubsection{Avaliação laboratorial}

Os exames laboratoriais foram definidos a partir da avaliação clínica e de neuroimagem, levando em conta as necessidades de cada paciente.

Uma avaliação laboratorial mínima com os seguintes exames foi realizada para todos os pacientes: hemograma, uréia, creatinina, sódio, potássio, cálcio iônico, glicemia de jejum, perfil hepático, perfil tireoidiano, vitamina B12, ácido fólico, homocisteína, CPK, perfil lipídico, VDRL, FTA-ABs e ELISA anti-HIV.

A seguir, três etapas de avaliação laboratorial foram propostas. Na primeira etapa, foram realizados testes bioquímicos ou avaliação molecular de genes 
específicos conforme a suspeita diagnóstica feita a partir da avaliação clínica e de neuroimagem.

Assim, nos pacientes com suspeita de ALD/AMN-X, foi realizada dosagem no plasma de ácidos graxos de cadeia muito longa no laboratório de Erros Inatos do Metabolismo do Hospital de Clinicas da UFRGS, em Porto Alegre.

Os pacientes com suspeita de acidúria L2-hidroxiglutárica foram submetidos à pesquisa de ácidos orgânicos na urina - realizada no laboratório de Erros Inatos do Metabolismo do Hospital de Clinicas da UFRGS, em Porto Alegre.

Foram realizados estudos genético-moleculares utilizando DNA genômico extraído de sangue periférico conforme os critérios abaixo (definidos a partir da disponibilidade dos exames à época da realização do estudo):

- Suspeita clínica de ADLD: pesquisa da duplicação de $L M N B 1$ por arrayCGH, utilizando a Human Genome CGH Microarray $60 \mathrm{~K}$, produzida pela Agilent Technologies, contendo cerca de 60.000 oligonucleotídeos distribuídos pelo genoma humano. Centro de Estudos do Genoma Humano da Universidade de São Paulo (CEGH - Profa. Carla Rosemberg).

- Suspeita clínica de doença de Alexander: pesquisa de variante patogênica em GFAP por sequenciamento Sanger (realizado no CEGH, aos cuidados do aluno de pós-doutorado Dr. Uirá Souto Melo).

- Suspeita clínica de síndrome de Sjögren-Larsson: pesquisa de variante patogênica em $A D L H 3 A 2$ por sequenciamento Sanger (realizado no CEGH, aos cuidados do aluno de pós-doutorado Dr. Uirá Souto Melo).

$\mathrm{Na}$ segunda etapa, os demais pacientes e aqueles que foram submetidos a uma das pesquisas anteriores e tiveram seu resultado negativo, foram submetidos a análise por sequenciamento de nova geração no Department of Molecular Neuroscience, pelo Dr. David S. Lynch, MD, sob coordenação do Prof. Henry Houlden, MD, PhD, da University College London. Inicialmente foram submetidos ao chamado exoma clinico ("focused exome sequencing"), utilizando o "Agilent Sure Select Focused Exome (Agilent)", de acordo com o protocolo do fabricante. A lista de genes analisados por esta técnica totaliza 6110 genes previamente implicados em doenças 
humanas ou potencialmente implicadas. As bases de dados HGMD, OMIM e ClinVar foram utilizadas para priorizar as variantes patogênicas.

Por fim, na terceira etapa, os pacientes submetidos ao sequenciamento do exoma clínico que não tiveram variantes patogênicas identificadas, foram submetidos ao sequenciamento completo do exoma, usando a plataforma HiSeq (Illumina).

Os pacientes com suspeita de acidúria L2-hidroxiglutárica, após a identificação da elevação de ácidos orgânicos na urina, foram submetidos a avaliação molecular por sequenciamento do exoma clínico para confirmação diagnóstica.

A avaliação de cariótipo, quando necessária, foi realizada pela Profa Angela Morgante, do CEGH.

Quadro 7 - Avaliação laboratorial em três etapas

\begin{tabular}{|c|c|c|}
\hline Etapas & Pacientes... & Exames bioquímicos ou genéticos \\
\hline \multirow[t]{5}{*}{$1^{\text {a }}$ etapa } & ALD/AMN-X? & AGCML (plasma) \\
\hline & L2HGA? & Ácidos orgânicos (urina) \\
\hline & ADLD? & Teste para $L M N B I$ \\
\hline & Doença de Alexander? & Teste para $G F A P$ \\
\hline & Síndrome de Sjögren-Larsson? & Teste para $A D L H 3 A 2$ \\
\hline $2^{\mathrm{a}}$ etapa & $\begin{array}{l}\text { Casos complexos ou sem hipótese } \\
\text { diagnóstica ou não diagnosticados na } \\
1^{\text {a } \text { etapa }}\end{array}$ & Sequenciamento do exoma clínico \\
\hline $3^{\mathrm{a}}$ etapa & Sem diagnóstico nas etapas 1 e 2 & Sequenciamento completo do exoma \\
\hline
\end{tabular}

\subsubsection{Avaliação neurofisiológica}

Eletroencefalograma (EEG) e eletroneuromiografia (ENMG) foram realizados conforme julgamento clínico.

O EEG foi realizado no Hospital das Clínicas da Faculdade de Medicina da Universidade de São Paulo (HCFMUSP) em equipamento digital Nihon Kohden, modelo 1200, de 32 canais. Os eletrodos foram colocados de acordo com o sistema internacional 10-20 para a colocação dos eletrodos; com os seguintes parâmetros de aquisição: filtro de alta frequiência de $70 \mathrm{~Hz}$, constante de tempo de 0,3 segundos, 
tempo de registro de 30 a 60 minutos incluindo registro de vigília e sono espontâneo (sempre que possível), provas de ativações como abertura e fechamento ocular, fotoestimulação intermitente e, naqueles que colaboraram, hiperpneia.

O registro foi acoplado ao vídeo digital para análise de eventuais alterações comportamentais.

Duas eletrencefalografistas experientes (Dra Eliana Garzon e Dra Joaquina Andrade) analisaram de forma independente e cega os traçados. Os registros foram classificados como normais ou anormais.

As anormalidades foram classificadas como decorrentes dos ritmos de base (carência de ritmos ou elementos fisiológicos, sincronia, excesso de ondas lentas), anormalidades não epileptiformes (presenças de ondas lentas contínuas ou em surtos) ou anormalidades epileptiformes (presença de paroxismos epileptiformes). Quanto à localização as anormalidades foram classificadas como regionais, hemisféricas, generalizadas ou multifocais.

Os exames de ENMG foram realizados pelo Dr Mário Wilson Brotto no HCFMUSP ou pela Dra Simone Amorim, colaboradora do grupo de Neurogenética do HCFMUSP. Foi utilizado equipamento da marca VIASYS - Nicolet, Madison, Winscosin, EUA, modelo Viking Quest, versão 7.5, com amplificador de 2 canais, portátil. Foram realizados estudos de conduções nervosas motoras (velocidades de condução, tempos de latência proximal e distal, amplitudes dos potenciais evocados motores e ondas F) e sensitivas (velocidades de condução, amplitudes dos potenciais evocados sensitivos e reflexo $\mathrm{H}$ no nervo tibial posterior), e eletromiografia (músculos paravertebrais e proximais e distais dos membros superiores e inferiores de pelo menos um dimidio, em repouso e na contração voluntária).

Os valores de normalidade para a neurocondução sensitiva e motora em adultos foram padronizados de acordo com os dados apresentados por Preston e Shapiro (2013). O protocolo mínimo incluiu a avaliação dos nervos mediano, ulnar, tibial e sural. Sempre possível, foram avaliados também os nervos axilar, radial, femoral e fibular. Os valores de normalidade para onda $\mathrm{F}$ e reflexo $\mathrm{H}$ são proporcionais à altura do paciente e para o seu cálculo foram utilizadas as fórmulas padronizadas por Oh (2003). 


\subsubsection{Avaliação por ressonância magnética}

Foram realizados exames de ressonância magnética de crânio em aparelho de 1,5 Tesla (GE Medical Systems, Milwaukee, Wisconsin, EUA) ou 3 Teslas (Philips Medical Systems, Best, Holanda)) no Instituto de Radiologia (InRad) do HCFMUSP com a realização das seguintes seqüências:

- Imagens volumétricas FLAIR VISTA no plano sagital com "field of view" $(\mathrm{FOV})=25 \mathrm{~cm}$, espessura $=0,6 \mathrm{~mm} /$ intervalo $=0,0 \mathrm{~mm}$, com matriz de 208x208, e com TE/TR=mínimo/6000ms e TI=1975ms.

- Imagem volumétrica FSPGR ponderada em T1, com FOV=26cm, espessura $=1,6 \mathrm{~mm}$, e matriz de 320 x 192, com TE/TR=mínimo/450$650 \mathrm{~ms}$ e $\mathrm{TI}=40 \mathrm{~ms}$.

- Imagem axial TSE ponderada em T1 com pulso de transferência de magnetização $(\mathrm{TM}), \mathrm{FOV}=23 \mathrm{~cm}$, espessura $=4,5 \mathrm{~mm} /$ intervalo $=0,5 \mathrm{~mm}$, matriz de 256x122, e com TE/TR=10/800ms.

- Imagem coronal TSE ponderada em T2 com saturação de gordura SPAIR, FOV $=20 \mathrm{~cm} /$ espessura $=4,5 \mathrm{~mm}$, intervalo $=0,5 \mathrm{~mm}$, com matriz de 400x321, e com TE/TR=80/321ms.

- Tensor de difusão: imagens axiais ponderadas em difusão com fator $\mathrm{b}=800 \mathrm{~s} / \mathrm{mm}^{2}$, com 15 direções de gradiente, com FOV=22,4cm, espessura $=2,0 \mathrm{~mm}$, com intervalo $=0,0 \mathrm{~mm}$, matriz de $112 \times 112$, e com $\mathrm{TE} / \mathrm{TR}=65 / 6106 \mathrm{~ms}$.

- Espectroscopia de prótons de voxel único ("single voxel”) com a técnica PRESS, TE $=30$ e TE $=135 \mathrm{~ms}$, espessura $=10 \mathrm{~mm}$.

Foram avaliados também estudos de ressonância magnética realizados em outros serviços em aparelhos de pelo menos 1,5 Tesla e que constassem de pelo menos as seguintes sequencias: axial T1 pré e pós infusão de gadolínio, axial T2, axial FLAIR, difusão e T2* / SWI.

Para fins de descrição de resultados, nos pacientes que possuíam mais de um estudo de ressonância magnética, consideramos apenas aquele que mais contribuiu para o diagnóstico (escolhido arbitrariamente pelos pesquisadores). 
Todas as imagens foram avaliadas em conjunto por um neurorradiologista com experiência na avaliação de casos de LD/LG (Prof. Dr. Leandro Tavares Lucato), pelo Prof. Dr. Fernando Kok e pelo autor desta tese.

\subsubsection{Avaliação anatomopatológica de biópsia muscular}

Pacientes com suspeita de acometimento muscular foram submetidos a biópsia, quando se julgou necessário. Tais biópsias foram realizadas pela Prof. Dra. Juliana Gurgel-Giannetti, que obteve material do músculo bíceps braquial, posteriormente seccionado com criostato em preparados de $8 \mathrm{~mm}$ de espessura.

As seguintes avaliações histoquímicas convencionais foram realizadas: hematoxilina e eosina, tricromo de Gomori modificado, técnica "periodic acidSchiff", "oil red O”, nicotinamida adenina dinucleotideo desidrogenase-tetrazolium redutase (NADH-TR), succinato desidrogenase (SDH), citocromo $c$ oxidase (COX) e adenosina trifosfatase (ATPase) pré-incubadas em pH 9,4, 4,63 e 4,35. Coloração pelo azul da Prússia de Perls foi feita pela equipe do Prof. Dr. Anders Oldfors, da Universidade de Gothenburg (Suécia), como descrito por Stevens (1990), com enriquecimento por DAB (Mochel et al., 2008) para identificação de depósitos de ferro. Também o Prof. Oldfors realizou a avaliação imuno-histoquímica e por microscopia eletrônica.

Para a imuno-histoquímica, as secções de $8 \mathrm{~mm}$ foram fixadas com formaldeído a $4 \%$, a $4^{\circ} \mathrm{C}$ por $10 \mathrm{~min}$, lavados em salina “Tris-buffered-Tween" 20 (TBS-T) por 10 minutos e, permeabilizados em série de metanol, lavado em TBS-T por 5 minutos e processados em "Dako Autostainer", usando "Dako EnVision TM Flex High pH". Os seguintes anticorpos foram aplicados por uma hora: anti-SDHB ab14714 Abcam (1:500), anti-MTCO1 ab14705 Abcam (1:2000) e anti-VDAC1 ab14734 Abcam (1:2000).

Avaliação por microscopia eletrônica foi feita em espécimes de tecidos que foram fixados em glutaraldeído, pós-fixados em OsO4 e embebidos em resina. Secções ultrafinas foram contrastadas com uranilacetato e citrato de chumbo. 


\subsubsection{Testes funcionais}

Foram realizados testes funcionais pela equipe do Prof. Dr. Roland Lill, da Universidade de Marburg (Alemanha), com material extraído do músculo de pacientes identificados como portadores de variante patogênica em FDX2. RNA extraído de músculo de dois dos nossos pacientes e de dois controles saudáveis foram usados para "quantitative reverse transcription PCR (RT-qPCR)". O RNA foi reversamente transcrito usando "primers" de FDX2 cobrindo a junção dos exons 4 e 5. Foi relizada a amplificação de cDNA e a expressão relativa do gene calculada.

Estudos com "Western Blot" foram realizados em tecido muscular para determinar a concentração protéica - detalhes técnicos em Gurgel-Giannetti et al., 2018.

\subsection{Aspectos éticos}

A pesquisa foi aprovada pela Comissão de Ética para Análise de Projetos de Pesquisa (CAPPesq) da Diretoria Clínica do HCFMUSP (número do parecer: 214/262) em 12/03/2013 - Apêndice A.

Todos os pacientes incluídos no estudo receberam informações sobre o que consiste o estudo, incluindo objetivos, metodologia, riscos e benefícios. Após informações, todos os pacientes ou responsáveis leram e assinaram o termo de consentimento livre esclarecido (TCLE - Apêndice B).

\subsection{Análise dos dados}

Trata-se de estudo descritivo que não comporta análise estatística.

O banco de dados foi construído em planilha do programa Excel 2011 da Microsoft e a organização dos dados foi realizada por meio de tabelas. 

5 Resultados 



\section{RESULTADOS}

Foram identificados 42 pacientes dentre 357 pacientes listados na base de dados do Ambulatório de Neurogenética do HCFMUSP como portadores de alterações na substância branca do SNC de presumível ou definida etiologia genética, no período de fevereiro de 2013 a março de 2017. Dentre os 42 pacientes, dois pacientes tinham menos de 16 anos no momento da avaliação e foram incluídos por serem familiares de um dos probandos e terem manifestações clínicas semelhantes. Os demais pacientes eram maiores de 16 anos. Assim, 11,7\% dos pacientes seguidos em nosso serviço à época foram categorizados como portadores de LD/LG. Destes, 38 (31 famílias) foram incluídos no estudo.

Os motivos de exclusão foram: uma paciente com síndrome de Tay-Sachs cuja alteração de substância branca não foi posteriormente confirmada, um paciente com esclerose múltipla e dois pacientes com doença inflamatória indeterminada (Figura 3). 


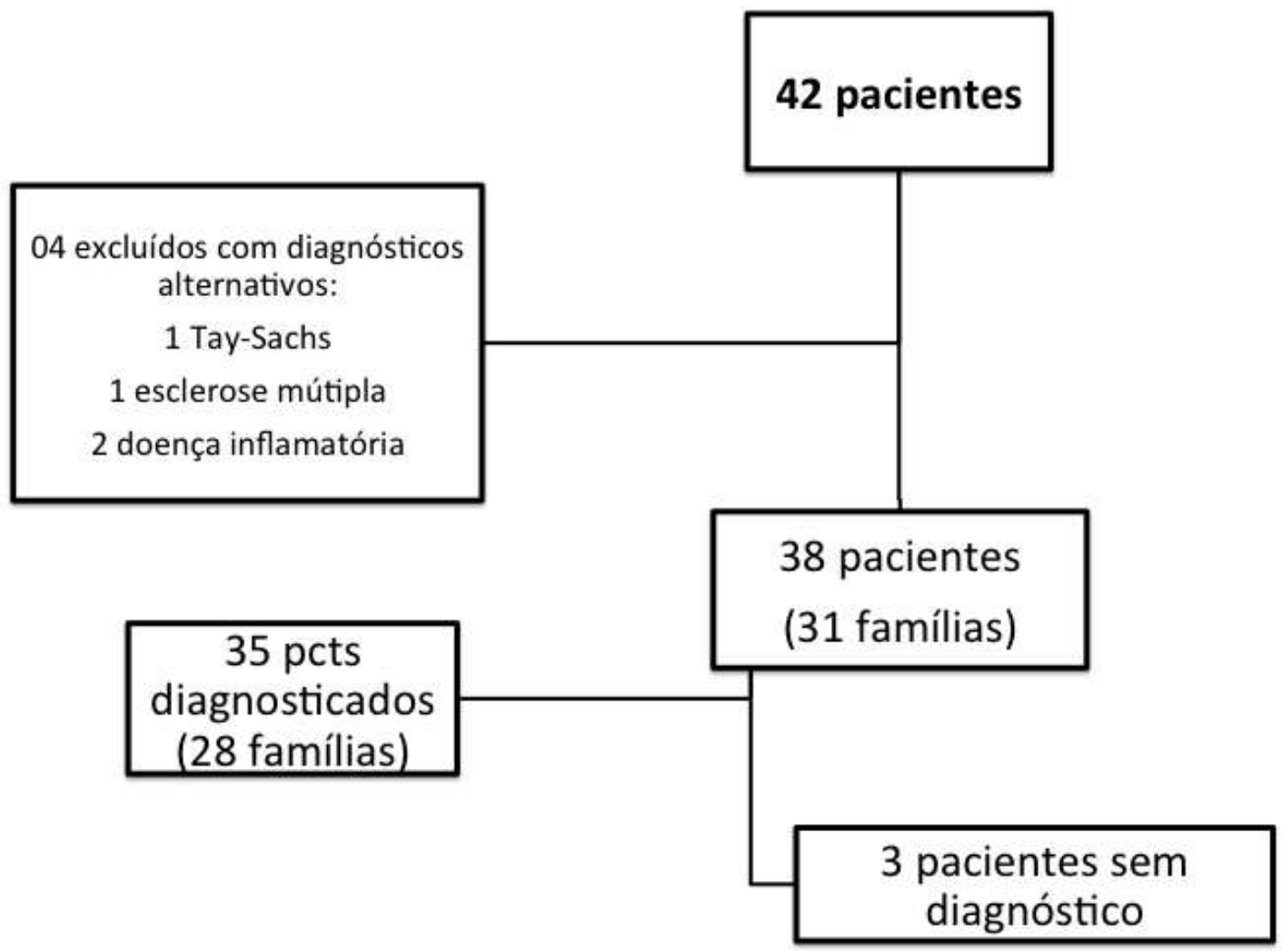

Figura 3 - Pacientes avaliados

Para facilitar a análise dos dados obtidos, os casos incluídos foram dispostos em três tabelas (Tabela 1 - caracterização clínica, Tabela 2 - caracterização genética, Tabela 3 - caracterização neurorradiológica, anexos A, B e C, respectivamente), agrupados por diagnóstico definitivo ou ausência do mesmo.

Três pacientes permaneceram sem diagnóstico mesmo após a realização de sequenciamento completo do exoma.

A avaliação clínica e de neuroimagem realizada pelo autor desta tese, seu orientador e um neurorradiologista experiente (Dr. Leandro Tavares Lucato) foi capaz de sugerir uma hipótese diagnóstica em 27 dentre os 31 probandos (87\%).

Dez dentre estes 27 probandos obtiveram confirmação diagnóstica por meio de exames bioquímicos $-32 \%$ de toda a série. Foram sete pacientes com ALD/AMN-X e três com L2HGA. Estes últimos ainda obtiveram confirmação diagnóstica por meio de avaliação molecular por exoma clínico. 
Dos 21 probandos sem diagnóstico restantes, quatro foram submetidos a testes de genes candidatos específicos (conforme a disponibilidade em nosso serviço). Em dois foi feita a pesquisa da duplicação de $L M N B 1$ por array-CGH, confirmando o diagnóstico de ADLD em um deles. Uma paciente com suspeita de doença de Alexander do adulto e um paciente com suspeita de síndrome de SjögrenLarsson tiveram seus diagnósticos confirmados pelo sequenciamento de GFAP e ALDH3A2, respectivamente.

Restando ainda 18 probandos sem diagnóstico, procedemos então com o sequenciamento do exoma clínico. Destes, 14 tinham pelo menos uma hipótese diagnóstica prévia e o exoma clínico confirmou 10 destas, a saber: quatro probandos com VWM, dois com HDLS, três com CADASIL e um com LBSL.

Em quatro destes 14 casos a hipótese clínica estava equivocada: uma suspeita de síndrome de Labrune que na verdade correspondia a um caso de HDLS; uma suspeita de VWM que correspondia a síndrome de Gordon-Holmes por variante patogênica em RNF216; e uma suspeita de VWM e uma de ADLD que não se confirmaram mesmo após o sequenciamento completo do exoma e os pacientes permaneceram sem um diagnóstico definitivo.

O sequenciamento do exoma clínico revelou ainda um diagnóstico previamente não-suspeitado de doença relacionada a $P L P 1$.

Assim, após as avaliações clínica, neurorradiológica, bioquímica e genética por sequenciamento do exoma clínico tínhamos 26/31 (83\%) probandos com diagnóstico definitivo. Fomos capazes de predizer o diagnóstico correto pela clínica e imagem em 23/31 probandos - 74\% de nossa série.

Restando ainda cinco famílias sem diagnóstico, procedemos para a última etapa de avaliação. O sequenciamento completo do exoma permitiu identificar variantes patogênicas em dois genes adicionais (PUS3 e FDX2), aumentando o percentual de casos com diagnóstico definitivo para 90\% (28/31). Assim, apenas três probandos permaneceram sem diagnóstico definitivo após o sequenciamento completo do exoma. A figura 4 mostra a frequência dos diagnósticos entre os probandos. 


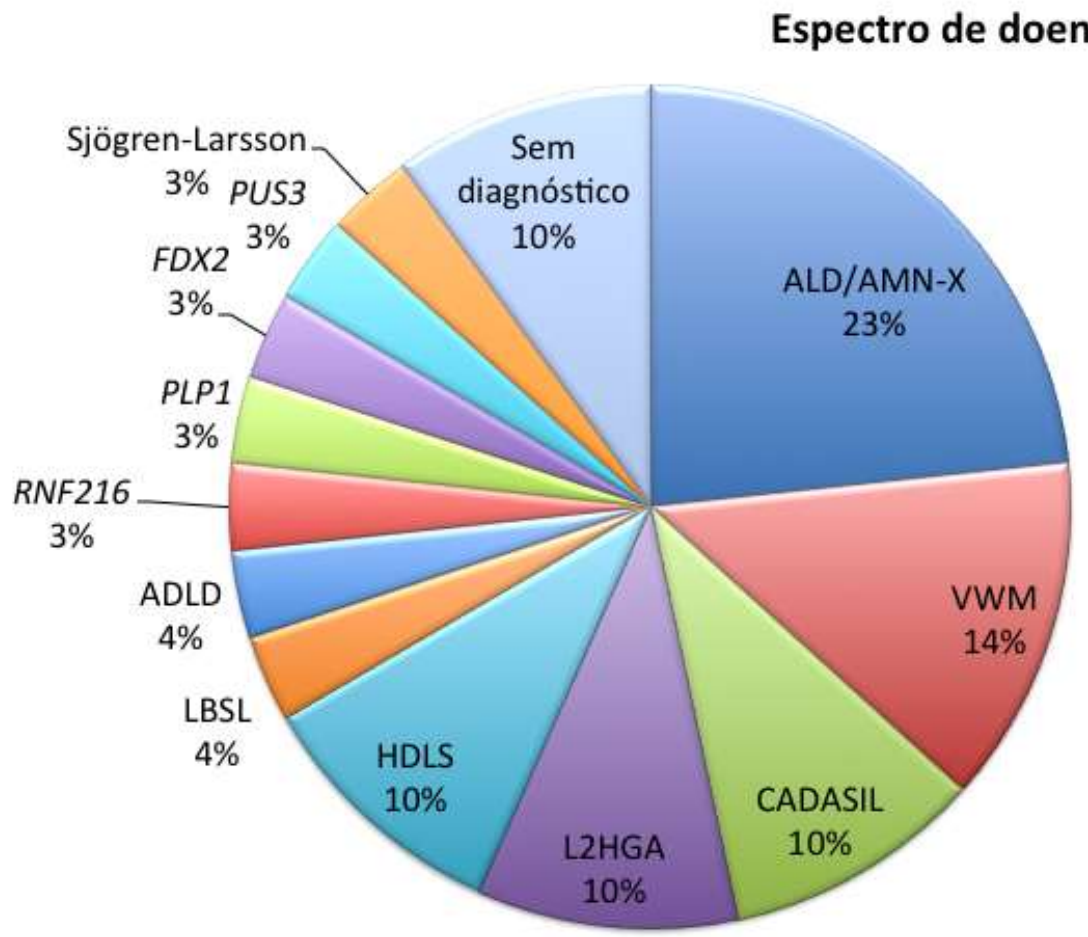

Figura 4 - Frequência dos diagnósticos entre os 31 probandos

Dentre os 38 pacientes incluídos, 23 tiveram idade de início dos sintomas após 16 anos de idade. Quatro tiveram idade de início após os 50 anos, sendo que dois deles não obtiveram diagnóstico definitivo. Dos 3 pacientes sem diagnóstico final, apenas uma teve idade de início dos sintomas antes dos 16 anos (aos três anos).

Dentre os 28 probandos com diagnóstico definitivo, oito (28\%) eram portadores de doenças autossômicas dominantes, 12 (42\%) eram portadores de doenças autossômicas recessivas e oito (28\%) eram portadores de doenças ligadas ao $\mathrm{X}$ (Figura 5). 


\section{Padrões de herança genética}

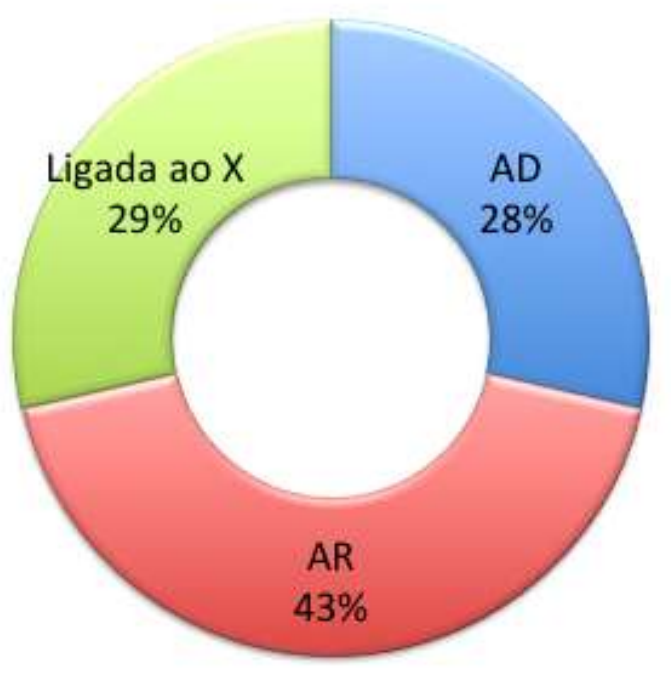

Figura 5 - Padrões de herança genética das doenças diagnosticadas

Em 14 probandos havia história familiar de outros indivíduos acometidos e em quatro havia história de consanguinidade explícita entre os pais, facilitando a hipótese de doença de origem genética.

Quadro 8 - Resultados da $1^{\mathrm{a}}$ etapa, na qual 13 pacientes obtiveram diagnóstico final (números referentes a probandos)

\begin{tabular}{|lll|}
\hline Pacientes com suspeita de: & & Confirmados \\
\hline ALD/AMN-X & 07 & 07 \\
L2HGA & 03 & 03 \\
ADLD & 02 & 01 \\
Doença de Alexander & 01 & 01 \\
Síndrome de Sjögren-Larsson & 01 & 01 \\
\hline Total & 14 & 13 \\
\hline
\end{tabular}


Quadro 9-Resultados das $2^{\mathrm{a}}$ e $3^{\mathrm{a}}$ etapas (números referentes a probandos)

\begin{tabular}{|c|c|c|c|c|}
\hline Pacientes com suspeita de... & & $\begin{array}{l}\text { Confirmados } \\
\text { na } 2^{\mathrm{a}} \text { etapa }\end{array}$ & $\begin{array}{c}\text { Diagnóstico final } \\
\text { alternativo }\end{array}$ & $\begin{array}{c}\text { Diagnóstico final } \\
\text { na } 3^{\text {a }} \text { etapa }\end{array}$ \\
\hline VWM & 06 & 04 & $R N F 216$ & \\
\hline CADASIL & 03 & 03 & & \\
\hline HDLS & 02 & 02 & & \\
\hline LBSL & 01 & 01 & & \\
\hline Labrune & 01 & - & HDLS & \\
\hline ADLD & 01 & - & & \\
\hline Total & 14 & 10 & 02 & \\
\hline \multicolumn{5}{|l|}{$\begin{array}{l}\text { Pacientes sem suspeita } \\
\text { diagnóstica prévia }\end{array}$} \\
\hline & 04 & & $P L P 1$ & PUS3 \\
\hline & & & & $F D X 2$ \\
\hline Total & 18 & 10 & 03 & 02 \\
\hline
\end{tabular}

\subsection{Espectro de doenças}

\subsubsection{Adrenoleucodistrofia/adrenomieloneuropatia ligada ao X}

Identificamos cinco pacientes com adrenomieloneuropatia $(1.1,2.1,3.1,4.1 \mathrm{e}$ 5.1) e três pacientes com adrenoleucodistrofia ligada ao $X(1.2,6.1$ e 7.1), oriundos de 7 famílias. Todos os pacientes deste grupo tiveram confirmação diagnóstica pela presença de elevação do AGCML. Infelizmente não foi possível realizar a análise molecular dos pacientes deste grupo. 


\subsubsection{Adrenomieloneuropatia ligada ao $\mathrm{X}$}

\subsection{Adrenomieloneuropatia ligada ao $\mathrm{X}$ - aspectos clínicos}

A idade média de início dos sintomas foi de 16,4 anos (extremos: 2 a 30 anos), sendo que dois pacientes tiveram início dos sintomas antes dos 16 anos.

A manifestação neurológica inicial em todos estes pacientes foi alteração de marcha. No entanto, três deles relataram manifestações não-neurológicas que antecederam o transtorno de marcha - dois apresentavam alopecia e um (5.1) apresentava dores articulares em membros inferiores quatro anos antes do início da alteração de marcha.

Apenas um paciente (3.1) apresentava queixas cognitivas, com dificuldade de organização e execução de tarefas mais complexas, como cuidar das próprias finanças, mas sem maiores repercussões funcionais. $\mathrm{Na}$ avaliação formal apresentava disfunção executiva e comportamento impulsivo e um pouco infantilizado, mas tinha memória, linguagem, praxias e habilidades visuoespaciais preservadas. Interessante notar que este paciente era o que apresentava maior tempo de evolução da doença (25 anos) no momento da avaliação. Este mesmo paciente tinha antecedente de transtorno depressivo maior e sofria de transtorno de ansiedade - também observado nos pacientes 1.1 e 4.1 .

Dentre os cinco pacientes com AMN-X, três apresentavam marcha em tesoura com componente talonante sobreposto, um apresentava marcha em tesoura sem ataxia sensitiva associada (5.1) e um, o paciente 3.1, tornara-se cadeirante após 23 anos de evolução da doença.

Os cinco pacientes apresentavam síndrome piramidal com espasticidade e reflexos tendinosos profundos exaltados em MMII, bem como sinal de Babinski bilateralmente. Apenas um paciente (4.1) tinha reflexos aquileus abolidos. Todos tinham reflexos vivos em MMSS, exceto o paciente 5.1, que os tinha hipoativos.

Três pacientes $(1.1,2.1$ e 4.1) apresentavam ataxia sensitiva de predomínio axial e em MMII, caracterizada pelas presenças do sinal de Romberg e do componente talonante da marcha.

Os cinco pacientes apresentavam sinais de polineuropatia sensitiva crônica em MMII, sendo que os pacientes 3.1 e 5.1 apresentavam apenas comprometimento 
da sensibilidade vibratória. Já os demais apresentavam perda das sensibilidades superficiais e profundas.

Nenhum paciente apresentava alterações em nervos cranianos. Apenas o paciente 2.1 não tinha queixas esfincterianas, enquanto dois se queixavam de urgeincontinência urinária (1.1 e 3.1) e dois de retenção urinária (4.1 e 5.1).

Três pacientes relataram crises convulsivas tônico-clônicas generalizadas, com pouquíssimos eventos ao longo da vida, com fácil controle medicamentoso.

Os cinco pacientes apresentavam insuficiência adrenal cortical e estavam em tratamento, exceto um (4.1), que apresentava insuficiência adrenal subclínica. Um deles (5.1) já havia apresentado sintomas clínicos (fadiga, hipotensão e hipoglicemia) e três apresentavam hiperpigmentação (1.1, 2.1 e 5.1). Um paciente (4.1) apresentava oligospermia e azospermia, sugerindo insuficiência testicular. Os demais não foram investigados para este fim.

Todos apresentavam quadro lentamente progressivo, sendo que o paciente 1.1 passou a usar muletas após 10 anos de evolução e o paciente 3.1 tornou-se cadeirante após 23 anos de evolução. O paciente 4.1 teve uma evolução atípica, com quadro relativamente estável por muitos anos. Entre dois e 28 anos apresentava marcha em tesoura e quedas frequentes, mas não notava piora progressiva. A partir daí houve piora progressiva, necessitando de apoio para deambular após os 31 anos. Os pacientes 2.1 e 5.1 ainda eram capazes de deambular sem qualquer auxílio no momento da avaliação.

Nenhum paciente deste grupo realizou EEG e apenas o paciente 4.1 foi submetido a ENMG, que mostrou polineuropatia axonal motora crônica.

\subsection{Adrenomieloneuropatia ligada ao $X-$ aspectos neurorradiológicos}

A RM de crânio foi normal em dois pacientes (1.1 e 2.1). Os outros três pacientes apresentavam apenas hipersinal em T2 e FLAIR em substância branca junto aos átrios e cornos occipitais de ambos os ventrículos laterais, sem restrição à difusão e sem impregnação pelo gadolínio. O paciente 4.1 apresentava predomínio frontal das lesões e ainda apresentava uma lesão expansiva nas porções inferiores do IV ventrículo, sugestiva de ependimoma (Figura 6). 


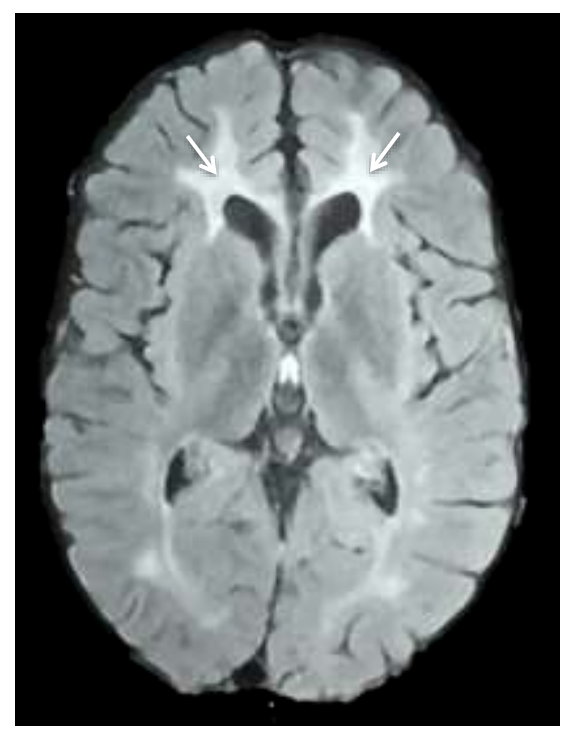

Figura 6 - RM de crânio do paciente 4.1. Acometimento de substância branca de predomínio frontal (setas), visto no axial FLAIR

Quatro pacientes realizaram RM de colunas cervical e torácica, sendo que em dois os exames foram normais (4.1 e 5.1) e dois apresentaram afilamento de medula torácica (1.1 e 2.1). Nestes observou-se tênue hipersinal em T2 nos tratos corticoespinhais bilateralmente, também no segmento torácico.

\subsubsection{Adrenoleucodistrofia ligada ao X}

Identificamos três pacientes com ALD-X, sendo que dois (6.1 e 7.1) tiveram os primeiros sintomas antes dos 16 anos. Ambos tinham um quadro bastante típico da chamada forma cerebral de ADL-X da infância.

5.1.1.3.1 Adrenoleucodistrofia ligada ao $\mathrm{X}$ - casos típicos - aspectos clínicos

Estes dois pacientes tiveram como manifestações iniciais alterações de aprendizagem, inicialmente atribuídas a transtorno de déficit de atenção e hiperatividade. Posteriormente evoluíram com com síndrome piramidal de liberação e deficitária, declínio cognitivo progressivo, sinais de polineuropatia periférica 
sensitivo-motora e perda visual progressiva. Ambos apresentavam epilepsia com crises focais e generalizadas, facilmente controladas com fármacos antiepilépticos.

Também apresentavam síndrome de Addison e um deles apresentava alopecia. O paciente 7.1 apresentou aos 12 anos de idade aumento indolor do volume testicular, seguido de redução volumétrica até ficar praticamente indectável sugerindo insuficiência testicular.

O paciente 6.1 tornou-se cadeirante mais precocemente, após 3 anos de doença, mas ainda era capaz de ir para as consultas em cadeira de rodas e interagir minimamente com o examinador após 19 anos de doença. Já o paciente 7.1 tornou-se cadeirante após 7 anos, mas em 9 anos já estava restrito ao leito, em mutismo acinético.

Avaliação por EEG mostrou desorganização difusa da atividade elétrica cerebral, sem atividade epileptiforme. Não foram submetidos à ENMG.

5.1.1.3.2 Adrenoleucodistrofia ligada ao $\mathrm{X}$ - casos típicos -aspectos neurorradiológicos

Ambos apresentavam alterações de RM de crânio muito semelhantes, com hipersinal em T2 e FLAIR acometendo simetricamente substância branca temporoparietooccipital bilateral. Havia acometimento de tratos corticoespinhais se estendendo para ramos posteriores de ambas as cápsulas internas e pedúnculos cerebrais. Notava-se acometimento de radiações ópticas e esplênio e corpo do corpo caloso (Figura 7). Curiosamente não apresentavam impregnação pelo gadolínio, nem tampouco restrição à difusão.

Ambos realizaram RM de colunas cervical e torácica que foram normais. 


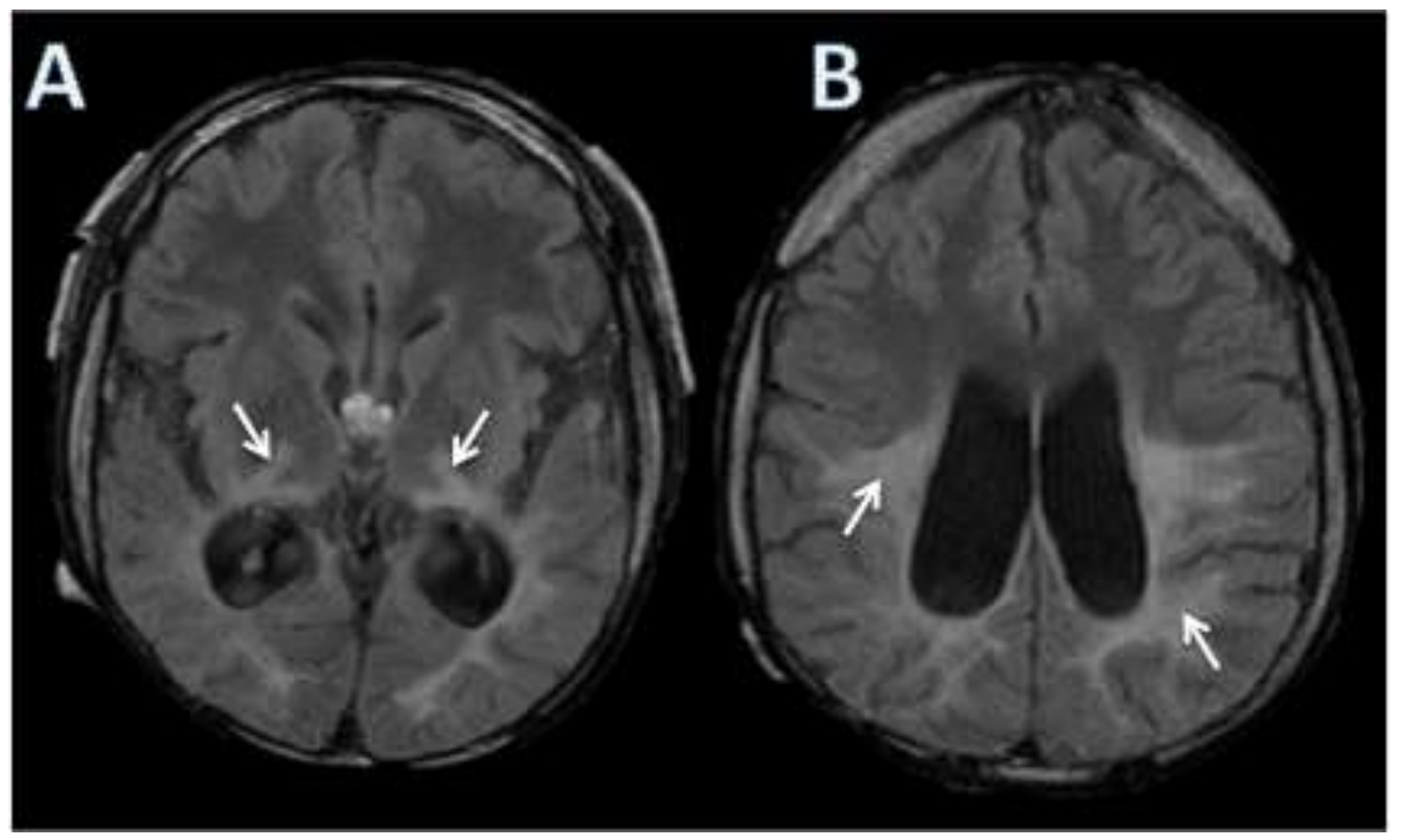

Figura 7 - Imagem axial FLAIR do paciente 7.1 mostrando acometimento de perna posterior de ambas as cápsulas internas (setas em A) e hipersinal em substância branca de predomínio parieto-occipital bilateral (setas em B). Há ainda aumento dos cornos posteriores dos ventrículos laterais

\subsection{Adrenoleucodistrofia ligada ao X - um caso atípico}

Já o paciente 1.2 teve uma apresentação clínica bastante peculiar, com predomínio das manifestações cognitivo-comportamentais, mas tendo como primeiro sintoma inequívoco da doença uma crise epiléptica tônico-clônica generalizada aos 28 anos. No entanto, já apresentava alterações comportamentais prévias, com impulsividade, etilismo, tabagismo, uso de drogas ilícitas, comportamento antissocial e humor deprimido desde a adolescência.

Pouco antes de apresentar a primeira crise epiléptica, apresentara delírios paranoides persecutórios, e desde então evoluiu com esquecimentos frequentes para fatos recentes e grande dificuldade de organização e manutenção da atenção. Dois anos antes da primeira crise epiléptica sofreu traumatismo cranioencefálico em acidente automobilístico. Seu exame neurológico era normal, exceto por disfunção executiva e certo embotamento afetivo com perda da prosódia durante o discurso.

Os achados da RM de crânio deste paciente também eram surpreendentes e pouco usuais em pacientes com ALD-X. Em seu primeiro exame já apresentava 
extensa área de hipersinal em T2 e FLAIR em substância branca fronto-parietotêmporo-occipital direita, com realce linear e periférico com restrição à difusão e impregnação pelo gadolínio. Havia ainda hipersinal no trajeto do trato corticoespinhal direito, no ramo posterior da cápsula interna (Figura 8).

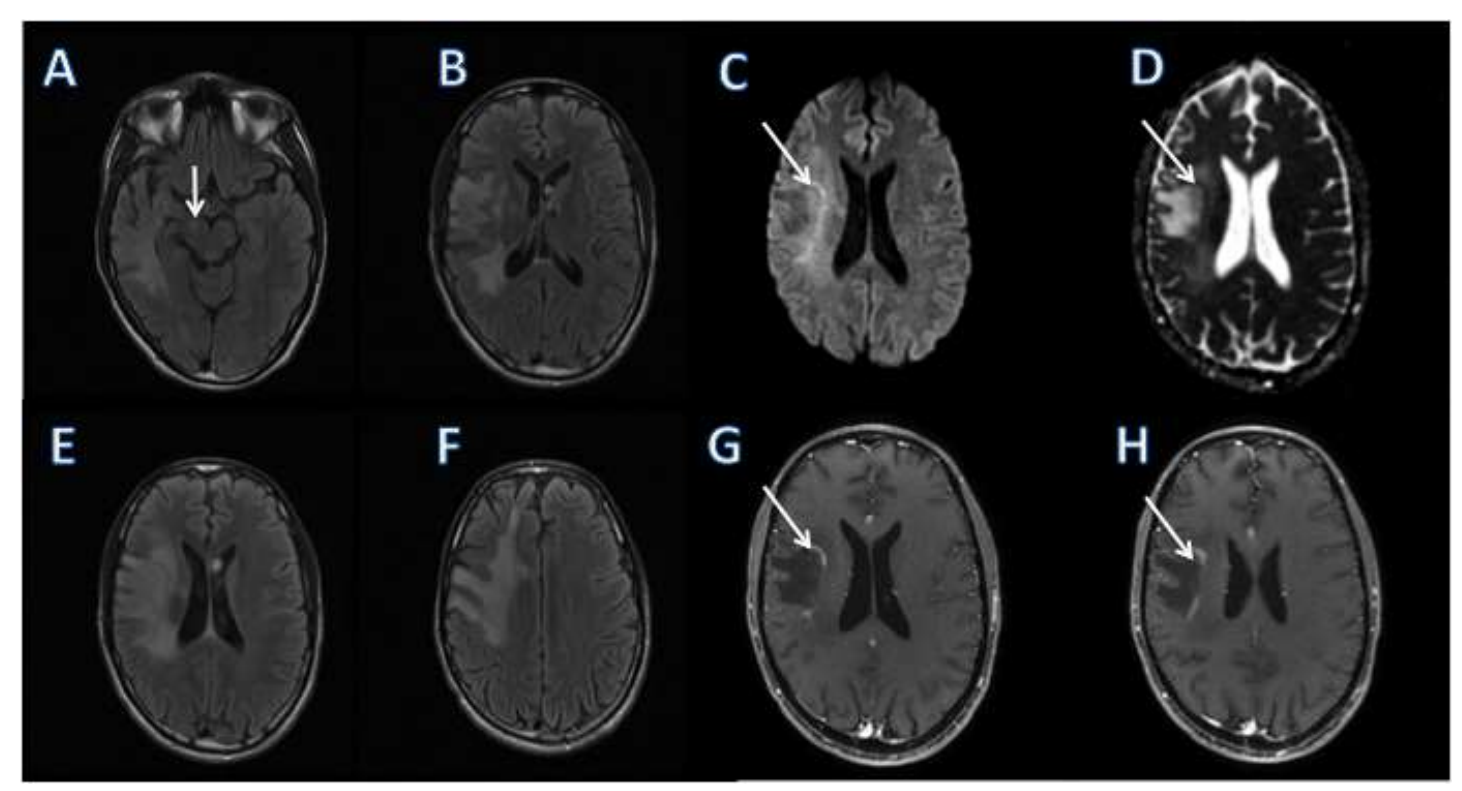

Figura 8 - Paciente 1.2 com ALD-X de apresentação assimétrica relacionada a trauma em região parietal direita. Imagens do primeiro estudo de RM de cranio, sequências axiais FLAIR mostrando acometimento difuso à direita (A, B, E, F), inclusive em trato corticoespinhal se estendendo até pedúnculo cerebral direito (seta em $\mathrm{A})$. Restrição periférica à movimentação das moléculas de água (hipersinal na difusão em $\mathrm{C}$ e correspondente hipossinal em ADC em D, setas) e impregnação periférica e descontínua pelo gadolínio (setas em $\mathrm{G} \mathrm{e} \mathrm{H}$ )

Uma nova RM de crânio obtida três anos depois mostrava aumento da área de hipersinal em T2 e FLAIR, se extendendo para joelho, corpo e esplênio do corpo caloso, bem como hipocampo e amigdala direita e centro semioval esquerdo. Foram realizadas $\mathrm{RM}$ de colunas cervical e torácica que estavam normais.

O EEG deste paciente mostrava desorganização difusa da atividade elétrica cerebral, mais evidente em hemisfério direito, e paroxismos de ondas agudas em região posterior direita. Apresentava ainda insuficiência adrenal subclínica. Não realizou ENMG e teve seu diagnóstico confirmado pela dosagem dos AGCML 


\subsubsection{Doença da substância branca evanescente}

Identificamos cinco pacientes, pertencentes a quatro famílias, com VWM, todos com confirmação genética.

\subsubsection{Doença da substância branca evanescente - aspectos clínicos}

A idade média de início dos sintomas foi de 34,6 anos (extremos: 20 a 52 anos) e todos os pacientes apresentaram declínio cognitivo, síndrome piramidal e ataxia cerebelar.

O declínio cognitivo manifestou-se inicialmente por disfunção executiva, frequentemente acompanhada de manifestações psiquiátricas como ansiedade, irritabilidade ou apatia. Aqueles com comprometimento mais grave também apresentaram apraxia e amnésia anterógrada e parcialmente retrógrada. Foi uma manifestação precoce nos três homens de nossa casuísta e ficou evidente nas duas mulheres apenas depois de cerca de 10 anos de evolução.

Todos apresentaram síndrome piramidal de liberação com reflexos tendinosos profundos exaltados, principalmente em membros inferiores, e sinal de Babinski em 4/5. Déficit de força foi observado em $3 / 5$ pacientes e nos três foi assimétrico. Espasticidade estava presente em três pacientes e dois pacientes apresentavam paratonia. Uma paciente (10.1) apresentava reflexos aquileus abolidos e flacidez distal, sugerindo possível neuropatia periférica associada (não comprovada por ENMG).

Os achados de incoordenação também foram assimétricos e em geral leves dismetria, decomposição de movimento, tremor de intenção e marcha atáxica (apenas dois pacientes). Um paciente (9.1) ainda apresentava distonia de membros superior esquerdo e um paciente apresentava discreta bradicinesia.

O exame das sensibilidades foi pouco fidedigno em dois pacientes (pelo déficit cognitivo) e normal nos outros três. Em dois pacientes observamos sacadas hipométricas e seguimento sacádico e em uma paciente observamos palidez de papila óptica. Disartria estava presente em $2 / 5$ pacientes.

Três pacientes apresentavam epilepsia, em geral de fácil controle e três apresentavam alterações do sono (insônia inicial). Uma das duas mulheres 
apresentou menopausa precoceaos 38 anos e a outra, que teve os primeiros sintomas da doença aos 52 anos, teve menopausa aos 45 anos.

Quatro pacientes (indivíduos 8.1, 9.1, 10.1 e 10.2) apresentaram os primeiros sintomas após traumatismo cranioencefálico. As manifestações iniciais foram diversas: coma após traumatismo cranioencefálico, quedas, déficit motor, crise epiléptica, amnésia anterógrada e neuralgia do trigêmeo. Apenas um paciente relatou piora episódica dos sintomas associada a dias quentes.

Todos apresentaram evolução lentamente progressiva, com aceleração da piora após traumatismo crânio encefálico em três. Apenas a paciente com maior tempo de duração da doença (26 anos) era cadeirante e os demais eram capazes de deambular sem apoio, embora com alterações da marcha (espástica e/ou atáxica).

A mediana de tempo decorrido entre os primeiros sintomas e o diagnóstico definitivo foi de 7 anos e o tempo mais longo foi de 26 anos. Uma paciente (indivíduo 11.1), cuja a manifestação inicial foi neuralgia do trigêmeo iniciado aos 52 anos, teve diagnóstico prévio de esclerose múltipla e recebeu tratamento com imunomodulador por cerca de 10 anos até a suspeita de um diagnóstico alternativo.

Apenas um paciente era filho de pais sabidamente consanguíneos. Em outras duas famílias, provenientes de cidades pequenas (número de habitantes inferior a 10.000), suspeitamos de consanguinidiade não-explícita.

Os exames laboratoriais e a análise do líquor não mostraram alterações relevantes em nenhum dos nossos pacientes.

O EEG foi realizado em três pacientes (10.1, 10.2 e 11.1), sendo normal em um (10.2) e mostrando desorganização difusa em dois (10.1 e 11.1). Nenhum paciente deste grupo foi submetido a avaliação por ENMG.

\subsubsection{Doença da substância branca evanescente - aspectos neurorradiológicos}

A RM de crânio mostrou em todos os casos hipersinal confluente em T2/FLAIR com correspondente hipossinal em T1, com predomínio periventricular e nos lobos frontais e parietais. Todos apresentaram rarefação da substância branca, com sinal em T2/FLAIR se aproximando do sinal do líquor. Também apresentaram cistos em geral periventriculares, mais comumente adjacentes aos cornos anteriores 
dos ventrículos laterais. Havia ainda atrofia cortical e afilamento de corpo caloso. Apenas em dois pacientes (10.2 e 11.1) observamos hipersinal em ponte e bulbo e apenas em um paciente observamos alteração de sinal em substância branca cerebelar (10.2). A Figura 9 mostra o aspecto característico da doença observado no FLAIR.

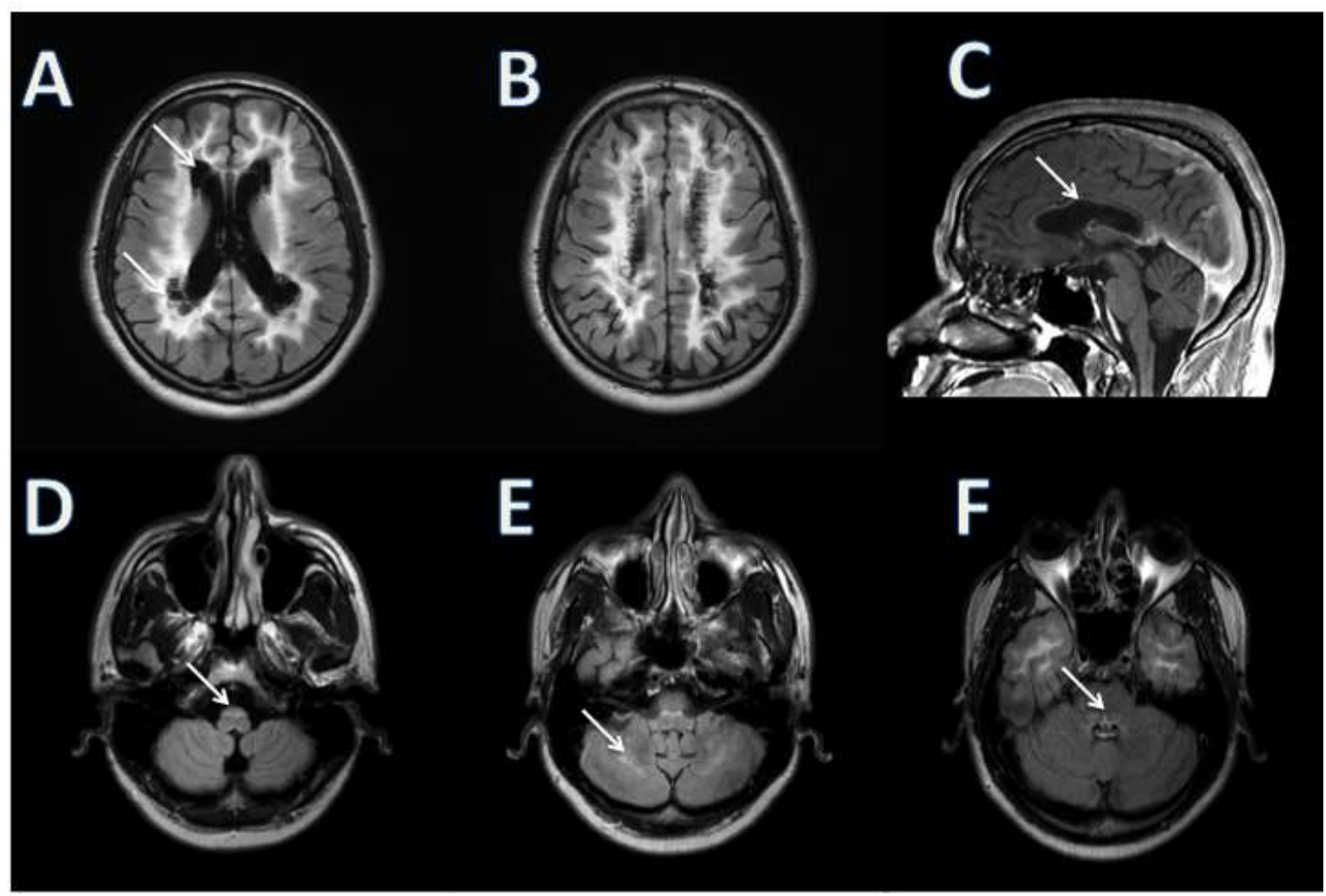

Figura 9 - Paciente 10.2 com VWM. Axial FLAIR em A mostrando acometimento difuso de substância branca com cistos periventriculares (setas em A); rarefação da substância branca visualizada em axial FLAIR (B); corpo caloso fino (C); hipersinal em FLAIR em topografia de olivas bulbares (D); hipersinal em substância branca cerebelar (E); hipersinal em ponte e lobos temporais $(\mathrm{F})$

\subsubsection{Doença da substância branca evanescente - aspectos genéticos}

O DNA dos pacientes 8.1, 9.1, 10.1 e 11.1 foi avaliada por exoma clínico e foram encontradas variantes patogênicas em EIF2B4 (paciente 10.1) e EIF2B5 nos demais. Todos pacientes deste grupo tinham a suspeita clínica de VWM antes da análise molecular. Os pacientes 8.1 e 9.1 carreavam a mesma variante patogênica em 
homozigose por troca simples de aminoácido, p.Arg113His, já previamente descrita (Leegwater et al., 2001). Estudos funcionais já demonstraram que esta variante patogênica em homozigose reduz a atividade da proteína eIF2 (Liu et al., 2011). Embora não sabidamente aparentados, ambos eram provenientes da mesma região (interior do estado da Bahia).

Esta mesma variante estava presente na paciente 11.1, em heterozigose composta. Já a segunda, por troca simples de aminoácido, é uma variante nova que os modelos de predição apontam como patogênica, promovendo a substituição de metionina por leucina em um resíduo conservado da proteína.

A paciente 10.1 era heterozigota composta para variantes patogênicas em EIF2B4. A primeira variante (c.[495+3delA], segundo os modelos de predição, afeta sítio de reformatação do RNAm. A variante p.Arg208Gln consiste em uma troca simples de aminoácido em um resíduo semiconservado, já tendo sido reportada em homozigose (Fogli et al., 2004) e em heterozigose composta (Ohlenbusch et al., 2005).

Os dados destes pacientes integram a série descrita no artigo que publicamos em parceria com o Departamento de Neurogenética da University College London (Lynch et al., 2017).

\subsubsection{Acidúria L2-hidroxiglutárica}

Identificamos quatro pacientes (03 famílias) com acidúria L2hidroxiglutárica, todos com evidências bioquímicas e posterior confirmação genética.

\subsubsection{Acidúria L2-hidroxiglutárica - aspectos clínicos}

Os quatro pacientes apresentavam história e evolução bastante semelhantes. Todos apresentaram os primeiros sintomas no primeiro ano de vida, com atraso do desenvolvimento neuropsicomotor, mas foram capazes de atingir os marcos motores do desenvolvimento. O paciente 13.1 teve como primeira manifestação postura anormal do pescoço por volta de 10 meses de vida e somente depois o atraso do desenvolvimento ficou mais evidente. 
Tornaram-se adultos com deficiência intelectual significativa, mas capazes de participar minimamente da vida familiar, comunicar-se com vocabulário restrito, ajudar em pequenos afazeres domésticos e realizarem atividades básicas da vida diária com o mínimo auxílio. Três dos quatro pacientes necessitaram pelo menos em algum momento de medicações antipsicóticas para controle comportamental de agressividade e irritabilidade excessivas.

Além do quadro cognitivo-comportamental, todos apresentavam ataxia cerebelar leve, axial e apendicular, e disartria. Os paciente 13.1 e 14.1 apresentavam marcha atáxica e base alargada ao assumir ortostase, sem sinal de Romberg. A paciente 14.2 apresentava marcha em tesoura e a paciente 15.1 já era acamada à época da avaliação.

Síndrome piramidal caracterizada por reflexos tendinosos profundos exaltados, espasticidade em MMII e sinal de Babinski estava presente em 3/4 pacientes. Epilepsia de início ainda na infância, com crises focais e generalizadas, em geral de fácil controle com apenas um fármaco antiepiléptico também esteve presente em três pacientes.

Movimentos anormais foram identificados em três pacientes. O paciente 13.1 apresentava hemidistonia à esquerda e retrocolo. Era o único que encontrava-se em uso de antipsicótico no momento da avaliação. A paciente 14.2 apresentava tremor cefálico intermitente em negação e distonia em mãos associada a careteamento facial. Já sua irmã (paciente 14.1) apresentava apenas careteamento facial. A paciente 15.1 também apresentava distonia em mãos e careteamento facial, mas sem tremor cefálico.

Todos apresentaram evolução estável, sem nítida piora do quadro na vida adulta, exceto pela paciente 15.1. Esta, aos 45 anos, evoluiu com afasia de expressão e hemiparesia direita completa secundária a glioblastoma multiforme. A família optou por tratamento paliativo e perdemos o seguimento desta paciente.

Os exames laboratoriais e o líquor não mostravam alterações relevantes, exceto pela espectrometria de massa de ácidos orgânicos na urina, que em todos os pacientes trazia o aumento significativo do ácido 2-hidroxiglutárico - sem, entretanto, discriminar seu enantiômero. 
O EEG foi realizado apenas nas pacientes 14.1 e 14.2. Ambas apresentaram desorganização difusa da atividade elétrica cerebral com predomínio de ondas teta, sendo que a paciente 14.2 apresentava ainda surtos de ondas delta de até $1,3 \mathrm{~Hz}$ de projeção generalizada.

\subsubsection{Acidúria L2-hidroxiglutárica - aspectos neurorradiológicos}

A RM de crânio foi bastante característica em todos os casos, com hipersinal multifocal subcortical em todos os lobos, poupando substância branca periventricular e com hipersinal em núcleos denteados e por vezes em globos pálidos e cápsula interna (Figura 10). Todos apresentaram certo grau de redução volumétrica. Espectroscopia foi obtida de apenas uma paciente e mostrou discreto aumento de mioinositol e redução de Naa (denotando redução da população neuronal) um achado pouco específico, mas que pode estar relacionado à gliose. A paciente 15.1 apresentou glioblastoma multiforme na evolução (Figura 11). 


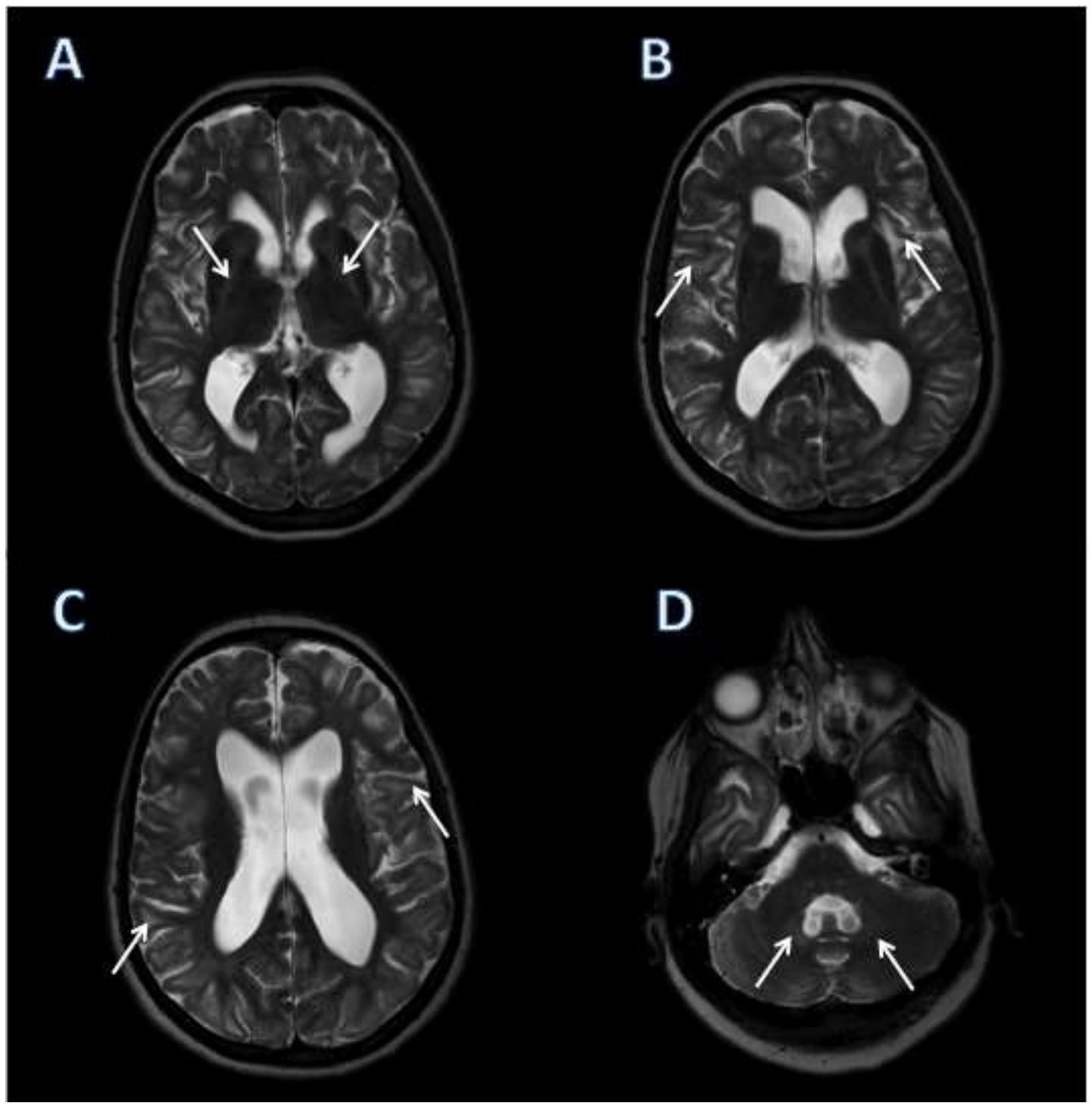

Figura 10 - Paciente 14.1 com diagnóstico de L2HGA. Imagens axiais ponderadas em T2 mostrando acometimento difuso da substância branca com predomínio subcortical e relativa preservação da substância branca periventricular (A-C). Notar hipersinal em cápsulas internas (setas em A), acometimento de fibras em "U" (setas em B e C) e hipersinal nos núcleos denteados (setas em D) 


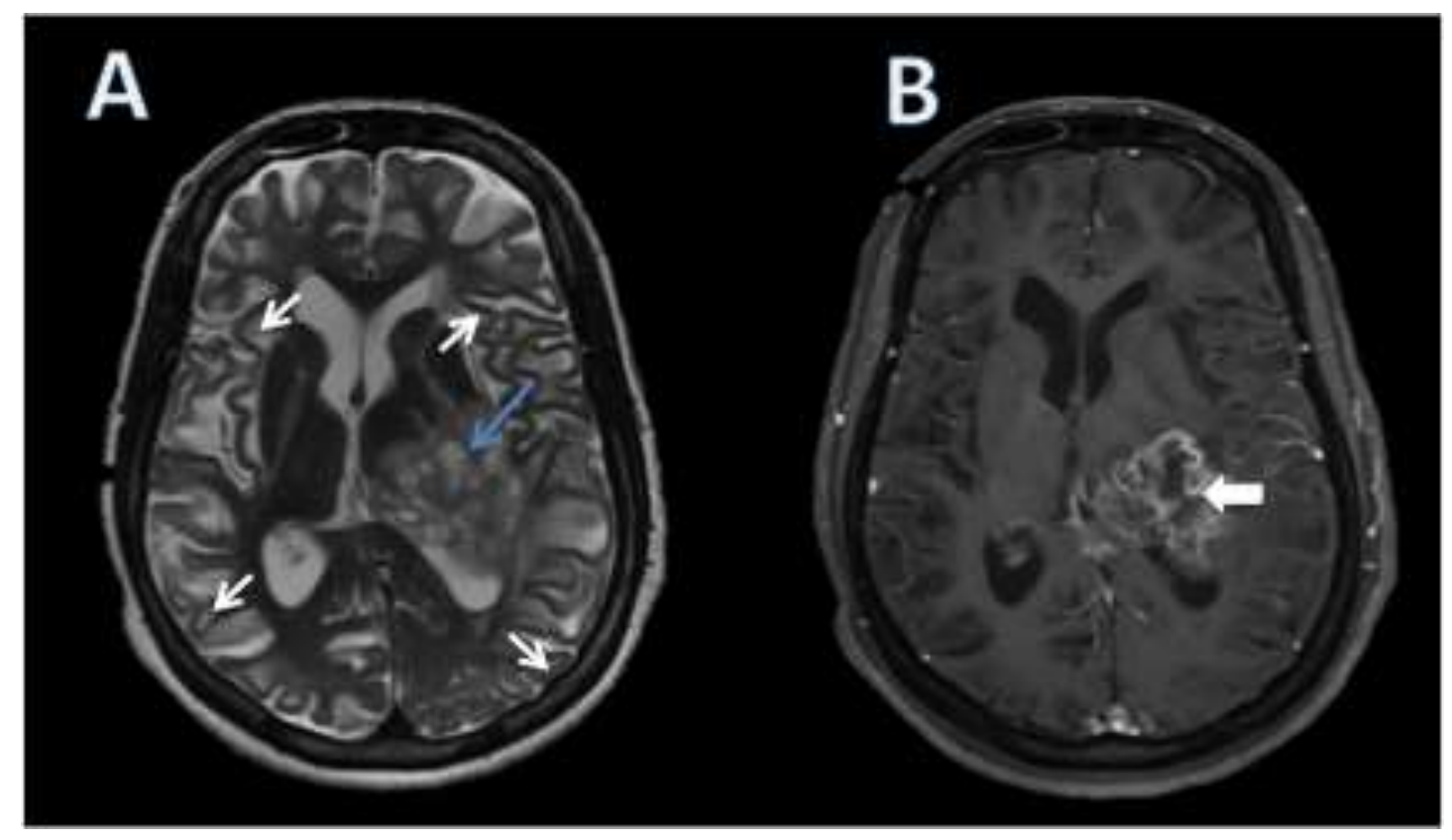

Figura 11 - Paciente 15.1 com diagnóstico de L2HGA. Em A axial T2 mostrando hipersinal difuso com predomínio subcortical (setas brancas) e processo expansivo núcleo-capsular esquerdo (seta azul), heterogêneo, com impregnação pelo gadolínio (mostrado em B, seta)

\subsubsection{Acidúria L2-hidroxiglutárica - aspectos genéticos}

A análise molecular mostrou que os pacientes 13.1 e 15.1 tinham a mesma variante em homozigose, c.530delC/p.Pro177fs, já descrita em população de descendência portuguesa (Vilarinho et al., 2005). A paciente 14.1 era homozigota para a variante patogênica por troca simples de aminoácido p.Gly211Val, já descrita por Steenweg et al. em 2010.

\subsubsection{Leucoencefalopatia difusa hereditária com esferóides}

Identificamos três pacientes com HDLS, todas do sexo feminino, sendo a idade de início as seguintes: 38, 47 e 50 anos. Apenas uma paciente tinha outro familiar acometido (irmão) e as demais eram casos esporádicos. 


\subsubsection{Leucoencefalopatia difusa hereditária com esferóides - aspectos clínicos}

As manifestações iniciais foram diferentes em cada uma: amnésia anterógrada; alteração comportamental e dor e diminuição de força em membro inferior direito. No entanto, as três apresentaram síndrome cognitivo-comportamental caracterizada por disfunção executiva, certa desinibição social, perda da crítica e apatia. As três também apresentaram insônia inicial.

Um sintoma que chamou a atenção na paciente 16.1 foi a significativa hiporexia e emagrecimento desde os primeiros sintomas. Familiares observaram que o irmão também apresentou quadro semelhante de início na sexta década de vida, com disfunção executiva e emagrecimento. Cerca de 3 anos após as primeiras manifestações, o irmão já se encontrava em mutismo acinético. Não tivemos oportunidade de examiná-lo e o mesmo faleceu após 3 anos de evolução da doença.

Em contrapartida, a paciente 17.1 apresentou ganho ponderal após o início da doença e a paciente 18.1 não teve alterações apreciáveis de peso no primeiro ano de doença.

A paciente 16.1 apresentava também enxaqueca com aura, o que não foi observado nas demais pacientes.

O exame neurológico das pacientes 16.1 e 17.1, além das alterações cognitivo-comportamentais, mostrava apenas uma leve redução do balanço passivo de uma dos membros superiores. A paciente 16.1 também apresentava leve assimetria de reflexos.

Já a paciente 18.1 teve uma evolução completamente diferente, mais rápida e com grave comprometimento motor. Houve perda progressiva de força inicialmente assimétrica que evoluiu para tetraparesia espástica, "dropped-head", disartria e síndrome cognitivo-comportamental. Após um ano dos primeiros sintomas já era cadeirante. Três anos após, foi submetida à confecção de gastrostomia e quatro anos após estava em mutismo acinético. Nesta fase apresentava tremor palatal síncrono com movimentos oculares nistagmóides e palidez de papila óptica bilateral. Foi a óbito após cinco anos de doença.

Os exames laboratoriais e a análise do líquor não mostraram alterações relevantes em nenhuma das três pacientes. 
O EEG da paciente 18.1 mostrava desorganização difusa assimétrica da atividade elétrica cerebral com predomínio de ondas teta. As demais pacientes não realizaram EEG. Nenhuma paciente deste grupo foi submetida a ENMG.

\subsubsection{Leucoencefalopatia difusa hereditária com esferóides - aspectos neurorradiológicos}

As RM de crânio das três pacientes mostraram hipersinal multifocal em T2/FLAIR assimétrico em lobos frontal e parietal, com frequente acometimento de corpo caloso e de trato corticoespinhal. Em 2/3 pacientes havia restrição à difusão das moléculas de água e pequenas calcificações esparsas. Apenas uma paciente, a mais grave, apresentava cavitações e nenhuma teve impregnação pelo gadolínio (Figuras 12 e 13).

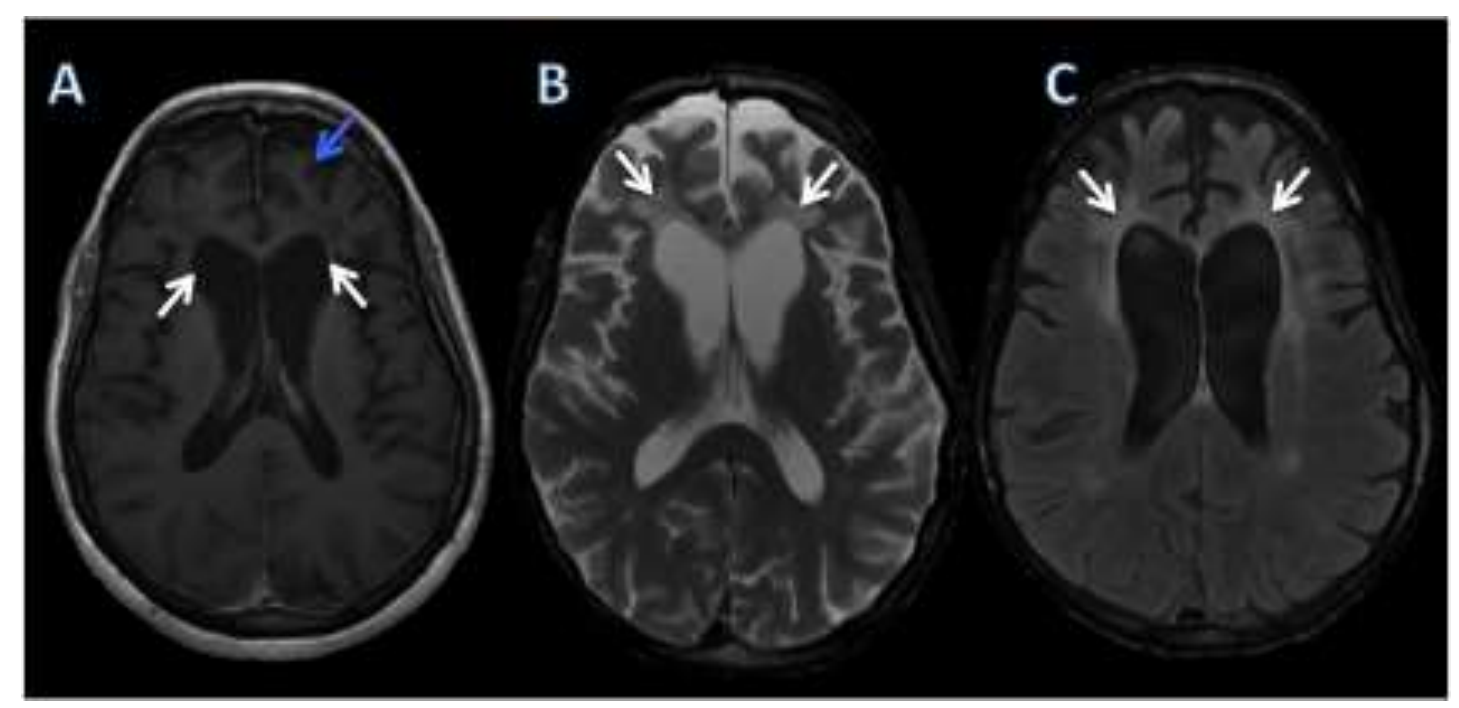

Figura 12 - Paciente 17.1 com diagnóstico de HDLS. Em A, axial T1 mostrando dilatação dos cornos anteriores dos ventrículos laterais (setas brancas) e atrofia cortical frontal assimétrica (seta azul), com hipossinal de substância branca; em B axial T2 e em C axial FLAIR, ambos mostrando hipersinal de substância branca frontal bilateral (setas) 

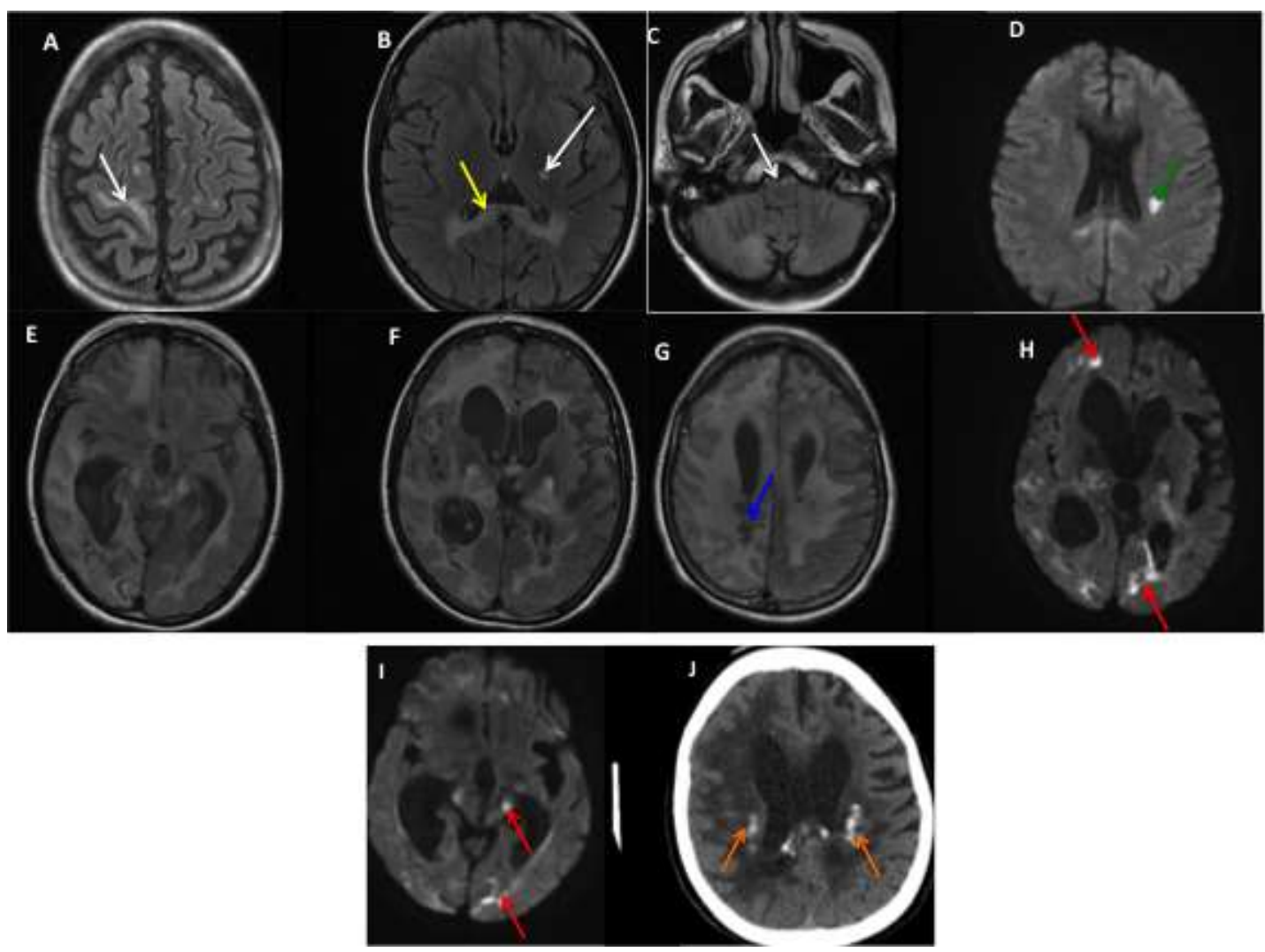

Figura 13 - Paciente 18.1 com diagnóstico de HDLS. Axial FLAIR (A-C) após 01 ano do início dos sintomas, mostrando hipersinal da substância branca com exuberante envolvimento dos trato corticoespinhais, principalmente o esquerdo, até o nível da decussação das pirâmides (setas brancas), além de acometimento de esplênio do corpo caloso (seta amarela). Em D observa-se restrição à difusão das moléculas de água no trato corticoespinhal esquerdo (seta verde). Nova RM do encéfalo (E-I) no quarto ano de evolução da doença mostra significativa progressão das lesões. Axial FLAIR (E-G) mostram proeminência dos ventrículos supratentoriais e hipersinal difuso da substância branca, predominantemente no hemisfério cerebral direito. Há áreas de sinal semelhante ao do líquor, com conteúdo discretamente hiperprotéico, dispersas, com certa distribuição venular, sugerindo áreas císticas/cavitadas (setas azuis). Apresentava ainda porções com restrição à difusão de moléculas de água (setas vermelhas em H-I) e calcificações esparsas, melhor visualizadas em TC de crânio (setas laranjas em $\mathbf{J}$ ) 


\subsubsection{Leucoencefalopatia difusa hereditária com esferóides - aspectos genéticos}

As pacientes 16.1 e 18.1 foram diagnosticadas por exoma clínico e a paciente 17.1 já havia realizado WES no CEGH antes da inclusão no estudo. Foram identificadas três variantes patogênicas nunca previamente descritas:1. c.2427_2428delCA/p.Ile810fs*19; 2. c.2654+1G>T/? e 3. c.2570C>T/p.Pro857Leu).

\subsubsection{CADASIL}

Identificamos três pacientes portadores de CADASIL.

\subsubsection{CADASIL - aspectos clínicos}

A idade de início dos sintomas variou de 30 a 37 anos (média 34,3 anos). Em 2/3 pacientes a história familiar sugeria herança autossômica dominante e a $3^{\text {a }}$ paciente era a única acometida de sua família.

Todos pacientes apresentaram acidentes vasculares encefálicos isquêmicos e apresentavam sinais focais correspondentes aos mesmos no exame clínico. Dois pacientes apresentavam enxaqueca com aura. Um deles (paciente 19.1) era pouco responsivo aos tratamentos habituais apresentava muitas vezes aura motora prolongada. A outra paciente (21.1) apresentava aura visual e sensitiva.

Os três apresentavam síndrome cognitiva com predomínio de disfunção executiva, mas também prejuízo de memória episódica. Interessante notar que dois pacientes mantinham-se independentes para atividades instrumentais da vida diária após 12 anos de evolução e um (paciente 19.1) estava totalmente dependente de terceiros após 10 anos de evolução.

O paciente 20.1 recebeu o diagnóstico de forame oval patente e foi submetido ao tratamento cirúrgico do mesmo como forma de prevenir novos eventos isquêmicos. No entanto, tais eventos continuaram ocorrendo.

Os exames laboratoriais e do líquor não mostraram alterações relevantes em nenhum dos casos.

O EEG foi normal em dois indivíduos e no caso 21.1 apresentava surtos de ondas lentas de projeção temporal esquerda. 
Nenhum paciente deste grupo foi submetido a ENMG.

\subsubsection{CADASIL - aspectos neurorradiológicos}

A RM de crânio mostrou hipersinal multifocal em T2/FLAIR compatível com lacunas isquêmicas e microangiopatia (Figura 14). Quando realizada na fase aguda de um novo déficit, mostrou restrição à difusão das moléculas de água.

Observamos também lesões em núcleos da base e dois pacientes apresentavam sinais de micro-hemorragias. Os três apresentavam hipersinal de cápsula externa e um paciente (19.1) não apresentava hipersinal em polos temporais.

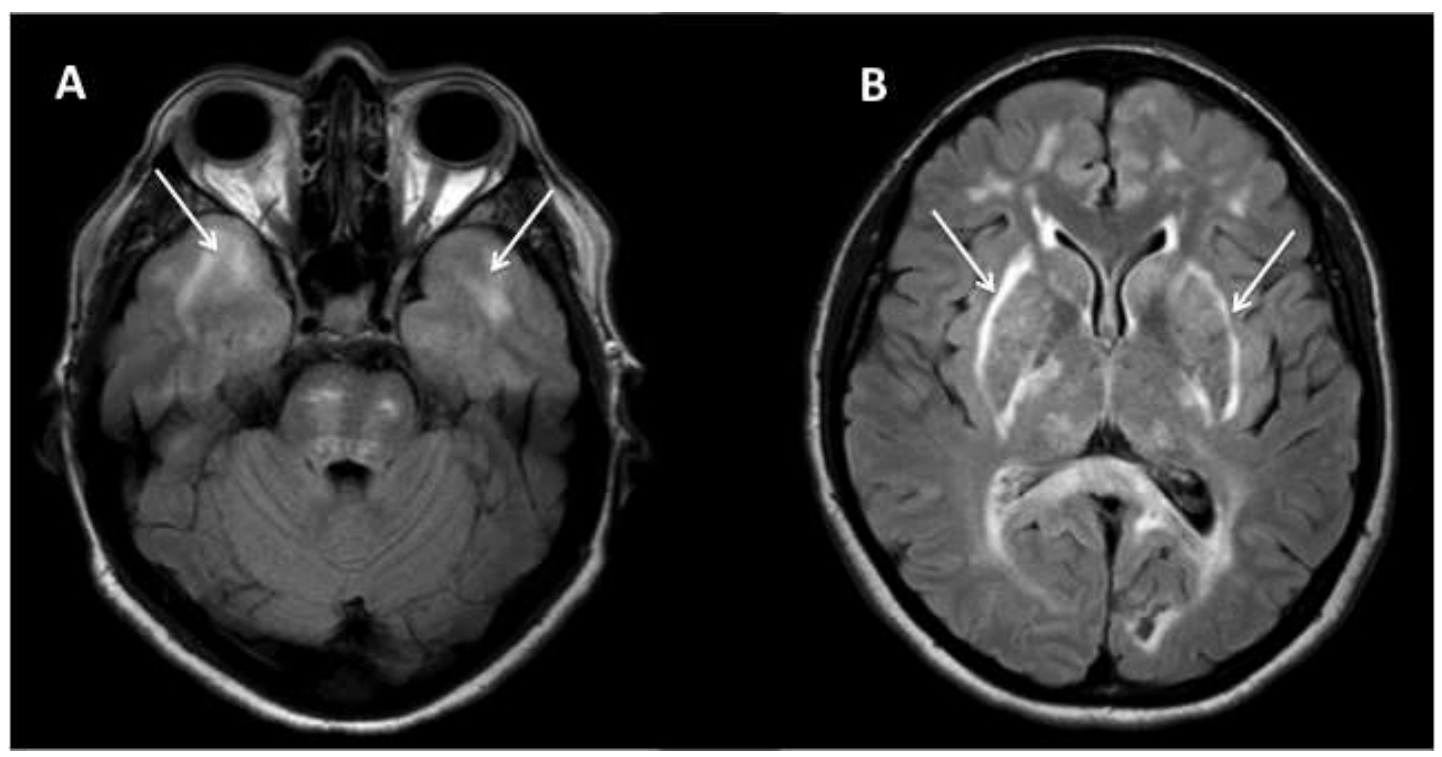

Figura 14 - Axial FLAIR do paciente 20.1 diagnosticado com CADASIL mostrando o acometimento típicos de polos temporais (A) e cápsula externa (B)

\subsubsection{CADASIL - aspectos genéticos}

A presença de variante patogênica em NOTCH3 foi confirmada por exoma clínico nos três casos. Coincidentemente, as três variantes patogênicas encontradas foram por troca simples de aminoácido e provocavam a substituição de arginina por cisteína, porém em posições diferentes da proteína - p.Arg169Cys, p.Arg332Cys e p.Arg133Cys. As três variantes já foram previamente descritas (Joutel et al., 1997; Oliveri et al., 2001). 


\subsubsection{Leucodistrofia desmielinizante autossômica dominante de início no adulto}

Identificamos um paciente com leucodistrofia desmielinizante autossômica dominante de início no adulto (ADLD).

\subsubsection{Leucodistrofia desmielinizante autossômica dominante de início no adulto - aspectos clínicos}

Tratava-se de um homem saudável até os 38 anos de idade, quando passou a apresentar disfunção erétil isolada. Nos anos subsequentes passou a apresentar episódios frequentes de pré-síncope por hipotensão postural e fadiga aos médios esforços. Aos 52 anos passou a apresentar urge-incontinência urinária e constipação intestinal.

Os primeiros sintomas motores surgiram aos 54 anos, com alteração da marcha e diminuição de força assimétrica inicialmente em MMII. Aos 56 anos tornou-se cadeirante e passou a apresentar também dificuldade para atividade motora fina de MMSS. Também neste período passou a queixar-se de esquecimentos frequentes, irritabilidade e humor deprimido.

O pai e um irmão do paciente apresentaram quadro semelhante e faleceram mais jovens - o pai aos 54 anos e o irmão aos 48 anos. Tinha uma irmã sexagenária e um filho de 30 anos assintomáticos.

Ao exame físico geral não mostrava alterações relevantes, exceto por hipotensão postural assintomática, sem resposta cronotrópica compensatória. Já ao exame neurológico apresentava desatenção, disfunção executiva, certa perseveração, mas mantinha memória, praxias, habilidades visuoespaciais e linguagem preservadas. Era cadeirante e apresentava tetraparesia espástica assimétrica e pior em MMII. Os reflexos tendinosos profundos eram exaltados em MMSS, presentes em MMII, exceto aquileus, que eram abolidos. Apresentava sinais de Hoffman, Tromner e Babinski bilateralmente e não apresentava reflexos axiais da face. Havia dismetria e disdiadococinesia em MMSS, assimétrica, e diminuição das sensibilidades dolorosa, vibratória e proprioceptiva em botas. Notava-se nistagmo evocado pelo olhar para esquerda, seguimento microssacádico e reflexo nauseoso abolido. 
Os exames laboratoriais e o exame do líquor não mostraram alterações relevantes.

A ENMG mostrou polineuropatia periférica desmielinizante sensitiva crônica. O EEG mostrou surtos de ondas lentas de projeção na região temporal esquerda.

\subsubsection{Leucodistrofia desmielinizante autossômica dominante de início no adulto - aspectos neurorradiológicos}

A RM de crânio (Figura 15) mostrava extenso acometimento de substância branca, difuso, simétrico, com acometimento das fibras em "U" e relativa preservação da região periventricular. Havia afilamento de corpo caloso e alteração de sinal dos ramos posteriores da cápsula interna, pedúnculos cerebelares superiores e médios e das fibras transversas da ponte. Havia ainda afilamento do bulbo e transição bulbo-medular. Não havia impregnação pelo gadolínio ou restrição à difusão.

Foram realizadas também RM de coluna cervical e torácica que mostraram alteração difusa do sinal em funículos posteriores e na topografia dos tratos corticoespinhais, particularmente na medula cervical. 


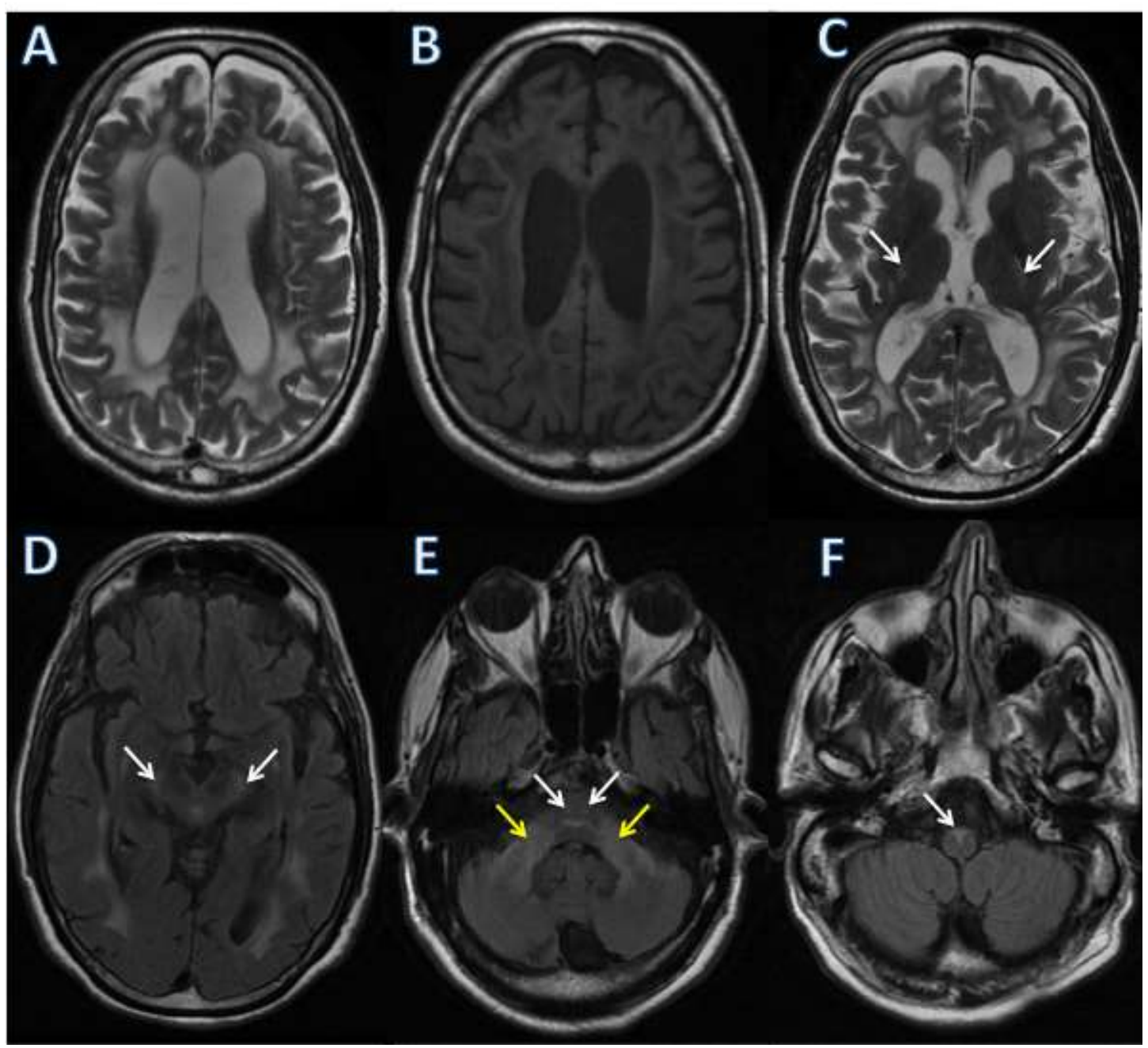

Figura 15 - Imagens do paciente com diagnóstico de ADLD. Hipersinal difuso em T2 em substância branca cerebral com correspondente hipossinal em T1 (A-B). Hipersinal em ambos os tratos corticoespinhais em cápsulas internas, pedúnculos cerebrais, ponte e decussação das pirâmides em bulbo, em T2 (C) e FLAIR (D-F) - setas brancas. Acometimento bilateral de braços da ponte (setas amarelas em $\mathbf{E}$ )

\subsubsection{Leucodistrofia desmielinizante autossômica dominante de início no adulto - aspectos genéticos}

Frente a quadro de leucodistrofia do adulto, provavelmente autossômica dominante e com disautonomia precoce, foi feita a hipótese de ADLD e solicitada a pesquisa da duplicação de $L M N B 1$ por array-CGH. Este estudo mostrou uma duplicação intersticial de 212 kb no braço longo do cromossomo 5, afetando a banda 
q23.2 entre as posições genômicas 126.074.816-126.287.368 (Build 36/Hg18 do genoma humano), que englobava $L M N B 1$.

\subsubsection{Doença de Alexander}

Identificamos uma paciente com doença de Alexander do adulto (Paiva et al., 2016).

\subsubsection{Doença de Alexander - aspectos clínicos}

Tratava-se de uma mulher que, aos 25 anos, após a segunda gravidez, passou a apresentar quedas frequentes, incontinência urinária e alteração da voz ("como se estivesse bêbada"). Por volta dos 32 anos apresentava perda de força em MIE, com progressiva dificuldade para deambular.

Aos 34 anos, iniciou perda de força em MSE e tornou-se cadeirante aos 35 anos. Apresentava ainda engasgos frequentes, obstipação intestinal, insônia, humor deprimido e apatia. Exceto por ser etilista e tabagista, não tinha outros antecedentes médicos relevantes.

Havia história familiar de câncer de mama (mãe faleceu em decorrência do câncer aos 46 anos), acidente vascular encefálico isquêmico (pai falecido aos 68 anos) e deficiência intelectual (em uma irmã que faleceu aos 8 anos). Contava ainda com seis irmãos saudáveis.

Ao exame neurológico apresentava: declínio cognitivo com predomínio de síndrome disexecutiva; tetraparesia espástica assimétrica, pior à esquerda e em MMII, com reflexos tendinosos profundos globalmente exaltados e sinal de Babinski bilateralmente; ataxia cerebelar de predomínio axial; sacadas hipométricas, com nistagmo evocado pelo olhar para esquerda, ausência de reflexo nauseoso e disartria e disfagia graves. Notadamente, não apresentava tremor palatal.

Os exames laboratoriais e do líquor não apresentavam alterações relevantes.

Foi submetida a avaliação por ENMG que foi normal. Não realizou EEG. 


\subsubsection{Doença de Alexander - aspectos neurorradiológicos}

A RM de crânio (Figura 16) apresentava hipersinal difuso de substância branca, com predomínio periventricular e poupando as fibras em "U". Havia hipersinal em pedúnculos cerebelares médios, bulbo e núcleos denteados.

Notava-se ainda significativa atrofia de bulbo e medula espinhal cervical, com relativa preservação da ponte. Estes achados, nas aquisições sagitais, formavam o "sinal do girino". Não havia impregnação pelo gadolínio ou restrição à difusão. A espectroscopia mostrava aumento de colina, redução de Naa e aumento das relações de mio-inositol.

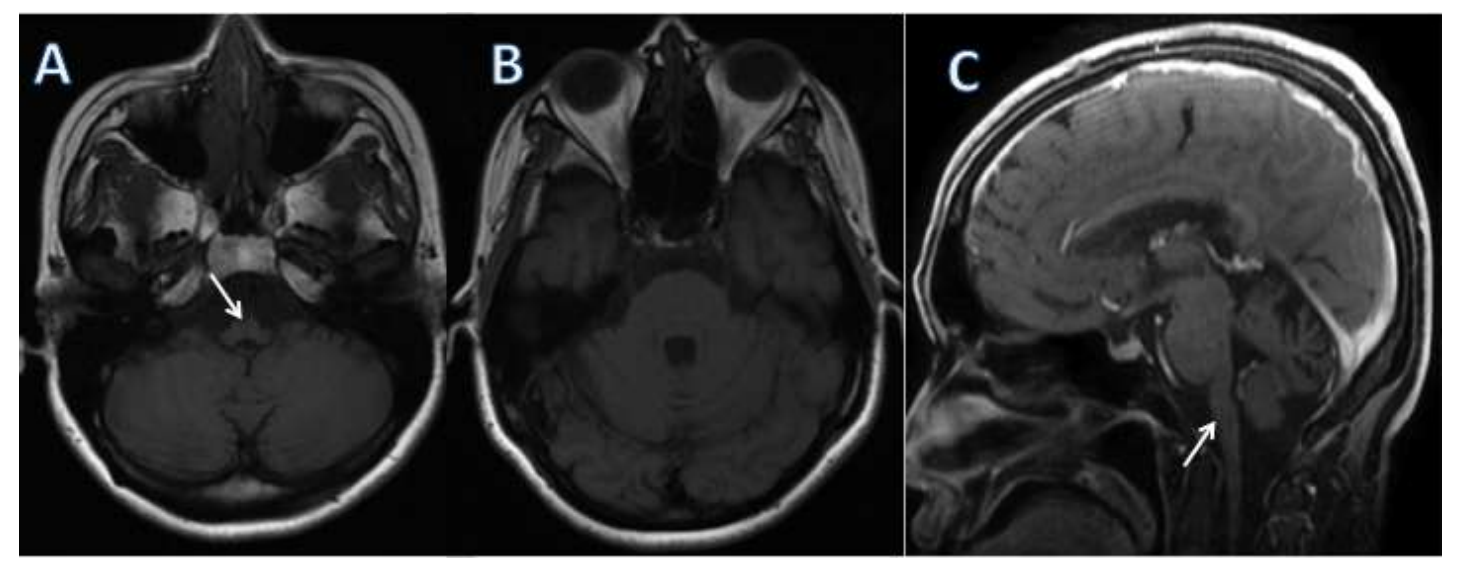

Figura 16 - Paciente com diagnóstico de doença de Alexander do adulto. Imagens ponderadas em T1 axiais (A-B) e sagital (C), mostrando atrofia de bulbo com preservação do volume da ponte e o característico sinal do girino (setas)

\subsubsection{Doença de Alexander - aspectos genéticos}

Pelo acometimento bulbar, espasticidade e ataxia associados ao achado do sinal do girino, fizemos a hipótese de doença de Alexander e foi solicitado o sequenciamento do gene GFAP. Identificou-se a variante c.809G>C (p.Arg270Pro), nunca previamente descrita na literatura médica e ausente entre cerca de 141 mil indivíduos da população mundial, conforme consultado na "Genome Aggregation Database" - GnomAD (Karczewski et al., 2019), sendo que os modelos computacionais preditores de patogenicidade (SIFT, PolyPhen e Mutation Taster) 
indicaram que ela fosse deletéria ou provavelmente deletéria. Não foram realizados estudos funcionais.

A paciente faleceu após insuficiência respiratória aguda aos 39 anos e não foi realizada necropsia.

\subsubsection{Síndrome de Gordon-Holmes}

Identificamos um paciente com a síndrome de Gordon-Holmes, no qual encontramos variante nunca previamente descrita em RNF216.

\subsubsection{Síndrome de Gordon-Holmes - aspectos clínicos}

Quadro iniciado aos 31 anos de idade com indisposição, adinamia, perda de memoria para fatos recentes, perda de objetos com frequência e dificuldade de organização. Passou a ter dificuldade com movimentos finos dos dedos e leve alteração da marcha, mas sem repercussão funcional.

Havia ainda irritabilidade e certa agressividade. Paralelamente, apresentava perda de libido e disfunção erétil. Investigação da queixa sexual em outro serviço mostrou hipogonadismo hipogonadotrófico, sem alterações em outros hormônios hipofisários. Recebeu por este motivo a prescrição de testosterona.

Não havia outros antecedentes mórbidos. Era filho de pais não consanguíneos, embora pertencessem à mesma localidade (zona rural do interior de Minas Gerais). Os pais, uma irmã e quatro irmãos eram saudáveis, mas um dos irmãos mais velhos apresentou quadro semelhante, também de início aos 31 anos, com declínio cognitivo, alteração da marcha e movimentos involuntários. Este irmão ficou acamado a partir dos 35 anos e faleceu aos 38 anos.

O exame físico geral não tinha particularidades. Já ao exame neurológico apresentava síndrome cognitiva com prejuízo significativo de memória episódica e disfunção executiva; equilíbrio preservado, mas dificuldade na marcha em tandem e presença de paracinesias; força e sensibilidades preservadas; reflexos tendinosos profundos presentes e simétricos em MMSS, vivos em MMII, com cutâneo-plantar em flexão bilateralmente; leve ataxia cerebelar caracterizada por discreta dismetria e 
decomposição dos movimentos; coréia generalizada leve, com predomínio dos movimentos em face e MMSS; sem alterações de nervos cranianos.

Os exames laboratoriais, exceto pelos hormônios sexuais, não mostravam alterações significativas. $O$ exame do líquor e o EEG foram normais. Não foi realizada ENMG.

Em sua última avaliação, aos 44 anos, demonstrava piora cognitiva, passando a requerer ajuda para atividades básicas da vida diária. Também nesta última avaliação demonstrava sintomas psicóticos, iniciados poucos meses antes, com delírio persecutório, ilusões ópticas, percepção delirante da realidade e agitação psicomotora, sem no entanto apresentar alucinações. O quadro motor permanecia inalterado, com coréia e ataxia cerebelar leves.

\subsubsection{Síndrome de Gordon-Holmes - aspectos neurorradiológicos}

A RM de crânio (Figura 17) mostrava hipersinal confluente e simétrico de substância branca supra e infratentorial em T2/FLAIR, com acometimento periventricular e subcortical, sem captação de gadolínio ou restrição à difusão. Apresentava ainda alteração de sinal em tálamos, cápsulas externas, pedúnculos cerebrais (com envolvimento de substância negra), ponte, pedúnculos cerebelares médios e núcleos denteados. A espectroscopia mostrava discreta redução na relação colina/Naa. 


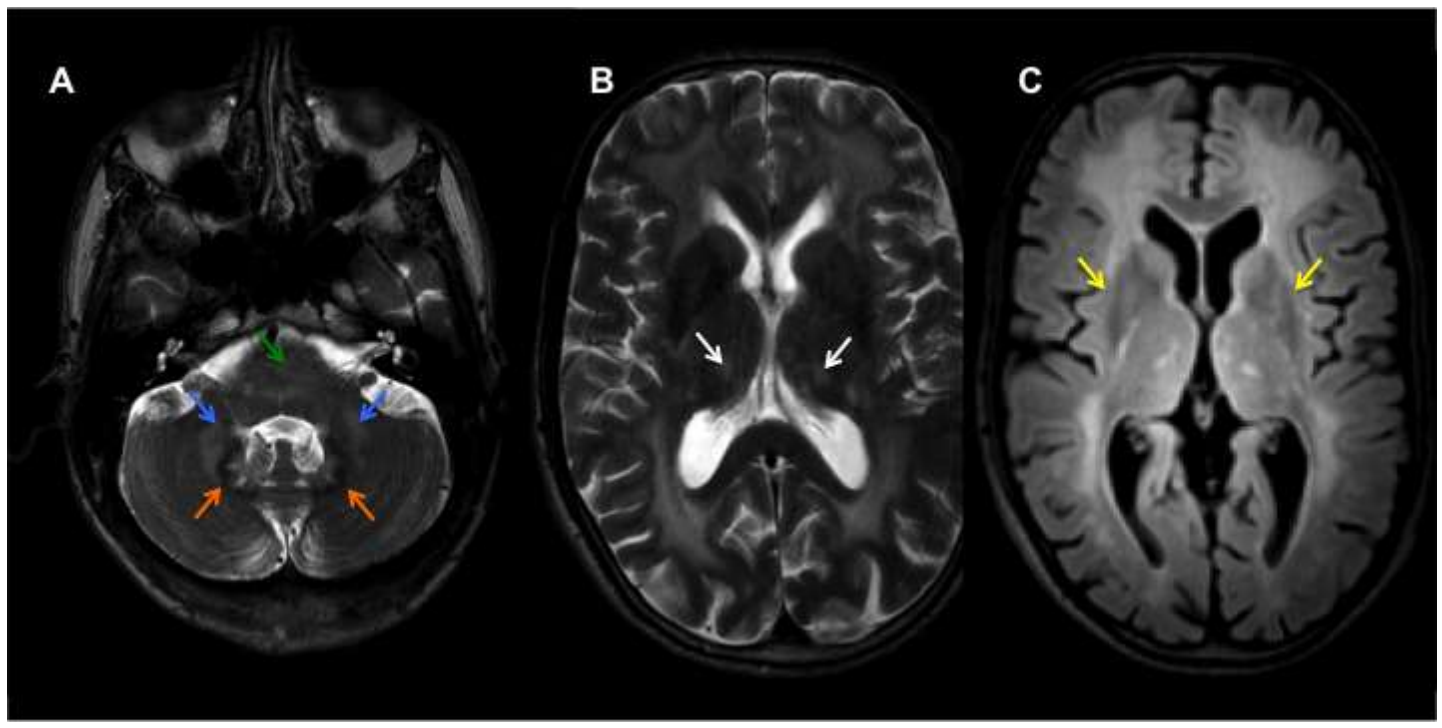

Figura 17 - Paciente com diagnóstico de síndrome de Gordon-Holmes por variante patogênica em RNF216. Imagens axiais ponderadas em T2 (A e B) e FLAIR (C) mostrando hipersinal bilateral e simétrico em substância branca, lesões em tálamos (setas brancas em B), cápsulas externas (setas amarelas em $\mathbf{C}$ ), pedúnculos cerebelares médios (setas azuis em A), ponte (seta verde em A) e núcleos denteados (setas laranjas em A)

\subsubsection{Síndrome de Gordon-Holmes - aspectos genéticos}

Antes da análise molecular tínhamos a hipótese diagnóstica de doença da substância branca evanescente, mas o exoma clínico encontrou um nova variante patogênica do tipo perda de sentido em homozigose em $R N F 216$, c.1482C>A (p.Tyr494*), que é relacionado à síndrome de Gordon-Holmes.

\subsubsection{Leucoencefalopatia com acometimento de tronco encefálico e medula e elevação de lactato}

Identificamos uma paciente portadora de leucoencefalopatia com acometimento de tronco encefálico e elevação de lactato (LBSL). 


\subsubsection{Leucoencefalopatia com acometimento de tronco encefálico e medula e elevação de lactato - aspectos clínicos}

Trata-se de uma paciente que era assintomática até os 5 anos de idade, quando passou a apresentar tremor de intenção e alteração da marcha, com desequilíbrio e pés arrastando.

O quadro foi lentamente progressivo e, aos 23 anos, ainda era capaz de deambular com apoio unilateral, mas apresentando quedas frequentes. Queixava-se ainda de constipação intestinal, e mantinha o controle do ritmo urinário.

Era a primogênita de uma prole de quatro e os pais eram consanguíneos, primos de primeiro grau. Desconhecia outros familiares com quadro semelhante.

O exame físico geral era normal, exceto por alterações tróficas de pele e fâneros dos pés, sugestivos de disautonomia. Não apresentava hipotensão ortostática. Ao exame neurológico apresentava comprometimento cognitivo leve por disfunção executiva, com as demais funções cognitivas preservadas. Assumia ortostase com ajuda, apresentava base alargada e sinal de Romberg. A marcha era em tesoura, com componente de ataxia sensitiva. Havia paraparesia espástica, com sinal de Babinski bilateralmente e reflexos globalmente exaltados, exceto por aquileus que estavam abolidos. Apresentava tremor de intenção, dismetria e disdiadococinesia bilaterais e simétricas, com piora significativa ao fechar os olhos, sugerindo ataxia cerebelar e sensitiva. As sensibilidades vibratória e proprioceptiva estavam diminuídas em MMII, e as sensibilidades tátil e dolorosa, preservadas. Apresentava seguimento microssacádico e sacadas hipermétricas, com discreto nistagmo evocado pelo olhar e disartria cerebelar.

Os exames laboratoriais, o EEG e o exame do líquor foram normais (inclusive a dosagem do lactato no líquor). Não foi submetida a ENMG.

\subsubsection{Leucoencefalopatia com acometimento de tronco encefálico e medula e elevação de lactato - aspectos neurorradiológicos}

A RM de crânio (Figura 18) realizada aos 23 anos mostrava hipersinal em T2/FLAIR na substância branca cerebral e cerebelar, confluente, de predomínio periventricular, poupando as fibras em "U". As lesões observadas em tronco encefálico eram bastante peculiares: alteração de sinal em pedúnculos cerebelares 
superiores e inferiores, tratos piramidais, espinocerebelares, mesencefálicos e trajetórias intraparenquimatosas de do nervo trigêmeo. Todas as alterações eram bilaterais e simétricas.

Havia restrição à difusão das moléculas de água nas fibras de projeção. Não houve impregnação pelo gadolínio. A espectroscopia mostrava redução na relação NAA/creatina e não houve aumento de lactato.

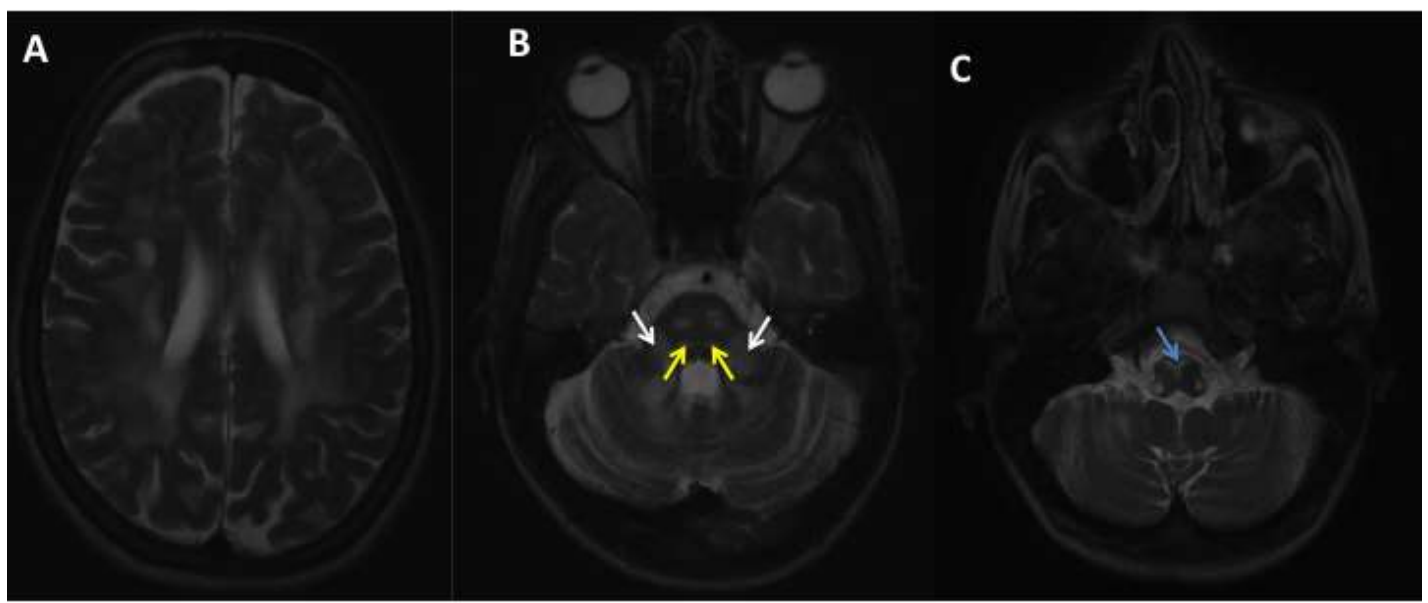

Figura 18 - Paciente com diagnóstico de LBSL. Axial T2 mostrando envolvimento confluente da substância branca cerebral (A), pedúnculos cerebelares médios (setas brancas) e porções intraparenquimatosas dos tratos do nervo trigêmeo (setas amarelas em B) e pirâmides bulbares (seta azul em C) - todas lesões bilaterais

\subsubsection{Leucoencefalopatia com acometimento de tronco encefálico e} medula e elevação de lactato - aspectos genéticos

A análise molecular por exoma clínico encontrou que a paciente era heterozigota composta para variantes patogênicas em DARS2. A primeira variante patogênica c.228-20_-21delTTinsC (p.Arg76Serfs*5) é uma indel, já previamente descrita (Scheper et al., 2007). A segunda variante identificada, c.1456C>T (p.Leu486Phe) é uma mutação nova de troca simples de aminoácido que leva à substituição de uma leucina por fenilalanina e é considerada patogênica. 


\subsubsection{Doença relacionada a $P L P 1$}

Identificamos um paciente com uma variante patogênica nunca previamente reportada em $P L P 1$.

\subsubsection{Doença relacionada a $P L P 1$ - aspectos clínicos}

Tratava-se de um homem, filho único de pais não-consanguíneos, que era hígido até os 30 anos de idade, quando passou a apresentar tremor cefálico em negação. Os sintomas começaram após o falecimento de sua mãe (por cardiopatia isquêmica).

Evoluiu poucos meses depois com distúrbio de marcha insidioso ("não conseguia dobrar os joelhos"), quedas da própria altura, urge-incontinência urinária e constipação intestinal. A partir dos 33 anos, apresentou declínio cognitivo lentamente progressivo caracterizado por perda de memória, disfunção executiva, confabulação e alterações de personalidade.

Aos 40 anos se tornou cadeirante e totalmente dependente de terceiros para atividades básicas da vida diária. Apresentava comportamento infantilizado, com risos frequentes e imotivados e repetição quase constante de algumas frases. Curiosamente, repetia há alguns anos que sentia dores de cabeça, mas não apresentava comportamento condizente ou resposta a qualquer analgésico.

Não apresentava morbidades associadas e desconhecia casos semelhantes ou pessoas com doenças neurológicas na família.

Ao exame apresentava significativo declínio cognitivo (MEEM 12/30), era cadeirante, mas conseguia assumir ortostase com apoio unilateral, demonstrando significativa instabilidade e base alargada. A marcha era em tesoura com ataxia cerebelar associada. A força estava preservada em MMSS, mas apresentava paraparesia espástica com força grau IV, reflexos exaltados em MMII e sinal de Babinski bilateralmente. Apresentava tremor cefálico tipo "não-não", sem direção preferencial. Os reflexos axiais da face estavam exaltados. Havia ataxia cerebelar de predomínio axial, com nistagmo evocado pelo olhar, sacadas hipermétricas e seguimento sacádico, além de disartria cerebelar com certo tremor de voz associado. O exame das sensibilidades não era fidedigno. 
Os exames laboratoriais, a ENMG e o exame do líquor foram normais. Não realizou EEG.

\subsubsection{Doença relacionada a $P L P 1$ - aspectos neurorradiológicos}

A RM de crânio (Figura 19) realizada após 10 anos de evolução da doença mostrava leve hipersinal em T2/FLAIR da substância branca, difuso, com isossinal em T1, sugerindo hipomielinização. Havia alteração de sinal dos pedúnculos cerebelares médios e não houve captação de contraste ou restrição à difusão das moléculas de água.

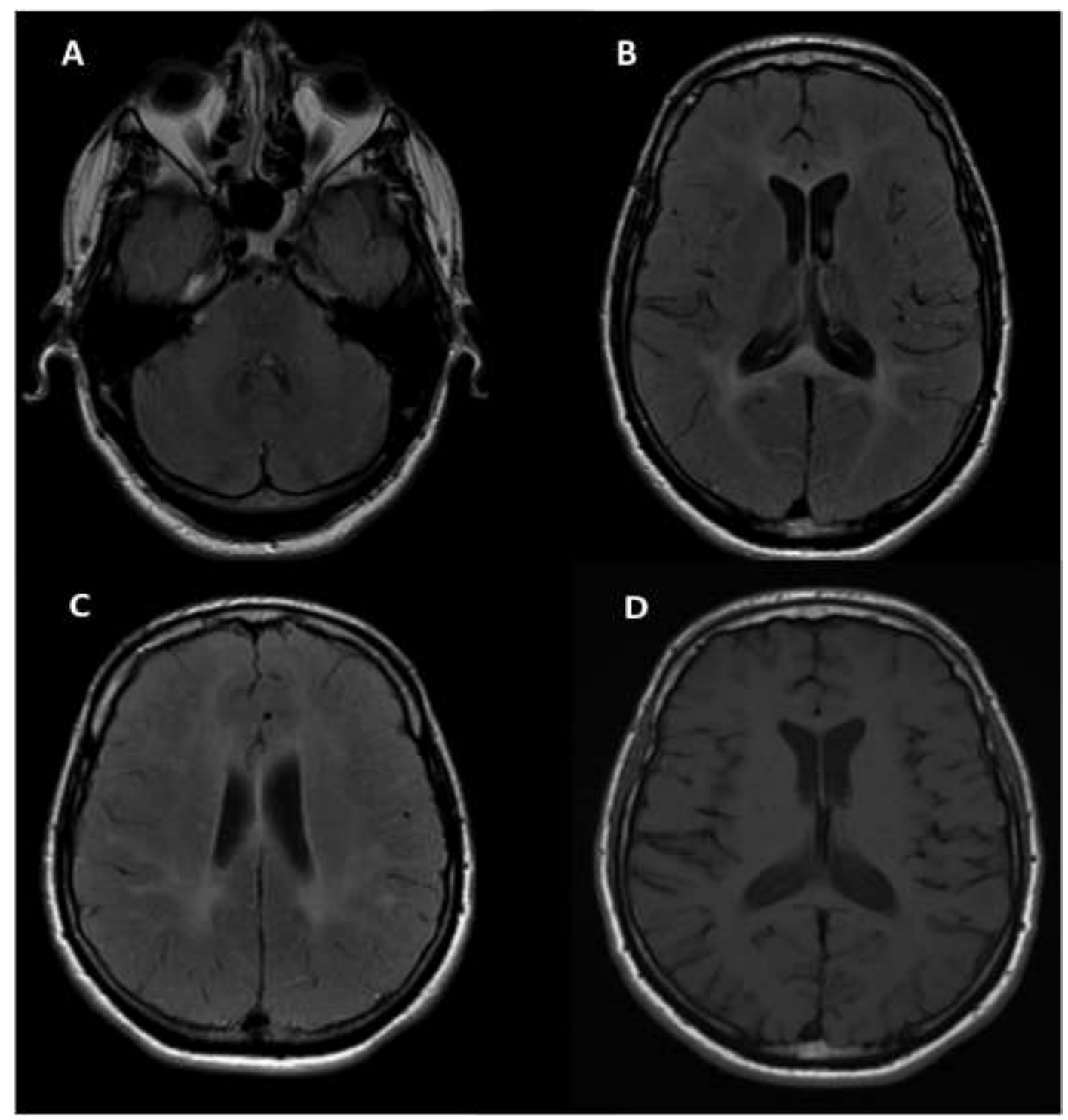

Figura 19 - Paciente com diagnóstico de doença relacionada ao PLP1. Axial FLAIR (A-C) mostrando tênue hipersinal difuso da substância branca, sem a respectiva correspondência de hipossinal em T1 (D) 


\subsubsection{Doença relacionada a $P L P 1$ - aspectos genéticos}

A análise molecular por exoma clínico identificou uma variante nunca previamente reportada, c.355dupG (p.Gly121Profs*83) que levava a mudança da matriz de leitura e consequente perda de função de $P L P 1$.

\subsubsection{Síndrome de Sjögren-Larsson}

Identificamos um paciente com a síndrome de Sjögren-Larsson (Paiva et al., 2018).

\subsubsection{Síndrome de Sjögren-Larsson - aspectos clínicos}

Tratava-se de um homem de 28 anos que apresentava ictiose congênita e criptorquidia que apresentou atraso do desenvolvimento neuropsicomotor notado a partir dos 6 meses de vida.

Chegou a sentar sozinho e falar poucas palavras simples, mas nunca deambulou e evoluiu posteriormente com involução da linguagem. Aos 18 meses teve crise convulsiva febril (episódio único). Evoluiu com grave deficiência intelectual e grave comprometimento motor associado a múltiplas deformidades articulares. Foi submetido a vários procedimentos ortopédicos na tentativa de corrigir o posicionamento dos membros (as maiores intervenções foram correção de luxação de quadril e tonotomia bilateralmente aos 15 anos). Foi submetido à plástica palpebral por xeroftalmia. Gastrostomia aos 21 anos por disfagia grave.

Não havia outros familiares acometidos e tinha 2 irmãos saudáveis. $\mathrm{O}$ pai e uma irmã apresentavam ictiose leve.

Avaliado aos 27 anos, apresentava deficiência intelectual grave, mas era capaz de manter comunicação por meio de gestual rudimentar com os pais. Anártrico, cadeirante, com múltiplas deformidades ósseas nos quatro membros, caixa torácica e coluna vertebral. Já em uso de gastrostomia, instalada aos 21 anos. Apresentava tetraparesia espástica grave, com reflexos exaltados.

O exame de coordenação, sensibilidades e a pesquisa do reflexo cutâneoplantar estavam prejudicados pelos quadros motor, cognitivo e ortopédico. Sem 
alterações de nervos cranianos. Fundoscopia direta sem alterações, mas de difícil execução técnica.

Os exames laboratoriais não mostravam alterações relevantes.

O EEG mostrava desorganização difusa da atividade elétrica cerebral, com surtos de ondas teta e paroxismos de ondas agudas de projeção temporal esquerda.

Não foi realizada ENMG.

\subsubsection{Síndrome de Sjögren-Larsson - aspectos neurorradiológicos}

A RM de crânio (Figura 20) realizada aos 27 anos mostrava extenso hipersinal em T2/FLAIR na substância branca supratentorial, com predomínio nos lobos frontais e parietais. Havia envolvimento de corpo caloso, mas a fossa posterior era normal. Apresentava alguns focos de restrição à difusão na região subcortical e não houve impregnação contraste paramagnético.

A espectroscopia mostrava picos de lipídios na substância branca e diminuição da relação NAA/creatina, sugerindo disfunção ou perda neuroaxonal. Havia ainda aumento das relações colina/creatina e mioinositol/creatina, sugerindo gliose.
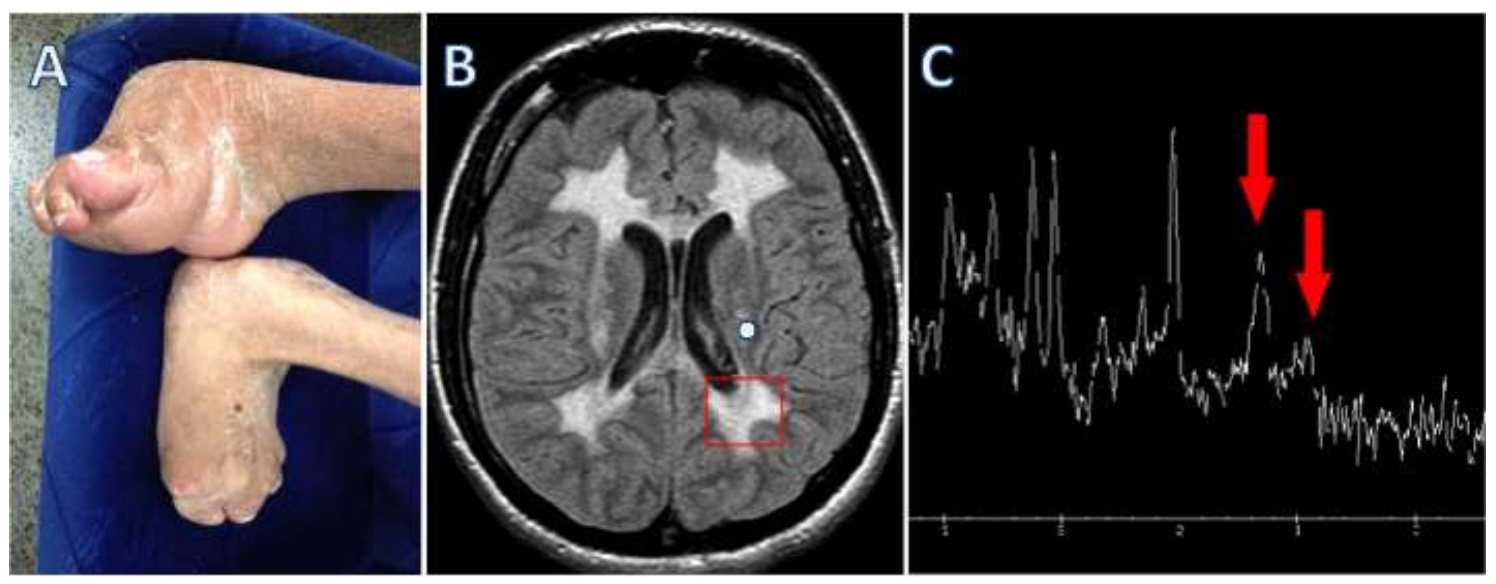

Figura 20 - Paciente com síndrome de Sjögren-Larsson em fase avançada. Em A observa-se ictiose congênita e deformidades ósseas em pés. Axial FLAIR (B) mostra leucoencefalopatia difusa. A espectroscopia (C), com tempo de eco $=30 \mathrm{~ms}$ e região de interesse colocada na substância branca parieto-occipital, mostrava pico de lipídios em 0,8-0,9ppm e em 1,3ppm (setas). O pico de $\mathrm{N}$-acetil-aspartato (NAA) estava diminuído, denotando perda ou disfunção neuroaxonal, e o pico de mioinositol (mI) estava aumentado, provavelmente relacionado à gliose 


\subsubsection{Síndrome de Sjögren-Larsson - aspectos genéticos}

A associação de deficiência intelectual, tetraplegia espástica, ictiose e leucoencefalopatia nos fez considerar a hipótese de síndrome de Sjögren-Larsson e pedir a pesquisa de mutação em $A D H L 3 A 2$. Identificamos que o paciente era heterozigoto composto para duas mutações de sítios de reformatação já previamente descritas: c.798+5G $>$ A de origem libanesa (materna) e c.1108-1G $>C$ de origem brasileira (paterna). Ambas as variantes levam a perda de função do gene (Rizzo et al., 1999; Lossos et al., 2006).

\subsubsection{Deficiência intelectual autossômica recessiva 55 (relacionada a PUS3)}

Identificamos duas irmãs com deficiência intelectual heterozigotas compostas para PUS3.

\subsubsection{Deficiência intelectual autossômica recessiva 55 (relacionada a PUS3) - aspectos clínicos}

Filhas de pais não consanguíneos, pertenciam a uma prole de cinco: um irmão com quadro semelhante que faleceu aos 22 anos, uma irmã assintomática que faleceu aos 28 anos por hidrocefalia e uma irmã saudável.

A paciente 22.1, com 44 anos em sua última avaliação, apresentou atraso do desenvolvimento neuropsicomotor e características dismórficas desde o nascimento. Apresentava baixa estatura e houve atraso de linguagem e motor para deambular. Sempre andou com dificuldades, mas sem apoio. Usou fraldas até sete anos de idade. Apresentava manchas azuladas em região lombar e na cabeça (manchas mongólicas), mas que desapareceram na idade adulta. Nunca aprendeu a ler ou escrever, tinha vocabulário bastante limitado e era independente para atividades básicas da vida diária, além de capaz de ajudar com pequenos afazeres domésticos.

Apresentou duas crises epilépticas na vida, a primeira aos 18 anos e a segunda aos 23 anos, com eventos sugestivos de crise focal discognitiva seguida de generalização secundária. Fez uso de carbamazepina por alguns anos, sendo posteriormente suspenso. 
Aos 35 anos teve fratura de bacia por queda da própria altura. A partir dos 37 anos passou a apresentar proteinúria persistente e em níveis crescentes associada a leve declínio da função renal, sem repercussões clínicas.

Até os 44 anos, nunca havia apresentado alterações comportamentais graves que requeressem intervenção. Porém, apresentou quadro psicótico persistente com alucinações auditivas e declínio na sua funcionalidade, sem alterações clínicas que o justifiquem.

Ao exame apresentava altura de $158 \mathrm{~cm}$ (percentil 10), peso $48 \mathrm{~kg}$ (percentil 10) perímetro cefálico $53 \mathrm{~cm}$ (percentil 10), deficiência intelectual moderada a grave, riso imotivado e disartria leve. Equilíbrio estático, marcha, força, tônus, reflexos tendinosos profundos, reflexo cutâneo-plantar, coordenação, sensibilidades e nervos cranianos sem alterações. Reflexos axiais da face presentes e de fácil obtenção. Apresentava ainda fácies sindrômica, escleras acinzentadas e genu valgo.

Os exames laboratoriais de rotina eram todos normais até os 37 anos de idade. A partir daí passou a apresentar proteinúria recorrente, até o máximo de 2,6g/L, mas com melhora espontânea. Houve concomitante perda de função renal (depuração de creatinina de $68 \mathrm{ml} / \mathrm{min}$ ), porém assintomática. Apresentou também elevação persistente de LDL-colesterol. O exame do líquor foi normal.

Já a irmã (paciente 22.2), com 37 anos na última avaliação, também apresentou atraso do desenvolvimento neuropsicomotor e aspectos dismórficos desde o nascimento (Figura 21). Aos 6 meses de vida, apresentou nefrite que foi tratada e teve recuperação completa.

Após o período de aleitamento materno exclusivo, feito até os 6 meses de vida, passou a apresentar diarreia crônica. Evoluiu com baixa estatura e baixo peso. Tal diarreia perdurou até os 5 anos de idade, quando recebeu diagnóstico de doença celíaca baseada em biópsia de duodeno. Após a adequação da dieta, houve resolução da diarreia.

Aos 5 anos de idade teve primeira crise convulsiva e desde então apresentou raras crises. Desde então, não apresentou involução ou novos eventos relevantes do ponto de vista neurológico.

No entanto, a partir dos 20 anos, passou a apresentar síndrome nefrótica. A biópsia renal mostrou glomeruloesclerose segmentar e focal (GESF) com depósito 
granular mesangial de $\mathrm{IgM}+$ e $\mathrm{C} 3+++$ na imunofluorescência. O quadro renal foi pouco responsivo à corticoterapia e evoluiu com disfunção renal progressiva. Aos 36 anos ingressou em programa de hemodiálise por insuficiência renal terminal nãooligúrica.

Apresentava ainda otite média recorrente; colesteatoma bilateral que foi operado aos 13 anos; hipotireoidismo; hipercolesterolemia; e osteoporose de início aos 32 anos, com fratura de fêmur não relacionada a trauma.

Ao exame apresentava deficiência intelectual moderada a grave, perímetro cefálico de $52 \mathrm{~cm}$ (percentil 3), altura $142 \mathrm{~cm}$ (abaixo do percentil 3), cifose, escoliose, escleras acinzentadas, fácies sindrômica (Figura 21) e genu valgo bilateralmente. Não apresentava sinais focais ao exame neurológico, apenas disartria com voz anasalada.

Os exames laboratoriais também só se alteraram após o início do quadro renal, com proteinúria maciça, elevação de LDL-colesterol e posterior evolução com aumento das escórias nitrogenadas. Por fim, quando já em hemodiálise, apresentava anemia de doença crônica e hiperparatireoidismo.

Os traçados de EEG de ambas as pacientes mostraram desorganização difusa da atividade elétrica cerebral por aumento de ondas teta, sem atividade epileptiforme. Não foi realizada ENMG. 


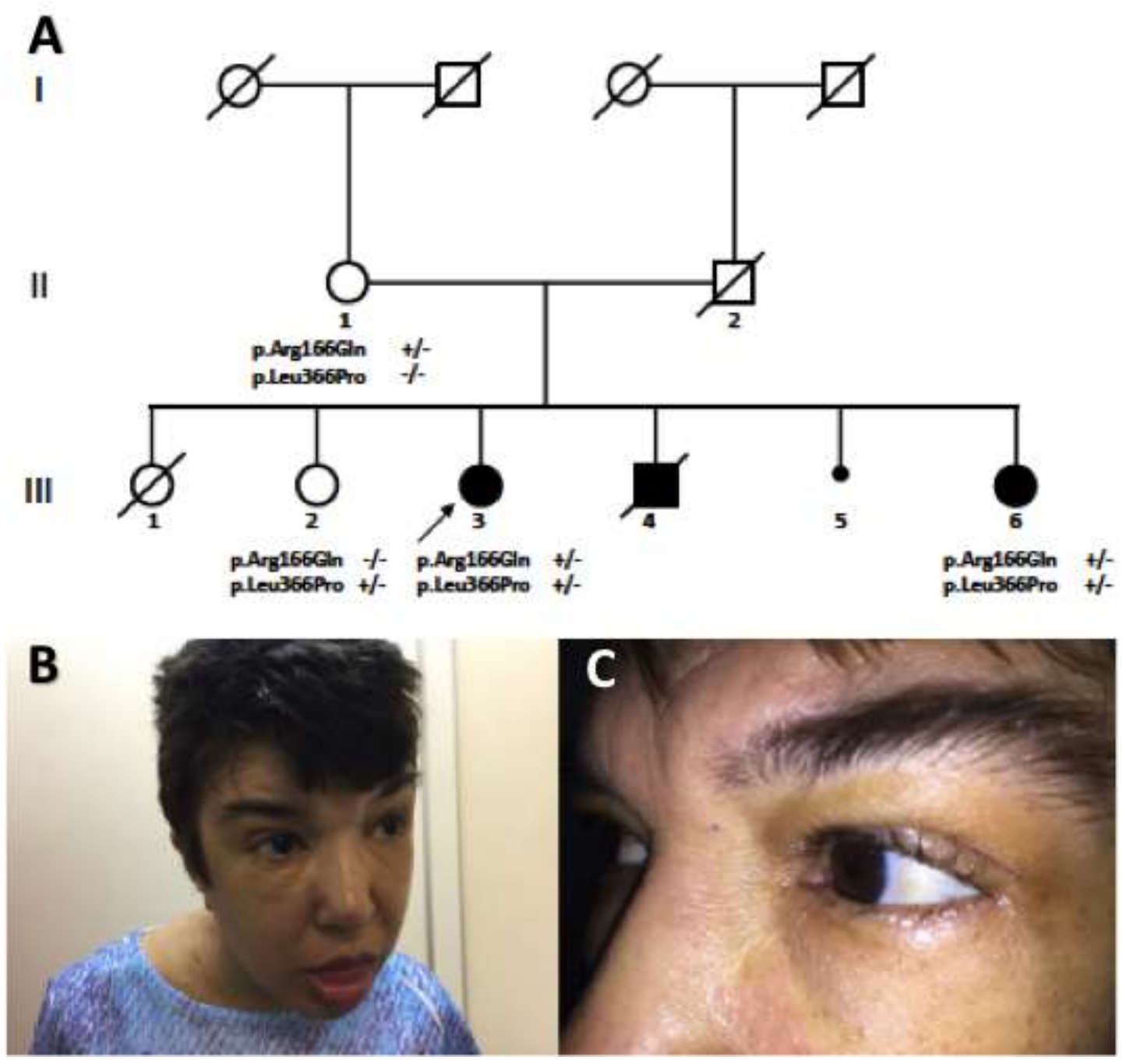

Figura 21 - Pacientes com deficiência intelectual relacionada a PUS3. Em A, heredograma da família das pacientes 22.1 e 22.2, mostrando como a mutação segregava na mesma. Fotografia da paciente 22.2 mostrando fácies sindrômica $(\mathbf{B})$ e esclera acinzentada $(\mathbf{C})$

\subsubsection{Deficiência intelectual autossômica recessiva 55 (relacionada a PUS3) - aspectos neurorradiológicos}

A RM de crânio mostrou alterações da substância branca em ambas as pacientes. A paciente 22.1 em RM de crânio realizada aos 42 anos de idade, apresentava alguns pontos de hipersinal no T2/FLAIR da substância branca cerebral de predomínio periventricular e tênue hipossinal na sequência PRESTO T2 nos globos pálidos e núcleos denteados. 
A RM de crânio da paciente 22.2 (Figura 22), realizada aos 39 anos, mostrou hipersinal difuso em T2/FLAIR em todos os lobos da substância branca cerebral, com acometimento se estendendo até as áreas subcorticais, bem como acometimento da substância branca cerebelar. Assim como a irmã, apresentava hipossinal na sequencia de suscetibilidade magnética (Ax 3D SWAN) em globos pálidos e núcleos denteados. Não havia acometimento de tronco encefálico.

Não apresentavam impregnação pelo contraste ou áreas de restrição à difusão.
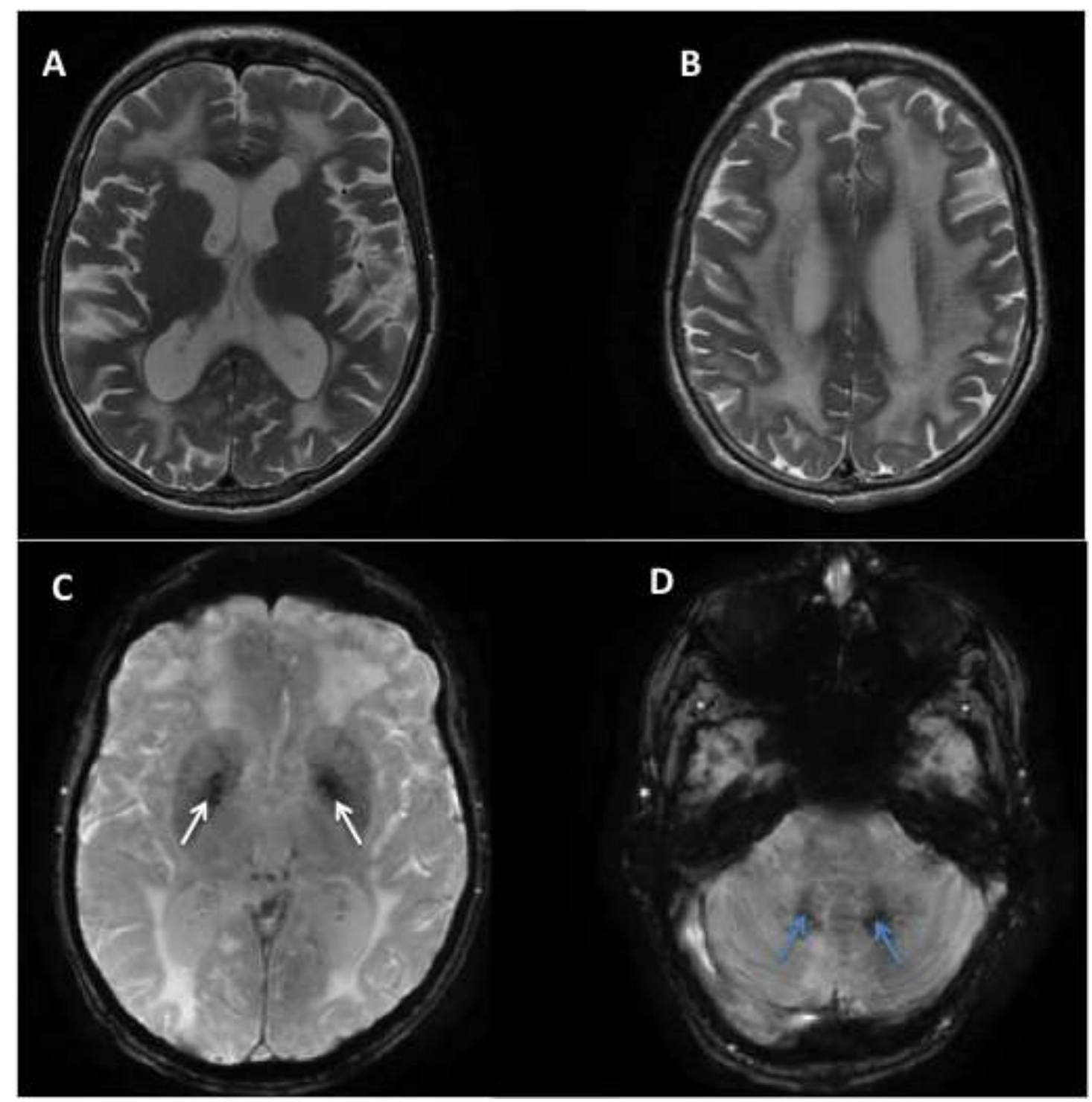

Figura 22 - RM de crânio da paciente 22.2 com diagnóstico de deficiência intelectual relacionada a PUS3. Axial T2 (A-B) da paciente 22.2 mostrando extensa alteração de sinal de substância branca. Sequencia de suscetibilidade (C-D) mostrando hipossinal em globos pálidos (setas brancas) e núcleos denteados (setas azuis) 


\subsubsection{Deficiência intelectual autossômica recessiva 55 (relacionada a PUS3) - aspectos genéticos}

A avaliação molecular por WES mostrou que elas não demonstravam homozigose significativa - como esperado, pois não há consanguinidade -, mas ao filtrar os dados para variantes deletérias, ambas eram heterozigotas compostas para PUS3 (Arg166Gln, Leu366Pro). Sequenciamos a mãe das pacientes que era heterozigota para p.Arg166Gln e a irmã saudável, que era heterozigota para p.Leu366Pro (o pai faleceu antes do início do estudo, impossibilitando a análise). Ambas as variantes são muito raras e em resíduos conservados (Figura 23). Os modelos de predição apontaram que ambas são patogênicas.
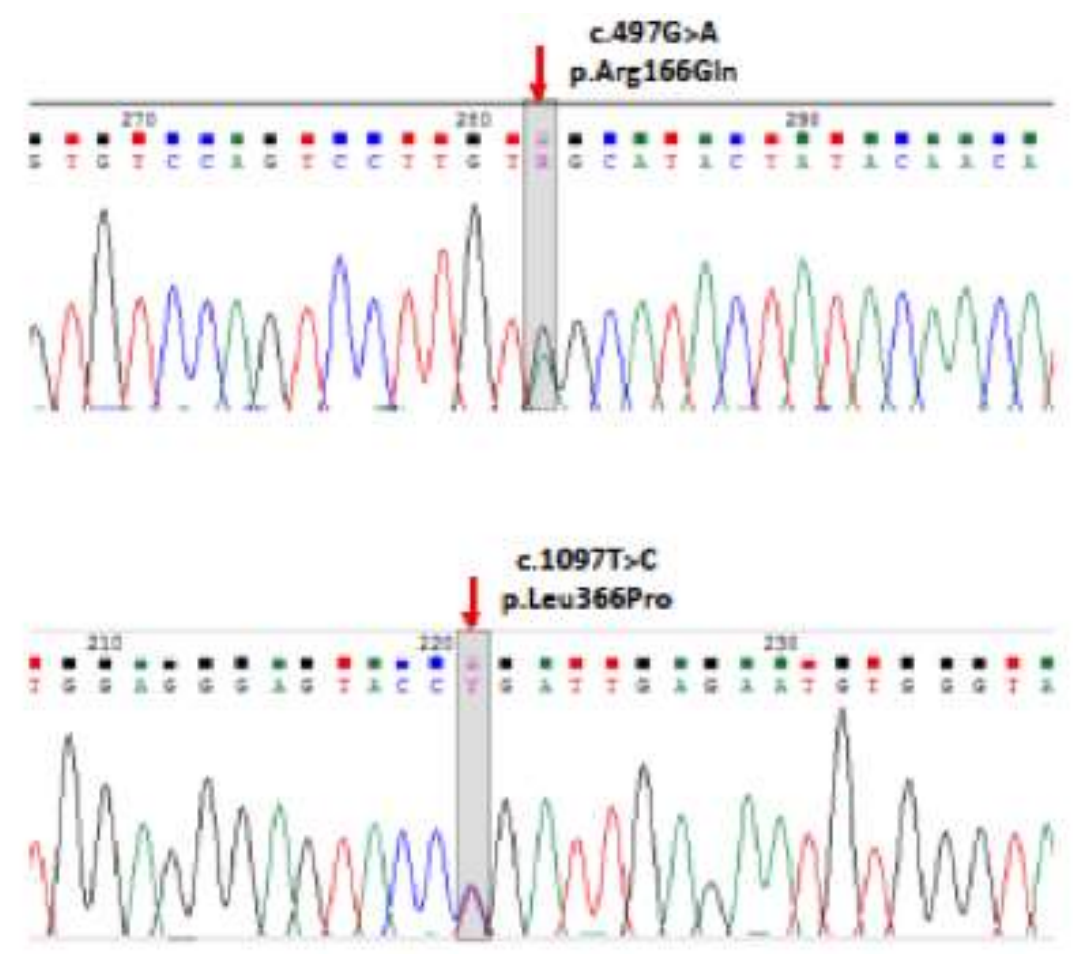

Figura 23 - Eletroferogramas do sequenciamento Sanger mostrando as variantes patogênicas c.497G>A (p.Arg166Gln) e c.1097T>C (p.Leu366Pro) em PUS3

\subsubsection{Encefalomioneuropatia relacionada a $F D X 2$}

Identificamos quatro pacientes pertencentes a mesma família portadores de variante patogênica em homozigose em $F D X 2$, que tem como produto uma 
ferrodoxina mitocondrial. O único fenótipo que havia sido associada a este gene era o de miopatia metabólica isolada (Spiegel et al., 2014).

A mesmo tempo e de forma independente, a equipe da Prof. Dra Juliana Gurgel-Giannetti, do setor de Neurologia Infantil da Universidade Federal de Minas Gerais (UFMG), identificou outros dois pacientes, procedentes da mesma região geográfica e que tinham o mesmo quadro clínico e a mesma variante patogênica em homozigose. A partir disto, se deu início a uma colaboração com o grupo da UFMG, o que permitiu, com apoio de outras instituições nacionais e internacionais, investigar de forma mais detalhada esta condição e viabilizar sua publicação (Gurgel-Giannetti et al., 2018).

A figura 24 mostra o heredograma desta família. A seguir detalhamos os achados dos quatro pacientes que avaliamos diretamente.

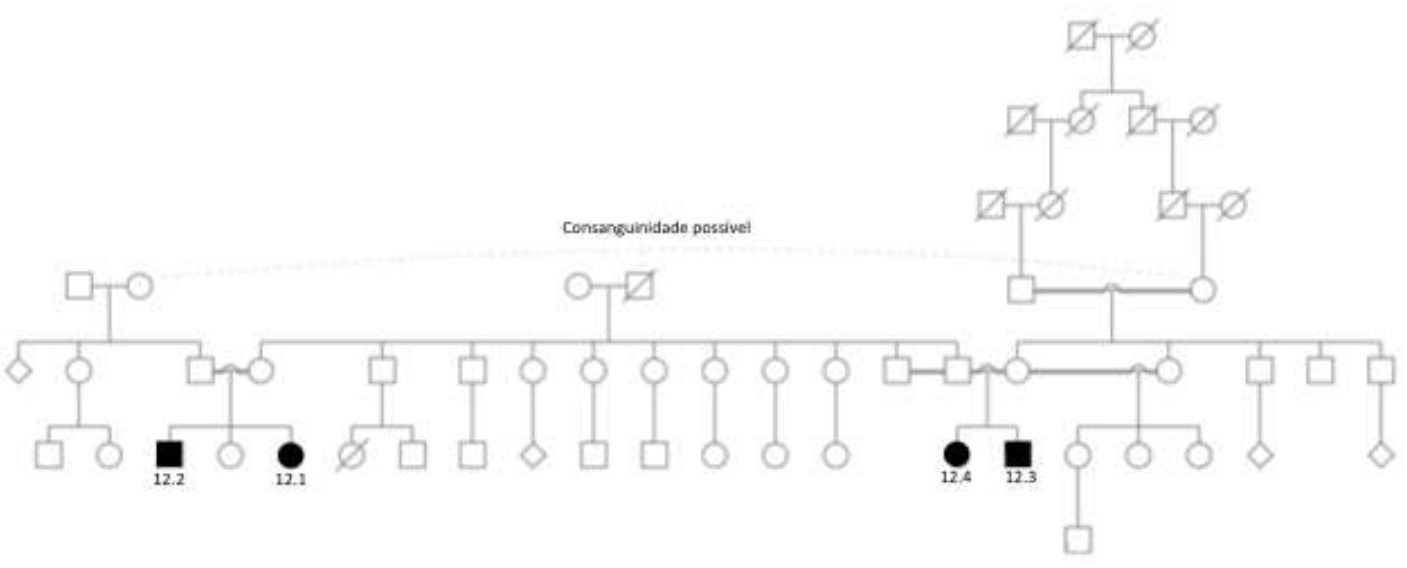

Figura 24 - Heredograma dos pacientes com diagnóstico de doença relacionada ao FDX2

\subsubsection{Encefalomioneuropatia relacionada a $F D X 2$ - aspectos clínicos}

A paciente 12.1, filha de pais consanguíneos, com 29 anos à época da avaliação, apresentava baixa acuidade visual e nistagmo desde o primeiro ano de vida. Ela nunca foi capaz de correr e apresentava quedas frequentes e marcha digitígrafa desde os 10 anos de idade. Não apresentou atraso do desenvolvimento neuropsicomotor e não apresentava queixas cognitivas ou psiquiátricas, exceto por ansiedade. 
Relatava episódios recorrentes de mialgia difusa e fraqueza generalizada associada principalmente ao frio - pelo menos desde os 17 anos de idade. Durante estes episódios ela frequentemente precisava de ajuda para deambular e recuperavase progressivamente. Apresentava ainda dor lombar crônica, dor em queimação nos pés desde a adolescência, vômitos pós-prandiais recorrentes sem causa aparente, hipermenorréia e infecções recorrentes do trato urinário. Mais recentemente passou a apresentar disfagia orofaríngea.

Ao exame neurológico apresentava: cognição normal; equilíbrio estático com base alargada e presença do sinal de Romberg; marcha anserina com componentes talonante e ceifante sobrepostos; tetraparesia de predomínio proximal (força grau III proximal em MMSS e IV distal, bem como grau IV em MMII), com leve atrofia de deltoides; reflexos tendinosos profundos presentes e simétricos em MMSS e abolidos em MMII; leve espasticidade em MMII; sinal de Babinski bilateralmente; dismetria e disdiadococinesia leves; perda de sensibilidades superficial e profunda em MMII; baixa acuidade visual (contar dedos a $30 \mathrm{~cm}$ ); palidez de papila bilateral; ptose palpebral bilateral; nistagmo evocado pelo olhar; hipomimia facial com fraqueza do músculo orbicular da boca; fala anasalada e tosse fraca. Havia ainda pés cavos, escoliose e perda da pilificação normal em MMII.

O paciente 12.2, com 34 anos à época da evolução, também apresentou baixa acuidade visual e nistagmo no primeiro ano de vida. Atingiu os marcos do desenvolvimento com pequeno atraso e apresentava quedas frequentes e certo desequilíbrio ao deambular, mas sem maiores limitações. Por volta dos 17 anos apresentou um episódio de dor lombar seguido de paraparesia crural que o deixou restrito ao leito por alguns meses e teve recuperação completa após cerca de um ano. Apresentava ainda queixa de cefaleia recorrente com características migranosas, epistaxe recorrente, dor lombar crônica e foi recentemente diagnosticado como portador de diabetes melito.

Ao exame neurológico, não apresentava alterações cognitivas de equilíbrio, marcha ou força. Os reflexos tendinosos profundos eram hipoativos e havia sinal de Babinski bilateralmente. Apresentava ataxia sensitiva leve, de predomínio axial e em MMII, diminuição das sensibilidades superficial e profunda em MMII, baixa da 
acuidade visual grave (contava dedos a $30 \mathrm{~cm}$ ), palidez de papila e nistagmo por incapacidade de fixação ("roving-eyes"). Havia ainda pés cavos.

O paciente 12.3, com 6 anos à época da avaliação, também apresentou nistagmo e baixa da acuidade visual notada por volta de 14 meses de idade. Andou com 17 meses e falou com 12 meses. Seu desenvolvimento neuropsicomotor foi adequado, apenas com algumas dificuldades atribuídas ao déficit visual. Nos últimos três anos apresenta infecções respiratórias recorrentes.

Ao exame físico apresentava perímetro cefálico superior ao percentil 90, peso e altura no percentil 50 e exame neurológico sem alterações, exceto por baixa acuidade visual, nistagmo pendular e reflexos tendinosos profundos globalmente hipoativos.

Por fim, a paciente 12.4, com 13 anos à época da última avaliação, apresentava o fenótipo mais complexo, com atraso do desenvolvimento neuropsicomotor notado já nos primeiros dias de vida, inicialmente por dificuldade de sucção. Foi um bebê hipotônico que sentou com ajuda aos 18 meses, andou com 24 meses, falou com 3 anos, reconheceu cores com 5 anos e foi capaz de escrever o próprio nome aos 8 anos. Por volta dos 3 anos, percebeu-se baixa da acuidade visual e avaliação oftalmológica documentou atrofia óptica bilateral. Apresenta infecções respiratórias e urinárias recorrentes, com piora da frequência nos últimos 3 anos.

Ao exame físico, seu perímetro cefálico estava abaixo do percentil 3, sua altura no percentil 10 e seu peso no percentil 25. Apresentava as seguintes alterações dismórficas: pavilhão auricular anterovertido bilateralmente, diástases dentárias, retrognatia, micrognatia, palato ogival, olhos amendoados, ponte nasal alta, dolicocefalia, braquidactilia, "puffy fingers", pés cavos e eritema pérnio em extremidades. Seu comportamento era bastante infantilizado, mas capaz de responder a perguntas simples do examinador.

Não apresentava problemas de equilíbrio estático ou marcha, exceto por deambular com os joelhos levemente flexionados. Não apresentava alterações de força, coordenação ou sensibilidades. Seu reflexos tendinosos profundos eram globalmente hipoativos e o cutâneo-plantar em flexão bilateralmente. Apresentava baixa acuidade visual (20/70 com correção em ambos os olhos) e palidez de papila 
bilateralmente, sem alterações de motricidade ocular extrínseca ou outras de nervos cranianos.

\subsubsection{Encefalomioneuropatia relacionada a FDX2 - aspectos neurorradiológicos}

A paciente 12.1 realizou somente uma RM de crânio que mostrou hipoplasia de ambos os nervos ópticos e do quiasma óptico e hipersinal em T2/FLAIR discreto, subcortical, multifocal na substância branca frontal, parietal e occipital.

O paciente 12.2 também realizou apenas uma RM de crânio que que não mostrou alteração de sinal, apenas atrofia de nervos ópticos e quiasma óptico.

Já a RM de crânio do paciente 12.3 realizada 1 ano e 8 meses de idade mostrou lesões multifocais com hipersinal em T2/FLAIR e hipossinal correspondente em T1 na substância branca supratentorial generalizado, com predomínio em lobos frontais, atingindo as fibras em "U", na região peritrigonal e em quase todo o corpo caloso. Um ano depois, novo exame mostrou o mesmo padrão com lesões adicionais em tálamos anterior e mesial, região periaquedutal e ponte. Em ambos exames havia hipoplasia de nervos ópticos e quiasma óptico. Não houve captação pelo gadolínio e a espectroscopia realizada no segundo exame foi normal. Havia restrição à difusão no primeiro exame que no segundo exame deu lugar à facilitação.

A primeira RM de crânio da paciente 12.4 , aos 8 meses de idade, mostrava certo aumento dos ventrículos laterais e mielinização incompleta, compatível com a idade, sem alterações de sinal. Novo exame aos 5 anos mostrou acometimento de: substância branca subcortical, com predomínio posterior; tálamos (poupando os tratos mamilotalâmicos e com envolvimento dos núcleos anteriores e lâminas medulares internas); e tronco encefálico (poupando os tratos corticoespinhais na ponte). Havia hipersinal da difusão, mas o $\mathrm{ADC}$ não estava disponível para definirmos restrição. Apresentava ainda hipocampos mal-rodados e atrofia/hipoplasia de nervos ópticos e quiasma óptico. Novos exames aos 9 e 10 anos de idade mostraram que as lesões de substância branca praticamente desapareceram. $\mathrm{Na}$ espectroscopia do penúltimo exame apresentou elevação de lactato. A figura 25 mostra os principais achados. 


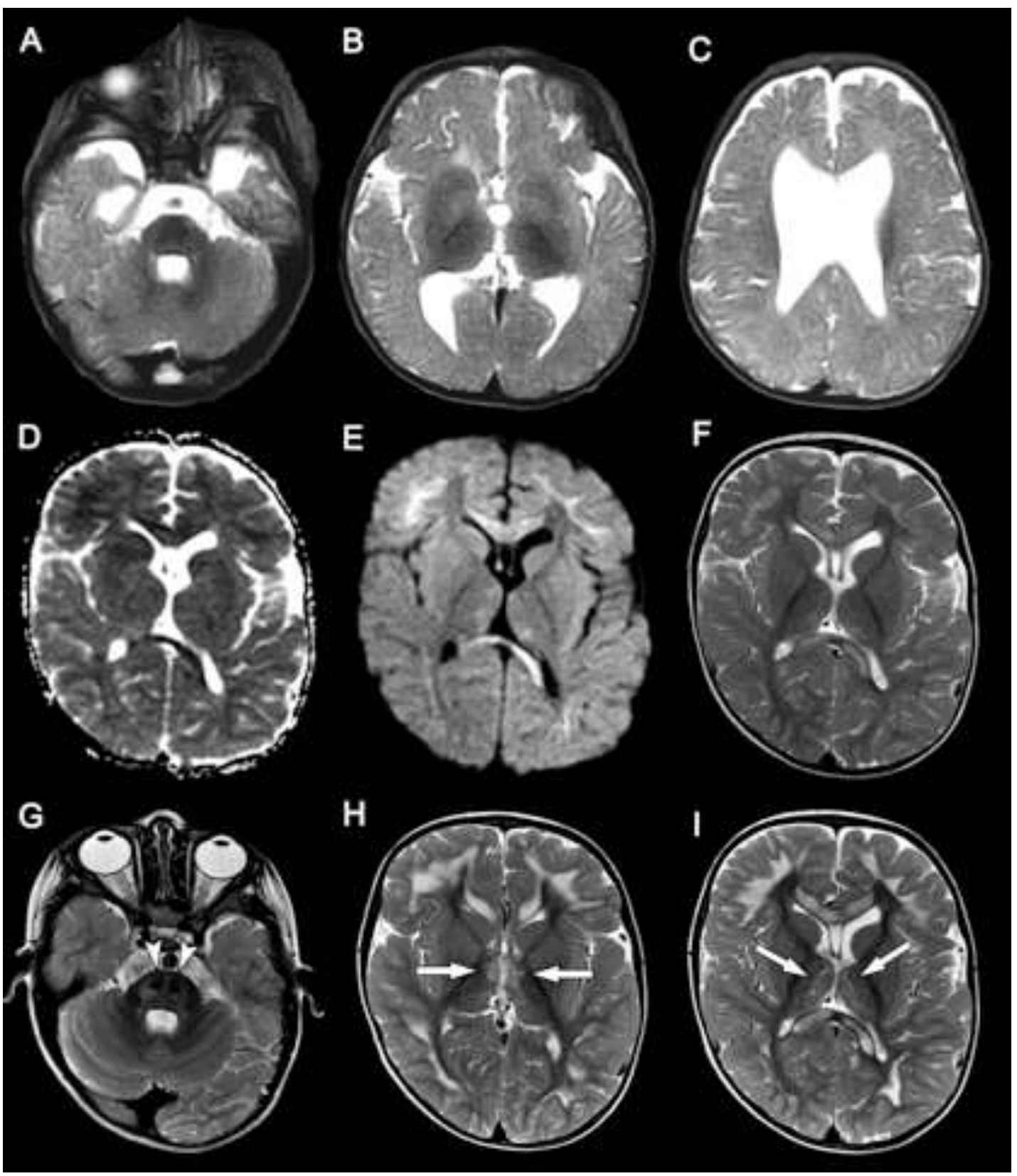

continua

Figura 25 - RM de crânio de pacientes com diagnóstico de doença relacionada a FDX2. Imagens axiais ponderadas em T2 (A-C) da paciente 12.4 aos 8 meses de vida sem alterações significativas. Nas imagens do paciente 12.3 quando tinha 1 ano e 8 meses (D-F) observa-se hipersinal em T2 na substância branca subcortical e em joelho e esplênio do corpo caloso, com restrição à difusão - talvez relacionada a edema intramielínico. Já aos 3 anos de idade, imagens ponderadas em T2 do paciente 12.3 (G-I) mostram progressão das lesões e também acometimento de ponte, mas poupando os tratos corticoespinhais (setas em G). Havia também acometimento de núcleos anteriores de ambos os tálamos, mas poupando os tratos mamilotalâmicos, vistos como ponto de hipossinal no meio da alteração de sinal (setas em H). Havia também envolvimento de lâmina medular interna (setas em I) 


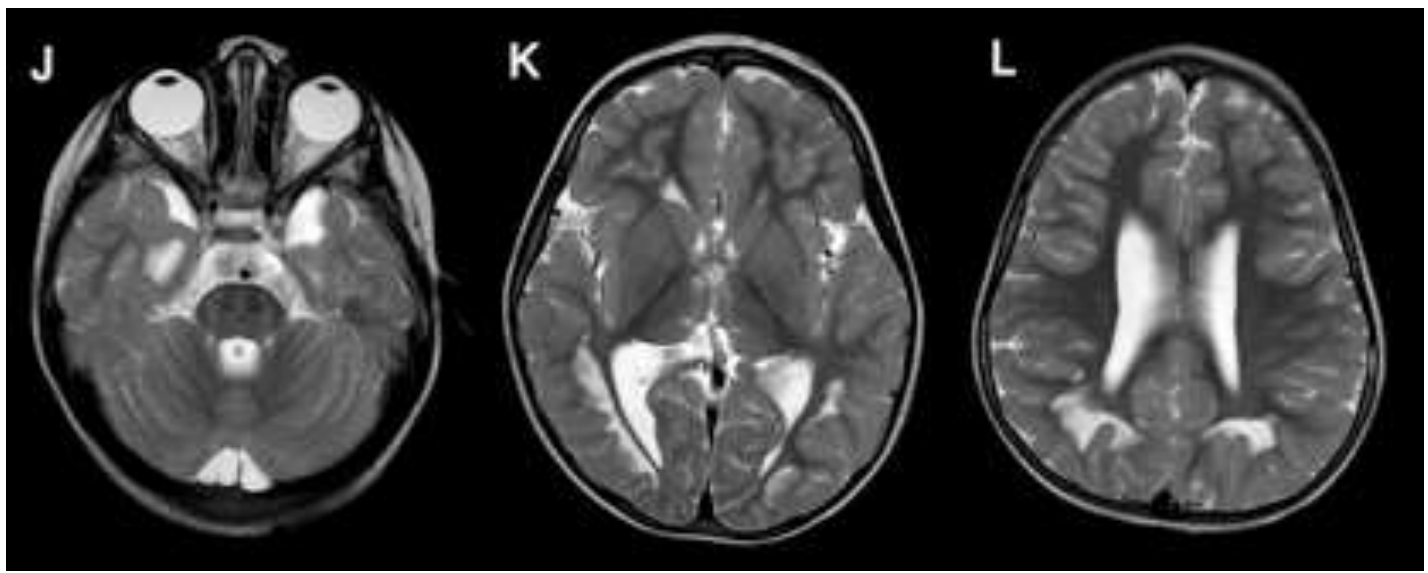

Figura 25 (continuação) Imagens ponderadas em T2 (J-L) da paciente 12.4 aos 5 anos mostram basicamente os mesmos achados do paciente 6.1 aos 3 anos, exceto pelo predomínio posterior

\subsubsection{Encefalomioneuropatia relacionada a FDX2 - aspectos neurofisiológicos}

A ENMG da paciente 12.1 mostrou uma polineuropatia periférica axonal motora crônica, com sinais de desnervação ativa, sem acometimento sensitivo ou miopático. Realizou também EEG que mostrou desorganização difusa da atividade elétrica cerebral por maior quantidade de ondas teta, carência de fusos do sono, e paroxismos de espícula-onda irregular nas regiões occipitais bilaterais, com difusão para áreas posteriores.

A ENMG do paciente 12.2 mostrou polineuropatia sensitivo-motora axonal. Este paciente não realizou EEG.

O paciente 12.3 foi submetido à ENMG que foi normal e não realizou EEG.

A ENMG da paciente 12.4 realizada aos 13 anos de idade mostrou polineuropatia sensitivo-motora crônica axonal. Realizou também potencial evocado visual estava no limite inferior da normalidade.

\subsubsection{Encefalomioneuropatia relacionada a FDX2 - aspectos laboratoriais}

Os exames laboratoriais da paciente 12.1 mostravam anemia leve persistente, microcítica, com anisocitose, sem reticulocitose, sem evidências de ferropenia, associada a neutropenia grave. Uma biópsia de medula óssea mostrou série 
granulocítica hipoplásica. Apresentava ainda TSH levemente elevado com T4 livre normal (hipotireoidismo subclínico). Espectroscopia para a pesquisa de ácidos orgânicos na urina mostrou grande aumento de ácido benzoico.

Os exames laboratoriais do paciente 12.2 mostravam anemia leve persistente, microcítica, associada a neutropenia moderada. Foi diagnosticado como portador de diabetes melito tipo 2 aos 33 anos de idade.

Os exames laboratoriais do paciente 12.3 mostraram anemia microcítica, neutropenia grave recorrente, TSH levemente aumentado com T4 livre normal, CPK, DHL, AST e lactato arterial levemente elevados. A anemia foi parcialmente responsiva à reposição de ferro.

Exames laboratoriais da paciente 12.4 mostraram anemia microcítica leve e persistente, associada a trombocitopenia, sem neutropenia, TSH levemente elevado com T4 livre normal, leve hiperamonemia e CPK, aldolase e lactato levemente aumentados. O exame do líquor aos 9 anos de idade foi normal, exceto por lactato no limite superior da normalidade. Cromatografias de aminoácidos séricos e de ácidos orgânicos urinários foram normais.

\subsubsection{Encefalomioneuropatia relacionada a $F D X 2$ - aspectos da biópsia muscular}

Os pacientes 12.1 e 12.2 foram submetidos a biópsia de músculo, realizada e analisada pela Prof. Gurgel-Giannetti. Ambos apresentaram fibras vermelhas rasgadas, SDH e COX negativas. As alterações eram mais intensas na paciente 12.1, na qual as fibras SDH- e COX-negativas eram agrupadas em áreas "patch-like" (Figura 26). Coloração específica para ferro demonstrou acúmulos puntiforme de ferro nestas mesmas fibras.

A microscopia eletrônica revelou inclusões paracristralinas mitocondriais em numerosas fibras. Nestas fibras inclusões irregulares eletron-densas frequentes foram identificadas e representam presumivelmente depósitos de ferro na mitocôndria.

A análise imuno-histoquímica das subunidades dos complexos mitocondriais II e IV mostraram significativa redução da expressão nas fibras com baixa atividade enzimática SDH e COX, enquanto a massa mitocondrial estava aumentada, conforme revelado pelo amrcador mitocondrial VDAC1 
Os pacientes 12.3 e 12.4 não foram submetidos à biópsia muscular.

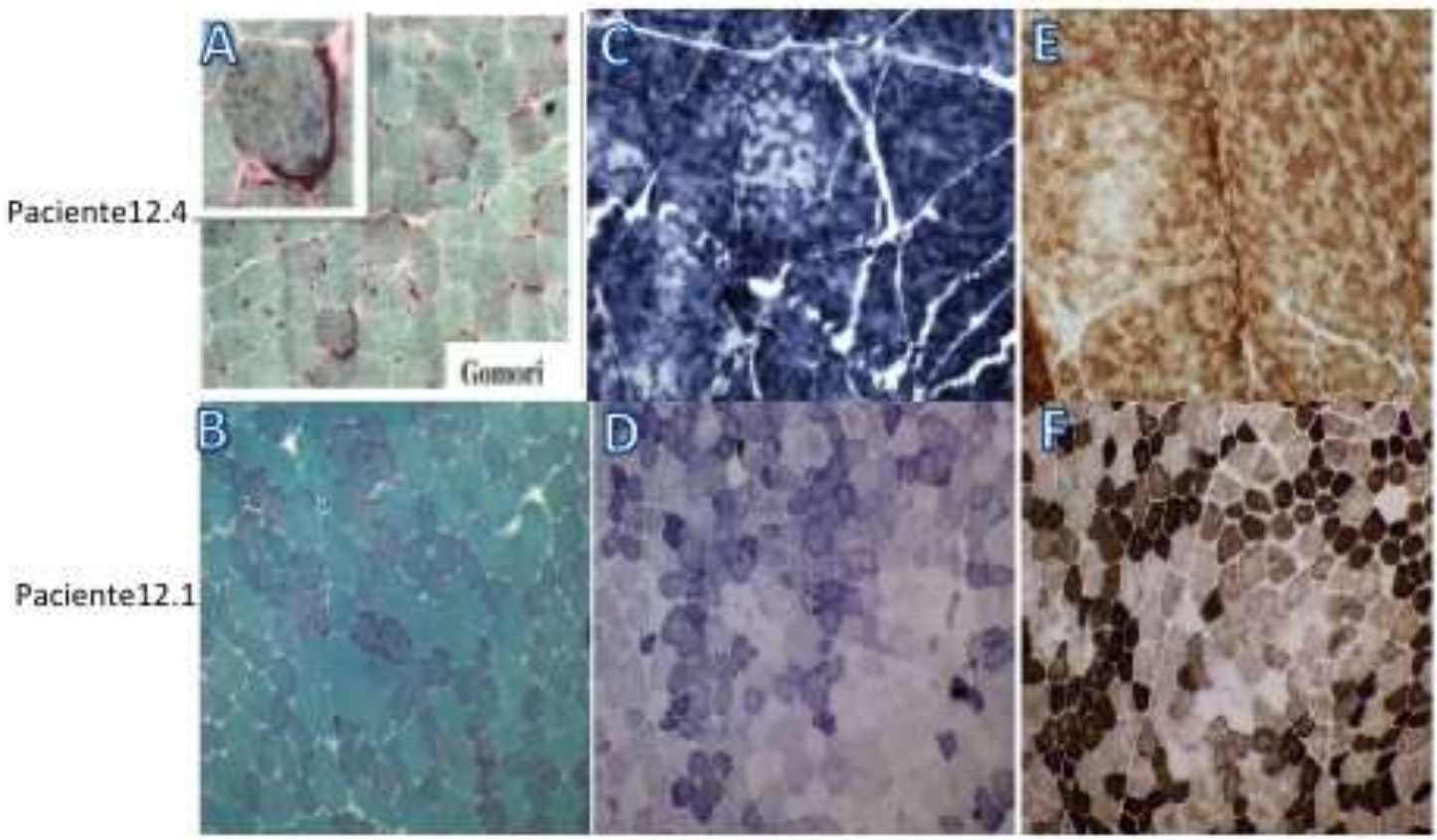

Figura 26 - Biópsia de músculo dos pacientes 12.1 e 12.4. Painéis A-B: amostras coradas com tricromo de Gomori demonstrando fibras vermelhas rasgadas; painéis C-D: coloração SDH-positivas; painéis E-F: fibras COX-negativas

\subsubsection{Encefalomioneuropatia relacionada a $F D X 2$ - aspectos genéticos}

Foi realizado o mapeamento de homozigose em todo o genoma de todos os pacientes desta família, o que revelou duas regiões de homozigose, uma região de $1 \mathrm{Mb}$ no cromossomo 19 (Chr19:9400194-10492040) e uma região de 500kb no cromossomo 2 (Chr2:89469319-89994709).

Foi então realizado o WES, limitando a análise a variantes raras, em homozigose, que não eram sinônimas ou intrônicas, e que mapeavam dentro das regiões de homozigose previamente identificadas. Assim a única variante encontrada foi em FDX2 (NM_001031734 c.431C>T, p.Pro144Leu), previamente chamado de FDX1L. Esta variante não foi encontrada nas bases de dados ExAC ou 1000G, mas foi encontrada em heterozigose em um de 600 controles da base de dados brasileira ABraOM (Naslavsky et al., 2017). 
Esta variante foi validada pelo sequenciamento Sanger, confirmando que todos os afetados eram homozigotos e os progenitores heterozigotos. A variante FDX2 p.Pro144Leu afeta um resíduo altamente conservado que é idêntico em todos os mamíferos com um gene ortólogo e em invertebrados.

A validação funcional da variante encontrada foi feita por "real-time RTPCR" em amostras de músculo dos pacientes, comparando com dois indivíduos normais. Não foram identificadas diferenças na expressão de RNAm entre pacientes e controles.

Para determinar se a variante patogênica afetaria a estabilidade da proteína, foram examinados os níveis da proteína FDX2 no músculo da paciente 12.1 e de um controle. Esta avaliação revelou uma significativa redução dos níveis de FDX2 na paciente, promovendo evidência adicional de que a variante $F D X 2$ p.Pro144Leu é patogênica.

A paciente 12.4, que tinha atraso dos desenvolvimento neuropsicomotor e características dismórficas que não foram observadas nos outros pacientes, foi avaliada também por cariótipo. Este revelou uma tetrassomia do braço curto do cromossomo 9, cariótipo:46, XX,+i(9)(p10). O cariótipo de seus pais também foi analisado e era normal.

\subsubsection{Encefalomioneuropatia relacionada a $F D X 2$ - um novo fenótipo}

Assim, podemos resumir o fenótipo como uma síndrome composta de: atrofia óptica congênita; episódios recorrentes de mialgia e fraqueza proximal desencadeados por frio, infecções ou exercícios físicos, sugerindo possível rabdomiólise; miopatia proximal tardia; polineuropatia sensitivo-motora axonal crônica de início por volta de 10 a 12 anos; sinais piramidais de surgimento tardio; leucoencefalopatia reversível ou parcialmente reversível; anemia microcítica com neutropenia ou trombocitopenia; e hipotireoidismo subclínico. Diabetes talvez seja parte do quadro clínico, de início na idade adulta e a biópsia muscular mostra fibras vermelhas rasgadas, SDH e COX negativas, com acúmulo de ferro (Figura 27). 


\section{Características clínicas: 6 pacientes (6-41 anos)}

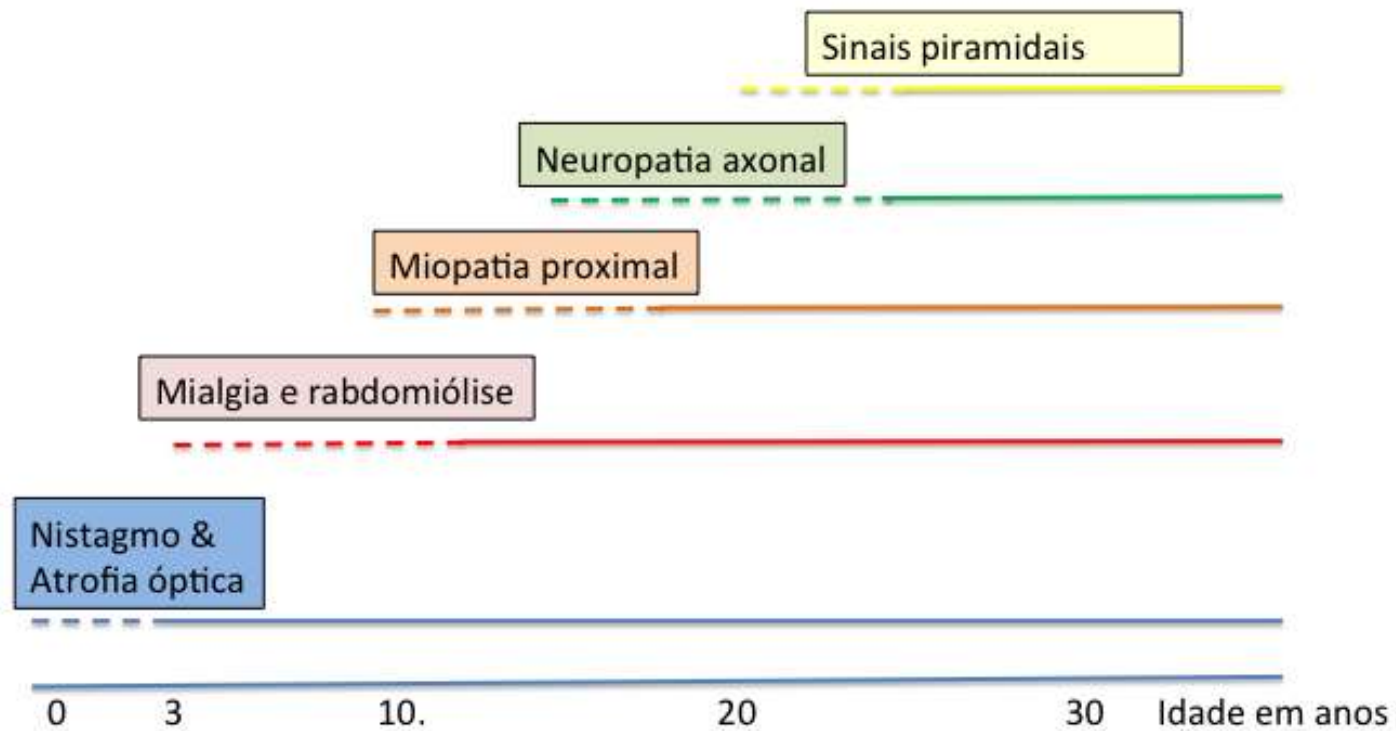

Figura 27 - Possível história natural da doença relacionada a FDX2: características clínicas respectivas idades de início inferidas a partir da observação de 6 casos (os 4 descritas nesta tese e 2 avaliados pela equipe da UFMG). A leucoencefalopatia não foi incluída por considerarmos que a mesma é assintomática

\subsection{Pacientes sem diagnóstico}

Em nossa série três pacientes não relacionados permaneceram sem diagnóstico mesmo após minuciosa revisão da apresentação clínica, radiológica e dos dados do sequenciamento completo do exoma.

A paciente 29.1, filha de pais não consanguíneos, nasceu com fenda palatina e passou a apresentar tremor de MMSS a partir dos três anos de idade. Após a menarca aos 12 anos, houve piora do tremor, que passou a ser também cefálico, e iniciou distúrbio de marcha (ebriosa). Após significativo estresse psicológico aos 16 anos de idade, houve agravamento do quadro motor e mudança de comportamento, tornando-se mais apática e infantilizada. Houve lenta progressão do quadro motor e declínio cognitivo. Teve menopausa precoce aos 27 anos.

Ao exame neurológico apresentava disfunção executiva, sinal de Romberg, marcha parieto-atáxica, paraparesia espástica com força grau IV, reflexos exacerbados em MMII, sinais de Babinski Hoffman e Tromner bilateralmente, 
tremor cefálico em negação, ataxia cerebelar global com componente de ataxia sensitiva sobreposto, sensibilidades profundas diminuídas em MMII, baixa acuidade visual bilateral, sacadas hipométricas e seguimento sacádico.

A RM de crânio mostrava um padrão de hipersinal da substância branca tênue em T2/FLAIR, difuso, com sinal preservado em T1 sugerindo hipomielinização.

Inicialmente pensávamos que poderia se tratar de doença da substância branca evanescente, mas nenhuma variante patogênica patogênica foi encontrada no exoma.

A paciente 30.1 era uma mulher hígida até 53 anos de idade quando iniciou quadro de alteração da marcha lentamente progressiva, com posterior acometimento de esfíncteres e declínio cognitivo. Tinha uma história muito sugestiva de herança autossômica dominante, com pelo menos três gerações de familiares acometidas.

Ao ser examinada aos 65 anos (13 anos de evolução) apresentava síndrome cognitiva caracterizada por disfunção executiva, amnésia anterógrada e apraxia ideomotora, marcha em tesoura com necessidade de apoio unilateral, paraparesia espástica e leve ataxia cerebelar global. Notavelmente, não havia hipotensão postural.

A RM de crânio mostrava hipersinal difuso em T2/FLAIR, periventricular e subcortical, sem captação de contraste ou restrição à difusão.

Por fim, o paciente 31.1 era um senhor de 73 anos que desde os 55 anos apresentava disfagia orofaríngea leve a moderada, sem progressão até os 67 anos, como sintoma isolado. Aos 67 anos, apresentou três episódios de síncope em curto espaço de tempo e, em um destes eventos, sofreu graves queimaduras em tórax, necessitando de traqueostomia e gastrostomia. Desde então não teve novos episódios de síncope, mas evoluiu com distúrbio de marcha lentamente progressivo, hipoacusia e perda visual. Desconhecia casos semelhantes na família.

Ao exame apresentava apenas ataxia cerebelar global leve, sacadas lentificadas e ausência do reflexo vestíbulo-ocular. A RM de crânio mostrava hipersinal em T2/FLAIR difuso, supra e infratentorial, com infartos e microhemorragias. Os exames laboratoriais e o exame do líquor não apresentavam alterações significativas. O sequenciamento do exoma também não identificou variantes patogênicas. 
6 Discussão 



\section{DISCUSSÃO}

O objetivo principal deste estudo foi caracterizar uma população adulta de pacientes com doenças da substância branca de etiologia genética, acompanhados em um centro de referência para doenças neurogenéticas. Descrevemos os aspectos clínicos e neurorradiológicos enfatizando aqueles com maior valor diagnóstico e conseguimos definir o diagnóstico em 28 de 31 famílias.

Este é um grupo de doenças raras bastante heterogêneo e nossa amostra confirma este aspecto, com 13 doenças diferentes sendo identificadas em 31 famílias. A doença mais frequentemente encontrada foi a ALD/AMN-X, diagnosticada em setes famílias. Tal achado está em consonância com a literatura, dado que é a LD/LG mais comum em crianças e adultos (Ayrignac et al., 2015; Waldman, 2018).

No entanto, é interessante notar que este grupo de pacientes com ALD/AMN$\mathrm{X}$ continha três pacientes com início da doença antes dos 16 anos. Se considerarmos apenas pacientes com idade de início dos sintomas superior a 16 anos, o grupo de pacientes com VWM se torna o principal representante (com 5 pacientes provenientes de 4 famílias).

Destas 13 doenças diagnosticadas, seis afetaram apenas um paciente - doença de Alexander, ADLD, síndrome de Sjögren-Larsson, LBSL, doença relacionada a PLPl e síndrome de Gordon-Holmes. Duas doenças são marcadamente novas (relacionadas a PUS3 e FDX2) e serão discutidas com maior profundida nas sessões subsequentes.

Dentre as 28 famílias com diagnóstico definitivo, metade tinha história familiar de outros acometidos e metade eram de casos esporádicos, o que está relativamente em linha com a literatura (Lynch et al., 2017), que afirma serem os casos esporádicos mais frequentes.

Interessante notar que dentre os sete pacientes diagnosticados com doenças sabidamente autossômicas dominantes, quatro não apresentavam história de outros familiares acometidos (dois de três pacientes com HDLS, um de três com CADASIL e uma paciente com doença de Alexander). Isto pode se dever a três fatores: casos de mutação de novo, que é comum em casos de doença de Alexander; doença 
autossômica dominante de penetrância incompleta, como acredita-se ser o caso da HDLS; ou não-paternidade.

Os estudos de caracterização clínica, neurorradiológica e genética de LD/LG são bastante escassos na literatura, principalmente quando buscamos por estudos em adultos (Ayrignac et al, 2015; Vanderver et al, 2016; Lynch et al, 2017). Todos têm como ponto de partida uma avaliação minuciosa da apresentação clínica e dos achados de imagem, mas diferem nas etapas de avaliação subsequentes.

Acreditamos que a escolha dos exames subsequentes nos referidos estudos foi largamente influenciada pela disponibilidade dos mesmos - como ocorreu com o nosso estudo. Assim, Ayrignac et al (2015), realizou testes bioquímicos e sequenciamento de genes específicos conforme a suspeita, mas não submeteu sua amostra à avaliação por NGS. Ainda assim, obteve diagnóstico definitivo em 98/154 (64\%) pacientes.

Já Vanderver et al. (2016a), em sua amostra inicial de 191 pacientes, foi capaz de apontar um diagnóstico direto em 101 pacientes (52,8\%). Para tal, além de testes bioquímicos, foi capaz de sequenciar diretamente vários genes candidatos, como EIF2B1-5, PLP1 ou GFAP. Assim, a amostra restante que foi encaminhada para NGS (71 pacientes) já tinha sido submetida a uma investigação mais ampla do que a nossa casuística. Destes 71, 25 obtiveram um diagnóstico final (35\%).

Estas diferenças no protocolo de investigação ajudam a explicar como obtivemos uma taxa de diagnósticos mais alta (28/31 ou 90\% dos casos). Utilizamos o protocolo sugerido por Ahmed et al. (2014) e tínhamos um repertório limitado de genes a serem testados individualmente (apenas GFAP, LMNB1 e ALDH3A2). Assim, na etapa de avaliação por exoma clínico, obtivemos uma alta taxa de diagnósticos, 13/18 pacientes ou 72\%.

Destes 18 pacientes submetidos à avaliação por exoma clínico, 16 foram aninhados à coorte inglesa da University College London e estão publicados na revista Brain (Lynch et al., 2017). Onze dentre os 26 pacientes que obtiveram diagnóstico final presentes nesta publicação são nossos pacientes. São eles: três pacientes com CADASIL, quatro com VWM e um paciente com cada um dos seguintes diagnósticos: doença relacionada a PLP1, LBSL, HDLS e síndrome de Gordon-Holmes. Optamos por excluir desta publicação os pacientes com diagnóstico 
bioquímico, em conformidade com os critérios adotados pela instituição inglesa. Dois pacientes (16.1 e 17.1) que foram submetidos à avaliação por exoma clínico e que tiveram diagnóstico final de HDLS não foram incluídos no referido artigo, pois foram avaliados após a publicação.

Cinco probandos foram avaliados por sequenciamento completo do exoma e três continuaram sem diagnóstico. Dois destes tinham características que nos faziam suspeitar fortemente de uma etiologia genética - uma paciente com início precoce dos sintomas e uma paciente com mais familiares acometidos - e ainda assim permaneceram sem diagnóstico.

Os motivos que podem explicar a incapacidade do exoma completo de diagnosticar estes pacientes são variados. Existem as limitações relacionadas ao próprio método - não avaliar regiões intrônicas ou variantes patogênicas por expansão de trinucleotídeos, e sua capacidade limitada de avaliação de variação no número de cópias. Podem se tratar de doenças adquiridas ou genéticas de origem poligênica ou mesmo de origem em variantes patogênicas de DNA mitocondrial (que não foi avaliado em nossos pacientes). Pode-se ainda especular que possuam variantes patogênicas ainda não relacionadas LD/LG. A avaliação de trios (DNA dos progenitores e do probando) poderia fornecer dados relevantes, mas infelizmente não foi possível para estes pacientes. Reavaliações futuras de seus dados ou a avaliação por sequenciamento completo do genoma poderão ajudar a elucidar estes casos.

As famílias que obtiveram diagnóstico por sequenciamento completo do exoma (as diagnosticadas com variante patogênica em FDX2 ou PUS3), foram excluídas do primeiro artigo que participamos e foi publicado na revista Brain (Lynch et al. 2017) por motivos distintos. A família portadora da variante patogênica em homozigose em FDX2 foi propositalmente excluída para maior investigação do papel da variante suspeita no quadro, tendo em vista que é um fenótipo completamente diferente do descrito anteriormente relacionado ao mesmo gene. Naquele momento não tínhamos elementos suficientes (estudos funcionais) para afirmar que era aquele o gene responsável pelo quadro.

Já a família posteriormente diagnosticada com a variantes patogênicas em PUS3 encontra-se publicada no suplemento do artigo de Lynch et al. (2017), na tabela com os casos sem diagnóstico final (são as pacientes N48 e N49 da referida 
tabela). O diagnóstico só foi feito após reanálise do exoma completo, ao filtrar os dados por variantes deletérias heterozigotas compostas. Cumpre salientar que o primeiro artigo associando PUS3 a qualquer fenótipo em humanos data de 2016 (Shaheen et al., 2016).

O caso desta família com variantes patogênicas em PUS3 ilustra bem uma grande vantagem do sequenciamento completo do exoma sobre a avaliação por painéis de genes: a possibilidade de reanálises futuras dos dados. Os painéis de genes não oferecem esta possibilidade. Possuem ainda uma outra desvantagem: dado o crescente número de genes identificados relacionados às $\mathrm{LD} / \mathrm{LG}$, os painéis podem se tornar rapidamente obsoletos ou incompletos.

Algumas doenças que frequentemente são citadas em artigos de revisão sobre LD/LG não foram identificadas na nossa casuística. Nos referimos especificamente sobre a ausência de pacientes com leucodistrofia metacromática ou doença de Krabbe - que também foram muito raras em populações de adultos com LD/LG (Ayrignac et al. 2015).

Obviamente, são doenças muito raras em adultos e este não é um estudo populacional capaz de alcançar uma amostra significativa. Mas suspeitamos que talvez estas doenças estejam demasiadamente destacadas na literatura neurológica de pacientes adultos com $\mathrm{LD} / \mathrm{LG}$ em detrimento de outras que foram mais frequentes nesta e em outras casuísticas, como VWM, HDLS e CADASIL.

\subsection{Doenças mais comuns em nossa casuística}

\subsubsection{Adrenomieloneuropatia e adrenoleucodistrofia ligada ao X}

Identificamos cinco pacientes com AMN-X e três pacientes com ALD-X e seus aspectos clínicos e neurorradiológicos em larga medida corroboram o que já está bem descrito na literatura (Engelen et al., 2012 e kemp et al., 2016). Assim, o predomínio de sinais piramidais sobre os sinais neuropáticos e a presença de RM de crânio normais ou com discretas alterações de sinal em substância branca posterior em pacientes AMN-X, já eram esperados. O mesmo pode-se dizer dos sintomas iniciais de ALD-X semelhantes a TDAH e sua evolução catastrófica. 
No entanto, alguns aspectos clínicos merecem destaque. O primeiro deles foi a observação sintomas cognitivos em um dos pacientes com AMN-X, o que ocorre em menos de $20 \%$ dos pacientes (Moser, 1997). Ressalta-se que era o paciente com maior tempo de evolução da doença.

A insuficiência adrenal estava presente em todos os pacientes, porém subclínica em dois. Isto mostra que esta valiosa síndrome clínica, capaz de direcionar o diagnóstico, deve ser ativamente investigada, por vezes com auxílio da Endocrinologia.

Um paciente com $\mathrm{AMN}-\mathrm{X}$ tinha achados laboratoriais compatíveis com insuficiência testicular, que também é uma síndrome clínica de alto valor diagnóstico, mas menos lembrada na prática. Talvez seja interessante incluir um espermograma como triagem em casos suspeitos.

Não encontramos na literatura associação entre ependimoma e ALD/AMN-X e acreditamos que a associação observada em um dos nossos pacientes com AMN-X seja espúria.

O caso mais desafiador foi, sem dúvida, o do paciente 1.2. A presença de lesão assimétrica na RM de crânio, a pobreza de sinais motores e a exuberância do quadro psiquiátrico o tornam um caso bastante atípico. Foi a história familiar, com um irmão acometido, que facilitou o diagnóstico.

\subsubsection{Doença da substância branca evanescente}

Identificamos cinco pacientes (4 famílias) com VWM, todos com a forma adulta da doença (início após os 16 anos). As manifestações clínicas com predomínio dos sintomas cognitivos, alteração da marcha e curso lentamente progressivo estão em linha com recente estudo publicado sobre a história natural de VWM (Hamilton et al., 2018).

Destacamos que uma das duas mulheres acometidas não teve falência ovariana precoce, e teve início bastante tardio, aos 52 anos. No estudo de Hamilton et al. (2018), a idade de início mais avançada foi de 54 anos. Sua apresentação inicial foi também bastante peculiar, com sintomas de neuralgia do trigêmeo. Não 
encontramos associação semelhante na literatura, embora a presença de cefaleia seja descrita - mas com características migranosas.

Esta mesma paciente teve o diagnóstico inicial de esclerose múltipla e recebeu tratamento para tal por longo período. Tal equívoco diagnóstico não parece ser incomum, mas uma avaliação cuidadosa da RM de crânio pode fazer o diagnóstico correto. Segundo Ayrignac et al. (2016b), as principais diferenças são: somente pacientes com esclerose múltipla apresentam lesões ovoides perpendiculares ao ventrículo lateral e lesões puntiformes justacorticais (100\% em esclerose múltipla e $0 \%$ em VWM); cerca de metade dos pacientes com VWM apresentam lesões infratentoriais simétricas, o que não foi observado em pacientes com esclerose múltipla. Na nossa paciente faltavam as características típicas de esclerose múltipla e existiam as cavitações e rarefação de substância branca supratentorial, assim como o acometimento simétrico de tronco, em tegmento da ponte.

Outro aspecto clínico que nos chamou a atenção neste grupo de pacientes foram as pioras relacionadas a traumatismo cranioencefálico, relatado em quatro dos cinco pacientes, mas a ausência de relatos de agravamentos por febre. Segundo Hamilton et al. (2018), febre foi um fator agravante mais comum do que trauma.

Com relação aos aspectos genéticos, identificamos uma família com variante patogênica em EIF2B4 e três famílias com variante patogênica em EIF2B5, o gene mais comumente implicado em VWM (Labauge et al., 2009 e Hamilton et al., 2018). Dois pacientes eram homozigotos para a variante mais comumente descrita (p.Arg113His), que tipicamente não causa doenças em crianças.

No entanto, não podemos afirmar que os fenótipos produzidos por esta variante patogênica sejam brandos, pois ambos os pacientes apresentavam limitações funcionais significativas principalmente por seus sintomas cognitivos. Lei $\mathrm{H}$ et al. (2010) considerou os pacientes homozigotos para esta variante patogênica como portadores de fenótipos mais brandos baseando-se na idade de início dos sintomas e no tempo para tornar-se cadeirante. Dentre os nossos três pacientes com variante patogênica em EI2B5, foi a paciente heterozigota composta a que apresentou o fenótipo mais brando, com início mais tardio e sintomas mais leves (neuralgia do trigêmeo). 


\subsubsection{Acidúria L2-hidroxiglutárica}

Identificamos três famílias (quatro pacientes) com L2HGA. Os quatro pacientes tiveram início precoce e curso protraído da doença, conforme esperado nesta condição. Interessante notar que, ao contrário das demais acidopatias orgânicas, a L2GHA não apresenta descompensações agudas e os pacientes podem chegar à idade adulta sem diagnóstico.

Dentre os aspectos clínicos, destacamos a presença de movimentos anormais em três pacientes. Duas irmãs apresentavam distonia em mãos e careteamento, achado raro, mas já descrito (Marcel et al, 2012). Uma delas apresentava tremor cefálico e o outro paciente apresentava hemidistonia e distonia cervical em retrocolo. Os movimentos anormais podem ser o sintoma a desencadear uma nova investigação na vida adulta e levar ao diagnóstico (Termsarasab e Frucht, 2014).

Uma dentre quatro pacientes desenvolveu gliobastoma multiforme. Algumas particularidades deste caso incluem o fato de que a paciente não tinha diagnóstico de L2HGA até apresentar os sintomas decorrentes do tumor - afasia e hemiparesia -, e a idade avançada em que o tumor foi diagnosticado (45 anos).

A maioria dos pacientes reportados com L2HGA que apresentaram tumor de SNC eram mais jovens quando do diagnóstico (Patay et al. 2012 e Patay et al, 2015). Este mesmo autor acredita que provavelmente a incidência de tumores em L2HGA seja alta - ao redor de $40 \%$. A presença de um caso dentre quatro na nossa pequena série, reforça esta impressão.

O tipo histológico encontrado é variável, nem sempre sendo gliomas de alto grau, mas outros pacientes já foram reportados com glioblastoma multiforme (Patay et al., 2012).

O mecanismo pelo qual a L2HGA aumenta a incidência de tumores de SNC ainda não é conhecido, mas é interessante notar que a mesma doença é simultaneamente mielinotóxica e tumorigênica. Também não há associações formuladas na literatura entre o genótipo e o maior ou menor risco de tumores. 


\subsubsection{Leucoencefalopatia difusa hereditária com esferóides}

A HDLS faz parte do pequeno grupo das doenças relacionadas à micróglia (junto com a doença de Nasu-Hakola). Identificamos três pacientes com HDLS, cerca de $9 \%$ da nossa série, prevalência comparável às encontradas em por Guerreiro et al. (2013) e Lynch et al. (2015). Confirmamos, portanto, HDLS como uma das principais LD/LG do adulto.

Embora a número de casos seja muito pequeno para qualquer inferência, destacamos que a paciente que teve início dos sintomas antes dos 40 anos teve progressão mais rápida da doença, evoluindo para óbito após 5 anos. A sobrevida média da HDLS é de 6,8 anos (Konno et al., 2017).

Esta mesma paciente (18.1) foi a primeira paciente a receber o diagnóstico de HDLS em nosso serviço. Inicialmente pensávamos tratar-se de um caso de síndrome de Labrune, pela presença de cavitações e calcificações nos exames de imagem. No entanto, avaliando retrospectivamente, observamos que as cavitações e calcificações presentes em nossa paciente são pequenas e periventriculares, como tipicamente descrito em HDLS (Konno et al., 2017). Por outro lado, a síndrome de Labrune tipicamente apresenta calcificações grosseiras e cistos exuberantes (Labrune et al., 1996).

As outras duas pacientes apresentaram-se com quadro cognitivocomportamental que, num primeiro momento, lembram degeneração lobar frontotemporal, variante comportamental. No entanto, a RM de crânio com alterações da substância branca frontoparietal, bilateral e o acometimento de corpo caloso nos direcionaram para a hipótese diagnóstica correta.

CSF1R codifica um receptor de superfície celular que é altamente expresso em células da linhagem mielóide, incluindo a micróglia do SNC (Stanley e Chitu, 2014). Tal receptor possui domínios extracelular, transmembrana e intracelular, sendo este um domínio tirosina-quinase. A ativação deste receptor leva à ativação de uma série de vias secundárias, essenciais para a sobrevivência, diferenciação e proliferação da micróglia. A maioria das variantes patogênicas descritas até hoje, são mutações por trocas simples de aminoácido no domínio tirosina-quinase do CSF1R (exons 12-21) (Konno et al., 2017). 
Encontramos três novas variantes patogênicas, todas no domínio tirosinaquinase (entre os exons 12-22), mas curiosamente apenas uma por troca simples de aminoácido (paciente 18.1, c2570C>T; p.Pro857Leu). Esta paciente está reportada na nossa publicação com o grupo da Queen Square (Lynch et al., 2017). A paciente 16.1 apresentava mutação por mudança do sítio de formatação ("frameshift mutation”) no exon 18, levando a perda de função. Já a paciente 17.1 apresentava mutação em sítio de "splicing" no exon 20, com consequência desconhecida sobre a proteína, mas presumimos também perda de função. Todas as variantes identificadas presumivelmente levam à formação de proteínas truncadas e à haploinsuficiência de $C S F 1 R$, como ocorre nas variantes patogênicas já previamente associadas à doença (Stabile et al., 2016).

\subsubsection{CADASIL}

Identificamos três pacientes com CADASIL, sendo este um dos diagnósticos mais frequentes. Acreditamos que sua prevalência possa ser ainda maior, pois sendo um diagnóstico relativamente mais conhecido dos neurologistas gerais, podem existir casos que não nos foram referenciados e continuam em seguimento nos ambulatórios de cefaleia ou neurologia vascular ou cognitiva.

Com relação aos aspectos clínicos, uma paciente não tinha história familiar, o que possivelmente se deve ao fato de ser ela portadora de mutação de novo ou de imprecisões na história familiar. Um paciente recebeu diagnóstico prévio de acidente vascular encefálico isquêmico secundário a forame oval patente e foi submetido a fechamento do mesmo. Isto ocorreu mesmo com uma história familiar claramente sugestiva de doença autossômica dominante.

O paciente 19.1 apresentava uma enxaqueca particularmente grave, com dores muito intensas e frequentes. Apresentava também aura complexa, com manifestações motoras e sensitivas graves, por vezes prolongadas - muitas vezes difícil de distinguir de um novo evento isquêmico. Foi refratário a todos os tratamentos profiláticos medicamentosos para enxaqueca disponíveis à época.

Importante ainda ressaltar que este é o único grupo de pacientes em que há hipersinal em T2 e FLAIR em polos temporais. No entanto, este não é um achado 
universal, pois o paciente 19.1, mesmo após dez anos de doença, não apresentava esta alteração (Lynch et al., 2017).

\subsection{Doenças com apenas um paciente diagnosticado}

\subsubsection{Doença de Alexander}

A paciente que diagnosticamos com doença de Alexander do adulto é um exemplo de correlação genótipo-fenótipo levando ao diagnóstico correto. Obviamente a raridade da condição a torna mais difícil de ser lembrada pelo neurologista geral. A apresentação assimétrica e a ausência de uma clara história familiar podem atrasar a hipótese de uma doença genética, mas a avaliação meticulosa particularmente da RM de crânio permitiu o diagnóstico correto (GraffRadford et al., 2014; Leite et al., 2014).

A história de uso de tabaco e bebidas alcoólicas poderia também induzir ao diagnóstico equivocado de síndrome de Marchiafava-Bignami, embora esta tenha um padrão de acometimento de substância branca diferente, com predomínio parietooccipital e lesão de corpo caloso (Lucato et al., 2015). Conforme comentamos na revisão de literatura da presente tese, a presença de tremor palatal poderia sugerir o diagnóstico, mas sua ausência não exclui a possibilidade de doença de Alexander, como comprova o caso da nossa paciente.

Ressaltamos ainda que encontramos uma variante patogênica nova que (p.Arg270Pro), como a maioria das mutações previamente descritas, é por troca simples de aminoácido. $\mathrm{O}$ mecanismo patogênico de todas as variantes patogênicas descritas até o momento parece ser por ganho tóxico de função da proteína filamentar glial ácida, a principal proteína filamentar intermediária de astrócitos maduros (Prust et al., 2011). No entanto, o mecanismo exato que leva à doença ainda não é completamente compreendido. Infelizmente não tivemos oportunidade de realizar estudos funcionais. Também não tivemos acesso a amostras do DNA dos pais, para averiguar se a paciente era portadora de fato de evento mutacional de novo, como a maioria dos pacientes com doença de Alexander, ou não. 
Como dicas para prática clínica, podemos deduzir deste caso que a doença de Alexander do adulto deve figurar nas listas de diagnóstico diferencial das LD/LG, bem como nas de paraparesias espásticas e ataxias-espásticas (de Bot et al., 2012).

\subsubsection{Leucoencefalopatia com acometimento de tronco encefálico e medula e elevação de lactato - LBSL}

A paciente que diagnosticamos como portadora de LBSL também figura entre aqueles pacientes em que a apresentação clínica e particularmente a imagem de RM de crânio permitem a formulação de hipótese diagnóstica antes da testagem genética.

O início precoce e a evolução lenta, chegando à vida adulta ainda deambulando, mesmo que com apoio, estão em consonância com a descrição original da doença (van der Knaap et al., 2003). Os achados de RM de crânio em fossa posterior são muito característicos, principalmente $\mathrm{o}$ acometimento bilateral $\mathrm{e}$ simétrico dos tratos intraparenquimatosos do nervo trigêmeo. Tal achado associado a leucoencefalopatia supratentorial difusa, acometimento de pirâmides bulbares, colunas posteriores da medula espinhal, núcleos denteados do cerebelo e pico de lactato na espectroscopia praticamente selam o diagnóstico (van der Knaap et al., 2003).

Curiosamente, não é comum o achado de elevação de lactato medido no líquor (Labauge et al., 2007), assim como não havia em nossa paciente. Esta também não apresentava elevação de lactato na espectroscopia - o que não afasta o diagnóstico. Outro aspecto interessante do presente caso é que, apesar de os pais referirem consanguinidade, a variante encontrada foi em heterozigose composta, como ocorre na maioria dos casos descritos até o momento. Acredita-se que as variantes patogênicas em homozigose possam ser letais ou gerarem fenótipos mais graves (Köhler et al., 2015).

\subsubsection{Síndrome de Sjögren-Larsson}

Identificamos um paciente adulto com síndrome de Sjögren-Larsson com o fenótipo típico desta doença, uma síndrome neurocutânea de início precoce. Apesar 
de se apresentar com a tríade clássica da doença de deficiência intelectual, diplegia espástica e ictiose congênita, o diagnóstico só foi concluído tardiamente. Isto nos motivou a escrever um breve relato para lembrar a comunidade médica deste diagnóstico (Paiva et al., 2018).

Vale ressaltar que o diagnóstico na vida adulta é facilitado por estar a síndrome já completamente manifesta. Na criança, há uma sequência característica de surgimento dos sintomas: parto prematuro de criança com ictiose congênita, com atraso do desenvolvimento neuropsicomotor antes de 30 meses e alterações retinianas após os 3 anos de idade (Willemsen et al., 2001 e Fuijkschot et al., 2012). Esta apresentação associada a leucoencefalopatia com presença de picos lipídicos na espectroscopia ajudam a orientar o diagnóstico.

A ictiose na síndrome de Sjögren-Larsson predomina em regiões flexoras e tende a ter aspecto liquenificado, com coloração amarelada, como vista em nosso paciente. Pode ser acompanhada por hipo-hidrose e intolerância ao calor, mas nosso paciente não apresentava estes dois últimos sintomas. Como diagnóstico diferencial de ictiose congênita podemos citar tricotiodistrofia, doença de depósito lipídico neutro, síndrome de Conradi-Hünermann-Happle, doença de Gaucher, síndrome ceratite-ictiose-surdez e síndrome de Netherton (Nagappa et al., 2017).

Nosso paciente chegou a atingir alguns marcos do desenvolvimento neuropsicomotor, com posterior regressão. Os pais não foram capazes de lembrar com exatidão sobre prematuridade e sintomas visuais na infância, o que nos leva a acreditar que talvez não fossem muito intensos. Infelizmente, o paciente não foi submetido a uma avaliação neuro-oftalmológica pormenorizada que permitisse definir a presença de maculopatia, presente na maioria dos pacientes.

As alterações retinianas típicas são depósitos cristalinos brilhantes perifoveolares associados a microcistos em fóvea e marcada redução do pigmento macular. Assim, além da baixa acuidade visual, há fotofobia (Fuijkschot et al. 2012).

Alguns achados clínicos de nosso paciente são pouco usuais, embora já tenham sido descritos: anartria, disfagia grave e crise febril na infância (Fuijkschot et al. 2012).

Os achados de RM de crânio também eram bastante característicos, com lesões em substância branca confluentes, hiperintensas em T2 e FLAIR, difusas, 
afetando também o corpo caloso e poupando fibras subcorticais e região infratentorial (Willemsen et al., 2004). No entanto, a presença de alguns pontos de restrição à difusão foram um achado inesperado, para o qual não temos uma boa explicação. Já os achados de espectroscopia, deram a pista definitiva para o diagnóstico.

Salientamos que a presença de picos lipídicos anormais na espectroscopia podem ocorrer em esclerose múltipla, doença de Niemann-Pick tipo C, deficiência de dihidroxiacetona fosfato aciltransferase e algumas doenças peroxissomais. No entanto, nestas condições os picos lipídicos são menos intensos do que os observados na síndrome de Sjögren-Larsson (Nagappa et al., 2017).

Uma grande variedade de variantes patogênicas em $A L D H 3 A 2$ é descrita em homozigose e heterozigose composta, resultando em perda de atividade enzimática (Willemsen et al., 2001). A variante c.1108-1G>C, de origem paterna, foi a mais frequentemente identificada em uma coorte brasileira prévia com nove pacientes. Tal variante também foi encontrada em pelo menos um paciente espanhol e especula-se sobre possível origem comum (Auada et al., 2006). Já a variante c.798+5G>A foi descrita por Rizzo et al. (1999), em uma família de origem libanesa. Ambas variantes presumivelmente levam a proteínas anormais por deleção de aminoácidos, sendo incapazes de exercer função catalítica e consequentemente reduzindo a atividade de FALDH (De Laurenzi et al., 1996).

\subsubsection{Leucodistrofia desmielinizante autossômica dominante de início no adulto - ADLD}

Identificamos um paciente com ADLD por meio da revisão da apresentação clínica e da imagem. A presença de disautonomia e história familiar sugestiva de herança autossômica dominante foram particularmente úteis para o diagnóstico correto neste caso.

A idade de início, a sequencia de surgimento dos sintomas, com a disautonomia precoce e o declínio cognitivo tardio, bem como a evolução lenta do nosso paciente podem ser consideradas típicas (Finnsson et al., 2015). No entanto, uma característica clínica que não havia sido previamente relatada é a polineuropatia 
desmielinizante sensitiva crônica. Não encontramos outra etiologia capaz de explicar melhor este achado em nosso paciente, tornando-se tentador especular que tal neuropatia periférica seja secundária à ADLD.

Do ponto de vista neurorradiológico, podemos considerar os achados de RM de crânio, coluna cervical e torácica também sugestivos da doença. Destacamos que o acometimento de medula, particularmente cervical, é um valioso achado, capaz de restringir as hipóteses diagnósticas a três principais: ADLD, LBSL e doença de Alexander.

Com relação aos aspectos genéticos é importante salientar que a variação no número de cópias (CNV) pode não ser identificada por NGS. Assim, idealmente todos os casos suspeitos de ADLD devem primeiro ser submetido a pesquisa de duplicação ou deleção em $L M N B 1$ por array-CGH ou MLPA.

De qualquer modo, vale mencionar que Pedroso et al. (2017) diagnosticaram um caso atípico de uma paciente heterozigota para variante patogênica de $L M N B 1$ por troca simples de aminoácido por meio de sequenciamento completo do exoma.

\subsection{5 - Síndrome de Gordon-Holmes}

Identificamos um paciente com a combinação incomum de declínio cognitivo, ataxia cerebelar, coréia, hipogonadismo hipogonadotrópico e leucoencefalopatia difusa que teve diagnóstico de doença neurodegenerativa relacionada a $R N F 216$ por meio do exoma clínico.

A característica clínica de maior valor diagnóstico neste caso é sem dúvida a presença de hipogonadismo hipogonadotrófico. Até o momento, apenas quatro genes foram relacionados a associação de ataxia e hipogonadismo hipogonadotrófico: RNF216, POLR3A, PLOR3B e PNPLA6 (Margolin et al., 2013; Wolf et al., 2014; Synofzik et al, 2014). No entanto, o hipogonadismo pode ser subclínico e merece ser ativamente pesquisado em pacientes com ataxia ou coréia ou demência ou leucoencefalopatia difusa de etiologia indeterminada (Santes et al., 2015).

A associação de hipogonadismo hipogonadotrófico e coréia é ainda mais rara, sendo relacionada a apenas dois genes: RNF216 e NKX2-1 (Balicza et al., 2018). Já a associação de demência e coréia, além da doença de Huntington, tem um diagnóstico 
diferencial mais amplo, podendo ser causada por variantes patogênicas em $C 9$ orf 72 , TBP (SCA17 ou "Huntington-like disease" (HDL) 4), PRNP (HDL1), JPH3 (HDL1), ATN1 (atrofia dentatorubropalidoluysiana - DRPLA), entre outros. A DRPLA seria um diagnóstico diferencial importante para o nosso caso, pois também causa leucoencefalopatia difusa.

Salientamos a ocorrência simultânea de ataxia cerebelar e coréia em nosso paciente, que já havia sido notada previamente em outros casos, embora nem sempre destacada (Santes et al., 2015).

Variantes patogênicas em RNF216 já foram relacionadas à síndrome $4 \mathrm{H}$ (Ganos et al., 2015), mas com achados de RM de crânio distintos. No nosso paciente não encontramos alterações de dentição, nem alterações de imagem sugestivas de hipomielinização.

Os achados de RM de crânio de nosso paciente em muito se assemelham aos descritos na literatura (Santes et al., 2015; Ganos et al., 2015), com leucoencefalopatia difusa confluente, acometimento de ponte, cerebelo e núcleos da base, bem como atrofia cortical e cerebelar.

\subsubsection{Doença relacionada a $P L P 1$}

Identificamos um paciente com uma nova variante patogênica em PLPl. Tratava-se de um adulto jovem, sem história familiar e com apresentação bastante incomum, cujo o diagnóstico só foi possível pelo exoma clínico.

Cumpre salientar que o isossinal da substância branca em T1 pode facilmente passar despercebido e a hipótese de uma LD/LG hipomielinizante não ser cogitada. Neste caso isto ocorreu e desviou nossa atenção para possíveis etiologias tóxicas (Filley, 2015). O acometimento difuso em T2 nos fez considerar intoxicação por tolueno, mas não havia história de exposição.

A identificação da hipomielinização é muito importante, pois pode orientar a pesquisa genética para os seguintes genes: PLP1, GJC2, TUBB4A, POLR3A, PLOR3B, CLCN2, NKX6-2 (Lynch et al., 2018). O aspecto tigróide da substância branca por vezes observado em crianças com PMD não parece ser específico de PMD nem tampouco comum em adultos (Rubegni et al., 2017). 
Pouco se sabe sobre outras características distintivas de RM de crânio capazes de reduzir ainda mais a lista de diagnósticos diferenciais de LD/LG hipomielinizante, principalmente em adultos. Exceção apenas para doença relacionada a TUBB4A que, além da hipomielinização, pode apresentar atrofia de cerebelo e gânglios da base (síndrome $\mathrm{H}-\mathrm{ABC}$ ). Entretanto, há relatos de adultos com hipomielinização sem alterações de cerebelo e gânglios da base (Lu et al., 2017).

Clinicamente, a associação de paraparesia espástica, ataxia cerebelar e demência em um homem adulto poderia ser melhor enquadrada no diagnóstico diferencial das paraplegias espásticas hereditárias ("hereditary spastic paraplegia” HSP) complicadas. No entanto, nos chamou a atenção o nistagmo evocado pelo olhar e o tremor cefálico em negação, semelhante ao titubeio descrito na forma clássica da doença de Pelizaeus-Merzbacher.

Assim, concordamos com a observação feita por Hobson e Kamholz (2013) sobre a dificuldade de distinguir uma forma tardia de PMD de uma forma complicada de SPG2. Acreditamos que casos como este geram argumentos para uma revisão de nomenclatura, talvez tendo o genótipo como base, conforme discutimos na revisão de literatura desta tese.

\subsection{Novas contribuições}

\subsubsection{Deficiência intelectual autossômica recessiva 55 (relacionada a PUS3)}

Identificamos duas irmãs com uma forma sindrômica de deficiência intelectual (DI) relacionada a PUS3, que estavam em acompanhamento em nosso serviço desde a primeira infância, mas que obtiveram diagnóstico definitivo somente na idade adulta.

DI pode ser causada por variantes patogênicas em diversos genes, que afetam diversos grupos proteicos. Isto sugere que numerosos processos biológicos críticos e não-redundantes desempenham funções na cognição normal. Um dos processos envolvidos parece ser o da modificação do RNAt, pois há uma lista crescente de 
genes humanos implicados em DI que atuam neste processo: FTSJ1, TRMT1, NSUN2, WDR4, ADAT3 e PUS3 (Torres et al., 2014).

PUS3 codifica uma enzima altamente conservada da família das pseudouridilases que catalisa a formação de pseudouridina em resíduos específicos de uridina no RNAt. Tal modificação ocorre após a transcrição e é considerada crítica para estrutura, função e estabilidade do RNAt (Hur e Stroud, 2007).

A primeira família descrita por Shaheen et al (2016) com DI relacionada a PUS3 era composta por três indivíduos sauditas de 3 a 15 anos com DI grave e alterações difusas da substância branca. Um paciente apresentava epilepsia e nenhum apresentava nefropatia. O sequenciamento completo do exoma detectou variante "nonsense" em homozigose (p.Arg435*), que levava a perda de função da proteína.

Nossas pacientes apresentavam uma forma mais leve de DI, se comparada à família saudita, e proteinúria/síndrome nefrótica de início após os 20 anos. Já os aspectos dismórficos descritos são bem semelhantes nas duas famílias. Sem dúvida, será muito interessante acompanhar se os pacientes da família original irão desenvolver alterações renais. Entramos em contato com o Prof. Fowzan S. Alkuraya, coautor da descrição original, e o mesmo afirmou que até o momento nenhuma anormalidade renal havia sido detectada.

Assim, acreditamos que o acometimento renal tardio observado em nossas pacientes amplia o fenótipo da doença relacionada a PUS3. Interessante notar que há raros relatos de associação de glomerulopatia (GEFS) resistente a corticoesteróides e variantes patogênicas em RNAt mitocondrial (Hotta et al., 2001; Guéry et al., 2003; Scaglia et al., 2003; Dinour et al., 2004). Também tubulopatia já foi relacionada a enzima envolvida na modificação do RNAt pós-transcrição (Edvardson et al., 2017).

Nossas observações ampliam o espectro fenotípico e alélico da doença relacionada a PUS3, bem como geram evidência adicional do papel da modificação pós-transcricional do RNAt nas doenças neurológicas, especialmente DI e LG. 


\subsubsection{Encefalomioneuropatia relacionada a $F D X 2$}

Identificamos uma família com uma condição nova, de início na infância, com características clínicas, radiológicas e patológicas incomuns. O sequenciamento completo do exoma permitiu identificar como causa uma variante patogênica em $F D X 2$. Este achado foi validado pela análise de segregação e pela demonstração de quase completa ausência da proteína FDX2 no tecido muscular dos pacientes afetados.

Por meio da avaliação conjunta desta família e da família estudada pela equipe da UFMG com apresentação semelhante, dada e presença de crianças e adultos acometidos, podemos inferir a história natural da doença. Clinicamente caracteriza-se por atrofia óptica e nistagmo de início precoce, antes dos três anos de idade. Na primeira ou na segunda década de vida, iniciam-se episódios recorrentes de mialgia e fraqueza muscular proximal desencadeada por infecções ou frio, com miopatia proximal progressiva. Polineuropatia axonal sensitivo-motora surge na segunda década ou na vida adulta, levando a fraqueza distal.

Uma leucoencefalopatia assintomática reversível ou parcialmente reversível surge na primeira infância e desaparece ao fim da primeira década. Anemia microcítica pode estar presente desde a primeira década, acompanhada ou não de leucopenia por neutropenia ou plaquetopenia. $\mathrm{Na}$ idade adulta surgem complicações endocrinológicas - hipotireoidismo subclínico e diabetes melito.

Curiosamente, existem pelo menos mais dois relatos de pacientes com variante patogênica em $F D X 2$, ambos com fenótipo mais brando de rabdomiólise recorrente e miopatia mitocondrial, com a mesma variante em códon de início (c.1A>T), mas sem os demais achados que encontramos em nossos pacientes (Spiegel et al., 2014 e Lebigot et al., 2017). Presume-se que tal variante levaria a perda de expressão de $F D X 2$. Em nossos pacientes demonstramos uma significativa redução da expressão de proteína no tecido muscular, apesar da quantidade normal de RNAm. Tal redução sugere instabilidade ou excesso de degradação da proteína anormal decorrente da variante que encontramos.

A leucoencefalopatia é encontrada em outros distúrbios da biogênese [FeS], como em variantes patogênicas de NFU1 e NUBPL. Alguns portadores de 
variante patogênica em $N U B P L$ apresentam melhora progressiva das alterações em corpo caloso e substância branca cerebral, mas com concomitante piora clínica (Kevelam et al., 2013). Em nossos pacientes observamos melhora progressiva das alterações em substância branca, tálamos e tronco encefálico, sugerindo uma leucoencefalopatia reversível ou ao menos parcialmente reversível.

Uma explicação possível para tal reversibilidade é a presença de edema intramielínico (hipersinal em T2 associada a restrição à difusão) presente em nossos pacientes e também encontrado em outras leucoencefalopatias reversíveis, como MLC1, HEPACAM e CLCN2 (Depienne et al., 2013).

Interessante notar que tal leucoencefalopatia foi assintomática, pois nenhuma criança apresentou sinais de acometimento de SNC (além da atrofia óptica) enquanto apresentavam lesões na RM de crânio. Entretanto, dois pacientes adultos apresentavam sinais piramidais leves, sem alterações de imagem que os justificassem. Tais sinais permanecem inexplicados e esperamos que o seguimento destes pacientes nos ajude a elucida-los.

Os achados anatomo-patológicos de biópsia muscular de nossos pacientes são também bastante incomuns. Tipicamente, pacientes portadores de miopatias mitocondriais apresentam fibras vermelhas rasgadas que na coloração por tricromo de Gomori são SDH-positivas e COX-negativas (Di Mauro e Gurgel-Giannetti, 2005). No entanto, nossos pacientes apresentavam alterações focais de fibras SDH- e COX-negativas. Tal achado é consistente com a função da proteína FDX2 na formação dos complexos respiratórios I-III e produção do heme A para o complexo respiratório IV (Sheftel et al., 2010).

Já a coloração para depósitos de ferro e a microscopia eletrônica mostraram inclusões mitocondriais que presumivelmente continham ferro. Esta combinação de acúmulo de ferro e fibras SDH- e COX-negativas também é encontrada em pacientes com miopatia por variante patogênica em ISCU (Olsson et al., 2008 e Kollberg et al., 2009). Tais semelhanças sugerem que ISCU e FDX2 são importantes para a homeostase do ferro celular (Paul e Lill, 2015).

Cumpre destacar que a paciente 12.4 apresentava deficiência intelectual e características dismórficas que acreditamos ser devidas a síndrome de tetrassomia do 
9p. Tais achados também foram encontrados em uma série de casos desta doença (El Khattabi et al., 2015).

Defeitos na biogênese do "cluster" [Fe-S] vêm sendo reconhecidos como causadores de doenças neurológicas. Seu papel crítico na função mitocondrial é exemplificado pela variedade de sinais e sintomas neurológicos, afetando SNC e SNP nestes pacientes. $\mathrm{O}$ estudo desta família permitiu comprovar o papel importante de FDX2 para a mitocôndria e as características da síndrome relacionada a sua variante patogênica.

\subsection{Painel de genes, exoma clínico e exoma completo}

Na próxima sessão discutiremos uma proposta de algoritmo de investigação dos casos suspeitos de LD/LG, mas antes cumpre discutir as vantagens e desvantagens de cada método de investigação genética.

No presente estudo, utilizamos sequenciamento pelo método Sanger ou "array-CGH" quando havia um único gene candidato, sequenciamento do exoma clínico e sequenciamento completo do exoma. Existem ainda os painéis diagnósticos que utilizam NGS que, embora não tenham sido utilizados neste estudo e dada a sua crescente popularidade, merecem uma breve consideração.

O tradicional sequenciamento pelo método Sanger é amplamente disponível para uso clínico. Utiliza a técnica de reação da polimerase em cadeia ("polymerase chain reaction" - PCR) para amplificação da região gênica de interesse e seu posterior sequenciamento. Os íntrons distantes dos éxons e as regiões promotoras não são rotineiramente avaliadas. É uma técnica de alta acurácia e interpretação clara, porém só possibilita testar um gene por vez e não é nem custo nem tempoeficiente se a probabilidade pré-teste de um resultado positivo for baixa. Caso sejam pedidos testes de forma sequencial, seu custo pode rapidamente ultrapassar os custos dos exames que utilizam a técnica de NGS.

No presente estudo realizamos o sequenciamento Sanger de gene suspeito ou "array-CGH" em quatro casos e, conforme esperado, naqueles em que a probabilidade pré-teste era alta, ou seja, com apresentação clínica muito sugestiva, confirmamos o diagnóstico. Foram três pacientes, com as seguintes suspeitas: doença 
de Alexander e síndrome de Sjögren-Larsson confirmados por sequenciamento sanger e ADLD confirmado por “array-CGH”. Já na paciente em que não obtivemos diagnóstico, a suspeita de ADLD era baixa, mas mesmo assim realizamos o "arrayCGH" em busca da duplicação ou deleção em $L M N B 1$, que foi negativa.

Os painéis de genes, o sequenciamento do exoma clínico e o sequenciamento do exoma completo são exames baseados na técnica de NGS. Esta técnica consiste em fragmentar o DNA, ampliá-lo e selecionar os exons de múltiplos genes de interesse para sequenciamento.

Os painéis de genes estão se tornando rapidamente mais disponíveis e a custos acessíveis para uso clínico em todo o mundo, sendo em geral o exame por NGS mais barato. São uma boa opção quando estamos diante de fenótipos superponíveis, sendo bastante acurados e de fácil interpretação. No entanto, é importante observar quais genes serão examinados por determinado painel, pois podem diferir de um serviço para o outro. Ainda, tais painéis não permitem reanálise em busca de novos genes e têm outra limitação importante - saber se o painel solicitado foi o painel correto.

Assim, os painéis podem ser muito úteis em alguns casos. Por exemplo, casos suspeitos de VWM, doença na qual cinco genes podem estar implicados e o sequenciamento Sanger seria custoso e demorado. Também em casos suspeitos de CADASIL, mas sem história familiar, pois haveria o diagnóstico diferencial com CARASIL ou CARASAL. Neste caso, deve-se averiguar previamente se os genes HTRA1 e CTSA constam no painel. No entanto, talvez com uma história familiar fortemente sugestiva de doença autossômica dominante, a pesquisa direta de mutação em NOTCH3 possa ser mais custo-efetiva.

Alguns casos do presente estudo, se tivessem sido considerados para a realização de painel de genes, poderiam gerar dúvidas, principalmente por não terem uma boa hipótese clínica pré-teste. Por exemplo, que painel seria mais apropriado para os pacientes com HDLS - painel de leucodistrofias ou de demências? E para o paciente que teve como diagnóstico final doença relacionada a PLP1 - painel de paraplegias espásticas ou de leucodistrofias? Obviamente pode-se argumentar que chegaríamos ao diagnóstico final independentemente do painel escolhido. Bastaria 
que os genes identificados figurassem em ambos os painéis - fato que depende da montagem do painel.

Já o exoma clínico é uma técnica de NGS também limitada, que avalia os exons dos genes que já foram previamente implicados em doenças humanas ou considerados potencialmente patogênicos. Para tal, utiliza bases de dados como HGMD, OMIM e ClinVar. Os genes incluídos na análise dependem do fabricante do kit para o exame. No presente estudo, foi utilizado "The Agilent SureSelect Focused Exome Technique" que avalia um total de 6110 genes (12Mb de sequências exônicas).

Tal técnica é obviamente muito mais abrangente do que a utilização de painéis, eliminando o problema da escolha do painel. É uma excelente opção quando estamos diante de casos com fenótipos atípicos ou de difícil caracterização e é um exame que possui excelente relação custo-benefício. Em casos de LD/LG tem desempenho semelhante ao do sequenciamento completo do exoma, obtendo diagnóstico em quase 30\% dos casos (Vanderver et al., 2016; Lynch et al., 2017).

No presente estudo, 18 pacientes foram avaliados por exoma clínico e 13 obtiveram diagnóstico definitivo nesta etapa (72\%). Esta taxa mais alta de diagnósticos na nossa casuística em comparação com os estudos internacionais pode ser atribuída ao fato de muitos dos nossos pacientes não terem sido submetidos a nenhum teste genético antes do sequenciamento do exoma clínico. No estudo realizado por Vanderver et al (2016) e mesmo nos casos da coorte inglesa da UCL (comunicação pessoal), vários pacientes tinham sido previamente submetidos a várias pesquisas genéticas, com sequenciamento Sanger de NOTCH3, EIF2B1-5, DARS2 entre outros.

No entanto, o exoma clínico apresenta a mesma limitação de reanálise em busca de novos genes, como ocorre com os painéis. Seu custo tende a ser superior ao dos painéis e inferior ao do sequenciamento completo do exoma.

Para aqueles casos em que não houve um diagnóstico após a realização de painel de genes ou sequenciamento do exoma clínico, a próxima etapa é o sequenciamento completo do exoma. Esta é uma técnica que permite a avaliação de todos os exons de todos os cerca de 20.000 genes humanos. É excelente para pacientes com fenótipos atípicos ou indeterminados, permite a identificação de novos 
genes patogênicos, tem uma boa correlação custo-benefício e permite reanálises futuras à luz de novos conhecimentos.

Esta análise mais abrangente gera uma questão ética relevante, que é a ocorrência de achados incidentais não correlacionados com a clínica. Assim, um paciente que realiza o sequenciamento completo do exoma por LD/LG, por exemplo, e tem o achado incidental de uma variante patogênica de APOE4, que aumenta o risco de doença de Alzheimer, pode gerar um debate se é correto ou não revelar este achado. Em geral, tal discussão deve ocorrer no aconselhamento pré-teste e, habitualmente só são revelados ao paciente as variantes que têm potencial correlação com seu quadro clínico - este é o procedimento adotado na maioria dos laboratórios de genética e foi o procedimento adotado neste estudo. Assim, a comunicação entre o clínico, com uma minuciosa caracterização do fenótipo, e o geneticista é fundamental, para definir quais variantes são relevantes para cada caso.

A interpretação do exoma completo pode ser difícil e nosso estudo traz dois exemplos desta dificuldade. O primeiro exemplo é das irmãs diagnosticadas como portadoras de doença relacionada a PUS3, que não obtiveram diagnóstico em uma primeira análise. Ao filtrar as variantes por presumível herança autossômica recessiva, as pacientes não apresentavam homozigose significativa, o que era esperado, dado que não havia história de consanguinidade. No entanto, ao serem usados filtros para variantes heterozigotas compostas raras e patogênicas, foram identificadas as variantes patogênicas em PUS3.

Já na família diagnosticada com doença relacionada a $F D X 2$, a dificuldade foi demonstrar que a variante identificada como patogênica era a real responsável pelo fenótipo encontrado, tendo em vista que era um fenótipo totalmente novo se comparado ao que se conhecia do fenótipo previamente relacionado ao FDX2. Assim, primeiramente demonstramos que a variante patogênica que encontramos segregava em duas famílias não aparentadas de acordo com um padrão de herança autossômico recessivo. Posteriormente conseguimos validação funcional ao demonstrar a redução dos níveis da proteína FDX2 no músculo dos pacientes afetados (Gurgel-Giannetti et al., 2018).

Por fim, casos que permanecem sem diagnóstico após sequenciamento completo do exoma continuam a ser um grande desafio. Para estes, os testes 
genéticos adicionais a serem considerados são o sequenciamento do exoma ou genoma mitocondrial ou o sequenciamento completo do genoma. A avaliação de DNA mitocondrial é muito difícil por meio do sequenciamento completo do exoma e não é habitualmente oferecida na forma de painéis. Já o sequenciamento completo do genoma é uma opção interessante para avaliação de variantes patogênicas intrônicas, em regiões promotoras e não-codificantes, bem como por variação no número de cópias. No entanto, trata-se de um exame de maior custo do que o sequenciamento completo do exoma, e principalmente de interpretação mais difícil, em geral restrito aos centros de pesquisa.

\subsection{Proposta de algoritmo diagnóstico}

Apresentamos agora uma sugestão de algoritmo diagnóstico para casos suspeitos de LD/LG, baseado no que realizamos e aprendemos com o presente estudo. Acreditamos que ele possa ser adaptado à realidade de cada serviço, a depender dos recursos disponíveis (Figura 28). 


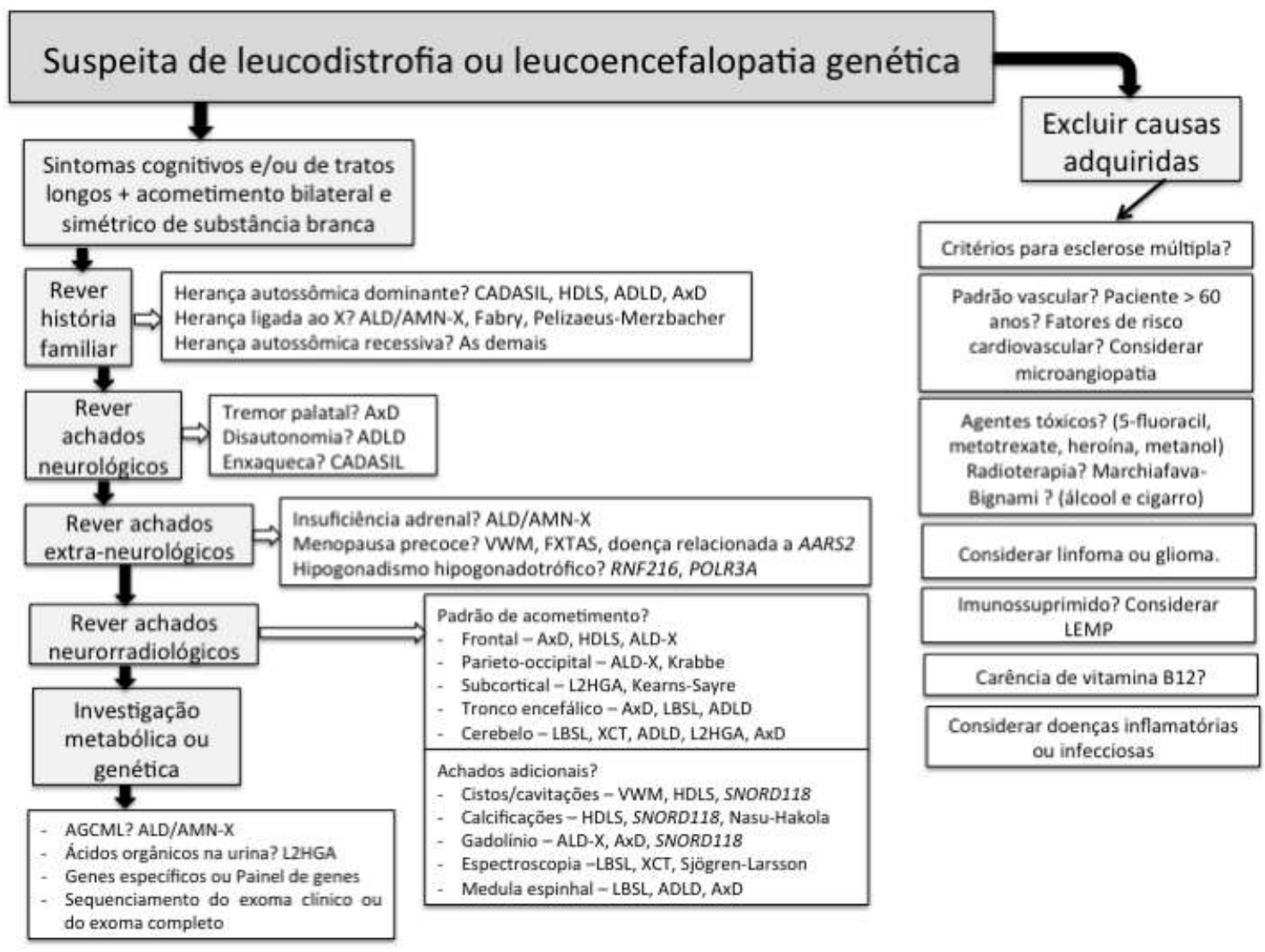

Figura 28 - Fluxograma de abordagem diagnóstica de pacientes com suspeita de leucodistrofia ou leucoencefalopatia genética. ADLD: leucodistrofia autossômica dominante desmielinizante do adulto; AGCML: ácidos graxos de cadeia muito longa; ALD/AMN-X: adrenoleucodistrofia/ adrenomieloneuropatia ligada ao X; AxD: doença de Alexander; CADASIL: "Cerebral Autosomal Dominant Arteriopathy with Subcortical Infarcts and Leukoencephalopathy" - Arteriopatia cerebral autossômica dominante com infartos subcorticais e leucoencefalopatia; FXTAS: "Fragile X Tremor/Ataxia Syndrome" - Síndrome tremorataxia ligada ao X; HDLS: "Hereditary Diffuse Leukoencephalopathy with Spheroids" - Leucoencefalopatia difusa hereditária com esferoides; L2HGA: "L-2-Hydroxyglutaric Aciduria" - Acidúria L2hidroxiglutárica; LBSL: "Leukoencephalopathy with Brainstem and Spinal cord involvement and Lactate elevation" - Leucoencefalopatia com acometimento de tronco encefálico e medula espinhal e elevação de lactato; LEMP: leucoencefalopatia multifocal progressiva; VWM: "Vanishing Whitte Matter Disease" - doença da substância branca evanescente; XCT: xantomatose cerebrotendínea. 


\subsubsection{Quando suspeitar de uma LD/LG genética}

Pacientes com algum dos seguintes sintomas:

- síndrome cognitivo-comportamental

- síndrome piramidal (principalmente se bilateral e simétrica)

- ataxia cerebelar ou sensitiva

- movimentos anormais

Associados a alterações bilaterais, simétricas e confluentes ou difusas da substância branca cerebral ou cerebelar, com acometimento ou não de tronco encefálico.

\subsubsection{Excluir doenças adquiridas}

Verificar exposição a possíveis agentes tóxicos

- metotrexate (principalmente intratecal)

- 5-fluoracil

- heroína ("chasing the dragon")

- metanfetamina

- metanol

- álcool e tabaco (doença de Marchiafava-Bignami)

Considerar esclerose múltipla se:

- história de surto-remissão

- múltiplas lesões de substância branca

- impregnação pelo contraste

- dedos de Dawson

- acometimento de fibras em "U"

- acometimento medula espinhal

- presença de bandas oligoclonais 
Considerar doença de pequenos vasos cerebrais se:

- maiores de 60 anos

- fatores de risco cardiovascular

- lacunas

- microhemorragias

- alteração de sinal significativa da ponte ou núcleos da base

Solicitar para todos os pacientes:

- hemograma

- função renal e eletrólitos

- perfil hepático

- perfil tireoidiano

- perfil lipídico

- vitamina B12, homocisteína, ácido metilmalônico

- cobre, ceruloplasmina

- ácido fólico

- amônia

- lactato

- vitamina $\mathrm{E}$

- sorologias para HIV, hepatites B e C, sífilis

- VHS, PCR, complemento

- FAN, fator reumatoide, anti-DNA, anti-SSA, anti-SSB, ANCA, anticorpo antifosfolípide, anticardiolipina, anticoagulante lúpico

- Enzima conversora da angiotensina sérica

- Imunoeletroforese de proteínas plasmáticas e urinárias

Considerar:

- pesquisa de anticorpos antineuronais e investigação de neoplasia oculta (na suspeita de síndrome paraneoplástica)

- possibilidade de imunossupressão e eventual pesquisa de vírus JC no líquor

- possibilidade de linfoma primário do SNC ou gliomatose cerebrii 
- possibilidade de leucoencefalopatia posterior reversível

\subsubsection{Rever história familiar:}

Padrão sugestivo de herança autossômica dominante:

- CADASIL

- HDLS

- ADLD

- Doença de Alexander

- Doença relacionada ao colágeno tipo IV (COLAA1)

- Vasculopatia retiniana com leucodistrofia cerebral (TREXI)

Padrão sugestivo de herança ligada ao X:

- ALD/AMN-X

- PMD/SPG2

- FXTAS

- Doença de Fabry

Padrão sugestivo de herança recessiva ou consanguinidade explícita ou implícita:

- todas as demais condições

Caso esporádico: manter todas as possibilidades em aberto

\subsubsection{Rever sintomas e sinais neurológicos}

Aqueles de maior valor diagnóstico:

- tremor palatal (Alexander)

- disautonomia (ADLD)

- enxaqueca (CADASIL, doenças mitocondriais) 


\subsubsection{Rever achados extra-neurológicos}

Aqueles de maior valor diagnóstico em adultos:

- insuficiência adrenal (ABCD1, POLR3A, POLR3B)

- menopausa precoce (EIF2B1-5, FMR1, AARS2)

- hipogonadismo hipogonadotrófico (RNF216, PNPLA6, POLR3A, POLR3B)

- diarreia crônica (CYP27A1)

- dismotilidade grastrointestinal grave (TYMP)

- alterações esqueléticas (doença de Nasu-Hakola)

\subsubsection{Rever achados neurorradiológicos}

Em busca de um padrão de imagem capaz de direcionar a um teste gênico específico ou grupo de genes.

Padrão de acometimento da substância branca:

- parieto-occipital (ALD/AMN-X; Krabbe)

- frontal (ALD-X; Alexander; HDLS)

- periventricular (inespecífico)

- subcortical (L2HGA)

- tronco encefálico (Alexander, LBSL, ADLD)

- cerebelo (XCT, Alexander, LBSL, ADLD, FXTAS)

Reconhecer características distintivas:

- cistos ou cavitações (VWM, HDLS, Labrune)

- lacunas (CADASIL, CARASIL, CARASAL)

- calcificações (HDLS, Labrune)

- impregnação pelo gadolínio (ADL-X, Alexander, Labrune)

- acometimento de medula (ADLD, LBSL, Alexander)

- alterações na espectroscopia (síndrome de Sjögren-Larsson, XCT, LBSL) 


\subsubsection{Investigação metabólica ou genética:}

Cumpridas as etapas anteriores, deve-se tentar formular uma hipótese diagnóstica ou pelo menos tentar definir um subgrupo de LD/LG para então definir que exame pedir - tendo em mente a realidade local e as considerações feitas na discussão sobre painel de genes, exoma clínico e exoma completo.

Assim, uma forte suspeita de ALD-X deve ser seguida da dosagem sérica dos AGCML ou do sequenciamento de $A B C D 1$ ou até mesmo da realização de um painel para LD/LG. Já uma suspeita de uma LD hipomielinizante pode ser seguida do pedido de um painel de genes ou do sequenciamento completo do exoma.

O uso indiscriminado de uma "segunda rodada" de exames laboratoriais, incluindo pesquisa bioquímica de LD/LG que são mais comuns na infância, mas bem raras em adultos, como o sugerido por Ahmed et al (2014), não nos parece adequado à nossa realidade. Deve-se considerar a dificuldade enfrentada em vários locais do Brasil para se ter acesso a exames como pesquisa de ácidos orgânicos na urina ou pesquisa da atividade enzimática da arilsulfatase, bem como o tempo que tais pesquisas podem adicionar na odisseia diagnóstica enfrentada por estes pacientes.

Assim, com a progressiva e rápida queda nos custos dos exames baseados nas técnicas de NGS, acreditamos que o melhor caminho em termos de relação custobenefício após avaliação clínica e neurorradiológica minuciosa depende da suspeita clínica e da disponibilidade de exames em cada serviço.

Sugerimos que somente uma suspeita muito forte deve desencadear um pedido de sequenciamento Sanger ou de exame bioquímico. Caso contrário, a realização de painéis ou do sequenciamento completo do exoma deve ser discutida. Dada a raridade destas doenças, acreditamos que o encaminhamento precoce destes pacientes para centros de referência pode beneficiá-los sobremaneira, com aconselhamento, investigação e eventual tratamento adequados. 


\section{Conclusões}





\section{CONCLUSÕES}

O presente trabalho de caracterização clínica, molecular e de neuroimagem de 38 pacientes (31 famílias) com leucodistrofias ou leucoencefalopatias genéticas permitiu concluir que:

1. O quadro clínico e neurorradiológico das LD/LG é muito heterogêneo e depende da etiologia subjacente.

2. O quadro clínico e neurorradiológico para cada etiologia encontrada tende a ser relativamente homogêneo.

3. As doenças mais comumente diagnosticadas foram ALD/AMN-X, VWM, CADASIL e HDLS.

4. A avaliação clínica e neurorradiológica minuciosas permitiram formular uma hipótese diagnosticada correta antes de teste confirmatório (bioquímico ou genético) em 23 das 31 famílias (74\%).

5. A avaliação genética não eviesada, seja por sequenciamento do exoma clínico ou sequenciamento completo do exoma, foi determinante para o diagnóstico correto em grande parte da nossa amostra.

6. A avaliação por sequenciamento completo do exoma permitiu a identificação de uma condição muito rara (doença relacionada ao PUS3), ampliando seu fenótipo, e um novo fenótipo associado a FDX2. 



\section{Anexos}



8 ANEXOS 
Anexo A - Tabela 1 - Caracterização clínica

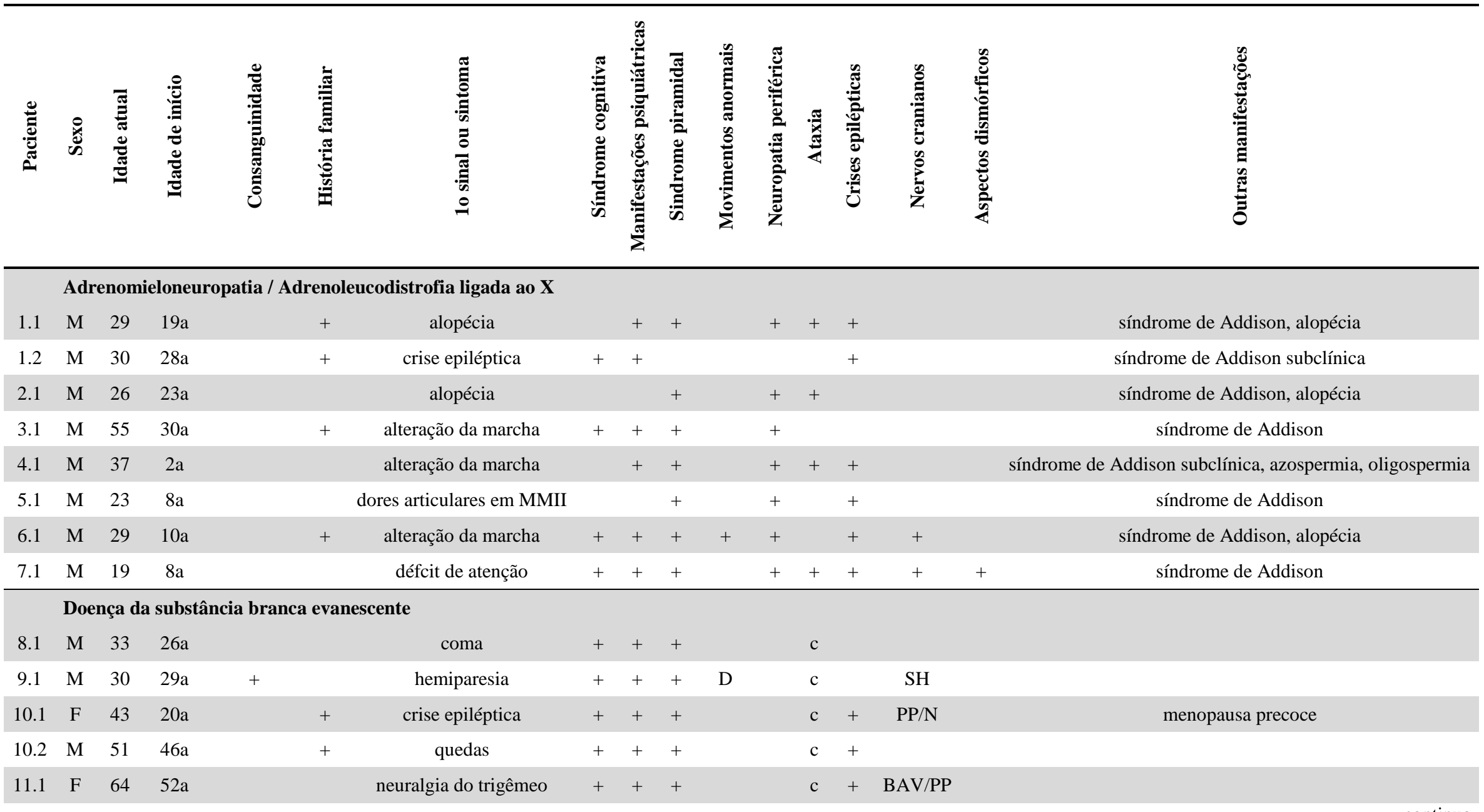


Anexo A - Tabela 1 - Caracterização clínica (continuação)

\begin{tabular}{|c|c|c|c|c|c|c|c|c|c|c|c|c|c|c|c|c|}
\hline 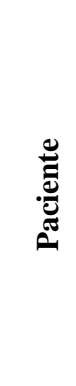 & 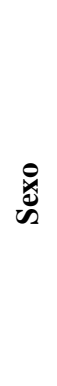 & 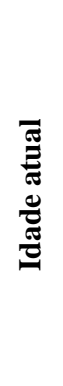 & 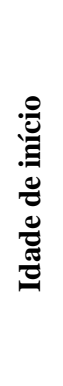 & 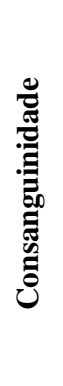 & 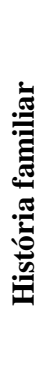 & 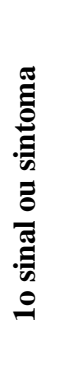 & 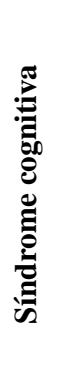 & 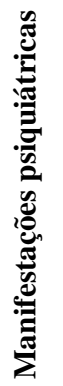 & 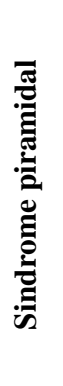 & 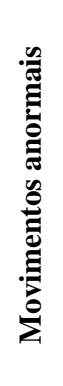 & 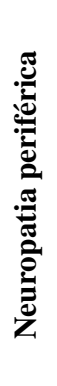 & 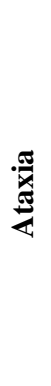 & 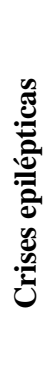 & 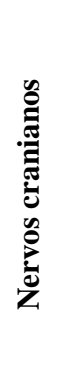 & 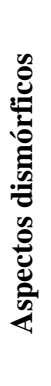 & 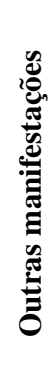 \\
\hline
\end{tabular}

\begin{tabular}{|c|c|c|c|c|c|c|c|c|c|c|c|c|c|c|c|c|}
\hline \multicolumn{17}{|c|}{ Encefalomioneuropatia relacionada a $F D X 2$} \\
\hline 12.1 & $\mathrm{~F}$ & 29 & $1 \mathrm{a}$ & + & + & BAV & & + & + & & + & $\mathrm{m}$ & & $\mathrm{BAV} / \mathrm{PP}$ & & bicitopenia, hipotireiodismo \\
\hline 12.2 & M & 34 & $1 \mathrm{a}$ & + & + & BAV & & + & + & & + & s & & $\mathrm{BAV} / \mathrm{PP}$ & & bicitopenia, hipotireoidismo, diabetes \\
\hline 12.3 & M & 6 & $14 \mathrm{~m}$ & & + & BAV & & + & & & & & & $\mathrm{BAV} / \mathrm{PP}$ & & bicitopenia, hipotireoidismo \\
\hline 12.4 & $\mathrm{~F}$ & 14 & $<1 \mathrm{a}$ & & + & dificuldade de sucção & + & & & & + & & & $\mathrm{BAV} / \mathrm{PP}$ & + & bicitopenia, hipotireoidismo \\
\hline \multicolumn{17}{|c|}{ Acidúria L2-hidroxiglutárica } \\
\hline 13.1 & M & 34 & $1 \mathrm{a}$ & + & & postura anormal do pescoço & + & + & & $\mathrm{D}$ & & $\mathrm{c}$ & + & $\mathrm{N}$ & + & \\
\hline 14.1 & $\mathrm{~F}$ & 34 & $<1 \mathrm{a}$ & & + & ADNPM & + & + & + & & & $\mathrm{c}$ & + & & & \\
\hline 14.2 & $\mathrm{~F}$ & 35 & $<1 \mathrm{a}$ & & + & ADNPM & + & + & + & $\mathrm{TC} / \mathrm{D}$ & & $\mathrm{c}$ & + & & + & \\
\hline 15.1 & $\mathrm{~F}$ & 45 & $<1 \mathrm{a}$ & & + & ADNPM & + & + & + & $\mathrm{D}$ & & c & & & & \\
\hline \multicolumn{17}{|c|}{ Leucoencefalopatia com esferóides axonais e glia pigmentada } \\
\hline 16.1 & $\mathrm{~F}$ & 48 & $47 \mathrm{a}$ & & + & amnésia anterógrada & + & + & + & & & & & & & perda ponderal \\
\hline 17.1 & $\mathrm{~F}$ & 53 & $50 \mathrm{a}$ & & & alteração comportamental & + & + & & & & & & & & \\
\hline 18.1 & $\mathrm{~F}$ & 43 & $38 \mathrm{a}$ & & & dor em MID & + & + & + & TP/D & & $*$ & & $\mathrm{PP} / \mathrm{N}$ & & baqueteamento digital e distrofia ungeal \\
\hline
\end{tabular}


Anexo A - Tabela 1 - Caracterização clínica (continuação)

\begin{tabular}{|c|c|c|c|c|c|c|c|c|c|c|c|c|c|c|c|c|}
\hline 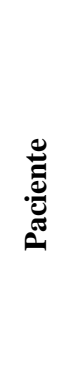 & 离 & 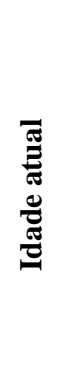 & 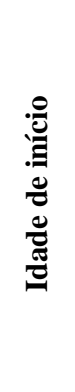 & 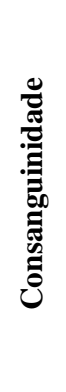 & 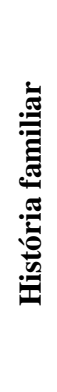 & 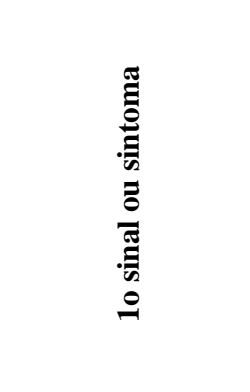 & 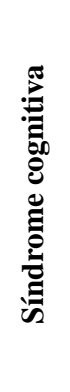 & 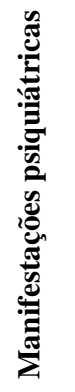 & 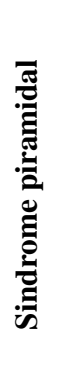 & 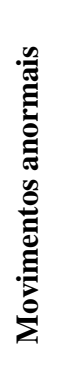 & 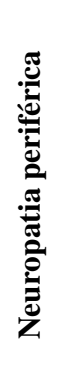 & 妥 & 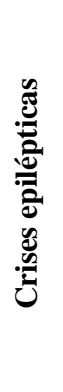 & 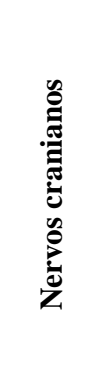 & 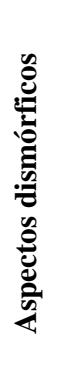 & 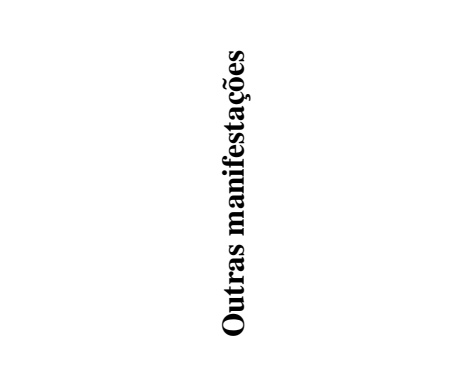 \\
\hline \multicolumn{17}{|c|}{ CADASIL } \\
\hline 19.1 & M & 40 & $30 \mathrm{a}$ & & + & cefaléia & + & + & + & & & $\mathrm{s}$ & & & & \\
\hline 20.1 & M & 49 & $37 \mathrm{a}$ & & + & hemiataxia súbita & + & + & + & $\mathrm{D}$ & & & & & & \\
\hline 21.1 & $\mathrm{~F}$ & 48 & $36 \mathrm{a}$ & & & cefaléia & + & + & + & & & $\mathrm{s}$ & & VIII & & \\
\hline \multicolumn{17}{|c|}{ Deficiência intelectual autossômica recessiva 55 (PUS3) } \\
\hline 22.1 & $\mathrm{~F}$ & 41 & $<1 \mathrm{a}$ & & + & ADNPM & + & + & & & & & + & & + & proteinúria \\
\hline 22.2 & $\mathrm{~F}$ & 37 & $<1 \mathrm{a}$ & & + & ADNPM & + & + & & & & & + & & + & síndrome nefrótica, doença celíaca \\
\hline \multicolumn{17}{|c|}{ Leucoencefalopatia desmielinizante autossômica dominante de início no adulto (ADLD) } \\
\hline 23.1 & M & 59 & $38 \mathrm{a}$ & & + & disfunção erétil & + & & + & & + & $\mathrm{c}$ & & $\mathrm{RN} / \mathrm{N}$ & & \\
\hline \multicolumn{17}{|c|}{ Doença de Alexander } \\
\hline 24.1 & $\mathrm{~F}$ & 39 & $27 \mathrm{a}$ & & & quedas & & & + & & & $*$ & & $\mathrm{RN} / \mathrm{N}$ & & \\
\hline \multicolumn{17}{|c|}{ Síndrome de Gordon-Holmes (RNF216) } \\
\hline 25.1 & M & 41 & $31 \mathrm{a}$ & & + & hipogonadismo & + & + & & $\mathrm{C}$ & & $\mathrm{c}$ & & & & hipogonadismo hipogonadotrófico \\
\hline
\end{tabular}


Anexo A - Tabela 1 - Caracterização clínica (conclusão)

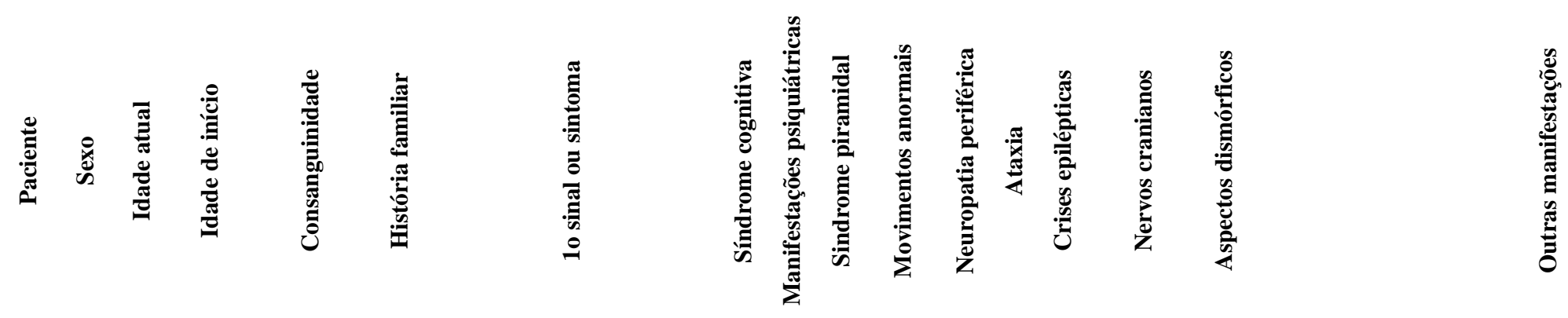

Leucoencefalopatia com acometimento de tronco encefálico e medula espinhal e elevação de lactato

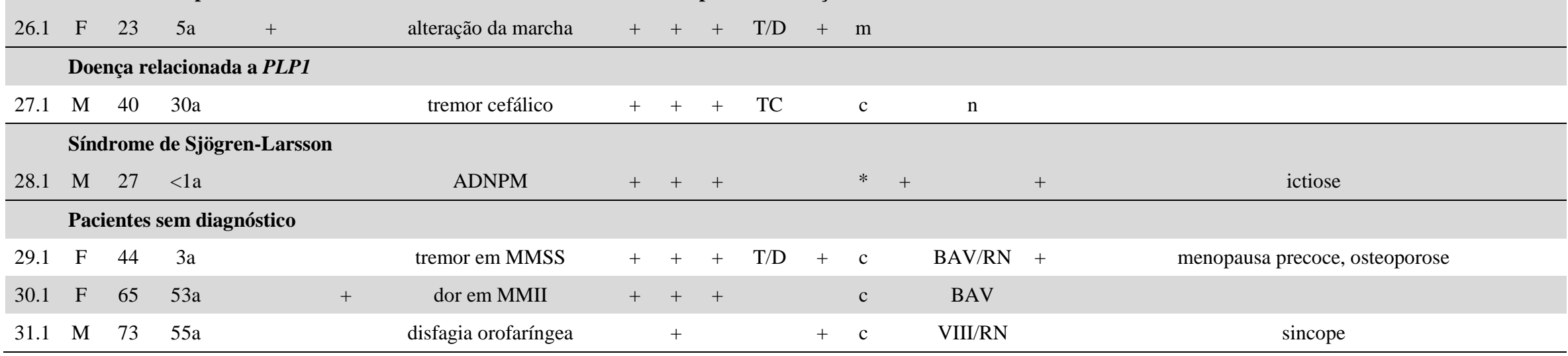

Pacientes 1.1-7.1: adrenoleucodistrofia/adrenomieloneuropatia ligada ao X; 8.1-11.1: doença da substância branca evanescente; 12.1-12.4: doença relacionada a FDX2; 13.1-15.1: acidúria L2-hidroxiglutárica; 16.1-18.1: leucoencefalopatia difusa hereditária com esferóides; 19.1-21.1: CADASIL; 22.1-22.2: deficiência intelectual autossômica recessiva relacionada a PUS3; 23.1: leucoencefalopatia desmielinizante autossômica dominante de início no adulto; 24.1: doença de Alexander; 25.1: síndrome de Gordon-Holmes; 26.1: leucoencefalopatia com acometimento de tronco encefálico e medula espinhal e elevação de lactato; 27.1: doença relacionada a PLP1; 28.1: síndrome de Sjögren-Larsson; 29.1-31.1: sem diagnóstico

Legenda: sexo $\mathrm{M}=$ masculino, $\mathrm{F}=$ feminino. $+=$ presente. $*=$ avaliação prejudicada pela gravidade da síndrome piramidal; $\mathrm{c}=$ ataxia cerebelar, $\mathrm{s}=$ ataxia sensitiva, $\mathrm{m}=$ ataxia mista. $\mathrm{D}$ $=$ distonia. $\mathrm{TC}=$ tremor cervical. $\mathrm{TP}=$ tremor palatal. $\mathrm{T}=$ tremor. $\mathrm{C}=$ coréia. $\mathrm{SH}=$ sacadas hipométricas. $\mathrm{PP}=$ palidez de papila. $\mathrm{N}=$ nistagmo. $\mathrm{BAV}=$ baixa acuidade visual. $\mathrm{VIII}=$ nervo vestíbulo-coclear. $\mathrm{RN}=$ reflexo nauseoso. 
Anexo B - Tabela 2 - Caracterização genética

\begin{tabular}{|c|c|c|c|c|c|c|c|}
\hline 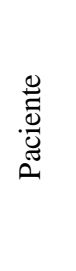 & 巳ัల & 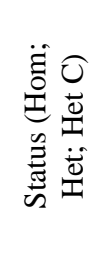 & $\begin{array}{l}\varangle \\
z \\
0 \\
0 \\
\stackrel{\Xi}{\Xi} \\
. \bar{\Xi} \\
>\end{array}$ & 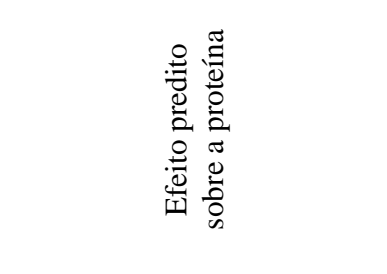 & 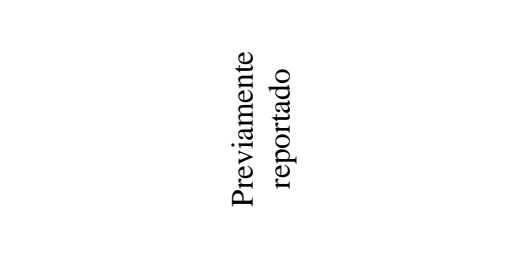 & 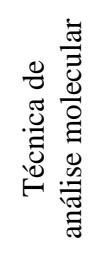 & 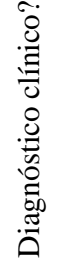 \\
\hline 8.1 & EIF2B5 & Hom & c. $[388 \mathrm{G}>\mathrm{A}] ;[388 \mathrm{G}>\mathrm{A}]$ & p.[Arg113His];[Arg113His] & $\operatorname{sim}$ & $\mathrm{EC}$ & + \\
\hline 9.1 & EIF2B5 & Hom & c. $[388 \mathrm{G}>\mathrm{A}] ;[388 \mathrm{G}>\mathrm{A}]$ & p.[Arg113His];[Arg113His] & $\operatorname{sim}$ & $\mathrm{EC}$ & + \\
\hline 10.1 & EIF $2 B 4$ & Het C & c. $[495+3 \operatorname{del} A(;) 623 \mathrm{G}>\mathrm{A}]$ & p.[? (;) Arg208Gln] & $\begin{array}{l}\text { não (mutação } 1 \text { nova variante; mutação } \\
2 \text { muito rara }\end{array}$ & $\mathrm{EC}$ & + \\
\hline 10.2 & $E I F 2 B 4$ & $*$ & $*$ & $*$ & $*$ & $*$ & + \\
\hline 11.1 & $E I F 2 B 5$ & Het C & c. $[388 \mathrm{G}>\mathrm{A}] ;[913 \mathrm{~A}>\mathrm{T}]$ & p.[Arg113His];[Met305Leu] & mutação 1 sim; mutação 2 não & $\mathrm{EC}$ & + \\
\hline 12.1 & $F D X 2$ & Hom & c. $[431 \mathrm{C}>\mathrm{T}] ;[431 \mathrm{C}>\mathrm{T}]$ & p.[Pro144Leu];[Pro144Leu] & não & SCE & \\
\hline 12.2 & $F D X 2$ & Hom & c. $[431 \mathrm{C}>\mathrm{T}] ;[431 \mathrm{C}>\mathrm{T}]$ & p.[Pro144Leu];[Pro144Leu] & não & SCE & \\
\hline 12.3 & $F D X 2$ & Hom & c. $[431 \mathrm{C}>\mathrm{T}] ;[431 \mathrm{C}>\mathrm{T}]$ & p.[Pro144Leu];[Pro144Leu] & não & SCE & \\
\hline 12.4 & $F D X 2$ & Hom & c. $[431 \mathrm{C}>\mathrm{T}] ;[431 \mathrm{C}>\mathrm{T}]$ & p.[Pro144Leu];[Pro144Leu] & não & SCE & \\
\hline 13.1 & $L 2 H G D H$ & Hom & c.[530delC];[530delC] & p.Pro177fs & $\operatorname{sim}$ & $\mathrm{EC}$ & + \\
\hline 14.1 & $L 2 H G D H$ & Hom & c.[G632T];[G632T] & p.Gly211Val & $\operatorname{sim}$ & $\mathrm{EC}$ & + \\
\hline 14.2 & $L 2 H G D H$ & $*$ & $*$ & $*$ & $*$ & $*$ & + \\
\hline 15.1 & $L 2 H G D H$ & Hom & c.[530delC];[530delC] & p.Pro177fs & $\operatorname{sim}$ & $\mathrm{EC}$ & + \\
\hline 16.1 & $C S F 1 R$ & Het & c.2427_2428delCA & p.Ile810fs $* 19$ & não & $\mathrm{EC}$ & + \\
\hline 17.1 & CSF1R & Het & c. $2654+1 \mathrm{G}>\mathrm{T}$ & $?$ & não & SCE & + \\
\hline 18.1 & CSF1R & Het & c. $2570 \mathrm{C}>\mathrm{T}$ & p.Pro857Leu & não & $\mathrm{EC}$ & $\begin{array}{c}\text { \# } \\
\text { tinua }\end{array}$ \\
\hline
\end{tabular}


Anexo B - Tabela 2 - Caracterização genética (conclusão)

\begin{tabular}{|c|c|c|c|c|c|c|c|}
\hline 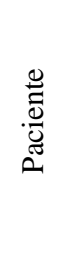 & ঠัர & 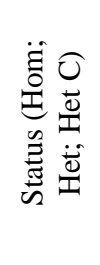 & 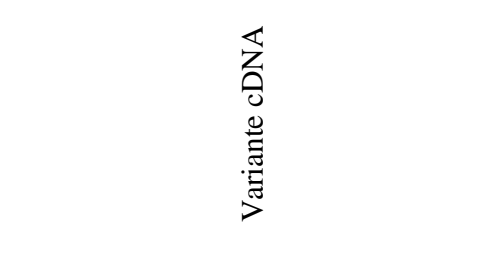 & 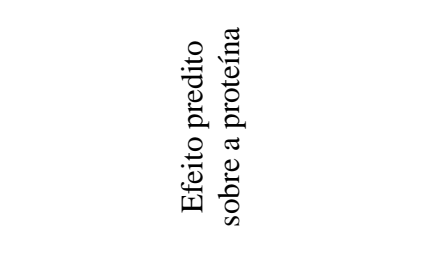 & 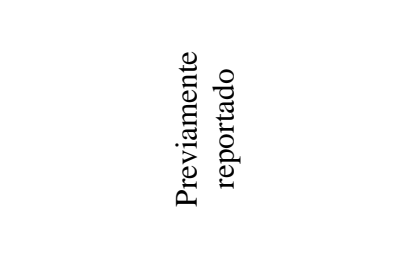 & 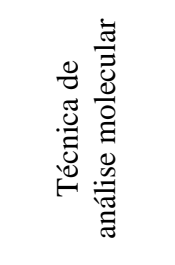 & 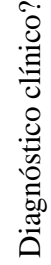 \\
\hline 19.1 & NOTCH3 & Het & c. $505 \mathrm{C}>\mathrm{T}$ & p.Arg169Cys & $\operatorname{sim}$ & $\mathrm{EC}$ & + \\
\hline 20.1 & NOTCH3 & Het & c. $994 \mathrm{C}>\mathrm{T}$ & p.Arg332Cys & $\operatorname{sim}$ & $\mathrm{EC}$ & + \\
\hline 21.1 & NOTCH3 & Het & c. $397 \mathrm{C}>\mathrm{T}$ & p.Arg133Cys & $\operatorname{sim}$ & $\mathrm{EC}$ & + \\
\hline 22.1 & PUS3 & Het C & c. [G497A];[T1097C] & p.[Arg166Gln];[Leu366Pro] & não & SCE & \\
\hline 22.2 & PUS3 & Het $\mathrm{C}$ & c. [G497A];[T1097C] & p.[Arg166Gln];[Leu366Pro] & não & SCE & \\
\hline 23.1 & $L M N B 1$ & Het & Dup 212Kb em Chr5q23.2 & $?$ & $\operatorname{sim}$ & array-CGH & + \\
\hline 24.1 & GFAP & Het & c. $809 \mathrm{G}>\mathrm{C}$ & p.Arg270Pro & não & Sanger & + \\
\hline 25.1 & $R N F 216$ & Hom & c. $[1482 \mathrm{C}>\mathrm{A}] ;[1482 \mathrm{C}>\mathrm{A}]$ & p.[Tyr494*];[Tyr494*] & não & $\mathrm{EC}$ & \# \\
\hline 26.1 & DARS2 & Het $\mathrm{C}$ & c. [228-20_-21delTTinsC];[1456C >T] & p.[Arg76Serfs*5];[Leu486Phe] & mutação 1 sim; mutação 2 não & $\mathrm{EC}$ & + \\
\hline 27.1 & $P L P 1$ & Het & c.355dupG & p.Gly121Profs $* 83$ & não & $\mathrm{EC}$ & \\
\hline 28.1 & $A L D H 3 A 2$ & Het C & c. $[798+5 \mathrm{G}>\mathrm{A}] ;[1108-1 \mathrm{G}>\mathrm{C}]$ & $?$ & $\operatorname{sim}$ & Sanger & + \\
\hline 29.1 & & & & & & SCE & $\#$ \\
\hline 30.1 & & & & & & SCE & \# \\
\hline 31.1 & & & & & & SCE & \\
\hline
\end{tabular}

Pacientes 8.1-11.1: doença da substância branca evanescente; 12.1-12.4: doença relacionada a $F D X 2$; 13.1-15.1: acidúria L2-hidroxiglutárica; 16.1-18.1: leucoencefalopatia difusa hereditária com esferóides; 19.1-21.1: CADASIL; 22.1-22.2: deficiência intelectual autossômica recessiva relacionada a PUS3; 23.1: leucoencefalopatia desmielinizante autossômica dominante de início no adulto; 24.1: doença de Alexander; 25.1: síndrome de Gordon-Holmes; 26.1: leucoencefalopatia com acometimento de tronco encefálico e medula espinhal e elevação de lactato; 27.1: doença relacionada a PLP1; 28.1: síndrome de Sjögren-Larsson; 29.1-31.1: sem diagnóstico

Legenda: Hom $=$ homozigoto. Het $=$ heterozigoto. Het $\mathrm{C}=$ heterozigoto composto $. \mathrm{EC}=$ exoma clínico. $\mathrm{SCE}=$ sequenciamento completo do exoma. $\mathrm{CGH}=$ comparative genomic hybridisation. * = não testado. \# = hipótese clínica incorreta. Dup = duplicação. 
Anexo C - Tabela 3 - Caracterização neurorradiológica

\begin{tabular}{|c|c|c|c|c|c|c|c|c|c|c|c|c|c|c|c|c|c|c|c|c|}
\hline $\begin{array}{l}\frac{\pi}{\pi} \\
\frac{\tilde{J}}{\pi} \\
\tilde{\Xi}\end{array}$ & $\mathrm{T} 1$ & 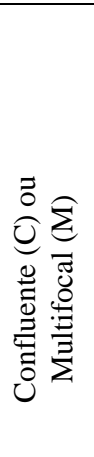 & 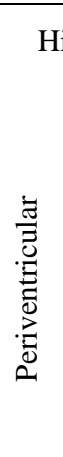 & 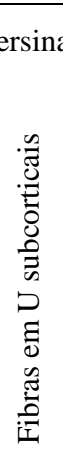 & 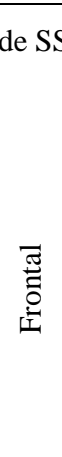 & 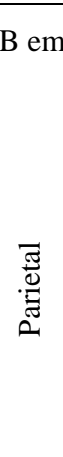 & 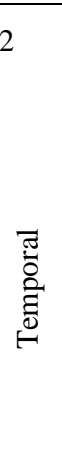 & 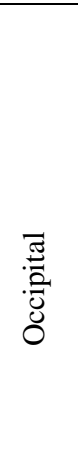 & 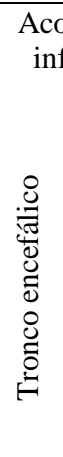 & 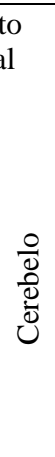 & 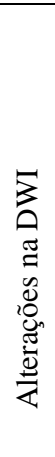 & 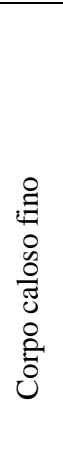 & 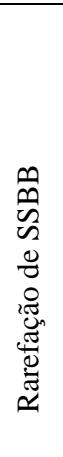 & 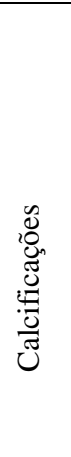 & $\overbrace{0}^{0}$ & $\begin{array}{l}\stackrel{0}{0} \\
\stackrel{\mathscr{E}}{\Xi} \\
\Xi\end{array}$ & 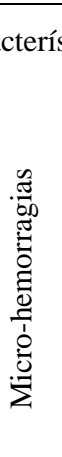 & 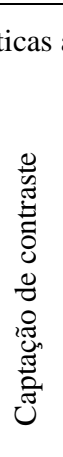 & 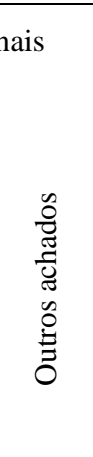 & 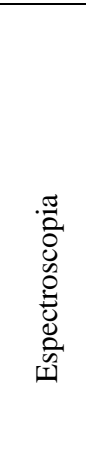 \\
\hline 1.1 & - & - & - & - & - & - & - & - & - & - & - & - & - & - & - & - & - & - & o & ND \\
\hline 1.2 & $\downarrow$ & $\mathrm{M}$ & + & - & + & + & + & + & - & - & + & - & + & - & - & - & + & + & - & ndn \\
\hline 2.1 & - & - & - & - & - & - & - & - & - & - & - & - & - & - & - & - & - & - & o & ND \\
\hline 3.1 & $\downarrow$ & C & - & - & - & + & - & + & - & - & - & - & - & - & - & - & - & - & - & $\mathrm{ND}$ \\
\hline 4.1 & $\downarrow$ & C & + & - & + & + & - & + & - & - & - & + & - & - & - & - & - & - & $x$ & ND \\
\hline 5.1 & $\downarrow$ & C & - & - & - & + & - & + & - & - & - & - & - & - & - & - & - & - & - & ND \\
\hline 6.1 & $\downarrow$ & C & + & - & - & + & + & + & - & - & - & + & - & - & - & - & - & - & $\mathrm{b}, \mathrm{f}, \mathrm{r}$ & ND \\
\hline 7.1 & $\downarrow$ & C & + & - & - & + & + & + & - & - & - & + & - & - & - & - & - & - & $\mathrm{b}, \mathrm{f}$ & ND \\
\hline 8.1 & $\downarrow$ & C & + & - & + & + & - & + & - & - & - & + & + & - & + & - & - & - & - & ND \\
\hline 9.1 & $\downarrow$ & C & + & - & + & + & - & + & - & - & - & + & + & - & + & - & - & - & - & ND \\
\hline 10.1 & $\downarrow$ & C & + & - & + & + & + & + & - & - & - & + & + & - & + & - & - & - & - & ND \\
\hline 10.2 & $\downarrow$ & $\mathrm{C}$ & + & - & + & + & + & + & + & + & - & + & + & - & + & - & - & - & - & $\downarrow$ NAA \\
\hline
\end{tabular}


Anexo C - Tabela 3 - Caracterização neurorradiológica (continuação)

\begin{tabular}{|c|c|c|c|c|c|c|c|c|c|c|c|c|c|c|c|c|c|c|c|c|}
\hline $\begin{array}{l}\frac{0}{\tilde{D}} \\
\overline{\tilde{D}} \\
0\end{array}$ & $\mathrm{~T} 1$ & 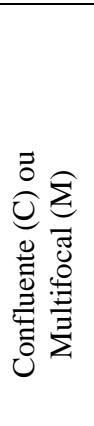 & 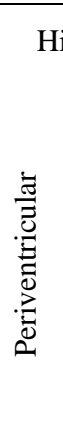 & 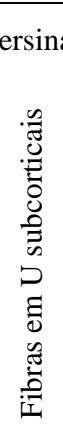 & $\begin{array}{l}\text { 惡 } \\
\text { 总 }\end{array}$ & 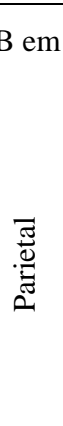 & 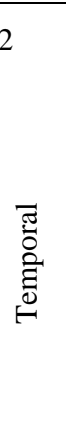 & $\begin{array}{l}\bar{\Xi} \\
\overline{0} \\
\overline{0} \\
0\end{array}$ & 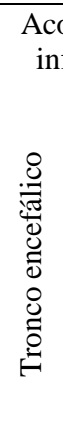 & $\begin{array}{l}\frac{0}{0} \\
\text { Uू } \\
\text { Uँ }\end{array}$ & 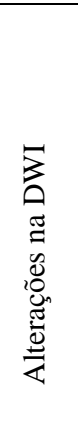 & $\begin{array}{l}\stackrel{0}{\Xi} \\
0 \\
0 \\
0 \\
\tilde{0} \\
0 \\
\stackrel{0}{0} \\
0\end{array}$ & 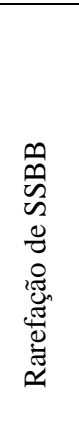 & 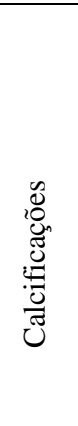 & $\overbrace{0}^{0}$ & 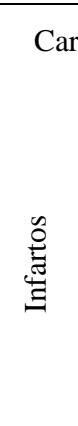 & 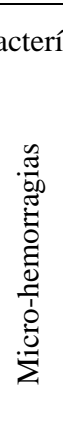 & 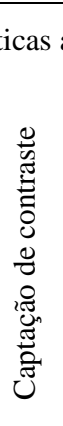 & 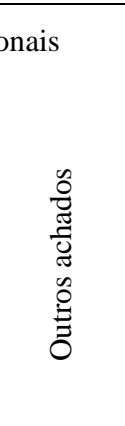 & 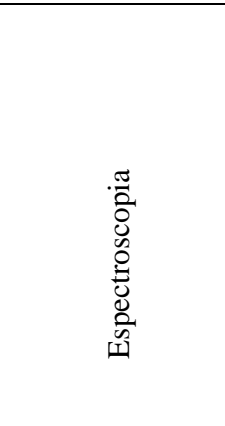 \\
\hline 11.1 & $\downarrow$ & $\mathrm{C}$ & + & - & + & + & + & + & + & - & - & + & + & - & + & - & - & - & - & ndn \\
\hline 12.1 & $\downarrow$ & M & - & + & + & + & - & + & - & - & - & + & - & - & - & - & - & - & a & ndn \\
\hline 12.2 & $\downarrow$ & M & - & - & - & - & - & - & - & - & - & - & - & - & - & - & - & - & $\mathrm{a}$ & ND \\
\hline 12.3 & $\downarrow$ & M & - & + & + & + & + & + & + & - & + & + & - & - & - & - & - & - & $\mathrm{a}, \mathrm{b}, \mathrm{c}$ & ndn \\
\hline 12.4 & $\downarrow$ & M & - & + & - & - & - & + & + & - & - & + & - & - & - & - & - & - & $\mathrm{d}$ & ndn \\
\hline 13.1 & $\downarrow$ & M & - & + & + & + & + & + & - & + & - & - & - & - & - & - & - & - & $\mathrm{e}$ & ND \\
\hline 14.1 & $\downarrow$ & M & - & + & + & + & + & + & - & + & - & - & - & - & - & - & - & - & $e, f, g$ & ND \\
\hline 14.2 & $\downarrow$ & M & - & + & + & + & + & + & - & + & - & - & - & - & - & - & - & - & $\mathrm{e}, \mathrm{g}$ & $\uparrow \mathrm{mI} ; \downarrow_{\mathrm{NAA}} ;$ \\
\hline 15.1 & $\downarrow$ & M & - & + & + & + & + & + & - & + & - & - & + & - & - & - & - & - & GBM & ND \\
\hline 16.1 & $\downarrow$ & M & + & + & + & + & - & - & - & - & - & - & - & - & - & - & - & - & $\mathrm{b}$ & ND \\
\hline 17.1 & $\downarrow$ & M & + & + & + & + & - & - & - & - & + & - & - & + & - & - & - & - & $\mathrm{b}, \mathrm{h}, \mathrm{i}$ & ND \\
\hline 18.1 & $\downarrow$ & $\mathrm{C}$ & + & + & + & + & + & + & + & + & + & + & - & + & + & - & - & - & $\mathrm{f}, \mathrm{j}$ & $\mathrm{ND}$ \\
\hline 19.1 & $\downarrow$ & M & + & - & + & + & + & + & + & - & + & - & - & - & - & + & - & - & $\mathrm{f}$ & ND \\
\hline 20.1 & $\downarrow$ & M & + & - & + & + & + & + & + & + & + & - & - & - & - & + & - & - & $\mathrm{b}, \mathrm{g}, \mathrm{k}, \mathrm{l}$ & ND \\
\hline 21.1 & $\downarrow$ & M & + & + & + & + & + & + & + & + & + & - & - & + & - & + & + & - & $\mathrm{b}, \mathrm{g}, \mathrm{k}, \mathrm{l}$ & ND \\
\hline
\end{tabular}


Anexo C - Tabela 3 - Caracterização neurorradiológica (conclusão)

\begin{tabular}{|c|c|c|c|c|c|c|c|c|c|c|c|c|c|c|c|c|c|c|c|c|}
\hline \multirow[b]{2}{*}{ 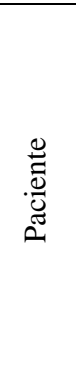 } & \multirow[b]{2}{*}{$\mathrm{T} 1$} & \multirow[b]{2}{*}{ 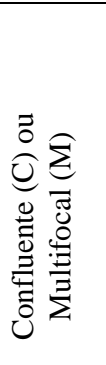 } & \multicolumn{5}{|c|}{ Hipersinal de SSBB em T2 } & \multirow[b]{2}{*}{ 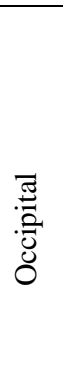 } & \multicolumn{2}{|c|}{$\begin{array}{c}\text { Acometimento } \\
\text { infratentorial }\end{array}$} & \multicolumn{10}{|c|}{ Características adicionais } \\
\hline & & & 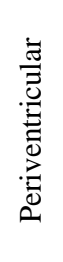 & 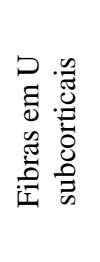 & 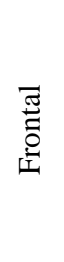 & 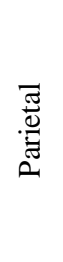 & 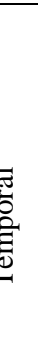 & & 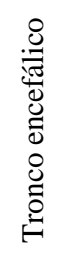 & 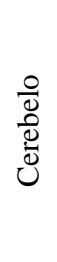 & 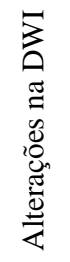 & $\begin{array}{l}0 \\
0 \\
0 \\
0 \\
\frac{0}{\pi} \\
0 \\
\vdots \\
0\end{array}$ & 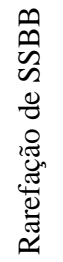 & 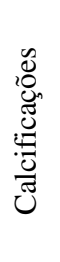 & $\stackrel{\mathscr{0}}{:}$ & 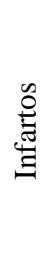 & 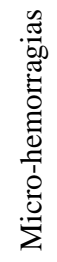 & 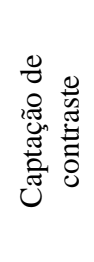 & 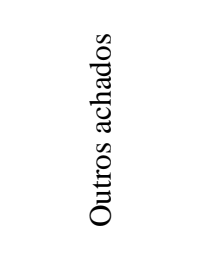 & 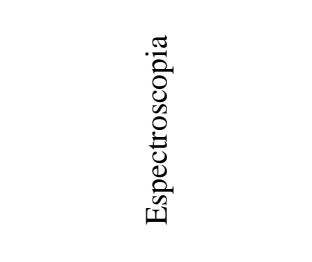 \\
\hline 22.1 & $\downarrow$ & $\mathrm{M}$ & + & - & - & - & - & - & - & - & - & - & - & - & - & - & - & - & - & ndn \\
\hline 22.2 & $\downarrow$ & $\mathrm{C}$ & + & + & + & + & + & + & - & + & - & - & - & + & - & - & - & - & - & ndn \\
\hline 23.1 & $\downarrow$ & $\mathrm{C}$ & - & + & + & + & + & + & + & + & - & + & - & - & - & - & - & - & $\mathrm{f}, \mathrm{m}, \mathrm{n}, \mathrm{o}$ & ND \\
\hline 24.1 & $\downarrow$ & $\mathrm{C}$ & + & - & + & + & + & + & + & + & - & - & - & - & - & - & - & - & $\mathrm{e}, \mathrm{m}, \mathrm{n}, \mathrm{o}, \mathrm{p}, \mathrm{q}$ & ^colina; $\downarrow$ NAA; $\uparrow$ mI \\
\hline 25.1 & $\downarrow$ & $\mathrm{C}$ & + & + & + & + & + & + & + & + & - & - & - & - & - & - & - & - & $\mathrm{c}, \mathrm{e}, \mathrm{l}, \mathrm{n}, \mathrm{r}, \mathrm{s}$ & $\boldsymbol{\Downarrow}_{\text {colina/NAA }}$ \\
\hline 26.1 & $\downarrow$ & $\mathrm{C}$ & + & - & + & + & + & + & + & + & + & - & - & - & - & - & - & - & $\mathrm{f}, \mathrm{m}, \mathrm{t}, \mathrm{u}, \mathrm{v}$ & $\downarrow$ NAA/creatina \\
\hline 27.1 & $\leftrightarrow$ & $\mathrm{C}$ & + & - & + & + & + & + & + & - & - & - & - & - & - & - & - & - & $\mathrm{n}$ & ND \\
\hline 28.1 & $\downarrow$ & $\mathrm{C}$ & + & - & + & + & + & + & - & - & + & - & - & - & - & - & - & - & $\mathrm{b}$ & picos de lipídios \\
\hline 29.1 & $\leftrightarrow$ & $\mathrm{C}$ & + & + & + & + & + & + & - & - & - & - & - & - & - & - & - & - & - & $\downarrow$ NAA \\
\hline 30.1 & $\leftrightarrow$ & $\mathrm{C}$ & + & - & + & + & + & + & - & - & - & - & - & - & - & - & - & - & - & ND \\
\hline 31.1 & $\downarrow$ & $\mathrm{C}$ & + & - & + & + & + & + & + & + & - & - & - & - & - & + & + & - & - & $\mathrm{ND}$ \\
\hline
\end{tabular}

Pacientes 1.1-7.1: adrenoleucodistrofia/adrenomieloneuropatia ligada ao X; 8.1-11.1: doença da substância branca evanescente; 12.1-12.4: doença relacionada a FDX2; 13.1-15.1: acidúria L2-hidroxiglutárica; 16.1-18.1: leucoencefalopatia difusa hereditária com esferóides; 19.1-21.1: CADASIL; 22.1-22.2: deficiência intelectual autossômica recessiva relacionada a PUS3; 23.1: leucoencefalopatia desmielinizante autossômica dominante de início no adulto; 24.1: doença de Alexander; 25.1: síndrome de Gordon-Holmes; 26.1: leucoencefalopatia com acometimento de tronco encefálico e medula espinhal e elevação de lactato; 27.1: doença relacionada a PLP1; 28.1: síndrome de Sjögren-Larsson; 29.1-31.1: sem diagnóstico

Legenda: $(+)$ = presente; $(-)$ = ausente. $\mathrm{ND}=$ não disponível. ndn = nada digno de nota. GBM = glioblastoma multiforme. SSBB = substância branca.

$\mathrm{a}=$ afilamento de nervo óptico e de quiasma óptico; $\mathrm{b}$ - hipersinal em corpo caloso; $\mathrm{c}=$ hipersinal em tálamos; $\mathrm{d}=$ rotação incompleta de hipocampo; e $=$ hipersinal em núcleos denteados; $\mathrm{f}=$ hipersinal em trato corticoespinhal; $\mathrm{g}=$ hipersinal em núcleos da base; $\mathrm{h}=$ atrofia de lobos frontais; $\mathrm{i}=$ atrofia de corpos estriados; $\mathrm{j}=$ ventrículos assimétricos; $\mathrm{k}=$ hipersinal em polos temporais; $1=$ hipersinal em cápsulas externas; $\mathrm{m}=$ acometimento de pedúnculos cerebelares superiores; $\mathrm{n}=$ acometimento de pedúnculos cerebelares médios; $\mathrm{o}=$ atrofia de medula; $\mathrm{p}=$ atrofia de bulbo; $\mathrm{q}=$ malformação cortical frontal; $\mathrm{r}=$ pedúnculos cerebrais; $\mathrm{s}=$ substância negra; $\mathrm{t}=$ pedúnculos cerebelares inferiores; $\mathrm{u}=$ tratos espinocerebelares; $\mathrm{v}=$ tratos dos nervos trigêmeos; $\mathrm{x}=$ ependimoma em IV ventrículo; * = pico em 2,5ppm, correspondente ao ácido hidroxiglutárico 
9 Referências 



\section{REFERÊNCIAS}

Ahmed RM, Murphy E, Parton M, Schott JM, Mummery CJ, Rohrer JD, Lachmann RH, Houlden H, Fox NC, Chataway J. A practical approach to diagnosing adult onset leukodystrophies. J Neurol Neurosurg Psychiatry. 2014;85:770-81.

Alexander WS. Progressive fibrinoid degeneration of fibrillary astrocytes associated with mental retardation in a hydrocephalic infant. Brain. 1949;72:373-81.

Atrouni S, Daraze A, Tamraz J, Cassia A, Caillaud C, Megarbane A. Leukodystrophy associated with oligodontia in a large inbred family: fortuitous association or new entity? Am J Med Genet. 2003;118A:76-81.

Auada MP, Puzzi MB, Cintra ML, Steiner CE, Alexandrino F, Sartorato EL, Aguiar TS, Azulay RD, Carney G, Rizzo WB. Sjögren-Larsson syndrome in Brazil is caused by a common c. $11081 \mathrm{G} \rightarrow \mathrm{C}$ splicesite mutation in the ALDH3A2 gene. $\mathrm{Br} \mathrm{J}$ Dermatol. 2006;154(4):770-73.

Ayrignac X, Carra-Dalliere C, Champfleur NM, Denier C, Aubourg P, Bellesme C, Castelnovo G, Pelletier J, Audoin B, Kaphan E, Seze J, Collongues N, Blanc F, Chanson JB, Magnin E, Berger E, Vukusic S, Durand-Dubief F, Camdessanche JP, Cohen M, Lebrun-Frenay C, Brassat D, Clanet M, Vermersch P, Zephir H, Outteryck O, Wiertlewski S, Laplaud DA, Ouallet JC, Brochet B, Goizet C, Debouverie M, Pittion S, Edan G, Deburghgraeve V, Le Page E, Verny C, Amati-Bonneau P, Bonneau D, Hannequin D, Guyant-Maréchad L, Derache N, Defer GL, Moreau T, Giroud M, Guennoc AM, Clavelou P, Taithe F, Mathis S, Neau JP, Magy L, Devoize JL, Bataillard M, Masliah-Planchou J, Dorboz I, Tournier-Lasserve E, Levade T, Tanguy OB, Labauge P. Adult-onset genetic leukoencephalopathies: A MRI patternbased approach in a comprehensive study of 154 patients. Brain. 2015;138:284-92. 
Ayrignac X, Boutiere C, Carra-Dalliere C, Labauge P. Posterior fossa involvement in diagnosis of adult-onset inherited leukoencephalopathies. J Neurol. 2016a;263:23618.

Ayrignac X, Menjot de Champfleur N, Menjot de Champfleur S, Carra-Dellière C, Deverdun J, Corlobe A, Labauge P. Brain magnetic resonance imaging helps differentiate atypical multiple sclerosis with cavitary lesions and vanishing white matter disease. Eur J Neurol. 2016b;23(6):995-1000.

Balbi P, Salvini S, Fundarò C, Frazzitta G, Maestri R, Mosah D, Uggetti C, Sechi G. The clinical spectrum of late-onset Alexander disease: a systematic literature review. J Neurol. 2010;257(12):1955-62.

Balicza P, Grosz Z, Molnár V, Illés A, Csabán D, Gézsi A, Dézsi L, Zádori D, Vécsei L, Molnár M. NKX2-1 new mutation associated with myoclonus, dystonia, and pituitary involvement. Frontiers Genetics. 2018;9:335.

Bielschowsky M, Henneberg R. Ueber familiare diffuse sklerose (Leukodystrophia cerebri progressive hereditária). J Psychol Neurol (Lpz). 1928;36:131-81.

Biesecker LG, Green RC. Diagnostic clinical genome and exome sequencing. $N$ Engl J Med. 2014;370:2418-25.

Bonkowsky JL, Nelson C, Kingston JL, Filloux FM, Mundorff MB, Srivastava R. The burden of inherited leukodystrophies in children. Neurology. 2010;75(8):718-25.

Bougea A, Velonakis G, Spantideas N, Anagnostou E, Paraskevas G, Kapaki E, Kararizou E. The first Greek case of heterozygous cerebral autosomal recessive arteriopathy with subcortical infarcts and leukoencephalopathy: An atypical clinicoradiological presentation. Neuroradiol J. 2017;30(6):583-5. 
Bouquet F, Dehais C, Sanson M, Lubetzki C, Louapre C. Dramatic worsening of adult-onset X-linked adrenoleukodystrophy after head trauma. Neurology. 2015;85:1991-3.

Brenner M, Johnson AB, Boespflug-Tanguy O, Rodriguez D, Goldman JE, Messing A. Mutations in GFAP, encoding glial fibrillary acidic protein, are associated with Alexander disease. Nat Genet. 2001;27:117-20.

Cailloux F, Gauthier-Barichard F, Mimault C, Isabelle V, Courtois V, Giraud G, Dastugue B, Boespflug-Tanguy O. Genotype-phenotype correlation in inherited brain myelination defects due to proteolipid protein gene mutations. Clinical European Network on Brain Dysmyelinating Disease. Eur J Hum Genet. 2000;8:83745 .

Carra-Dallière C, Horzinski L, Ayrignac X, Vukusic S, Rodriguez D, Mauguiere F, Peter L, Goizet C, Bouhour F, Denier C, Confavreux C, Obadia M, Blanc F, de Seze J, Sedel F, Guennoc AM, Sartori E, Laplaud D, Antonie JC, Fogli A, BoespflugTanguy O, Labauge P. Natural history of adult-onset eIF2B-related disorders: a multicentric survey of 24 cases. Rev Neurol (Paris). 2011;167(11):802-11.

Carswell R. Pathological anatomy: illustrations of the elementary forms of disease. London: Longmans, Green; 1838.

Chinnery PF. Mitochondrial Disorders Overview. 2000 Jun 8 [Updated 2014 Aug 14]. In: Pagon RA, Adam MP, Ardinger HH, et al., editors. GeneReviews ${ }^{\circledR}$ [Internet]. Seattle (WA): University of Washington, Seattle; 1993-2017.

Cho KH, Shim SH, Kim M. Clinical, biochemical, and genetic aspects of SjögrenLarsson syndrome. Clin Genet. 2018;93(4):721-30.

Costello DJ, Eichler AF, Eichler FS. Leukodystrophies: classification, diagnosis, and treatment. Neurologist. 2009;15(6):319-28. 
Dallabona C, Diodato D, Kevelam SH, Haack TB, Wong LJ, Salomons GS, Baruffini E, Melchionda L, Mariotti C, Strom TM, Meitinger T, Prokisch H, Chapman K, Colley A, Rocha H, Ounap K, Schiffmann R, Salsano E, Savoiardo M, Hamilton EM, Abbink TE, Wolf NI, Ferrero I, Lamperti C, Zeviani M, Vanderver A, Ghezzi D, van der Knaap MS. Novel (ovario) leukodystrophy related to AARS2 mutations. Neurology. 2014;82:2063-71.

de Bot ST, Willemsen MAAP, Vermeer S, Kremer HPH, van de Warrenburg BPC. Reviewing the genetic causes of spastic-ataxias. Neurology. 2012;79:1507-14.

de Laurenzi V, Rogers GR, Hamrock DJ, Marekov LN, Steinert PM, Compton JG, Markova N, Rizzo WB. Sjögren-Larsson syndrome is caused by mutations in the fatty aldehyde dehydrogenase gene. Nat Genet. 1996;12:52-7.

Depienne C, Bugiani M, Dupuits C, Galanaud D, Touitou V, Postma N, van Berkel C, Polder E, Tollard E, Darios F, Brice A, de Die-Smulders CE, Vles JS, Vanderver A, Uziel G, Yalcinkaya C, Frints SG, Kalscheuer VM, Klooster J, Kamermans M, Abbink TE, Wolf NI, Sedel F, van der Knaap MS. Brain white matter oedema due to ClC-2 chloride channel deficiency: an observational analytical study. Lancet Neurol. 2013;12(7):659-68.

Di Donato I, Banchi S, Federico A, Dotti MT. Adult-onset genetic leukoencephalopathies. A focus on the more recently defined forms. Curr Mol Med. 2014;14(8):944-58.

DiMauro S, Gurgel-Giannetti J. The expanding phenotype of mitochondrial myopathy. Curr Opin Neurol. 2005;18:538-42.

Dinour D, Mini S, Polak-Charcon S, Lotan D, Holtzman EJ. Progressive nephropathy associated with mitochondrial tRNA gene mutation. Clin Nephron. 2004;62:149-54. 
Dooves S, Bugiani M, Postma N, Polder E, Land N, Horan S, et al. Astrocytes are central in the pathomechanisms of vanishing white matter. $J$ Clin Invest. 2016;126(4):1512-24.

Duran M, Kamerling JP, Bakker HD, van Gennip AH, Wadman SK. L-2hydroxyglutaric aciduria: an inborn error of metabolism? J Inherit Metab Dis. 1980;3:109-12.

Dutra LA, de Aquino CC, Barsottini OG. Sjögren-Larsson syndrome: case report and review of neurologic abnormalities and ichthyosis. Neurologist. 2009;15(6):332-4.

Edvardson S, Prunetti L, Arraf A, Haas D, Bacusmo JM, Hu JF, Ta-Shma A, Dedon PC, de Crécy-Lagard V, Elpeleg O. tRNA N6-adenosine threonylcarbamoyltransferase defect due to KAE1/TCS3 (OSGEP) mutation manifest by neurodegeneration and renal tubulopathy. Eur J Hum Genet. 2017;25(5):545-51.

Eichler F, Duncan C, Musolino PL, Orchard PJ, De Oliveira S, Thrasher AJ, Armant M, Dansereau C, Lund TC, Miller WP, Raymond GV, Sankar R, Shah AJ, Sevin C, Gaspar HB, Gissen P, Amartino H, Bratkovic D, Smith NJC, Paker AM, Shamir E, O'Meara T, Davidson D, Aubourg P, Williams DA. Hematopoietic stem-cell gene therapy for cerebral adrenoleukodystrophy. N Engl J Med. 2017;377:1630-8.

El Khattabi L, Jaillard S, Andrieux J, Pasquier L, Perrin L, Capri Y, Benmansour A, Toutain A, Marcorelles P, Vincent-Delorme C, Journel H, Henry C, De Barace C, Devisme L, Dubourg C, Demurger F, Lucas J, Belaud-Rotureau M-AA, Amiel J, Malan V, De Blois M-CC, De Pontual L, Lebbar A, Le Dû N, Germain DP, Pinard JMM, Pipiras E, Tabet A-CC, Aboura A, Verloes A. Clinical and molecular delineation of Tetrasomy 9p syndrome: report of 12 new cases and literature review. Am J Med Genet A. 2015;167(6):1252-61.

Engelen M, Kemp S, Visser M, Geel B, Wanders R, Aubourg P, Poll-The BT. Xlinked adrenoleukodystrophy (X-ALD): clinical presentation and guidelines for diagnosis, follow-up and management. Orphanet J Rare Dis. 2012;7(1):1-14. 
Faiyaz-Ul-Haque M, Al-Sayed MD, Faqeih E, Jamil M, Saeed A, Amoudi MS, Kaya N, Abalkhail H, Al-Abdullatif A, Rashed M, Al-Owain M, Peltekova I, Zaidi SH. Clinical, neuroimaging, and genetic features of L-2-hydroxyglutaric aciduria in Arab kindreds. Ann Saudi Med. 2014;34(2):107-14.

Farina L, Pareyson D, Minati L, Ceccherini I, Chiapparini L, Romano S, Gambaro P, Fancellu R, Savoiardo M. Can MR imaging diagnose adult-onset Alexander disease? Am J Neuroradiol. 2008;29:1190-6.

Filley C. Occupation and the risk of chronic toxic leukoencephalopathy. In: M. Lotti and M.L. Bleecker, Editors. Handbook of Clinical Neurology, Vol. 131 (3rd series) Occupational Neurology. Amsterdam: Elsevier BV; 2015. v.131, p.73-91.

Finnsson J, Sundblom J, Dahl N, Melberg A, Raininko R. LMNB1-related autosomal-dominant leukodystrophy: Clinical and radiological course. Ann Neurol. 2015;78:412-25.

Fogel BL, Satya-Murti S, Cohen BH. Clinical exome sequencing in neurologic disease. Neurol Clin Pract. 2016;6:164-76.

Fogli A, Schiffmann R, Bertini E, Ughetto S, Combes P, Eymard-Pierre E, Kaneski CR, Pineda M, Troncoso M, Uziel G, Surtees R, Pugin D, Chaunu MP, Rodriguez D, Boespflug-Tanguy $\mathrm{O}$. The effect of genotype on the natural history of eIF2B-related leukodystrophies. Neurology. 2004;62(9):1509-17.

Fogli A, Schiffmann R, Hugendubler L, Combes P, Bertini E, Rodriguez D, Kimball SR, Boespflug-Tanguy O. Decreased guanine nucleotide exchange factor activity in eIF2B-mutated patients. Europ J Hum Genet. 2004b;12:561-6.

Fogli A, Boespflug-Tanguy O. The large spectrum of eIF2B-related diseases. Biochem Soc Trans. 2006;34(1):22-9. 
Fuijkschot J, Theelen T, Seyger M, Graaf M, Groot I, Wevers R, Wanders R, Waterham H, Willemsen M. Sjögren-Larsson syndrome in clinical practice. J Inherit Metab Dis. 2012;35(6):955-62.

Fussiger H, Jardim LB, Saute JA. Letter Re: Cathepsin A-related arteriopathy with strokes and leukoencephalopathy (CARASAL). Neurology. 2017;88:1776.

Ganos C, Hersheson J, Adams M, Bhatia K, Houlden H. The 4H syndrome due to RNF216 mutation. Parkinsonism \& Related Disorders. 2015;21(9):1122-3.

Giorgio E, Rolyan H, Kropp L, Chakka AB, Yatsenko S, Di Gregorio E, Lacerenza D, Vaula G, Talarico F, Mandich P, Toro C, Pierre EE, Labauge P, Capellari S, Cortelli P, Vairo FP, Miguel D, Stubbolo D, Marques LC, Gahl W, BoespflugTanguy O, Melberg A, Hassin-Baer S, Cohen OS, Pjontek R, Grau A, Klopstock T, Fogel B, Meijer I, Rouleau G, Bouchard JP, Ganapathiraju M, Vanderver A, Dahl N, Hobson G, Brusco A, Brussino A, Padiath QS. Analysis of LMNB1 duplications in autosomal dominant leukodystrophy provides insights into duplication mechanisms and allele-specific expression. Hum Mutat. 2013;34:1160-71.

Golomb MR, Walsh LE, Carvalho KS, Christensen CK, DeMyer WE. Clinical findings in Pelizaeus-Merzbacher Disease. J Child Neurol. 2004;19:328-31.

Graff-Radford J, Schwartz K, Gavrilova RH, Lachance DH, Kumar N. Neuroimaging and clinical features in type II (late-onset) Alexander disease. Neurology. 2014;82:49-56.

Guerreiro R, Kara E, Le Ber I, Bras J, Rohrer JD, Taipa R, Lashley T, Dupuits C, Gurunlian N, Mochel F, Warren JD, Hannequin D, Sedel F, Depienne C, Camuzat A, Golfier V, Du Boisguéheneuc F, Schottlaender L, Fox NC, Beck J, Mead S, Rossor MN, Hardy J, Revesz T, Brice A, Houlden H. Genetic analysis of inherited leukodystrophies: genotype-phenotype correlations in the CSF1R gene. JAMA Neurol. 2013;70:875-82. 
Guery B, Choukroun G, Nöel LH, Clavel P, Rötig A, Lebon S, Rustin P, BellanéChantelot C, Mougenot B, Grünfeld JP, Chauveau D. The spectrum of systemic involvement in adults presenting with renal lesion and mitochondrial tRNA(Leu) gene mutation. J Am Soc Nephrol. 2003;14(8):2099-108.

Gurgel-Giannetti J, Lynch DS, Paiva ARB, Lucato LT, Yamamoto G, Thomsen C, Basu S, Freua F, Giannetti AV, de Assis BDR, Ribeiro MDO, Barcelos I, Sayão Souza K, Monti F, Melo US, Amorim S, Silva LGL, Macedo-Souza LI, ViannaMorgante AM, Hirano M, Van der Knaap MS, Lill R, Vainzof M, Oldfors A, Houlden H, Kok F. A novel complex neurological phenotype due to a homozygous mutation in FDX2. Brain. 2018;141(8):2289-98.

Hamilton E, van der Lei H, Vermeulen G, Gerver J, Lourenço C, Naidu S, Mierzewska H, Gemke R, de Vet H, Uitdehaag B, Lissenberg-Witte B, Group V, van der Knaap M. Natural history of vanishing white matter. Ann Neurol. 2018;84(2):274-88.

Heim P, Claussen M, Hoffmann B, Conzelmann E, Gartner J, Harzer K, Hunneman DH, Kohler W, Kurlemann G, Kohlschutter A. Leukodystrophy incidence in Germany. Am J Med Genet. 1997;71:475-8.

Heubner O. Ueber diffuse hirnsklerose. Charité-Ann. 1897;22:298-310.

Hirano M. Mitochondrial Neurogastrointestinal Encephalopathy Disease. 2005 Apr 22 [Updated 2016 Jan 14]. In: Pagon RA, Adam MP, Ardinger HH, et al., editors. GeneReviews ${ }^{\circledR}$ [Internet]. Seattle (WA): University of Washington, Seattle; 19932017.

Hobson GM, Kamholz J. PLP1-Related Disorders. 1999 Jun 15 [Updated 2013 Feb 28]. In: Pagon RA, Adam MP, Ardinger HH, et al., editors. GeneReviews ${ }^{\circledR}$ [Internet]. Seattle (WA): University of Washington, Seattle; 1993-2017. 
Hotta O, Inoue CN, Miyabayashi S, Furuta T, Takeuchi A, Taguma Y. Clinical and pathologic features of focal segmental glomerulosclerosis with mitochondrial tRNALeu(UUR) gene mutation. Kidney Int. 2001;59:1236-43.

Hudson LD, Puckett C, Berndt J, Chan J, Gencic S. Mutation of the proteolipid protein gene PLP in a human X chromosome-linked myelin disorder. Proc Natl Acad Sci U S A. 1989;86(20):8128-31.

Hur S, Stroud RM. How U38, 39, and 40 of many tRNAs become the targets for pseudouridylation by TruA. Mol Cell. 2007;26:189-203.

Hurst S, Garbern J, Trepanier A, Gow A. Quantifying the carrier female phenotype in Pelizaeus-Merzbacher disease. Genet Med. 2006;8:371-8.

Jack LS, Benson C, Sadiq MA, Rizzo WB, Margalit E. Segmentation of retinal layers in Sjögren-Larsson syndrome. Ophthalmology. 2015;122(8):1730-2.

Jones DE. Early relapsing multiple sclerosis. Continuum (Minneap Minn). 2016;22(3):744-60.

Joutel A, Vahedi K, Corpechot C, Troesch A, Chabriat H, Vayssière C, Cruaud C, Maciazek J, Weissenbach J, Bousser MG, Bach JF, Tournier-Lasserve E. Strong clustering and stereotyped nature of Notch3 mutations in CADASIL patients. Lancet. 1997;350(9090):1511-5.

Joutel A, Favrole P, Labauge P, Chabriat H, Lescoat C, Andreux F, Domenga V, Cecillon M, Vahedi K, Ducros A, Cave-Riant F, Bousser MG, Tournier-Lasserve E. Skin biopsy immunostaining with a Notch3 monoclonal antibody for CADASIL diagnosis. Lancet. 2001;358:2049-51.

Karczewski K, Francioli L, Tiao G, Cummings B, Alföldi J, Wang Q, Collins R, Laricchia K, Ganna A, Birnbaum D, Gauthier L, Brand H, Solomonson M, Watts N, Rhodes D, Singer-Berk M, Seaby E, Kosmicki J, Walters R, Tashman K, Farjoun Y, 
Banks E, Poterba T, Wang A, Seed C, Whiffin N, Chong J, Samocha K, PierceHoffman E, Zappala Z, O’Donnell-Luria A, Minikel E, Weisburd B, Lek M, Ware J, Vittal C, Armean I, Bergelson L, Cibulskis K, Connolly K, Covarrubias M, Donnelly S, Ferriera S, Gabriel S, Gentry J, Gupta N, Jeandet T, Kaplan D, Llanwarne C, Munshi R, Novod S, Petrillo N, Roazen D, Ruano-Rubio V, Saltzman A, Schleicher M, Soto J, Tibbetts K, Tolonen C, Wade G, Talkowski M, Consortium T, Neale B, Daly M, MacArthur D. Variation across 141,456 human exomes and genomes reveals the spectrum of loss-of-function intolerance across human protein-coding genes. Biorxiv. 2019;531210. Disponível em: 〈https://gnomad.broadinstitute.org/>. Acesso em: 30 de março de 2019.

Karle KN, Biskup S, Schüle R, Schweitzer KJ, Krüger R, Bauer P, Bender B, Nägele T, Schöls L. De novo mutations in hereditary diffuse leukoencephalopathy with axonal spheroids (HDLS). Neurology. 2013;81:2039-44.

Kaul R, Gao GP, Balamurugan K, Matalon R. Cloning of the human aspartoacylase cDNA and a common missense mutation in Canavan disease. Nat Genet. 1993;5(2):118-23.

Kevelam SH, Rodenburg RJ, Wolf NI, Ferreira P, Lunsing RJ, Nijtmans LG, Mitchell A, Arroyo HA, Rating D, Vanderver A, van Berkel CG, Abbink TE, Heutink P, van der Knaap MS. NUBPL mutations in patiens with complex I deficiency and distinct MRI pattern. Neurology. 2013;80:1577-83.

Kevelam SH, Steenweg ME, Srivastava S, Helman G, Naidu S, Schiffmann R, Blaser S, Vanderver A, Wolf NI, van der Knaap MS. Update on Leukodystrophies: A historical perspective and adapted definition. Neuropediatrics. 2016;47:349-54.

Köhler C, Heyer C, Hoffjan S, Stemmler S, Lücke T, Thiels C, Kohlschütter A, Löbel U, Horvath R, Kleinle S, Benet-Pages A, Abicht A. Early-onset leukoencephalopathy due to a homozygous missense mutation in the DARS2 gene. Mol Cell Probe. 2015;29(5):319-22. 
Kollberg G, Tulinius M, Melberg A, Darin N, Andersen O, Holmgren D, Oldfors A, Holme E. Clinical manifestation and a new ISCU mutation in iron-sulphur cluster deficiency myopathy. Brain. 2009;132(8):2170-9.

Koopman WJ, Willems PH, Smeitink JA. Monogenic mitochondrial disorders. $N$ Engl J Med. 2012;366(12):1132-41.

Konno T, Tada M, Tada M, Koyama A, Nozaki H, Harigaya Y, Nishimiya J, Matsunaga A, Yoshikura N, Ishihara K, Arakawa M, Isami A, Okazaki K, Yokoo H, Itoh K, Yoneda M, Kawamura M, Inuzuka T, Takahashi H, Nishizawa M, Onodera O, Kakita A, Ikeuchi T. Haploinsufficiency of CSF-1R and clinicopathologic characterization in patients with HDLS. Neurology. 2014;82:139-48.

Konno T, Yoshida K, Mizuno T, Kawarai T, Tada M, Nozaki H, Ikeda SI, Nishizawa M, Onodera O, Wszolek ZK, Ikeuchi T. Clinical and genetic characterization of adult-onset leukoencephalopathy with axonal spheroids and pigmented glia associated with CSF1R mutation. Eur J Neurol. 2017;24:37-45.

Kühl J-S, Suarez F, Gillett G, Hemmati P, Snowden J, Stadler M, Vuong GL, Aubourg P, Köhler W, Arnold R. Long-term outcomes of allogeneic haematopoietic stem cell transplantation for adult cerebral X-linked adrenoleukodystrophy. Brain. 2017;140(4):953-66.

Labauge P, Roullet E, Boespflug-Tanguy O, Nicoli F, Le Fur Y, Cozzone PJ, Ducreux D, Rodriguez D. Familial, adult onset form of leukoencephalopathy with brain stem and spinal cord involvement: inconstant high brain lactate and very slow disease progression. Eur Neurol. 2007;58:59-61.

Labauge P, Horzinski L, Ayrignac X, Blanc P, Vukusic S, Rodriguez D, Mauguiere F, Peter L, Goizet C, Bouhour F, Denier C, Confavreux C, Obadia M, Blanc F, de Sèze J, Fogli A, Boespflug-Tanguy O, Natural history of adult-onset eIF2B-related disorders: a multi-centric survey of 16 cases. Brain. 2009;132(8):2161-9. 
Labauge P, Carra-Dalliere C, Champfleur NM, Ayrignac X, Boespflug-Tanguy O. MRI pattern approach of adult-onset inherited leukoencephalopathies. Neurol Clin Pract. 2014;4:287-95.

Labrune P, Lacroix C, Goutières F, de Laveaucoupet J, Chevalier P, Zerah M, Husson B, Landrieu P. Extensive brain calcifications, leukodystrophy, and formation of parenchymal cysts: A new progressive disorder due to diffuse cerebral micoangiopathy. Neurology. 1996;46(5):1297-301.

Lanska DJ, Currier RD, Cohen M, Gambetti P, Smith EE, Bebin J, Jackson JF, Whitehouse PJ, Markesbery WR. Familial progressive subcortical gliosis. Neurology. 1994;44:1633-43.

Lebigot E, Gaignard P, Dorboz I, Slama A, Rio M, de Lonlay P, Héron B, Sabourdy F, Boespflug-Tanguy O, Cardoso A, Habarou F, Ottolenghi C, Thérond P, Bouton C, Golinelli-Cohen MP, Boutron A. Impact of mutations within the [Fe-S] cluster or the lipoic biosynthesis pathways on mitochondrial protein expression profiles in fibroblast from patients. Mol Genet Metab. 2017;122:85-94.

Leegwater PA, Vermeulen G, Könst AA, Naidu S, Mulders J, Visser A, Kersbergen P, Mobach D, Fonds D, van Berkel CG, Lemmers RJ, Frants RR, Oudejans CB, Schutgens RB, Pronk JC, van der Knaap MS. Subunits of the translation initiation factor eIF2B are mutant in leukoencephalopathy with vanishing white matter. Nat Genet. 2001;29(4):383-8.

Lei H, Berkel C, Wieringen W, Brenner C, Feigenbaum A, Mercimek-Mahmutoglu S, Philippart M, Tatli B, Wassmer E, Scheper G, Knaap M. Genotype-phenotype correlation in vanishing white matter disease. Neurology. 2010;75(17):1555-9.

Leite CC, Lucato LT, Santos GT, Kok F, Brandão AR, Castillo M. Imaging of adult leukodystrophies. Arq Neuropsiquiatr. 2014;72(8):625-32. 
Liu R, van der Lei HD, Wang X, Wortham NC, Tang H, van Berkel CG, Mufunde TA, Huang W, van der Knaap MS, Scheper GC, Proud CG. Severity of vanishing white matter disease does not correlate with deficits in eIF2B activity or the integrity of eIF2B complexes. Hum Mutat. 2011;32(9):1036-45.

Lossos A, Khoury M, Rizzo WB, Gomori JM, Banin E, Zlotogorski A, Jaber S, Abramsky O, Argov Z, Rosenmann H. Phenotypic variability among adult siblings with Sjögren-Larsson syndrome. Arch Neurol. 2006;63:278-80.

Lu Y, Ondo Y, Shimojima K, Osaka H, Yamamoto T. A novel TUBB4A mutation G96R identified in a patient with hypomyelinating leukodystrophy onset beyond adolescence. Hum Genome Var. 2017;4:17035.

Lucato LT, Freua F, Kok F. Chronic stage of Marchiafava-Bignami disease. Arq Neuropsiquiatr. 2015;73(10):890.

Lynch D, Jaunmuktane Z, Sheerin U-M, Phadke R, Brandner S, Milonas I, Dean A, Bajaj N, McNicholas N, Costello D, Cronin S, McGuigan C, Rossor M, Fox N, Murphy E, Chataway J, Houlden H. Hereditary leukoencephalopathy with axonal spheroids: a spectrum of phenotypes from CNS vasculitis to parkinsonism in an adult onset leukodystrophy series. J Neurol Neurosurg Psychiatry. 2015;87(5):512-9.

Lynch DS, Zhang WJ, Lakshmanan R, Kinsella JA, Uzun GA, Karbay M, Tüfekçioglu Z, Hanagasi H, Burke G, Foulds N, Hammans SR, Bhattacharjee A, Wilson H, Adams M, Walker M, Nicoll JA, Chataway S, Fox N, Davagnanam I, Phadke R, Houlden H. Analysis of mutations in AARS2 in a series of CSF1Rnegative patients with adult-onset leukoencephalopathy with axonal spheroids and pigmented glia. JAMA Neurol. 2016;73(12):1433-39.

Lynch DS, Paiva ARB, Zhang WJ, Bugiardini E, Freua F, Lucato LT, Macedo-Souza LI, Lakshmanan R, Kinsella JA, Merwick A, Rossor AM, Bajaj N, Herron B, McMonagle P, Morrison PJ, Hughes D, Pittman A, Laurà M, Reilly MM, Warren JD, Mummery CJ, Schott JM, Adams M, Fox NC, Murphy E, Davagnanam I, Kok F, 
Chataway J, Houlden H. Clinical and genetic characterization of leukoencephalopathies in adults. Brain. 2017;140(5):1204-11.

Lynch DS, Wade C, Paiva ARB, John N, Kinsella JA, Merwick Á, Ahmed RM, Warren JD, Mummery CJ, Schott JM, Fox NC, Houlden H, Adams ME, Davagnanam I, Murphy E, Chataway J. Practical approach to the diagnosis of adultonset leukodystrophies: an updated guide in the genomic era. J Neurol Neurosurg Psychiatry. 2019;90:543-554.

Margolin DH, Kousi M, Chan YM, Lim ET, Schmahmann JD, Hadjivassiliou M, Hall JE, Adam I, Dwyer A, Plummer L, Aldrin SV, O`Rourke J, Kirby A, Lage K, Milunsky JM, Chan J, Hedley-Whyte T, Daly MJ, Katsanis N, Seminara SP. Ataxia, dementia, and hypogonadotropism caused by disordered ubiquitination. $N$ Engl $J$ Med. 2013;368:1992-2003.

Marras C, Lang A, van de Warrenburg BP, Sue CM, Tabrizi SJ, Bertram L, Mercimek-Mahmutoglu S, Ebrahimi-Fakhari D, Warner TT, Durr A, Assmann B, Lohmannn K, Kostic V, Klein C. Nomenclature of genetic movement disorders: recommendations of the international Parkinson and movement disorder society task force. Mov Disord. 2016;31:436-457.

Mathis S, Goizet C, Tazir M, Magdelaine C, Lia AS, Magy L, Vallat JM. CharcotMarie-Tooth diseases: an update and some new proposals for the classification. $J$ Med Genet. 2015;52:681-690.

Mehta A, Hughes DA. Fabry Disease. 2002 Aug 5 [Updated 2017 Jan 5]. In: Pagon RA, Adam MP, Ardinger HH, et al., editors. GeneReviews ${ }^{\circledR}$ [Internet]. Seattle (WA): University of Washington, Seattle; 1993-2017.

Melberg A, Hallberg L, Kalimo H, Raininko R. MR characteristics and neuropathology in adult-onset autosomal dominant leukodystrophy with autonomic symptoms. AJNR Am J Neuroradiol. 2006;27:90411. 
Merzbacher L. Eine eigenartige familiär-hereditäre Erkrankungsform (aplasia axialis extracorticalis congenita). Z Gesamte Neurol Psychiatrie’. 1910;3:1-138.

Meuwissen M, Halley D, Smit L, Lequin M, Cobben J, de Coo R, van Harssel J, Sallevelt S, Woldringh G, van der Knaap M, de Vries L, Mancini G. The expanding phenotype of COL4A1 and COL4A2 mutations: clinical data on 13 newly identified families and a review of the literature. Genet Med. 2015;17(11):843-53.

Mimault C, Giraud G, Courtois V, Cailloux F, Boire JY, Dastugue B, BoespflugTanguy O. Proteolipoprotein gene analysis in 82 patients with sporadic PelizaeusMerzbacher Disease: duplications, the major cause of the disease, originate more frequently in male germ cells, but point mutations do not. The Clinical European Network on Brain Dysmyelinating Disease. Am J Hum Genet. 1999;65:360-9.

Miura T, Mezaki N, Konno T, Iwasaki A, Hara N, Miura M, Funayama M, Unai Y, Tashiro Y, Okita K, Kihara T, Ito N, Kanatsuka Y, Jones DT, Hara N, Ishiguro T, Tokutake T, Kasuga K, Nozaki H, Dickson DW, Onodera O, Wszolek ZK, Ikeuchi T. Identification and functional characterization of novel mutations including frameshift mutation in exon 4 of CSF1R in patients with adult-onset leukoencephalopathy with axonal spheroids and pigmented glia. J Neurol. 2018; 265(10):2415-24.

Mochel F, Knight MA, Tong WH, Hernandez D, Ayyad K, Taivassalo T, Andersen PM, Singleton A, Rouault TA, Fischbeck KH, Haller RG. Splice mutation in ironsulfur cluster scaffold protein ISCU causes myopathy with exercise intolerance. Am J Hum Genet. 2008;82: 652-60.

Morell P, Wiesmann U. A correlative synopsis of the leukodystrophies. Neuropediatrics. 1984;15(suppl):62-65.

Moser HW, Raymond GV, Lu SE, Muenz LR, Moser AB, Xu J, Jones RO, Loes DJ, Melhem ER, Dubey P, Bezman L, Brereton NH, Odone A. Follow-up of 89 
asymptomatic patients with adrenoleukodystrophy treated with Lorenzo's oil. Arch Neurol. 2005;62:1073-80.

Moser H, Raymond GV. Leukodystrophy and Myelin. In: Raymond GV, Eichler F, Fatemi A, Naidu S. Leukodystrophies. London: Mac Keith Press; 2011. p.1-4.

Mosser J, Douar AM, Sarde CO, Kioschis P, Feil R, Moser H, Poustka AM, Mandel JL, Aubourg P. Putative X-linked adrenoleukodystrophy gene shares unexpected homology with ABC transporters. Nature. 1993;361(6414):726-30.

Nagapa M, Bindu PS, Chiplunkar S, Gupta N, Sinha S, Mathuranath PS, Bharath RD, Taly AB. Child Neurology: Sjögren-Larsson syndrome. Neurology. 2017;88:e1e4.

Nahhas N, Sabet Rasekh P, Vanderver A, et al. Autosomal dominant leukodystrophy with autonomic disease. 2016 Jan 7. In: Pagon RA, Adam MP, Ardinger HH, et al., editors. GeneReviews ${ }^{\circledR}$ [Internet]. Seattle (WA): University of Washington, Seattle; 1993-2017.

Namekawa M, Takiyama Y, Aoki Y, Takayashiki N, Sakoe K, Shimazaki H, Taguchi T, Tanaka Y, Nishizawa M, Saito K, Matsubara Y, Nakano I. Identification of GFAP gene mutation in hereditary adult-onset Alexander's disease. Ann Neurol. 2002;52:779-85.

Nezu A, Kimura S, Takeshita S, Osaka H, Kimura K, Inoue K. An MRI and MRS study of Pelizaeus-Merzbacher disease. Pediatr Neurol. 1998;18:334-7.

Ng SB, Turner EH, Robertson PD, Flygare SD, Bigham AW, Lee C, Shaffer T, Wong M, Bhattacharjee A, Eichler EE, Bamshad M, Nickerson DA, Shendure J. Targeted capture and massively parallel sequencing of 12 human exomes. Nature. 2009;461(7261):272-6. 
Nicholson AM, Baker MC, Finch NA, Rutherford NJ, Wider C, Graff-Radford NR, Nelson PT, Clark HB, Wszolek ZK, Dickson DW, Knopman DS, Rademakers R. CSF1R mutations link POLD and HDLS as a single disease entity. Neurology. 2013;80:1033-40.

Oh SJ. Clinical electromyography: nerve conduction studies. 3rd ed. Philadelphia: Lippincott Williams \& Wilkins; 2003.

Ohlenbusch A, Henneke M, Brockmann K, Goerg M, Hanefeld F, Kohlschütter A, Gärtner J. Identification of ten novel mutations in patients with eIF2B-related disorders. Hum Mutat. 2005;25(4):411-6.

Oliveri RL, Muglia M, De Stefano N, Mazzei R, Labate A, Conforti FL, Patitucci A, Gabriele AL, Tagarelli G, Magariello A, Zappia M, Gambardella A, Federico A, Quattrone A. A novel mutation in the Notch3 gene in an Italian family with cerebral autosomal dominant arteriopathy with subcortical infarcts and leukoencephalopathy: genetic and magnetic resonance spectroscopic findings. Arch Neurol. 2001; 58(9):1418-22.

Olsson A, Lind L, Thornell LE, Holmberg M. Myopathy with lactic acidosis is linked to chromosome 12q23.3-24.11 and caused by an intron mutation in the ISCU gene resulting in a splicing defect. Hum Mol Genet. 2008;17:1666-72.

Online Mendelian Inheritance in Man, OMIM®. \# 236792 1-2-hydroxyglutaric aciduria; 12hga. Disponível em: $<$ http://omim.org/entry/236792?search=12hga\&highlight=12hga>. Acesso em: 12 mai. 2017.

Orthmann-Murphy J, Salsano E, Abrams C, Bizzi A, Uziel G, Freidin M, Lamantea E, Zeviani M, Scherer S, Pareyson D. Hereditary spastic paraplegia is a novel phenotype for GJA12/GJC2 mutations. Brain. 2009;132(2):426-38. 
Padiath QS, Saigoh K, Schiffmann R, Asahara H, Yamada T, Koeppen A, Hogan K, Ptácek LJ, Fu YH. Lamin B1 duplications cause autosomal dominant leukodystrophy. Nat Genet. 2006;38:1114-23.

Paiva ARB, Melo US, Freua F, Dória D, Cabral KSS, Macedo-Souza LI, Lucato LT, Kok F. Typical clinical and neuroimaging features in Sjögren-Larsson syndrome. Arq Neuropsiquiatr. 2018;76(4):283.

Paiva ARB, Freua F, Lucato LT, Parmera J, Dória D, Nóbrega PR, Olávio TR, Macedo-Souza LI, Kok F. A novel GFAP mutation in a type II (late-onset) Alexander disease patient. J Neurol. 2016;263(4):821-2.

Paul VD, Lill R. Biogenesis of cytosolic and nuclear iron-sulfur proteins and their role in genome stability. Biochim Biophys Acta. 2015;1853:1528-39.

Pareyson D, Fancellu R, Mariotti C, Romano S, Salmaggi A, Carella F, Girotti F, Gattellaro G, Carriero MR, Farina L, Ceccherini I, Savoiardo M. Adult-onset Alexander disease: a series of eleven unrelated cases with review of the literature. Brain. 2008;131:2321-31.

Parikh S, Bernard G, Leventer RJ, van der Knaap MS, van Hove J, Pizzino A, McNeill NH, Helman G, Simons C, Schmidt JL, Rizzo WB, Patterson MC, Taft RJ, Vanderver A on behalf of the GLIA Consortium. A clinical approach to the diagnosis of patients with leukodystrophies and genetic leukoencephalopathies. Mol Genet Metab. 2015;114(4):501-15.

Patay Z, Mills JC, Löbel U, Lambert A, Sablauer A, Ellison DW. Cerebral Neoplasms in L-2 Hydroxyglutaric Aciduria: 3 New Cases and Meta-Analysis of Literature Data. Am J Neuroradiol. 2012;33(5):940-3.

Patay Z, Orr B, Shulkin B, Hwang S, Ying Y, Broniscer A, Boop F, Ellison D. Successive distinct high-grade gliomas in L-2-hydroxyglutaric aciduria. J Inherit Metab Dis. 2015;38(2):273-7. 
Pedroso JL, Munford V, Bastos AU, Castro LP de, Marussi VHR, Silva GS, Arita JH, Menck CFM, Barsottini OG. LMNB1 mutation causes cerebellar involvement and a genome instability defect. J Neurol Sci. 2017;379:249-52.

Pelizaeus F. Ueber eine eigenartige familiäre Entwicklungshemmung vornehmlich auf motorischem Gebiet. Arch Psychiatrie Nervenkr. 1899;31:100-4.

Polten A, Fluharty AL, Fluharty CB, Kappler J, von Figura K, Gieselmann V.Molecular basis of different forms of metachromatic leukodystrophy. $N$ Engl $J$ Med. 1991;324(1):18-22.

Preston DC, Shapiro BE. Electromyography and neuromuscular disorders: clinicalelectrophysiologic correlations. 3rd ed. Philadelphia: Elsevier Saunders; 2013.

Prust M, Wang J, Morizono H, Messing A, Brenner M, Gordon E, Hartka T, Sokohl A, Schiffmann R, Gordish-Dressman H, Albin R, Amartino H, Brockman K, Dinopoulos A, Dotti MT, Fain D, Fernandez R, Ferreira J, Fleming J, Gill D, Griebel M, Heilstedt H, Kaplan P, Lewis D, Nakagawa M, Pedersen R, Reddy A, Sawaishi Y, Schneider M, Sherr E, Takiyama Y, Wakabayashi K, Gorospe JR, Vanderver A. GFAP mutations, age at onset, and clinical subtypes in Alexander disease. Neurology. 2011;77:1287-94.

Rademakers R, Baker M, Nicholson AM, Rutherdord NJ, Finch N, Soto-Ortolaza A, Lash J, Wider C, Wojtas A, DeJesus-Hernandez M, Adamson J, Kouri N, Sundal C, Shuster EA, Aasly J, MacKenzie J, Roeber S, Kretzschmar HA, Boeve BF, Knopman DS, Petersen RC, Cairns NJ, Ghetti B, Spina S, Garbern J, Tselis AC, Uitti R, Das P, Van Gerpen JA, Meschia JF, Levy S, Broderick DF, Graff-Radford N, Ross OA, Miller BB, Swerdlow RH, Dickson DW, Wszolek ZK. Mutations in the colony stimulating factor 1 receptor (CSF1R) gene cause hereditary diffuse leukoencephalopathy with spheroids. Nature Genet. 2012;44:200-5. 
Raini G, Sharet R, Herrero M, Atzmon A, Shenoy A, Geiger T, Elroy-Stein O. Mutant eIF2B leads to impaired mitochondrial oxidative phosphorylation in vanishing white matter disease. J Neurochem. 2017;141(5):694-707.

Regis S, Biancheri R, Bertini E, Burlina A, Lualdi S, Bianco MG, Devescovi R, Rossi A, Uziel G, Filocamo M. Genotype-phenotype correlation in five PelizaeusMerzbacher disease patients with PLP1 gene duplications. Clin Genet. 2008;73:27987.

Renaud D. Clinical approach to leukoencephalopathies. Semin Neurol. 2012;32:2933.

Renaud D. Adult-onset leukoencephalopathies. Continuum (Minneap Minn). 2016;22(2):559-78.

Richards A, van den Maagdenberg AMJM, Jen JC, Kavanagh D, Bertram P, Spitzer D, Liszewski MK, Barilla-LaBarca ML, Terwindt GM, Kasai Y, McLellan M, Grand MG, Vanmolkot KRJ, de Vries B, Wan J, Kane MJ, Mamsa H, Schäfer R, Stam AH, Haan J, de Jong PTVM, Storimans CW, van Schooneveld MJ, Oosterhuis JA, Gschwendter A, Dichgans M, Kotschet KE, Hodgkinson S, Hardy TA, Delatycki MB, Hajj-Ali RA, Kothari PH, Nelson SF, Frants RR, Baloh RW, Ferrari MD, Atkinson JP. C-terminal truncations in human $3^{\prime}-5^{\prime}$ DNA exonuclease TREX1 cause autosomal dominant retinal vasculopathy with cerebral leukodystrophy. Nat Genet. 2007;39(9):1068-70.

Rizzo WB, Dammann AL, Craft DA. Sjögren-Larsson syndrome. Impaired fatty alcohol oxidation in cultured fibroblasts due to deficient fatty alcohol:nicotinamide adenine dinucleotide oxidoreductase activity. J Clin Invest. 1988;81(3):738-44.

Rizzo WB, Carney G, Lin Z. The molecular basis of Sjögren-Larsson syndrome: mutation analysis of the fatty aldehyde dehydrogenase gene. Am J Hum Genet. 1999;65:1547-60. 
Robinson M-È, Rossignol E, Brais B, Rouleau G, Arbour J-F, Bernard G. Vanishing white matter disease in French-Canadian patients from Quebec. Pediatr Neurol. 2014;51(2):225-32.

Rubegni A, Battisti C, Tessa A, Cerase A, Doccini S, Malandrini A, Santorelli FM, Federico A. SPG2 mimicking multiple sclerosis in a family identified using next generation sequencing. J Neurol Sci. 2017;375:198-202.

Russo LS, Aron A, Anderson PJ. Alexander`s disease: A report and reappraisal. Neurology. 1976;26:607-14.

Rutten J, Lesnik Oberstein SAJ. CADASIL. 2000 Mar 15 [Updated 2016 Jul 14]. In: Pagon RA, Adam MP, Ardinger HH, et al., editors. GeneReviews ${ }^{\circledR}$ [Internet]. Seattle (WA): University of Washington, Seattle; 1993-2017.

Rzem R, Veiga-da-Cunha M, Noel G, Goffette S, Nassogne MC, Tabarki B, Scholler C, Marquardt T, Vikkula M, Van Schaftingen E. A gene enconding a putative FADdependent L2-hydroxyglutarate dehydrogenase is mutated in L2-hydroxyglutaric aciduria. Proc Nat Acad Sci. 2004;101(16):849-54.

Sakai N, Inui K, Fujii N, Fukushima H, Nishimoto J, Yanagihara I, Isegawa Y, Iwamatsu A, Okada S. Krabbe disease: isolation and characterization of a full-length cDNA for human galactocerebrosidase. Biochem Biophys Res Commun. 1994;198(2):485-91.

Santens P, Van Damme T, Steyaert W, Willaert A, Sablonniere B, De Paepe A, Coucke P J, Dermaut B. RNF216 mutations as a novel cause of autosomal recessive Huntington-like disorder. Neurology. 2015;84:1760-6.

Scaglia F1, VogelH,Hawkins EP, Vladutiu GD, Liu LL,Wong LJ.Novel homoplasmic mutation in the mitochondrial tRNATyr gene associated with atypical mitochondrial cytopathy presenting with focal segmental glomerulosclerosis. Am J Med Genet A. 2003;123A:172-8. 
Schiffmann R, van der Knaap MS. An MRI-based approach to the diagnosis of white matter disorders. Neurology. 2009;72:750-9.

Schiffmann R, Fogli A, van der Knaap MS, et al. Childhood ataxia with central nervous system hypomyelination/vanishing white matter. 2003 Feb 20 [Updated 2012 Aug 9]. In: Pagon RA, Adam MP, Ardinger HH, et al., editors. GeneReviews ${ }^{\circledR}$ [Internet]. Seattle (WA): University of Washington, Seattle; 1993-2017.

Schon EA, DiMauro S, Hirano M. Human mitochondrial DNA: roles of inherited and somatic mutations. Nat Rev Genet. 2012;13(12):878-90.

Seeman P, Krsck P, Namestkova K, Malikova M, Belsan T, Proskova M. PelizaeusMerzbacher's Disease (PMD) - Detection of the most frequent mutation of the Proteolipid protein gene in Czech patients and famillies with the classical form of PMD. Ceska Slovenska Neurol Neurochir. 2003;66:95-104.

Seitelberger F. Structural manifestations of leukodystrophies. Neuropediatrics. 1984;15(suppl):53-61.

Sheftel AD, Stehling O, Pierik AJ, Elsasser HP, Muhlenhoff U, Webert H, Hobler A, Hannemann F, Bernhardt R, Lill R. Humans possess two mitochondrial ferredoxins, FDX1 and FDX2, with distinct roles in steroidogenesis, heme, and Fe/S cluster biosynthesis. Proc Natl Acad Sci USA. 2010:107: 11775-80.

Simons C, Wolf NI, McNeil N, Caldovic L, Devaney JM, Takanohashi A, Crawford J, Ru K, Grimmond SM, Miller D, Tonduti D, Schmidt JL, Chudnow RS, van Coster R, Lagae L, Kisler J, Sperner J, van der Knaap MS, Schiffmann R, Taft RJ, Vanderver A. A de novo mutation in the $\beta$-tubulin gene TUBB4A results in the leukoencephalopathy hypomyelination with atrophy of the basal ganglia and cerebellum. Am J Hum Genet. 2013;92(5):767-73. 
Shaheen R, Han L, Faqeih E, Ewida N, Alobeid E, Phizicky E, Alkuraya F. A homozygous truncating mutation in PUS3 expands the role of tRNA modification in normal cognition. Hum Genet. 2016;135(7):707-13.

Shendure J, Ji H. Next-generation DNA sequencing. Nat Biotehcnol. 2008;26:113545.

Shiihara T, Sawaishi Y, Adachi M, Kato M, Hayasaka K. Asymptomatic hereditary Alexander's disease caused by a novel mutation in GFAP. J Neurol Sci. 2004; 225(12):125-7.

Sjögren T, Larsson T. Oligophrenia in combination with congenital ichthyosis and spastic disorders: a clinical and genetic study. Acta Psychiatr Neurol Scand Suppl. 1957;113:1-112.

Sondergaard CB, Nielsen JE, Hansen CK, Christensen H. Hereditary cerebral small vessel disease and stroke. Clin Neurol Neurosurg. 2017;155:45-57.

Southwood CM, Garbern J, Jiang W, Gow A. The unfolded protein response modulates disease severity in Pelizaeus-Merzbacher disease. Neuron. 2002;36:58596.

Souza PVS, Pinto WBVR, Oliveira ASB. Lumbago and alopecia in patient with leukodystrophy: think on CARASIL. Arq Neuropsiquiatr. 2016;74(7):599-600.

Spiegel R, Saada A, Halvardson J, Soiferman D, Shaag A, Edvardson S, Horovitz Y, Khayat M, Shalev SA, Feuk L, Elpeleg O. Deleterious mutation in FDXIL gene is associated with a novel mitochondrial muscle myopathy. Eur J Hum Genet. 2014; 22:902-6.

Srivastava S, Naidu S. Alexander Disease. 2002 Nov 15 [Updated 2015 Jan 8]. In: Pagon RA, Adam MP, Ardinger HH, et al., editors. GeneReviews ${ }^{\circledR}$ [Internet]. Seattle (WA): University of Washington, Seattle; 1993-2017. 
Stabile C, Taglia I, Battisti C, Bianchi S, Federico A. Hereditary diffuse leukoencephalopathy with axonal spheroids (HDLS): update on molecular genetics. Neurol Sci. 2016;37(9):1565-9.

Stanley ER, Chitu V. CSF-1 receptor signaling in myeloid cells. Cold Spring Harb Perspect Biol. 2014;6:a021857.

Steenweg ME, Jakobs C, Errami A, van Dooren SJ, Adeva Bartolomé MT, Aerssens P, Augoustides-Savvapoulou P, Baric I, Baumann M, Bonafé L, Chabrol B, Clarke JT, Clayton P, Coker M, Cooper S, Falik-Zaccai T, Gorman M, Hahn A, Hasanoglu A, King MD, de Klerk HB, Korman SH, Lee C, Meldgaard Lund A, MejaskiBosnjak V, Pascual-Castroviejo I, Raadhyaksha A, Rootwelt T, Roubertie A, RuizFalco ML, Scalais E, Schimmel U, Seijo-Martinez M, Suri M, Sykut-Cegielska J, Trefz FK, Uziel G, Valayannopoulos V, Vianey-Saban C, Vlaho S, Vodopiutz J, Wajner M, Walter J, Walter-Derbort C, Yapici Z, Zafeiriou DI, Spreeuwenberg MD, Celli J, den Dunnen JT, van der Knaap MS, Salomons GS. An overview of L-2hydroxyglutarate dehydrogenase gene (L2HGDH) variants: a genotype-phenotype study. Hum Mutat. 2010;31(4):380-90.

Steenweg ME, Ghezzi D, Haack T, Abbink TE, Martinelli D, van Berkel CG, Bley A, Diogo L, Grillo E, Te Water Naude J, Strom TM, Bertini E, Prokisch H, van der Knaap MS, Zeviani M. Leukoencephalopathy with thalamus and brainstem involvement and high lactate 'LTBL' caused by EARS2 mutations. Brain. 2012;135(5):1387-94.

Steinber SJ, Moser AB, Raymond GV. X-linked adrenoleukodystrophy. 1999 Mar 26 [Updated 2015 Apr 9]. In: Pagon RA, Adam MP, Ardinger HH, et al., editors. Gene Reviews [Internet]. Seattle (WA): University of Washington, Seattle; 1993-2017.

Stenson PD, Ball EV, Mort M, Phillips AD, Shiel JA, Thomas NST, Abeysinghe S, Krawczak M, Cooper DN. The Human Gene Mutation Database (HGMD®): 2003 Update. Hum Mutat 2003;21:577-81. The Human Gene Mutation Database. 
Http://www.hgmd.cf.ac.uk/ac/gene.php?gene=abcd1.

Disponível

em:

<http://www.hgmd.cf.ac.uk/>. Acesso em: 04 de março de 2019.

Stevens A. Pigments and minerals. In: Bancroft JD, Stevens A, editors. Theory and practice of histological techniques. Edinburgh: Churchill Livingstone; 1990. p. 24567.

Sundal S, Lash J, Aasly J, Oygarden S, Roeber S, Kretzochman H, Garbern JY, Tselis A, Rademakers R, Dickson DW, Broderick D, Wszolek ZK. Hereditary diffuse leukoencephalopathy with axonal spheroids (HDLS): a misdiagnoses disease entity. J Neurol Sci. 2012;314:130-7.

Sundal C, Wszolek Z. Adult-Onset Leukoencephalopathy with Axonal Spheroids and Pigmented Glia. 2012 Aug 30 [Updated 2014 Dec 18]. In: Pagon RA, Adam MP, Ardinger HH, et al., editors. GeneReviews ${ }^{\circledR}$ [Internet]. Seattle (WA): University of Washington, Seattle; 1993-2017.

Sundblom J, Melberg A, Kalimo H, Smits A, Raininko R. MR imaging characteristics and neuropathology of the spinal cord in adult-onset autosomal dominant leukodystrophy with autonomic symptoms. AJNR Am J Neuroradiol. 2009;30:328-35.

Suzuki S, Iwaki T, Arakawa K, Furuya H, Fujii N, Iwaki A. An autopsy case of adult-onset hereditary spastic paraplegia type 2 with a novel mutation in exon 7 of the proteolipid protein 1 gene. Acta Neuropathol. 2011;122(6):775-81.

Synofzik M, Gonzalez MA, Lourenço CM, Coutelier M, Haack TB, Rebelo A, Hannequin D, Strom TM, Prokisch H, Kernstock C, Duur A, Schöls L, LimaMartinez MM, Farooq A, Schüle Rebecca, Stevanin G, Marques Jr W, Züchner S. PNPLA6 mutations cause Boucher-Neuhäuser and Gordon Holmes syndromes as parto f a broad neurodegenerative spectrum. Brain. 2014;137:69-77. 
Tikka S, Baumann M, Siitonen M, Pasanen P, Pöyhönen M, Myllykangas L, Viitanen M, Fukutake T, Cognat E, Joutel A, Kalimo H. CADASIL and CARASIL. Brain Pathol. 2014;24(5):525-44.

Torres AG, Batlle E, Ribas de Pouplana L. Role of tRNA modifications in human diseases. Trends Mol Med. 2014;20:306-14.

Uhlenberg B, Schuelke M, Rüschendorf F, Ruf N, Kaindl AM, Henneke M, Thiele H, Stoltenburg-Didinger G, Aksu F, Topaloğlu H, Nürnberg P, Hübner C, Weschke B, Gärtner J. Mutation in the gene enconding gap junction protein alpha 12 (connexin 46.6) cause Pelizaeus-Merzbacher like disease. Am J Hum Genet. 2004;75(2):251-60.

van Berge L, Hamilton EM, Linnankivi T, Uziel G, Steenweg ME, Isohanni P, Wolf NI, Krägeloh-Mann I, Brautaset NJ, Andrews PI, de Jong BA, al Ghamdi M, van Wieringen WN, Tannous BA, Hulleman E, Würdinger T, van Berkel CG, Polder E, Abbink TE, Struys EA, Scheper GC, van der Knaap MS; LBSL Research Group. Leukoencephalopathy with brainstem and spinal cord involvement and lactate elevation: clincal and genetic characterization and target for therapy. Brain. 2014;137(4):1019-29.

van der Knaap MS, Barth PG, Stroink H, van Nieuwenhuizen O, Arts WFM, Hoogenraad F, Valk J. Leukoencephalopathy with swelling and a discrepantly mild clinical course in eight children. Ann Neurol. 1995;37:324-34.

van der Knaap MS, Barth PG, Gabreels FJM, Franzoni E, Begeer JH, Stroink H, Rotteveel JJ, Valk J. A new leukoencephalopathy with vanishing white matter. Neurology. 1997; 48:845-55.

van der Knaap MS, Breiter SN, Naidu S, Hart AA, Valk J. Defining and categorizing leukoencephalopathies of unknown origin: MR imaging approach. Radiology. 1999;213(1):121-33. 
van der Knaap MS, Naidu S, Pouwels PJW, Bonavita S, van Coster R, Lagae L, Sperner J, Surtees R, Schiffmann R, Valk J. New syndrome characterized by hypomyelination with atrophy of the basal ganglia and cerebellum. Am $J$ Neuroradiol. 2002a;23:1466-74.

van der Knaap MS, van der Voorn P, Barkhof F, Van Coster R, Krageloh-Mann I, Feigenbaum A, Blaser S, Vles JSH, Rieckmann P, Pouwels PJW. A new leukoencephalopathy with brainstem and spinal cord involvement and high lactate. Ann Neurol 2002b;53:252-8.

van der Knaap MS, van der Voorn P, Barkhof F, van Coster R, Krageloh-Mann I, Feigenbaum A, Blaser S, Vles JS, Rieckmann P, Pouwels PJ. A new leukoencephalopathy with brainstem and spinal cord involvement and high lactate. Ann Neurol 2003;53:252-8.

van der Knaap MS, Valk J. Magnetic Resonance of Myelin, Myelination and Myelin Disorders. Berlin: Springer; 2005a. Cap 1, p.1-19: Myelin and White Matter.

van der Knaap MS, Valk J. Magnetic Resonance of Myelin, Myelination and Myelin Disorders. Berlin: Springer; 2005b. Cap 65, p.481-95: Leukoencephalopathy with vanishing white matter.

van der Knaap MS, Valk J. Magnetic Resonance of Myelin, Myelination and Myelin Disorders. Berlin: Springer; 2005c. Cap 43, p.334-7: Leukoencephalopathy with vanishing white matter.

van der Knaap MS, Salomons GS, Li R, Franzoni E, Gutierrez-Solana LG, Smit LM, Robinson R, Ferrie CD, Cree B, Reddy A, Thomas N, Banwell B, Barkhof F, Jakobs C, Johnson A, Messing A, Brenner M. Unusual variants of Alexander's disease. Ann Neurol 2005d;57:327-38.

van der Knaap MS, Ramesh V, Schiffmann R, Blaser S, Kyllerman M, Gholkar A, Ellison DW, van der Voorn JP, van Dooren SJ, Jakobs C, Barkhof F, Salomons GS. 
Alexander disease: ventricular garlands and abnormalities of the medulla and spinal cord. Neurology. 2006;66:494-8.

van der Knaap MS, Salomons GS. Leukoencephalopathy with brain stem and spinal cord involvement and lactate elevation. 2010 May 25 [Updated 2015 Feb 12]. In: Pagon RA, Adam MP, Ardinger HH, et al., editors. GeneReviews ${ }^{\circledR}$ [Internet]. Seattle (WA): University of Washington, Seattle; 1993-2017.

van der Knaap MS, Bugiani M. Leukodystrophies: a proposed classification system based on pathological changes and pathogenetic mechanisms. Acta Neuropathol. 2017;134(3):351-82.

van Domburg PHMF, Willemsen MAAP, Rotteveel JJ, de Jong JGN, Thijssen HOM, Heerschap A, Cruysberg JRM, Wanders RJA, Gabreels FJM, Steijlen PM. SjögrenLarsson syndrome: Clinical and MRI/MRS findings in FALDH-deficient patients. Neurology. 1999;52:1345-52.

Vanderver A, Tonduti D, Schiffmann R, Schmidt J, van der Knaap MS. Leukodystrophy Overview.2014 Feb 6. In: Pagon RA, Adam MP, Ardinger HH, et al., editors. Gene Reviews [Internet]. Seattle (WA): University of Washington, Seattle; 1993-2017.

Vanderver A, Prust M, Tonduti D, Mochel F, Hussey HM, Helman G, Garbern J, Eichler F, Labauge P, Aubourg P, Rodriguez D, Patterson MC, van Hove JLK, Schmidt J, Wolf NI, Boespflug-Tanguy O, Schiffmann R, van der Knaap MS on behalf of the GLIA Consortium. Case definition and classification of leukodystrophies and leukoencephalopathies. Mol Genet Metab. 2015;114(4):1494500.

Vanderver A, Simons C, Helman G, Crawford J, Wolf NI, Bernard G, Pizzino A, Schimidt JL, Takanohashi A, Miller D, Khouzam A, Rajan V, Ramos E, Chowdhury S, Hambuch T, Ru K, Baillie GJ, Grimmond SM, Caldovic L, Devaney J, Bloom M, Evans SH, Murphy JL, McNeill N, Fogel BL, Schiffmann R, van der Knaap MS, 
Taft RJ. Whole exome sequencing in patients with white matter abnormalities. Ann Neurol. 2016a;79(6)1031-7.

Vanderver A. Genetic leukoencephalopathies in adults. Continuum (Minneap Minn). 2016b;22(3):916-42.

Verhoog J, Fuijkschot J, Willemsen M, Ketelaar M, Rotteveel J, Gorter JW. SjögrenLarsson syndrome: motor performance and everyday functioning in 17 patients. Dev Med Child Neurol. 2008;50(1):38-43.

Vilarinho L, Cardoso ML, Gaspar P, Barbot C, Azevedo L, Diogo L, Santos M, Carrilho I, Fineza I, Kok F, Chorão R, Alegria P, Martins E, Teixeira J, Fernandes H, Verhoeven NM, Salomons GS, Santorelli FM, Cabral P, Amorim A, Jakobs C. Novel L2HGDH mutations in 21 patients with L-2-hydroxyglutaric aciduria of Portuguese origin. Hum Mutat. 2005;26(4):395-6.

Wajner M, Coelho M, Ingrassia R, de Oliveira AB, Busanello EN, Raymond K, Flores-Pires R, de Souza CF, Giugliani R, Vargas CR. Selective screening for organic acidemias by urine organic acid GC-MS analysis in Brazil: fifteen-year experience. Clin Chim Acta. 2009;400(1-2):77-81.

Waldman AT. Leukodystrophies. Continuum (Minneap Minn). 2018;24(1):130-49.

Wider C, Van Gerpen JA, Dearmond S, Shuster EA, Dickson DW, Wszolek ZK. Leukoencephalopathy with spheroids (HDLS) and pigmentary leukodystrophy (POLD): a single entity? Neurology. 2009;72:1953-9.

Willemsen MAAP, Lodewijk IJ1st, Steijlen PM, Rotteveel JJ, de Jong JGW, van Domburg PHMF, Mayatepek E, Gabreels FJM, Wanders RJA. Clinical, biochemical, and molecular genetic characteristics of 19 patients with the Sjögren-Larsson syndrome: Characterization of the leukoencephalopathy. Brain. 2001;124:1426-37. 
Willemsen MAAP, van der Graaf M, van der Knaap MS, Heerschap A, van Domburg PHMF, Gabreels FJM, Rotteveel JJ. MR imaging and proton MS spectroscopic studies in Sjögren-Larsson syndrome: Characterization of the leukoencephalopathy. AJNR Am J Neuroradiol. 2004;25:649-57.

Wolf NI, Vanderver A, van Spaendonk RML, Schiffmann R, Brais B, Bugiani M, Sistermans E, Catsman-Berrevoets C, Kros JM, Pinto PS, Pohl D, Tirupathi S, Stromme P, Grauw T, Fribourg S, Demos M, Pizzino A, Naidu S, Guerrero K, van der Knaap MS, Bernard G, On behalf of the 4H Research Group. Clinical spectrum of $4 \mathrm{H}$ leukodystrophy caused by POLR3A and POLR3B mutations. Neurology. 2014;83:1898-905.

Wong LJC. Mitochondrial syndromes with leukoencephalopathies. Semin Neurol. 2012;32:55-61.

Wortham NC, Proud CG. eIF2B: recente structural and functional insights into a key regulator of translation. Biochem Soc Trans. 2015;43(6):1234-40.

Yamamoto Y, Craggs L, Baumann M, Kalimo H, Kalaria RN. Review: molecular genetics and pathology of hereditary small vessel diseases of the brain. Neuropathol Appl Neurobiol. 2011;37:94-113. 


\section{Apêndices}





\title{
10 APÊNDICES
}

\subsection{Apêndice A - Aprovação da Comissão de Ética para Análise de Projetos de Pesquisa da Faculdade de Medicina da Universidade de São Paulo}

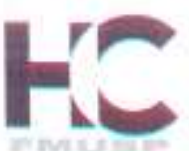

\author{
Hospital das Clínicas da FMUSP \\ Comissão de Ética para Análise de Projetos de Pesquisa - CAPPesq
}

\section{PROJETO DE PESQUISA}

Titulo: LEUCOENCEFALOPATIAS GENETICAMENTE DETERMINADAS DE INICIO NA IDADE ADULTA: CARACTERIZAÇĀO CLINICA, ELETROFISIOLOGICA E DE NEUROIMAGEM

Pesquisador Responsável: Prof.Dr, Fernando Kok - Versäo: 1

Pesquisador Executante: Anderson Rodrigues Brandāo de CAAE: 11980213.5 .0000 .0068

Paiva

Finalidade Acadêmica Doutorado

Instituiçäo: HCFMUSP

Departamento: NEUROLOGIA

\section{PARECER CONSUBSTANCIADO DO CEP}

Registro on-line: 10298

Número do Parecer: 214.262

Data da Relatoria: 06/03/2013

Apresentaçăo do Projeto: As leucoencefalopatias constituem um grupo de doenças raras, geneticamente determinadas, que afetam a bainha de mielina e que podem manifestar-se em crianças ou na idade adulta. Os autores apresentam uma abrangente revisảo da literatura sobre o tema expбém com clareza os objetivos do estudo que eståo já contidos no título do projeto: Leucoencefalopatias geneticamente determinadas de inicio na idade adulta: caracterização clinica, eletrofisiológica e de neuroimagem.

Objetivo da Pesquisa: $\mathrm{O}$ objetivo da pesquisa, já mencionado no titulo do projeto, será a caracterizaçäo de leucoencefalopatias geneticamente determinadas de inicio na idade adulta. O estudo serd em parte retrospectivo através de compilaçăo de dados de pacientes já diagnosticados e que se encontram em seguimento na Clinica Neurológica do Hospital das Clinicas e, também prospectivo, com a inclusāo de novos pacientes que preencham os critérios de seleçăo adotados. A caracterizaçăo dos casos será baseada em: a) avallaçăo clínica; b) ressonância magnética de crånio; c) eletroencefalograma; d) eletroneuromiografia; ejestudo de potenciais evocados visual, auditivo e somato-sensorial e eventualmente outros exames laboratoriais conforme julgamento clinico.

Avaliaçăo dos Riscos e Beneficios: Os riscos sẳo minimos: dor e eventual hematoma nas coletas de sangue; dor e desconforto causados pela introduçăo de agulha e pelos estímulos elétricos durante o exame de eletroneuromiografia e desconforto pela exposiçāo a ruidos durante a realizaçăo de ressonáncia magnética. Os beneficios poderăo ser săo representados por avanças nos conhecimentos a respeito deste grupo de doenças.

Comentários e Consideraçŏes sobre a Pesquisa: A metodologia do estudo está elaborada de forma adequada e e enquadra-se tipicamente nos propósitos de linhas de investigação em Hospital de atendimento a casos complexos e raros.

Consideraçōes sobre os Termos de apresentação obrigatória: Os termos obrigatórios requeridos foram devidamente apresentados

Rua Dr, Ovidio Pires de Campos, 225 - Prédio da Administraçăo - 59 andar

CEP 05403-010 - Såo Paulo - SP.

$55112661-7585$ - 5511 2661-6442 ramais: 16, 17, 18 | marcia carvalho@hc.fm.usp.br 


\section{Hospital das Clínicas da FMUSP}

Comissão de Ética para Análise de Projetos de Pesquisa - CAPPesq

Recomendações: 0 projeto de estudo está elaborado atendendo as normas éticas e dado o potencial de beneficios recomendamos sua aprovação.

Conclusōes ou Pendências e Lista de Inadequaçōes: Com base nas consideraçб̄es anteriores e năo havendo pendências ou inadequaç̋̋es sugerimos concluimos que o estudo seja aprovado

Situaçăo do Parecer: Aprovado

Necessita Apreciaçāo da CONEP: Não

Consideraçōes Finais a critério do CEP: Em conformidade com o item IX.2 da Resolução CNS n² 196/96 - cabe ao pesquisador: a) desenvolver o projeto conforme delineado; b) elaborar e apresentar relatórios parciais e final; c)apresentar dados solicitados pelo CEP, a qualquer momento; d) manter em arquivo sob sua guarda, por 5 anos da pesquisa, contendo fichas individuais e todos os demais documentos recomendados pelo CEP; e) encaminhar os resultados para publicaçăo, com os devidos créditos aos pesquisadores associados e ao pessoal técnico participante do projeto; f) justificar perante ao CEP interrupçăo do projeto ou a năo publicaçåo dos resultados.

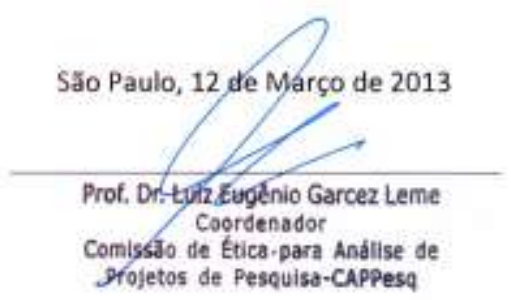

Rua Dr. Ovidio Pires de Campos, 225 - Prédio da Administraçăo - $5^{2}$ andar CEP 05403-010 - São Paulo - SP.

5511 2661-7585 - 5511 2661-6442 ramais: 16, 17, 18 | marcia.carvalho@hc.fm.usp.br 
10.2 Apêndice B - Termo de consentimento livre e esclarecido

\section{HOSPITAL DAS CLÍNICAS DA FACULDADE DE MEDICINA DA} UNIVERSIDADE DE SÃO PAULO-HCFMUSP

\section{TERMO DE CONSENTIMENTO LIVRE E ESCLARECIDO}

DADOS DE IDENTIFICAÇÃO DO SUJEITO DA PESQUISA OU RESPONSÁVEL LEGAL

1.NOME:

DOCUMENTO DE IDENTIDADE $\mathrm{N}^{\circ}$ : SEXO : .M $\square \mathrm{F} \square$

DATA NASCIMENTO: .........................

ENDEREÇO

$\mathrm{N}^{\circ}$ APTO:

BAIRRO: CIDADE

CEP: TELEFONE: DDD (.............)

2.RESPONSÁVEL LEGAL

NATUREZA (grau de parentesco, tutor, curador etc.)

DOCUMENTO DE IDENTIDADE : SEXO: $\mathrm{M} \square \mathrm{F} \square$

DATA NASCIMENTO.: .....................

ENDEREÇO: $\mathrm{N}^{\mathrm{o}}$ APTO:

BAIRRO: CIDADE:

CEP: TELEFONE: DDD

DADOS SOBRE A PESQUISA

1. TÍTULO DO PROTOCOLO DE PESQUISA : LEUCOENCEFALOPATIAS GENETICAMENTE DETERMINADAS DE INÍCIO NA IDADE ADULTA: CARACTERIZAÇÃO CLÍNICA, ELETROFISIOLÓGICA E DE NEUROIMAGEM.

PESQUISADOR RESPONSÁVEL: Prof.Dr. Fernando Kok

CARGO/FUNÇÃO: Médico Supervisor INSCRIÇÃO CONSELHO REGIONAL N ${ }^{0} 32.255$

PESQUISADOR EXECUTANTE: Anderson Rodrigues Brandão de Paiva

CARGO/FUNÇÃO: Médico INSCRIÇÃO CONSELHO REGIONAL No 126.690 (CREMESP)

UNIDADE DO HCFMUSP: Neurologia Clínica - Divisão de Clínica Neurológica

3. AVALIAÇÃO DO RISCO DA PESQUISA:

$\begin{array}{lll}\text { RISCO MÍNIMO } & \square & \text { RISCO MÉDIO } \square \\ \text { RISCO BAIXO } & \mathbf{x} & \text { RISCO MAIOR } \square\end{array}$

4.DURAÇÃO DA PESQUISA : 3 anos 
1 - Estamos fornecendo estas informações com o intuito de solicitar que o senhor(a) ou seu dependente participe voluntariamente de um estudo descritivo que visa melhorar o entendimento de um grupo de doenças raras que se caracterizam pela presença de desmielinização. A mielina é uma substância que contribui para o funcionamento dos nervos e atua como o revestimento de um fio elétrico. O objetivo do estudo é investigar as manifestações clínicas desse grupo de doenças e de como os exames complementares podem contribuir para o seu diagnóstico.

2 - Serão realizados alguns exames de sangue, urina e liquido cefalorraquiano; procedimentos que avaliam o funcionamento elétrico dos nervos (eletromiografia) e do cérebro (eletroencefalograma e potenciais evocados) e exames para estudar a imagem do cérebro (ressonância magnética).

3 - Para estudar as manifestações clínicas o médico coletará informações a respeito da história da doença e fará perguntas além de o examinar cuidadosamente, como é feito habitualmente em consultas médicas mas com especial atenção a parte neurológica.

As amostras de sangue serão obtidas por meio de coleta de sangue de veia periférica. A urina será obtida por meio de coleta em frasco estéril. O liquido cefalorraquiano será obtido por punção lombar, que será realizada por profissional medico.

Para estudar o funcionamento do cérebro e dos nervos, poderão ser realizados eletroencefalograma, eletroneuromiografia, potencial evocado visual e potencial evocado auditivo. A escolha dos exames que serão realizados depende dos sintomas que o(a) senhor(a) ou dependente apresenta e da hipótese diagnóstica que foi realizada. Esses exames precisam de uma colaboração mínima e por isso serão realizados sem sedação.

O eletroencefalograma é um exame que estuda as correntes elétricas geradas pelo cérebro através de um registro gráfico. Consiste em fixar pequenos fios no couro cabeludo para detectar a atividade elétrica do cérebro. $\mathrm{O}$ exame deve ser realizado durante o sono e com a pessoa acordada.

A eletroneuromiografia é um exame que avalia a função dos nervos e dos músculos. É dividida em duas partes: o estudo de condução nervosa e a eletromiografia de agulha. $\mathrm{O}$ estudo de condução nervosa estuda a função dos nervos. Consiste na aplicação de impulsos ou choques elétricos de baixa intensidade nos nervos periféricos com o objetivo de estimulá-los e produzir uma resposta. A segunda etapa é representada pela eletromiografia de agulha. Nessa fase, pequenas agulhas descartáveis são introduzidas nos músculos para a análise da atividade do músculo em repouso e durante a contração. Uma sensação de picada é sentida quando a agulha é inserida no músculo. Apesar de o exame ser composto por choques elétricos e introdução de agulhas nos músculos, a maioria dos pacientes tolera o procedimento muito bem.

Os potenciais evocados são exames que medem as respostas elétricas do cérebro a estímulos sensoriais externos como visão (potencial evocado visual) ou audição (potencial evocado auditivo). Os potenciais evocados visuais (PEV) são testados colocando-se pequenos fios na parte de trás da cabeça e estimulando a visão de cada olho separadamente por meio de uma tela quadriculada que passa em uma tela de computador. Cada olho é estimulado por duas vezes, sendo que a duração total do procedimento pode ser de $45-60$ minutos.

Os potenciais evocados auditivos são testados colocando-se fios na região lateral do couro cabeludo e estimulando a audição de cada ouvido separadamente através de um fone que emite um click sonoro. Cada ouvido é estimulado por duas vezes e o procedimento pode demorar entre 30 a 45 minutos.

A ressonância magnética é um exame que fornece uma imagem detalhada do cérebro. Para sua realização, o (a) senhor(a) deverá entrar no aparelho da ressonância que tem formato de túnel. O exame tem duração de 20 a 30 minutos e durante sua realização, deverá ficar imóvel e escutará um barulho alto para o qual usará um protetor de ouvido. Por esse motivo algumas pessoas não conseguem cooperar e precisam de sedação. Caso ela seja necessária, será feita por anestesista.

Todos os exames serão realizados no Hospital das Clínicas e com horário previamente marcado.

4 - Não haverá inicialmente nenhum benefício direto para o (a) senhor(a). Como vantagem, terá acesso a exames de maior complexidade e a uma revisão de todos os exames. A possibilidade de definir um diagnóstico poderá ter implicações futuras, uma vez que as doenças estudadas nesta investigação têm origem genética e desta forma apresentam risco de se repetir na família. Além disto, o diagnóstico poderá contribuir para o planejamento do tratamento e da reabilitação. . 
6 - Em qualquer etapa do estudo, você terá acesso aos profissionais responsáveis pela pesquisa para esclarecimento de eventuais dúvidas. Os principais investigadores são Prof.Dr. Fernando Kok / Dr. Anderson Rodrigues Brandão de Paiva que podem ser encontrados na Avenida Dr. Enéas de Carvalho Aguiar, 255,5 ${ }^{\circ}$. Andar, Divisão de Clínica Neurológica - Cerqueira César - 05403-000, Telefone(s) 3069-6401 / (71) 9924-9888 .

Se você tiver alguma consideração ou dúvida sobre a ética da pesquisa, entre em contato com o Comitê de Ética em Pesquisa (CEP) - Rua Ovídio Pires de Campos, 225 - 5º andar - tel: 3069-6442 ramais 16, 17, 18 ou 20, FAX: 3069-6442 ramal 26 - E-mail: cappesq@ hcnet.usp.br

7 - É garantida a liberdade, a qualquer momento, da retirada deste consentimento e da saída do estudo, sem qualquer prejuízo à continuidade do tratamento na Instituição;

09 - As informações obtidas serão analisadas em conjunto com as informações de outros pacientes do estudo e não será divulgada a identificação de nenhum paciente;

10 - Pais e responsáveis terão direito a acesso aos resultados do estudo que sejam do conhecimento dos pesquisadores;

11 - Não haverá despesas pessoais para os participantes em qualquer fase do estudo, incluindo consultas e exames. Também não haverá compensação financeira relacionada à sua participação.

12 - Em caso de dano pessoal, diretamente causado pelos procedimentos ou tratamentos propostos neste estudo (com relação causal comprovada), você terá direito a tratamento médico na Instituição, bem como às indenizações legalmente estabelecidas.

13 - Os pesquisadores têm o compromisso de utilizar o material coletado somente para esta pesquisa. Os dados obtidos no estudo, de interesse científico, poderão ser submetidos a publicação em revistas ou jornais da área médica.

Acredito ter sido suficientemente informado a respeito das informações que li ou que foram lidas para mim, descrevendo o estudo "Leucoencefalopatias geneticamente determinadas de início na idade adulta: caracterização clínica, eletrofisiológica e de neuroimagem"

Eu discuti com o Dr. Anderson Rodrigues Brandão de Paiva sobre a minha decisão em participar nesse estudo. Ficaram claros para mim quais são os propósitos do estudo, os procedimentos a serem realizados, seus desconfortos e riscos, as garantias de confidencialidade e de esclarecimentos permanentes. Ficou claro também que minha participação é isenta de despesas e que tenho garantia do acesso a tratamento hospitalar quando necessário. Concordo voluntariamente em participar deste estudo e poderei retirar o meu consentimento a qualquer momento, antes ou durante o mesmo, sem penalidades ou prejuízo ou perda de qualquer benefício que eu possa ter adquirido, ou no meu atendimento neste Serviço.

Assinatura do paciente/representante legal

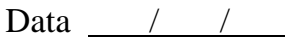

Assinatura da testemunha

Data / /

Para casos de pacientes menores de 18 anos, analfabetos, semi-analfabetos ou portadores de deficiência auditiva ou visual.

\section{(Somente para o responsável do projeto)}

Declaro que obtive de forma apropriada e voluntária o Consentimento Livre e Esclarecido deste paciente ou representante legal para a participação neste estudo. 


\subsection{Apêndice C - Endereços eletrônicos dos artigos científicos relacionados a esta tese publicados em revistas indexadas}

Artigos como primeiro autor ou coautor (em ordem cronológica):

Leite CC, Lucato LT, Santos GT, Kok F, Brandão AR, Castillo M. Imaging of adult leukodystrophies. Arq Neuropsiquiatr 2014;72(8):625-632.

https://doi.org/10.1590/0004-282X20140095

Freua F, Parmera JB, Doria DO, Paiva AR, Macedo-Souza LI, Kok F. Leukodystrophy with premature ovarian failure: think on white matter disease. Arq Neuropsiquiatr 2015;73(1):65.

https://doi.org/10.1590/0004-282X20140183

Paiva ARB, Freua F, Lucato LT, Parmera J, Dória D, Nóbrega PR, Olávio TR, Macedo-Souza LI, Kok F. A novel GFAP mutation in a type II (late-onset) Alexander disease patient. J Neurol 2016;263(4):821-822.

https://doi.org/10.1007/s00415-016-8065-8

Lynch DS, Paiva ARB, Zhang WJ, Bugiardini E, Freua F, Lucato LT, MacedoSouza LI, Lakshmanan R, Kinsella JA, Merwick A, Rossor AM, Bajaj N, Herron B, McMonagle P, Morrison PJ, Hughes D, Pittman A, Laurà M, Reilly MM, Warren JD, Mummery CJ, Schott JM, Adams M, Fox NC, Murphy E, Davagnanam I, Kok F, Chataway J, Houlden H. Clinical and genetic characterization of leukoencephalopathies in adults. Brain 2017;140(5):1204-1211.

https://doi.org/10.1093/brain/awx045

Paiva ARB, Pucci Filho CR, Porto AM, Feltrin FS, Kok F, Camargo CHF. When multiple sclerosis and X-linked adrenoleukodystrophy are tangled. Neurol Clin Pract 2018;8(2):156-158.

https://doi.org/10.1212/CPJ.0000000000000431

Paiva ARB, Melo US, Freua F, Dória D, Cabral KSS, Macedo-Souza LI, Lucato LT, Kok F. Typical clinical and neuroimaging features in Sjögren-Larsson syndrome. Arq Neuropsiquiatr 2018;76(4):283.

http://dx.doi.org/10.1590/0004-282x20180024

Gurgel-Giannetti J, Lynch DS, Paiva ARB, Lucato LT, Yamamoto G, Thomsen C, Basu S, Freua F, Giannetti AV, de Assis BDR, Ribeiro MDO, Barcelos I, Sayão Souza K, Monti F, Melo US, Amorim S, Silva LGL, Macedo-Souza LI, ViannaMorgante AM, Hirano M, Van der Knaap MS, Lill R, Vainzof M, Oldfors A, Houlden H, Kok F. A novel complex neurological phenotype due to a homozygous mutation in FDX2. Brain 2018;141(8):2289-2298.

https://doi.org/10.1093/brain/awy172 
Lynch DS, Wade C, Paiva ARB, John N, Kinsella JA, Merwick Á, Ahmed RM, Warren JD, Mummery CJ, Schott JM, Fox NC, Houlden H, Adams ME, Davagnanam I, Murphy E, Chataway J. Practical approach to the diagnosis of adultonset leukodystrophies: an updated guide in the genomic era. J Neurol Neurosurg Psychiatry 2019:90:543-554.

http://dx.doi.org/10.1136/jnnp-2018-319481

Resende LL, Paiva ARB, Kok F, da Costa Leite C, Lucato LT. Adult Leukodystrophies: A Step-by-Step Diagnostic Approach. Radiographics 2019;39(1):153-168.

https://doi.org/10.1148/rg.2019180081

De Paiva A, Lynch D, Melo U, Lucato L, Freua F, de Assis B, Barcelos I, Listik C, de dos Santos D, Macedo-Souza L, Houlden H, Kok F. PUS3 mutations are associated with intellectual disability, leukoencephalopathy, and nephropathy. Neurol Genet 2019;5(1):e306. https://doi.org/10.1212/NXG.0000000000000306 
10.4 Apêndice D - Imaging of adult leukodystrophies. Arq Neuropsiquiatr 2014;72(8):625-632.

This work is licensed under the Creative Commons Attribution 4.0 International License. To view a copy of this license, visit http://creativecommons.org/licenses/by/4.0/ or send a letter to Creative Commons, PO Box 1866, Mountain View, CA 94042, USA.

Leite CC, Lucato LT, Santos GT, Kok F, Brandão AR, Castillo M. Imaging of adult leukodystrophies. Arq Neuropsiquiatr 2014;72(8):625-632.

https://doi.org/10.1590/0004-282X20140095 


\title{
Imaging of adult leukodystrophies
}

Imagem nas leucodistrofias do adulto

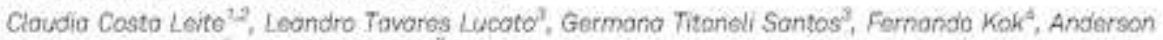
Rodrigues Branoát, Mauricio Castillio"

\begin{abstract}
Anstpact

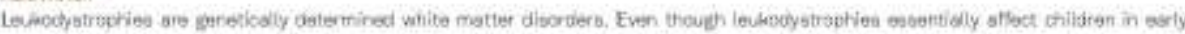

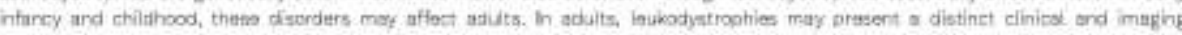

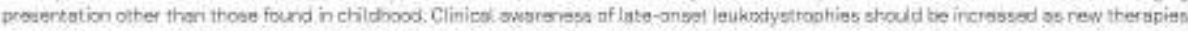

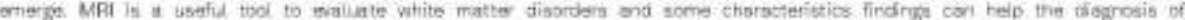

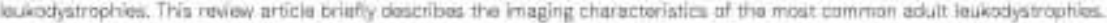

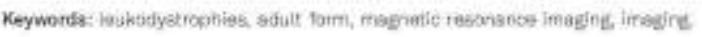

ncsumo

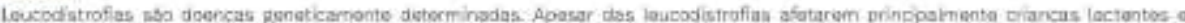

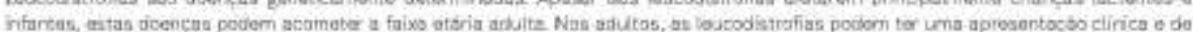

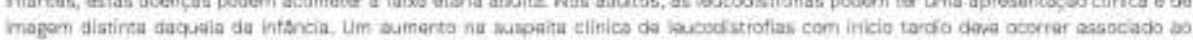

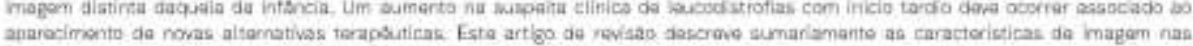

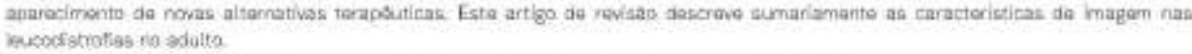

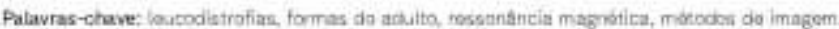

Lecikodyatrophies are genetically determined disonifers that primarly affect the white mattec, In recent years. advanoes in molecular genetics bave made the characterization and diagoosis of many keukodyatrophies possidle with the identification of defective genes Fuithermate, the wide apread use of uagnectic resonaroe imajiag (MRI) allows the identification of white matter changes even at the beginning of the disease, in pre-symptomatic patients and carriers

Even though leukadystrophies essentially affect children ard presert in eaty infency and chllilhood. these disorders may affect aduits and many times, with a distinct clinical and imaging presectations other than those found in chlllhood As kukodystrophlies are a heteromeneous poup of diseased many pethological frodings ane common to all such as demye luation, bypomyelination and vacualization. Commonly the white muitter inwkivement is bilateral and symmetric:

Adult leukodystrcphiex or late-onset leukndyntrophies can manisest initially as soleted prychiatric symptoms suct as cogniative decline, behavioral problems, memacy loas psychosis and dementia Other clinical manifestations
Inclinte motor signs, peripheral neuropathy, bulbsr dyafunc. tion and eplepay. Furthermore. in actults, disease progres sion ts dower for comparison to the chilthood sultypes of the same leukodystrophy.

Cirnical awareness of late-danect leukadyctsaphips ahould be increased, as now therapeutic approsches have been develaped, such as tem cell transplantation, enzyne replacement and gene therapy. MRI is a useful tool to evalus. ate new forms of keukodystropities and to allow longitudinal studies of disease progression ${ }^{22}$. The ain of this teview is to briefly descr be the imagting characteratirs of the most common adult keukodystrophied.

\section{IMAGING FINDINGS}

$X$ - linked adrenoleukodystrophy $(X-A L D)$

$X$ linked adrenoleukodystropky (X-ALD) in asacinted with the socumulation of very lang chain fatty acida (VLCFA) in senum, neural tissues and adrenal glands. The

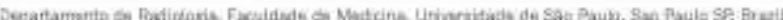

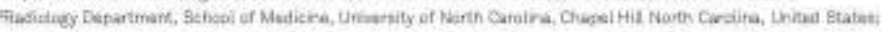

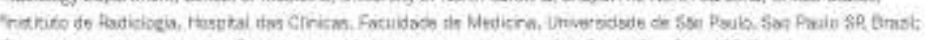

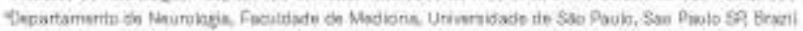

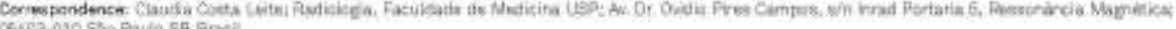
66+e3.010 Sho Pailo SE, Qnasi.

Confict of ntemest. There is no connict of intareet to doctars

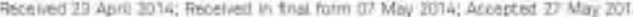



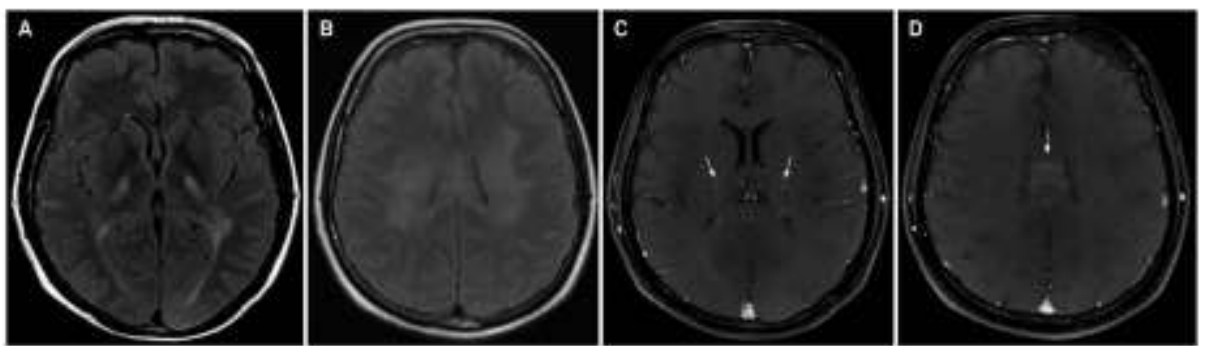

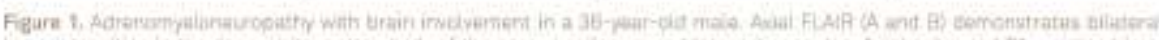

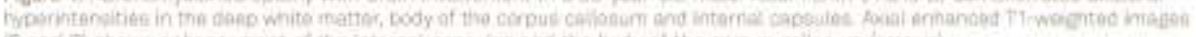

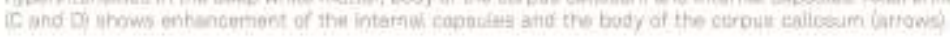

mutation associated is ALDX is in the ABCDI gene. The cell accumulation of VLCEA causes demyclination in the central nervias systern (CNS) and sell destraction in the adrenal gands. As an X-tinkeed inherited disease, $X$-Al.D affects mostly males. In adult males the predomitiant form is adrenomyckneuropathy. AL.D mutation may oocur In women and they somotimes manifest milder symptoms: Adrenomyeloneuropathy is a slowy progressive discease that presents with adrenal insufficiency, distal axonopethy (predominantly affecting the corticuspinal tracts and dorsal columns of spinal cond) and peripheral neuropatty't, The clinical presentation is usually spastic paraparesis. Brain MUI shows siens of involverment af the corticospinal trats, dorsal columns, corpus callosum and periventricular white matter (Figure 1). Around 200 of adrenomyeloneuroputhy patienis develop a more severe phenotype called adult cerebral adrenoleukodystrophy. Poychiatric signis, followed by motor signs, optic atrophy, epilepsy and death characterize this form of cerebral ALD.
As in childhood ALD, contrast enhanoement can be reen in the periphery of the white matter lesions' (Figare 2). Cerebral aduli form can manifest as asymmetrie focal lesions sametimes mimicking a tumor, and in sorre reparts has been related to previous traumatic episodes (Figure 3)"

Heterozygous wornen are usually asymptomatio of present brisk tendon reflexes and impaired vibration sensation. An ill-defined pain syndrome may occur. in $15 \%$ of fernales progressive spastic paraparesis can ensue around 40 years of age, Very marely, the X-ALD women present adrenal imsufficiency or brain involverment. Bnin MRI can be normal or be similar to that seen in adrenonseckneuropathy ${ }^{203}$.

\section{Metachromatic leukodystrophy}

Metachromatic leukndystrophy is an autosomal tecessive bsosomal disease casused by a deficiency of the enzyme arysullatase A (ARSA) that leads to the accumulation of sulfatides in oligodendrocytes. Schwant cells and socoe neurons causing
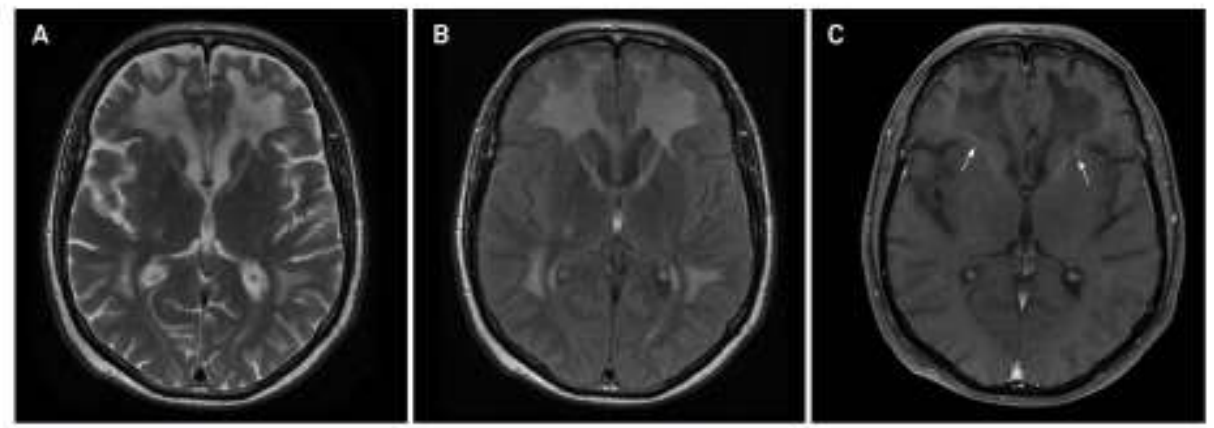

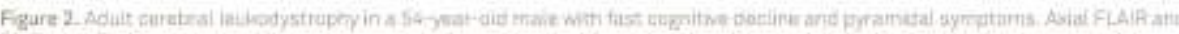

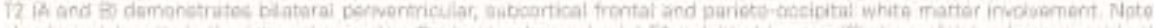

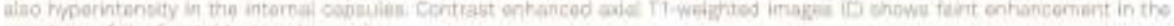
cerwhery of the frontini lesioni cartawe 

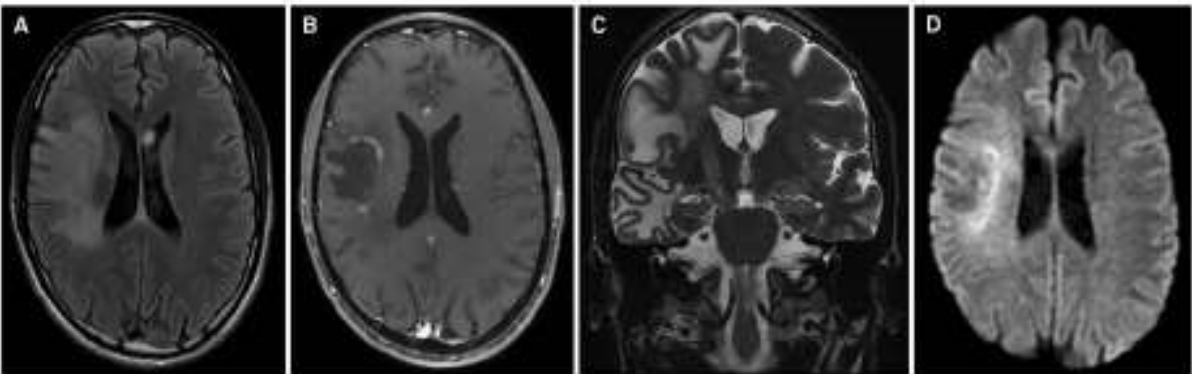

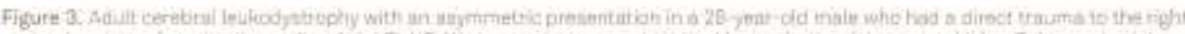

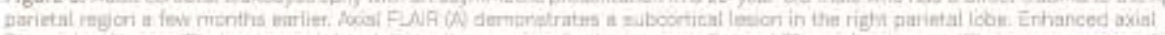

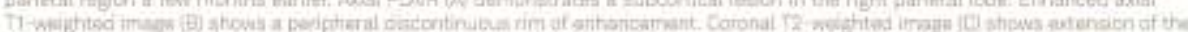

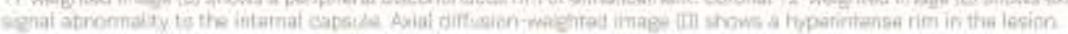

demaclination both in the central as well as in the periphera nervous systems. Nkre than 100 mutations causing mota. chromatic keuloodystrophy hase been identified.

The adult-onset form, which occurs atter 16 years of ago, accounts foe $20 \%$ of caser. The disease can manifest as late as the seventh decide of life? In afulthond the main clinical presentations are psychiatric problems (cogaitive, behavioral problems and memory deficits) sometimes mimicking schizonghrenia followed by motor siens, such as sqastic para paresis, cerebellar ataxia and mild polyneuropathy. The disesse course is self-limiting 30

MR1 shows a bilateral periventricular leukoencephalopothy predominantly in the frontal regions, sparing the U-fibers in the initial phase of the disease. The corpus callosum can be affected. Cortical atrophy is also seen predominantly late in the ovurse of the discases

Krabbe's disease (Globoid cell leukodystrophy)

Krabbe's disesse is an autosornal recessive lysossonal stor age disease caused by the deficiency of b-galactocerebrosidase (GALC) enzyme activity. The GALC defect ksods to the accumulation of galactocerebroside and prychosine. which causes oligodendrocyte apontosis and fliksis. The gene encoding for GNLC is localtzed to clromosome 14q31. Unfortunately, net ther the galactocerebrosidase activity nor the gene mutation can define the genotype in Krabbe disease ${ }^{\text {ta }}$

Adult Krabbe patients are older than 16 years, and the disease can manifest as late as in the fitth decade of life Clinically late onset forms present pyramidal tract involve ment with spactic paraparesis or tetraparesis. A peripheral decnyelinating polyneuropothy oxcurs in up to $61 \%$ of patients. sometimes being asymmetric and involving bulhar musctes Progressive cogaitive decline, seizures and cortical blindness can also ensure. The discose progression is show tus

On MRI, the deep nupratentorial and cerebellar white matter-are affected. Pyramidal tructs, splenium of corpus callasum and optic radiation can present byperintensity on T2-weighted and FIAIR images. The signal abnormalities in the corticospinal tracts start in the perirolandic regions and extend to eorcina raliata, internal capsules, cerctors peduncles ventral part of the poos and medulla bilaterally (Figure 4) Corpus callosum atrughy can also be seen. In rare cocasions. MRI can be normal ${ }^{\text {ser }}$

\section{Alexander disease}

Alexander disease is a beukodystrophy characterized pathologically by diffuse Rosenthal fibers accumulation in astrocyte cytoplasm. The defect associated with this disease is located in the gene encoding for GFAP (fial fibrillary acid protein. After the identification of the pene defect. the number of adult-onset cases described in the literature has increased.

In Alexander disesse, Hosenthal fibers ane scattered throxughout the cortex and in white mutter and are most numerous in the subpial, perivascualar and subependyrmal regions. The adult-onset form is diagsnosed after 12 years of ape up to the eighth secade of life. Clinical presentation includes a siowly progressive bulbar dysfunction (dysptiagia. dysarthria. Gysphonial. pyramidal signs and ataxia. with normal psychic and intelloctuad functions. When present, petatal myockoous is sagestive of this diagnosis ${ }^{\text {initiv }}$

MRI sbows mild- to- senere atrophy of the medulla oblongata extending caudally to the cervical spinal cord. sometimes associated with signal abnormalitios (Figure. 5) MEdbrain tepmentum atrophy has also been described, with preservation of the pontine base and this finding is quite specific of adult-onsee Alexander disease". Basal gangia abnormalities (diffuse or patchy) have also been described. especially in patients under 40 years of age. In a few cases, periventricular garland that is typical of the jonerlle form has been documented. Contrast enhancement is also reported in som potients especially in those under 40 years of age". Relatives 

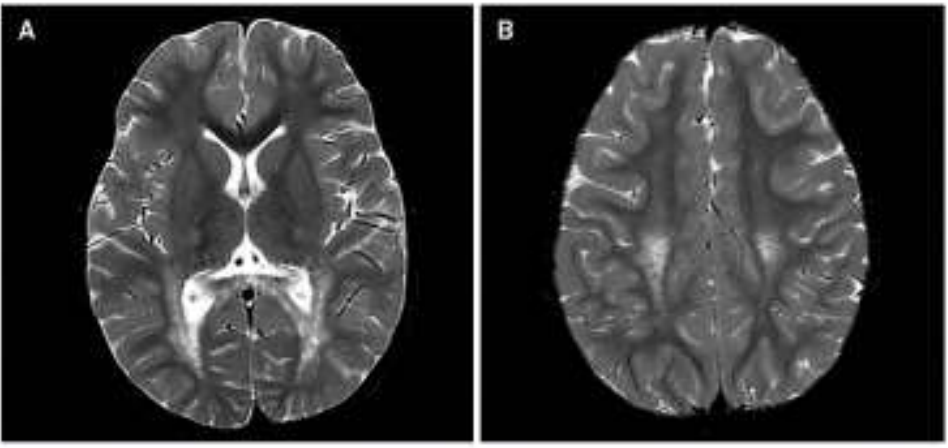

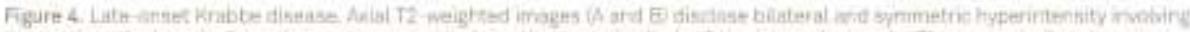

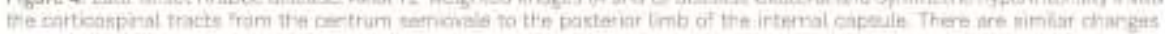
approcieted $\pi$ tha meleriami af corpur callooum

with the gyne mutation but without clinical manifostations (asymptomatic: Mlexander diseuse) can ponsent a pernesitricular band of signal abnormality on MH"

Vanishing white matter disease

Vanishing white matter disease petients bave matations in the elF2B (eusaryotic initiation factor 2B) complex penes. A mild variant of this disease has been described in adolescence and adulthood. The clinical onset in the juvenile or aduit forms is chaxacterized by migraine, psychiatric symptoms and dementic. Pseudobulthur pulisy and progressine spastic paripansis have also been dexcribed.

Woencen present ovirian insufficiency (dysegresis) and letakodystrophy, a condition known as avaribleakodystrophy. The ovarian failure may pnecode neurukapic symptoms ${ }^{20}$.

MTI can show enlangegnent of the laterai ventricles and the white matter can be nomal of present hyperintensity on T2-weighted and F1.MIR images (Figure 61, Limited subcortical white matter hypointensity on FLAIR associated to the cystic breakdown or cositation can be seen ${ }^{6 !}$,
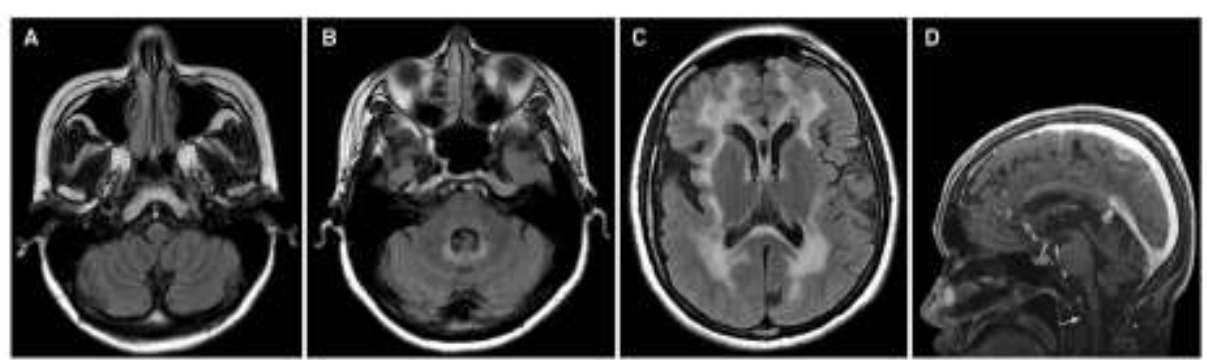

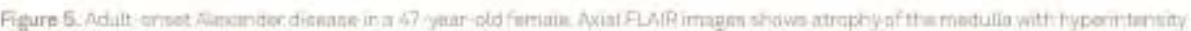

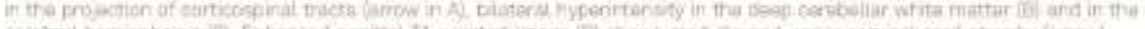

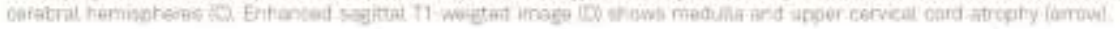



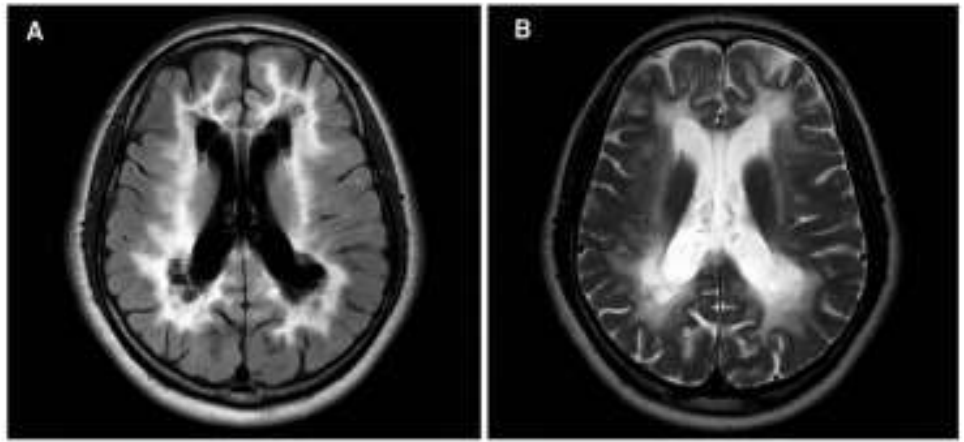

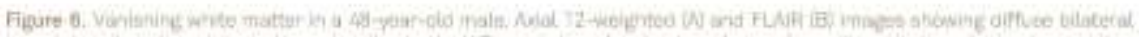

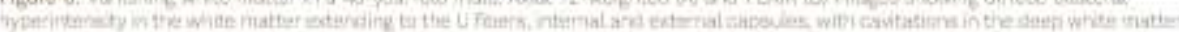

Adult-onset autosomat dominant leukodystrophy (ADLD)

Adult-onset autosomal dominant leukodystrophy (ADLD) is a very nare slowh progressive neurolagical disorder chancterbed by symunetric widespreat myelin loss in the CNS. Patients asaally present in the fourth to sixth decades of life with autonornic symptoms, bowel and biudder dysfine tion, and orthostatic byotension. fater pogstessing to prr anidal sympeoms and ataxia". The gene that causes ADID is bacated in chromisene 5q31. Two nearopathological pher vations makse this leakodystroghy unigzie presenvation of ob godendrogita in the presence of sabtotal demyelination and a lack of astroglicosis?

The signal intenaity ahoormalities afe most penninent in the frontoparietal white matter. cerebellar peduncles, corticospinal tracts and curpus callosum (Figire 7). The periventricular white matter is relatively spased. The changes in the uppermos corticospinal tracts underiying the motor cortex may moresent, the eariest modiologic imaging manifestation of the disense and also can be geen in asymotomatic family
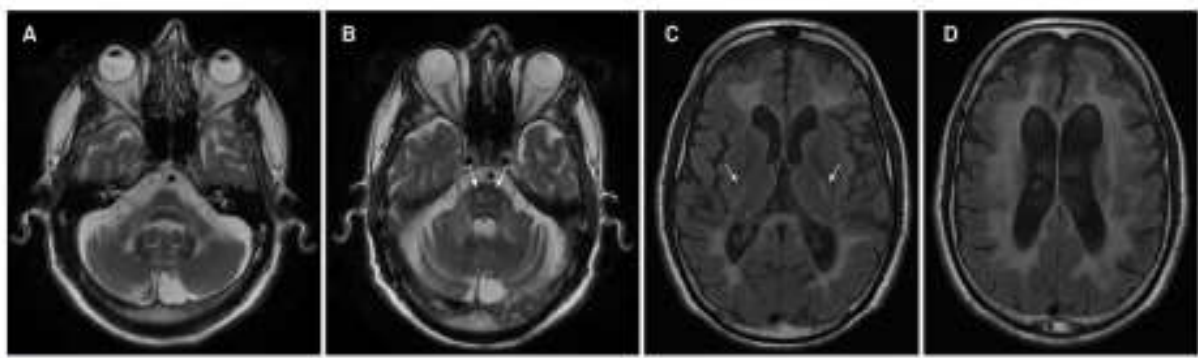

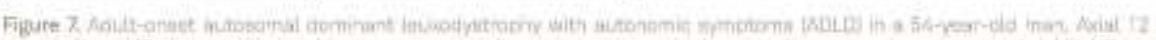

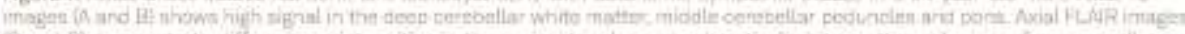

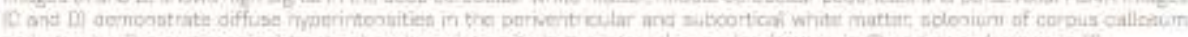

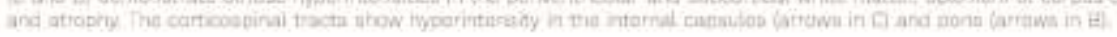



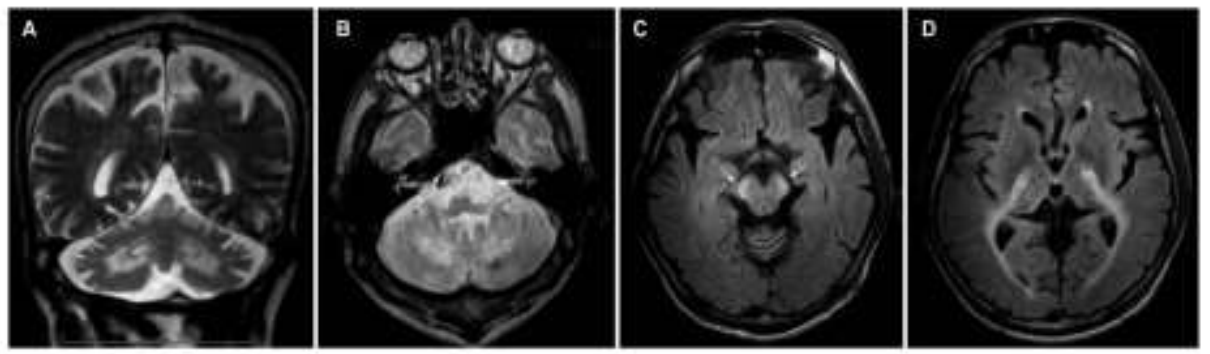

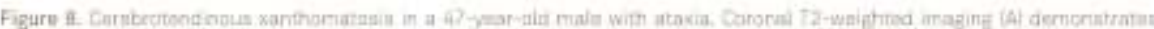

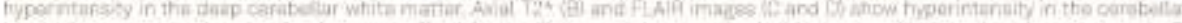

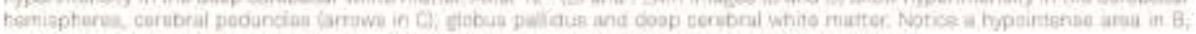

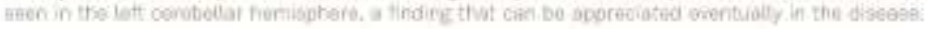

Achilikis tendon'. Early treatment is important as patients can benefit from therapy"

MTI stows hyperintensity an T2-weighted images in the dentate nacleus, cerebellar white matter (Figune 8), cerebetlar poduncles, pyramidal tracts, periventricular white matter, corpus callosum and basal ganglia. In the late stages, hypointensity on T2-weighted irages can bo seen in the dentate naxdeus'. Brain und serebellar atrophy can also be seen",

Nasu-Hakola disease

Nasa-Hakola disease (NHD) or polycystic lipomembra. nocas osteodysplasia with sclerosing leukoenocephalopathy is a rare, autosomal reessive disonder. caused by matations in two genes: THEM 2 and DAP 12 NHD is characterized by a combination of diffiase bone cysts and pre-senile dernentia. Most of the NID patients first present in early adulthood with skeletal abriơmalities (osseous phase). Neurological symptoms manifest in the fourth decade of life as psychiatric symptoms and memory loss (neuropsychiatric phase) wikch precedes the dementia phase. Progressive decline evolves to a profound dementia und death by the fifth docade of life $e^{2 \text { t. }}$

Bone imaging shows multigle cystix-like besions leating to fractures in the wrists and ankles. In the brain, calcifications in the basal ganglia can be soen an CT, while cortical atrophy and nonspecifec white matter imelvement are best appreciated using MRI (E)

\section{Cadasil and carasil}

CADASIL and CAKASIL ace small vessel fiseases ussorciated to ischemia and/or hemorrhage, diffise white matter disease and vascular dementia"

CADASIL is an acronym standing for cerchral autosemeal dominant arteriopathy with subocatical infarcts and leukouncephalopatly: while CARASL is similar, but is recessine instead of dorminant.

CADASIL is casused by the mutation in NOTCH3 gene and affects adolescents and adults presenting with migraines. transient ischemic attacks, strokes, psychilatro
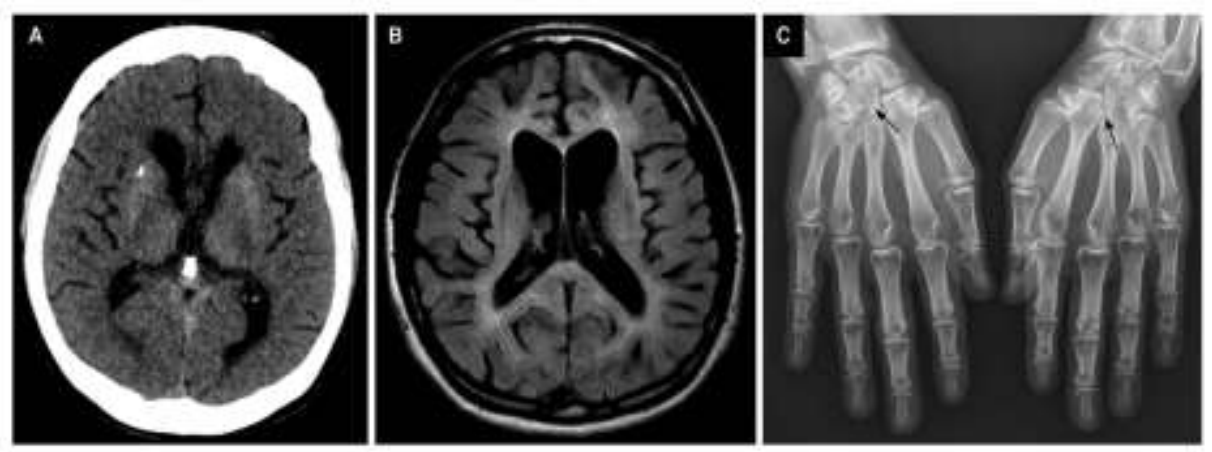

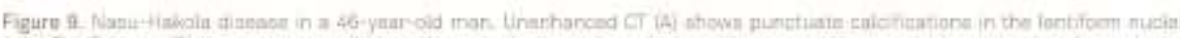

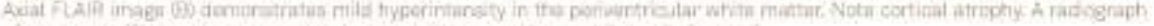

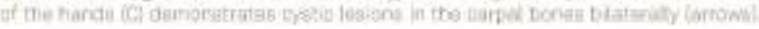



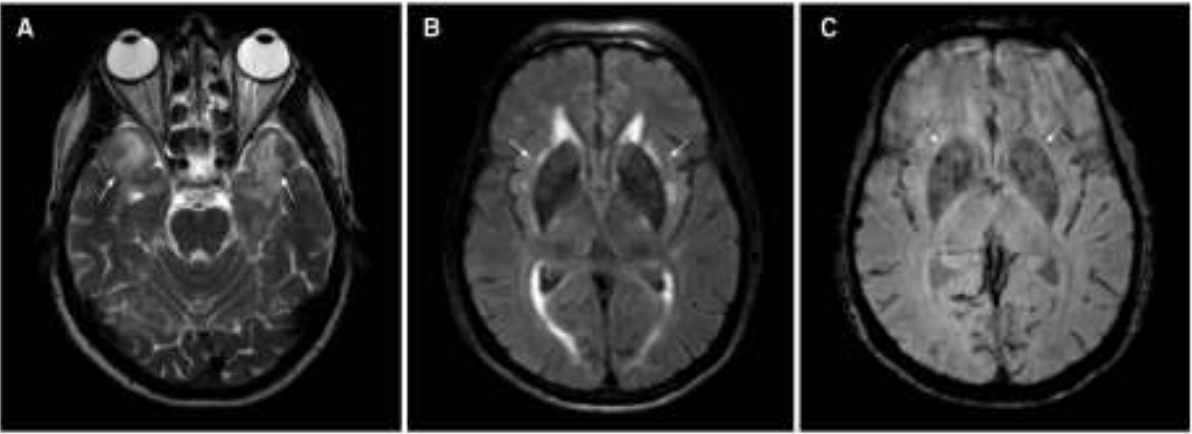

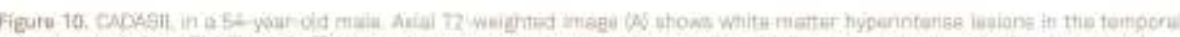

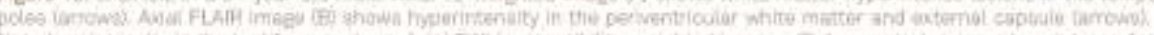

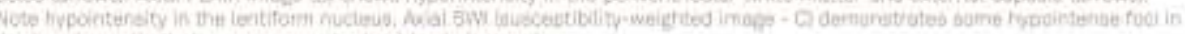

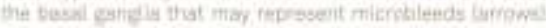

disonders and eognitive dectine. CADASHL. is the most cour mon cause of inherited vascular dementia in adnits.

White matter involvement is uscally found in the external capsules and anteriar temporal poles, this last kacation being bighly suggestive of CADASIL. The corpus callosum is less frequently invohed. MRI changes procede the onset of symptoms by 10-15 years. On T2-weighted and FLAIR images there are round, prodominantly periwentricu lar lesions in the centrum semiovale, external eapsules and anterior temporal poles (Figare 10) The signal changes tend to be symmetrical. Bassal gunglia, thalamus, brainstem and corpus callosum can alsa be involved. Enlarged Virchow Fobin spocees, small foci of restricted diffusson suspestim resent infurcts and microhemorrhape or T2* imatges were described as well. The MFu abnormalities appear in the fourth decade of life and incresase with age vars

CARASIL affects a younger population than CADASII Tho necrological symptoms are transient ischemic astacks and strokes. The MFI findings are diffiese white matter changes and lacunar infarcts ${ }^{*}$.

Other snall vessel genetically inherited disease, is the so called autosomal dominant metinal vasculopothy with leuke. dystrophy and TREXI mutation. It can present with white matter inwolvement in the brain and screbellum and aneas of contrast entancenent
Other reported instanes of adult-areset leukoodystrophies include Pelinacus-Merzharter disesese and vocudating mosplencephalic keskoenecphalopothy with subcortical cysts. PelizaensMerzbocher is rarely descrived in abults and the MRT findings include white matter diffuse T2-hyperintensities sparing snall focal areax MTU $\alpha$ patients with vacioluting leuloencephalopathy with subcortical eystr in adults shows befateral extensive white matter changes with cysts in the temponol regons, some-

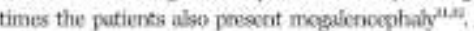

Final nmarks, levakudystrophiss should be kept in mind in the differential diamosis of hilateral whate matter dsesise in adults. Some imuging findings can help sugesest a final diagnosis. Invohement of the corticospinal tract cau be seen in Krabbec's dissesse, adrenonyekneruropethy, cerebrotendinuas xanthomatosis and ADLD. Contrast enhancernent can be seen in the adhit cerebral form of ALD and Alexander disease. In adult-ones Nexander disease atrophy und sfenat aboomalities can be seen in the medulla oblongata and cervical coed. Limited sabcortical hypointensity on FLAIR images is presert sametimes in covarioloskodydrophy, Dentate nuxkess and cerebellar white matter abnormalities can occur in conbrotendinous manthuxnatosis. Binin calcifications whitte matter abnormulitics und bone costs are present in Nusu-Hakola disease In CADASTl. involvement of the extemal capsules and anterios temporal poles ame chanacteriatic.

References

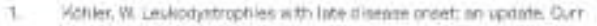
Opin Nesuró 2010.23:234-24

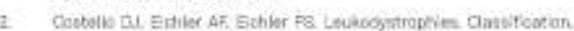

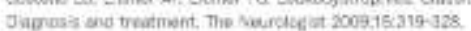

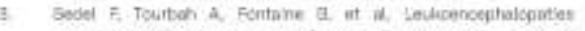

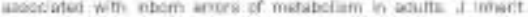

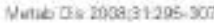

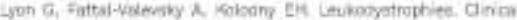

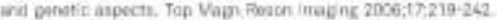

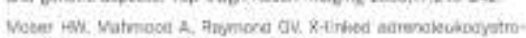

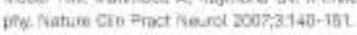

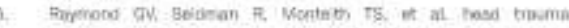

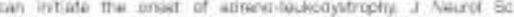
$2010.200 \times 0.74$ 


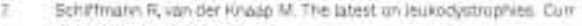

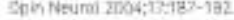

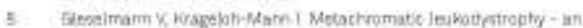

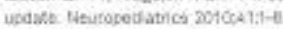

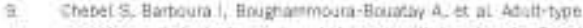

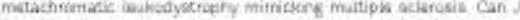

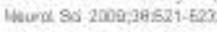

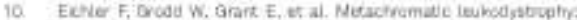

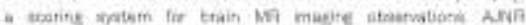
2009:3079g-198?

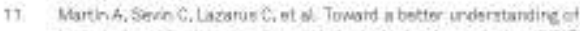

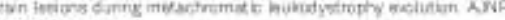
2012:333797- vast

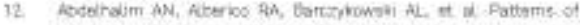

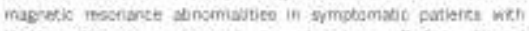

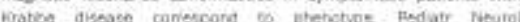
$304,50123 \cdot 136$

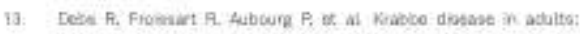
iees of 15 tamat and

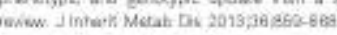

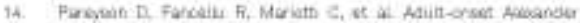

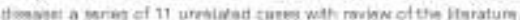

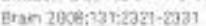

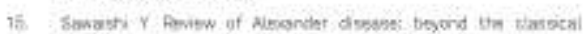

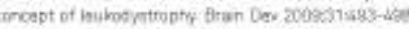

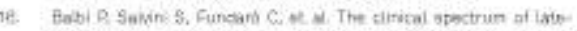

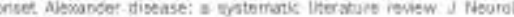
30to:262:1965, ta92

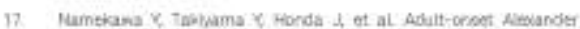

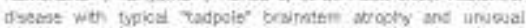

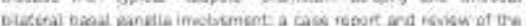

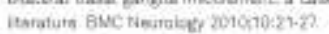

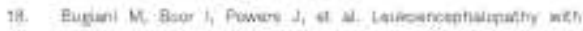

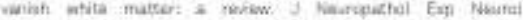
actocosas? 698

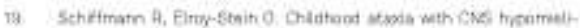

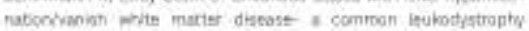

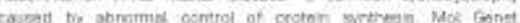

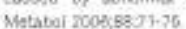

20. Wide C, Vin Gerpes JA. Wazuex ZKC Leumensegholopaty with

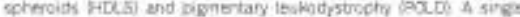

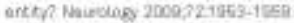

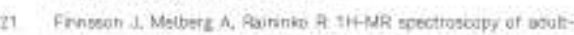

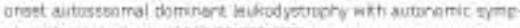
tims seworadiblezi $2013.650933-893$

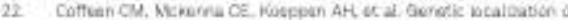

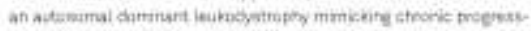

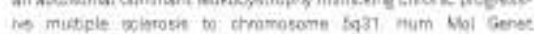
ascosatis?.301

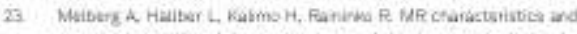

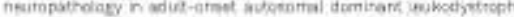

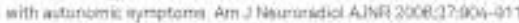

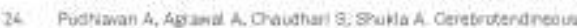

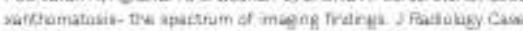
Past :0127:-1:-

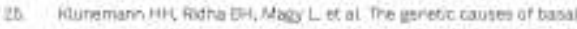

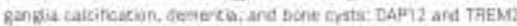

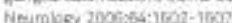

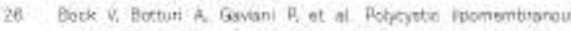

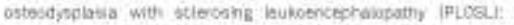

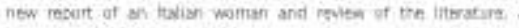
Meuml sci 2013;32f:115-1 to

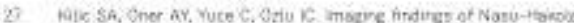

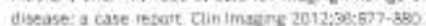

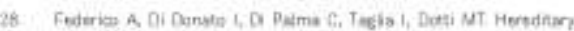

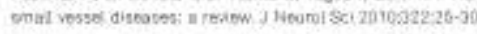

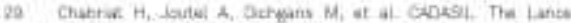

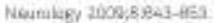

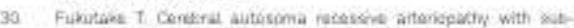

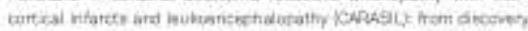

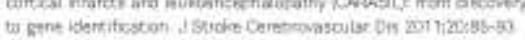

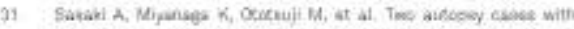

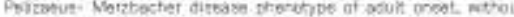

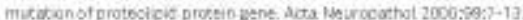

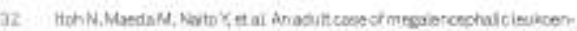

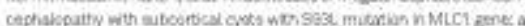

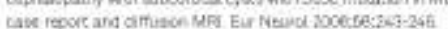


10.5 Apêndice E - Leukodystrophy with premature ovarian failure: think on white matter disease. Arq Neuropsiquiatr 2015;73(1):65.

This work is licensed under the Creative Commons Attribution 4.0 International License. To view a copy of this license, visit http://creativecommons.org/licenses/by/4.0/ or send a letter to Creative Commons, PO Box 1866, Mountain View, CA 94042, USA.

Freua F, Parmera JB, Doria DO, Paiva AR, Macedo-Souza LI, Kok F. Leukodystrophy with premature ovarian failure: think on white matter disease. Arq Neuropsiquiatr 2015;73(1):65.

https://doi.org/10.1590/0004-282X20140183 


\section{Leukodystrophy with premature ovarian failure: think on vanishing white matter disease (VWMD)}

Leucodistrofia com falência ovariana prematura: pense na doença da substância branca evanescente

Fernando Freua, Jacy Bezerro Parmero, Denise de Oliveira Dorio, Andersan Rodrigues Brandưo de Paiva, Lucia Ines Macedo-Souza. Fernando Kok

A 46-rear-old female presented progressive hand tremor at age of 8 associated to cognithe and motor deterioration She developed insapscitating head tremor and was wheetchair-bound 12 years after onset. Premature owarian fuilan (POF) occumed at 27 -year-18d. In the last 3 years, head tremor became less intemse, but she remained with horiontal bidincoxonal nistaumas.

Vanishing white matter disesse (VWMD) is an untosomal recessive fisorider characterized by cercbellar ataxia, spasticity, and cognitive impairment $t^{12}$. Brain MTU discloses sym metric and diffuse white matter kesions (figure). VWMD manifests from infancy to aduithood; in female, POF may occur'- it is caused by matations in both alleles of one of five genes coding for subunits of eukaryotic translation initiation factor 28 ,
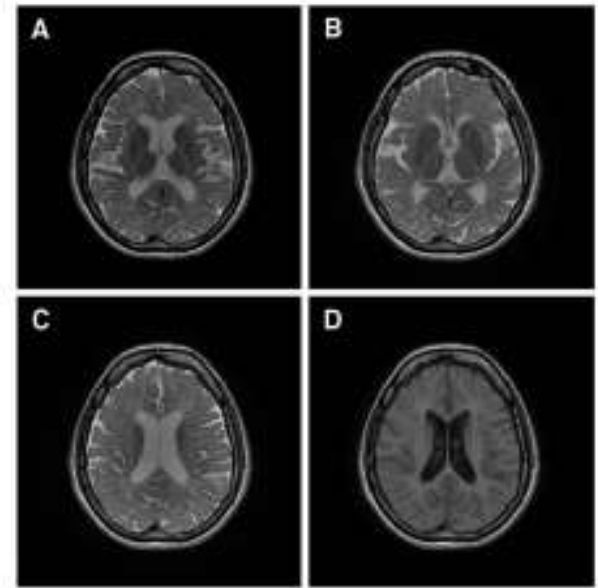

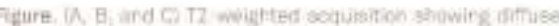

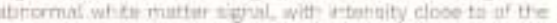

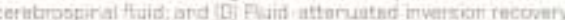

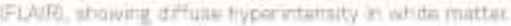

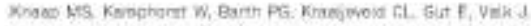

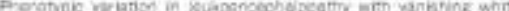

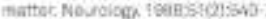

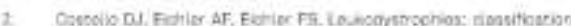

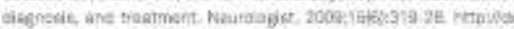
doimg

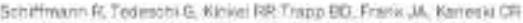

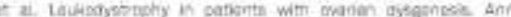

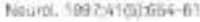

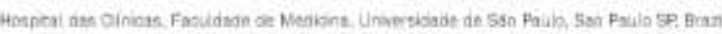

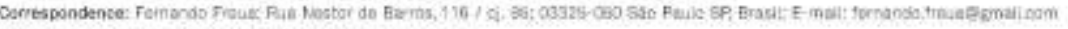
Contist of interest: There ie no oontiat of inotrest to gosive.

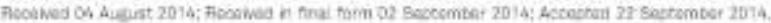


10.6 Apêndice F - A novel GFAP mutation in a type II (late-onset) Alexander disease patient. J Neurol 2016;263(4):821-822.

Reprinted by permission from Springer Nature: Springer Nature, Journal of Neurology - A novel GFAP mutation in a type II (late-onset) Alexander disease patient. Paiva ARB, Freua F, Lucato LT, Parmera J, Dória D, Nóbrega PR, Olávio TR, Macedo-Souza LI, Kok F. COPYRIGHT 2016, advance online publication: 1 Jan 2016

https://doi.org/10.1007/s00415-016-8065-8 
INeurol

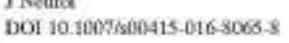

\section{A novel GFAP mutation in a type II (late-onset) Alexander disease patient}

Anderson Rodriques Brandžo de Paiva ${ }^{1} \Phi$ - Fernando Freua ${ }^{1}$ - Leandro Tavares Lueato ${ }^{2}$.

Jacy Parmera' - Denise Dória ${ }^{1}$ - Paulo Ribeiro Nóbrega ${ }^{1}$, Thiago Rosa Otávio'.

Lúcia Inês Macedo-Soaza ${ }^{3}$ - Fernando Koh ${ }^{1}$

Receivod: 14 hnury 2016/Revisod: 9 Febmary $2016 /$ Accepted: 10 Fobruary 2016
OSpringer-Venlag Herlin Heidelberg 2016

Dear Sirs,

Alexander disease (AxD) is a rare ncurodegenerative disoriler caused by mutations in GFAP gene, encoding glial fihrillary acidic protein, and affects pinarily astrocytes. Two clanical subtypes are described: an early onset one characterived by failure to thrive, macroceptialy and predominanty trontoparietal leakodysthroptry - named type I; and a late-onsel phenotype, type II, characterized by spastic gait, cercbellar ataxia and atrophy of the medulla [1].

A 36-year-old woman presented to oar service with a slowly peogressive complaint with loss of halance, frequen falk, mild dysarthria, and urinary incontinence initiated aftet hes second uneventful pregnancy, when she wat 25 -year-old. By the age 32 , she developed weakness on her Ieft lower limb. Two years later, the kett arm was also affected, and sbe became wheekchair-bound when she was; 35. She became depressed, apathetic and experiencol insommia. Her past medical hisory was remarkable by tobaceo and alcohol abuse. Her mother died at age -46 dae to breast cancer, her father died at age 68 after ischemic stroke complicarions, and she bad eight siblings - one trother died ate age 34 of sadden death, one sister died at age 8 years (she was diagnosed with mental retardation.

[e] Andersan Redrigues Brandio de Pavia artrasdao Ex oi combr

1. Nexogenetics. Newnlogy Departanem, Howpotal das Crimicas ta Uniweridast de Sip Pindo. Av Di Fincis de Carralho Aguiar, 255, S6so Pamla, SP 05403-000, Brazal

I Radiology lasstate, Hospital das Calnicas da Universidate de

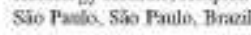

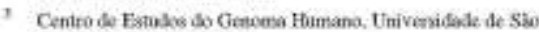
Panlo. Sio Panla, Brail but no further information were available). The six remaining siblings were healthy, On neurologic exam she scored 23/30 on the Mini Mental State Examination, and presented an asymmetric spastic quadriparesis, wors on the left hemibody, gredominantly axial cerebellar ataxia. hypometric burizontal succades, gaxe-evoked nystagmus to the left, absent gag-reflex, dysarthria aed dyspbagia. There was no palatal tremor. Ancillary tests. CSF inalysis and nerve conduction studies were uremarkable MRI disclosed aboormal petiventricnlar white malter hyperintensity and "tadpole atrophy", suggesting AxD (Fig 1) Molecular analysis of GFAP gene disclosed a novel pathogenic variant chr $12: 42989,137 \quad \mathrm{C}>\mathrm{G}, \quad \mathrm{c} .899 \mathrm{G}>\mathrm{C}$ (p.Arg270Pro), in exon 5. Algorithms of pathogenicicy prediction (SIJT, PolyPhen, and Mutation Taster) are in agrectacent that this variant is deleterious of peobably damaging. She died of acule respiratory failure at 39 , presumably by pulmoeary embolism-necropsy was declined.

This is a challenging case and the diagnosis was not saspected until a detailed review of the MRI was done by an experienced neuroradiologist ( L T.L.). The adali-cmset asymmetric presentation wichout a clear family history might divert the clinician away from a possible genetic etiology $[2,3]$. The tobacco and slcolol abase could also be mislesting, raising the possibility of a MarchiafavaBigaani disease, alihough this one has a quite distincr MRI pottern with demyelination of the corpus callosum [4]. Another important clinical clue for the diagnosis of lateonset AxD that was lacking in this patient was palaral tremox. The presence of that sign in a patient with spasticatsoxia syndrone would have narrowed the differential dingnosis to $\mathrm{AxD}$ and progressive ataxia and palatal tremox syndeome. The presence of atrophy of medulla and upper cervical spinal conil peompted to a target molecular analysis 

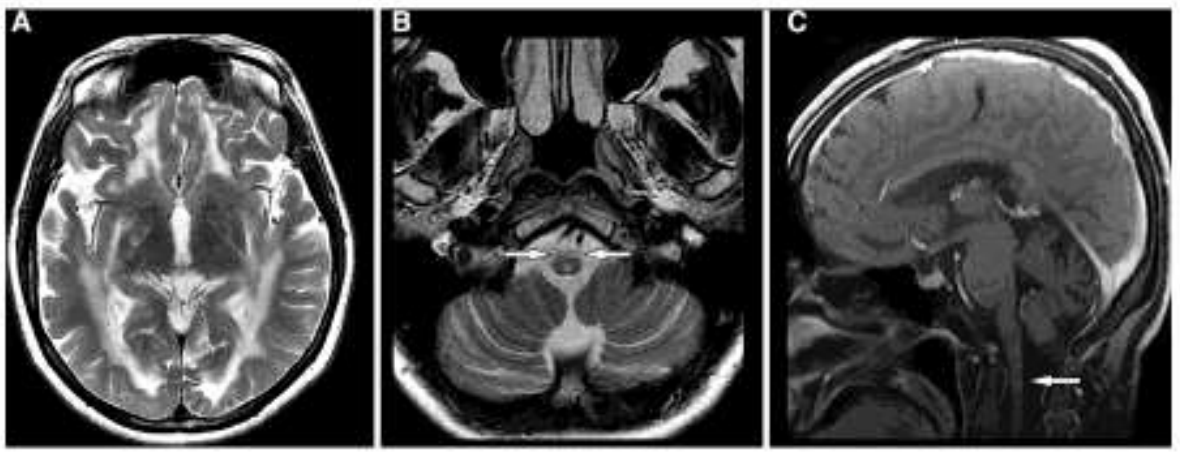

Fig 1 Axial Tz-urighical images (a, b) dencedrate-symmethe

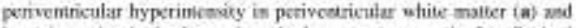
hyperintensity in both corticospinal tracts carroves in bi. Sugittal

that makle the comect diagnowis. This is a miswense mutation and involves an arginine residtic, like the majority of the 110 previously reported pathogenic variants.

We highlight that, despite being an autosomal domisant condition. the majonty of the cases are due to de novo mutations and a high indes of suspicion is necded to nost miss this diagnosis.

Cempliance with ethical standarch.

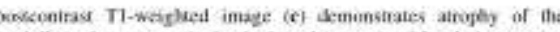
madulla and upper cervical spinal coed farrowi with relikive sparing of the pans, the se-called "udpole acrophy"

\section{References}

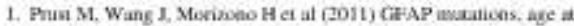
onses, and elinical sublypes in Alexatater disere. Neurologe 77:1287-1204

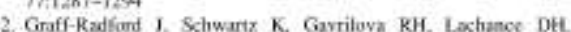

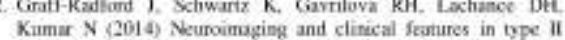

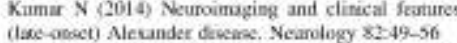

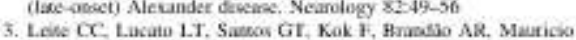

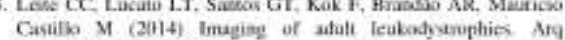

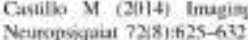

Conflicts of iuterest The zuthors mpont ba disclosutes retevamt io de manasctip.

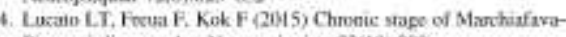
Hignami disease. Ary Nesorupsiquiar 73/101:890

Ethical approval This seasy was apgroved fy the Insimesomal

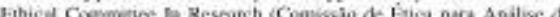
Projoles de Pexpaisa?

Informat eonsent Writwed informed conem was otsained from the

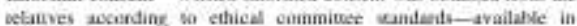
Portuguse. 
10.7 Apêndice G - Clinical and genetic characterization of leukoencephalopathies in adults. Brain 2017;140(5):1204-1211.

Reprinted by permission from Oxford University Press: Oxford University Press, Brain - Clinical and genetic characterization of leukoencephalopathies in adults. Lynch DS, Paiva ARB, Zhang WJ, Bugiardini E, Freua F, Lucato LT, MacedoSouza LI, Lakshmanan R, Kinsella JA, Merwick A, Rossor AM, Bajaj N, Herron B, McMonagle P, Morrison PJ, Hughes D, Pittman A, Laura M, Reilly MM, Warren JD, Mummery CJ, Schott JM, Adams M, Fox NC, Murphy E, Davagnanam I, Kok F, Chataway J, Houlden H. COPYRIGHT 2017, advance online publication: 2 Mar 2017

https://doi.org/10.1093/brain/awx045 


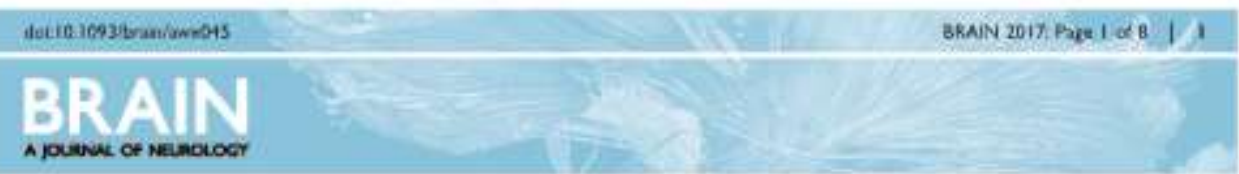

\section{REPORT}

\section{Clinical and genetic characterization of leukoencephalopathies in adults}

David S. Lynch, 1,2 Anderson Rodrigues Brandão de Paiva, ${ }^{3}$ Wei lia Zhang ' Enrico Bugiardini, ${ }^{4}$ Fernando Freua, ${ }^{3}$ Leandro Tavares Lucato, ${ }^{5}$ Lucia Inês Macedo-Souza, ${ }^{6}$ Rahul Lakshmanan, ${ }^{7}$ Justin A. Kinsella, ${ }^{3}$ Aine Merwick, ${ }^{9,10}$ Alexander M. Rossor, ${ }^{4,11}$ Nin Bajaj, ${ }^{12}$ Brian Herron, ${ }^{13}$ Paul McMonagle, ${ }^{14}$ Patrick ). Morrison, ${ }^{15}$ Deborah Hughes,' Alan Pittman, 'Matilde Laurà, ${ }^{4}$ Mary M Reilly, Jason D Warren, ${ }^{16}$ Catherine J Mummery, ${ }^{16}$ Jonathan M. Schott, ${ }^{16}$ Matthew Adams, ${ }^{7}$ Nick C. Fox, ${ }^{16}$ Elaine Murphy, Indran Davagnanam, ${ }^{7}$ Fernando Kok, ${ }^{3}$ Jeremy Chataway ${ }^{17}$ and Henry Houlden ${ }^{1, \text { It }}$

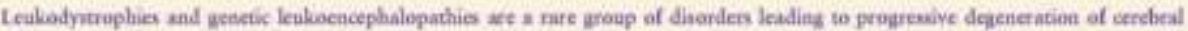
whise matrer. They are suociated with a spectram of dinical pheantyper dominatod by dementia, poychiatrie thanjes, movement

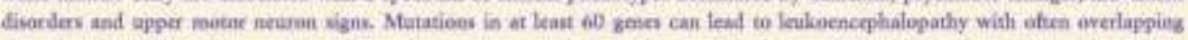

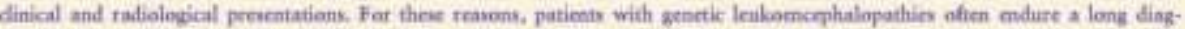

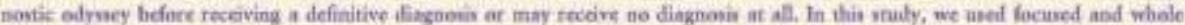

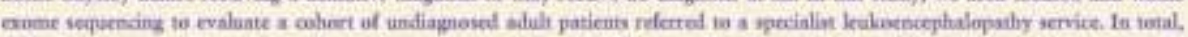

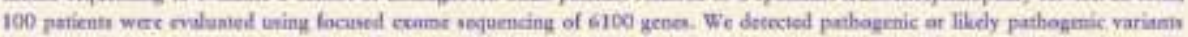
is 26 cases. The meat frequently muatel genes wer NOTCHS, HIFIIS, AARS2 and CSF1R. We then carried oat while exnene

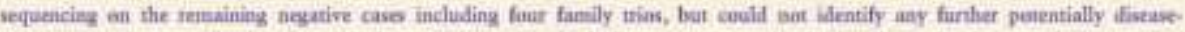

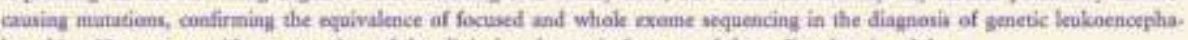
lopathies. Hete wi pravide un averview of the dinizal and generic featuse of these diaorden in adults.

1 Depurment of Molecular Neurosience, UCL. Institate of Nearology, London, UK

2 Leorund Woltson Experimental Neurology Centre, UCL Institute of Neurology, London, UX

3. Neatogenitics Unit, Neurology Department, Haspital das Clinicas de Universidade de Säo Paulo, São Paula, Braxil

4 MRC Centre far Nenrommscalar Disezses, UCL. Institute of Nearolopy, Londrin, UK

5 Instimuso de Radiologia, Hospotal das Clinicas du Universidade de São Paulo, Sra Paula, Brazil

6 Centro de Estudos do Genoma Humano, Universidade de Sáo Paulo, St̃o Pasio, Brazi

7 Lysholm Depertment of Neurundrologr, Nationst Hospital for Neatology and Neurosurgety, Quetu Squarr, Landon, UK

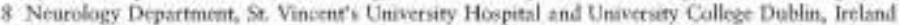

9 Charles Dent Metabolic Unit, Nanional Hospital for Neurology and Nearosurgery, Queen Square, Landon, LK

10 Chelsea and Westminster NHS Foundation Trust, Loodon, UK

11 Sobell Deparmont of Mator Neuroscienoe and Movement Disorders, VCL Institute of Nearology, Londan, LX

12 Department of Neurology, Queces Medical Center, Nottingham, UX

13 Department of Neuroparthology, Koyal Victoria Hospest, Belfase, Northern Ireland, Uh

14 Department of Nesrology, Royal Victuria Hoppetal, Belfast, Northern Ireland, LK

15: Centre for Cancer Researsh and Call Brology, Quesas Liniversiry of Belfast, 97 Lisbum Road, Belfast BT9 7AE, LK

16 Dementis Feseatech Centre, DCL. Institute of Neurologr, Landon, UX

17 Department of Nrurainflammation, 1 C Institute of Nrerology, London, UX

18 Netirogenertics Labocatory, National Hospuial tor Neunology and Neurousrgery, Quern Square, Loedon, UK

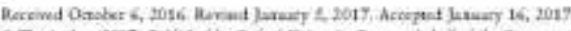

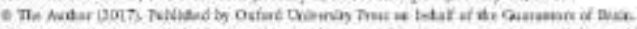

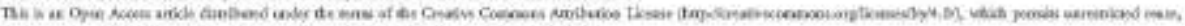

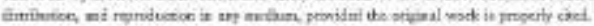


Cotrespendence to: De David S. Lyada,

Departinent of Molectular Neuroscience.

UCL. Institute of Neurology, Queen Square,

London WCIN 3EG,

IX

E-maih. David.tymch.13êdacuk

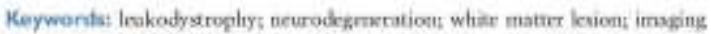

Abbreviation WES = whole excome sequencing;

\section{Introduction}

Lesubodystrophies and generic leakoencephaloparhies repre seat a diverse group of disorders in which there is progressive degeneration of CNS white matter. They can present in children or adulos, often with a constellarion of clinical fearures including dementia, morament disonders, ataxia and upper motor neurot signs, accompanied by hyperinrerse stenal abeormalicies in she brainkpinal cord on $T_{2}$. weighred MRI Canderver of al., 2015y

There are at keast 60 genes implicated in the development of these disonders, involvod in diverse cellalat patbways including myelin formation, mitochondrial health and protrin translation Parikh $d$ al, 2015). This heteregeneity, in combination with often overlapping clinical and radiological phenorypes, make definitive diagnosis challerging. In addition, the large number of genes and pathwrys involved means that the traditional approach to dsagnosis, involving extensive metabolie and biochenical tesring, is time consuming, costly, and often fails to reach a diagnosis (Richands of al., 2015ia)

In recest years, advances have been made in the under. standing of leukodystrophy and leskencenchaloparty in children, with particular emphasis on improvements in diagnostic approich (Vanderver it ah, 2016). However, little is known about the generic spectrum of these disorders in aduls, where in many cases a definitive diagnosis is not reached.

In this atudy, we uned focused and whole exome sequen cing (WES) to generically evaluare a cohort of 100 adult patients with undiagnosed leukodystrophy/kukenencephalopachy, describe the clinical spectran of these disonders in adules and explore the efficiency of next peneration sequening in their diagnosis.

\section{Materials and methods}

\section{Patient recruitment}

Paticoss were recruited froen the Queen Square. Aduh

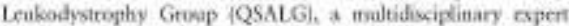
group that acvepes referrals an parients with undagnoned leur. kodystropbyfleulboencephalopathy, the Denentia Research Center and Nerrogrartios Drpartments of the Naxicrial Hospital for Neurology and Nearosurgery, Londar and the
Neurology Deparement of the Universiry of Sẵo Prolo, Bessil. The primary indasion stimna induded the pesmos of a progressive nearolagical syndrome with promiant $\mathbf{T}_{2}$. wrightrd hyperintensity of the crrebmilspisial cord white matter, which was confhornt and not comsistrnt with an

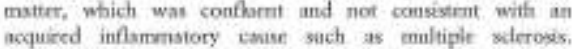
acquired infammstory tasise sach as multiple soderoses:
Hartanatological, biochemical and metabolic testing was per. formed by the referning centre apcoeding to published guide. lines (Ahumed ot al, 2014). All parients underwent Round 1 irvestigations to exclude accuired causes sach as infections ot antrimene sindeores and Round 2 imesrigations 19 ex.

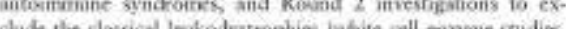

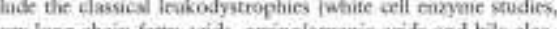
ery loog chain faciy acids, aminolorgatic acids and bile alcohols). Some patients aloo underwent additional mosdehorve of brsin biopsy. Patients were only included if a dirganos conld not be reached after these investigations, Informed coront was obrained from all study participanss for gerestic anslysis and the study was carried our with institational ethical appromal. All patieats were at least 16 years old at the time of referral to our ceostes.

\section{Focused exome and whole exome sequencing}

Genomic DNA was extmeted from peripberal blood frmphogytes. Focused exome seguenaing was performed using the Agilent Sure Select Foased Exame (Apilmt) acording in the mumafacturer's prococol. WFS was performed using Nertera chrmistry (Illumima Inch. Sequencing was perfocmord using the HiSec pistorom (tllamina).

Tor filumim fasta soquencing data were mapoed to the human reference assenhly, by19 |GRCh.37; UCSC penome trowser by Namolign Software (Notnocraft Incl. After of maval of PCA daplicates (Picard) and reads withoet a moval of PCR daplicates (Picard) and reads without a
uniogue mapping location, vaniants were extracted using the

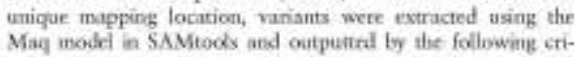
ictia: construs quality $>30$, SNP quality $>30$ and too mean square mapging qualisy $>30$. These variant calls were then annocated using Aunovar software (Wang of at, 2010).

\section{Variant prioritization}

We hitially protitized variants in knowa leakodystrophyigen-

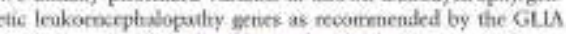
exnsortium in 2015 (Parikh et al, 2015). We removed synonvinouslintmonic variants and variants with minoe allele fre quency (MAF) $>0.01$ on the ExAC databuse.

Potentially pottogmic variants prece confermed using con-

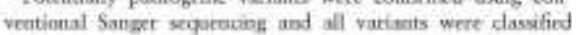




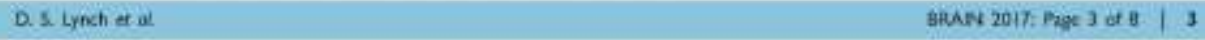

using American Collegs of Medical Genetios (ACMG) crimria (Richands ef al, 2015th.

\section{Results}

Focused exome sequencing identified pathogatic or likely pathogenic variantw in known leukodystrophyneuknencephalopatby genes in 26 cases (Tahle 1\%. The most fre quently mutated genes were EIF2B $1 / 5$ causing vanishing whice raater (VWM), CSFIR, causing adolr onser leukoencephaloparthy with axonal spheroids and pigmenoed glis IALSP, AARS2, casising a letkoencephalonathy with ovarfan failueve and $\mathrm{NOTCH}$, causing cerebral autosomal dominant arteriopathy with suhcortical infarces and les: koenoephalopathy (CADASIL) (Fig. 1). We detected vari ants of uncertain significance in POLR3A, MRPS22 and TNR in three parients (Supplementary material).

To assess the urility of foctsed exome sequencing com. pared to WES we sequenced the remaining 71 negative cases (includirg for fantly rios) taing. WES. Howeres, we did not make any further diagnnese from thix approach, confirming that in adult letikoencephaloparthies, WES offers to kenefit over focnsed exone sequencing. This is likely because the target coverage is berter on focused exome conipared to WES. In our study, coverage metrics stowed that focused exome bad mean target coverage of 140 with $99 \%$ of targered hases read $>10$ times, compand so WES where mean targered coverage was 66 with $94 \%$ of tar eeted bases tead $>10$ times (Fig. 1 ?

It was not possible re predict prospectively whish cases were likely to be posirive far a known disease gene. While negarive cases had a slightly older age of onser /mean 35 years) compared to positive cases (niean 32 years), this was not stariscically different funpaired $t$ - test $7^{t}$-value 0.50 . Similarly, while more positive cases had a faraily history (positive cases $42 \%$, negative cases $24 \%$, this was also not staristically siguifican (Fisher's exact test $P$-value 0.10. There was no difference in rypical dinical fearure or MRI appearance betwecri the two groups (Supplementary Tabie 1).

\section{Disease spectrum}

Vasishing whice matter

We ilentified five patients with VWM disease, fout with mestations in EIF2BS and one with mutations in EIFZBS. The average age of onser of neurological symproms was 36 years. The most frequent sgmpenms reporred were cognitive decline, ataxia and epilepsy, Of the three famale cases, two experienoed prenuature ovaran failue, with the remaining female case indergoing memopuse at age 45 years. One parient (Patient P7) presented with trigeminal neuralga aged 52 yeats, and was initially diagnosed with multiple sclerosis following an ahnormal MRI scan. Ten years later, she developed partial eprilepsy and cognione dechine and a tepeat MRI showed findings cypical of VWM In all cases,
MRI demenstrated helateral confluest $T_{2}$ weightedFL AIR (fleidarcensated inversion recosery) hyperinnensicies : with white matter rarefaction and global atropby.

\section{CADASIL.}

We identified four parients with mutations in the NOTCH gene. The arerage aze at onset for these patients was 35 years. bohaenic seroke and migraine with aura were the most common symptoms, occurring in three of four $\mathrm{pa}$ pents. One partient (Pationt $\mathrm{P} 4$ ) presented with a prepontine sebarachnoid haemontage, Congnitive decline was mild in all cases. One parient (Patient P4) had no progression 5 years from sympeom onset; the remaining three patients had enild oognitive impaiment oply afrer 10 years of follow-up. The NOTCHB cases were the only patients to demonstrate $\mathbf{T}_{2}$-weightedFL.AIR hyperintensiry in the temporal poles (Fig, 2A), although this was not universal, with Patient P1 not-showing tempotal pole ahuonnalities on imaging taken more than 10 years after symuptom onset.

\section{CARASAL}

We identified a single pationt with the recontly described syndrome of cathepsin A-relased arteriopady wich srokes and letekencephalopatby (CARASAL) (Sugiani of af., 2016). The rationt had a history of mieraine since age 20 in addition to hypertension and depression. She developed persistent tacial pain at age 42 yeirs, which was acconpa. nisd by very mild cognitive symptoms consisting of problems with episodic memory and facial mengirion. By age 48, the syndrome had progressed and the patient developed mild behavioural thanges with some disinhibition. MiniMental Scate Examination was $27 / 30$ and perfotnance 10 was 99. The neurological examination was normal. The parime's farher had died from suroke at age 60 years bat no other family members were known to be affected. MRI denonserared extensive signal aboormality in the deep and perivestrictular white matter sparing the U-filures, extending into the thalames, basal genglia, pyramidal and tegrental tracts, the superior and middle cercbellat poduncles and the right dentate nucleus. A few old lacaunes were demnnstrated in the doep grey matter nuclei, ahthough no acose infarcts or microhacmorthages were present if 2 , 26). Boch the history and imaging appesrance semongly saiggezed CADASII, but no NOTCH3 mutation was identifiad. The same heteroxygues CTSA metation, $9975 \mathrm{C}>\mathrm{T}$, p.Ru25C, described in rwo families by Engiani $d$ al. (2016) was detected by focused exome secuencing, confirming the diasnosis of the novel entity CARASAL.

\section{CSFIR}

We idearifed four parients with murations in CSPIR, which causes A1SP (llademakers of at, 2011), Mean age of onser was 47 years. Two patients Patients $P 22$ and 127) preseused with cognicive decline and psyctuatric symptone followed later by upper limb dyspraxia, alien imb phemomenon and parkinkonism. Patients P20 and P21 presented with ataxia and spasticity, and later 


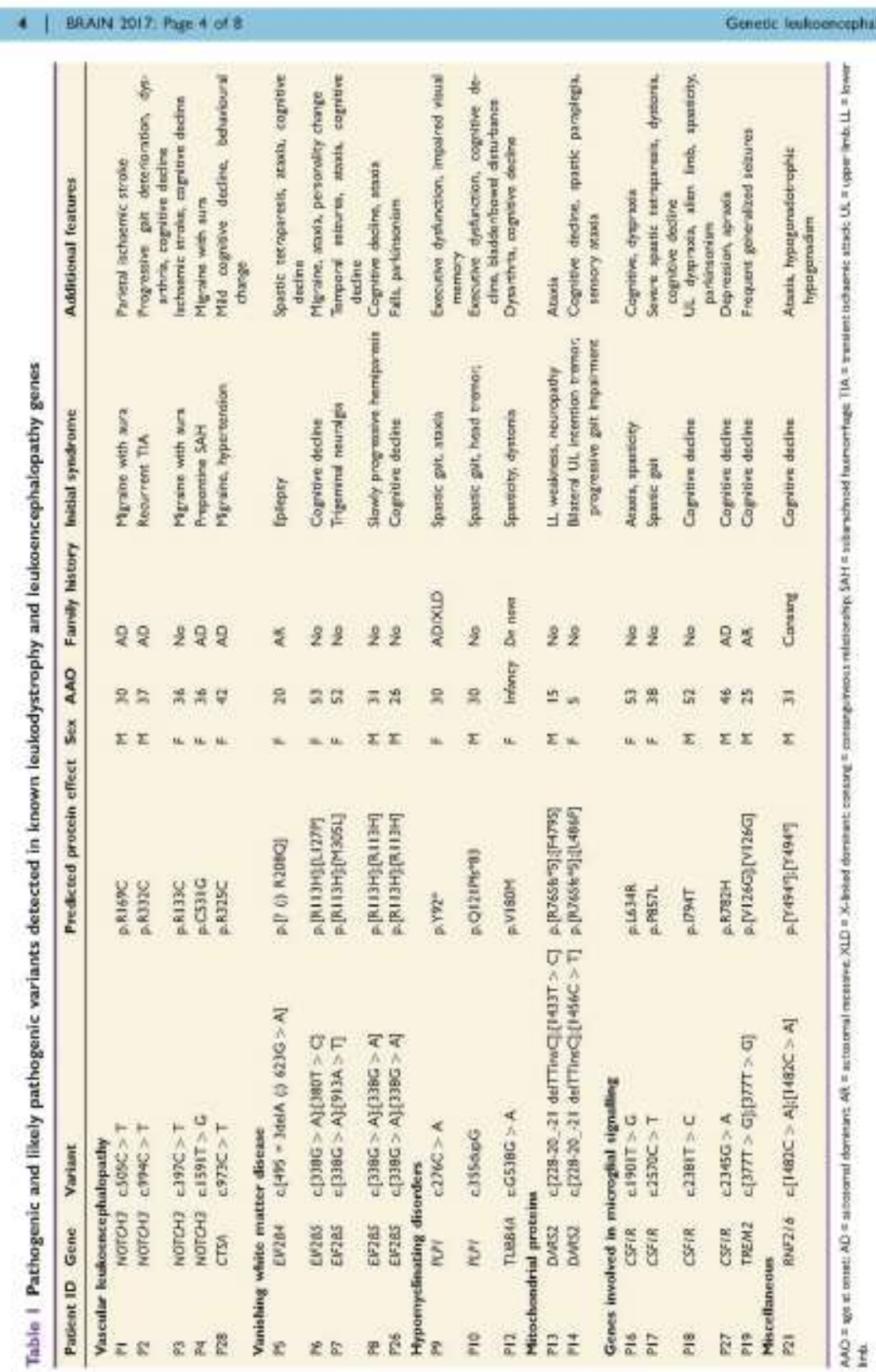




\section{Pathogenic/Likely Pathogenic Variants}
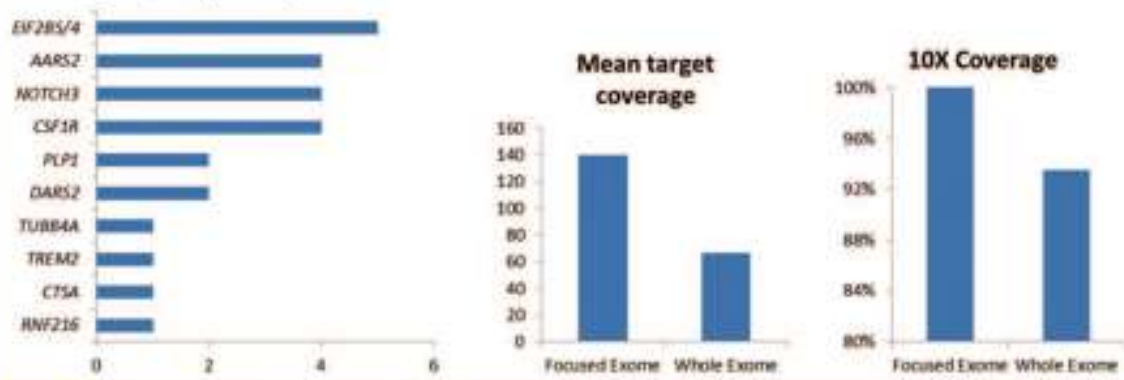

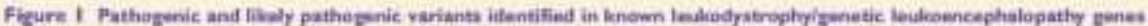
anit caverage metries car fonued exome and wes.
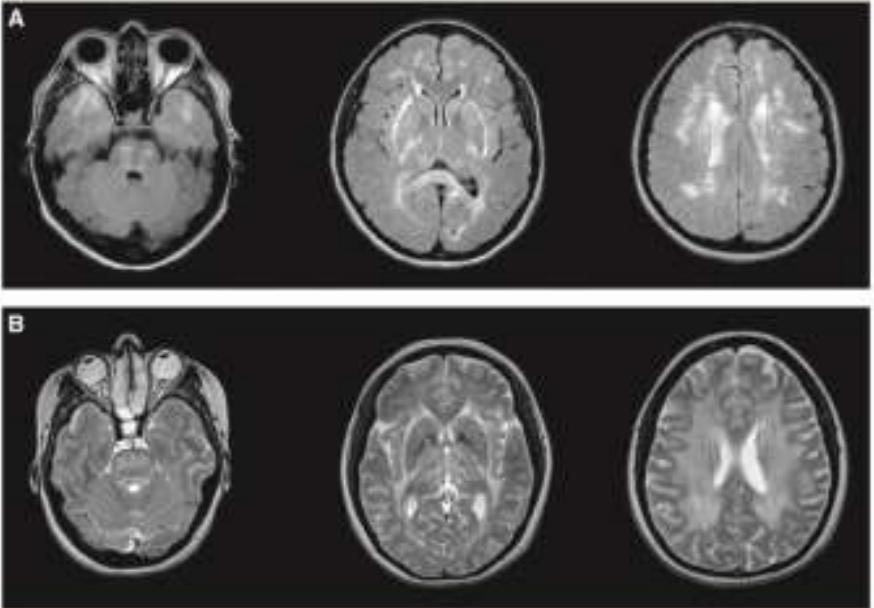

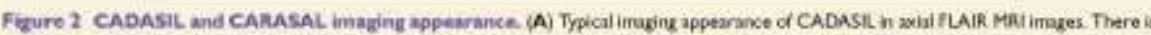

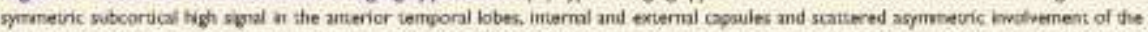

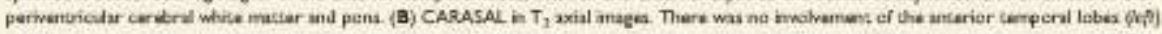

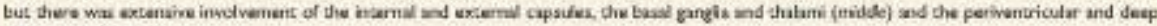

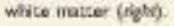

deceloped cognitive decline. In all cases, thete was significant cognitive decline within 2 years of onset. MRI in all cases demonstrated slightly asymmetric $T$, hyperinteme signal abnormality in the cerebral white matter affecting the frontal, parietal and termporal lobes with trequent isvolvement of the corticospinal tracts and atropby of the creebral white matter and cotpus callosum. Puoctate areas of restricted diffision wre aloo evidest in the setebral whize matter, which persisted and somerimes increased over time. 

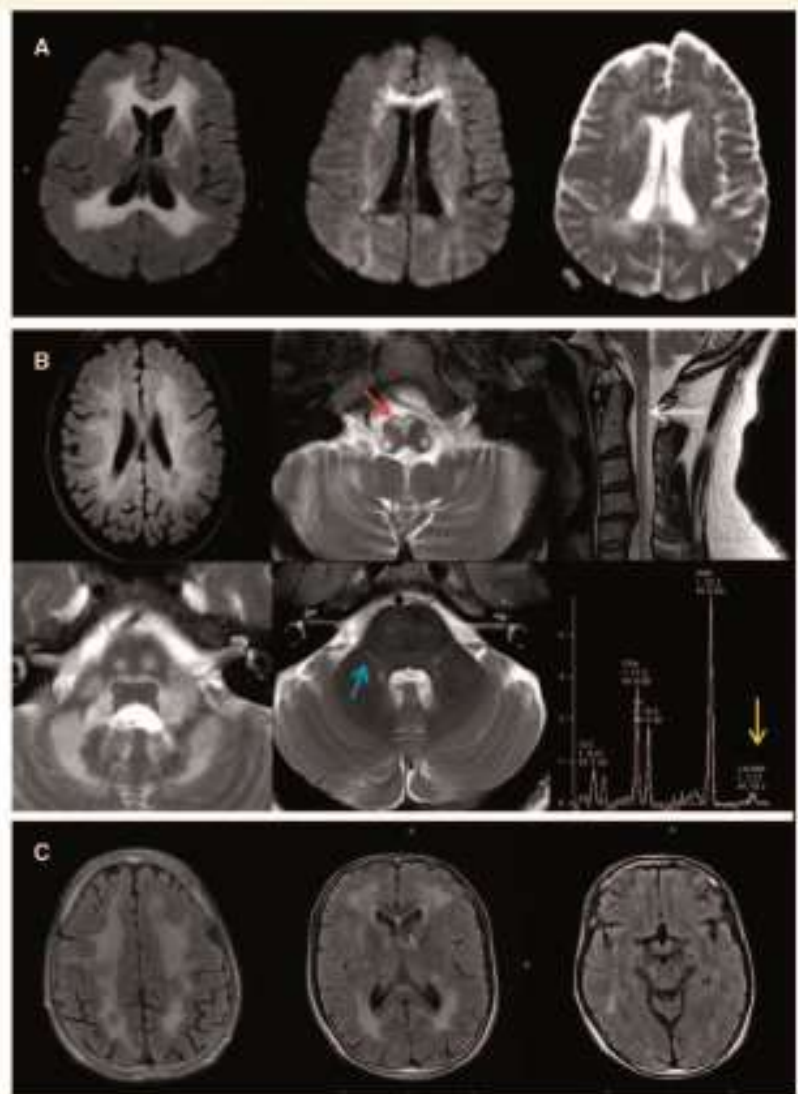

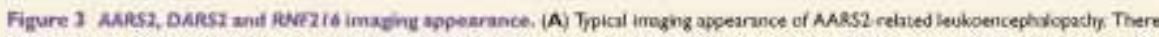

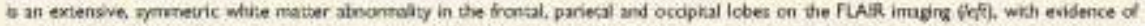

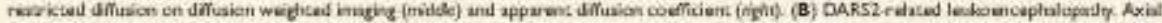

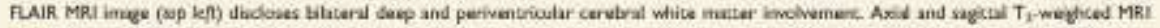

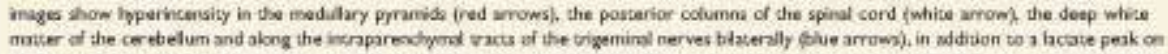

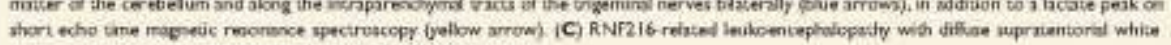

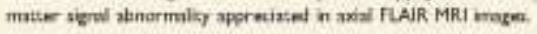

\section{AAAS2}

Five patients were identified with biallelic mutations in AARS2, whicb has recently been associated witb a novel ovario-teukodystrophy iDallabona et at, 2014k. The clinical details and mutztioxs detected sre reported in moxe derail elsewhere it ynch et at, 2016). Briefly, the phenotype consisted of adult ceset leukoencephalopathy with a variable combination of demesta, upper motot neuroe sogns, ataxia and evarian falure in females. MRI revealed slightly asymmetric aboormal $T_{2}$ byperintense signal in the frontoparietal and periventricular white matter, with white marter rarefaction, involvement of the corpus callosien and pyramidal tracts and puactate areas of restricted diffusion, reminiscent of ALSP (Fig, IA). In one case for which brain 


\begin{tabular}{|c|c|}
\hline D. S. Lynch et al. & BPUN 2017: phes 7 of 817 \\
\hline
\end{tabular}

tissue was availabje, frequent axonal sphemids and pigmensed microglia were seen.

Hypomyelinating disorders

We identifind three parients with mutarioes in genes catising bypoumelination. Two pabents were bound to carry loss-offunction mutatives in PLP1. Poth patients de veloped sympeona at age 30 years, A female parient (Patient P9), carrying a novel nonserse mutation, presented with progressive spastic poraplegat and gait ataxia, followed by execontive dysfunction and impaired visual mernory. It has been shown that sympeome manifest more commonly in femak patients cartying nonsctse mutations in PLPI iHuns et aL, 2006) $A$ male proien (Patient P10s, camping a novel framechitt muxation, presented with a "no no' head tremor, pat disturhanos and bowel and bladder syngeoms at age 30 yeats. On examination at age 40 years, there was severe cognitive inpaiment with frontal release siens, severt spastic paraparesis tequiring whedchair tac, idenotos aprayia and nesr constane head tremor. Ficeh parienss demonstrated mildly increased cerebral whice matter signal on $T_{2}$-weighted/FLAIR imaging, with the whire mater agpearing isointense on $\mathrm{T}_{\mathrm{1}}$-weighted images, indicaring, hyporvvetination.

We isenrifed a novel de nozo mutation in $T U B B+A$ in a 24 year-old female wich a childhood oaset dystonic syndronxe with severe lower limb spasticity, dysarthria, cogni. tive decline and epilepsy (Tatient P12). Mru revealed extensive $\mathrm{T}_{\text {- }}$-weighted hyperintensing of the periventricults and cerchellar whise marter estendieg to the posterier limb of rhe internal capsuls. The white matrer appeared notrnal on $T_{1}$-aveighred imaging. The basal ganglia and cerebellam were not visibly involved by age 24 years.

DARS2

We detected two patients with novel dompound beteroxy foos mucations in DARS2, the mitochondral aminoscyl tRNA syotherase for aspartic acid. Recessive metations in this sene are associared with the disorder leukoenoephato pathy with brainstem and spinal cord involvement and berare elevation (L.BSL.) (Scheper $a$ at., 2007). Parient P17 presented at ase 8 years with exercise indoced calf cramps. By age 16, he had developed distal weakness and warting with impaired deep rendon reffexes and pes cavus. By age 23 there was bilareral extensor plantars and he was diapnosad with bereditary spastic paraplegia with distal amworrophy. The ratient continesed to dexline and by his 40 s had developed a moderate gait ataxia with severe distal weaknesa and ensory neuroparhy. MII revealed $T_{2}$ byperintinse senal abnotmality in the cerebral whire matter, splenimu of the corpus callosim, medullary pysamids, medial $\mathrm{km}$ nisci, intranarenchymal trigerainal nervs, superont, middle and inferior cerebellar peduncles, eerebellar white inurter and donsal columus and lateral corricospinal tracts in the spinal cord, A lactate peak was detected on intermediate and hog echo time mágnetic rescrance spectroscopy, These Endings met the radiological criteria for diagnosis of
LBSL., and the diagrosis was confirmed by the detection of the compound hererogygoss DARS2 variases. Pations P18 developed upper limb intention tremor and sowily progres. sive gair impaiment at age 5. There was slow pmogression: and gradeal dievelopment of a sensory ataxia. By age 25 she had spastic parapiegia with redoced verhal fluency and mild cognitive impairment. The MRI was consistent wirh IISI and this was confirmed by the presence of compoxind beterozygous DARS2 mursions (Fil 38).

\section{RNF216}

We identified a novel homozygous nonsense mutation in RNF216 in a 42 year-old male with showly progressive cog: nitive decline, gait impaimaent and erectile dysfunction, srarting at age 31 rears. A brother was also affected, with a more rapid progression and dexth at age 38 years. On examinasion, there was evidence of mild cognitive ins. pairment (MMSE 25/30), mild cerebellist ataxia and choreic movements of the hards and face. MRI demonstrated a symmetrical and diffuse supra and infra-tintorial leukoencephaloparthy with involvement of the thalamas, external caperites, pons, middle cerebellar peduncles and dentate nuckens (Fig, $3 \mathrm{C}$.

\section{Discussion}

We used froused exone sequencing as an approach to diag nosis in a heterogeneous group of unsolvod adult leukodystrophickseneric leukoenceghaboparhies. All of the parients in our sohert had previously been extensinety invesripated withourt diagnosis. In a cohort of 100 patients, we made a definixive diagnosis in 26 . This diagnostic rate compares favourably $m$ other stridies using a similar approach. In par ticular, Vanderver et al, (2016) made a diugnosis in 25 cases from 71 fimilies, all of whom were childbood onset cases with full family trios, In general, diagnostic rates in adult onses generic disorders tend to ke lower than in children. This is because the population is more heterogeneoess, often consaining some parients with acquiral disorders such as severe small vessel disease and bocasse familial DNA is not often avsilable in adtale oniset cases.

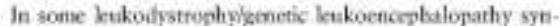
Iromes there is a close phenorype-genocype relariooship allowing for accurate pre-rost prediction. For example, the presence of atasia and hypogonadictophic hypogoniadism with lenkoonexphalopathy stromely sugarses Gondon Holmes syndrome due to RNF216 matations. Similarly, partecular MRI patterns might significantly reduce the number of genes to sereen, such as when byponyelination is the predoninant fearime of the stecife and striking feasures of LBSL. Homever, there temsin a large number of patients who all prescret in a similar way with a sabacure dementing illness with pyramidal and extrapyranidal features and a symmerric, nonspecific white matrer ahnormality. In these sass, extensive bioshemscal or netabolso testing is less likely to be helpful aftec initial scroening is performed (Ahmed 
at al, 2014). Wirhout specific pretest probability, sequestial candidate gene secoursing is rime consuming, expengive asd can significantly delay diagnosis. By contrast focised exome sequencing is an efficient approach to diagnosis as it simulcancoiasly covers all known ganes causing lenkodystrophies' generic leukoencephalopartives.

The number of new geoses implisated in gebectic beskoencophaloparhies is growing each year. This provides challespes for the nse of rarseted panels, which inevisably hecome obsnlete whan a number of new genes are described Lsing a focised exome anorosich offorts this, as the data can be reanalysed intermittently in light of new genstic discoveries and corgpares favourably with regand to conerage when oompared to WES.

In summary, focused exorae sequence nerforms as well as WES in the diagnosis of adult anses leukodystrophiss, providieg a definite genetic diagnosis in $26 \%$, and revesting variants of undertain significance in $3 \%$. The 71 negative cases in our cohort continue to peesent a diagnostic challenge: Sorm of these may nor have a Mendelian monopertix disonders, being either acquired, or due to the interaction of namerous generic variants in a polygenic fashion. Some patiens mey carty pachopenic intronic varianos in known genes ot ocher muitarions not readily detected by NGS including heterozygotes copy number varianes. Finally, some patients will carry pathogenic variants in genes not ver linked to leakodystrophies/generic knokencephalopa thies. Further whisle exometgenome sequencing along with family segregation and functional stodies may in furure re solve some, if not all, of these cases.

\section{Acknowledgements}

The authoos would tike to thank the patients and their families for participation in this stedy.

\section{Funding}

This stuily was supported by the Medical Research Coancit, The Leonard Wolfson Experimental Neurology Centre, The Wellowe Truse and The Brain Research Truse (BRT). This study was alwo sepported by the National Instinite for Healch Resesrch (NIHR), Dniversicy College London Hospitals J IKCHHIUCL - Biomedical Rrsearch Centre (BRC) and the NIHR Queen Square Dementia Biomstical Reseatch Unit.

\section{Supplementary material}

Supplementary matrial is availabic at Brain online.

\section{References}

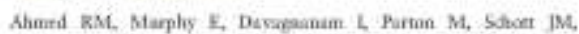

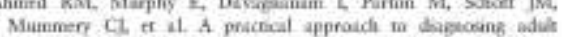

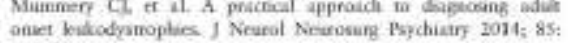
oniet bestion.

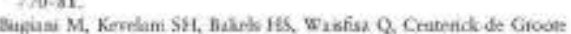

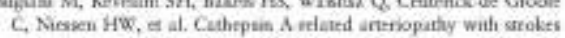

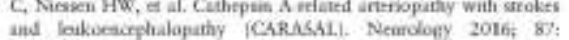
1777-86.

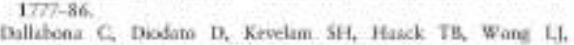
Salomons GS, at at. Noved (ovirio) irukodysempliy related to AAkS2 wauroes. Neutobogy 2014 i $82,2063-71$

Hurse S, Cartern I. Trepanirt A, Gow A. Qeanitymg de carriet

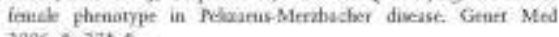
$2006 ; 3: 37 t-3$

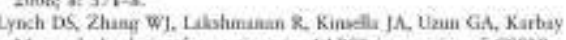

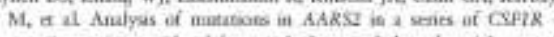

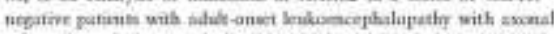

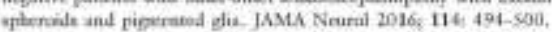

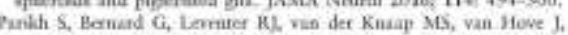

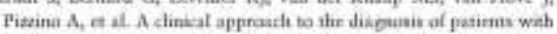

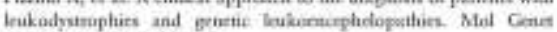
Mrtah 2015, 114, 501-15.

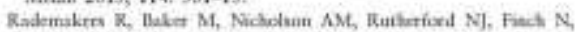

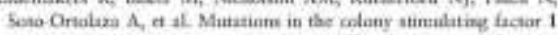

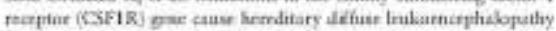
with qheraik Nat Canas 2011; $44: 200-5$.

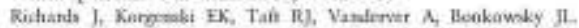

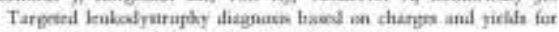

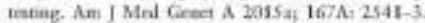

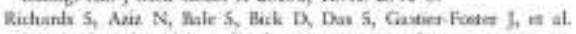

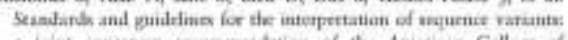

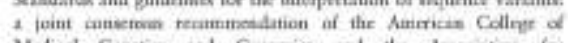

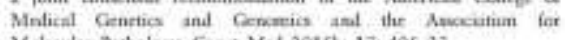
Miniscular Puthalay, Comet Mol 2015h; 173 405-13.

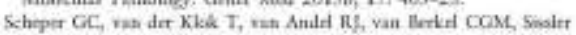

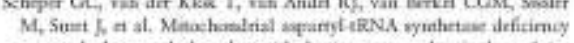

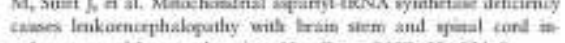
volvement and lactate devation. Nar Gener $2097,391534-9$.

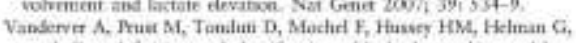

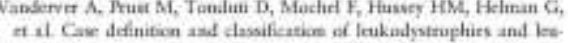

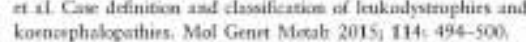

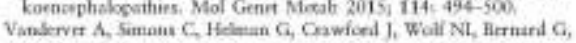

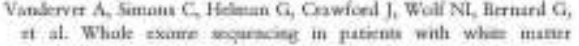
It al. Whale exoure squnciegs in putients

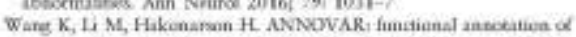

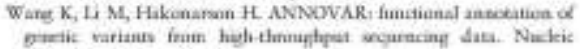
derits kes $20104381+164$ 
10.8 Apêndice $H$ - When multiple sclerosis and X-linked adrenoleukodystrophy are tangled. Neurol Clin Pract 2018;8(2):156-158.

Paiva ARB, Pucci Filho CR, Porto AM, Feltrin FS, Kok F, Camargo CHF. When multiple sclerosis and X-linked adrenoleukodystrophy are tangled. Neurol Clin Pract 2018;8(2):156-158.

https://doi.org/10.1212/CPJ.0000000000000431 


\section{When multiple sclerosis and X-linked adrenoleukodystrophy are tangled}

A challenging case

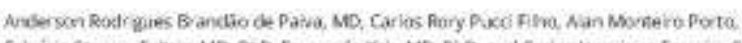

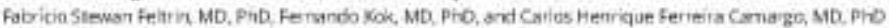

Diagnosis of multiple selerosis (MS) is often difficult because of the wide range of dinical presentations and the absence of biomarkers or specific test to confirm the cisease. The condition can therefore be confounded with other inflammatory or genetic conditions that affect the CNS, like inherited leukoencephalopathies. Among inberited leukenencephaloparhies, X-linked adrenoleukodystrophy (X-AL.D) figares out as ooe of the most commons. ${ }^{2,2}$

$\mathrm{X}-\mathrm{NLD}$ is associated with mutations in ABCDI on $\mathrm{X}$ chromosome, lesdiny to ac cumalation of very long-chain fatty acids (VLCFAs) and oansequent functional changes in adrenal cortex, CNS, bladder, and bowel tissue. ${ }^{23}$

Women who are heterorygoas for these mutations may present with neurologic symptoms but are generally asymptomatic. They may possent with brisk deep tendon reflexes or nild lateonset spastic paraparesie. Brain or adrenal involvement are esceptionally rare.

\section{Case report}

A 46 year old woman presented with changed right homonymous hemunopiz and dizzy spells that improved spontaneously. Afrer 2 year, she presented with binocular peristent vertical diplopia, ocular skew deviation, uphest nystagmos, dizxy spells, hyperrefertia, and Bubinski sign on the left side. Her family history was remarkable for 2 sons who received a dugnosis of $\mathrm{X}$ AL.D - a 21 syear-old with genetically confirmed diagnosis of cerebral form X wl.D and a 27. year-old with X-linked adrononsyeloneuropathy. Her MRI showed elongated areas of T2 hyperintensities, somse sriented perpendicularly to the cortical or pial surfaces of the cerebral bentispheres. Lesions in the jurtacortical, periventricular, and infratentorial conviartments were observed, ope of which showed an annular pattem of gadolinium uptalte. Lesions were also visible in the callosal-septal interiace (figure). There were infratentorial hesions in the poas, one of which followed the intrapontine trigeminal nerve tract. Taken together, these findings are suggentive of densyelinating disease, such as MIS.

CSF analysis revealed oligodonal immunoglobulin G bands (OlgGRs). The patient's synap. toms improved after stete received methylprednisolone. She was diagrosed with MS and given interfenon- \&- th. Her Fxpanded Disability Status Seale remained at I.S, and she has been lrept on immunomodulatory therapy. Based on ber famíly history, we ondered serum VLCFA dosage, which was elevated.

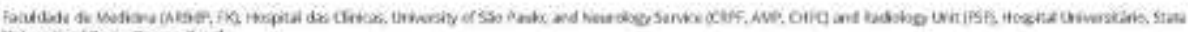
Irwantiys

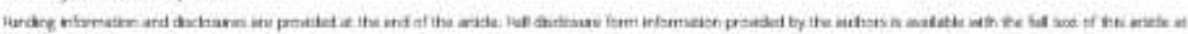

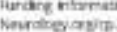


Figure MAI findings
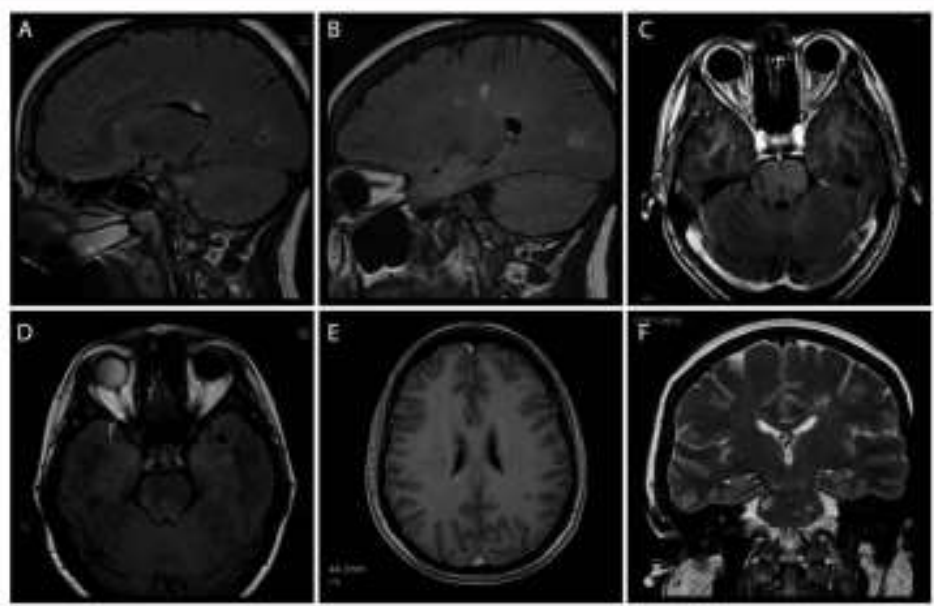

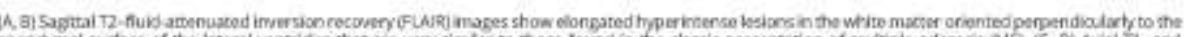

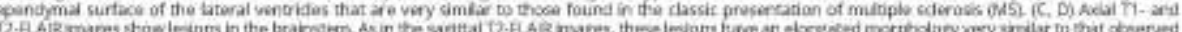

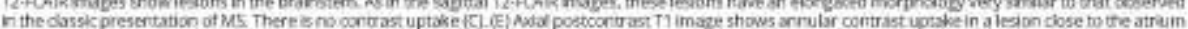

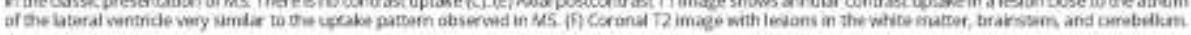

\section{Discussion}

The clinical and bbotatory findings for our patient were fairly typical of relapsing remitting MS, but she also had VLCFA accumalation, confirming an X-ALD carret status, The pas. tient met the diagnostic criteria and responded to pulse methylprednisolone therapy. Unlike other cases of X-ALD in women described previously, this patient did not present spastic paraparesis, and her cerebral symptoms were exceed ingly rare for a woman with $\mathrm{X}$-ALD. ${ }^{\text {th }}$ Her symptoms manifested in 2 clearly defined relapses. Brais MRI also showvd multifocal supratentorial and infratentorial white matter chunges at various stages, including a gadolinium-enhaneed lesion.

In X-ALD, as in MS, MRI findings vary, In more typical cases, these include signs of demyelination starting at the splenimu of the corpus callosum with intermediate areas of demyelination and perivascular inflummation, particularly in the frontal, parietal, and occipital lobes. Changes in the corticospinal tract and gadolinium enhancement may also occut. However, oaly a small proportion of women present with this number of signs of the disesse in the brain. ${ }^{2,4}$ While in MS there is usually multifocal demyelination, X-ALD is charncterized by extensive confluent demyelination. MRI in MS usaally sbows multifocal lesions disseminated in the periventricular, juxtacortical, and

Neurologyorg/CP

Copyright $=2018$ American Acpdermy of Neuroiogy. Unauthorized reproduction of thin article is prohibitad, infratentorial compartments and can also reveal spinal cord involvement. The lesions, which are very common in the callosal-eeptal interface, are wsally stall, elongated, and oriented perpendicularty to the pial surface of the ventric ulat system of the cortical surface of the brain. MRI findings can also include acute gadolinium enhanced lesions. These may disappeat over time, with little damage to the underlying parenchyma, or may evolve to pronounced tissue Aamage, usually with axobal damage, and black holes may be seen. To confirm a diagnosis of MS, imaging findings should show dissemination of the lesions in space and time. In adult-anset $X-A L D$, a wide range of MRI abnormalities can be seen. These may be restricted to the pyramidal tracts or be diffuse, involving the serebral bemispheres, posterior limbs of the internal capsules, brainstem, and cerebellum. In this subgroup in particular, it is not uncommon for X-ALD to be mistiagrosed as MS ${ }^{\text {t }}$

Another confounding factor in the diagnosis was the finding of OIgGBs, which are common in patients with MS, but this is not specific and can also be present in patients with X.A.D. Adrenocortical insufficiency is rare in women $(\mathrm{t} \%)$, and our patient tested negative.

Obeying Occam's ravoe, strictly acthering to available diagnostic criteria, is otten the best principle to disentangle misleading findings.

Peuxology Cinital Proction. | Valume 8, Niumiter 2 | April 2018 157 


\section{Author contributions}

A.R. Brandío de Pawa: analyxis and interpretation of the data, drafting and revising the manuscript for intellectual content. C.R. Pucci Filho: analysis and isterpretation of the data, drafting the manuscring for intellectual content. A. Monteiro Porte: analysis and interpretation of the data. F.S. Feltrin: analysis and interpretation of the data, drafting the mansocringt for intellectual content. F. Kols: resising the manuscript for intellectial cootent. C.H. Ferreira Camargo: design and conceptualization of the study, anslysis and interpretation of the data, revising the manuscript for intellectual content.

\section{Study funding}

No targeted funding reported.

\section{Disclosure}

A. Brandio Paiva, CR. Pucci Fitho, A. Monteiso Porto, and F.S. Feltrin report no disclosures. F. Kok ververs on the editoriul advisory board of Anquaivos de Neuropsiquiatria; is author on a patent re: Methyimalonic acid determination by tanden mass spectrometry using stable isotope; is Medical Director of
Mendelics Genomic Analysis, a NGS laboratory, since 2013; has rectived speaker honoraria from Actelion Phamaceut. icals; and is a sharehoider in Mendelics Genomic Analysix. C. H. Ferreirn Camargo reports no disclosures. Full disclosure form information prosided by the anthors is available with the full text of this article at Neurologyorg/cp.

Teceived Seprember 6, 2017. Acoppted in final form Norember 6.2017

\section{References}

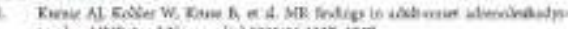

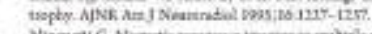

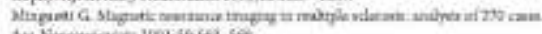

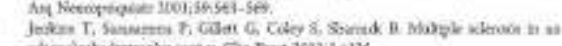

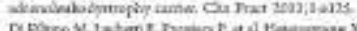

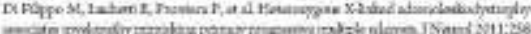
$125-314$

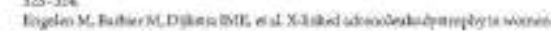

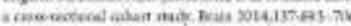

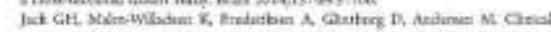

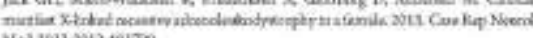

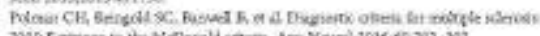

\section{Practical Implications}

Nearology ${ }^{*}$ Clintcal Practice is committed to providing dinical insights helpful to neurologists in everyday practice. Fact Full Cave indudes a 'Practical Implications' statement, a peart of wisdom for the practicing dinician. 
10.9 Apêndice I- Typical clinical and neuroimaging features in Sjögren-Larsson syndrome. Arq Neuropsiquiatr 2018;76(4):283.

This work is licensed under the Creative Commons Attribution 4.0 International License. To view a copy of this license, visit http://creativecommons.org/licenses/by/4.0/ or send a letter to Creative Commons, PO Box 1866, Mountain View, CA 94042, USA.

Paiva ARB, Melo US, Freua F, Dória D, Cabral KSS, Macedo-Souza LI, Lucato LT, Kok F. Typical clinical and neuroimaging features in Sjögren-Larsson syndrome. Arq Neuropsiquiatr 2018;76(4):283.

http://dx.doi.org/10.1590/0004-282x20180024 


\section{Typical clinical and neuroimaging features in Sjögren-Larsson syndrome}

Características clínicas e neurorradiológicas típicas na síndrome de Sjögren-Larsson

Anderson Rodrigues Branddo de Paivo?, Uirá Souto Melo?. Fernando Freua t, Denise Dória', Katiane Soyào Souza Cabral', Lucio Inès Macedo-Souzaz', Leandro Tovares Lucato., Fernanda Kok'

Sjögren-larsson syndrome is an antosomal recessive disorder characterized by ichthyosis, intedlectual disability, spas. tic paraplega, macular dystrophy, and leukoencophalopathy, It is cansed by mutations in $A L D H 3 A 2$, which leads to accumulation of long chain fatty alcohols. Herein we report ou a 28-year-old man with congenital ichthyosis (Figure A) and profound intellectual disability. who is severely spastic and bad undergone several orthogedic procedures for correction of deformities. Brain MPI disclosed leukoencephalopathy and cortical atrophy (Figure B), while MR spectroscopy allowed identification of peaks assignex to lipids (Figure C), Sequencing of ALDHBA2 revealed he is a compound heterozygote for two previousty-reported splice site mutations: matemally inherited $c ; \% s+5 \mathrm{G}>\mathrm{A}$ and patemally transmitted c1108-1 G >C. Treatment of Sjogren-Larsson syndrome is symptomatic:
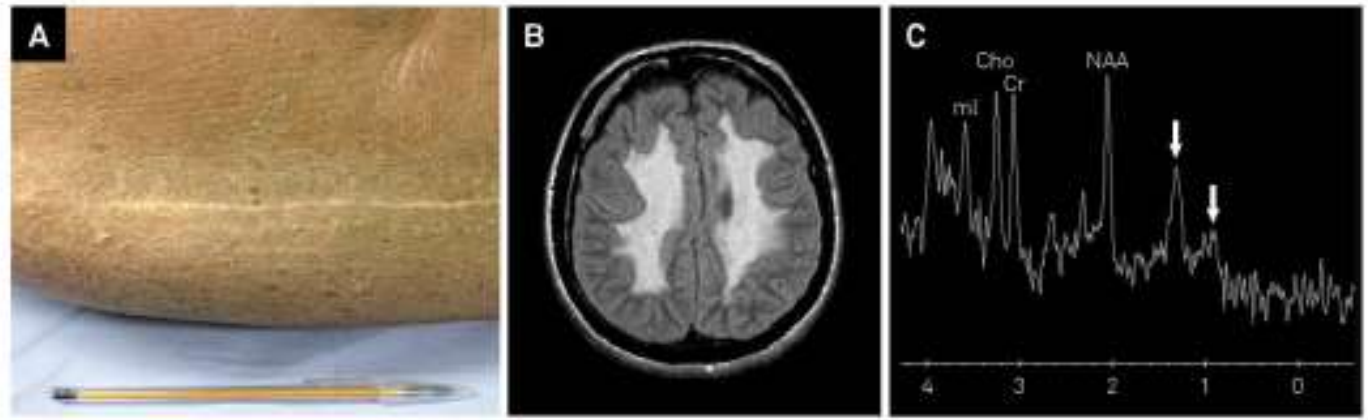

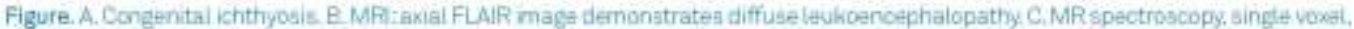

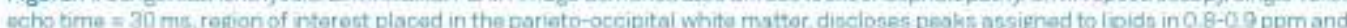

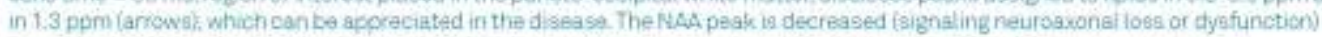
and the $\mathrm{ml}$ peak is incressed probably related to gliosisl, NAM N-acetyl aspartate, Or: creatina, Cho: choline; mi.myo-inositol.

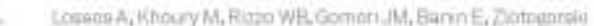

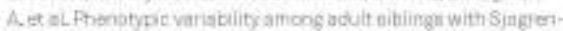

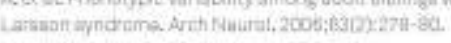
htton:Ad

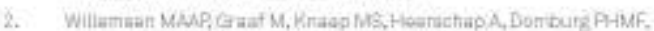

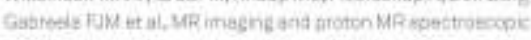

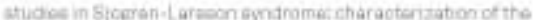

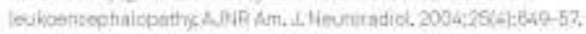
Aizao W, Carnayti, im Z, The malacular basis of Sjogen

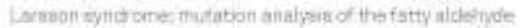

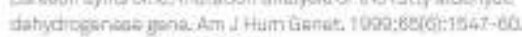

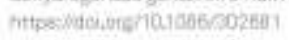

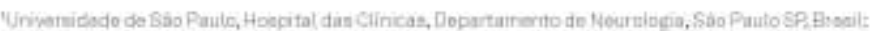

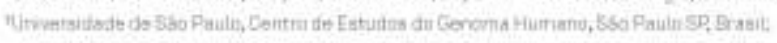

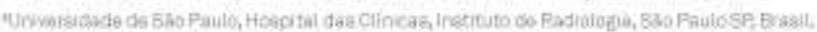

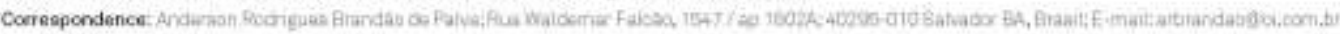

Conflict of interest: Therw as no conflict of intarant to daclark.

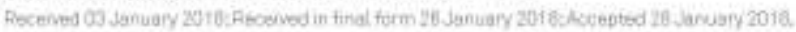


10.10 Apêndice J - A novel complex neurological phenotype due to a homozygous mutation in FDX2. Brain 2018;141(8):2289-2298.

Reprinted by permission from Oxford University Press: Oxford University Press, Brain - A novel complex neurological phenotype due to a homozygous mutation in FDX2. Gurgel-Giannetti J, Lynch DS, Paiva ARB, Lucato LT, Yamamoto G, Thomsen C, Basu S, Freua F, Giannetti AV, de Assis BDR, Ribeiro MDO, Barcelos I, Sayão Souza K, Monti F, Melo US, Amorim S, Silva LGL, Macedo-Souza LI, Vianna-Morgante AM, Hirano M, Van der Knaap MS, Lill R, Vainzof M, Oldfors A, Houlden H, Kok F. COPYRIGHT 2018, advance online publication: 13 Jul 2018 https://doi.org/10.1093/brain/awy172 


\title{
A novel complex neurological phenotype due to a homozygous mutation in FDX2
}

\author{
Juliana Gurgel-Giannetti, ${ }^{1 *}$ David S. Lynch, ${ }^{2,3} *$ Anderson Rodrigues Brandão de Paiva, ${ }^{4}$ \\ Leandro Tavares Lucato, ${ }^{5}$ Guilherme Yamamoto, ${ }^{6}$ Christer Thomsen, ${ }^{7}$ Somsurro Basu, \\ Fernando Freua, ${ }^{4}$ Alexandre Varella Giannetti, ${ }^{9}$ Bruno Della Ripa de Assis, ${ }^{4}$ Mara Dell \\ Ospedale Ribeiro, ${ }^{4}$ Isabella Barcelos, ${ }^{4}$ Katiane Sayão Souza, ${ }^{4}$ Fernanda Monti, ${ }^{4}$ \\ Uirá Souto Melo, ${ }^{6}$ Simone Amorim, ${ }^{4}$ Leonardo G. L. Silva, ${ }^{6}$ Lúcia Inês Macedo-Souza, ${ }^{6}$ \\ Angela M. Vianna-Morgante, ${ }^{6}$ Michio Hirano, ${ }^{10}$ Marjo S. Van der Knaap, " Roland Lill,",12 \\ Mariz Vainzof, ${ }^{6}$ Anders Oldfors, ${ }^{7}$ Henry Houlden ${ }^{2,3}$ and Fernando Kok ${ }^{4,6}$
}

"These authors contributed equally to this work.

Defeas in iron-sulphur (Fe-S) durter biogeneris are increasingly recognired as causing nearalogical discase. Murations in a number of genes that encode protcias involved in mitnchoadrial [FeS] jrotein asumbly lead to complex neurulogical phenotypes, One dass of proteins esseatial in the early cluster assenbly are ferroloxins, FDX2 is uhiquitously expresed and is essential in the de movo lormation of [2Fe-2S] cluster in humans. We describe and genecically define a novel comples neurological synifrome identified in two Brailian families, with a novel homoxygous mutation in FDX2. Patients were dinically evaluated, underwent MEL, nerve condaction studies, EMG and muade biopsy, To defiae the senetic aetiology, a combiantian of hamaxyosity mapping and whole eaveme sequencing was performed. We identified aix patients from two apparently unrclated families with autasomal recesive inheritance of a complex neurological phenotype involving optic atrophy and nystagmus developing by age 3 , fallowed by myopathy and recurrent episodes of cramps, myalyia and musde weakness in the first or second decade of life. Senaory-motor axonal seuropathy led to progressive distal weakness. MRI disclosed a revernble or partially reversible leulowencsphalopathy. Muscle biopsy demonstrated an unasual pantern of sczional succinate dehydrogenase and cyochrome $c$ oxidase deficioncy with iron accumulation. The phenorype was mapped in both families to the vame bomaryour missense mutation in FDX2 [c.431C > T, p.P144t). The deleterious effect of the mutation was validated by real time reverse transcription palymerase chain raction and westem blot analywis, which demanstraned normal expressina of FDX2 mRNA but severely reduced expressian af FDX2 protrin in musde tisne. This stuly descrihes a novel camplex arutalagical phenotype with umasual MRI and masde biopiy feanures, condusively mapped to a mutation in FDXZ, which encoder at ubiquitously expressed mitochandrial ferredoxin esential for early [Fe-5] cluster biogenesik.

1 Department of Paediatrics, Universidade Federal de Minzs Gerais, Belo Horizonte, Bcazal

2 Department of Molecular Neuroscience, UCL. Institute of Neurology, London, UK

3 Leonard Wolfson Experimental Nearology Centre, UCL Instmite of Neurology, Londoth, UK

4 Neurogenetics Unit, Neturology Department, Hospital das Clinicas da Linversidade de São Paulo, São Paulo, Brazil

5 Neuroradiology Section, Hospital das Clinicas da Universidade de São Paulo, ST̃o Paulo, Brazil

6 Human Genome and Stem Cell Research Center, Department of Genetics and Evolutionary Baology, Instinuto de Biocièncias, Universidade de São Paslo, São Panlo, Brazil

7 Deparmient of Pathology and Genetics, Sahlgrenska Linversity Hospital, University of Gothenburg, Sweden

8 Institute for Cytobiology and Cytopathology, Philipps-Universitat Marburg, Robert-Koch-Strasse 6, 35032 Marburp, Germany

9 Department of Surgery, Federal University of Minas Gerais, Belo Horizonte, Brazil

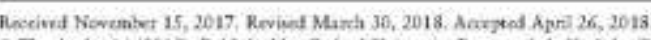

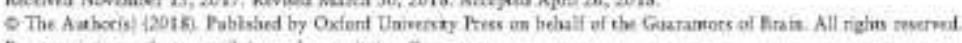

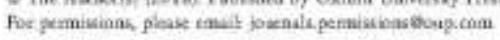


10 Department of Neurology, Columbia University Medical Center, New York, USA

11 Department of Child Neurelogy, VU University Mesalcal Center, Amstredam, The Netherlands

12 LOEWE Center for Synthetic Mierobiology, SynMikro, Hans-Meerwein-Strasse, 35043 Marburg, Gernany

Cortespondence to: De Juliana Girgel Giannetti

Rua Santa Catanina 1042, 201, Belo Horizonte, Brazil

E-mail: gurgeljứfyahoo,combr

Cortespondence may also be addressed tor De David Lyoch

Department of Molecular Neuroscience, UCL Institute of Neurology, Queen Square, London, WCIN 3BG UK

E-mail: david $\_$ynch.13बid.ac.uk

Keywards: FDX2; brain; nerve; muscle; optic atrophy

Abbreviations: $[\mathrm{Fe}-\mathrm{S}]=$ iron-sulphur; $\mathrm{COX}=$ cytocbreme 6 oxidase; $\mathrm{SDH}=$ sucsinate deliydtogenase

\section{Introduction}

Iron-salphur [Fe-S] clusters are essential biological cofactors found in all living organisms, from archaea to eukaryotes. (Fontecave, 2006; Lill, 2009). They consist of protein-bound $\mathrm{Fe}$ ions, linked by sulphide bridges and are essential in a large numbet of electron transfer reactions. [Fe-S] clusters are almost unique in their ability to access various redox states over a wide range, with electron transport roles in critical processes like the mitochondrial respiratory chain. [Fe-S] clusters have also been found to play important roles in more diverse cellular pathways from catalysis to gene regulation (Beinert ef al., 1997; Rouaul, 2015]. The biogenesis of [Fe/S] proteins in the mitochondria is a complex process and takes place in several stages (Braymer and Lill, 2017). The early stage of biogenesis involves a cysteine desulphurase as a source of sulphur and frataxin as a potential source of iron, with the cluster being formed on the scalfold protein iron-sulphur cluster assembly enzyme (ISCU). The newly made [2Fe-2S] cluster is then rransferred to numerous downstream biogenesis proxeins that will use the colactor for transfer to target [FelS] proceins sach as the subunits of mitochondrial complexes I and II.

Another class of proteins essential for de now [2Fe-2S] cluster assembly on ISCU are ferredoxins. Webert et al. 2014; Boniecki et al, 20177. Humans possess two ferredoxins, FDX1 and FDX2 (formerly FDX1L) (Sheftel of al. 2010). While both proteins localize to the mitochondrion, expression of FDX1 is highest in the adrenal gland, where the protein functions in the steroid synthesis pathway. FDX2, however, is ubiquitously expressed and is essential in the formation of [Fe-S] clustern in humans (Sheftel et al., $2010)$.

Muranons in a number of genes that encode proteins involved in [Fe S] cluster assembly lead to complex nenuro. logical phenotyper iStehling et al., 2014). The most common of these syndromes is Friedreich's ataxia, an autosomal recessive mulnisystem neurodegenerative disorder characterized by ataxia, peripheral neuropathy and cardiomyopathy (Beilschmidt and Puccio, 2014). It is rypically caused by a trinucleotide tepeat intronic expansion in EXN, encoding fracaxin (Dür et al., 1996). Loss of func tion mutations in ISCU lead to myopathy with severe ex ercise intolerance (Mochel et af, 2008; Olsson et al., 2008; Nordin et al., 2011; Legari ot al., 2017) and mutations in NUBPL, an [FeS] protein involved in complex 1 assembly (Sheftel ef al., 2009\%, lead to leukoenoephalopathy, ataxia and developmental regression (Calvo ef al., 2010), In 2014, a single case was described with isolated mitochondrial my. opathy due to a homozygous translation start site mutation in FDX2 (Spiegel et al., 2014). More recently, mutations in FDXR, encoding ferredoxin reductase, were described in eight patients with a syndrome including bearing loss, optic atrophy and sensory neturopathy (Paul et al., 2017).

In this study, we describe the clinical phenotype of six patients from two apparently unrelated Braxilian families but living in the same goographic region with a complex phenotype including optic atrophy, reversible leukoence phalopachy, mitechondrial myopathy with exercise intoler. ance and axonal polyneuropathy and, in some patients, pramidal signs. Using a combination of homozygosity mapping and whole exome sequencing, we mapped this phenotype to the same homozygors, deleterious mutation in FDX2.

\section{Materials and methods}

\section{Subjects}

Clinical evalaation was pefformed on both families by two independent research grongs that shared their data. All patients were clinically and neurologically evaluated, and underwent EMG and netve conduction studies and muscle biopsy.

We received approval of the ethical standands conmittee at both institutious (Sĩo Paulo University and Federal University of Minas Gerais) and writter informed consent was obtained from all included family members.

\section{Neuroimaging}

Al patients underwent at least one exam. We analysed 13 brain MRIs performed at different ages ranging from 8 
months to 41 years. Since Mitis were performed in different centres, analyses was based mairly on multiplanar FLAIR, T. and $T_{2}$-weighted images. Intensiry of $T_{4}$ changes were geaded in a scmi-guantitanive inanner as absert, mild, moderate of severe. Diffusion-weighted images and appurent diffusion coefficient maps, when avalable, were serutimizod in the search for lesions with restricted diffusion. Magnetic resconance spec. troscopy was also analysed when available, and we focused on the detection of lactate peaks.

\section{Muscle biopsy}

Muscke biogsies were performed on the biceps beachialis and cryostat sections wer obrained wish 8 un thickness. Conventional histodhemical tedniques were performed. haematoxytin and eosin, modified Gomori trichroms, Periodic acid-Schiff tectmique, Oil Red $O$, reduced nicotinamide adenine dinaclecside detydrogenase-tetrazolium reductase (NADH-TR), succinate dehydrogenase (SDH), cytodarome $\mathrm{e}$ oxidase $(\mathrm{OOX})$, and aikenosine triphosphatase

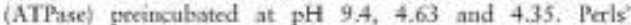
Prussian Blue staining was perfoemed as descrited iStevens, 1990) and with DAB enhancenent (Mochel, 2008) to idensify iroo deposition.

For immunohistochemistry, $8 \mu \mathrm{m}$ sections were fixed in $4 \%$ formaldebyde at $4^{\circ} \mathrm{C}$ foe $10 \mathrm{~min}$, wasted in Trisobuffered saline-Tween 20 (TRS-T) for $10 \mathrm{~min}$, permeabilized in a graded methanol series $170 \%$ tomin, $95 \% 10$ min, $100 \%$ $20 \mathrm{~min}, 95 \%, 10 \mathrm{~min}, 70 \% 10 \mathrm{~min})$, washed in TBS-T for 5 min and furtber processed in a Dako Autostaince using the Dako FaVision FLEX High pH kit. The following antibodies were applied for $1 \mathrm{br}$ anti-SDHB ab14714 Abcam (1:500\%, anti-MTCOI ab14705 Abcam $\langle 1+2000\rangle$ and anti-VDAC1 abi4734 Abcam (1:2009)

Electron microscopy was performed on tissne specimens that had been fixed in gfutaraldehyde, post-fixed in $\mathrm{OsO}_{4}$ and embedded in resin. Ultrathin sections were contrasted with aranyl acetate and lead citrate.

The tespiratory chain enzyme analysis was performed on froeen tissue using spectrophotosnetry (DiMauro ef al., 1987).

\section{Molecular analysis}

Genome wide genotyping was performed on Patients 1-4, both parness and an unaffected sibling froen Family 1 using the Axiom* Genome-Wide LAT i Array (Affymetrix). Runs of homozygosity were identified using PLINK software (Phurcell et al, 2007). Whole exome sequencine wis pxrformed on Patients 3 and 4 from Fumily 1 and in four nembers (Paticats 5, 6 and parents of Patient 5) from Family 2 using the Agilent SareSelect Exou Earichument kit. Segregation of the FDX2 mutation was confirmed by Sanger sequencing of FDX2 exon 5 using the following primer sequences Forward: 5 , ATCCTCCOCACTTOCAGTIC-3; Reverse: 5'-TCTTAAGC TCCTGGCCTCAA-3.

Priot to whole exome sequencing, Sanger sequencing of FARS2, SDHA and SDHB was performed in Paticnt S, and no potential pathogenic variant was identified in hoenorygosity or compoand beterozygosity in this sulyect. Cytogenetic investipation was pecformed oc cultured peripheral blood lymphocytes from Patient 1 and her parents, including G- and C-banding, and fluorescent in sitn hybridization [F1SH analyses.

\section{Functional studies}

Human RNA extraction, cDNA synthesis and RTqPCR

RNA extractod from asascie from four patients and two healthy controls was used for countitative reverse transcription PCR (R'T-qPCR). RNA extraction was performed using TRlzot (Thermofisber Scicntific) and RNA quality was evaluated by agarose gel electrophoresis: and all sampies had 260:230 ratio above 1.90 , measured using a NanoDrop (Thermofisher Scientific). Total RNA (1 Haghily was reversetranscribed with aligoidT primers using SuperScript ${ }^{\text {TM III }}$ First-strand Synthesis System (Thermohisher Scientific). FDX2 primes for RT-aPCR spanned the exon 4-5 junction- Forwand 5'. GTGAGTGAAGACCACCTGGAT-3; Reverse 5'. GCCA TGTCTAGCATGTCGIC-3,

RT-qPCR was normalized to TBP and the cDNA amplification was performed using Applied Plosystems" 7500 Fast Real-time PCR Svatem. Relative gene expersion was calculased using. 2-ASCr method (Schmittgen and Livak, 2008) Each experiment was performed in triplicate considering stand. and deviation of triplicate positive when $<0,1$.

\section{Western blot study}

Muscle tissue was tysed in RIPA buffer (Pience) and protein concentration was detennined with Pierce $660 \mathrm{~mm}$ protein assay. Lysed skeletal muscle samples were subjected to SDSPAGE $(6-18 \%$ gradient gels Stehling et al., 2018) and imennostaining. Antibodies were targeted agsinst FDX2 daffinity purified, Sheftrl et al., 2010\%, $\mathrm{F1} \omega / \mathrm{h}$ subunits of courplex $\mathrm{V}$ Akind gift of Drs H. Schigger and L. Wietig, 1:10003, VDAC (Cell Signalling Technology, 1:1000), tubulin (Sigma, 1:10 000 ), and actin (BD Transduction Labotateries, 1:2000).

\section{Results}

We identified six patients from two apparently unrelatod Brazilian families living in the same geographic area with a complex multisystem phenceype: childhood onset of optic atrophy, recuirtenr episodes of myalgia and/or proximal weakness, axonal polyneuroparhy, pyramidal signs ipresent in two patients) and reversible or partially reversible leskeencephalopathy on MRI. A summary of clinical findings is presented in Tables 1 and 2 , and a simplifed pedigree of Families 1 and 2 is shown in Fig. 1.

\section{Clinical findings}

The firse recognizable clinical sign in all patients was nys. tagmus, secondary to low visual acuiry cansed by non pro gressive optic atrophy, seen before the age of 3 years in all patients. A mild motor delay was observed in all patients, except Patient 1, who bad a global developmental delay, and Patient 5, who had a normal development.

In all patients there was evidence of recurrent episodes of cramps, myalgia and muscle weakness, often precipitated 
by exercise, infections or low temperarure. These events started in childhood or adolescence, sometimes leading to temporary loss of ambularion for 1 ro 3 weeks. In Patient 5, a creatine kinase level during an eqisode was $>3000$ Uh, indicating thabdenyolysis.

Motor fearures included a combination of myopathy, upper motor nearon dysfunction and sensori mooor axonal neur opathy. Weakness was progressive in Patient 6, who became whelchair-bound at the age of 33 years. Hypoactive deen tendon reflexes were seen in all individuals, excepe Patient 5. Babinski signs with mild spasticity were seen in Parients 3 and 4. Sensory ataxia, characterized by positive Romberg sign and decreased vibration and pesition sensitivicy, was present in Patients 3 and 4 . Permanent weakness was related to atge and disease duration, since it was present in rwo of the three adult patients: Patient 3 had proximal and distal involvenent, and Parient 6 only distal weaknes, Clinical franures of neuropartby and abnornal nerve conduction scudy were seen in all four older patients with more than 10 years of age. Finally, peosis was seen in Parients 3 and 6 . (Table 2),

In Family 1, all rested members (Patients 1-4) had mild microcytic anaenua without iron deficiency, sometimes accompanied by thrombocytogaenia or neurropaenia.

All patients underwent nerve conduction snuties and E.MG, which showed sentori-motor polyneuropathy in Patients 1,3 , 4 and 6 , but no absormalities in Patients 2 and 5.

Additionally, Patient 1 had global developmental delay, intellectual disability and dysmorphic fearures, characterized by protruding ears, micrognathia, high arched palate, almond-shaped eyer, high nasal bridge, dolicocephaly, and brachydactyly. The dysmorphic features wete thought to be due to an unselated and separate condition not affecting the other five pacients described here.

\section{Neuroimaging}

The common finding observed in brain MRI from all patients was the presence of hypoplastic opoic nerves and chiasm (Fig. 2) In three patients, magnetic resonance abnomalities progressed in a somewhat similar fashion (Patients 1,2 and 5). In Patient 2 the first exam done at 1 year and 8 months demonstrated $\mathrm{T}_{2}$ hyperintensity invol ving subcortical and deep cerebral white matter and corpus callosum (genu and splenium), associated with restricted diffusion. There was also mild pontine $\mathrm{T}_{2}$ hyperintensity sparing both corticospinal tracts and some thinning of the isthmus of the corpus callosum. Magnetic resonance findings were more evident between 3 and 5 years of age, not only the white matrer lesions, but also the pontine changes and a peculiar patrern of thalanic involvement. This pattern was characterized by $\mathrm{T}_{2}$ hyperintensity and restricted diffusion in anterior nuclei, sparing mammil lothalamic tracts and extending also to the internal medullary lamina.

By the age of 7 to 9 years of life, MRI changes presented remarkable improvement In two patients, Patients 1 and 5 , MRI exams at this age became essentially notmal, except 
Table 2 Summary of the neurological findings

\begin{tabular}{|c|c|c|c|c|c|c|c|c|c|c|}
\hline Patient & $\begin{array}{l}\text { Learning } \\
\text { disability }\end{array}$ & $\begin{array}{l}\text { Low visual acuity and } \\
\text { optic atroptyy }\end{array}$ & Ptosis & $\begin{array}{l}\text { Proximal } \\
\text { wealiness }\end{array}$ & $\begin{array}{l}\text { Distal } \\
\text { wealkness }\end{array}$ & $\begin{array}{l}\text { Pes } \\
\text { cavus }\end{array}$ & $\begin{array}{l}\text { Sensory } \\
\text { abnormalidies }\end{array}$ & DTRs & Spasticity & $\begin{array}{l}\text { Babinstdi } \\
\text { sign }\end{array}$ \\
\hline $\mathrm{PI}$ & + & + & + & - & $=$ & + & - & $\mathrm{H}$ & - & - \\
\hline$P_{2}$ & - & - & - & - & - & - & - & $\mathrm{H}$ & - & - \\
\hline P3 & - & - & + & + & + & + & + & $H$ & Mild & + \\
\hline $\mathrm{PA}$ & - & - & - & - & $=$ & + & + & H & Med & + \\
\hline PS & - & - & - & - & - & - & - & $N$ & - & - \\
\hline P6 & - & - & + & - & + & + & + & $H$ & - & - \\
\hline
\end{tabular}

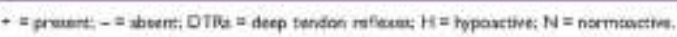

Table 3 Summary of the neuroimaging findings from the six patients performed at different ages

\begin{tabular}{|c|c|c|c|c|c|c|c|c|}
\hline Age & $\begin{array}{l}\text { CaseimR } \\
\text { number }\end{array}$ & $\begin{array}{l}\text { Subcartical } \\
\text { white matter } \\
\text { ( } T_{1} \text { lypertensity) }\end{array}$ & $\begin{array}{l}\text { Thalamus } \\
\text { ( } \mathrm{T}_{2} \\
\text { hypertensity) }\end{array}$ & $\begin{array}{l}\text { Brainstem } \\
\left(T_{2}\right. \\
\text { hypertensity })\end{array}$ & $\begin{array}{l}\text { DWI } \\
\text { hyperintensity }\end{array}$ & $\begin{array}{l}\text { Restricted } \\
\text { diffusion } \\
\text { (ADC map) }\end{array}$ & $\begin{array}{l}\text { Carpes } \\
\text { callosum } \\
\text { (thinning) }\end{array}$ & $\begin{array}{l}\text { Mas } \\
\text { (lactate peaks) }\end{array}$ \\
\hline $3 \mathrm{~m}$ & Pl/OI & + & - & - & NA & NA & $\begin{array}{l}\text { Mild gobal; posterior } \\
\text { pmdominante }\end{array}$ & NA \\
\hline $1 \times 8 \mathrm{~m}$ & P2/01 & $\cdots$ & - & - & Yes & Yes & Isthmos & NA \\
\hline $3 y$ & $P 202$ & $+\cdots$ & $\cdots$ & $\cdots$ & Yes & $\begin{array}{l}\text { No (faciatared } \\
\text { diffusion) }\end{array}$ & Iathmus & NA \\
\hline $3 y$ & PSOOL & $++\infty$ & $\leftrightarrow$ & $\leftrightarrow$ & Yes & NA. & Isthmus & Yes \\
\hline $5 y$ & P1/02 & $+\cdots$ & $\cdots$ & $\cdots$ & Yes & NA & $\begin{array}{l}\text { Mild global; posterior } \\
\text { predominance }\end{array}$ & NA \\
\hline $6 y$ & P5/02 & ++ & + & + & Yes & Yes & Isthmus & Yes: \\
\hline $7 y$ & P5/03 & + & + & + & Yes & Yes & Isehmis: & NA \\
\hline $9 y$ & P5/O4 & - & - & - & No & $\mathrm{Na}$ & Inthmis & No \\
\hline $9 y$ & P1/03 & + & - & + & Yes & Yes & $\begin{array}{l}\text { Mild zatual, posterier } \\
\text { predominance }\end{array}$ & No \\
\hline $10 y$ & PI/04 & - & - & + & No & No & $\begin{array}{l}\text { Mid gobal; postenor } \\
\text { proderninante }\end{array}$ & No \\
\hline Adult & P3:Or & + & - & - & No & Na & $\begin{array}{l}\text { Mild zobal; posterier } \\
\text { prodeminunce }\end{array}$ & No \\
\hline Adout & PSTOI & - & - & - & No & No & Norma & NA \\
\hline Adult & PSWOI & - & - & - & No & No & Norma & No \\
\hline
\end{tabular}

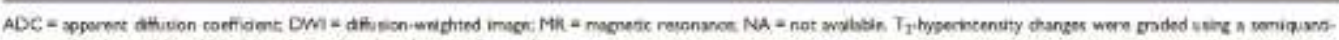

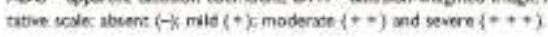

for some callosal thinning. In two parients (Parients 4 and 6), brain imaging was obcained at adult lite and the exams were otherwise normal (except for the optic pathway involvement), In the youngest adult patient (Patient 3) there were also potchy $T_{2}$ hyperinterse abnormalities throughous the supratentorial white matter (without diffusion changes) and reduced thickness of the corpus callosum, particularly the posterior porrions.

Latctate peaks were found using magnetic resonance spectroscopy in only one patient (Patient S), from the four patients who had at least one magnecic resonancr spectroscopy exam in our series. In this patient lactate peaks were found when the patient presented significant structural MRI changes tat 3 and 6 years oldi, and were not present when strucuiral MRI was essenrially normal (ar age 9). In the other three patients the magnetic resonance spectroscopy was performed when the brain MRI has mild white matter abnormaliries (Patienss 1 and 3) or when is was normal (Parient 5).
In Patients 1,2 and 5, who were clinically evalatated at the time that the brain magnetic resonance showed the white macter, thalames and brainstem abnormalities, there was no evidence of any pyramidal or extrapyramidal signs in the neurological examination. Only one patient was submicted to an MRI during the firse year of life, af the age of 8 months, and this exam revealed some widening of the lateral ventrickes and mild diffuse $T_{2}$ hyperintensity in white matter (suggesting at least some delay in myelination) (Parient 1). However, this parient has also a coincidental chromosomal abnormalicy.

\section{Muscle pathology}

Patients $3-6$ anderwent muscle biopsy and in all samples there was the presence of ragged red fibres and SDH and COX negative fibres. Respiratory chain enzyme analysis was only performed in Parient 5 and showed no abnormalities. In Patient 5 , the muscle biopsy was performed at 3 


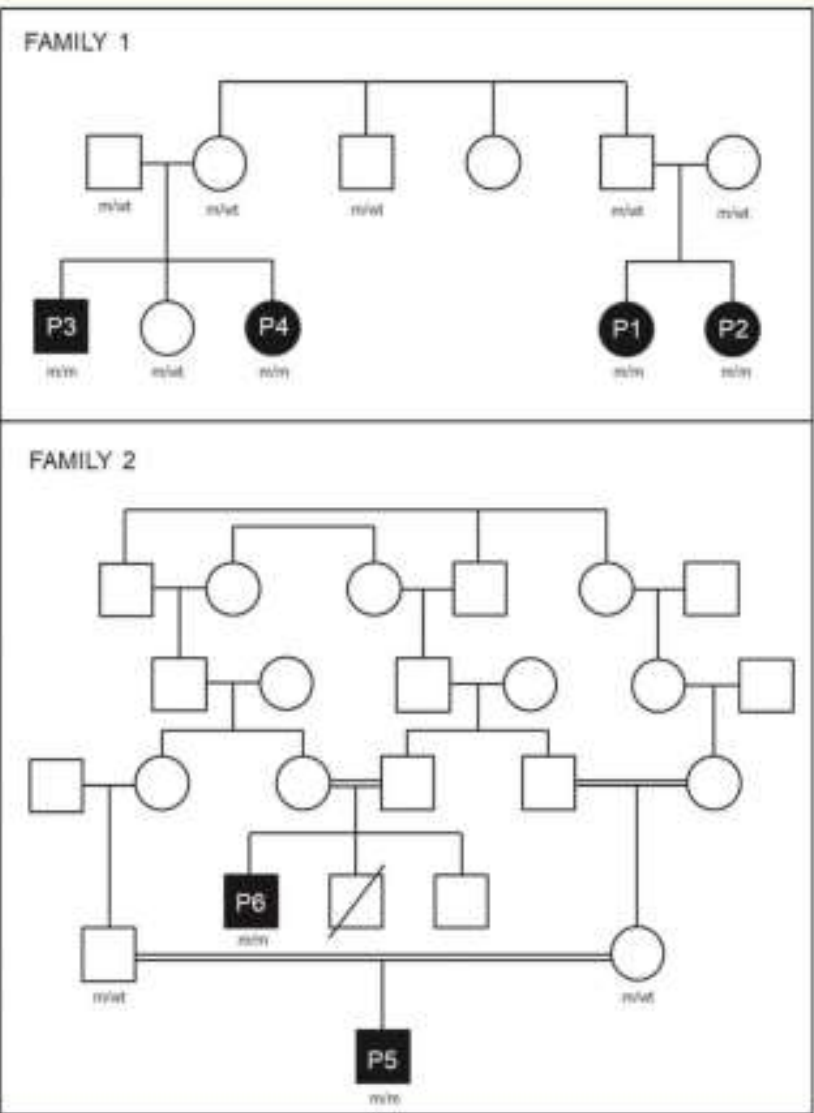

Figure I Pedigree of Families 1 and 2. Filled boxes are affected memibers and unfilled boxes are unaffected. Genocypes are shown where $m=$ mutary, wt $=$ wild type.

years of age and the proportion of ragged red fibres was less frequent than in the others patients. The other three patients (Patients 3,4 and 6) underwent mascle biopsy in adult life.

In Patient 3, the muscle showed more intense alterations, which are illastrated in Fig, 3.

There were SDH- and COX-negative fibees that were clustered together in parch-like areas (Fig. 3A and B) Furthermore, punctate iron accumulation was observed in SDH and COX deficient fibres by iron staining (Fig $3 \mathrm{C}$ ). Electron nicroscopy revealed mitochondrial paracrystalline inclusions in numerous fibres. In these fibres frequent elec tron-dense irregular inclusions were identified that presamably represent iton deposition in the mitochondria (Fig 3D). Immunohistochemical analysis of couplex II and com plex IV subunits showed markedly reduced expression in fibes with low SDH and COX enzymatic activity i Fig. 3E, $\mathrm{F}, \mathrm{H}$ and I) while mitochondrial mass was increased as revealed by the mitochondrial marker VDAC1 iporin; Fig. 3G).

\section{Genetic results}

Genome-wide homorygosity mapping in all affected members of Family 1 revealed two shared homozygous regions, a $1 \mathrm{Mb}$ region on Chromosome 19 iChr19: 9400194 10492040 ) and a $500 \mathrm{~kb}$ region on Chromosome 2 \{Chr2t 89469319-89994709\}, We next examined the whole exome sequencing data from Family 1, limiting our analysis to race, bomozygous yariants that were not synoaymous or intronic and mapped within the regions of bomozygosity identified. The only such variant defected 


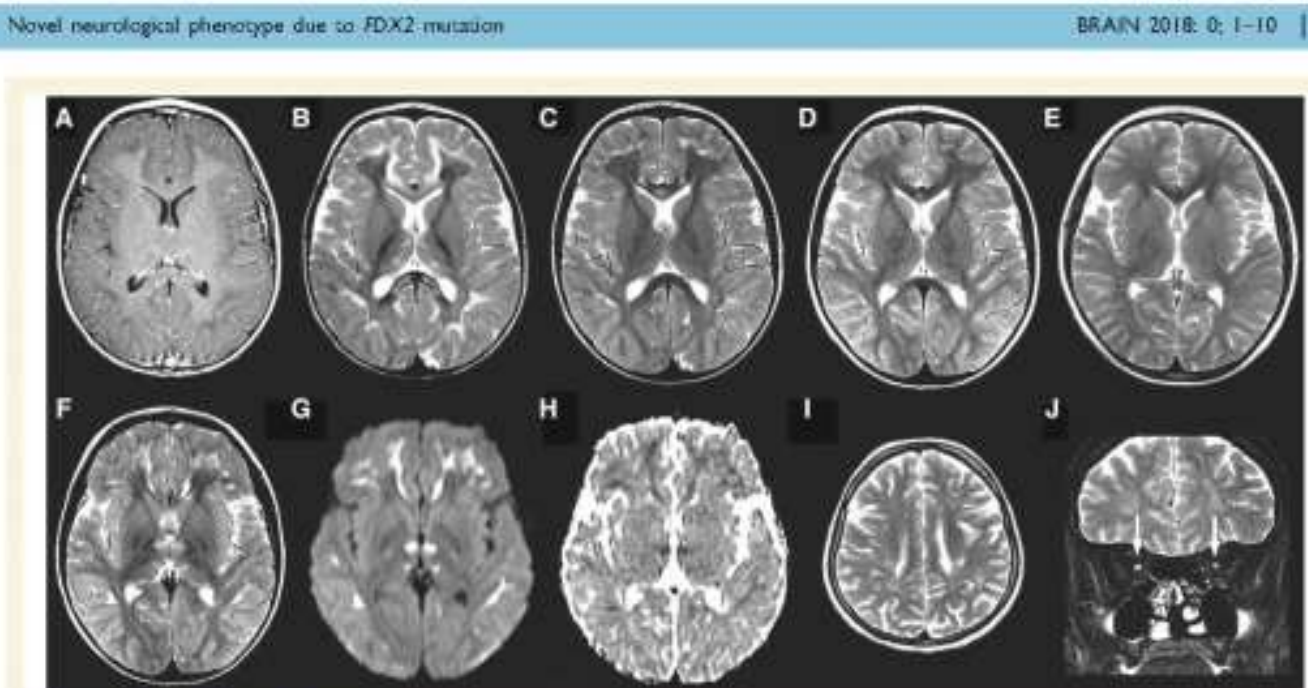

Figure 2 Neuroimaging findings. In Subiecs 5 , at age 3 yeara, nxal $T_{1}$-meighted post-contrast imege (A) demonstrates lypocimensity in the subcorsical white matcer, without abnormal enhancement, Axial $T_{2}$ weighted images from the sume patiant as ages $3\langle$ (B), $6(C), 7(D)$ and 9 year:

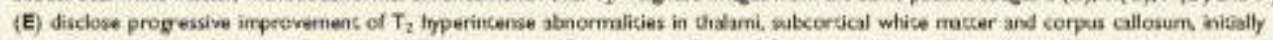
apprecinted in B. Axial $T_{2}$-weigfited image from the sane patient at age 6 years (F) shows sparing of mammillotahmic tacts, seen as $T_{3}$ hpoinserse dots in the centrs of the signal diange in che snterior portion of chalami. Considering the subsequert improvemert, the ressicted

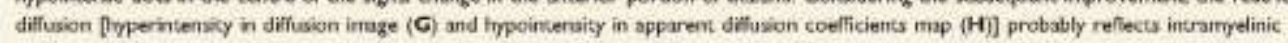

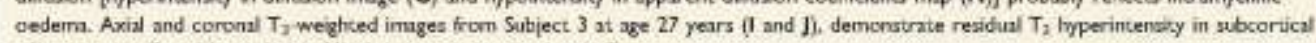
white matier (i) and hypoplasia of both opcic nerves (arrows in J).

was in FDX2 (NM 001031734 c.431C $>$ T, p.PI44L) This variant was not found in the ExAC of $1000 \mathrm{G}$ data bases but was found in the hetecorygous state in 1 of 600 controls from the Brazilian ABraOM database (minor allebe frequency: 0.000821) (Naslavsky ot al., 2017). We validated the variant by Sanger sequencing, confirming that all affected family members were bomozygous, whereas the patients' parents and an unaffected sibling, were all het erozygous. Patient 1 , who bad some additional dysmorphic features not seen in the other five patients described, was found to carry a coincidental tetrasomy for the short arm of chromorome 9, karyotypes $46, \mathrm{XX},-$ i 49$)(\mathrm{p} 10)$. Botb ber parents had normal karyotypes.

Family 2 underwent independent genetic stiolies. The index case (Patient 5) was first investigated for mutations in EARS2 (Steewey, et al., 2012), because of the reversible lenkoencephalopathy, and for mutations in the SDHA and SDHB (Alston et al., 2012), based on the presence of SDH negative fibres in muscle biopsy. No mutations were identified in these genes. Whole exome sequencing analysis was periormed in four members of this family and the same FDX2 mutation detected in Family 1 was identified as the only segregating variant, homorygous in the two affected patients (Patients 5 and 6 ) and beterozygous in the parents of Patient 5.

The FDX2 p.P144L variant affects a highly conserved residue that is identical in all mammals with an orthologous gene, and in invertebrates such as Drosophila melanogaster and Caenorhabditis elegans.

\section{Functional validation of the FDX2 mutation}

Real-time RT-PCR was pertormed using muscle samples from Patients $3-6$ and control muscle from two unrelated individuals. We identified no difference in FDX2 mRNA expression between patients and controls (Fig; 4 A).

To determine whether the mutation affected protein stability, we examined the FDX2 protein levels in muscle from Patients 3 and 6 tone patient from each family) and two unrelated controls by immunostaining. This revealed a severe reduction of FDX2 levels in patients as compared to controls. Equal protein loading was confirmed by Ponceau $\mathrm{S}$ staining (not shown) and by immunoblotting tor a number of other mitochondrial $\left(\mathrm{F} 1 \boldsymbol{\alpha}^{\prime} \beta, \mathrm{VDAC}\right.$, and cytosolic (actin, tubulin) proteins (Fig, 4B). The low amount of $\mathrm{FDX} 2$ in patient samples provides additional evidence that the FDX2 p.P144L mutation is pathogenic.

\section{Discussion}

In this study, we describe a novel childhood onset disorder in two families with unusual clinical, nadiological and 


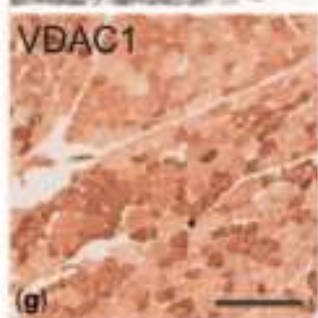

(a)
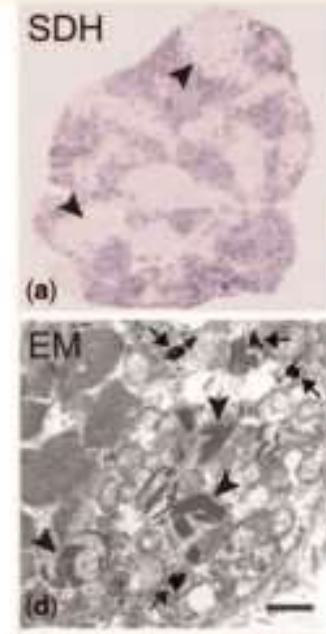

(e)

(b)
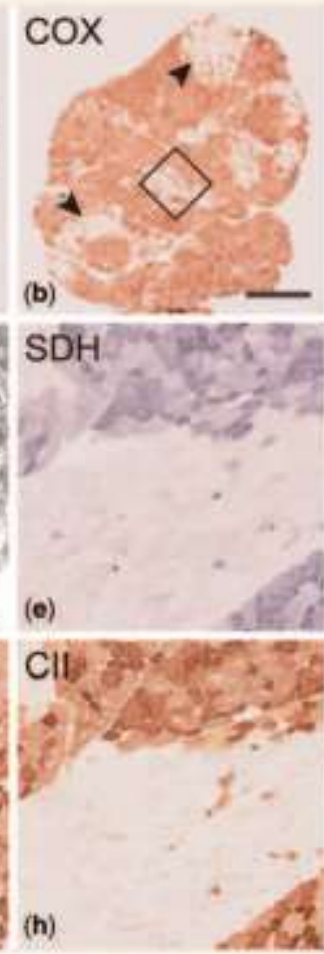

(c)
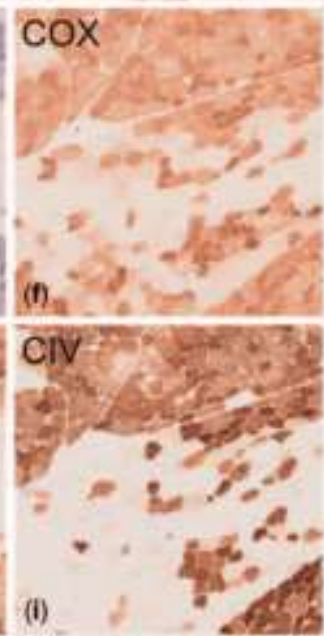

Figure 3 Musche biopyy from Patient 2 demoentrating mitochondrial myopathy and iron deposition. (A-C) are serial sections sthewing an overview of the encire muscle bicpsy cross section. Note the focal deficiency of SDH and COX attecting numerous adjacent fibres in

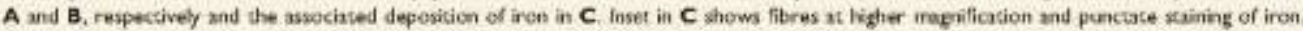

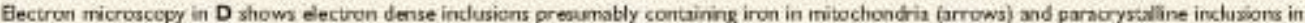

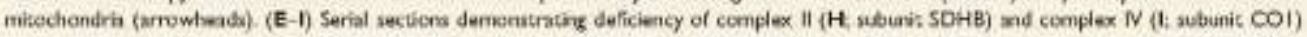
corresponding wo the focal encyme histechernical deficiency of $\mathrm{SOH}(\mathrm{E})$ and $\mathrm{COX}(\mathrm{F})$. Micochoodria are present in the corresponding regions as revesled by VDACI immunohiscocherristry (G). The box in B marks the region shown at higher magnification in serial sections (E-1). Scale bar $=1 \mathrm{~mm}$ in A-C (bar shown in B). Scale bar in $\mathrm{D}=1$ jum. Scale bar $=250$ jam in E-I (bar shown in G).

pathological features. The clinical syodrome included earlyonset optic atrophy, recurtent episodes of myalpia with progressive myopathy, axonal polyneuropatby and a variety of baematological and endoctine abnormalities including microcytic anaemia, subclinical bypotbyroidism, diabetes mellitus and reversible leukoencephalopatby. We used a combination of bomozygosity and whole exome sequencing to identify the cause as a recutrent bomozygous mutation in FDX2. We validated our findings grenetically through segregation analysis and biochemically by demonstrating the almost complete absence of FDX2 protein by western blot in affected patient tissue.

Our clinical assessments of six patients with ages ranging from childhood to adult life allow us to infer the natural history of this disotder. Nystagmus and optic atrophy was the first sign of the disease and was present in the first 3 years of life in all six patients. Myopathic features. developed during the first or second decade of life and presented with mild proximal weakness in limbs and/ot recurrent acute episodes of myalgia and weakness precipitated by triggers such as cold weather and infections. Axonal neuropathy developed in the second decade or in adulthood leading to progressive distal weakness.

Interestingly, two individual reports bave implicated mutations in FDXZ causing a relatively discrete pbenotype of mitochondrial myopatby and rhabdomyolysis without the additional features seen in our patients, or the unique radiological or pathological changes described bere (Spiegel et al., 2014; Lebigot et al., 2017). Both perviously teported cases shared the same mutation affecting the ATG statt codon of FDX2 (c,1A > T) and was predicted to lead to loss of FDX2 expeession. Despite normal mRNA levels of FDX2, we could demonstrate severely reduced protein expression in patient tissue, which could represent 
A

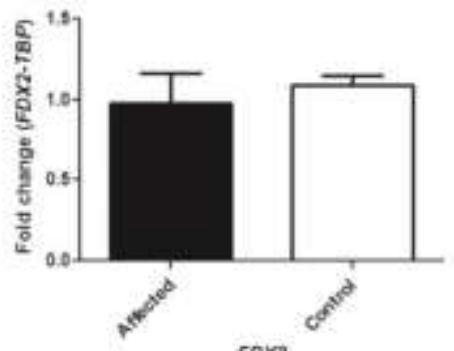

Fox

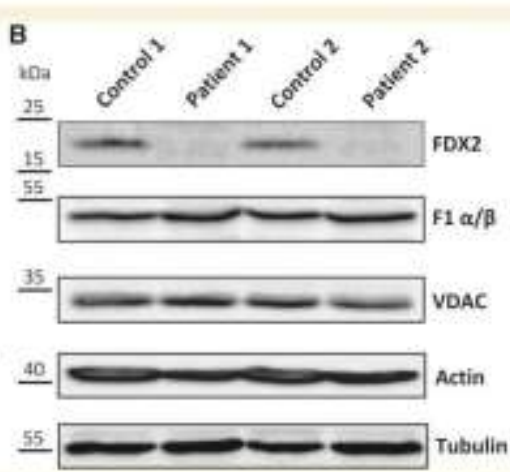

Fizgure 4 Functional studies, (A) RT $q$ PCR showing relative FDX2 expression normalized to TBP in parients and concrols. (B) Western bloteing

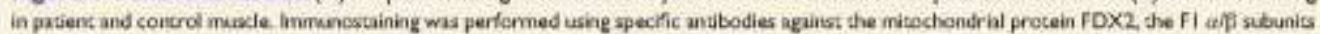
of complex $V$, and the volage-dependent ation channel (VDAC, porin). Staining agairw actis and cubulin served as a loating conerol.

instabulity or excess dezradation of misfolded or otherwise dysfunctional protein.

The extensive and muitisystem involvement in out pa tients is reflected by the phenotype associated with muta tions in the gene of an essential FDX2 interaction partner within the $[\mathrm{Fe}-5]$ cluster assembly machinery, FDXR, encoding ferredoxin reductase. These paticnts develop opric arrophy in addition to deafness and sensory neuropathy (Paul et al., 2017).

Leukoencephalopatby is reported in several other disonders of [Fe S] biopenesis, e.g. NFU1 and NUBPI, muta tions. In NUBPL mutations (Kevelam et al., 2013; Abting et al, 2015), some patients show progressive improvement of signal abnormality in the corpus callosum and cerebral white matter, although this occurs in the setring of clinical worsening over time (Kevelam et al., 2013). In out patients we observed a progressive improvement of the white matter, thalamus and brainstem lesions compatible with reversible or partially reversible leukoencephalopathy. This finding is intriguing and further studies will be nesessary to explain the improvement of the cerebral aboormalities. However defects in MLCI, HEPACAM and CLCN2 cause kulcoencephalopathies characterized by intramyelinic oedema (T-hyperintersity in subcoctical white matter and corpus callosum, associated with restricted diffusion), and in some the intramyelinic cedema can be reversible (Depienne ot at., 2013). This may explain the reversiblity seen in our patients in whom intramyelinic oedema was a feature.

Interestingly, we observed that the leakoencephalopathy did not show a clinical cortelation. None of the three patients (Patients 1,2 and S) demonstrated any pyramidal or extrapyramidal signs at the time that the brain MRI demonstrated white matter, thalamus and brainstem abnocmalities. Therefore, we can conclude the leukoencephalopatby related to the FDX2 p.P144L mutation was reversible and asymptomatic in the patients bere described. However, in two adult patients mild uppet motor neuron sipns were observed indicating that the pyramidal tracts may become involved over time. Follow up of these patients can clatify this neurological finding.

The muscle bistology in our patients is unusual, with a pattern characterized by fibres with mitochondrial peoliferation in Gomori tricheome staining, and clusters of fibres that were SDH- and COX-negative. This bistochemical abnomality is unusual for classical mitochondrial myopathies in which the tagged red fibres are SDH positive and COX negative (DiMauro and Gurgel-Giannetti, 2005). The histopatholowical findings are also different to findings in most cases of mitochondrial complex II deficiency, in which there are ragged red fibres that are SDH negative but positive in the COX reaction (Alston et al., 2012). These findings are consistent with the function of FDX2 in the [Fe/S] clister assembly of respiratory complexes IIII and heme A produc tion for complex IV iSheitel at al., 2010). The immunobistocbemical deficiency of subunits of complexes II and IV showed the same distribution as the enzyme histochemical deficiency of COX and SDH indicating that defective assembly of the respiratocy chain complexes cause the enzyme deficiency. The patchy distribution of deficiency and variabiity from one cell to another remains unexplained.

The peculiar and characteristic regional SDH and $\mathrm{COX}$ deficiency and irov accumulation as revealed by iron staining and efectron microscopy observed bere have also been reported in ISCU myopatby IOlsson of al., 2008; Kollberg et al., 2009). These similarities suggest that both ISCU and FDX2 are important for cellular iron homecostasis via their tole in the maturation of cytosolic IRP1 to an aconitase (Paul and Lill, 2015).

Defects in [Fe-S] cluster biogenesis are incteasingly recognized as causing neurological disease. They play a critical role in mitochondrial function, which is exemplified by the varied neurological features in these cases, affecting the CNS as well as peripheral nerve and muscle. In conclusion, this study reveals that a biallelic mutation in FDX2 causes 
a complex childhood onser syndrome with unusual histo pathological features, and confirms the important role that FDX2 plays in mirochondrial health and disease.

\section{Acknowledgments}

Maurilio Pacheco e a Larissa Torres: logistic support in Alfenas (MG, Brazil).

\section{Funding}

This work was in part financed by Consetho Nacional de Desenwolvimento Cientifico e Tecnologico - CNPq, Fapernig, FAPESP-CFPID \& INCT-CNPqi; The Leonard Wolfson Experinvental Neturology Centre, The Medical Research Council (MRC) and the Wellcome Trast. R.L. acknowledges generous financial support from Deutsche Forschungsgemeinschaft (SPP 1927) and networking support from the COST Aetion FeSEioNer (Contract CA15133). The Swedish Research Council Proj no 2012-02014 (to A.O.).

\section{References}

Ahting U, Mayr MA, Vanlander AY, Hardy SA, Santra S, Makowska C et al. Clinical, bioshemical, and entetic spectum of grven patients with NFUI defisiency, Front Genet 2015 ; ff 123

Alston CI, Dsvison JE, Meloai F, van der Westhuizen FH, He L Hornig Do HT, et al. Recessive grnaline SDHA and SDHE muta nons cuusing leskiodystrapky and isolited anitochondrul complex 1 deficiency, I Med Geaer 2012: 49: 569-77,

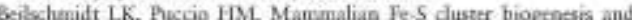
irs implication in drease. Jlochime 2014; 100: 48-60,

Beinert H. Holm R.H, Manck E. Iren-salfar clesterst nature's modulas, mulepurpose structares Saence 1997: 2777 653-9.

Baniecki MT, Freibert SA, Muhlenhoif U, Lill R, Cygles M. Structure and functional dynamias of the initochoedrial Fe/S duster syathesis complex. Nat Comunin 2017; 8: 1287 .

Braymer II, Lill R. Iron-wulfur cluster boageness and trafficking in mitochondrit, J fliol Chrm 2017, 292, 12754-63.

Calwo SE, Tucker EJ, Compton AG, Kirty DML, Crzwforl G, Burn NP, it al. Hight throapteput, pooled sequencing ideutifes mutanion in NUBPI, and FOXRED1 in humas complex I deficiency, Nat Geoer 2010; 42: 851-58.

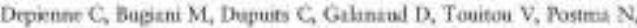

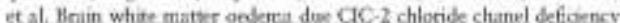
an obvervational enatytical study. Lancet Neorol 2013: 12:659-68.

biMauro \&. Gurgel-Giannetsi J. The expanding phenotype of mito chondrial myopzthy. Curr Opin Neurol 2015; 18: 538-42.

DiMauro 5, Servidei 5, Zeviani M, DiRocco M, DeVivo DC DiDonato $S$, et al. Cytochrome $c$ axidise defiency in Leigh symdrome. Ann Neurol 1987, 22: 498-506.

Duirr A, Consee M, Apid Y, Campuxane Y, Mirmard C, Pener C, et at. Clinical and peneric ohnomalinies in patiens with friedrrich? ataxis. N Engl f Med 1996; 335: 1169-75.

Fontrave M. Iron-sulfur dusters: everexpanding rolos. Nar Chen Biol 2006; $2 \div 171-4$.

Kevelam SH, Rodenburg RI. Woll NI, Ferreirs P, Lansing RI.

Nietmans LG, et at. NUBPL inutations in patiens with complex I deficiency and distinct MR1 pattern. Nesurology 2013, 30t 1577-83.
Kollberg G, Tulinius M, Melibeng A, Darin N, Andmen O, Halmgren D, of al. Clinical manifstation sad a bew ISCU mutation in tron-

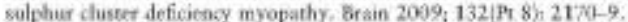
Leligat E, Gaiguand P, Dorbax. Slama A, Rio M, de Lonluy P, et al. Impact of murations within the [FeS] dasser of the lipoic biosynthesis pathways on mitochoodrial protein expression profiles in filmoblass freen parients. Mol Gener Merab 2012; 122: 85 - 94 .

Legati A, Reyes A, Cecsateli Berni C, Srehise 0 , Marcher S, Lampenti $C_{3}$ es al. A novd de novo dominut mutation in $150 \mathrm{C}$ associatnal with mitochandrial myopathy. I Med Genrt 2017; 54, 815-24.

Lil R. Finction and biogentses of iron-sulphur protens. Nature 2009; $460 ; 831-38$.

Mochel F, Knielte MA, Tong WH, Hemander D. Ayyad K, Taivassalo $\mathrm{T}, \mathrm{A}$ al. Splior matasion in iroe-sulfur dustir scaffold protein ISCU causes mpoputhy wilh exercise intoletanc. Am J Hum Gent 2008; 82: $652-60$.

Naslavsky MS, Yamameto GL, de Almrida TF, Earuina SAM, Sunaga DY. Phe N, et al, Fyomic vatiants of an elderty cohors of Braxilians. in the ABraOM database. Hum Mutat 2017, 38: 751-63.

Nordin A, Larson E, Thornell LE, Holmbery, M. Tissue-sprtcifs sphl cing of ISCU ranits in a steletal musde phenotype in myopathy with lactic acidosis, while complete loss of ISCU results in early embryonic death in mice. Ham Genet 2011, 129:371-78.

Olssan A, Lind L Thoetrill LE, Holreberg M. Mropathy with lectic

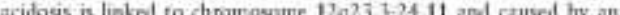

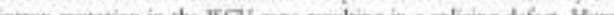
Mal Gent 20088 17 i $666-72$.

Panl A, Drecourt A, Petit F, Deguine DD, Vasnier G, Oufadem M, et al. FDXR matations cause sensorial neuropathies and expand the. spectruin of minacandrial Fe S Synthesis Deseases. Am I Hum Genet 2017, 101: 630-7.

Paul VD, Lill R. Biogenesis of sytosolic and suclest ifon sulfur proteins and their role in genonse stability. Biochim Biophys Acta 2015; $1853,1528-39$

Purcell S, Neale B, Todd-Brown X, Thomas L, Ferreina MA, Bender D, et al. PLINK: a tool set for whole genome association and papula: tion based linkage unalyses. Am J Ham Genet 2007, 81: 559-75.

Rouault TA. Iron-aulfur prateins hiding in plain sight. Nat Chem fiol $2015 ; 11: 442-5$.

Schmitgen TD, Livak $X$. Analyzing tral time PCR data by the coen parative CT) wethod. Nut Protoc 2008; 3t 1101-08.

Shefitt AD, Strhling O, Pierik AJ, Netz DJ, Kesscher S, Elsisser HP, et al. Harsun adi, an mos-sulfar clusar assercbly factot for resgira: tory complex 1. Mol Cell Biol 2009; 29: 6059-73.

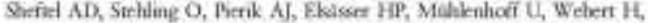
er al. Huimans possess rwo minodhondrial ferredoosins, FDX1 and FDXZ2, wah distind mits in steradogreses heve, and FeS cluster biasynthesis. Proc Narl Acoul Sci USA 2010: 10\%: 11775-80.

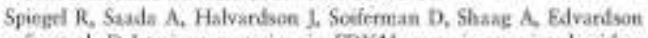
S, et al. Delettrious muturion in FDX11. gene is aseociated with a aonel mitoshondrial musde myopathy, Eur J Hum. Gener 2014; 22 : $902-6$.

Sterweg MF, Ghezsi D, Hsack T, Ablink TF, Msrtincli D, van lerkd

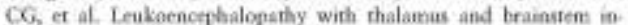
volvernent and high ladate 'LTBL'caused by EARS2 mutations. Brain 2012, 13577 57? 1397-94.

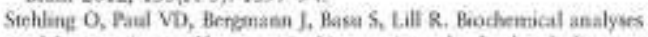
of human iroe-sulfur protein biogrnesin and of redatod diseases. Methods Enxymol 2018, 599, 227-63.

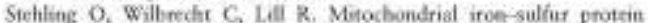
hiogrnesis and human disuse. Boochimue $2014 ; 1006 \mathrm{r} 61-77$.

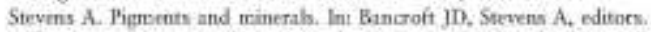
Theory and practice of histological teclenicues, Edinburght Churchill Livingstowe, 1990 , p. $245-67$.

Webent H, Freibert Sa, Gallo A, Heidenreich T, Limne U, Amlacher S, et al. Functional reconstitution of mitochondrial Fe/S chaster symthe sis on lsul revezls the involvement of ferredoxin. Nat Commun 2014: 5: 5013. 
10.11 Apêndice K - Practical approach to the diagnosis of adult-onset leukodystrophies: an updated guide in the genomic era. J Neurol Neurosurg Psychiatry 2019:90:543-554.

This work is licensed under the Creative Commons Attribution 4.0 International License. To view a copy of this license, visit http://creativecommons.org/licenses/by/4.0/ or send a letter to Creative Commons, PO Box 1866, Mountain View, CA 94042, USA.

Lynch DS, Wade C, Paiva ARB, John N, Kinsella JA, Merwick Á, Ahmed RM, Warren JD, Mummery CJ, Schott JM, Fox NC, Houlden H, Adams ME, Davagnanam I, Murphy E, Chataway J. Practical approach to the diagnosis of adultonset leukodystrophies: an updated guide in the genomic era. J Neurol Neurosurg Psychiatry 2019:90:543-554.

http://dx.doi.org/10.1136/jnnp-2018-319481 


\section{Q REVIEW OPEN ACCESS \\ Practical approach to the diagnosis of adult-onset leukodystrophies: an updated guide in the genomic era}

David S Lynch, ${ }^{1,2}$ Charles Wade, ${ }^{2}$ Anderson Rodrigues Brandão de Paiva, ${ }^{3}$ Nevin John, ${ }^{4}$ Justin A Kinsella, ${ }^{5}$ Aine Merwick, ${ }^{6}$ Rebekah M Ahmed, Jason D Warren," Catherine J Mummery, ${ }^{8}$ Jonathan M Schott, ${ }^{8}$ Nick C Fox, ${ }^{8}$ Henry Houlden, Matthew E Adams, Indran Davagnanam, ${ }^{910}$ Elaine Murphy, Jeremy Chataway ${ }^{4}$

- Addikional saterial is pusished entine only To wew please vist the punal conlite

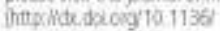
jhie-2016-319481?

for riun tered affilistions : see ied at aiftele.

Correspondence to

Di Dasid Styno, Depoument of Molecular Neurugonoce UO instrute of tieuigibgy. Londan

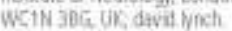
boud acik

Alocened 19 Augst 3018 Fievere of 24 Septesiber 2011 sompted 2 October 2015
(7) Check for updates

Q Authoribs (or that encloyed's 20 18. Ae-us unem toed indar ce ky Puthlishad by BMI

To dte: Lynch D.5, Wade C Paiva AQR a al / Mowol Newrsuxg Porchiaby Esut

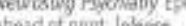

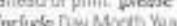

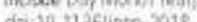

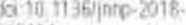
319481

\section{ABSTRACT}

Adult-onset lewkooystrophos and genetic

eukoencephalopathies comprise a diverse group of neulodegenerative đisorders of white matte witha vide age of coset and phenotypic spectrum. Paterits with white mattet abnomal ties defected on MRt offen present a bagnostic chalenge to both general and sfedalist neutologists. Patients typically present with a rogirswe sodrome induding varicus conibingtions of cognitive impaiment, movement disondes ataxis and upper motor neuton sigls. There are a numbet of im rortant and treatahle amuired causes for this maging and ditsica presentation. There ale dso a very latge number of genetic causes which due to theit relative ratity and sometimes valable and cherlapping presentotions can be dificult to diagnose. In this review, we provida a strictured espreach to the diagnosis of intierited disoders of white mattar in aduits. Whe describe clinacal and radiobgikal dues to ad diagnosrs. and we present an overvew of both common and rats genetic whife matter discoders. We provide atvice on testing for axpured couses, on exduding small wersel discrase mitnies, and detailed achice on metabolic and genetic testing available to the fractising neulologist. Common qenetic euvoencephalopathies disoussed it detial include CSF $1 R$, AARS2, crebral arteriopathy with subcortical infarcts and eukpencephakpathy ICADASIL), and mischandria and melabolic dsorders.

\section{INTRODUCTION}

Adult patients with exteneive white matter hyper intensaties on MRI present the acurologise with a complex diagnostic task. There are a wide variety of disorders that can lead to these imaging appearances, including inflammatory, intective and malignant causes, as well as extensive small vessel disesse, Often the most difficult patients to dagnose however are those with presumed genetic conditions, including the classical leukodystrophirs, where the primary pathology is based in the myelin, or the senetic leukoenoephalopathies, where the pathology is mainly neuronal or systemic. Patients may present with a wide spectrum of clin. ical features includiag cognitive and neunopsychistrie changes, movement disorders, spasticity and seizures. The diversity of genetic setiologies combined with the often-overlapping clinieal and radiological phenotypes can make definitive diag. nosis challenging.

In 2014 we set out a practical approach to navi gate through the maze. ${ }^{1}$ However, even in the space of 5 years, there has been a subseantial increase in the number of implicated genes. Improved pheno. type-genotype correlation and increased access to advanced sequencing techinologies have therefore changed our diagnostic approach.

This new review provides an opportunity to apdate and refine our practical approach for the diagnosis of senetic teukoencephalopathies in the era of whole genome sequencing. We would strongly recommend that it be read with the previous paper to avoid any repetition. As before, we emphasise the need to exclude as far as possible any acguired disorder, emphasise facets of the relatively connmoner classical leukodystroghiesleukoencephalopathies, then highlight newer emerging disesses. Clinical/MR1 features which point towards certain conditions are described. We end with an algorithm that we have found useful and deseribe car own experience.

For clarity, we are describing an appeoach where the symptoms have bezun after the age of 16 and the MRI shows widespread cranial white matter change on standard (T2, fluid-attenuated inversion recovery (FL.AIR)) sequences.

\section{Excluding common acquired}

eukoencephalopathies

As emphasised previously it is imperative that treatable and accuired causes of white matter discase are ruled out as far as possible, before the patient is referred for investigation of a genetic leakodystrophy. As a minimum, all patients should undergo infective screening, including testing for HIV syphilis, hepatitis $\mathrm{Bj} / \mathrm{C}$ and tuberculosis. Patients with a history of immunosuppression should be tested for progressive multifoeal leukoencephalopathy by cerebrospinal fluid (CSF) examination for the pres ence of $\mathrm{JC}$ virus. $A$ high index of suspicion should remain for neoplasia, including primary ecntral oervous system (CNS) fymphoma and gliomatosis cerebri. A careful history will reveal if the patient has been exposed to chemotherapyiradiotherapy 

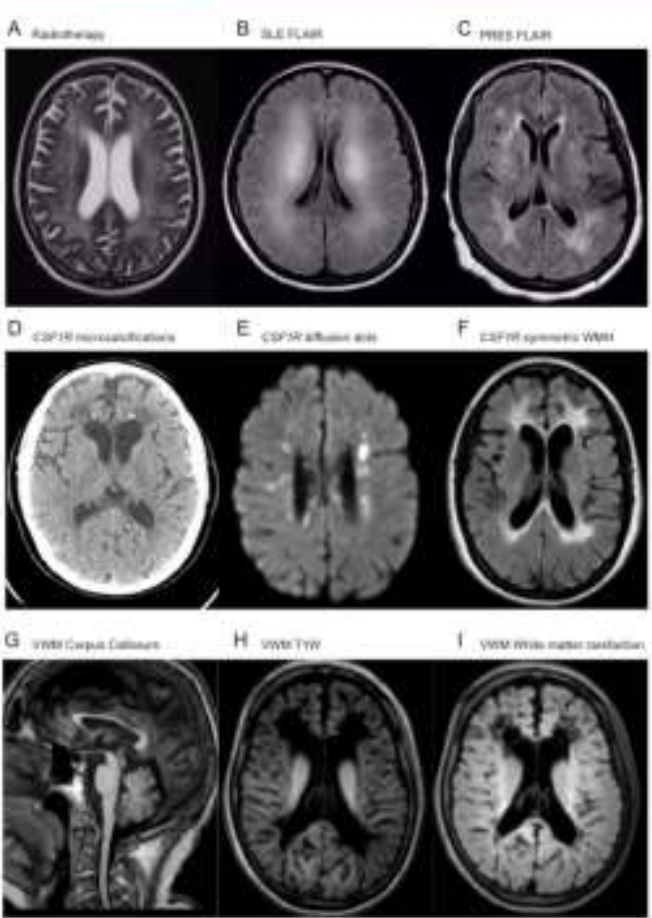

Figure 1 Axial T2-weighted MRi of nadiotheapy changes (A), as well as axial FLAR MRi of orebral Systemic Lupus Eythematosus (SLE) (B) and PRES iC demonstrating symmetrical and confiuent pefiventicular and subcortiral white matter signal hoperintensity 3 WMAHY Axial non contrast CT demonstrating subcortica volume loss punctate calification and confluent hypodensity adjacent to the frontal hams of the lateral ventricles (D). Axal B1000 DW and FLAIR MUU accuisitions showing DWI arid punctate lesions (E) as well as conilluent perwerticular hyperintunse signai changes (fF) in CSF IR leukodystrophy. MAl sagittal TTW accuisition showing affluse thirining of the corpous callosum (G) as weil as axial TIW ( $\mathrm{H})$ and FLAIR fi) sequences demonstrating confluent rarefaction of the subcortical and periventricular white matter adjacent to the frontal harns and ventricular trigones of the lateral ventrides in WWM dsease. FLAIR, fludidtenuated inuersion recovery; PRES, posterior teverstble leakencephalopathy syndrame, $T 1 W, T 1$-weighted WWM, vanisting white matter.

(figure 1A) (in particular 5-fluorouracil and metbotsexate) and recreational drags like heroin or methanol, which can all lead to confluent, symunetrical leukoencephalopathy. Treatable inflammatory disonders like systemic lupus erythematosus must be considered (figure 1B,C). Posterior reversible leukoencephalopatiny syndrome causes a dramatic leukoencephalopativy otten with infancts and microhaemorrhages (figure 1D), which improves over time. Further guidance on the initial work-up of these patients can be found in round 1 investigations (online supplementary table 1 in Ahrned $t$ al, Journal of Neurology. Neurasargens, and Psychisatry.

Features sagrestive of an acquired disorder include rapid onset, steroid responsiveness, systemic features, MRI gadolinium enhancement and cervical cond involvement-although of course there are exceptions as discussed below:
Severe small vessel disease or genetic leukoencephalopathy? A large number of patients referred for investigation will not be diagnosed with a generic leukodystrophy, but instead will be diagnosed with severe acpuired small vessel disease. These patients are more likely to present at an older age, have significant cardiovascular risk factors, and clinkilly are often isymptomatic or experience slow, indolent decline. They lack a clear family history to stagigest a genetic origin. Imaging is likely to show increased T2FLAIR signal in the periventricular and cerebral white matter, the bast ganglia, pons and cerebellum with chronic lacames and cerebral microblends. ${ }^{2}$ In contradistinction to many inflammatory disorders such as multiple sclerosis, cervical cord imaging will be normal. In older patients $\langle$ ege $>60$ years), extensive genetic testing is unlikely to reveal a canse. However, in patients with this imaging anpearance at a youmger age, consideration should be given to the genetic forms of small vessel disease (eg, cerebral arteriopathy with subcorticat infarcts and leukoencephalopathy (CADASIL), COL4AI), which are discussed below.

Clinical and radiological pattem recognition

Many adult-onset leukoencephalopathies present in the same waty, with a variable degree of cognitive decline, spasticity, apraxia and ataxia. This presentation is non-spexific, and in these cases a non-biased approach using knowledge of the most frequent syndromes and next-generation seguencing technologies is the mast efficient ronte to a diagnosis. However, many of the syndromes described below have particular clues to diagnosis which may be found in a careful history and neurological examination. The mode of inheritance is impottant and can limit the number of conditions to cossider (table 1): however, the nost common inberitance pattern in aduits is sporadic. This may suggest an autosomal recessive node of inheritance in a small family, reduced penetrance in an autosomal dominant condition or even a censored tamily history. The ethnicity of the patient and geographical region of origin are relevant as the frequency of each disorder can vary substantially in different regions.

$>$ The most helptul and disceiminating symproms and signs are described in table 2 . These inchide the importance of noxing endocrine abnormalities soch as premanure ovarian tailure (POF) (vanishing white matter (VWM) disease, AARS2) of hypogonadotrophic hypogonadism (Gordon Holmes syndrome, POL.R3-related disotders). Movement disorders such as prominent parkinsonism or chorea are important, as are the presence of early autonomic (LMNBI) or urinary symptoms (adult polyglucosan body disease?. Peripheral demyelinating neuropathy may suggest metschromatic leakodystrophy (MLD), and adrenal failure is highly suggestive of adrenoleakodystrophy (ALD).

Similarly to the clinical presentations, the radiological appearance of gentetic leukoencephalopathies can be non-specific, but there are important features to note, Deep white matter diffusion abrormulitics bave been well described in CSF IR and AARSZ, in addition to prominent involvement of the corpus cillosum. A patchy leukoencephalopathy with lacunes, microhaenuorhages and anterior tempoeal loke involvement is suggestive of a yascular disorder stch as CADASIL or cathepsin A-related arteriogathy with strokes and leukoencephalopathy (CARASAL). Hypomyelination is an importint signt to note, as there are only a small number of genetic diseases known to canse this radiological appearance. Useful radiological signs cin be foemd in table 3 . 


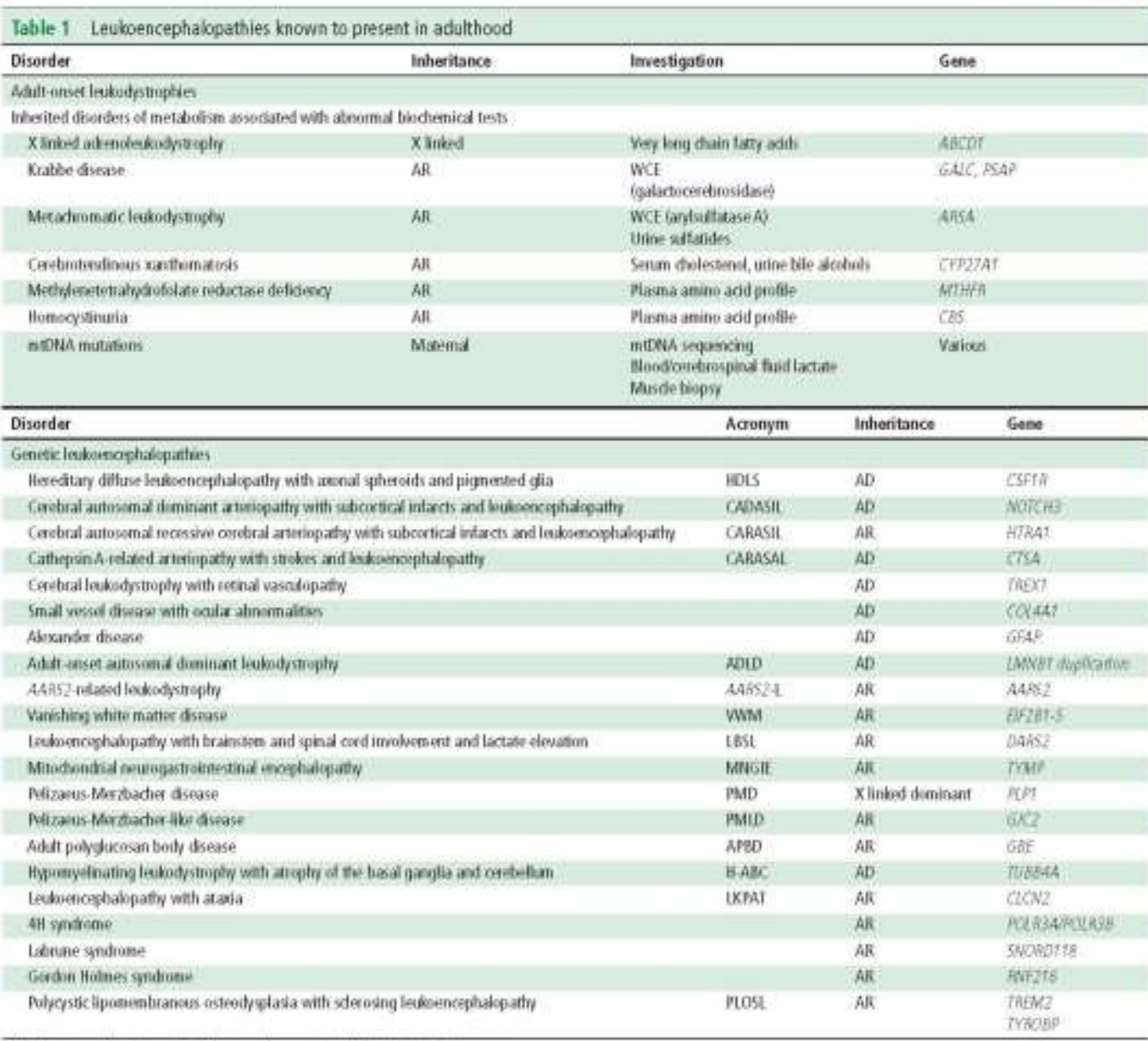

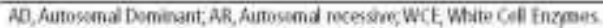

Metabolic leukodystrophies

After excluding common acquired leukocneephalopathies the first prionty should be to identify patients with an inberited metaholic disonder. A small number of tests will detect the diseases that present in adulthood. Recommended testing includes a very long chain fatty acid (VLCFA) profile in men (ALD), specific white ofl enzyme activities (Krabbe discase, MLD, raised serum cholestanol/urinary bile alcohols (octebrotendinous xanthomatosis (CTX)) and plasmu amino acids (nethylenetetrahydeofolate reductase (MTHFR) deficiency and homocystinuria) (table 1).

\section{$X$ linked ALD}

Adult-onset ALD is a rare X linked metabolic disorder of peroxisomal Gatry acid beta-axidation which results in the accumulation of VLCFA in plasma and tissues, including white matter and the adrenal eortex.

ALD is associated with three main phenotypes, indading Addison-only disease, adrenomyelonteuropathy (AMN) and oerebral ALD (CALD). Addison-only prexents most commonly by age 8 years, and although it begins without evidenos of neurological abnormality some degree of disability (most commonly $\mathrm{AMN}$ ) usually develops later. Indeed, virtually al patients with ALD who reach adulthood develop AMN, usually between 20 and 30 years of age. AMN is a non-inflammatory distal axonopathy, and is characterised by progressive spasstic parapiaresis sensory ataxia, sphincter dysfanction, impotence and pain. CAID usually only affects men and presents with rapidly progressive inflammatory demyelination in the brain, leading to rapid cognitive and neurological decline, dementia, ataxia, seixures and death.

MRI is always abnormal in neurologically symptomatic met with cerebral disease. Early changes include T2FLAIR hyper intensities in the parieto-occipital regions and splenium of the corpus callosum. A minority of patients will demonstrate signal abnormalities predominantly in the frontal lobes and genu of the corpus callosum. Peripheral rim enhancement is a typical ieature, ${ }^{+2}$ 


\section{Neurogenetics}

Table 2 Clinical features that can be associated wath specific leukodrstrophies

Clinical daracteristics of specilic leukodystrophies

hemsiar ovasian filare $\quad$ WMA

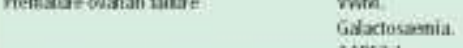

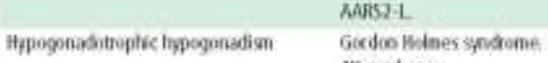

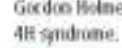

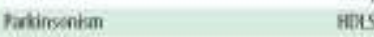

Gorea Gordon Bdmes syndome

Filat mpodenus sesarder dsease

Avood peripherat nesogatly AID.

ISSi
APED
CTX.
MPD.

Marupatity MAD

Cptic atrophy

MD.

Krathe doesse.

ALD.

PMD miteVA autations.

Auterdinefidoeng ALP.

Dented dincranalses $\quad$ AH spolone

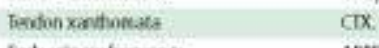

Eait/ winary freqsency APtD

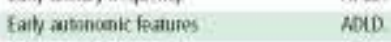

Eatly scaminent atacts $\mathrm{CTX}$.

Grodce Hotnes spademe

IKPAT

Myraine weith aura

Catararts

CAMASIL

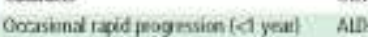

Krabte dhese:

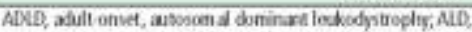

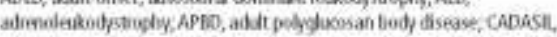

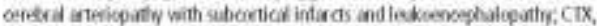

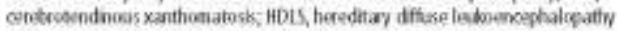

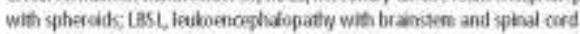

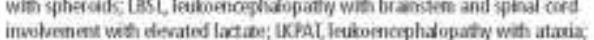

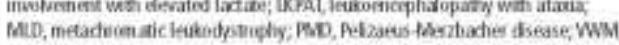
variving wetite manet.

Elevated levels of VLCEAs in the blood are auggeative of a peroxisomal disceder, and the diagenosis of ALD can be confirmed by sequencing of the ABCDI gene. Early diagnosis and family screening are essential to reduce the risk of untreated bypoudrettalism, and to identify early those patients who may benefit from haematopcietic stem cell transplantation (HSCT).

\section{Krabbe disease}

Krabbe discase is a tare autcosmal recessive disorder caused by loss of function mutations in GALC, leading to deficiency of galsctocerebrosiduse, a lysosomal enzyme responsible for the degradation of galactocerebroside to ceramide and galactose. In Krabbe diseuse, galactocerebroside aceumulates in the peripheral and central nervoas system prodacing eereloral atrophy loss of myelin, gliosis and globoid cells?

There are three forms of Krabbe disease: infantile, juvenile and adult. The infantile form is the mose severe and ustally presents between 3 und 6 months of age. After a normal neonatal period, thase affected develop a rapidly progressive course involving irritability, hyperaesthesia, visal and hearing loss, severe cognitive and motor deterionation, and seizares. This groop rarely survives beyond 2 years. Nerve conduction studies
Table 3 Imaging features associated with specific leukodystrophies

Imaging chwacteristics of spectic leukodystrophies

\begin{tabular}{|c|c|}
\hline Fontéf pessiningor & Nexandes disene \\
\hline Bast gandia atenomalibes & 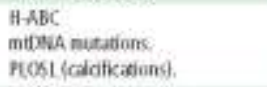 \\
\hline teppanydisation & 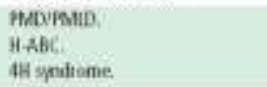 \\
\hline Anetio vesipoed lobe signal abosmsity & $\begin{array}{l}\text { CADASA. } \\
\text { CARASIL } \\
\text { CAMASAL. }\end{array}$ \\
\hline Deep white matre affusine dots & $\begin{array}{l}\text { HDAS, } \\
\text { AARS2-L }\end{array}$ \\
\hline Corpus calosuse imolvement & 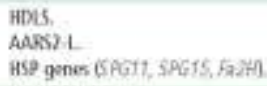 \\
\hline 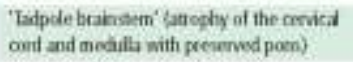 & Alexandet diwane \\
\hline Dentale indes signal diangulysts & $\operatorname{cIX}$ \\
\hline Spind errd abtomalities & 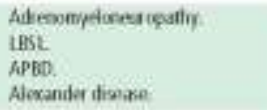 \\
\hline Made cercteds and cerietral petiondes & URPAL \\
\hline Contrast antanoanent & $\begin{array}{l}\text { AII } \\
\text { Alexander diseres } \\
\text { Krabbe disene. }\end{array}$ \\
\hline 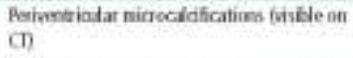 & HDSS. \\
\hline Extemive caldifcatiues and gasts & Lanne symitone. \\
\hline Bone costs un $X$-riay & nOSL. \\
\hline
\end{tabular}

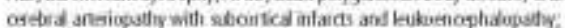

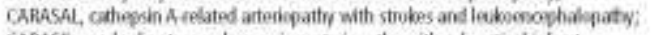

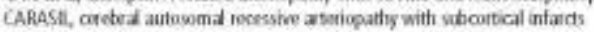

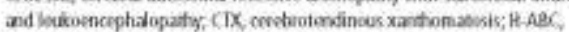

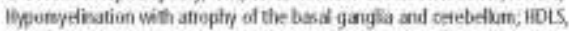

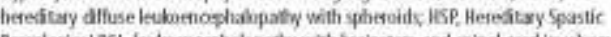

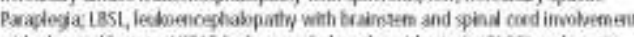

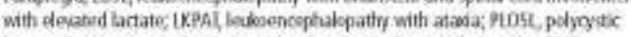

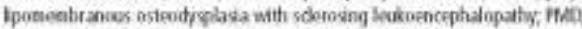

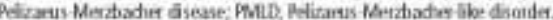

show a demyelinating peripheral neuropathy and CSF analysis may reveal increased total protein concentration."

Juvenile and adult (late) forms of the disease have a milder, mone varied phenotype, a slawer rate of progression and a significantly longer lifespan (although we have observed a rapid deteriorstion ower a year in one case). Typical features include spasticity, dementix, ataxia, peripheral neuropathy and visual lose. The T2/FLAIR signal abnormality in Krabbe discase predominantly affects the corticospinal tracts, from the cortex, through the cocona radiata internal capsules and cerebral peduneles. The optic radiations are frequently involved, and intracranial ealeifications have been reported, but may only be apparent on CT imaging. ${ }^{10}$

The diagncsis of Krabbe disease can be made by assay of galac. tosylocramidase activity via white cell enzyme testing.

\section{Metachromatic leukodystrophy}

MLD is an autosomal recessive disoeder eaused mainly by deficient activity of arylsulfatase A (ARSA). ARSA is responsible for the desaifation of cerebroside sulfate, a major glycolipid of myelin, and decreased ARSA activity leads to the accamulation 
of cerebroside salfate in the CNS arid peripheral nerves (as well as the kidneys and other visceral organs). The result is central and peripheral demyelination.

In almest all cases, reossive mutations in the ARSA gene are responsible, although very rarely MLD can be caused by inutations in the PSAP gene. ${ }^{12}$ Thee major subtypes exist-late infian. tile (uge 6 months to 2 years), juvenile (age $3-16$ years) and adult (age $>16$ ). Peripheral neuropathy oceurs in all foems and gallbladder involvement (byperplastic polyps) is also common. Late infantile onset is associated with poor prognosis (dearlt typically occers within 5-6 years) and manifests as regression of motos skills, gait abnormalities, seizures, ataxia, hypotonia, extensor plantars and optic atrophy. Juvenile discase presents similarly but is more heterogeneous. Progression is slower, and these chil. dren may survive until early adulthood. Adult onset is usually heralded by dementia, behavioural difficulties, and in a minoeity with psychasis ${ }^{13}$

Nerve conduction studies show marked slowing. Brain MRI reveals symmetric periventricular white matter lesions und cortical atrophy, often with a tigroid or stripe pattem, eaused by the appearance of the spared perivascular white matter. ${ }^{14}$ Disgnosis is established by demonstrating deficient ARSA activity in leucacytes (white cell enzyme testing) or eultared skin fibroblasts. Clinicians should be aware of the pseudodeficiency state, in which ARS A activity levels are low, but do not cause disease. In pseudodeficiency, the activity level is typically $5 \% 0-2090$ of controls. ${ }^{15}$ In affected individuals with MLD, unine sulfatide excretion is increased, generally tenfold to a hundred-fold greater than controls. Urine sulfatide exeretion may therefore be ased to differentiate pseudodeficiency from deficiency. However, the assay for urine sulfatide exceretion is not currently routincly available in the UK and, as testing foe the pseudodeficiency variants can be done rapidly, this is the usual first-line test.

No curative treatment is currently available, but HSCT has slowed disease progression in some patients ${ }^{26}$ Other promising novel treatmentsinclade gene therapyand enzyme replacement.

\section{Cerebrotendinous xanthomatosis}

$\mathrm{CTX}$ is an autcsomal recessive disorder of bile acid synthesis caused by mutation of the eytochrome P450 gene CYP27A1, resulting in the production of defective sterol 27-hydroxylase. Consequently, CTX is associated with high levels of cholestanol in plasms and its accumulation in tissac. This gives rise to hallmark clinical manifestations of chronic diarrhoea, bilateral cata. racts, tendon xanthomas or tendon thickening, and neurological dysfunction, 11

Typical neurological manifestations can include intellesrual disability, autism, behasicural and psychiatric problems. dementia, ataxia and epilepsy. MRI studies show oerebral and oerebellar atrophy, extensive white mater lesions of the spinal cond, and bilateral T2/FLAIR byperintensity of the dentate nuclei and surrounding white matter.

Cholestanol eoncentrations are increased in plasma, brain, xanthomas and bile. Increased quantities of bile alcohols ane useful as a secondary diagnostic test. CSE levels of cholestanol, cholesterol, apolipoprotein B, apolipopeotein $\mathrm{Al}$ and albumin are increased. ${ }^{\text {a }}$

Treatment is with chenodeoxycholic acid a cholesterol $7 a$,hy. droxylase enzyme inhibitor), which is effecrive in impeoving biochemical findings, and in those without advanced disease may improve or stuhilise neurological fratures.

\section{MTHFR deficiency}

Autcosomal recessave mutations in the MTHFK gene cause. It spectrum of symptoms, with onset ranging from childhood to adulthood. Biochemically, there are elevated plasma homocysteine, bomocystinuria and low methionine levels. Patients may develop seizures cognitive declins, recarrent thrombotic stroke and leukoestcephalopathy. The neurological signs may improve with treatment, the mainstay of which is folic acid and betaine sapplementation 20

\section{Genetic leukoencephalopathies}

Since oar previous review, a number of conditions have gained in prominence or have been newty deseribed. They are diagnosed genetically, although ss shown in tables 2 and 3 there can be typical diagnostic features to focus the genetic analysis.

\section{CSFIR}

Mutations in the CSF1R (colony stimulating factor-1 receptor) gene are known to cause an adult-onset leukodystrophy termed herediany diffuse leakoencephalopathy with spheroids (HDLS), ${ }^{21}$ This eondition has been shown to be cene of the most common cunses of adalt-onset leakodystrophy, acoounting for approximately 1000 of eases. ${ }^{22}$. First described in a large Swedish kindred, ${ }^{23}$ this is an autosomal dominant disorder in which affected members develop a clinical coarse chamaterised by dementia, psychiatric changes and motor decline. The age of anset is variable, even within families bat typically patients develop symptoms in their 408 (range $18-78$ years). The penetrance of the disorder is not known, but is likely to be high. Becatse of incomplete penetrance fand the possibility of de nowo mutations), some affected patients will not have a family history and may appear to have a sporadic disorder.

The condition is found worldwide and has a well-described dinical phenotype. Prominent symptoms inciude parkinsonism, ${ }^{24}$ which is usually not levodopi-responsive, and upper motor neuron signs such as spasticity and ataxia. A recent large review found the mean disease duration to be 6.8 years from grmptom onset to death. ${ }^{2}$

Pathologically the disease is characterised by the presence of axtrogliosis with myelin and axonal los and frequent axonal spheroids in the cerebral white matter. The spheroids are visible with H\&EE staining, but also stain positive for neurotilaments, p62 amyloid precurace protein APP and B amyloit. There are typically pigmented microglia present which are autofluorescent and stain positive for CD68. The pathological appearance of this disorder is relatively specific and lends the diseasc its name. Prior to the identification of the responsible gene, the diagnosis of HDLS coald only be confiemed pathologically.

The MRt appeanance of HDLS is consistent, with typical features including confloent, largely smmetric $T 2$ byperintense/T1 hypointense signal abnormality in the frontoparietal and periventricular white matter, which spares the U-fibres, and involves the pyeamidal traets and corpus cllosum ${ }^{25}$ Punctate areas of restricted diffusion may be present (termed deep white matter diffusion dots) and their appearance may even mimic CNS vasculitis. 2 Calcifications may be present, particularly in the periventricular white matter adjacent to the frontal hoens (figare $1 \mathrm{D}-\mathrm{F}$ ).

It was shown in 2011 that HDLS is largely caused by mutations in the CSFIR gene ${ }^{21} 27$ Almose all mutations are found in the tyrosine kinase domain of the CSFIR protein and the majority of mutations are missense. A stuall number of splice site, frameshift and indel mutations have also been identified. 


\section{Neurogenetics}

\section{AARS2}

Mutations in AARS2 (alanyl-transter (t)RNA synthetase 2) are emerging as a rare cause of leukcodystrophy with samilar cinical, imaging and madiological phenotype to CSFIR mutations. ${ }^{28} 29$ This is an autosomal recessive disorder, bat frequently appears sporadic, with a younger age of onset than CSFIR (mean age 29 years, range $15-44$ years). However the initisl symptoms aee very similar, with psychiatric changes and cognitive decline, parkinsonism, pyramidal signs, ataxia and seizares. Almost all female cases have experienced POF, although no endocrine or reproductive abnormalitics ane found in men. MRI features include largely symmetric and contluent $\mathrm{T} 2$ hyperintense/T1 hypointense white matter signal change in the frontoparietal white matter, corpus eallosum and pyramidal tracts. There are punctate areas of restricted diffusion on diffusion weighted imaging (DWI) often running paraliel to the ventricles $A$ distingaishing feature from CSF $1 R$ is that the white matter signal suppresses on FLAIR imaging, indicating a degree of rarefaction. ${ }^{2}$

The clinical picture aver time remains similar to CSF1R, with early oognitive symptoms followed by severe and rapid motor decline. Mose patients are fully dependent within 5 years of symptom conset. In one case, parthological features of HDLS were foand on brain biopsy, with axon and myelin loss and frequent axonal spheroids containing neurofilament, p62, APP and 8 amyloid. Pigmented microglia were also seen, and the pathologieal features were felt to be indistingushable from HDLS. In another ease, no pathological abnormalities were found in a brain biopsy ${ }^{20} 30$ and further pathological deseriptions are required.

AARS2 encodes a t-RNA synthetase responsible for correctly loading alanine onto tRNA-ala for the trandation of mitochondrial proteins. Most commonly patients will have compound heterozygous AARS2 mutaticas, although homorygous cases have also been reported. Loss of function mutations (frameshift, nonsense, splice site) are the most common, but there are some parhogenic missense mutations, including the recuerent R199C mutation. Mutations in this class of genes (tRNA synthetases) are increasingly implicated in a diverse range of neurological disorders $^{\text {si }} 32$

\section{WWM disease}

VWM disease is an autosonal recessive disorder characterised by progressive nearological impairment and the cystic degeneration of white matter that is visible on MRI. It most commonly presents in childhood, but many aduit-onset cases have been reported. The most frequent presenting features include ataxia, spasticity scizures and cognitive decline, Often paticnts will experience episodes of severe neurological deterioration after a minor insult, such as a head traisma, an infection or even emotional distress. ${ }^{35}$ An additional featore in women with VWM is POF; henoe, VWM is sometimes referred to ats ovarioleukodystrophy.

In one study of adalt-ontset VWM, the mean age of onset wis found to be 31 years, with clinical features including neurological and psychiatric presentations. Feequent MRI features included cerebral and eerebellar atrophy and cavitating leskoencephalopathy with invalwement of the corpus callosum. ${ }^{41}$. The characteristic feature is that the periventricular white matter takes on the same signal intensty ss the CSF on T2-weighted and FLAIR imaging (figure 1G-1). VWM is caused by homozy. gous and compound heterozygons mututions in any of the five genes that encode the sabunits of the translation initiation factor EIF2B (EIF2B1-EIF2B5).
Vascular leukoencephalopathies

A number of different senes come under the umbrella rerm of vascular leukoenoephalopathies, including NOTCH3 (CADASIL), HIRAI (cerebral autcosomal recessive arteriopathy with sabcortical infarcts and leukoencephalopathy (CARASIL)), CTSA (CARASAL), COLAAI and TREXI.

\section{Cerebral arteriopathy with subcortical infarcts and} leukoencephalopathy

CADASIL is caused by heterozygous mutations in the NOTCH3 gene. The condition is autosomal dominant and is characterised by recurrent stroke at a young age, eognitive decline, migraine with aura and depression. ${ }^{36}$ The mean age of first stroke is 46 years and typically the events are subcortical, ischaemic lacunes Reversible episodes of encephalopathy may also occur. On beain MRI, the first abnormality detected is often white matter signal abnormality in the temporal poles Over time the burden of white matter lesions increases, with the periventricular, frontoparictal and external capsular white matter most affected. ${ }^{37}$ There are frequently dilated perivas cular spaces and subcoetical lacunes Microhacmoerhages may be detected on gradient echo imaging (figure $2 \mathrm{~A}-\mathrm{C}$ ). The diag. nosis is supported by the finding of granular asmiophilic material in small arterioles by electron microscopic examination of tissse, usually a skin biopsy. Pathogenic. NORCH3 mutations lead to the gain or loss of a cysteine residue in one of the epidermal growth factor-like repeat (EGFr) domains of the NOTCH3 peotein. These EGFr domains noemally contain six cysteine residues, and any alteration in this number has been shown to lead to NOTCH3 asgregation, NOTCH3 mutations are not fully penetrant, but it has been shown that cysteine altering mutations affecting the first six EGFr domains are the most penetrant and are associated with the highest burden of white matter disease.

\section{Cerebrai autosomal recessive arteriopathy with subcortical} infarcts and leukoencephalopathy

This antosomal recessive disorder is ea ased by biallelic mutations in the HTRA1 gene. CARASIL was first identified and is most common in Japan, but cases in Europe and South America have also been identified. ${ }^{35}{ }^{40}$ Cintically it is chancterised by dementia, parkinsonism, upper motor aeuron signts, and extrancurological featuresincluding alopecia and back pain with spondylosis deformans. Acute strokes are common and the typical age of onset is the teenage years to $20 \mathrm{~s}$. MRI sppearance is similar to CADASII. (above), with spondylosis deformans potentially visible on spinal imaging ${ }^{\text {at }}$

Recently, it has been proposed that heterozygous HTRA mutations an also lead to autosomal dominant severe small vessel disease, In one stady these patients were termed 'manifesting heterozygotes with CARASIL and were described with simular but less severe phenotype to recessive mutations ${ }^{42}$ Spondylosis was found in all manifesting heterozygotes. Howwever, another recent study found that the phencrype of heterozygous HTRA 1 mutations was different from both CADASIL and CARASIL, and no extraneurological feasures were observed, although the imaging appearance was similar, ${ }^{43}$

Cathepsin A-related arteriopathy with strokes and leukoencephalopathy

This very recently described entity due to heterozygons muta. tions in the CTSA gene is named eathepsia A-relatedarteriogathy with strokes and leukoencephalopathy (CARASAL). The initial 


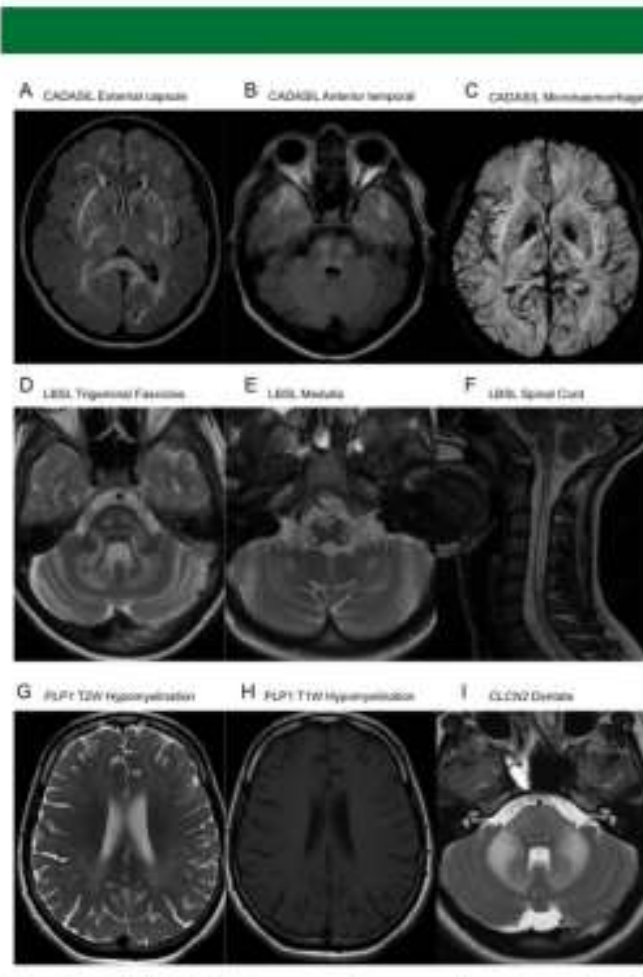

Figure 2 Axial FLAiR Mal sequences demonstrating confuent signal hyperintensity irwolving the external capsules posterior limb of the insernal capsules, peritriganal white matter and splenium of the corpus calosum (A), as well as of the subcortical white matter of the teenporal poles and central pons (B) in CADASIL. Mirimal intensizy projection from a suscepthilfty weighted imaging acquisition MAI demonstrating multiple purctate foci of paramagnetic susceptbilty limited within the thalamus, left putamen and subcortical witite matter of the latt occipital Iobe $(C)$ in keeping with multiple microhaemortiaces in CADASIL. Axial TWW MRI sequences demorstrating signal typecintensizy within the trigeminal fasocles and cerebelar white matter $(D)$, as well as within the pyramids decussation of the medial lemnisciand inferiar cerebellar peduncles at the level of the medulla colongata (E) in LBSL.A sagittal TZW sequence of the upper spinal tord in the same patent demonstrates contiguous longitudenaly extensive signal hyperintensity of the darsal columns and latera cortical spinal tracts ( $\mathrm{F}$ ). Axial T2W (G) and $11 \mathrm{~W}$ (t) MRI sequences in a patient with Pelizeeus-Mertbacher disease illustrating the confluent diffuse T2W Typerintense signa within the white matter of the cerebrim, apoearing uniemaikable on the TIW sequences, suggestive of hypomyelination. Axial T2W sequences demonstrating confluent. hyperintense signal change within the pons middle cerebellar pedindes and dertate midei in a patient with a CNCL2 levoodystroptry (I). CADASI, cerebval arteriopatty with subcortical infarcts and leukcencephalopathy: FLAIR, fluid-attenuated inversion recovery: TIW, TI-weighted; LBSL, leukcencephaiapothy with brainstern and spinal cord inwolvement with elevated lactate; T2W, T2-weighted.

report described two Dutch families, distantly related, in whom members were affected by a sevece leukoencephalopithy, accompunied often by is:haemic or haemorrhasic stroke, therapy-resistast hypertension and Later cogitive decline. ${ }^{\text {At }}$ The MRI pattern was very similat to CADASII. Since the initial report, another case has been described from the UK with identical imaging and

a similar phenotype, althongh with additional prominent beain stem features reported. ${ }^{35}$ To date, all putients described have carried the same $\mathrm{R} 325 \mathrm{C}$ mutation in CTSA, It is uncleat whether this is the only mutation in CTSA which is causal for CARASAl or whether further mutations will be identified.

\section{COLAAT and TREXI}

Boch COL $4 A 1$ and TKEXI are associared with lenkoencephalopathies in which ceular or retinal abnormalities may be present. $\mathrm{COL} 4 \mathrm{AI}$ is characterised by diffuse lenkoencephalopathy, often with dilated perivasular spaces and microhaemorthages, and retinal abnormalities including arteriolar tortucsity or retinal haenorrhage, ${ }^{4 h}$ It is an autosomal dominant disoeder and shows itcomplete penetrance. Additional CNS features include intra. cerebral hacmorrhage, calcifications and cerebellar atrophy. Ocular abnormalities are not exclusively confined to the retina in $\mathrm{CO}$-4AI with anterior segment dysgenesis, comgenital cataract and nystagmus all reported. ${ }^{47} \Lambda$ second form of leukoencephalopathy with retinal vasculopathy is caused by heteroxygous frameshift mutations in the c-terminus of the TREXl gene, ${ }^{4 h}$ In addition to the microvascular disease of the retina which can lead to visal loss. Raynaud's phenomenon and migraine are both frepuently found, ${ }^{49}$ A phenocype of TREX1 mutations called hereditary endotheliopathy with retinoputhy, nephropathy and stroke may present with progressive, contrast-enhancing lesions with surrounding oedema, which may be mistaken for tumours. Calcifications are found in more than $50 \%$ of patients. ${ }^{\text {st }}$

\section{Mitochondrial DNA mutations}

Mitcohondrial DNA mutations are a rare canse of adult-onset leukoencephalopathy. Typically patients-will present with a multisystem disorder, often including short stanire, migraine, sensorineiseal deafness, cardiac defects and excrcise intolerance. There is often involvement of the deep grey structures on imaging such as the basal ganglia and thalames, but symmetrik: and confluent white matter abnormalicies can ocatr ${ }^{52}$ Strokelike episodes or cortical blindness would point to mitochondrial encephalopatby with lactic acidosis and stroke-like episodes $(\mathrm{m} 3243 \mathrm{~A}>\mathrm{G})$. myoclonms, seimres and ataxia are smgges. tive of mitcolondrial encephalopathy with nagged red fibres (m.8344A $>\mathrm{G}$ ). Periventriculat signal ahnomalities have been reported in Leber's hereditary optic neuropathy, hut only as a minor feature. ${ }^{5}$ Common mitochondrial point mutations can be readily screened in blood, but if these are negarive and a suspicion of mibochondrial discase remains, next-generation sequencing of the complete mitochondrial genome from the muscle may be necessary. Clinicians should be aware that exome segpuencing and panel-based sequencing typically target only meleor genes that is, not mitochondrial DNA. There are methoxk to extract mitochondrial DNA sequence from exome data, but this is not commonly done.

\section{Nuclear encoded mitochondrial genes}

There ate a lange number of nucleat encoded genes with established or putative mitochondrial functions $(>1000$ in Mito Cartay ${ }^{44}$ This section could never be exhaustive, and some genes. such as AARS2 and DARS2, are discassed elsewhere in detail. Many of these disorders are only known to affect children, but rwo disorders of miDNA maintenance can present with prominent lesikoencephalopatloy in adulthood, namely mitochon. drial neurogastrointestinal encephalomyopathy (MNGIE) and POLG mutations. MNGIE is an autusomal recessive disorder caused by mutations in the TYMP gene, ${ }^{55}$ It usually presents in 


\section{Neurogenetics}

adulthood with ptosis, drronic progressive external ophthalmoplegia, gastroentestinal dysenotility induding pseudo-abstruction, peripheral neuropathy, and diffuse leukcencephalopathy. $A$ similar disorder can be caused by mutations in $P O L G$, although these cases asually have less prominent leukoencephalopathy. ${ }^{\text {se }}$ Involvement of the pulvinar of the thalamus has been reported in POLG mutations" Nudear encoded mitochondral gene defects au be identified by whole exome or panel sequencing. Variants, either single nucleotide variants or deletions, of $\mathrm{mtDNA}$ are usually identified by specific miDNA sequencing from affected tissue, often musde.

Leukoencephalopathy with brainstem and spinal cord imolvement with elevated lactate

Leukoencephalopathy with brainstem and spinal oord involvement with elevated lactite (LBSL) is an unusual and rare leukoencephalopathy caused by autosomal recessive mutations in the DMRS2 gene. ${ }^{18}$ Lsually patients develop symptoms in childhood, bat the condition tends to be slowly progressive and evolves over time, so the diagnosis is ustally made when the patient is an adult. The most common presentation consists of childhood onset of distal weakness and wasting, with pes cavus, and initially patients may be given a diagnosis of hereditary sensory motor neturopathy. Over time, upper motor neuron signs including spasticity and extensor plantar responses develog. Slowly progressive ataxia is another common feature, and is dae to both cerebellur involvernent and dorsal column loss. The neuroimaging appearunce of LBSL is quite distinct, with a diffuse T2 hypenntense sigmal abnormality of the cerebral and eerebellar white matter corpus callosum, medullary pyramids, medial lemniseus, intraparenchymal course of the trigeminal nerves, superior, middle and inferior cerebellar pedindes, and the dorsal columns and lateral corticospinal tracts of the spinal cord. A lactate peak is seen on megretic resonance spectroscopy, but biood and CSF lactate are not elevated ${ }^{\$ 2}$ (figure $2 \mathrm{D}-\mathrm{F}$ ). DARS2 matations are usually compound heteroxygous, and the most frequent varnant is a splice site mutation in intron $22^{53}$ This region is poorly covered by next-generation sequencing approaches, and singlegene testing is recommended if the dinical and radiological picture is sugestive of LBSL

\section{Alexander disease}

Caused by heteroxygons mutations in GFAP, Alexander disease has infantile, faventile and adult onset forms ${ }^{60}$ Mutations ure often de novo, and young children typically present with seizures, motor regression and macrocephaly GFAP enoodes the glial fibrillar acidic protein, an essential component of astro cytes, Alexander discase is characterised pathologically by the presence of Rosenthal fibres, which are lang, filamentioas ecsinophilic fibres largely composed of GFAP protein. ${ }^{\mathrm{st}}$

In infantile cases, death occurs before 2 years. In juvenile cases, onset is between 4 and 10 years and is typified by ataxia, cognitive decline and bulbar symptoms. Survival can be ap to 20-30 years Adults tend to present with bulbar or pseudobulbar palsy, spasticity, ataxia, cognitive decline and dysautonomia,

The MRI pattem in Alexander disease often falls into two extremes. In most infantile and juvenile cases, there is extensive white matper abnormality with a frontal predominance. In adults, however, the abnormalities are often restricted to the posterior foess, particularly utrophy of the medulla and cervical spinal cond. Often the lesions are contrast-enhancing, or there may be contrast enbanecement of the ventricalar lining or periventricular rim. ${ }^{6}$

\section{LMNB1 duplication}

Duplication of LMNB1 causes a form of adult-onset, autosounal dominant leukodystrophy (ADLD) characterised by autonomic dysfunction, spasticity, ataxia and eognitive decline. Symptoms asually develog in the fifth or sixth decade. "Autonomic ssmptoms may be prominent and include orthostatic hypotension, uriuary incontinence, ectistipation and erectile dysfunction. MRI festures indude T2W/FLAIR hyperintensity of the subcortical and deep cerebral white matter, the cerebellar peduncles the pyramidal tracts and hrainstem. ${ }^{6 t}$ It is important to note that copy number variants are not reliably identified by next-generation sequencing. Therefors, if ADLD is suspected clinically, specific testing for LMNB1 duplications should be performed.

Hyponyelinating disorders (PIP1, GSC2, TUBBAA, POLR3A, POLR3B, CICN2, NKXE-2]

Hyponyelination is an extremcly useful radiological sign, and in adults can significantly reduce the number of potential genes to test. Hyponyelination sbould be considered where the T2 FLAIR hyperintensity is diffuse, and often seents to be affecting all of the white matter unifotmly. In contrast to demyelinating disorders where the white matter signal is hypointense on $\mathrm{TI}$ imaging, in hyponyelination it may be isontense, or mildly hypointense or hyperintense. ${ }^{65}$ This sign is easily overiooked if the $\mathrm{Tl}$ sequences are not examined (figure $2 \mathrm{G}-\mathrm{H}$ )

The most common cause of hypomyelinating leukoencephalopathy is Pelizaeus-Merzhacher disease (PMD), caused by mutations in the proteolipid gene PLP1. The most eommon presentations of PMD include the connatal form, where symptoms are present at the time of birth, and the classical form where symptoms develop within the first months of life." Symptoris begin with nystagmus, bypotonia, ataxia and head tremor. Later motor and language development is delayed. PLP1 duplications are the most common mutation type in children. As $P I P I$ is an $\mathrm{X}$ linked gene, typically male patients are more severely affected than female patients. The connatal and classical forms are not seen in female patients. However, female PLPI mutationi carriers can develop symptoms in adulthood. The phenorype in women often consists of slowly progressive spastic paraplegia and this presentation has been assigned $\mathrm{SPC}_{2}{ }^{2}$. The most common mutation type in female carriers who manifest

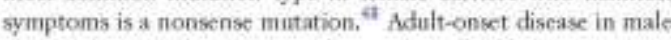
patients is more aggressive, with prominent head tremcr, ataxia, spasticity and cognitive decline. MRI in both male and female patients shows a diffuse bypomyelinating leakodystrophy which is byperintense on T2/FLAIR and often isointense or mildly hyperintense on T1. The pattern can resemble tiger stripes (tigroid pattern).

Autosomal recessive matations in GIC2 are a cause of a Pelizaeus-Merzbacher-like disonder. ${ }^{\text {"9 }}$ The phenotype is similar to that of PUPI mutations but inale and female patients are equally affected. Like PLP1, most patients have onset of synuptons in early life, but there are reports of later onset with slow progrest sion into adulthood, aggain mootly manifesting by spastic pan. plegia, cerelellar signs und a bypomyelinating picture on MRI.?

Autosomal mecessive mutations in CLCN2 are a very mare cause of adult-onset leukoencephalopathy, with findings mainiy limited to the posterior limb of the internal eapsules, the dentate nuclews the cerebral peduncles and middle serebellar pedundes (figure 21). There may be evidence of restricted diffusion in these areas. There may be more extensive involvement of cere bellar white matter, and cerebral white matter mity demonstrate 
fearures of hyponyelination. In adults, the most common presentation is mild cerebellar ataxia.

A number of other genes have been associated with hypony. elination, including TUBB4A (with basal ganglia abrormalities), POLR3-related disorders (dental abnormalities and hypogonad otrophic hypogonadismi) ${ }^{7 i}$ and NKX6-2. . $^{74}$ ahthough to date these syndromes are only described with childhood onset.

\section{Very rare genes (RNF216, TREM2, SNORDI18)}

Gordon Holmes syndrome is a rare aurosomal recessive disorder characterised by hypogonadotrophic hypogonadism and ataxia. It is usually accompanied by cognitive decline, diffuse leukoen. cephalopastiy with cerebellat atroplyy and chorea. Age of onset is variable and the disotder is caused by mutations in the gene RNF216. The combination of cheres and dementia is reminiscent of an autosomal recessive form of Huntington disease. ${ }^{75}$

Polycystic lipomembranous osteodysplasia with sclerosing leukoenoephalopathy, also known as Nasu-Hakola disease, is a rare syndrome catused by autosomal recessive nutations in TREM2 or TYROBP. The disorder usually presents in adulthood, with bone pain and pathological fractures due to bone cysts: Later, a severe neuropsychiatric syndrome develops due to a peogressive leukoencephalopathy. It is most common in Japan and Finland. ${ }^{76}$ Different TREM2 variants are also significant risk factors for Alzheimer disease.

Labrune syndrome, also known as keukoencephalopathy with brain calcification and cysts, is a rare autosonal recessive disorder cassed by mitations in SNORD I IS. Labrune syndrome mose commonly presents in early life, but there are reports of patients preseuting in their $50 \mathrm{~s}$. The syndrome consists of peogressive dementia, with motor decline and seizures. Lange areats of cystic degeneration and calcification occur with a symmetric leukoencephalopathy affecting the periventriculae, deep and subcortical whire marter, ${ }^{73}$ SNORDits is not well
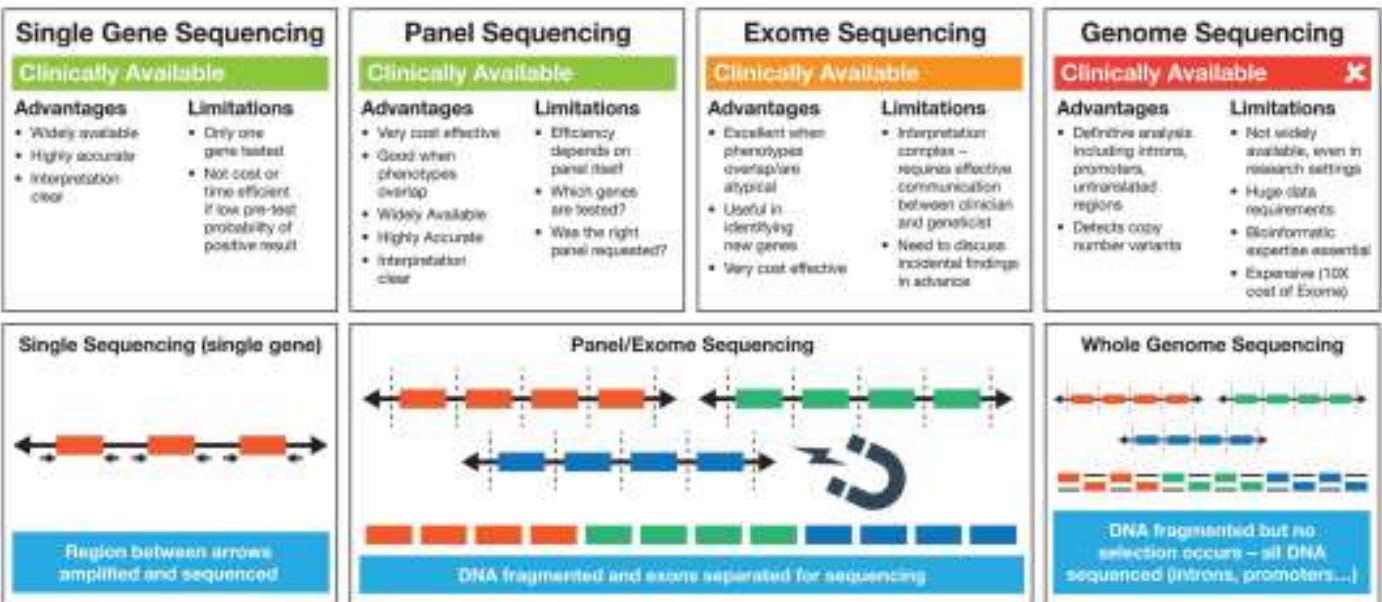

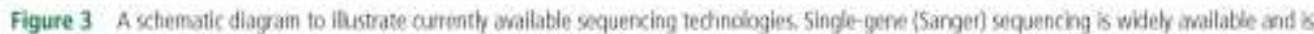
performed by ampliting coding regions of the gene of interest by PCR, before sequencing these regiens. Introns and promoter regions are nat routinet;

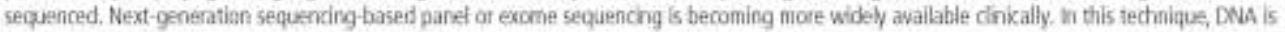
fragmented, and the exons of multiple genes of interest are selected aut for sequencing. Although marn gornes are sequenced, again colly the coding regions are selected. In whicle genome seouencing, which is not rutinely atalabla to cliricians yet, the DNA is also framented, but all the resulting DNA is sequencing. wathout a selection step, This results in a bane amount of data, as the coding repions, intergesic regions, intons and promoters of all human genes are sequanced. Advanced bininfarmatics and computing technology are a required part of whole gencme secuencing.

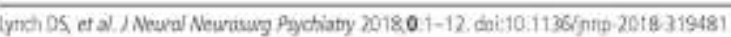

covered by next-generation sequencing, and in the right dinical

The Queen Square Adult Leukodystrophy Group

The Queen Square Adult Lenkodystrophy Group (QSALG) is a multidisciplinary special interese group with input fromi group bas investigated 116 patients with a wide variety of whit marter syndromes, referred from hospitals worldwide, In our a diagnosis can be made in approximately half o parients (54). The most common diagnoses are found in online supplementary figure 1 . The most common diegnosis reached choodrial diseases, ALD and multiple sclenosis. The remainder of diagnoses were highly heterogeneous, with often only one of at most two cases for each disorder. There were 15 diagnoser that afred only one patien each, and these induded CADASIL and CARASIL, PLPI mutations, Alexander disease and Fabry drsease, VNM discase and familial British dementia. This review

\section{Diagnostic algorithm} As described above, initial assessment should focus on the exclasion of common acquired causes and severe smatl vessel disease (round 1). If these initial tests are negative and the patient is should include white cell enzyge activities, a VLCFA profile (in men), plasma doblestanol and bile alcohols and plasma amino acids, to exclude the dassical leukodystrophies which can present in adulthood (round 2). This step is important, at 


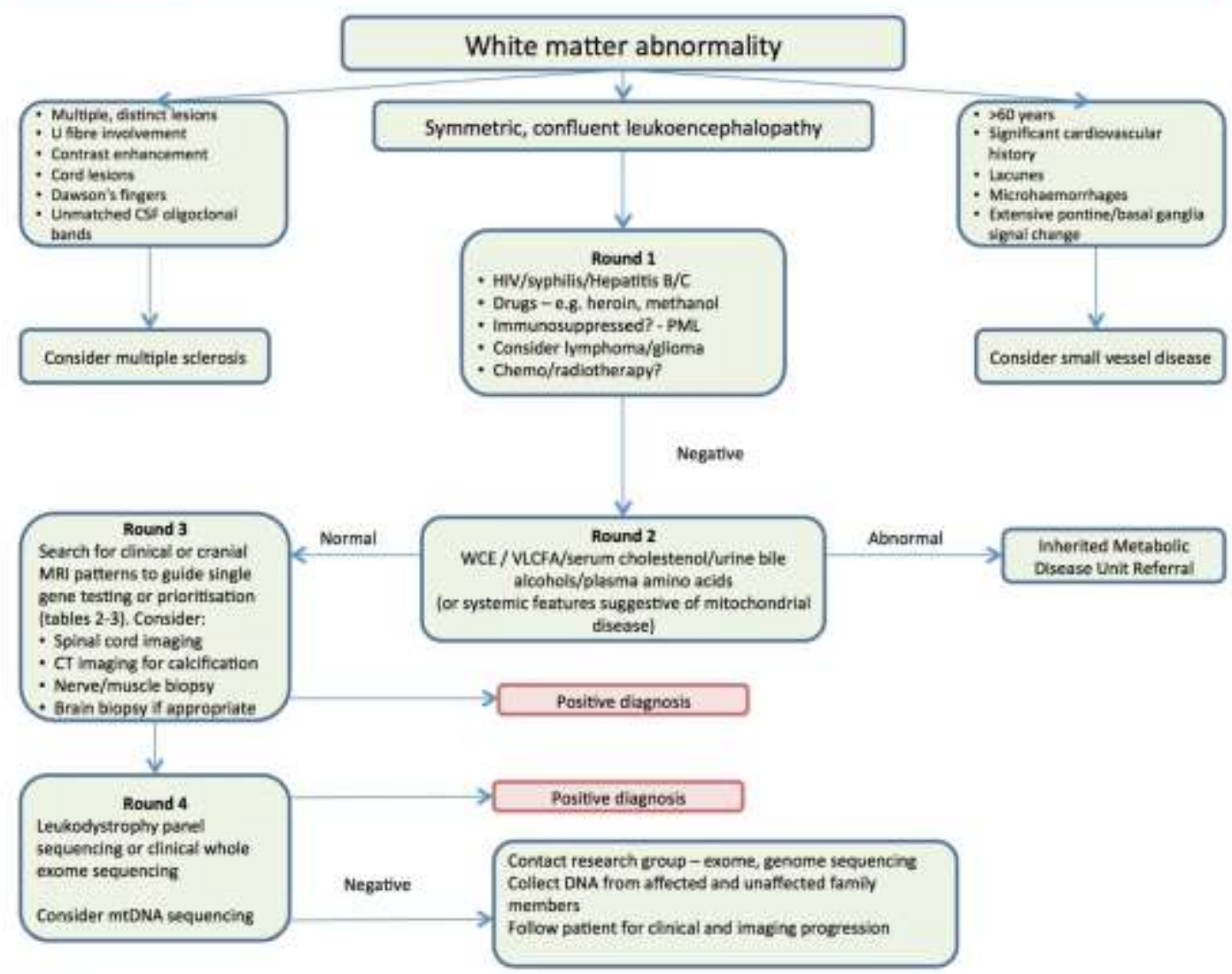

Figure 4 A recommended algorithm for the evaluation of adults with suspected inherited white matter discrders, CSF, cerebrospinal fluid; miDNA, mitochondrial DNA; FML, progressive multifocal leukotoncephalopatty; VICFA, very long chain farty acds; WCE, White cell enzymes.

enzyme replacement thenapy and stem cell transplant are being explored as treatment options for some of these conditions.

If metabolic testing is not revealing, then the clinician should move on to genetic testing in the context of nound 3 clinical or imaging patterns. A schematic illustrating the differenoes between sequencing approaches can be found in figure 4 . Next-generation sequencing via diagnostic panels is becoming mose widely available through regional genetic testing services, and these can be the most rapid and cost-effective route to diagnosis, It is worth determining which genes ate covered by the panel revpested, as each panel will differ depending on its desigr. If there is no access to a diagnostic panel, then consideration should be given to single-zene testing guided by the clinical and radiological phenotypes descritied above and found in tables 1 and 2. It should be noted that sungle-gene testing is a low-yield route to dagnosis, and if a number of genes are seguenced the cost will quickly exceed that of a diagnostic panel. There are a smatl mumber of genes where a panel will not be sufficient for diagnosis, usually where copy number variants are a significant concern, and these woold include LMNB1 and PLP1. In these cases, clinical suspicion should guide directed testing.

If a panel-bused approach is not successfal bat a genetic lenkoencephakopathy is still considered likely, then consideration should be given to whether rbe disorder might be due to a muthtion in the mitochondrial gemame (not targeted by traditional pancls). It may be necessary to contact a research group who can offer more extensive generic testing including whole exom or even whole genome sequencing, In these cases, it is heipful to have obtained DNA from as many affected and unaffected family members as possible.

In our experience of difficult-to-diagnose patients who have already heen extensively investipated, a focused exome panel led to a diagnosis in almost $30^{\circ} 6$ of patients.

\section{DISCUSSION}

Leskoencephakopathes are a heterogeneous group of disorders with a wide nange of genetic and acguired causes. They are frequently difficult to diagnose, and patients with these disonders typically undergo a large number of expensive, time-consuming and often invasive tests over a long timeframk. This presents a significant burden to patients who usually are deterionating from a severe and progressive neurological syndrome. The aim of the treating neurologist should be to make a definitive diagnosic as this allows for better prognostication, more definitive family counselling and prevents further worry about the diagnisis. We 


\section{Neurogenetics}

hope that we have given a current useful, straigheforwurd logical algonthm that others will find useful. It is clear that careful clinical and radiological assessment, in combination with early usc of focalsed genetic testing, is needed to maximise the probahility of making these diagnoses. However, even with this approach, more than half of patients currently do not receive a definitive diagnosis. " This may be because the disonders are so heterogeneous or because there are still more genes to be described. Advances in genetic technology like whole genome sequencing may solve some cases, but only in combination with a thoroagh phenotypic approach.

Utimately these diagnoses are important beciuse the development of novel therapies for these disorders depends primarily on forming cohorts of patients for clinical trials. HSCT from donoes is a potential treatment for ALD, MLD and it number of other disonders, Recently gene correction has also shown promise. In principle, gene correction (cg, through lentiviral transduction of the patient's avm cells) should be possible in most lass of function genetic disorders, but to show efficacy in mare diseases sufficient numbers of patients must be identified. ${ }^{\text {in }}$

As in 2014, the authors are happy to be contacted to discuss or see adult-onset patients with possible leukodystrophies of genetic leukoensephalopathies.

\section{Author affiliations}

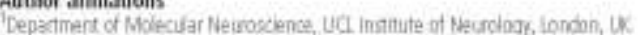

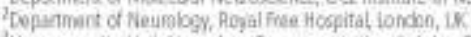

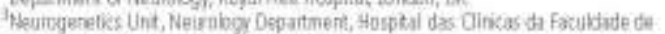
Medcra da Univergitada de 5 so favio, 5 to Paupo, Brat

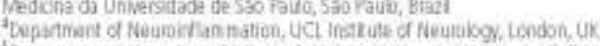

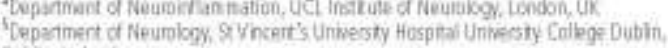
Dielin, ireland

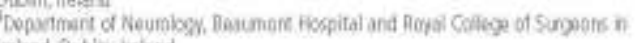
Feiand, Outin, heiand

Menofy and Cognicon Cink, Departinent of Chical Neurcocience, Hoval fince

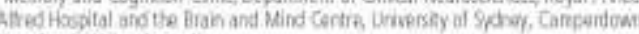
levs South Whines, Australlis

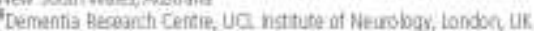

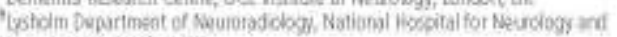
Neuworoany tondon il

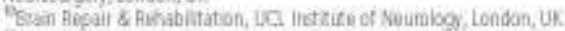

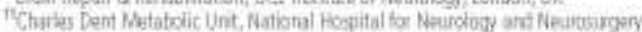

Dusan Squale Iandon ur

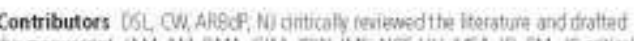

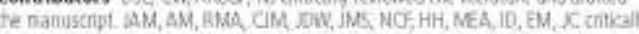

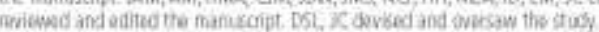

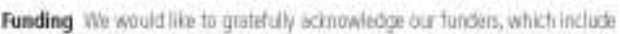

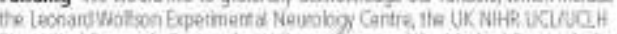
Biomedical Hestarch Cantre, the Welcnme Pus and the Med cal fieseanch Counci Competing interests Now dodusd.

Patient consent Hof requireit

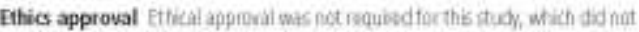
Itroblue human-poiticipants or then dati

Provenance and peer teview Nat zumeissioned eitemally jats levesed Data sharing statomeat There are no additional unputilithed dota

Open access This is an ogen access anticle distribited in acopoldacce with the

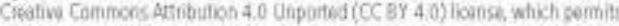

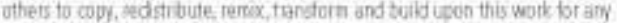

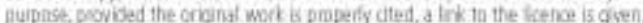

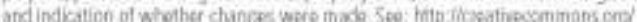
licensebitavi of

\section{REFERENCES}

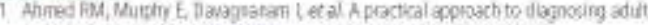

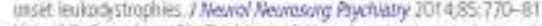

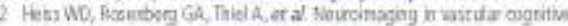

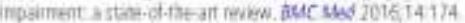

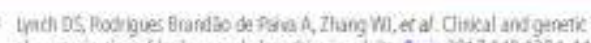

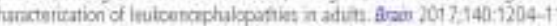

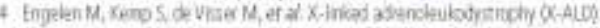

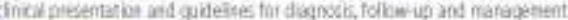
Aphane $/$ have is 2012751

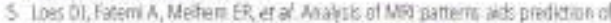

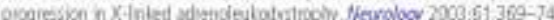

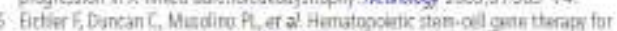

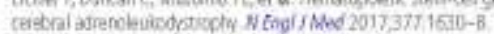

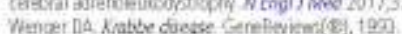

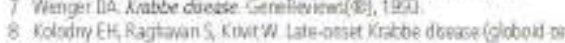

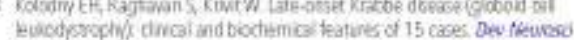
Lucdporolin/

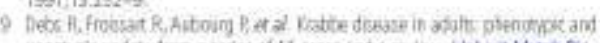

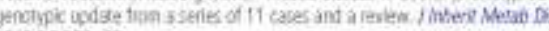
$013,36,850-6 \cdot 2$

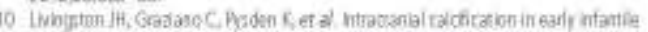

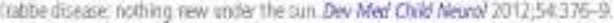

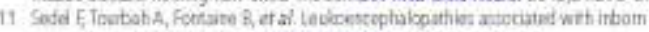

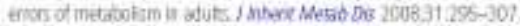

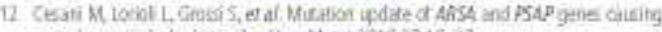

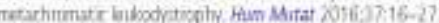

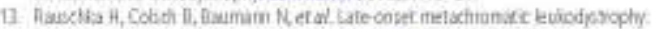

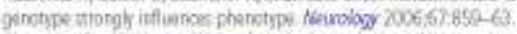

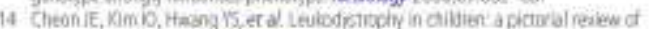

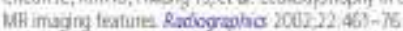

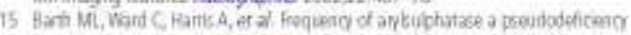
assodised murations in a hesthy population. 1 Wed Geret 199431,$56 ;-7$ ]

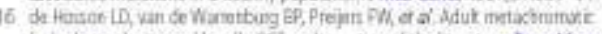

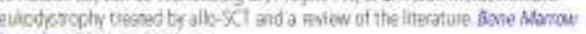
Tansaben $2011,061071-5$

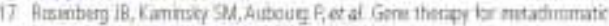

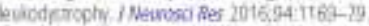

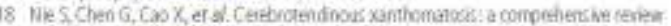

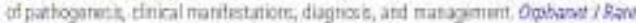
as 20149179

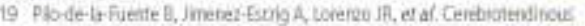

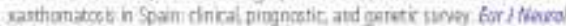
mH1 $181702-11$

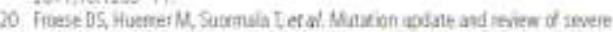

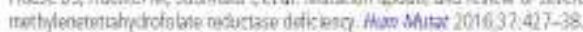

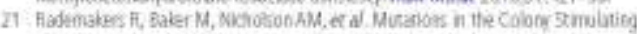

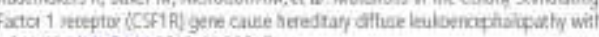
phemids: tiat boot zot1:44:200-5

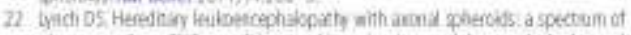

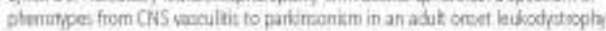

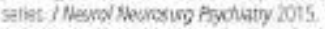

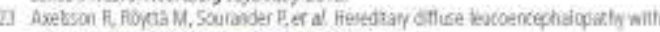

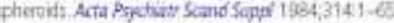

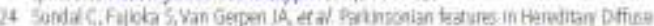

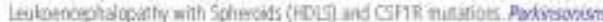

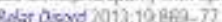

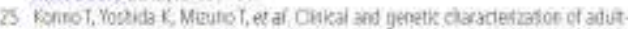

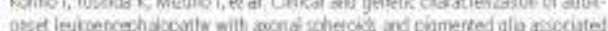

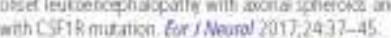

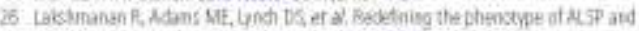

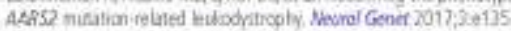

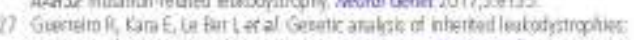

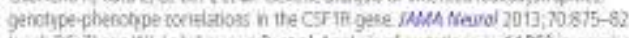

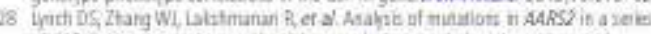

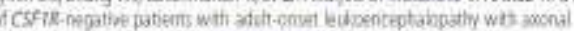

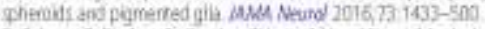

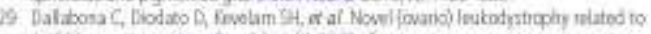

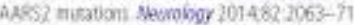

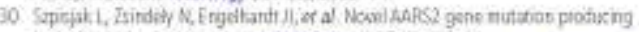

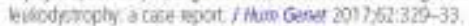

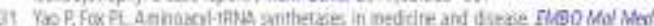
$013: 5337-4$ ?

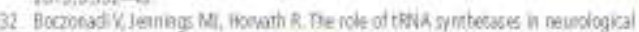

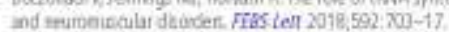

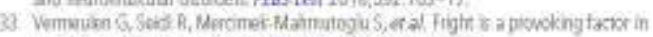

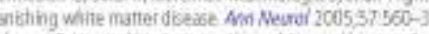

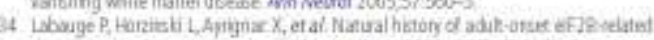

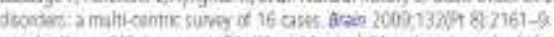

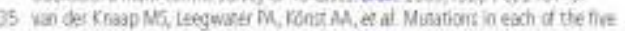

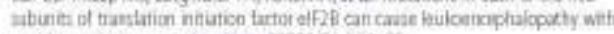

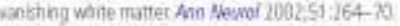

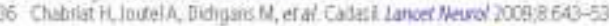

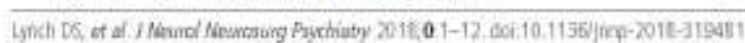




\section{Neurogenetics}

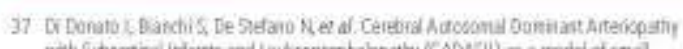

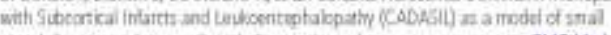

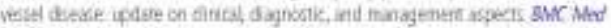
$7017,15,41$

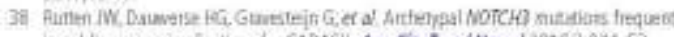

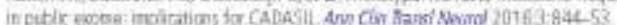

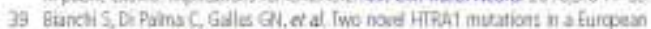

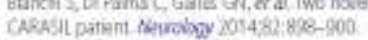

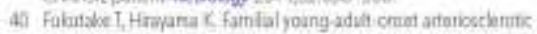

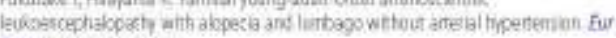
theund $19953569-79$

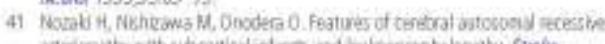

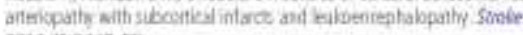
2016:4539477-5:

42. Norali $H$, Kato $T$, Nhatmus $M$, ef af Datint nolesular mechanisms of

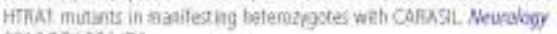
2015,86196474

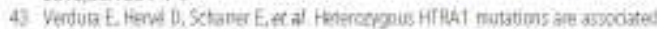

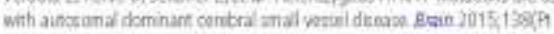
gith $2347-58$

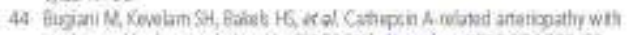

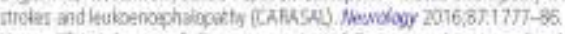

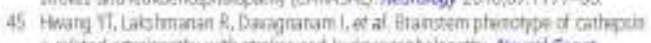

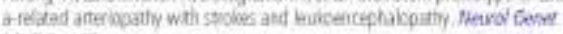
$2017: 3 \% 155$

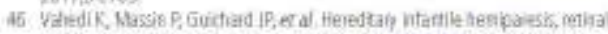

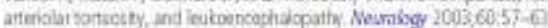

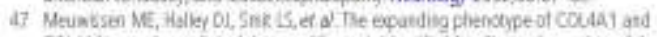

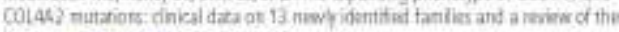
liesture, Genel Mod 2015,17843-53

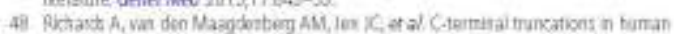

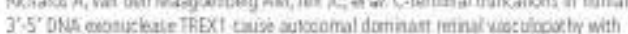

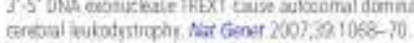

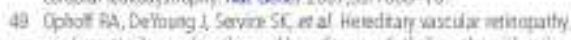

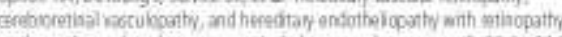

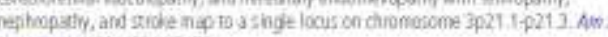
How $6000 \mathrm{r} 2001356447-53$

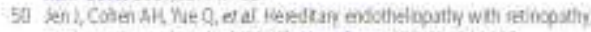

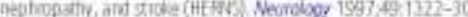

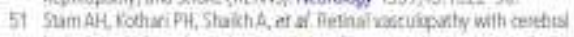

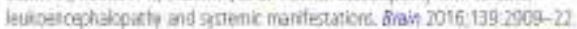

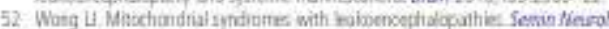
X017:37065-61

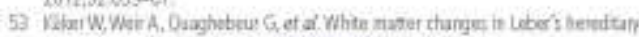

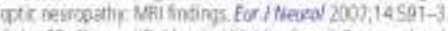

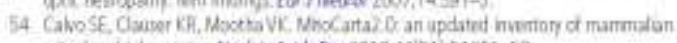

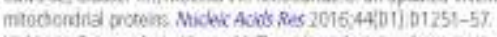

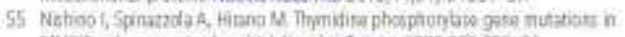

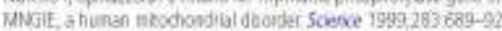

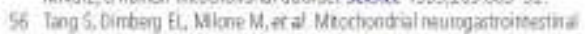

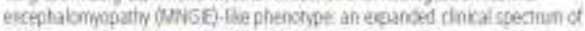

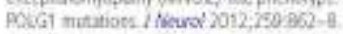

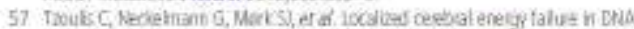

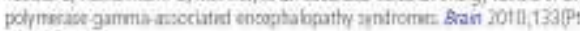
5):1425-13?

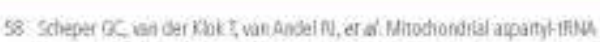

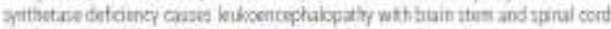

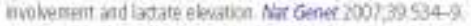

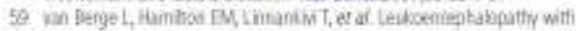

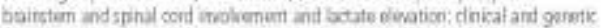

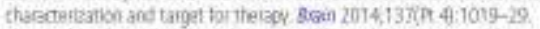

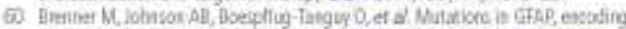

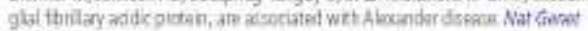
$2001.27117-20$

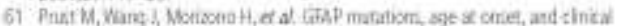

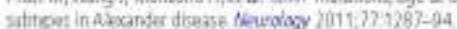

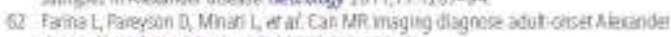

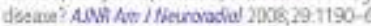

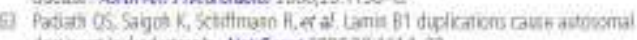

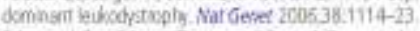

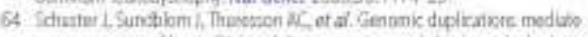

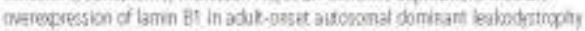

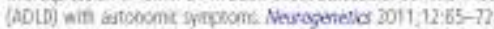

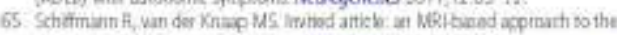

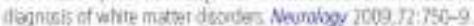

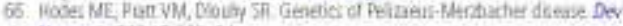
Mewnexi 1090, 15:382-94

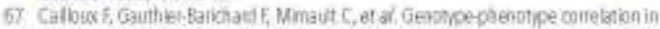

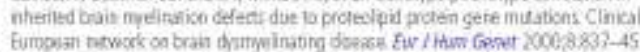

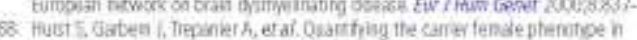

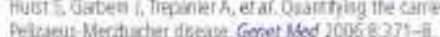

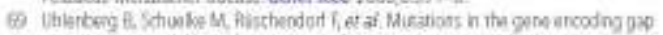

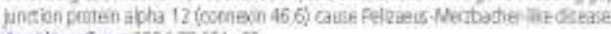
Am fhum Gene 200475 . $51-0$

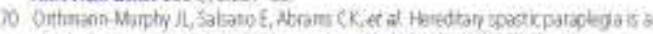

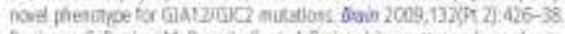

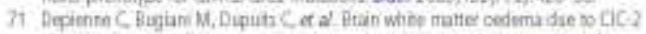

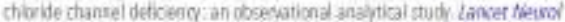
20t3:12:55-68

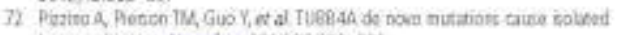
typonpelinason Newobgy $201489858-902$

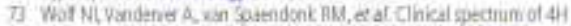

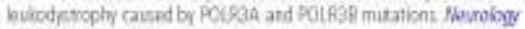
huicdercophy caisd

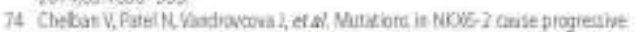

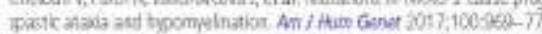

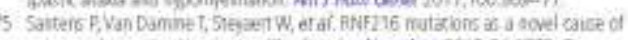

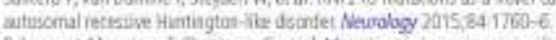

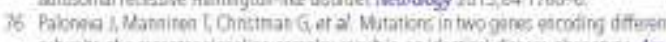

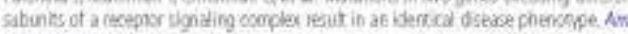
thas Gever $2002 ; 71: 656-61$ ?

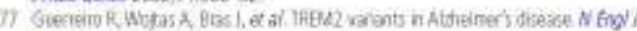
$\operatorname{Mod} 2013,368: 117-27$

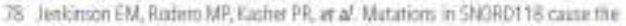

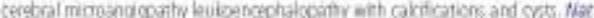
Goret 2016;4s:1185-92.

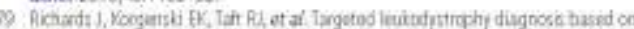

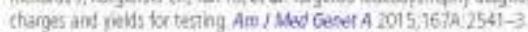

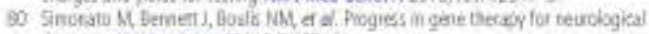

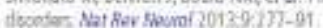


10.12 Apêndice L - Adult Leukodystrophies: A Step-by-Step Diagnostic Approach. Radiographics 2019;39(1):153-168.

Reprinted by permission from copyright holder Radiological Society of North America.

Resende LL, Paiva ARB, Kok F, da Costa Leite C, Lucato LT. Adult Leukodystrophies: A Step-by-Step Diagnostic Approach. Radiographics 2019;39(1):153-168.

https://doi.org/10.1148/rg.2019180081 


\section{Adult Leukodystrophies: A Step- by-Step Diagnostic Approach}

Luras Lapas Ratende, MD

Andersow Radrigues Brundalo de Paizu, $M D$

Fornando Kol, $M D, P$, D

Cloudia da Cara Laik, MD, PhD

Landro Tonure Lurata $M D, P H D$

Aboreviationat CADASIL $=$ ceretinal auto somit domicant artericonthy wits subconical

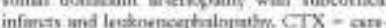

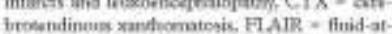

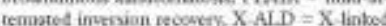
adreodevitodyserphy

RadieGraphios 2019, 99:153-16is

hupe:Vloi.org/tR.1148/rg. 2019180081

Content Cases MI MVI

Frum the Neuroentiobsy Serteon, Insinin it

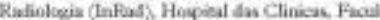
Aale de Mofictira da Liamenidale de Sro Pawe HFC. FMgusF R. Dr. Cidio Pres de Canpos

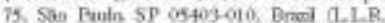

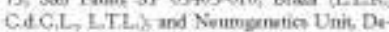

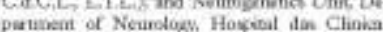

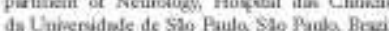
A.R.R.,. F. .). Pecipient of a Cenificste of Merit awand for anteducosion exhibit at the 2017 nSNA Armual Meetire Resened Manth 12

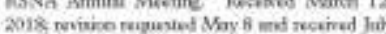

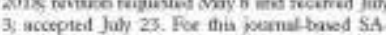
CME activis, the amion C.ACL ant LTI

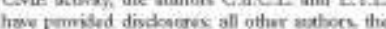

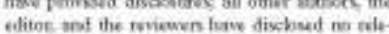

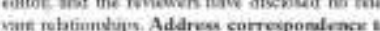

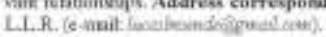

TRSNU, 2010

SA-CME LEARNING OBJECTIVES

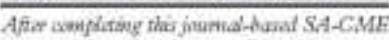
artictity, partiapuntr wall ke able wo

- Discuss a framework ther could help

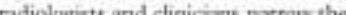
milisums

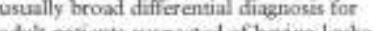
adult pabents saspected of having lewkodystrophy.

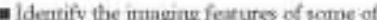
the most previlent adult leakodystroplies.

- Describe the key mage poins that rigght least to a conafirusd disgansis in pabere. arpected of having adult leukadystoplives.

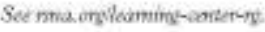

Leukodystrophies usually affect children, but in the last several decades, many instances of adult leukodysirophies have been reported in the medical literature. Because the elinical manifestation of these diseases can be nonspecific, MRl can help with establishing a diagnosis. A step-by-step approach to assist in the diagnosis of adult leukodystrophies is propersed in this article. The first step is to identify symmetric white matrer involvement, which is more conmonly observed in these patients. The next step is to fit the symmetric white matter involvement into one of the proposed patterns. However, a patient may present with more than one pattern of white matter involvement. Thus, the third step is to evaluate fot five distinct characteristics -including enhancement, lesions with signal intensity similar to that of cerebrospinal fluid, susceptibilityweighted MRI signal intensity abnormaliries, abnormal peaks at MR spectroscopy, and spinal cond involvement - to further narrow the differenrial diagnosis.

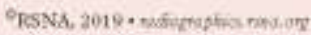

\section{Introduction}

Leukodystrophies currently are detined as genetically determined disorders that primarily affect the white matter of the central nervous system, regardless of the structural white matter component, molecular process, patient age group, and discase course involved. Genetic testing is of paramount importance (1).

Although these disorders primarily manifest in early infancy and childhood, they may also affect adults, who occasionally present with clinical and imaging findings that are distinct from those observed in childten $(2,3)$. There is growing recognition that Jeukodystrophies may manifest initiatly during adulthood (4).

Adult leukadystrophies usually are progressive disenses. Patients may present with movement disturbance, vision problems, hearing impairment, imbalance, memory loss, behavioral changes, and artention deficits $(5-8)$.

Because the clinical manifeststion of leubodystrophy can be nonspecific, MRI has been used as a powerful paraclinical tool; it sometimes can be the key to narrowing the diagnosis, cven at the early stages of the disease in presymptomatic patients and cartiers $(5,7)$. Symmetric involvement in the white matrer at MRI is an essential finding in padients with adult leukodystrophies, because it commonly is associared with inherited disonders. However, the imaging pattern of adult leukodystrophy can vary according to the disease and its time course $(9,10)$.

In addition to symmetry, many other MRI features can help in reaching a final diagnosis in patients who are presumed to have adult leukodystzophy or at least in narrowing the list of diagnoses for which to evaluare as part of the differential diagnosis. An algorithm that allows evaluation of all of these characteristics has been developed to help differentiate among white matter diseases overall (11). 


\section{TEACHING POINTS}

- Symuetric imolwoment in the wevite matis at MRI is an ef sentid finding in padents with adit leskodystroplies, be cause it coirmonily is assoclated with inherited disonders.

- 72 wighted and thid.attenuared mersion recovery GLWFO Mal we the hest sequerces to use to detemino white mattor nodvement.

- Sometimes the same pacient presents with more than one pattern during the time course of the drean, and a given ket. bodystroph ty may maifent weth more than one of these pat cems In this sibsation, seseding for distinctive fondarks (step 3) will huip to merict the condriors to corsisder in the d: ferercial dingnosis and target the specific confirmatory tests.

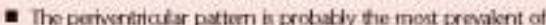
al pattems, and mintiad dotinct doeaser, incladeng dseases cher insileukodysthopties, canmarifest widh periventricular endwernent.

- MR spectronocen might be used as a polestal norimasione tionackir of trasmerit reporke in treatable dseases suth arCXX

The purpose of this review is to adapt this algorithm for adult leukodystrophies and to demonstrate the imaging features of some of the most prevalent forms of this disease. The approach we propose here must be used mainly as a framework. The characterization of all possible types of leukodystrophies and eventual atypical presentations is beyond the scope of this review.

\section{Step 1: Identify Symmetric White} Matter Involvement

Symmetric white matter involvement at MRI is a typical finding in patients with leukodystrophies. Thus, recognizing this involvement is important when leukodystrophies are suspected, although there are exceptions to this partern (12). T2weighted and fluid-attenuated inversion-recovery (FI_AIR) MRI are the best sequences to use to determine white matter involvement, as shown in Figure 1, which illustraces symmetric whire matter involvement compared with an asymmetric pattern. White matter lesions appear as hyperintensity on T2-weighted and FL.AIR MR images and hypo-or isointensity on T1-weighted images. Depending on the cause and stage of the disease, signal intensity may vary. Familiarity with typical manifestations is important (13).

Important exceptions to this rule are genetically defined vasculopathies, such as CADASIL, in which abnotmalities in signal intensity (fe, increased signal intensity on T2-weighted or FLAIR MR images) can be multifocal and asymmetric instead of symmetric, especially in the early phases of the disease. However, these diseases usually manifest with other distinctive MRI findings that can help in reaching the correct diagnosis.
In addition to recognizing symmetric white matter inwolvement, characterizing the white matter involvement pattern is necessary to continue with the differential diagnosis.

\section{Step 2: Look for a White Matter} Involvement Pattern

The next step in the diagnostic approach is to look for the pattern of white matter involvement. There are six patterns of white matter involvement with which radiologists should be aware to reduce the list of possible diagnoses, as shown in Figure 2. However, sometimes the same patient presenrs with more than one partern during the time course of the disease, and a given leukodystrophy may manifest with more than one of these patterns. In this situation, searching for distinctive findings (step 3 ) helps to restrict the conditions to consider in the differential diagnosis and target the specific confirmatory rests.

\section{Parieto-occipital Pattern}

X-Inked Adrenoleukodystrophy-X-X-linked adrenoleukodystrophy (X-ALD), one of the most common adult leukodystrophies, is caused by at mutation in the adenosine triphosphate-binding cassette subfamily $\mathrm{D}$ member 1 gene ( $A B C D 1$ ), which codes for an adenosine rriphesphare-binding cassette transporter and is located in the peroxisomal membrane. The biochemical hallmark of this condition is an elevation in serum levels of very long-chain fanty acids, which also accumulate in neural tissues and in the adrenal gland. Molecular confirmation of X-ALD is performed by sequencing the $A B C D I$ gene $(10,13,14)$.

In adults, there are different forms of X-AL.D. The most common is "pure" adrenomyeloneuroparhy, which manifests with slowly progressive spastic paraparesis, sensory disturbances, and bladder dysfunction. These patients usually experience spinal cord atrophy, mainly in its thoracic segment, but the brain shows no abnormalities. The cerebral manifestation of $\mathrm{X}-\mathrm{ALD}$ is less frequen in adults and is characterized by psychiatric features followed by dementia, ataxia, seizures, and even dearh. In these patients, MR images of the brain are similar to those observed in children with ALD, and the spinal cord shows no abnormalities. Other patients present with intermediate forms of the disease that include involvement of the spinal cord and brain $(3,15-17)$.

Approximately $80 \%$ of men with the cerebral form of X-Al.D have abnormalities at MRI (ic, high signal inrensity on T2-weighted or FIAIR MR images) in the parieto-occipital white matter, splenium of the corpus callosum, visual and audi- 

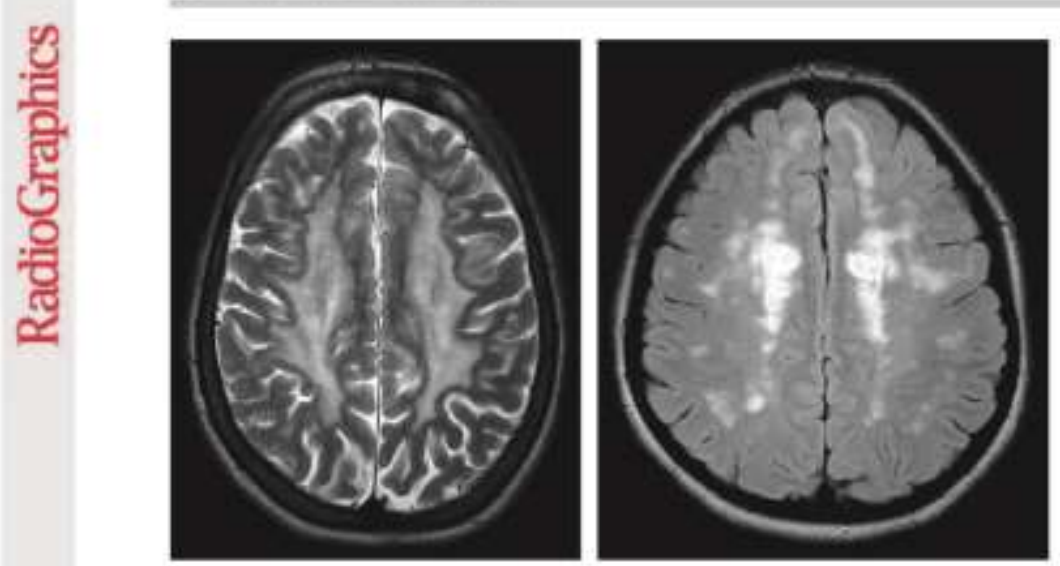

Figure 1. Symmetric versus asymmetric white matter involvernent in two paticnts, (a) Avial T2 waighted MR image in a 23 -year-old womar with leiserencephakopathy with brainstem and spiral cord invobe ment shows symmetric white mat. ter imvolversent, (b) Avial PAis aR inter inter pattem in a 46-yoar-old woman with crebral sutomomal dominan atteriopathy with subcortical in farcts and leukoescephialopathy a.

b. (CADAsi).

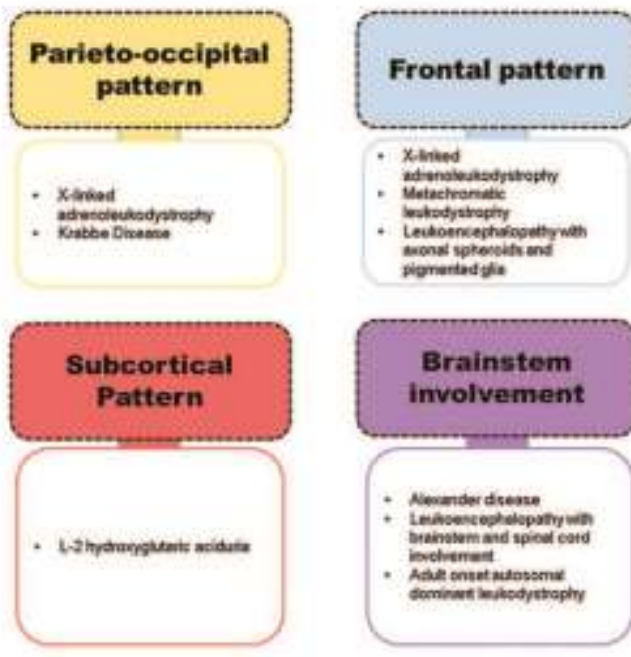

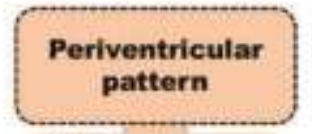

White mat ter involvement pat tems and examples of differential diaqnosis: FXTAS - fragile $X$ asso ciated tremor or ataxia

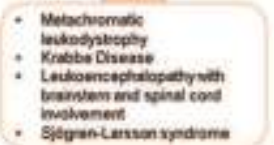

Sitprencumanxpdame

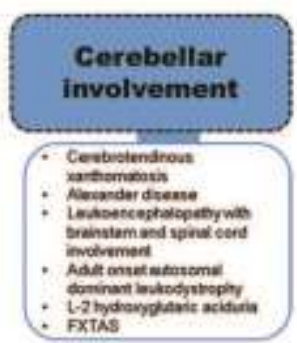
syndrome. tory pathways, and occasionally the corticospinal tract (Fitg 3). However, these features may not manifest concomitandly in a given patient.

Isolated corticospinal tract or cerebellar white marter tnvolvement at MRI of the brain is seen in a small number of patients and represents more slowly progressive involvement $(13,18,19)$. Contrast material enhancement on T1-weighted MR images at the edges of affected whire matter is predictive of clinical activity and disease progres$\operatorname{sion}(20)$.

\section{Krabbe Disease (Globold Cell Leukodystro.}

phy). - Krabbe disease is an autosomal recessive lysosomal storage disease caused by deficiency of the $\beta$-galactocerebrosidase enzyme, which leads to oligodendrocyte apoptosis and gltosis (21).
Adult Krabbe disease can manifest as late as the 5th decade of life. Clinically late-onset forms manifest with pyramidal tract involvement and spastic paraparesis or tetraparesis. A peripheral demyelinating polyneuropathy occurs in up to $60 \%$ of patients and may be asymmetric and involve bulbar muscles. Progressive cognitive decline, seizures, and cortical blindness aiso can ensue. The disease progression is slow $(22-27)$.

MRI may show bilateral white matter involvement or may be normal even when the patient has neurologic symptoms. Predominant parietooccipital white matter changes and involvement of the splenium of the corpus callosum typically are observed (Fig 4). T2-hyperintense changes are observed along the corticospinal tracts, the 
Figure 3. X-AID in thire patients, (a) Axial 12 -weighted MR image in a 36-year-old man shows paricto-occipital symmetric white mattor hyperintensity, (b) Contrast enhanced axdal T1 uwdighted MR image in the same paticnt shows enhanoernent foci ha the white mattes (arrow). (C) Axal T2 weighted MR image in the same patient as in a and b shows corticospinal tract inwolvement (anows). (d) Sagktal

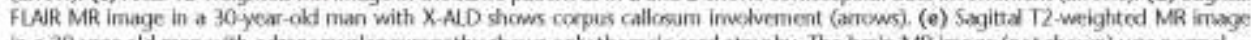
in a 29 -year-old man with adrenomydoneiropathy shows only thoracic cord atrophy. The brain MR image (not stown) war nomal.

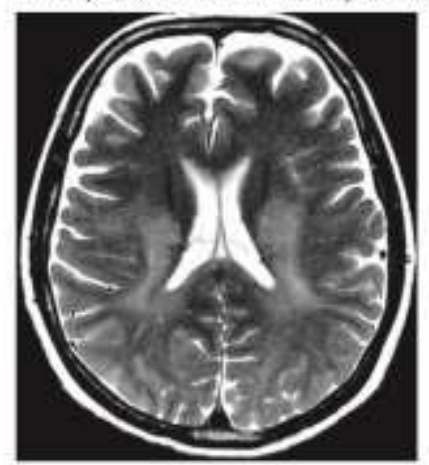

a.

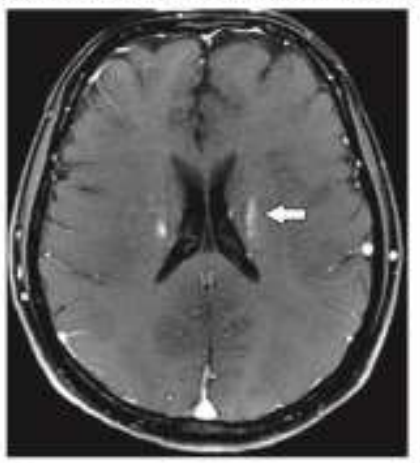

b.

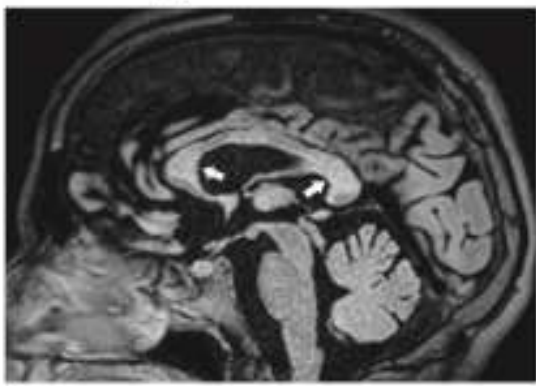

d.

posterior limb of the internal capsule, and the pyramidal tracts in the brainstem $(15,25,28)$.

\section{Frontal Pattern}

$\boldsymbol{X}$-ALD.-Patients with $\mathrm{X}$-AL.D also may present with a frontal partern of white mater involvement (Fig 5). The features of this disease were described in the parieto-occipital pattern section. Frontal white matter is involved in approximately $15 \%$ of children with $\mathrm{X}$-ALD but also can be scen in adult patients (Fig 5).

When there is concomitant involvement of parieto-occipital and frontal white matter, patients usually experience rapidly progressive disease $(13,18,19)$.

Metachromatic Leukodystrophy,-Merachromatic leukodystrophy is an autosomal recessive lysosomal condition due to arylsulfatase A (ARS $A$ ) gene mutations, resulting in deficiency of the enzyme arylsulfatase A (ASA) that leads to accumulation of 3-O-sulfogalactosylceramide (sulfatide) in oligodendrocyres, Schwann cells, and some neurons $(29,30)$.

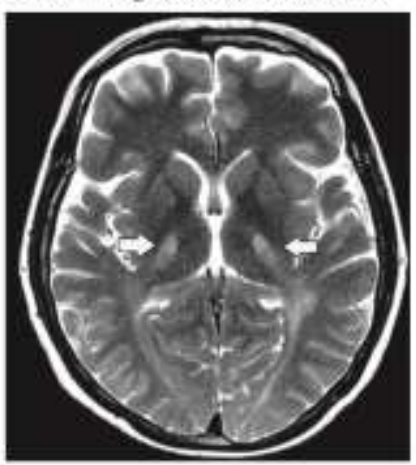

c.

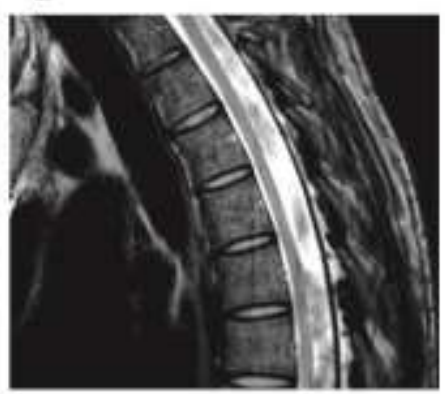

e.

Adults account for approximately $20 \%$ of patients with metachromatic leukodystrophy. The initial symptoms are often behavioral and psychiatric changes, followed by a slow decline in memory and intellectual abilities. Later, the onser of motor symptoms including spastic paraparesis and cerebellar ataxia and peripheral neuropathy occur. Cholecystitis due to accumulation of sulfatide in the gallbladder wall is an important nonneurologic complication (31).

MRI findings consist of confluent, symmetric T2 hyperintensity in the frontal or periventriculat white matter (Fig 6 ). The subcortical $U$ fibers are spared, and frequently some frontal predominance is present in patients with adult-onset metacluromatic leukodystrophy. Loss of white matter volume results in brain atrophy in the late stages of the disease $(32,33)$.

\section{Leukoencephalopathy with Axonal Spheroids} and Pigmented Glia.-Leukoencephalopathy with axonal spheroids and pigmented glia also can show a frontal pattern; however, it will be discussed in step 3 , because these additional 


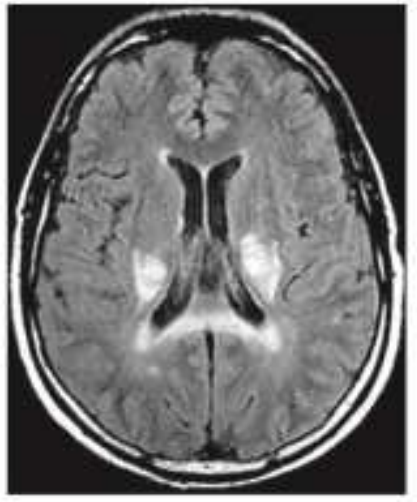

a.

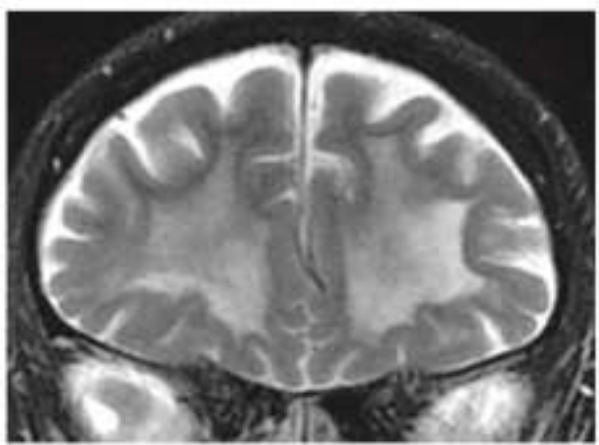

a.

features are a more substantial diagnostic clue for this disease.

\section{Periventricular Pattern}

The periventricular pattern is probably the most prevalent of all patterns, and myriad distinct diseases, including diseases other than leukodystrophies, can manifest with periventricular involvement

Metachromatic Leukodystrophy.-MRI findings in patients with metachromatic leukodystrophy also can reveal a periventricuiar white matter pattern without lobar predominance $(32,33)$.

Krabbe Disease. - J css commonly, Krabbe disease can manifest as diffuse periventricular white matter inwolvement (7).

\section{Leukoencephalopathy with Brainstem and} Spinal Cond Involvement.-Leukoencephalopathy with brainstem and spinal cond involvement may manifest with a periventricular involvement

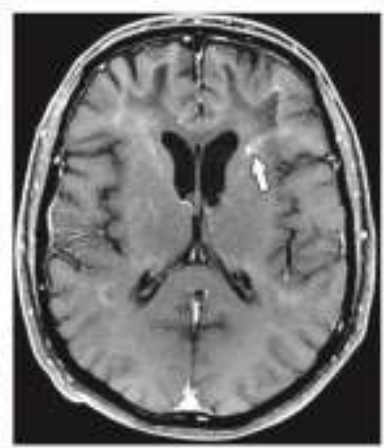

Figure 5. XND in a 54 yearold man. Coro nal T2 weighted Mir image (a) shows pre dominant inopherpent of frontal white matter including periphesal en hancervent (anow) or the coresponding axil contrast-enthanced T1 weighted MR image (b). b.

pattern, as shown in Figure 2. However, because brainstem involvement is characteristic, it is discussed in the brainstem involvement section.

Sjögren-Larsson Syndrome.-Sjögren-L,arsson syndrome is a rare autosomal recessive disorder chanacterized by spastic diplegia or tetraplegia, dementia, speech disturbance, and congenital ichthyosis, Sjögren-Larsson syndrome is caused by inactivating mutations in the aldehyde dehydrogenase 3 family membet $\mathrm{A} 2$ gene $(A L$. $D H 3 A 2)$, which encodes for fatty aldehyde dehydrogenase (FALDH) and results in abnormal metabolism of long-chain aliphatic aldehydes and alcohols $(3,4,35)$.

Ar MRI, parients show diffuse white matrer hyperintensity on FL $A I R$ and T2-weighted MR images, mainly in the periventricular white matter of the frontal lobes and at the level of the cenrrum semiovale and corpus callosum (Fig 7).

MR spectroscopy allows disclosure of some ancillary changes that eventually can be of some help. Spectroscopic abnormalities consist of 

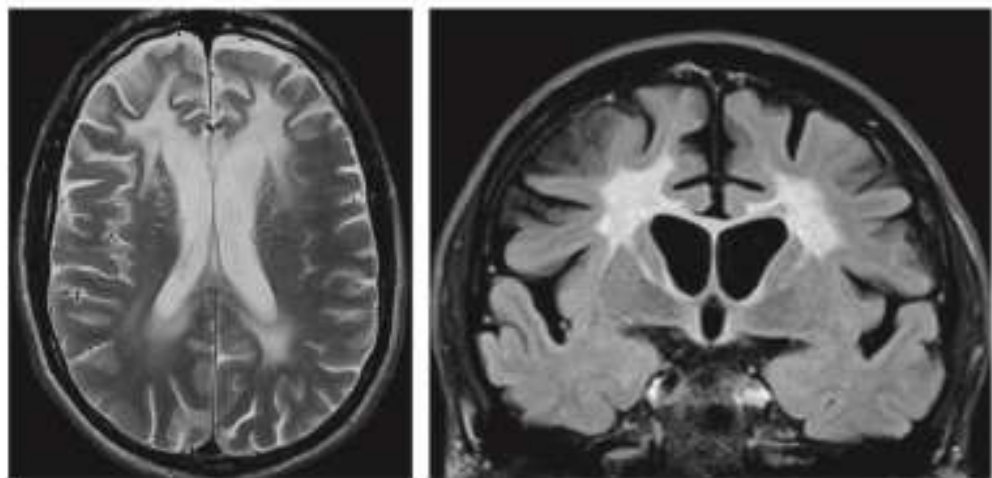

b.
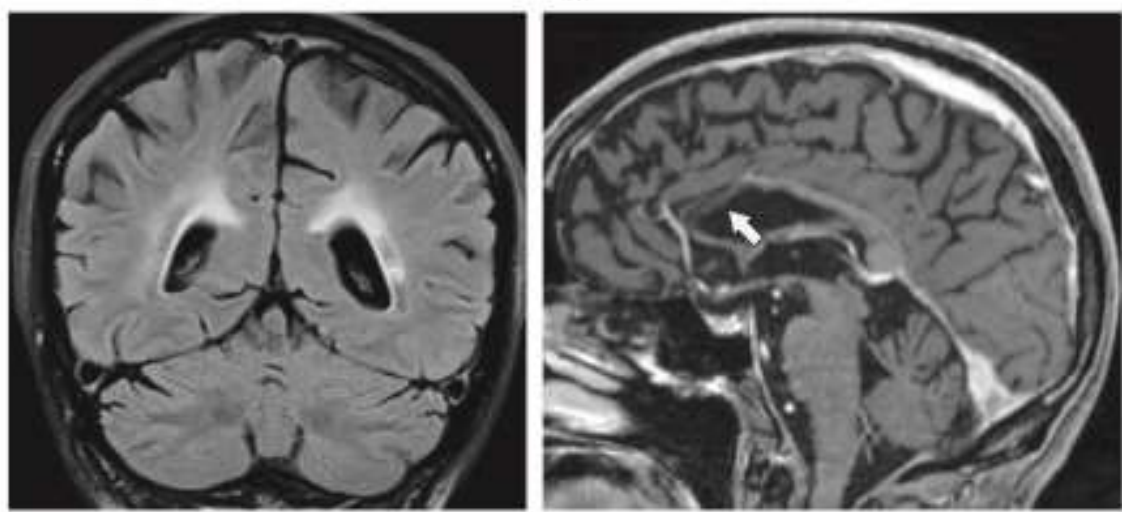

d.

Figure 6. Metachromatic keskochystrophy in a 51 yoar old man. (a) Axial 72 weighted MH imooge shows the prodomi nance of frontal white matter involvernent, (b, c) Coronal FLAIR inarges show the frontal white matter involurmenis ascociated with atrophy (b) but also show pexterior pestuentricular bilateral lesions (c). (d) Sagltal tefomatted coptrast-enhanred three dimersional T1- weikgted MR imsoge shows brain atrophy (mainky frontal), with corpus calosum implverment (arnow). There is no contrast enhimcernent

lipid peaks in the white matrer, which are relared to the accumulation of lipid substrates that occurs in Sjogren-L_arsson syndrome, especially a peak located at $1.3 \mathrm{ppm}$. $N$-acetyl aspartate peaks are ustially relatively preserved, and elevated levels of creatine, choline, and myoinositol can be seen $(34,36)$.

\section{Subcortical Pattern}

L-2-hydtoxyglutaric aciduria is a rare neurometabolic disorder with autosomal recessive inheritance (L-2-hydroxyglutarate dehydrogenase $[L .2 H G D H]$ gene) that is characterized by leukoencephalopathy that predominantly affects subcortical white matter (Fig 8) (14).

Patients initially may appear asymptomatic or may have a static encephalopathy. The neurologic symptoms are progressive and include cerebellar ataxia and intellectual decline. Hearing loss is another possible symptom of the disease. In certain patients, these features become apparent only in adulthood. Increased I.2-hydroxyglutaric acid in urine is diagnostic (37).

MRI in patients with L-2-hydroxyglutaric aciduria shows predominant subcortical white matter involvement, initially focal and evolving to become confluent. Periventricular white matter is spared. Increased signal intensity on T2-weighted or FL.AIR MR images mary be observed in the globus pallidus, and less importantly, in the caudate nucleus and putamen, with symmetric distribution. These same signal intensity abnormalities also may be observed in the dentate nucleus (38).

\section{Brainstem Involvement}

Alexander Disease,-Alexander disease is the result of an autosomal dominant mutation in 


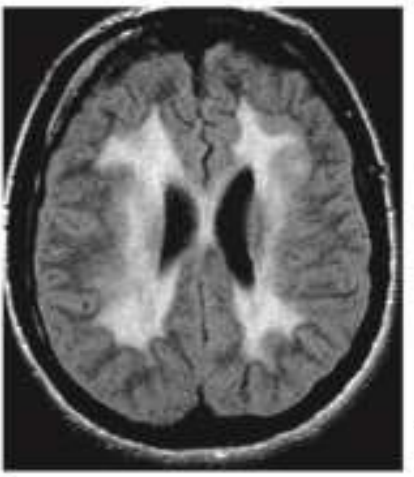

a.

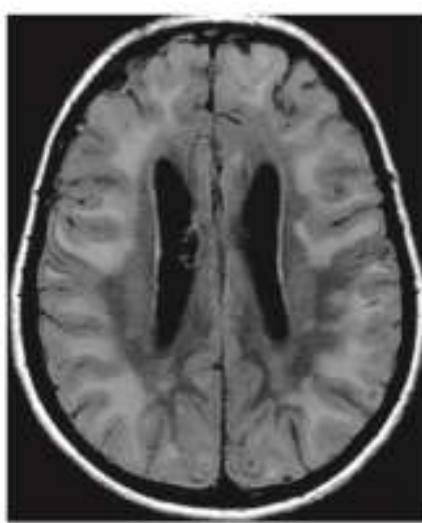

a.

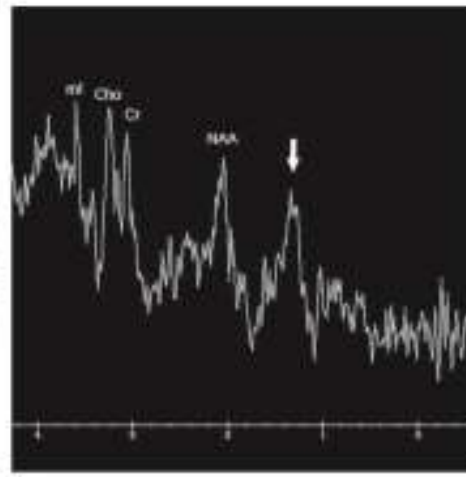
Figure 7 . Latephase Sjögren-
tarsson syndrome in a 27 -yeareld man. (a) Axial FLAIR MF im old man. (a) Axial flAIR Mif im. matter involvement prottem (b) Proton spectrascopk image of the frontal whe metter, obsained with a wien echo time shows a with a shen collo the shows ad nom a peaks at 1.3 ppon (arrow) ndicating lipld deposition. Oho = choline, $C r=$ areatine, $r i=$ myo hositol $N A t=$ Nacctyl aspartate

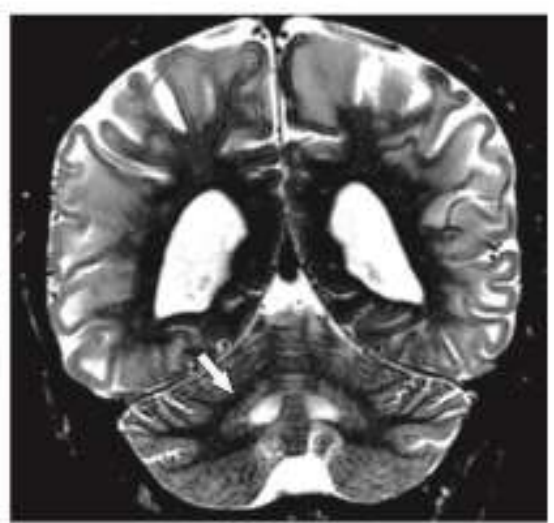

Figure 8. L-2-ingtroxy glutaric aciduria in 29-year old woman. (a) Axial PLAa image shows a subcortical pattem of white matter in voluement. (b) Coronal vohement. (b) Coronal
T2-weighted MR image shows the same pattern and bilateral byperin. tensities in the dentate nuclei (arrow), which nucted (arrow), which are commanly observed in paticnts with this disease the glial fibrillary acidic protein (GFAP) gene. These mutations usually are de novo but may be hereditary in patients with adult-onset disease. This condition is characterized pathologically by diffuse Rosenthal fiber accumulation in astrocyte cytoplasms. Molecular testing is diagnostic, and a brain biopsy is no longer required to confirm the diagnosis $(37,39)$.

The clinical presentation includes slowly progressive bulbar dysfunction (dysphagia, dysarthria, and dysphonia), pyramidal signs, and ataxia, with normal cognitive and intellectual functions. When present, palatal myoclonus is suggestive of this diagnosis $(8,40,41)$.

MRI findings in patients who develop Alexander disease in atulthood differ substantially from those of the early-onset form of the disease (Fig 9). White matter signal intensity abnormalities (increased signal intensity on T2-weighred and FLAIR MR images) and mild to severe atrophy of the medulla oblongata extending caudally to the upper cervical spinal cond are the hallmarks of this condition. Middle cerebellar peduncle signal intensity abnormalities also may be observed, and patchy enhancement may be present in affected tegions $(39,42,43)$

Leukoencephalopathy with Brainstem and Spinal Cond Involvement.-Leukoencephalopathy with beainstem and spinal cord involvement is a rare autosomal recessive disorder related to aspartyltRNA synthetase 2 (DARS2) mutations. Diagnostic criteria have been developed. This condition is a monogenic disease directly related to mutations in the gene encoding mitochondrial aminoacyltRNA synthetase (44). Parients with adult-onset disease have been reported to have progressive pyramidal, dorsal column, and cerebellar dysfunction. Symptoms include motor dererioration, progressive spastic ataxia, cognitive decline, and sensory neuropathy $(45-47)$.

At the brainstem level, typical MRI findings include trigeminal mesencephalic tract hyperintensity on T2-weighted and FLAIR MR images 

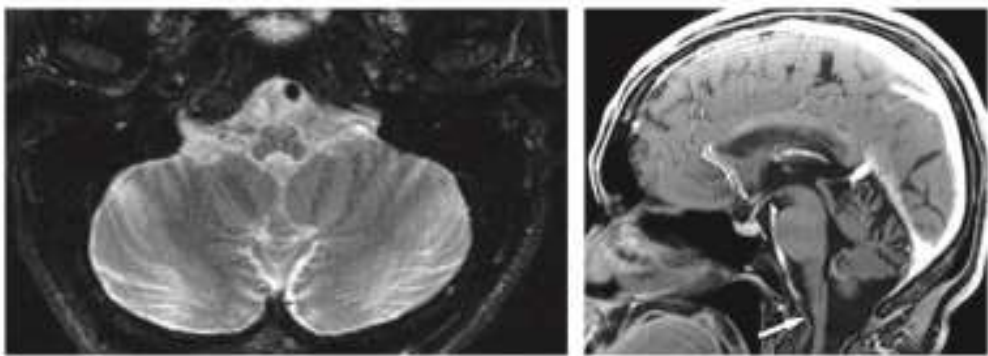

b.
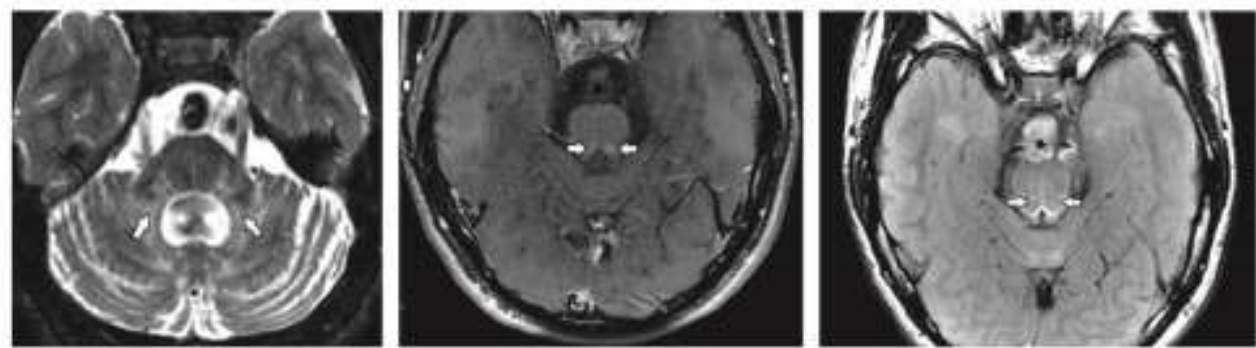

c. d.

e.

Figure 9. Alexander disense in two patients, (a) Axial I2-meighted MR image in a 36-jear-old woman shows atiophy of the me dulla with some hyperintense areas. (b) Sagittal contrat enhanced $\Pi 1$ weighted MR imoge in the sanne patient shows atrophry of the cervicomedullary junction (arnow), a common finding in patients with this condition. (c) Axial reformatted three-dirnensional T2 weighted MR image in a 20 year old man shows bilaterd midde coebellar pedunde involvement (arrows). (d) Axial contrast enhanced 77 -weighted MR image in the same patient shows enharocement fod (arrows) in the sarne region. (e) Axial FLNR image in the same patient as in $c$ and $\mathbf{d}$ showe hyperintense kskons in the mesencephalon (arrows),

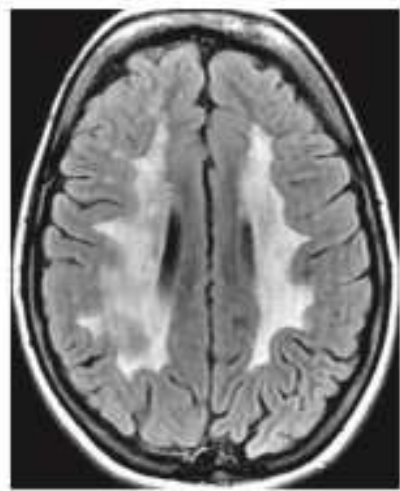

a.

Figure 10. Leuksencephalopathy with brainstem and spinal cord imolvement in a 19 -year old woman. (a) Axial

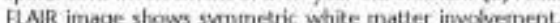
(b) Axial I 2 weighted MR image shows select the brainstem (arrowhears) and cerebellag (bent inom) fyperintensi ties, inclading the intraperenchymal trasts of the trigening lal T2 weighted MR imege hours cerviral opinal cord in. volvement, characterizad by hyperintense areas. (d) Proton MR spectroecopic imege with a short echo fine shows an incteraed lactate peck (toc).
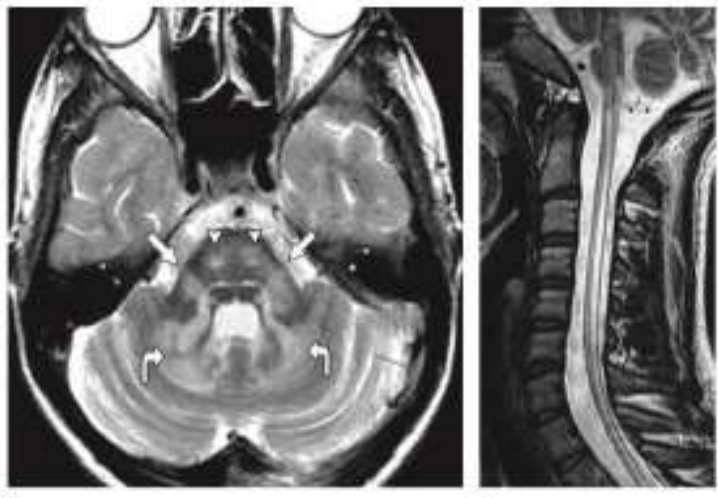

c.

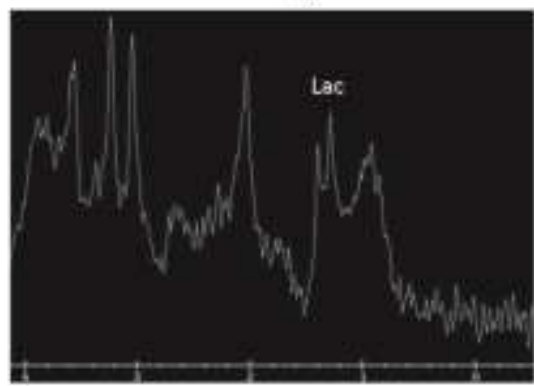

d. 


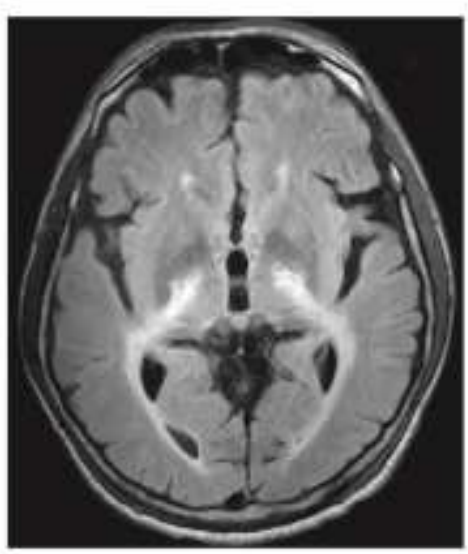

Figure 11. $\mathrm{crX}$ in a 46 -year-old man. (a) Axial FLAR MR iniage shows symmetric white inatter inwolvement. (b) Axial T2 weighted MR image shows deep cerebellar hyperintensizies. (c) Proton MH spectroscopic image of the cercbellar hemisphere with a stort echo time shows increased lactate flac) and lipid (Lp) peaks and a decreased Nacesyl asportote $(\mathrm{N} U \mathrm{l} \text { ) })_{\text {peak }}$

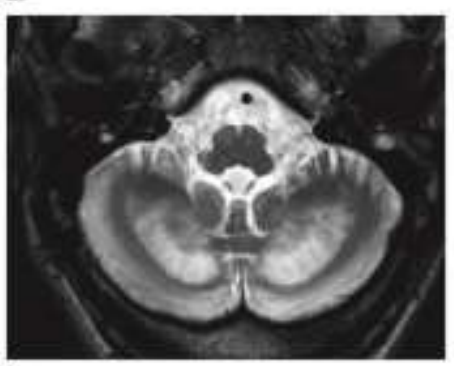

b.

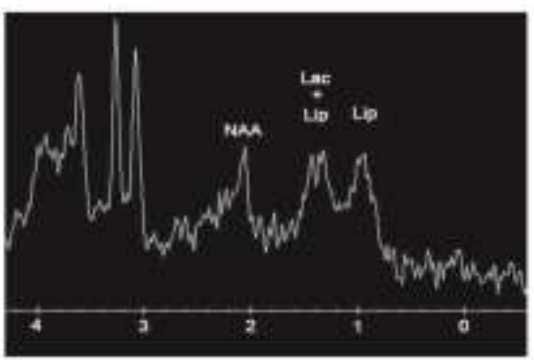

c. and medial lemniscus and pyramidal tract lesions (Fig 10). Involvement of the inferior and superior cerebellar peduncles and deep cerebellar white matter are frequently obserwed. There is also selective involvement throughout the entire length of the pyramidal tracts, including the spinal cord $(14,37)$. MR spectroscopy occasionally allows visualization of lactate peaks.

\section{Aduit-onset Autosomal Dominant Leukodystro-} phy.-Adult-onset autosomal dominant leukodystrophy also has brainstem involvement, but it will be discussed under the associated spinal cord involvement section in step 3 .

\section{Cerebellar Involvement (Including Middle Cerebellar Peduncles)}

Cerebrotendinous Xanthomatosis.-Cerebrotendinous xanthomatosis (CTX) is a treatable autosomal recessive disorder and is characterized as a lipid storage disease caused by a mutarion of the cytochrome P 450 family 27 subfamily A member 1 (CYP27AI) gene, which leads to a deficiency of the mitochondrial enzyme 27-hydroxylase. This enzyme catalyzes one of the first steps in the metabolism of sterols, CTX results in the deselopment of a tendinous xanthoma, early cataracts, diarrhea, and leukoencephalopathy. If left untreated, patients might develop progressive dementia and psychiatric symptoms $(7,48-50)$.

The earliest and most relevan MRI fearures of CTX are involvement of the cerebellar white matter (Fig 11). High signal intensity in the deep periventricular white matter and low or high signal intensity in the dentate nucleus on T2-weighted MR images is characteristic. T2hypointense areas may be observed and probably represent hemosiderin deposition $(15,37)$.

MR spectroscopy in patients with CTX shows increases in lactate and lipid peaks and a decreased $N$-acetyl aspartate peak, mainly in the cerebellum. The presence of tipid peaks is reasonable because CTX is a lipid storage disease (5t).

Alexander Disecrse--In Alexander discase, the involvement of the deep cerebellar white matter occasionally can be appreciated, as can middle cerebellar peduncle signal intensity abnormalities (7).

Leukoencephalopathy with Brainstem and Spinal Cord Involvement.-Leukcencephalopathy with 
Figure 12. Fragle $X$-associated tremo and/or ataxia symbrome in a 70 yrear-aks man. Axial H ANR MR image shows symmetric biateral hyperinteristics is the middle cerebellar peduncles (arrows).

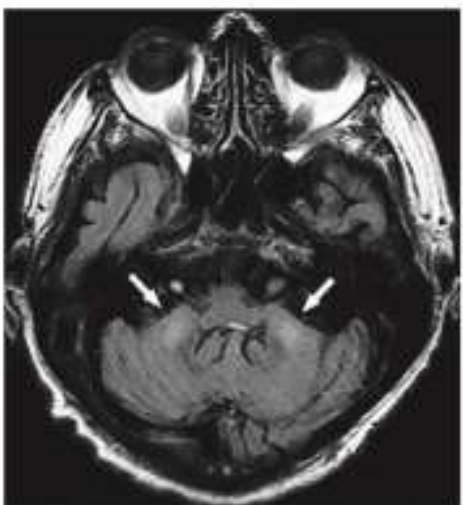

Figure 13. Distinctime features and talated ionditions to carsicter in the differential diagnosis.
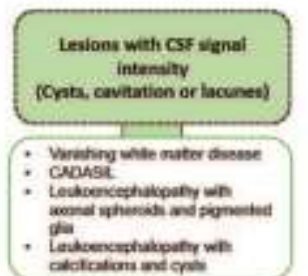

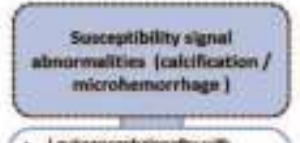

+ Leabenceghasepiabivin

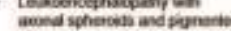
ina cocicition ind opis Nowitiduch abeas$$
\text { seave }
$$
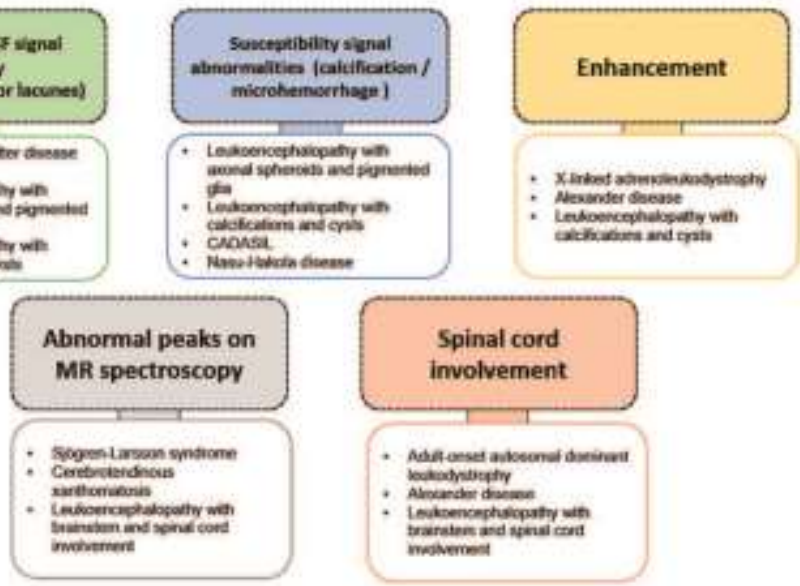

brainstem and spinal cond involvement is another enticy that sometimes manifests as cerebellar white matter involvement (46).

\section{Adult-onset Autosonal Dominant Leukodystro-}

phy.-Adult-onset autosomal dominant leukodystrophy also has cerebellar involvement but will be discussed in step 3 .

L-2-Hydroxyglutaric Aciduria,-L-2-hydroxyglutaric aciduria can manifest with involvement of the dentate nuelei, as can be seen in Figure 8.

\section{Fragile $X$-associated Tremor and/or Ataxia Syn} drome.-Fragile $\mathrm{X}$-assoctated tremor and/or ataxia syndrome is caused by fragile $\mathrm{X}$ intellectual disability 1 (FMRI) gene permutations and leads to cerebellar ataxia, tremor, and peripheral neuropathy.

At MRI, diffuse symmetric middle cerebellar peduncle T2 hyperintensities are a radiologic hallmark of this disease, but they are not akways present (Fig 12). Other radiologic tindings include deep cerebellar white matter lesions and mild to modetate cerebellar atrophy $(12,14,52)$.

Step 3: Recognize Distinctive Features In this section, we will review distinctive imaging findings that can further restrict the differential diagnosis of leukodystrophies. There are five types of distinctive findings that clinicians should recognize. These findings are illustrated in Figure 13.

\section{Lesions with Cerebrospinal Fluid Signal Intensity}

The presence of lesions that show signal intensity similar to that of cerebrospinal fluid on images from all MRI sequenoes can be a distinctive finding, although these lesions can have diflerent causes and pathophysiologic mechanisms. FL.AIR MR images ate of paramount importance for the correct identification of these lesions, which can represent, among other entises, cysss, cavitations, or lacunae. 


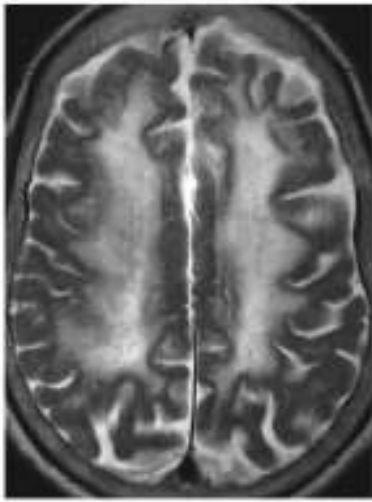

a.

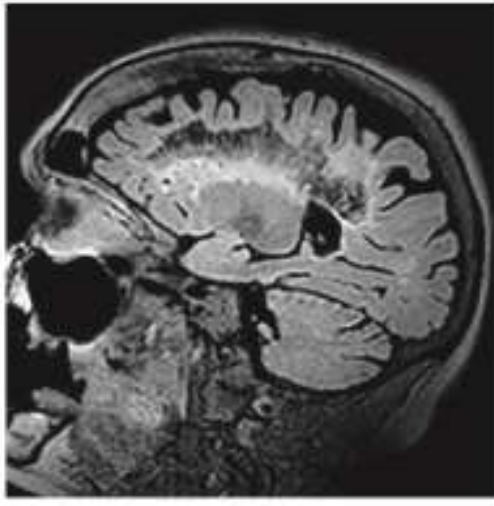

b.
Figure 14. Vanishing whilte matter disease in a 65 -year-old woman. (a) Axial TZ-wecicyited MPR mage shous diffuse white patter une she yperintenstion bilateral cen trum semiovale. (b) Sagittal FLN MR irmage shows hypointense ar eas within the 12 signal intersity abnormality, which represent cys tic ratefaction of white matter.
Vanishing White Matter Disease. - Vanishing white matter disease is related to eukaryotic translation initiation factor $2 \mathrm{~B}$ subunit $\alpha 1-5$ (EIF2B1-5) gene mutations. A mild variant of this disease has been described in adult patients The symptoms in the adult-onset form are migraine, spasticity, psychiatric symptoms, cerebellar signs, seizures, and dementia. Pseudobulbar palsy and progressive spastic paraparesis also may be present $(9,14,15)$.

T2-kreighted MRI may show normal white matter signal intensity or diffuse increased white matter signal intensicy and enlargement of the lateral ventricles (Fig 14), Over time, FLAIR MR images show progressive rarefaction and cystic degeneration until the white matter shows isointensity compared with that of the cerebrospinal fluid.

Cerebellar white matter is relarisely spared. Signal intensity abnormalities in the midbrain and the pons may be observed $(53,54)$. In the end stage, cerebral hemispheric white marter mily have vanished entirely, leaving only the ventricular walls and the cortex, with almost no white matter in between, replaced by this cystic degeneration (15).

CADASIL-CADASIL is the most common hereditary cerebral small-vessel disease. CADASII. is caused by a mutation in the $\mathrm{NOTCH}_{3}$ gene and is the major cause of inherited vascular leukoencephalopathies $(10,14)$.

Adult patients with CADASIL usually present with migtaine with a mean patient age at onsec of 30 years, while the age of onset for ischemic events usually is when patients are in their lare 40 s. As microvascular changes progress, patients may deselop seizures, cognitive dysfunction, and psychiatric symptoms. MRI changes usually precede the onset of symptoms by $10-15$ years $(9,15)$.

At MRI, the first changes are round or oral lesions in the periventricular white matter and centrum semiovale, and these lesions are usually multifocal. These abnormalities subsequently become diffuse and symmetric and involve the external capsule and temporal poles (Fig 15).

Parients can present with lacunac secondary to small-vessel infarcts, which appear as areas of signal intensity similar to that of cerebrospinal fluid on images from all sequences. Another lesion with the same MRI signal intensity behavior in this disense is believed to be a distended subcortical perivascular space, which usuatly is found in the temporal poles (55).

Small foci of restricted diffusion that suggest recent infarcts and microhemorrhages on susceptibility-weighted images have been described as well. Microhemorrhages can be a distinctive finding for vasculopathy, and a T2*or susceptibility-weighted MRI sequence must be performed in every patient who presents with leukodystrophy $(56,57)$.

\section{Leukoencephalopathy with Axonal Spheroids} and Pigmented Gila.-Besides the presence of small cysts that have similar signal intensity to that of cerebrospinal fluid, calcifications also can be detected in patients with this disease; for this reason, this disease is discussed in the next section (susceptibility signal infensity abnormalities).

\section{Leukoencephalopathy with Calcifications and} Cysts.-As suggested by the name, cysts that sometimes resemble cerebrospinal tluid signal intensity can be found with all sequences, as can calcifications (also discussed in the next section).

\section{Susceptibility Signal Intensity}

Abnormalities (Calcification and/or Microhemorrhage)

Lesions that appear as susceptibility signal intensity abnormalities, which manifest as hypointensity 

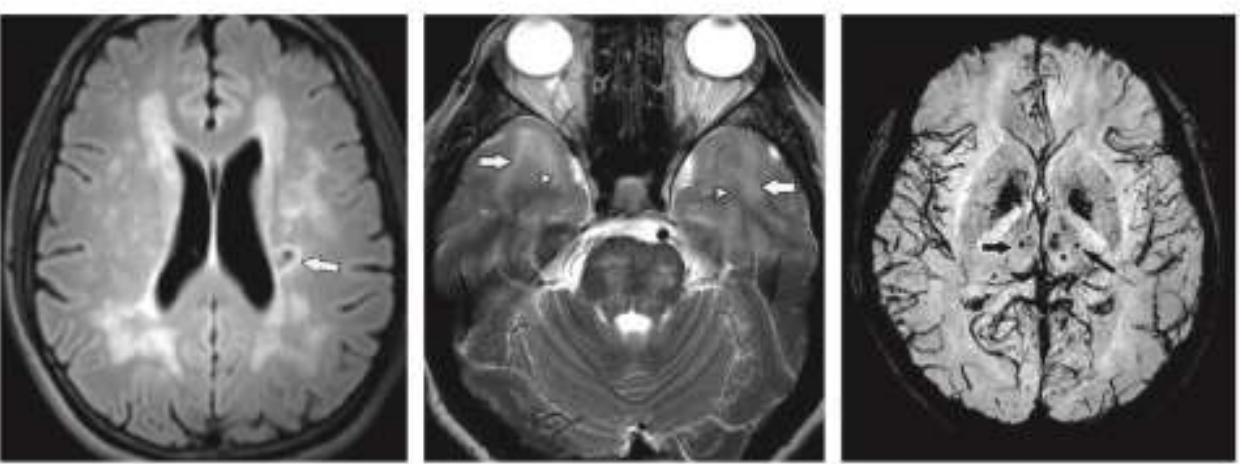

a.

b.

c.

Figure 15. CADASII in two patients. (a) Avial FAR MR image in a 40-year-old man shows cavitated sequedac representing a lscuna

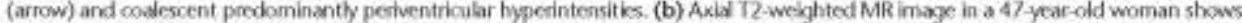

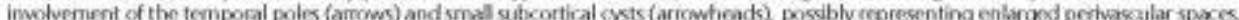
which can be seen in patients with this condition. There are also T2 hyperinterse: lesions in the braindem. (c) Axid susceptibiliky wesighted insoge in the same pasien as in b shows mikrohemontages that appear as hypointerse foci in both thalami (arrows).

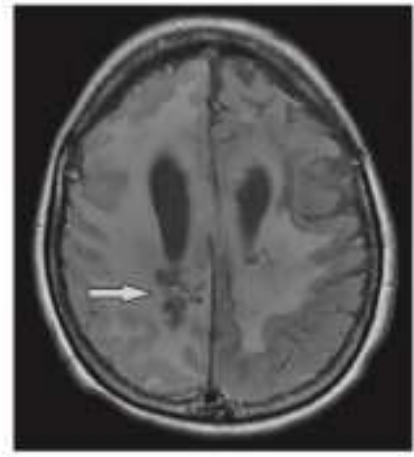

a.

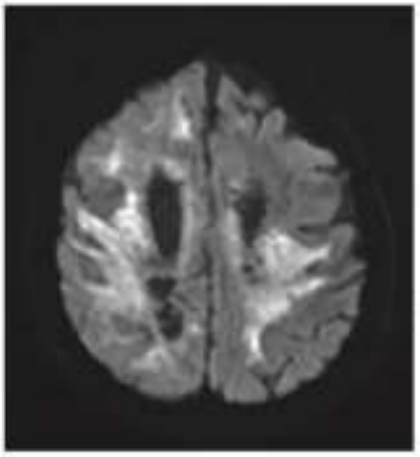

b.

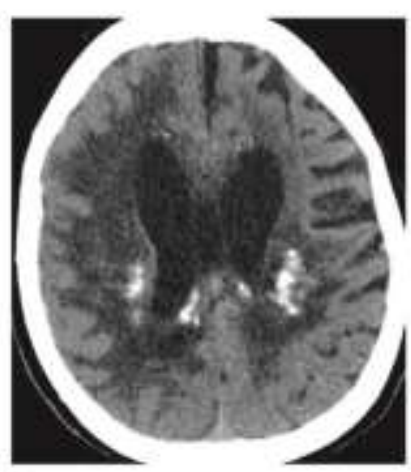

c.

Figure 16. Late-phase keukoencephabopattry with anonal spherobds and pigmented glia in a 43 yecar-old woman. (a) Axial FLAR MR image stows symmetric white matter involvement with diffuse hyperintensity and cysts (arow). (b) Acial diffusion weighted MR image shows areas of restrikted diffusion, which was confirmed on the apparent diffusion coeflicient map (not shown). (c) Nonen. hanoed CT image shows belateral decp and periventricular cerebral calcifications.

on images from $\mathrm{T} 2^{*}$ - or susceptibility-weighted MRI sequences, can be a distinctive finding that indicates calcifications or hemorrhage. Separating calcifications from hemorrhages is possible with the use of CT or the processed phase images of susceptibility-weighted MRI

\section{Leukoencephalopathy with Axonal Spheroids} and Pigmented Glia--Studies (58-61) have shown that these parhologically defined encities are the result of autosomal dominant mutations in the colony-stimulating factor 1 receptor (CSF1R) gene. Both familial and de novo mutations have been described. Unilike other leukodystrophies, this disease manifests exclusively in adults, with most cases occurring in patients in the 20-50-yeat age range. The clinical picture consists of behav- ioral changes, dementia, motor impairment (Parkinsonism, paraparesis or tetraparesis, and ataxia), and epilepsy (62).

MRI leatures include a frontal patretn of involvement of the white matter, which often is associated with restricted diffusion, in the early phases of the disease (Fig 16). There is confluent involvement of the white matter in the late phases, when some foci of restricted diffusion may persist. Small cysts, thinning of the corpus callosum, and calcifications also may be seen. The calcifications are described as small, symmetric, and mainly located adjacent to the anterior horns of the lateral ventricle and in the parietal subcortical white matter, exhibiting preserved basal ganglia. Thin-section CT may be useful for their detection (63). 


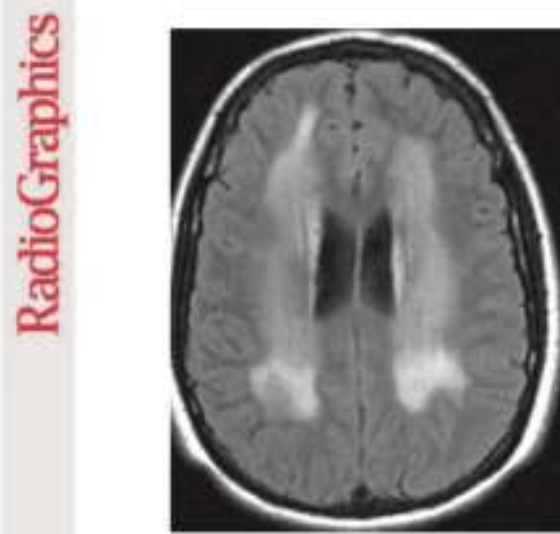

a.

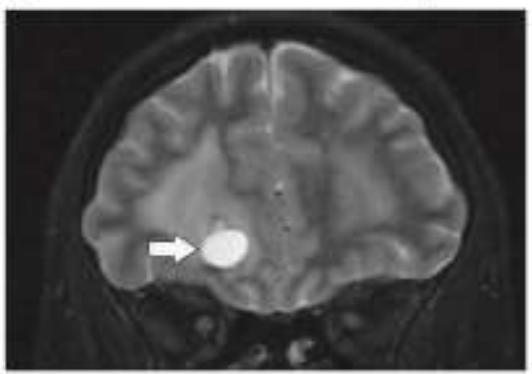

d.

\section{Leukoencephalopathy with Calcifications and}

Cysts. - Leukoencephaloparhy with calcifications and cysts is a genecic disorder relared to a mutation in the small nucleolar RNA, C/D box 118 (SNORD118) gene, which was identified recently. This disease is considered a microangiopathy, and as can be observed of other vasculopathies, asymmetric involvement of white matter may be a characteristic on MR images (Fig 17) (64-66).

In addition to asymmetric diffuse bitatera] leukcencephatoparhy, ealcifications and cysic changes with mass eflect can be seen. The calcifications tend to be large and can be observed anywhere in the brain but mostly in the basal ganglia. Gadolinium contrast enhancement sometimes can be obsetved $(64-66)$.

CADASH-Microhemorrhages are a good marker of a vasculopathy and can be a clue for the diagnosis of genetically inherited vasculopathies such as CADASIL (14).

Nasu-Hakola Disease-Polycystic lipomembranous osteodysplasia with sclerosing leukoencephalopathy, or Nasu-Hakola disease, is a rare autosomal recessive disorder caused by mutations in the triggering receptor expressed on myeloid

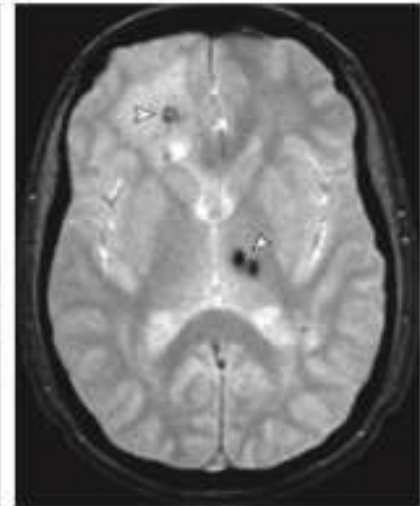

c.

Figure 17. Leukoencephialopatily with cadifications and cysts in a 25 year old man. (a) Axial FLNR MR image shows relatively symurietric whilie mattes imolvesnent. (b) Axial contristenhanced I1-weighted MR image slows a right frontal cyst (arrowhead) and two enhancement foci (arrows). (c) Axial T2* weighted MR image slows colifications (at. mowheads) in the right frontal besion and left thalamus. (d) Coronal $\mathrm{I}_{2}$ weighted MR inarge better shows the right frontal cyat (artow). (Case courtesy of Leonit Terezinha Feltrin, MD.)

cells 2 (TREMZ) and TYRO protein rytosine kinase binding protein (TYROBP) genes. Bone pain and fractures usually arise between the $3 \mathrm{rd}$ and 5th decades of life, followed by development of presenile cognitive impairment and death by the 5 th decade of life $(10)$.

Bone imaging shows multiple cystic-like lesions leading to fractures in the wrists and ankles. In the brain, MRI shows nonspectific white matret involvement and cortical and corpus callosum atrophy, while calcifications in the basal ganglia can be seen at CT (Fig 18) $(9,67,68)$.

\section{Enhancement}

Enhancement is a distinctive characteristic that can be found in a few adult leukodystrophies such as X-ALD (Fig 3), Alexander disease (Fig 9), and leukoencephalopathy with calcifications and cysts (Fig 17).

\section{Abnormal Peaks at MR Spectroscopy} Abnormal peaks at MR spectroscopy can be found in parients with certain leukodystrophies. Although abnormal peaks are relatively nonspecific most of the time, they can be a relevant ancillary finding in some clinical scenarios.

Figure 7 shows a patient with Sib̈gren-Larsson syndrome who has increased lipid peaks in the white matter; the peak at $1.3 \mathrm{ppm}$ is somewhat distinctive in parients with the disease.

Figure 11 shows a patient with a diagnosis of CTX who shows increases in lactate and lipid peaks and a decreased $\mathrm{N}$-acetyl aspartate peak 


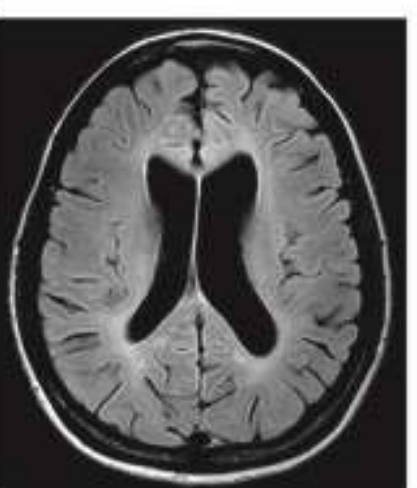
a.

figure 18. Nasu-Haknla disease in a 34 yearolow woman. (a) Axial ALAR MR image shows diffuse atrophy and slight symmetsic periventricular white matter hyperintensity, (b) Nosenhanced CT inage shows basal ganglia calcifications (arrow). (c) Hand rasiograph shows at least one carpal bone cyst (amowhead).
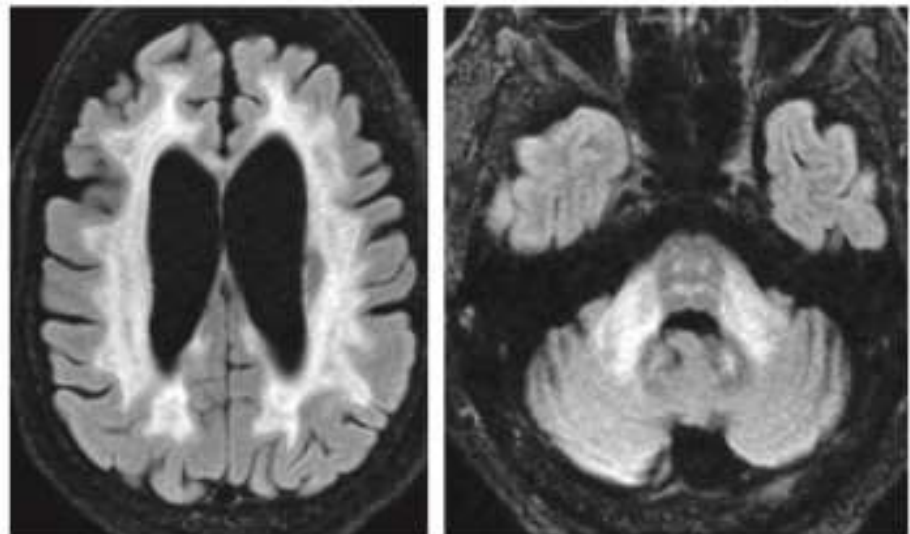

b.
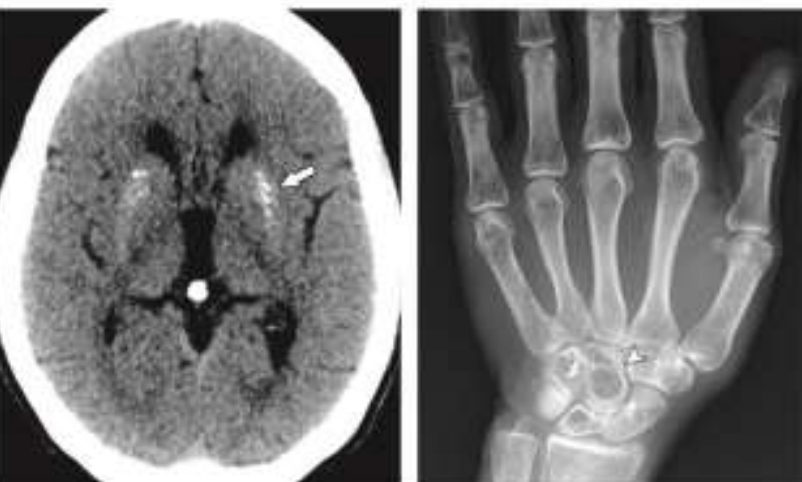

c.

Figure 19. Adult-onset autosomal dominant kuloodystrophy in a 59-ycar-old man, (a, b) Axial ALAR MR imajges show symmetrik corebral whike matter kesions (a) and a selextive pattern of brainstem and middle cerebjellar pedunde involvement (b). (c) Cervical spine sagittal T2-wesghted MR image shows spinal cond atrophy.

in the cerebellum. These are nonspecific findings, but because this disease is related to lipid accumulation in the central nervous system, MR spectroscopy might be used as a potential noninvasive biomarker of treatment response in treatable discases such as CTX (51). Occasionally, MR spectroscopy can show the presence of lacrate peaks in patients with leukoencephalopathy with brainstem and spinal cord involvement, as shown in Figure 10.

\section{Associated Spinal Cord Involvement}

Adult-onset Autosomal Dominant Leukodys.

trophy.-Adult-onset autosomal dominant leukodystrophy is related to lamin $\mathrm{B} 1$ (LMNBI) gene duplication. The clinical presentation is characrerized by autonomic dysfunction, pyramidal signs, and cerebellar ataxis in the 4 th or 5 th decade of life $(69,70)$.

Signal intensity abnormalities increased signal intensity on T2-weighted or FLAIR MR images) are most prominent in the frontoparietal white matter, cerebellar peduncles, corticospinal tracts, and corpus callosum (Fig 19). The changes in the uppermost corticospinal tracts underlying the motor cortex may represent the earliest imaging manifestation of the disease and can be seen in asymptomatic family members. Atrophy of the brainstem and spinal cord also may be observed. The MRI lesion pattern, in combination with the typical clinical symptoms and mode of 
inheritance, is quite suggestive of the diagnosis of autosomal dominant leukodystrophy (69).

Alexander Disease.-In patients with Alexander disease, involvement of the upper cervical spinal cord occasionally can be appreciated, most often extending from the medulla (41).

\section{Leukoencephalopathy with Brainstem and} Spinal Cord Involvement. - As indicated by its name, this disease can manifest with sigmal intensity abnormalities in the spinal cord, which helps in diagnosing this disease (46).

\section{Conclusion}

Diagnosing adult leukodystrophies remains complex and challenging. Clinicians and radiologists should recognize MRI white matter involvement patterns and distinctive characteristics; in addition, they should work together when facing such a suspicion.

In summary, although not neglecting the complexity of the subject, our approach can be helpful as a starting point to provide an algorithmic analysis of MRI examinations of patients suspected of having adult leukodystrophy in an attempt to reduce the list of differential diagnoses and target specific confirmatory tests.

Disdosares of Confficts of interest-C.A.C.L. Atsivibien related to the prosat artide: disclosed no relenumt relationshiph Active ties not riarsir to the preswit artide grantsigrants pesdiag from

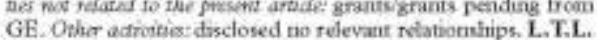

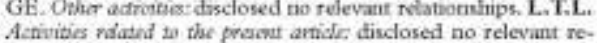

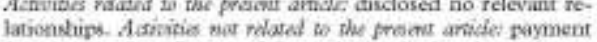
for a lecture from llinacoo. Other anticitier: disclosed no relevant relationships.

\section{References}

1. Kevelam SH, Steenweg ME, Srivatiwa S, et al. Update on keukodystroptries: a historical perspective and adapted definicion. Neuropediarries 2016:47 (6):340-354.

2. Costello D], Eichler AF, Euchlar FS. Leakodystroplies classificarion, diagnosis, and treatment. Neurologist $2009 ; 15(6): 319-328$

3. Pastores GM. Leukoenceptalopathies and leakodystro. shies. Conriourus (Minneap Minn) 2010.16/2 Dementai) $: 102-119$

4. Helman G, Venkateswaran S, Vunterver A. The spectrum of adult-onset heritablewhite-noster divonders. Hande Chin of adult-onsetheritable white-14

5. van der Kneap MS, Bugiuni M. Leukodystrophies: a proposed dassificaion spstam kised en puthological ctranges sand pathogenetic mecharissos. Acta Neuropathol (Berl) $20172134(3): 351-382$.

6. Pankh S, Bernand G, Leventer RJ, et al, A cinicul approach to the diagnoois of parients with leukodystrophies and genetse leukoencephalopechies. Mol Genet Metab 2015:114(4) $501-515$.

7. Kohler W, Curiel J, Vaadenver A. Adaltbood leakadystrophos. Nat Rey Neurol 2018;14(2);:94-105.

8. Lynch DS, Rodrigues Bracıdăo de Paiva A, Zhaag WJ, et al. Clinical and sonetic ctaracienzanion of levkosncephas-

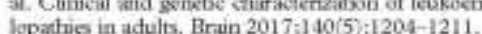

9. Leite CC, Lucato LT, Santos GT, Kow, F, Brandsós AR, Castillo M. Imaging of adult leukodystroptoes. Arq Nevropaiquiatr $2014,72,8,: 625-6.12$.
10. MorgenlanderJC.MRI poreroserrcachofaduli-cosetinherited keukoenoxplalopatties. NeurolClin Prict 201 $6 ; 6 ; 2): 96$.

1. Schiffinam R, van der Kragp MS. Imsired erticle an MRIbased approacti to the diagnosis of white maser disorder. based approact to the diagnosis of
Neurobogy $2009 / 72(8): 750-759$.

12. Aynignac X. Carra-Dalliere C. Menjot de Chamodieur N, et al. Adult-onset penetic leukoenseplulopathes: a MRI partern-based approash in a coarmprebensive study of 154 patients. Brien 2015;138(A7 2):284-292.

13. Renaud DL. Adult-onset leukoencephalopatties. Continuurb (Minneap Minn) 2016:22(2 Dementia) 559-578.

14. Ayngar X, Boutiere C, Carri-Dalliere C, Labauge P. Postenior foss imvolvement in the diagnosis of aduh-onset intorited leukoencephalowathes. I Neurol 2016:26)(12): 2361-2368.

15. Almeed RM, Murphy E, Davegnasam I, er al. A practical apposach to diagnosing adult orset Jeukodbstroplies )

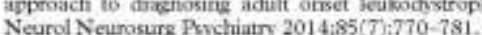

16. Moser HW. Adrenoleukodystroplay: phenoove, genetics. pathogenesis andtherapy-Brin I997; 120(Pt8): 1485-1508.

17. Kumar AJ, Köhler W, Kruse B, er al. MR findings in adultonset adtenoleukodystrophy. ANNR Am J Neururadiol $1995 ; 16(6): 1227-1237$

18. Loes DJ, Faremi A, Methem ER, et al Anadyes of MRI parterns auds prediction of progression in X-tinked adrenoleuloodystrophy. Neurology 2003,61(3):369-374.

19. Loss DJ, Hite S, Moser H, et al. Adreooleuhodyurophy a sconing method for brain MR observations. AINR Am J Neuroridiol 1904:15 (9):1761-1766.

20. Melhem RR, Loes DJ, Georgiades CS, RomandGV, Moser $\mathrm{HW}$. X-linked adrenoleubadystrophys the role of contrastentanced MR imaging in predictity diseste progression.

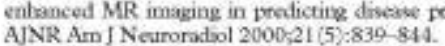

21. Abdelhahim AN. Alserioo RA. Barczykawaki AL, Duffiner PK. Pasterns of magnebe resonance mmaging abnormalites in symptomatic patients with Krabbe disense correspond to phenorspe, Pediatr Neurol $2014 ; 50(2)+127-134$.

22. Köhler $\mathbb{W}$. Leukodystrophies with late disease onset: an updase. Curr Opio Neurol 2010:23(3):234-241.

23. Debs R, Froissant R, Aubourg P, of al. Krabbe chease in adults: phenotypic and genotypec updare frosn a series of 11 cases and a feview, J lnberit Metab Dis 2013:36(5):
859-868.

24. Sedel F, Tourbah A, Fonsaine B, et al. Leukoencephalopsthes associated with inborn errors of metabolism in aduits. I Inherit Metab Dis 2008:31 (3);295-307.

25. Hasain AM. Alruwaiin M. Aldosari M. Krable disease: neurophyssologic studies and MRI correlations. Neurology $2004,63(4): 617-620$

20. Werger DA, RafiMA, Lui P, Dato J, Costantinu-Ceccarini E. Krabbe disease: genetic aspects and progress towand theray. Mol Genet Metab 2000;70(1):1-9.

27. Wenper DA, RafiMA, Lus P. Molecular genetics of Knabe disease (ghoboid cell ksuloodsurophy): diagnosticand diniced implications. Hum Mutat 1997;10 4):263-270

28. Furina $L$, Burss A, Finocchiso G, et al. MR mming and proton MR spectroscopy in adult Knabbe diseste, ANRR Am I Neuroratiol 2000;21(8): 1478-1482.

29. van Rappand DE, Boelens IJ, WolfNI. Metschmenancliculodystropay disessespectrum and apponoches for treament. Best Dract ResClin Fectocinal Metro 2015;29:2):261-273.

30. Cesani M. Lorioli L., Grossi S, et al. Mutation updve of ARSA and PSAP genes causing metachromatic keukndystropky. Hum Mutat $2016537(1): 16-27$.

31. Hageman AT, Galredts FJ, de Jong JG, eral. Clinicsl symptoms of adult metachrumatic leukod strophy and arylsalfatase A peseudodeficienc, Arch Neurol 1995:52(4):408 413 .

32. Groesctiel 8, Keliret C, Engel C, et al. Metacturumatic leukadystrophys natural course of cerebral MRI changes ii relation to clinical course. J Inherit Metab Dis $2011 ; 34(5)+1095-1102$.

33. Eichker F, Grodd W, Grant F, et al. Met achircmatic lealkodystrophy: a socoring system for brain MR imsging observations. ANR Am I Neurerstiol 2009-30(10): 1893-1897.

34. Van Mieghern F, Van Goethern JW, Parizel PM et al. MR of the brain in Sjögren-Larssco syndroms. AJNR Am 1 Neuroratiol 1997;18(8):1561-1563. 
35. Rizzo WB. Genebs and prospective thenupeutic nurgets for Sicignen-larssou syadrome. Expent Opin Orphan Drugs 201 6:A(4):395-405.

3. Willemsen MAAP, Van Der Graf M. Van Der Knaap MS, et al. MR imagne and proten MR spectrosoopic studies in Sjögren-Larsson syndrome: charscterization of the leukoenerphalopathy. ANR Am J Netirondiol $2004 ; 25(4): 649-657$.

37. Vanderver A. Genetic leakoenexplatopathies in aduls. Continutun (Minneap Minn) 2016;22 (3):916-942.

38. Steerweg. ME, Salomons GS, Yapici Z er al, L-2-Hudroxyglutinc acidurix pattern of MR imoing ahnomrulities in 56 pabients. Radology 2000:251 (3) 856-865.

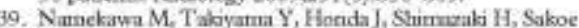
K. Nakano I. Adatt-onsest Alexander disense with typical

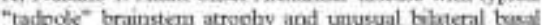
"tadpole" brainstem atrophy and unusual biateral basal ganglia involvernent: a cse zejort
fure. BMC Neurol 2010;10(1)+21

10. Balbi P, Salvisis, Fundarò $\mathrm{C}$, etal. Theclinical spectrum of late-onset Alexander diveate: a systematjc fiteranure review. f Neural 2010;257(12):1955-1962.

41. SowsishiY. Review of Alexurderdisene beyoudthe dissical concept of leukadystroplyy. Brain Dev2009;31(7):493-498,

42. Parcyson D. Frecella R, Mariotri C, et al. Adult-onser Alexander disease: a senes of eleven unrelated cases with teview of the fiteratare. Beain 2009:131(Pt 9) :2321-2331.

17. van der Kraap MS, Nivdu S, Breiter SN, et al. Alexander

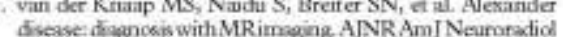
diverse: diponosis with

44. Scheper GC, van der KlokT, van Andel RJ, et al. Mirochondrial uspartyl-tRNA ynthstise defisency causes leukivencephalopathy with brain stem and spinal eard involvernent and betate elevation. Nar Genet $2007 ; 39(4) 534-539$

15. van der Knaap MS, Solornors GS. Leulwericephalopachy with beain sem and spinal oond ievolverneat and lastate devation. In: Adum MP, Andinger HH, Pagoa RA, et ul,

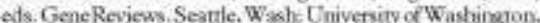

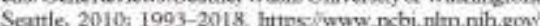
books: NBK 43417i. Undated Februasy 12,2015. Accessed Nowember 20, 2018

46. Latouger P, Dorboz I, Eymard-Pierre E, Dereeper $\mathrm{O}$, Boespfoug-Tanguy 0 . Climcally asymptornatieadult porieat with extensive L.BSLL MRI patten and DARS2 muturions. I Neurot $2011 ; 258(2) ; 335-337$

17. Tzoulis C. Tran GT, Gjerde IO, et al. Leukoenoephalopathy with brainstem and spinal cord imolvement caused by a novel mutation in the DARS2 gene. I Neurol $2012: 259(2 ;: 292-290$

19. Bjirkhem I, Fausa O, Hopen G, Ottebro 11, Pedersen II, Skrede $\mathrm{S}$. Role of the 26 -hydroxylase in the biosynthesis of bik acids in the normal state und in cerebeotendinous xaatho-

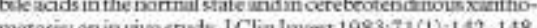

10. Decti MT, Rufa A, Federico A. Cerebrotendinous xamtiomutosis: heterogencity of clinical phenotypewithevidence of previously undescribed ophehalnotogical findings. J Inherit Metab Dis $2001: 24(7): 606-706$

50. Federieo A, Dort MT, Cerebrotendinous xanhounstoss: clinical manifestations, diagnostic criteria, pathogenesis, and theray. J Child Neurol $2003 ; 18(9) \cdot 633-638$.

51. Einkiruçu EK, Otaday MC, Taneja AK, Laite CC, Kok P, Lucato LT, MR spectroscory detects linid peaks in cerebootendinous varthocontosis. ANNR Am j Neuraradiel $2010.31(7): 1347-1349$

52. Bruabery jA, Jacquensont $S$, Hagerrmun RJ et al. Fragile $\mathrm{X}$ gremutation carriers: chancteristic MR maging findings of abalt male patients with propressive cerebellar and sognitive dysfunction. ANR Am I Neuromdal $2002: 23(10): 1757-1766$

53. van der Knamp MS, Rarth PG, Gabreets F, et at A new leukoencephaloparty with vanishing white manter. Neuroloc $1007 ; 48(4)-845-855$

54. Schiffinann R, Eroy-Stein O. Childhood atrecia with CNS lopomyelimation'vanshing white matter dosersei a common leukadystrophy cuused by abromal control of protein syothesis. Mol Getet Merab 2006-38(1) +7-15.

55. van Den Boom R, Lesnik Oberstein SA, van Duinen SG, et al. Suboortical hacunar lesions: an MR inngiag finding in patients with cerebol mutosormal dorminum arteropostry with subcorrical infarcts and leukoencephalogathy. Rodiol-

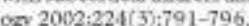

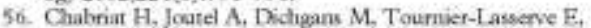
Bousser MG. Cadasil. Lancet Neurol 2009;8,77;643-653.

77. Narayan SK, Gideman G, Kalania RV, Ford GA, Chinnery 1. Narayan SK, Gorman G, Kalana RN, Ford GA, Chinnery
PF. The minimum prevalenee of CADASIL in northeast England. Nearology 2012;78(13):1025-1027.

58. Kanos T, Yosleda K, Mizino T, et al, Climocal and genetic chanacterization of adult-aaset leukoencephalopathy with isonal sphesoids and rogmented gliassocsated with CSFIR mutation. Eur ] Neurol 2017,24,1):37-45,

50. Karte KN, Biskap S, Schule R et al. De nowo mutation in bereditury difruse leukoenceplalopothy with uxomal ephercids (HDIS). Neurolose 201 3:81/23):2030-2044.

60. Nicholson AM, Baker MC, Find NA et al CSEIR nutations link POLD and HDLS as a single disease entity. Neurology 2013080(11):1033-1040.

61. Rademakers R, Baher M, Nicholson AM, et al. Mutations it the colorty stimulatung factor I recepror (CSFIR) gerte cause bereititary diffuseleukoenceghelopathy with spheroids. Nat Gense 2011; 44(2);200-205.

62. Wider C, Vin Gerpen JA. DeArmondS, Shuster EA, Diclson DW, Wroplek ZK. Leskoencephalotanty with spheroids IHDLS) and pomentary bukodystrophy (TOLD): a single envity? Neurology 2009672(22):1953-1959.

63. Konno T, Broderick DF, Mezali N, et al. Diannustic value of hrain edcifications in adult-onset leuloencephabomatto with axonal spheroids and pigmented glas. ANR AmI I with axonil spheroids and pigr

64. Ayriznas X, Nicolas $G$, Carra-Daltière C, Hannequin D. Labauge P. Brain calcifications in adult-onset gebetic leukemoepbalopethies: a review. JAMA Neurol $201774(8)=1000-1008$.

65. Livingston JH, Maskr J, Jenkinson E. ef al. Leukvencephalopatby with califications and cysts: a purely neuroingeal disorder distinc from Coats plus. Neuropediatries $2014 ; 05(3): 175-182$

66. Jentionson FM. Rodeto MP, Kosher PR, et al, Mutations in SNORD1 18 cause the cerebeal microangiopathy leu.

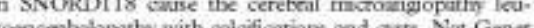
kenceptrabovatis wither Genet 2017,49(2);317.] lutps:/doi.org/10,1038/ng.3661.

67. Palobera J, Autu T, Rauninks R, et al, CNS manifestations of Nasu-Hakola diseasc a frontal dernentia with bone cysts. Neurology 2001,56(11) 1552-1558

68. Kilic SA, Oner AY, Yuce $\mathrm{C}$, Oxlu IC. Imaging findings of Nasu-Hakola diseaset a case teport. Clen lmaging $2012 ; 36 ; 6 ; 877-480$.

69. Melbery A, Hallbers L. Kalimo H, Raininke R, MR ctraracteristios and necuroputbology in aduit-onses autosomal

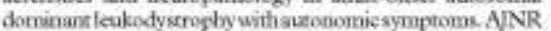
Am I Neurorafiol 2006;27 (6):904-911.

70. Coffeen CM, MeKenra CF. Koepren AH, et al. Generic

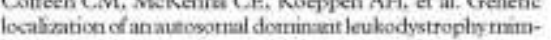
icking chr ckic progressive multiple sclerosisto chnomosome. 5431. Hum Mat Genet 2000):9(5):787-793. 
10.13 Apêndice M - PUS3 mutations are associated with intellectual disability, leukoencephalopathy, and nephropathy. Neurol Genet 2019;5(1):e306.

This work is licensed under the Creative Commons Attribution 4.0 International License. To view a copy of this license, visit http://creativecommons.org/licenses/by/4.0/ or send a letter to Creative Commons, PO Box 1866, Mountain View, CA 94042, USA.

De Paiva A, Lynch D, Melo U, Lucato L, Freua F, de Assis B, Barcelos I, Listik C, de dos Santos D, Macedo-Souza L, Houlden H, Kok F. PUS3 mutations are associated with intellectual disability, leukoencephalopathy, and nephropathy. Neurol Genet 2019;5(1):e306.

https://doi.org/10.1212/NXG.0000000000000306 


\title{
PUS3 mutations are associated with intellectual disability, leukoencephalopathy, and nephropathy
}

\author{
Anderson Rod igues Brandäo de Paka, MD, David S. Lynd, MD, PhD, Uiră Souto Melo, Pho,

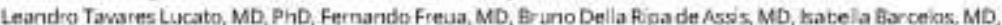 \\ Clarice Listic MD, Diego de Castro dos Santos, MD. Lúca Inês Macedo-Souza, Pho. Henry Houiden, MD. Pho. \\ and Fernando Kolk, MD, PnD \\ Noard Genet 2019;5*306, doni10.1212/NXG.0000000000000306
}

Mutations in PUS3, which encodes a highly conserved enzyme responsible for post-
transcriptional modification of tRNA, have been shown in a single family to be a cause of
nonsyndromic intellectual disability (ID) ${ }^{1}$ In this study, we used whole-exome sequencing
(WES) to identify biallelic mutations in PUS3 associated with syndromic ID with dysmorphic
features, white matter disease (WMD), and renal abnormalities in a nonconsanguineous family from Brazil.

\section{Clinical findings}

We evaluated 2 sisters (figure, A) who had ID, renal abnormalities, diffuse WMD, and dysmorphic features. Their brother was similarly affected and died at age 22 years of complications of renal disease. The parents were nonconsanguineous from Northeast Brazil and Southern Italy, We obtained approval from the institutional ethics committee and written informed consent from family members.

The first patient ( $\mathrm{P} 1 ; \mathrm{III}-3$; figure, $\mathrm{A}$ ) was noted to have global developmental delay after age 1 year. As a child, she could understand short sentences, but expressive language was limited to monosyllables. She was diagnosed with profound ID but was independent in basic activities of daily living (ADLs). She had 2 focal dyscognitive seizures with secondary generalization, at age 18 and 23 years, responsive to carbamazepine. At age 37 years, asymptomatic proteinuria and reduced creatinine clearance were detected. At 44 years, she developed psychosis, with prominent auditory and visual halludinations and episodes of aggression. Physical examination revealed her to be on the 10th centile for height, weight, and head circumference and to have genu valgum. In addition, neurologic examination revealed dysarthria, pseudobulbar affect, with impaired gait and balance.

The second patient ( $\mathbf{P 2}$; III-6; figure, A) also presented with short stature, neurodevelopmental delay, and dysmorphic features. She was diagnosed with acute nephritis at age 6 months and coeliac disease at age 5 years. She also developed generalized phenobarbital responswe seizures. She was able to walk and could complete ADLs with assistance. At age 20 years, she developed nephrotic syndrome due to focal segmental giomerulosclerosis (FSGS) with mesangial granular deposits and positive IgM and $\mathrm{C} 3$ immunoftuorescence. She did not respond to steroids and developed end-stage renal failure requiring hemodialysis, Physical examination revealed that she was on the 3rd centile for height, weight, and bead circumference and to have gray

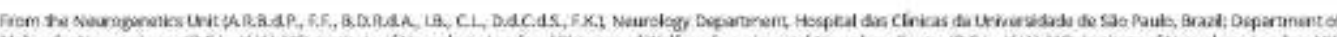

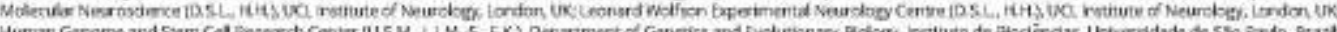
Fent

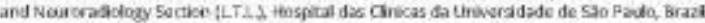

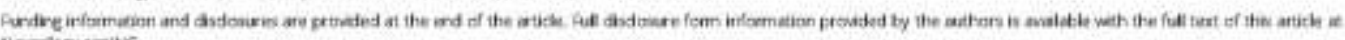
Noursegvary

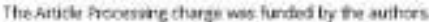

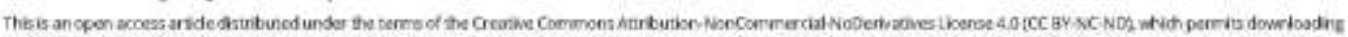

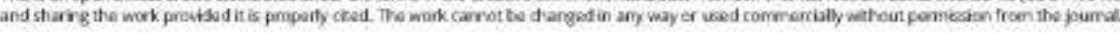


Figure Genetic and radiologic findings
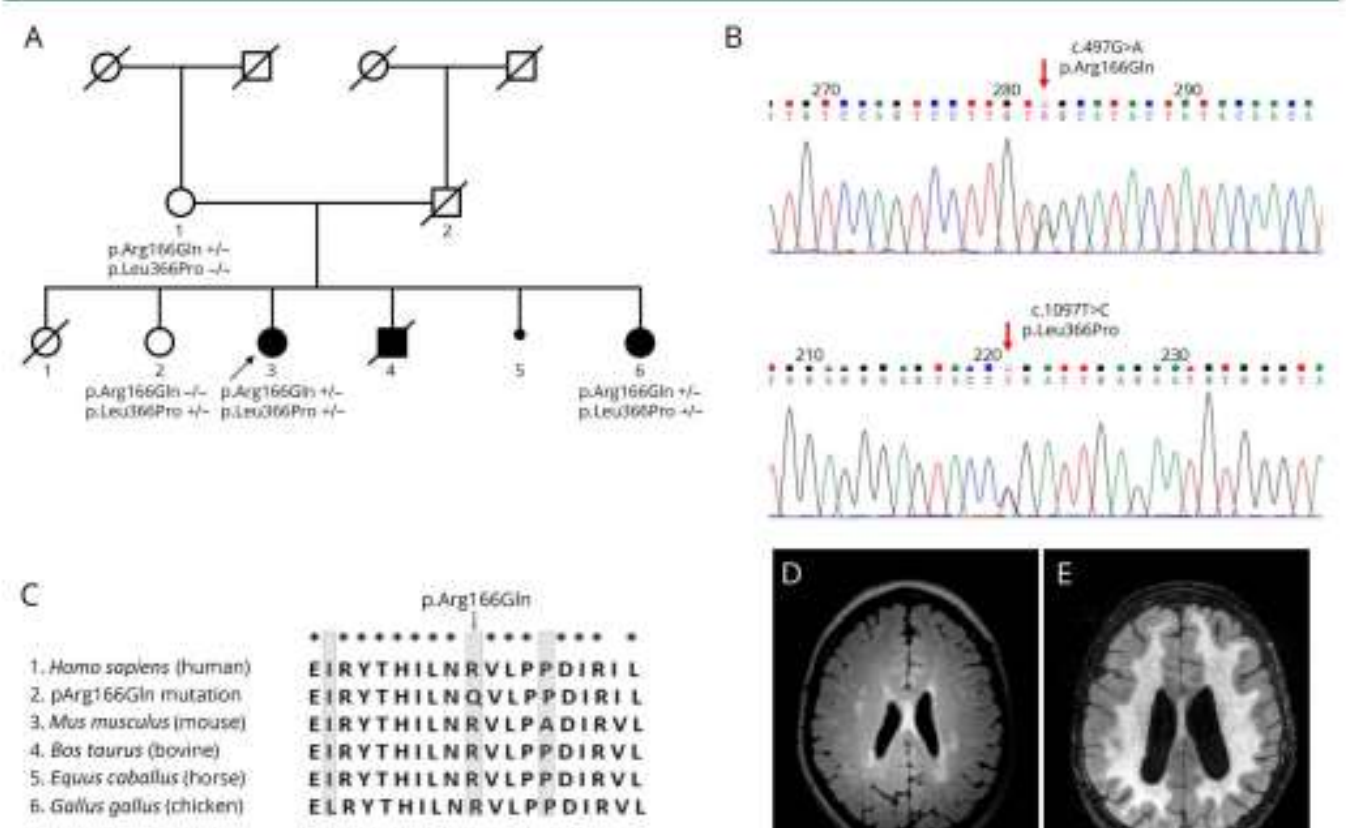

1. Homo sagiens (hyuman) 2. parg166Gin mutation 3. Mus muscrulus imouse) 4. Bos tourus (bovine)

5. Equus coballus shorsei

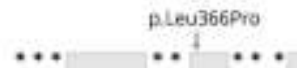

VXTHMLYSMLQGLDTVPVP VKTHMLYSMPQGLDTVPVP VKTHMLYSMLQGLDSVMVT VKTQMLYSMLQGLDSVALP VKTH IVYSMLQGLDSAAY VKTQVLHSMLA GLDTAPMA
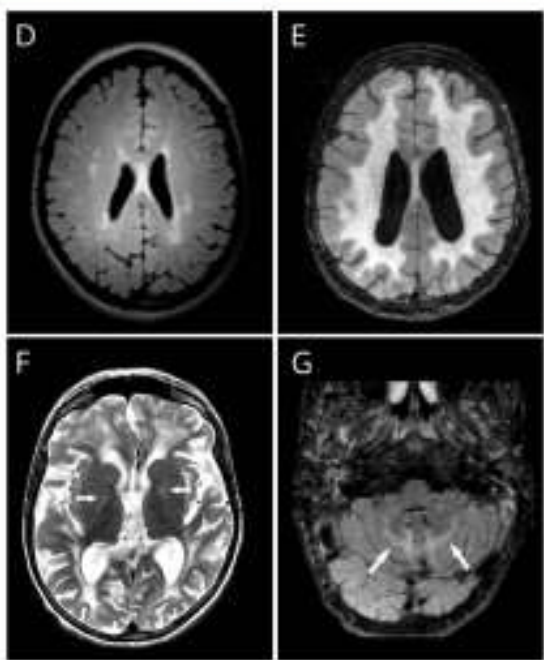

(W) Family pertigree: 2 affected individuals were compound heterozygotes for p.Arg $166 \mathrm{Gln}$ and p. Leu366 Pro PUS3 mutations, whereas their healttiy mother and sistar wore hecerozygotes for only 1 of the mutatians. (i) Sanger sequencing electropherograma showing bath c.497G>A (p.Arg165Gin]

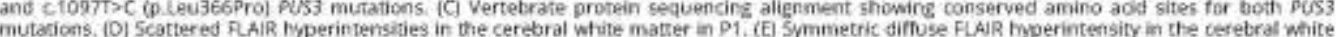
matter in 92 . (A Axial T2-weighted image discloses not only the white matter changes in 92 but also mild T2 hyperintenscy in the globus pallidus

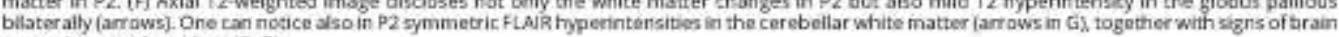
parenctryma volume loss $(E-G)$.

sclera, genu valgum, pseudobulbar affect, and dysarthria. She died at age 40 years of complications of community-acquired pneumonia.

\section{Neuroimaging findings}

MRI identified white matter aboormalities in both patients. In $\mathrm{p} 1$, there were scattered $\mathrm{T} 2 /$ tluid-attenuated inversion necovery (FLAIR) hyperintensities in the cerebral white matter, more prominent in periventricular zones (figure, D) In $\mathrm{P} 2$, there was symmetric diffuse T2/FLAIR byperintensity in the cerebral and cerebellar white matter with extension to the subortical areas, mild T2 hyperintensity in the globus pallidus balaterally, and signs of brain parendymal volume loss (figure, E-G). There was no gadolinium enhancement or areas of restricted diffusion.

\section{Genetic findings}

We performed WES on both patients and filtered the data for a presumed autosomal recessive inheritance pattern. There were no regions of homozygosity and no shared rare homozygous variants. However, when filtered for damaging, rare compound heterozygous mutations, we identified bialletic mutations only in PUS3 (p.Arg166Gin;p.Leu366Pro) 
(figure, B). Both are very rare and highly conserved residues among vertebrates. We confirmed the mutations by Sanger sequencing and demonstrated that they were inherited in trans.

\section{Discussion}

PUS3 codes for pseudourydilate synthase, a highly conserved enzyme responsible for posttranscriptional modification of tRNA $^{2}$ which is critical for its structure, function, and sta. bility. Most of these modifications have been recently recognized in a growing number of human genes leading to ID-FTS1, TRMT1, NSUN2, WDR4, ADAT3, and PUS3. ${ }^{3}$

The original report of PUS3-related disonder describes a family with 3 affected individuals (age: $3-15$ years) from Saudi Arahia with severe $\mathrm{D}$, multifocal white matter dhanges, and in a single patient, epilepsy. No nephropathy was reported. WES detected a homorygous truncating nutation (p.Arg 435Ter), predicting to lead to a loss of function. In our patients, affected individuals have a milder intellectual compromise and devaloped proteinuria/ nephrotic syndrome after age 20 years. In addition, the white matter abnormalities were more extensive in our patients.

Of interest, a well-known mechanism of WMD is disruption of protein translation as is seen in mutations in mitochondrial aspartate (DARS2) or glutamate (FARS2) transfer-RNA synthase. It is also noteworthy that leakoencephalopathies usually cause progressive neurologic deterioration and not static encephalopathy with $\mathrm{ID}$, as occurred in our patients.

The late-onset renal involvement obeerved in our patients expands the phenotype of PUS3-related disorder. Steroidresistant FSGS has been rarely associated with mutations in mitochondrial tRNA in patients with other features typical of mitochondrial dysfunction. ${ }^{4.7}$ Recently, tubulopathy was reported in deficiency of tRNA N6-adenosine threonylcarbamoyltransferase, an enxyme involved in posttranscriptional tRNA modification.

This study expands the known phenotypic and allelic spectrum of PUS3-related disorder. In addition, it provides further evidence of the relevance of postranscriptional modification of tRNA in neurologic diseases. Given these additional findings, we believe the phenotypic spectrum of PUS3 mutations to be wider than the initial report.

\section{Acknowledgment}

The authors thank the patients and their family for participating in this study.

\section{Study funding}

No targeted funding reported.

\section{Disclosure}

A.R.B. de Paiva, D.S. Lynch, and U.S. Melo report no disclosures L.T. Lucato has received speaker honotaria from Bracoo Imaging

\begin{tabular}{|c|c|c|c|}
\hline Name & Location & Role & Contribution \\
\hline $\begin{array}{l}\text { Anderson } \\
\text { Rodrlgues } \\
\text { Brandiso de } \\
\text { Paiva, MD }\end{array}$ & 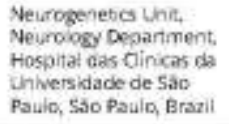 & Authof & $\begin{array}{l}\text { Study concept } \\
\text { and design, } \\
\text { acquistion of } \\
\text { dast, and wnting } \\
\text { the maniscript. }\end{array}$ \\
\hline $\begin{array}{l}\text { Davids. } \\
\text { Lyneh, MD. } \\
\text { PhD }\end{array}$ & $\begin{array}{l}\text { UCL Institute of } \\
\text { Neurobogy, Londan, } \\
\text { United Kirgodom }\end{array}$ & Auttor & $\begin{array}{l}\text { Study concept } \\
\text { and design. } \\
\text { acquistion of } \\
\text { dora, and writing } \\
\text { the manuscript. }\end{array}$ \\
\hline $\begin{array}{l}\text { Uira Souto } \\
\text { Meio, PhD }\end{array}$ & 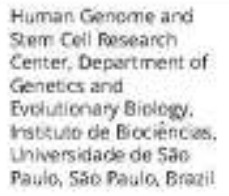 & Aisthor & $\begin{array}{l}\text { Acpulistion of } \\
\text { dara and critcal } \\
\text { revsion of the } \\
\text { manusonpt. }\end{array}$ \\
\hline $\begin{array}{l}\text { Leandro } \\
\text { Tavares } \\
\text { Lucato, MD. } \\
\text { PhD }\end{array}$ & $\begin{array}{l}\text { Neuroradiology } \\
\text { Section, Hospital das } \\
\text { Clinicas da } \\
\text { Universidade de Sado } \\
\text { Pauln, Săb Paulo, Brozil }\end{array}$ & Authof & $\begin{array}{l}\text { Acquistion of } \\
\text { cara and critical } \\
\text { revision of the } \\
\text { maruscript. }\end{array}$ \\
\hline $\begin{array}{l}\text { Fernando } \\
\text { Freus, MD }\end{array}$ & $\begin{array}{l}\text { Nevergenetics Uni, } \\
\text { Neimoiogy Oepartment, } \\
\text { Hospitiai das Clincis das } \\
\text { Unhwersidade de Såc } \\
\text { Paulo, Sáo Paula Brazil }\end{array}$ & Author & $\begin{array}{l}\text { Accuisition of } \\
\text { deka and sritical } \\
\text { revision of the } \\
\text { manuscript. }\end{array}$ \\
\hline $\begin{array}{l}\text { Bruno Della } \\
\text { Ripa de Assis, } \\
\text { MO }\end{array}$ & 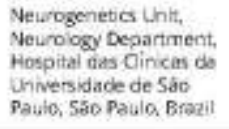 & Author & $\begin{array}{l}\text { Actiulsition of } \\
\text { casta ard critcal } \\
\text { revision of the } \\
\text { manuseript. }\end{array}$ \\
\hline $\begin{array}{l}\text { Esabella } \\
\text { Bartelos, Mo }\end{array}$ & 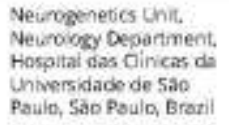 & Authof & $\begin{array}{l}\text { Acesuistion of } \\
\text { deca and critical } \\
\text { revision of the } \\
\text { maruscript. }\end{array}$ \\
\hline $\begin{array}{l}\text { Clarice Listik } \\
\text { MD }\end{array}$ & 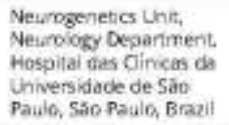 & Author & $\begin{array}{l}\text { Acruisition of } \\
\text { deta and critical } \\
\text { revision of the } \\
\text { maruseript. }\end{array}$ \\
\hline $\begin{array}{l}\text { Dlego de } \\
\text { Castro dos } \\
\text { Santos, MD }\end{array}$ & 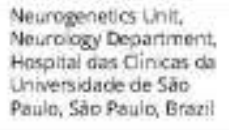 & Author & $\begin{array}{l}\text { Accuisition of } \\
\text { cora and critical } \\
\text { revsion of the } \\
\text { maruserfipt. }\end{array}$ \\
\hline $\begin{array}{l}\text { Lúcia inès } \\
\text { Matéte- } \\
\text { Souza, Phd }\end{array}$ & 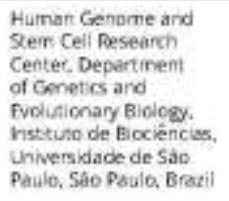 & Authot & $\begin{array}{l}\text { Acruisition of } \\
\text { deca ard eritcal } \\
\text { revaion of the } \\
\text { manuscript. }\end{array}$ \\
\hline $\begin{array}{l}\text { Henry } \\
\text { Houiden, MD, } \\
\text { PhD }\end{array}$ & $\begin{array}{l}\text { UCi Institute of } \\
\text { Neutoiogy. London } \\
\text { United Kingoin }\end{array}$ & Auttor & $\begin{array}{l}\text { Crtical revision of } \\
\text { the manuscript }\end{array}$ \\
\hline $\begin{array}{l}\text { Fernande } \\
\text { Kok, MD, Pho }\end{array}$ & $\begin{array}{l}\text { Neurogenetics Unit, } \\
\text { Neunology Dopartment, } \\
\text { Hosplial das Cincas } \\
\text { do Uriversidide de } \\
\text { Sto Pauba Sao Pau/a, } \\
\text { Erazl }\end{array}$ & Author & $\begin{array}{l}\text { Crsical revision of } \\
\text { the manuscript }\end{array}$ \\
\hline
\end{tabular}

Neuroiogr Genetics | Volume 5. Number 1 | February 20193 
do Brasil and has served on the editorial board of Anquives de Neum-Psiquiatria. F. Fretu, B.D.R. de Assis, L. Barcelos, C. Listik, D. Castro Santos, and L.L. Macedo-Souza report no disclosures. H. Houlden has received governmental and/or foundation/ society support from the Medical Research Council (MRC) UK, the BRT, the MDA USA, Muscular Dystrophy UK, Ataxia UK, Muscular Dystrophy UK, Rosetrees Trust, the Wellcome Trust, and the National Institute for Health Research (NIHR) UCL/UCLH BRC. F. Kok has served on the editorial board of Arquivos de Neuro-Psiquiatria; holds a patent for methylmalonic acid determination by tandem mass spectrometry using stable isotope; is enployed as Medical Director for Mendelics Genomic Analysis; has acted as a spesker for Actelion Pharmaceuticals at the NPC symposia and for BioMarin Pharmaceuticals at the CLN2 symposia; and has been a shareholder of Mendelics Genomic Analysis. Full disclosure form information provided by the authors is arsilable with the full text of this article at Neurology.org/NG.

\section{Publication history}

Heceived by Naurology: Geotics August 13, 2018. Accepted in final form November 8, 2018.

\section{References}

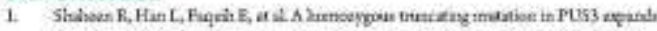

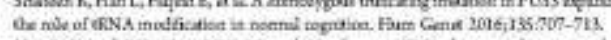

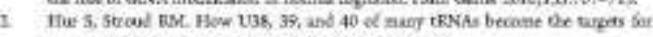

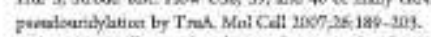

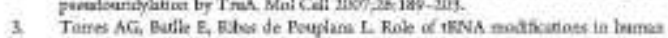

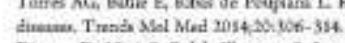

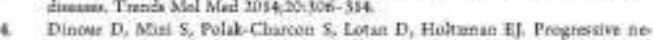

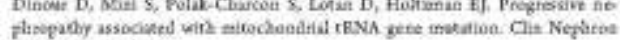
Filavediy associst

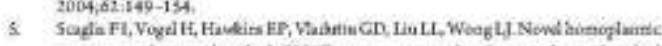

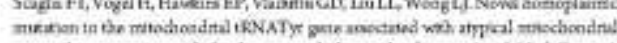

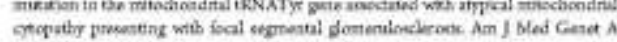
2001, $1245,172-17$

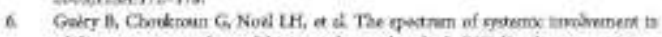

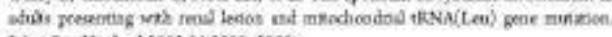
JAm Soc Nequint 20003:4-3059-2xok.

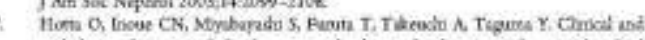

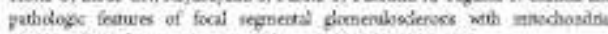

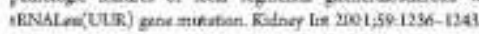

